Thiago Mio Salla

\title{
O FIO DA NAVALHA: Graciliano Ramos e a revista Cultura Política
}


Thiago Mio Salla

\title{
O FIO DA NAVALHA: Graciliano Ramos e a revista Cultura Política
}

\author{
Volume I
}

Tese de Doutorado apresentada ao Programa de Pósgraduação em Ciências da Comunicação, Área de Concentração "Teoria e Pesquisa em Comunicação", Linha de Pesquisa "Estética e História da Comunicação", da Escola de Comunicações e Artes da Universidade de São Paulo, como exigência parcial para obtenção do Título de Doutor em Comunicação.

Orientador: Prof. Dr. Ivan Prado Teixeira. 
SALLA, Thiago Mio

O fio da navalha: Graciliano Ramos e a revista Cultura Política. São Paulo: T.M. Salla, 2010.

2v, $721 f$.

Tese de Doutorado apresentada ao Programa de Pós-graduação em Ciências da Comunicação, Área de Concentração “Teoria e Pesquisa em Comunicação”, Linha de Pesquisa "Estética e História da Comunicação”, da Escola de Comunicações e Artes da Universidade de São Paulo, como exigência parcial para obtenção do Título de Doutor em Comunicação.

Orientador: Prof. Dr. Ivan Prado Teixeira.

1. Graciliano Ramos 2. Cultura Política 3. Estado Novo 4. Viventes das Alagoas 5. "Quadros e costumes do Nordeste" 
Thiago Mio Salla

\section{O FIO DA NAVALHA: Graciliano Ramos e a revista Cultura Política.}

Tese de Doutorado apresentada ao Programa de Pós-graduação em Ciências da Comunicação, Área de Concentração "Teoria e Pesquisa em Comunicação”, Linha de Pesquisa "Estética e História da Comunicação", da Escola de Comunicações e Artes da Universidade de São Paulo, como exigência parcial para obtenção do Título de Doutor em Comunicação.

Orientação: Prof. Dr. Ivan Prado Teixeira.

BANCA EXAMINADORA

$\operatorname{Prof(a).~Dr~(a).~}$

$\operatorname{Prof}(\mathrm{a}) . \operatorname{Dr}(\mathrm{a})$.

$\operatorname{Prof}(a) . \operatorname{Dr}(a)$.

$\operatorname{Prof}(\mathrm{a}) . \operatorname{Dr}(\mathrm{a})$.

Prof(a). Dr (a).

São Paulo de de 2010 
A todos aqueles que, deste e do outro lado do rio, ajudaram a remar meu barquinho de papel 


\section{Agradecimentos}

Gostaria de agradecer em primeiro lugar, aos meus pais, Dalva e José, que incansavelmente batalharam por minha formação, pessoal e estudantil, possibilitando-me chegar aqui onde estou, bem como seguir adiante. Não esqueço também de meu irmão Thomas, distante fisicamente, mas sempre presente em pensamento.

Em seguida, agradeço imensamente a meu orientador e amigo, Ivan Prado Teixeira, que desde o início me acolheu, estimulou e ajudou em todos os aspectos do presente trabalho. As páginas que aqui seguem não teriam sido possíveis sem seu apoio, críticas, comentários, sugestões e correções.

Como não poderia deixar de ser, dedico também profundos agradecimentos ao Conselho Nacional de Desenvolvimento Científico e Tecnológico (CNPq), pelo auxílio inicial, mas, sobretudo, à Fundação de Amparo à Pesquisa do Estado de São Paulo (FAPESP) que ao longo de quatro e meio anos forneceu todos os recursos necessários para a execução desta pesquisa. Muito obrigado.

Sou grato ainda a um conjunto imenso de pessoas:

Aos professores João Adolfo Hansen e Valetim Facioli, presentes nas qualificações tanto do Mestrado como do Doutorado Direto, que por meio de críticas, sugestões bibliográficas, questionamentos, empréstimos de materiais, sempre trabalharam para a melhoria da presente tese.

Aos professores(as) Yêdda Dias Lima, Wander de Melo Miranda, Eduardo Morettin, Marcos Napolitano, Rubens Machado, Nicolau Sevcenko, Hélio de Seixas Guimarães, Maria Augusta Fonseca, Sandra Nitrini, Eduardo Martins, Murilo Marcondes de Moura, Marcelo Ridenti, Adriana Coelho Florent, Marcos Muller, José Marques de Melo, Mayra Rodrigues Gomes, Plínio Martins Filho que de alguma maneira, em momentos diferentes, contribuíram com dicas, livros, sugestões e críticas para a realização desta pesquisa. 
À Luiza Ramos, filha de Graciliano Ramos, que me concedeu autorização para consultar os prontuários do artista presentes no de Fundo de Polícias Política do Arquivo Público Estado do Rio de Janeiro.

A Moacir Medeiros Sant’ana, à época diretor do Arquivo Público de Alagoas, que me recebeu muito bem, facilitando-me o acesso às empoeiradas coleções de periódicos maceioenses presentes no acervo da instituição.

À Mônica Aparecida Guilherme da Silva Bento, do Instituto de Estudos Brasileiros, incansável na procura de caixas e mais caixas de documentos esquecidos e fora do catálogo. Uma santa. Não esqueço também de Jorge Luiz, da Coordenadoria de Periódicos da Biblioteca Nacional, que apesar das limitações da instituição, soube contorná-las, facilitandome o acesso aos materiais consultados. À Liliane Zembarg do Centro de Documentação e Memória da Unesp por encurtar burocracias. À Ângela Chagas do Projeto Portinari, que solicitamente enviou-me uma crônica de Graciliano ainda inédita em livro, presente no acervo da entidade. Ao João Tenório da Casa Museu Graciliano Ramos que forneceu-me uma cópia da coleção do jornal $O$ Índio. E a todos os funcionários dos arquivos visitados, inclusive aqueles que fizeram muito, simplesmente, ao não dificultarem a pesquisa realizada.

Ao João Batista Marçal, estudioso do movimento operário no Rio Grande do Sul, que me remeteu a cópia de um texto de Graciliano, ainda inédito em livro, publicado na revista gaúcha Horizonte.

À amiga Ann Marie Buyers, lá de Maceió, que não só fotografou alguns jornais alagoanos para mim, como também localizou um texto inédito de Graciliano no acervo do Instituto Histórico e Geográfico de Alagoas.

A Ricardo Gaiotto, à época mestrando da Unicamp, que me enviou alguns textos da revista Dom Casmurro, antes de eu consultá-los pessoalmente na Biblioteca Nacional.

À Marina Takami pelo envio de informações e imagens da revista getulista Brasil Novo. 
À Maria Carolina Pinto pela revisão de alguns trechos iniciais do texto que ora segue e pela acolhida afetuosa. Este último aspecto vale também para Antônio Senador, o tio Toninho, sempre carinhoso e receptivo.

À Luciana Gomes Elias, pelo suporte psicológico ao longo de praticante todos os anos deste trabalho.

A Luiz Maklouf Carvalho, amigo sempre solícito, além de interlocutor privilegiado em todos os assuntos, sobretudo literatura e jornalismo. Aprendi muito com ele.

Aos amigos-irmãos queridos Gustavo Prudente, Rafaela Muller, Rita Monte, Victor Farat, Eliza Capai, Luís Soji, Pablo Moronta e Maurício Moreira Bertges, agradeço, sobretudo, o carinho e a atenção de todas horas (apesar de tê-los visto pouco nos últimos tempos). Ao último da lista, seguem também agradecimentos extras por ter me emprestado sua câmera fotográfica, com qual capturei as imagens dos documentos que acompanham os diferentes capítulos da pesquisa.

À querida Janaína Marcoantonio, grande amiga também, pela tradução do resumo.

Em particular, agradeço à Daniela Senador, companheira no começo dessa jornada, que acompanhou minhas dúvidas, avanços e questionamentos, tanto acadêmicos quanto existenciais e afetivos, ensinando-me muito e ajudando-me sempre a ir adiante.

Ao amigo de infância Túlio (mais conhecido como Getúlio), pela hospedagem nas terras cariocas, em virtude da realização das intermináveis pesquisas de campo.

E, por fim, gostaria de agradecer à Daniela Damiati, parceira atual, que além da prestimosa, ou melhor, da inestimável ajuda na reta final, soube ouvir com muito carinho e paciência minhas lamúrias, inseguranças e vacilações, temperando-as sempre com esperança e amor. 


\section{Resumo}

A presente pesquisa tem como objetivo estudar os quadros nordestinos publicados por Graciliano Ramos na revista getulista Cultura Política, principal publicação do Departamento de Imprensa e Propaganda (DIP), do Estado Novo, entre março de 1941 e maio de 1943. Levando-se em conta a materialidade de tais escritos, ou seja, o fato de terem sido veiculados num suporte editorial e num tempo específicos, procura-se examinar os efeitos (agregativos e desagregativos) por eles produzidos no periódico oficial, bem como as estratégias empregadas pelo artista para mover-se em meio a um terreno minadíssimo, de articulações políticas comprometedoras, durante o regime de 1937. Como se depreende da análise dos textos propriamente ditos e dos debates culturais dos quais estes participavam, observa-se que o escritor, no momento em questão, parecia equilibrar-se sobre o fio de uma navalha: se de um lado a necessidade de colaboração impunha-se, de outro, percebe-se na seleção das tópicas, no gênero e no modo de elocução adotados em seus “Quadros e costumes do Nordeste” (nome da seção em que estes foram estampados inicialmente), seu receio em comprometer-se com os postulados do governo ditatorial.

Paralelamente, como forma de ampliar o corpus de escritos de Graciliano Ramos, esta tese disponibiliza, em anexo, uma proposta de edição de 58 textos do autor, ainda inéditos em livro, recolhidos ao longo das pesquisas de campo em diferentes arquivos brasileiros. Trata-se de crônicas, artigos, cartas, discursos e até do trecho de uma peça de teatro até então desconhecidos do grande público, que ajudam a compor um perfil mais acabado do artista e de sua obra como um todo.

Palavras-chave: Graciliano Ramos; Cultura Política; Estado Novo; Viventes das Alagoas; “Quadros e costumes do Nordeste”. 


\begin{abstract}
The aim of this study is to analyze the Northeastern portraits that Graciliano Ramos published in the magazine Cultura Política [Political Culture], the main publication of Estado Novo's Departamento de Imprensa e Propaganda [New State's Department of Press and Propaganda], or DIP, from March 1941 to May 1943. Given the material nature of such writings, that is, the fact that they were publicized in a specific time and editorial medium, we seek to examine their (consonant and dissonant) effects on the official publication, as well as the strategies used by the artist to move about on a political minefield during the regime initiated in 1937 . As it is inferred from the analysis of the very texts and from the cultural debates in which they took part, it can be noticed that the writer, at that moment, seemed to be balancing on a razor's edge: if, on the one hand, he was urged to cooperate, on the other, his fear of committing himself to the postulates of the dictatorship is perceived in the topics he selected and in the genre and style he adopted in his "Quadros e costumes do Nordeste" [Northeastern portraits and customs] (title of the section in which such texts were initially printed).
\end{abstract}

At the same time, expanding the corpus of Graciliano Ramos’ writings, this study also makes available, as an appendix, a proposal for editing 58 texts by the author, not yet published in book, gathered during our fieldwork in various Brazilian archives. They consist of chronicles, articles, letters, speeches and even an excerpt of a play, still unknown to the general public, which help to delineate a more accurate profile of the artist and his work as a whole.

Keywords: Graciliano Ramos; Cultura Política; Estado Novo; Viventes das Alagoas; “Quadros e costumes do Nordeste”. 


\section{Sumário - Volume 1}

Introdução

PARTE I - Divulgação e recepção dos textos e a

trajetória jornalística de Graciliano Ramos

Capítulo 1 - Graciliano e a edição das crônicas

1.1. Críticas às edições de Linhas Tortas e Viventes das Alagoas..........................................31

1.2. Identificação e solução parcial dos problemas apontados..............................................38

1.3. Tentativa de sistematização das crônicas........................................................................40

1.4. As publicações dos "Quadros e costumes do Nordeste”

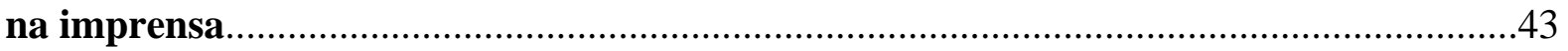

1.5. A recepção dos textos de Cultura Política.................................................................4

1.6. Enunciados-tipo e enunciados-ocorrência: proposta de análise.....................................54

Capítulo 2 - O percurso do cronista

2.1. O Parayba do Sul: da capital para a província...........................................................59

2.2. $O$ Índio: da província para a província.....................................................................66

2.2.1. A série "Garranchos"........................................................................................75

2.2.2. O final de sua colaboração em $O$ Índio..............................................................77

2.3. Jornal de Alagoas e a revista Novidade: política

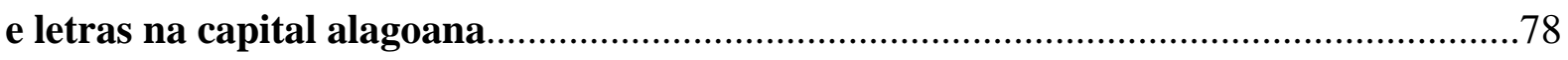

2.4. A consolidação do escritor e o cronista-articulista.....................................................94

2.5. Saída da prisão e o trabalho efetivo na imprensa carioca.............................................98

2.5.1. A polêmica envolvendo Mário de Andrade,

Jorge Amado e Joel Silveira......................................................................................102

2.5.2. O concurso da José Olympio e a tematização de seus

romances nas crônicas 
PARTE II - Debates culturais dos anos de 1930 e

1940 e a mediação editorial de Cultura Política

\section{Capítulo 3 - A poética de Graciliano pari passu}

às diretrizes estadonovistas

3.1. Introdução

3.2. "Realismo” na tematização do sertão

3.3. Graciliano e a representação do sertão

3.4. A especificação da crítica ao Romantismo.

3.5. A visada “classista” no tratamento do sertanejo

3.6. O caráter do escritor e o Estado Novo.

3.7. A crítica generalizada ao Modernismo.

3.8. O repúdio ao individualismo e a defesa da

idéia de "romance social"

3.8.1. Política e letras

\section{Cultura Política e seu discurso}

4.1. O Departamento de Imprensa e Propaganda.

4.2. Outras publicações estadonovistas

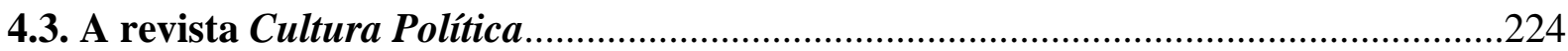

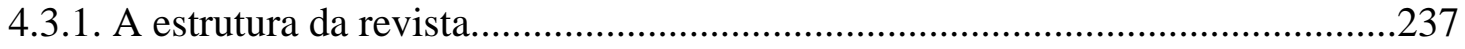

4.3.2. Incorporação de novas seções........................................................................248

4.3.3. A segunda fase de Cultura Política ...................................................................249

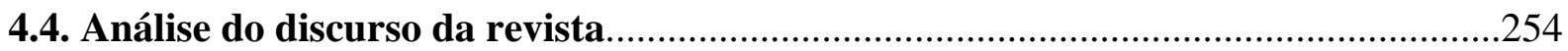

4.4.1. A cultura, o “espírito nacional” e a legitimação

do regime.

4.4.2. A recusa ao liberalismo e a nova concepção

de democracia. 
4.5. Editoriais ou paratextos explicativos.

4.5.1“Influência política sobre a evolução social,

intelectual e artística do Brasil”

4.5.2. Apresentação das subseções “Quadros e

Costumes"

\section{PARTE III - Análise dos “Quadros e costumes do}

Nordeste": as estratégias do autor consubstanciadas no texto

Capítulo 5 - Panorama geral da estrutura, das funções e do enquadramento dos quadros nordestinos

5.1. Introdução

5.2. Aspectos panorâmicos dos “Quadros e costumes do Nordeste”

5.3. Efeitos das estratégias textuais de Graciliano

5.3.1. Os paratextos

5.4. Além da crônica.

5.5. Reenquadramento dos textos quanto aos gêneros

5.6. O estatuto de "real" dos textos.

5.6.1. A revista e o enquadramento cronístico.

5.6.2. O registro histórico

Capítulo 6 - Estudo específico dos quadros enquanto artefatos verbais e eventos culturais

6.1. No começo, um olhar sobre o carnaval.

6.1.1. A política individualista em cheque.

6.1.2. O combate ao provincianismo.

6.2. D. Maria Amália, a personificação do coronelismo 


\section{Capítulo 7 - Contraponto e a republicação dos quadros}

\section{gracilianos}

\subsection{Marques Rebelo e o contraponto dos “Quadros e costumes} do Centro e do Sul”.

7.1.1. O comprometimento com a ideologia estatal.

7.2. Graciliano e a republicação dos quadros nordestinos

Conclusão.

\section{Bibliografia}

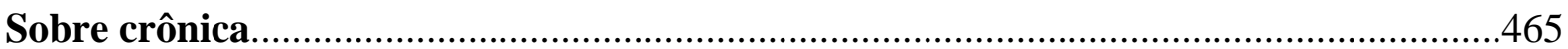

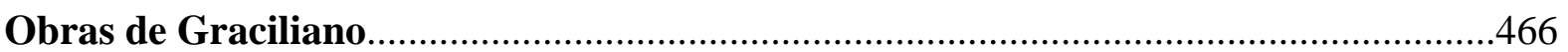

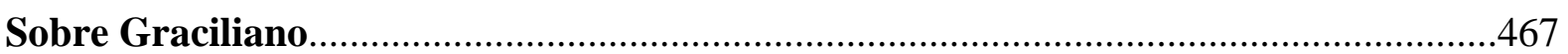

Textos de Graciliano ainda inéditos em livro

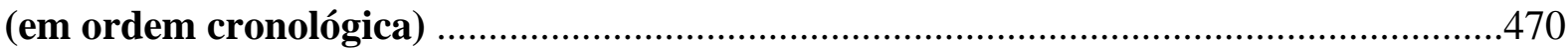

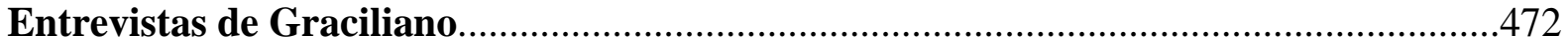

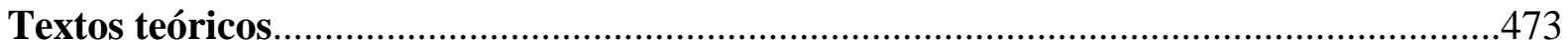

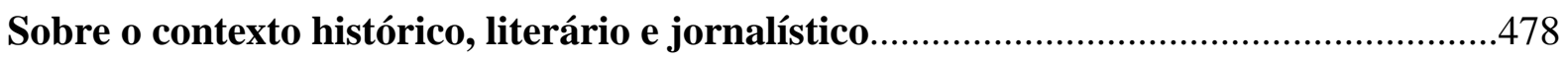

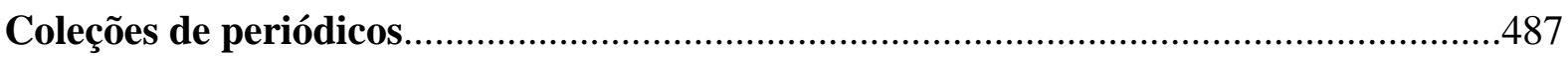

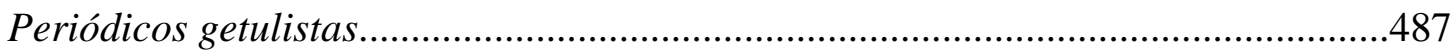

Periódicos comunistas ou influenciados

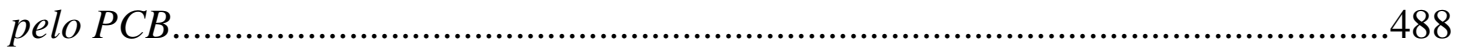

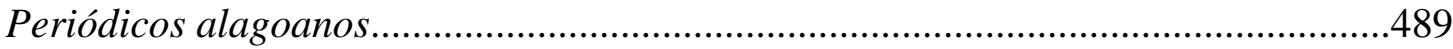

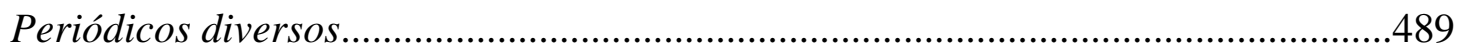

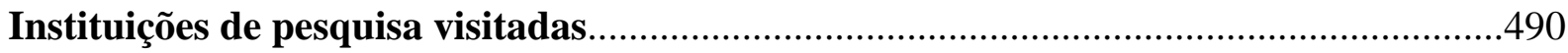




\section{Introdução}

Este trabalho tem por objetivo examinar o conjunto de quadros nordestinos publicados por Graciliano Ramos no periódico getulista Cultura Política: revista mensal de estudos brasileiros, entre março de 1941 e maio de 1943, os quais, em sua grande maioria, foram reunidos na obra póstuma Viventes das Alagoas (1962) ${ }^{1}$. Em linhas gerais, a escolha de tais textos, conhecidos como "Quadros e costumes do Nordeste" (nome da seção em que foram publicados inicialmente), justifica-se em função tanto do mérito literário quanto do caráter polêmico e controverso dos mesmos, pois foram escritos para o principal veículo de doutrinação ideológica do Departamento de Imprensa e Propaganda (DIP), do Estado Novo regime que encarcerou o autor de Angústia, sem acusação prévia, de março de 1936 a janeiro de 1937. Além disso, na trajetória jornalística do escritor, as vinte e cinco crônicas que redigiu para a publicação governista, ao longo de mais de mais de três anos (com intervalos), representam sua colaboração mais intensa e duradoura em um único periódico².

Partindo-se dos textos propriamente ditos, do enquadramento estadonovista conferido a eles pela revista getulista e do debate cultural do qual tais escritos participavam naquele momento histórico específico (início dos anos de 1940), pretende-se investigar a relação estabelecida entre artista e Estado, com ênfase nas estratégias empregadas pelo primeiro para equilibrar-se sobre uma espécie de fio de navalha ao longo do regime de 1937: se de um lado a necessidade de colaboração impunha-se, como se depreende de sua contínua e duradoura participação como autor e revisor da publicação ${ }^{3}$, de outro percebe-se no gênero e no modo de elocução adotados em seus "Quadros e costumes do Nordeste” (nome da seção em que foram publicados inicialmente) o receio do romancista em comprometer-se com a ideologia do governo ditatorial.

\footnotetext{
${ }^{1}$ Na verdade, a colaboração de Graciliano em Cultura Política estendeu-se até agosto de 1944, mas seus dois últimos trabalhos, "A viúva Lacerda" e "Booker Washington", saídos depois de maio de 1943, deixaram de enfocar a vida nordestina, tanto que foram reunidos no volume Linhas Tortas, mais genérico e abrangente, e não em Viventes das Alagoas, obra que reúne textos de temática regionalista, privilegiados por esta pesquisa. Por tais razões foram retirados do escopo analítico do presente trabalho.

${ }^{2}$ Nos dois primeiros anos da revista, 1941 e 1942, o escritor alagoano contribuiu com 21 textos. Em 1943, escreveu apenas dois e mais dois no ano seguinte. Além disso, exercia também a função de revisor.

${ }^{3}$ Como sugere o discurso biográfico construído sobre Graciliano, dificuldades financeiras enfrentadas pelo autor justificariam sua longa permanência como colaborador do órgão de direita. Segundo Facioli, tal hipótese "simplista e moralista" só seria verificável enquanto mostra da "fragilidade orgânica da intelectualidade do país, sempre dependente em quase tudo das classes dominantes" (FACIOLI, Valentim. Um homem bruto da terra. In: Bosi et al. Graciliano Ramos. São Paulo: Ática, 1987, p.69).
} 
Nesse sentido, mais do que se embasar em dados recolhidos do discurso biográfico construído sobre Graciliano, o estudo dos gestos artístico e político do escritor, depreendidos da veiculação de seus quadros nordestinos em Cultura Política, repousa, em primeiro lugar, no exame dos efeitos produzidos por tais escritos no ambiente discursivo da revista getulista. Em outras palavras, ao invés de se partir do autor, ou mesmo do homem para se produzir sentido sobre sua obra, sobretudo no caso de matéria tão polêmica, realizar-se-á movimento inverso: serão tomados como base os textos gracilianos propriamente ditos, ou melhor, a materialidade destes textos, ou seja, o fato de eles terem sido publicados num suporte editorial e num tempo específicos ${ }^{4}$, para, então, chegar-se às relações estabelecidas entre o artista alagoano e o Estado Novo, de acordo com o repertório do período.

Em geral, os “Quadros e costumes do Nordeste”, de Graciliano, constroem para si um lugar diferenciado, mas não isolado, muito pelo contrário, nas páginas do periódico oficial, distanciando-se tanto dos habituais panegíricos como de estudos dissertativos dedicados a diferentes aspectos da vida nacional. Ao mesmo tempo, em tais escritos, o narrador adota certo de tom de problematização na abordagem de usos, personagens e situações identificadas com o universo nordestino. No entanto, não endereça suas críticas ao status quo getulista, ou seja, ao Nordeste de seu momento de enunciação, pois, contrariamente ao que se esperava de um cronista moderno (seus textos de Cultura Política são tratados pela revista e pelos críticos como “crônica”), recuava suas narrativas num distante passado sertanejo, tratando-as de maneira distanciada (com ênfase na utilização da $3^{\mathrm{a}}$ pessoa).

Nesse processo, seus quadros costumavam orientar-se pelo efeito de ficção, aproximando-se, sobretudo, dos protocolos do conto e do retrato, seja de tipos ou de situações. Paralelamente, configuravam-se de tal maneira que tornava não só possível como adequada sua apropriação pelo veículo estadonovista. Esse processo, aparentemente incongruente, de uma participação escrita como linha de fuga, mas que, no entanto, revela-se ajustável às coordenadas traçadas pelo periódico, viabilizava-se mediante a estratégia do autor de trabalhar de maneira inconclusa e alegórica com certos lugares-comuns norteadores da retórica oficial, em

\footnotetext{
${ }^{4}$ Tem-se aqui como base a afirmação de Chartier: “Os textos não existem fora dos suportes materiais (sejam eles quais forem) de que são os veículos. Contra a abstração dos textos, é preciso lembrar que as formas que permitem sua leitura, sua audição ou sua visão participam profundamente da construção de seus significados" (CHARTIER, Roger. “A mediação editorial”. In: Os desafios da escrita. São Paulo: Editora UNESP, 2002, p.61$62)$.
} 
situações ficcionais localizadas no passado. Como, por exemplo, retratar um coronel sertanejo, enquanto personificação da política individualista da Primeira República (tema recorrente ao longo dos “Quadros e costumes do Nordeste”), deixando em aberto se essa figura fora eliminada pelo Estado que se dizia Novo ou se ela continuava atuante na vida local brasileira. Graciliano não responde à questão. Ele apenas a coloca, deixando a resposta ao leitor. A revista, por outro lado, tomando às rédeas do sentido, ajuizava a primeira leitura como a correta, considerando o passado como algo superado. Nesse sentido, segundo a ótica governamental, o texto do autor seria visto como contrapondo para exaltar a suposta novidade do regime de 1937 que, supostamente, teria posto fim aos mandões regionais, em proveito do império do bem coletivo.

Portanto, em Cultura Política, ao imitar a estrutura do conto e do retrato ficcionalizado e não o discurso de referência imediata ao real da crônica, o artista produz um distanciamento, que força o leitor a adentrar no mundo ficcional construído e a desvendar os sentidos codificados pela trama. Apesar de gozar de relativa autonomia, tal universo figurado guardava semelhanças com o universo sócio-cultural do receptor, permitindo-lhe estabelecer correspondências entre um e outro. Logo, tendo em vista as possibilidades de leitura abertas pela narrativa, situada no passado, caberia a este destinatário interpretar, em perspectiva histórica, se o quadro apresentado pelo escritor permanecia inalterado ou fora modificado com o passar do tempo. Obviamente, o enquadramento do texto e o direcionamento do sentido deste, realizados pela aparelhagem paratextual e discursiva da revista, privilegiaram a segunda hipótese, procurando tomá-lo como contraponto para exaltar o novo, inscrito no próprio nome do regime de 1937.

Por outro lado, admitindo-se a continuidade dos problemas atribuídos pelo Estado Novo ao passado liberal, de acordo com a primeira hipótese interpretativa aberta pela ambivalência dos quadros nordestinos, a colaboração do artista seria portadora de uma crítica à ditadura getulista, ressaltando a aparente ineficácia desta na superação das mazelas do país. A vida nacional pouco teria mudado depois da chegada de Getúlio ao poder: os políticos continuaram a advogar em causa própria, os coronéis permaneceram no comando da vida local, o ensino mantivera-se precário, a vida sertaneja, miserável etc. Logo, a manutenção desse mesmo estado de coisas, confirmado pelo próprio transcurso da história brasileira, serviria para reforçar o caráter atual das narrativas do escritor, que desvinculadas de Cultura Política e republicadas em outros suportes, deixariam mais clara tal perspectiva questionadora. Em 
outras palavras, as colaborações de Graciliano, além de vencerem a facticidade (sobretudo, por imitarem a estrutura da ficção), não se restringiriam às coordenadas ideológicas traçadas pelo suporte original em que foram publicadas, o que confirmaria a falta de compromisso estrito do escritor com o ideário getulista.

No entanto, apesar de preverem tal sentido negativo, sobretudo quando se extrapola o momento de enunciação inicial e suprime-se o suporte "Cultura Política", mostra-se completamente insustentável afirmar que Graciliano criticaria o Estado Novo nas páginas da principal publicação oficial. Conforme repisado até o momento, muito pelo contrário, os textos trabalhavam com tópicas estadonovistas e eram organizados retoricamente de tal maneira que permitia o ajuste e adequação dos mesmos às diretrizes do periódico oficial. Este, em perspectiva tutelar, participava de forma direta da construção do sentido dos escritos, fornecendo-lhes toda uma ambiência discursiva estadonovista que lhes dirigia a leitura numa direção favorável ao regime. Essa constatação reforça a eficácia do veículo no enquadramento de uma colaboração equívoca e problemática, distante da ladainha encomiástica da maioria dos demais articulistas.

Quanto à recepção, em grande parte das referências ou abordagens críticas dos "Quadros e costumes do Nordeste”, predomina o procedimento de desvincular os textos do discurso cultural de Cultura Política. Ao mesmo tempo, louva-se a astúcia do escritor, que, sorrateiramente, teria tecido comentários críticos ao regime nas páginas de sua principal publicação. Nesse sentido, o artista não só distanciava-se do enquadramento oficial fornecido pelo periódico como desdizia um a um os postulados estadonovistas. Tais leituras pressupõem que o escritor alagoano, ao invés de dirigir-se ao leitor prefigurado pela publicação getulista, projetaria uma espécie de voz ideal, ajustada à imagem de lisura e correção atribuída ao homem Graciliano Ramos, a qual, por sua vez, teria se amalgamado ao perfil do artista Graciliano Ramos ${ }^{5}$. No entanto, longe de desvincular-se das circunstâncias históricas e

\footnotetext{
${ }^{5}$ No caso da recepção crítica da obra de Graciliano Ramos, é farta a tradição que procura utilizar homem para explicar a obra, com destaque para o estudo Fiç̧ão e confissão (1992), de Antonio Candido, publicado primeiramente em 1955. Em levantamento feito nos anos 1980, Verdi observou que de um total de 177 textos críticos dedicados à produção ou à vida do autor, 63 apresentavam uma visão de conjunto da obra, 30 detinhamse na biografia do escritor, 25 tematizam o livro Vidas Secas e 22 o volume S. Bernardo. Diante dos dados, ele concluiu que o maior objeto de atenção dos estudiosos não seriam os componentes estéticos de cada texto singular, mas os processos criativos genéricos adotados por Graciliano, com predomínio de certa visada impressionista e do interesse pelo anedotário biográfico e pela psicologia do autor alagoano (VERDI, Eunaldo. Graciliano e a crítica literária. Florianópolis: Ed. da UFSC, 1989, p.50-61).
} 
retóricas específicas de sua elocução, os quadros nordestinos, como se verá, revelam-se ajustados, apesar das dissonâncias, à publicação getulista.

Em perspectiva diversa dessa tradição de leitura, como repisado até aqui, o presente trabalho procurará examinar os efeitos (de agregação e desagregação) produzidos pelos "Quadros e costumes do Nordeste” na ambiência jornalística da revista oficial. Paralelamente, levará em conta um dado, até então desconhecido, que colabora ainda mais para ressaltar o caráter polêmico de tais textos: três deles foram republicados, sem modificações, logo depois do fim do Estado Novo, em 1946, no periódico comunista Revista do Povo - Cultura e Organização Popular. O estudo do novo papel desempenhado pelos quadros, ao serem reeditados no órgão de esquerda, servirá para ressaltar as propriedades ambivalentes dos mesmos, ajudando, por fim, a compreender melhor o significado por eles produzido no órgão de direita. Nesse processo não se tem a intenção de condenar ou absolver o artista. Ao invés de buscar justificativas para suas ações, tentar-se-á compreendê-las, levando-se em conta o perfil de suas convicções e o repertório discursivo do momento histórico em questão.

Tendo em vista a realização de tais propósitos, esta pesquisa organizou-se em três partes distintas. Na primeira, procura-se examinar a edição e a recepção das crônicas de Graciliano, bem como a trajetória geral do artista na imprensa. Na segunda, o foco recai sobre o discurso cultural dos anos 1930 e 1940 e, mais especificamente, sobre a mensagem oficial veiculada pela revista getulista Cultura Política. Na terceira, toma corpo a análise dos "Quadros e costumes do Nordeste” e a participação destes escritos nos debates do momento em que foram produzidos.

A Parte I, por sua vez, divide-se em dois capítulos. No primeiro deles, realiza-se uma crítica a edição dos dois livros nos quais foram reunidas, postumamente, as crônicas de Graciliano: as obras Linhas Tortas e Viventes das Alagoas, ambas de 1962. Em seguida, efetua-se uma tentativa de classificação e sistematização do conjunto das produções jornalísticas do artista para, enfim, chegar-se à especificação do objeto da presente pesquisa: os quadros nordestinos publicados pelo escritor alagoano em Cultura Política e depois reeditados no veículo comunista Revista do Povo - Cultura e Organização Popular. Nesse momento, empreende-se ainda o estudo da recepção crítica dos “Quadros e costumes do Nordeste” e situa-se a abordagem que será privilegiada pelo autor da pesquisa nas páginas seguintes. 
No segundo capítulo, com o intuito de se definir melhor o lugar ocupado pelos "Quadros e costumes do Nordeste” no conjunto das produções estampadas por Graciliano em jornais e revistas, examina-se o longo percurso do artista como rabiscador de textos em prosa para imprensa. Parte-se do início de seu trabalho efetivo como cronista - a série “Traços a Esmo”, publicada jornal fluminense Parayba do Sul, em 1915, - e prossegue-se até suas últimas colaborações dirigidas, sobretudo, a periódicos vinculados, oficialmente ou não, ao PCB, no início da década de 1950. Nesse roteiro, é incluída a análise de escritos do artista ainda inéditos em livro, recolhidos ao longo do trabalho de campo efetuado em diferentes arquivos brasileiros. Trata-se de 57 textos, entre eles crônicas, contos, cartas discursos e até o trecho de uma peça de teatro que ajudam a recompor com mais detalhes as relações do autor de Caetés com o jornalismo brasileiro.

Continuando, a Parte II agrupa os capítulos três e quatro. No primeiro destes, procura-se construir um paralelo entre as diretrizes poéticas de Graciliano, presentes em seu metatexto (sobretudo nas crônicas), e certas orientações estadonovistas (encontradas em escritos de Cultura Política; do suplemento “Autores e livros”, publicado semanalmente pelo jornal A Manhã; em discursos presidenciais; e em obras de diferentes ideólogos do regime). Durante tal processo associativo, foram observados alguns pontos de contato entre o discurso graciliânico e o oficial, que, por sua vez, relacionavam-se, de uma maneira geral, com determinados posicionamentos defendidos pelos autores de 1930, principalmente os nordestinos, tais como o questionamento do individualismo e do subjetivismo; destaque para a função social da obra de arte; valorização de uma perspectiva sociológica, focada em dados históricos e econômicos, que preteria outra, considerada apenas literária, e por extensão, artificial; ênfase no tratamento da matéria regional, entre outros pontos.

Já no quarto capítulo, privilegia-se o estudo da configuração, da estruturação e do sentido do discurso oficial veiculado por Cultura Política ao longo de suas diferentes fases. Assim, foram analisados os editoriais, seções e paratextos, interpostos pelos editores da revista a cada volume, que procuravam fixar, interpretar e orientar a leitura das produções de Graciliano e dos demais colaboradores. Nesse movimento, procurou-se estabelecer um paralelo entre a atuação do regime de 1937 e o trabalho realizado pela publicação estadonovista: enquanto o governo caracterizava-se pela centralização do poder político, o veículo destacava-se pela centralização do poder simbólico na medida em que procurava se colocar como um “espelho” 
do Brasil ao tratar das mais variadas áreas e assuntos, além de reunir um corpo diversificado e amplo de articulistas.

Ao longo de tal processo analítico da revista, ganhou destaque o exame do conceito estadonovista de "espírito nacional” (que apresentava as variações de "alma nacional”, “essência nacional”, entre outras), paralelamente ao estudo da concepção de cultura definida pelo regime, a qual se apresentava como um fato social amplo, tutelado pelo governo. A investigação de tais elementos, centrais na articulação da retórica oficial, mostrou-se fundamental para a análise do papel desempenhado pelos textos de Graciliano em Cultura Política, bem como tornou mais evidente a hierarquização e o controle exercidos por esta sob as matérias publicadas.

Por fim, a terceira parte é dividida em três capítulos: os de número cinco, seis e sete. O primeiro deles detém-se na análise geral do microtexto dos “Quadros e costumes do Nordeste, estabelecendo pontes associativas entre estes e o macrotexto da realidade discursiva com qual dialogam. Tal empreendimento inclui, entre outros aspectos, a categorização dos escritos; o exame das estratégias textuais empregadas pelo artista para colaborar sem se comprometer; o estudo dos paratextos introdutórios às colaborações gracilianas, bem como o reenquadramento destas quanto ao gênero; e o efeito de real reivindicado pelos quadros ficcionais.

Como forma de particularizar as hipóteses lançadas no item anterior, o sexto capítulo engloba o exame detido de alguns dos "Quadros e costumes do Nordeste" tidos como mais representativos. Entre eles está o texto da primeira participação de Graciliano na revista, posteriormente intitulado como "Carnaval”; o retrato do coronel de saias D. Maria Amália, personagem apresentada como uma espécie de personificação do mandonismo interiorano; e a narrativa "Uma visita inconveniente”, em que alegoricamente refere-se ao ensino secundário do país.

Por sua vez, no sétimo capítulo, examina-se a produção do companheiro de seção de Graciliano, Marques Rebelo, responsável pela composição dos “Quadros e costumes do Centro e do Sul”. Estes, juntamente com os textos do autor de Vidas Secas sobre a vida nordestina, compunham o mosaico do país pretendido pela abordagem espacial e testemunhal 
da brasilidade, proposta pela revista Cultura Política ${ }^{6}$. Ao contrapô-los, procura-se, por posição e oposição, definir melhor as particularidades do discurso do artista alagoano presentes no periódico. Logo em seguida, prosseguindo com a investigação da especificidade dos “Quadros e costumes do Nordeste”, analisa-se, também de maneira contrastiva, a republicação de três deles, no veículo comunista Revista do Povo Cultura e Orientação Popular. Tal trabalho incluiu o estudo da conformação semântica e dos efeitos produzidos pelos escritos gracilianos em sua nova ambiência editorial, bem como os próprios desdobramentos do transplante das colaborações do órgão de direita para o órgão de esquerda.

Finalmente, anexada em volume a parte, segue uma proposta de edição dos 58 textos de Graciliano Ramos, ainda inéditos em livro, recolhidos em diferentes arquivos brasileiros, ao longo desta pesquisa. Intitulada como “Garranchos”, nome de uma série de crônicas estampadas por Graciliano no jornalzinho $O$ Índio, de Palmeira dos Índios, tal iniciativa pretende colaborar, ainda que modestamente, para a ampliação do corpus de escritos do artista alagoano e com isso fornecer mais subsídios tanto para a recomposição de sua trajetória literária e jornalística, como para melhor fundamentação de determinados elementos concernentes a sua poética.

Além disso, como forma de especificar os vínculos do artista alagoano com a imprensa e solucionar, ainda que parcialmente, certos problemas bibliográficos encontrados em seus livros de crônicas, o apêndice do presente trabalho apresenta os seguintes materiais: lista dos contos e trechos de memórias e romances do escritor, desde Caetés (1933) até Memórias do Cárcere (1953), que foram publicados, primeiramente em jornais e revistas; lista de dados coletados sobre local e data da primeira veiculação em periódico de parte das crônicas de Linhas Tortas e Viventes das Alagoas; e relação com todas as colaborações de Graciliano saídas na imprensa, organizadas cronologicamente.

\footnotetext{
${ }^{6}$ Depois do quinto número da revista (de julho de 1941), como forma de ampliar o espectro de imagem fragmentada da nacionalidade, passam a ser publicados também os “Quadros e costumes do Norte”, sob a responsabilidade do jornalista paraense Raimundo Pinheiro.
} 
PARTE I - Divulgação e recepção dos textos e atrajetória jornalística de Graciliano Ramos 


\section{Capítulo 1 - Graciliano e a edição das crônicas}

\subsection{Críticas às edições de Linhas Tortas e Viventes das Alagoas}

Levando-se em conta as 137 crônicas de Graciliano Ramos coligidas nas obras póstumas Linhas Tortas e Viventes das Alagoas, 99 na primeira e 38 na segunda, e outros 58 textos do escritor ainda inéditos em livro, identificados e reunidos pela presente pesquisa, e mais quatro já inclusos em diferentes volumes ${ }^{7}$, a produção do artista alagoano, publicada primeiramente na imprensa, mas que não foi recolhida por ele próprio em suporte livresco, totaliza 198 escritos.

A organização e a categorização de tal conjunto amplo de escritos esbarrava, inicialmente em dois problemas, relacionados, sobretudo, às edições falhas e lacunosas, que se perpetuaram em sucessivas reedições, das duas obras supracitadas. Além de não agruparem um número considerável de textos do autor, que permanece desconhecido do grande público, à espera de uma edição em livro, ambos os volumes não fornecem informações bibliográficas fundamentais, como data e local da primeira publicação em periódico da grande maioria das narrativas que agrupam. A ausência de tais dados impossibilita a recomposição exata do percurso cronístico do escritor e, conseqüentemente, o estudo aprofundado de seus textos, pois os recupera de maneira abstrata, desconsiderando a mediação editorial exercida pelo suporte jornalístico, quando da veiculação inicial dos escritos.

Nesse sentido, antes de entrar especificamente na análise e na categorização das crônicas aludidas acima, convém apresentar uma breve crítica às edições tanto de Linhas Tortas quanto de Viventes das Alagoas, bem como descrever, ainda que rapidamente, o trabalho de localização dos textos desconhecidos do escritor.

Em 1953, a Livraria Editora José Olympio publicou o então mais completo conjunto das obras de Graciliano Ramos, em dez volumes. Em tal trabalho, relançava-se alguns livros, já

\footnotetext{
${ }^{7}$ Faz-se referência aqui aos livros Graciliano Ramos (1987), organizado por Alfredo Bosi, Valentim Facioli e José Carlos Garbuglio; 10 romancistas falam de seus personagens (1946), editado por João Condé; e ao volume 46 do Boletim Bibliográfico da Biblioteca Mário de Andrade (1985). A especificação dos textos de Graciliano, veiculados primeiramente na imprensa, e depois reunidos em tais obras pode ser encontrada entre os anexos.
} 
então consagrados em diversas edições isoladas, tais como Caetés $^{8}$, S. Bernardo ${ }^{9}$, Angústia $^{10}$, Vidas Secas ${ }^{11}$, Infância ${ }^{12}$, Insônia ${ }^{13}$ e editava-se pela primeira vez Memórias do Cárcere (em quatro volumes) ${ }^{14}$. Dois anos depois, tal conjunto era novamente relançado e a ele era acrescida a segunda edição de Viagem ${ }^{15}$.

Depois de adquirir os direitos autorais do escritor, em março de 1960, a Livraria Martins Editora, de São Paulo, projetou a reedição de sua obra completa conhecida até então, acrescentando a ela quatro volumes póstumos, que saíram em 1962, juntamente com os demais títulos da coleção: Linhas Tortas (crônicas), Viventes das Alagoas (crônicas), Alexandre e outros Heróis (literatura infanto-juvenil) e Cartas (compilação da correspondência pessoal de Graciliano).

Segundo relato de Ricardo Ramos, a transferência dos direitos de publicação das obras de Graciliano para a editora paulista deveu-se ao descaso da José Olympio para com a obra de seu pai. As vendas cresciam ao mesmo tempo em que a obra do autor alagoano era deixada de lado no planejamento anual da editora:

Suportamos aquela situação mais do devíamos, por crédulos e confiantes, habituados à amizade, às relações pessoais, afinal José Olympio lançara o Angústia com o autor na cadeia [...] A Casa, a partir de 1955, mudara de rumo. Apegara-se às figuras públicas, adiara os escritores que investira. Demoramos a entender, no entanto percebemos ${ }^{16}$.

\footnotetext{
${ }^{8} 1$ ed. Rio de Janeiro: Schmidt Editor, 1933; 2 ed. Rio de Janeiro: Livraria José Olympio Editora, 1947 ; e 3 ed. Rio de Janeiro: Livraria José Olympio Editora, 1952.

9 ed. Rio de Janeiro: Ariel Editora LTDA, 1934; 2 ed. Rio e Janeiro: Livraria José Olympio Editora, 1938. 3 ed. Rio de Janeiro: Livraria José Olympio Editora, 1947; 4 ed. Rio de Janeiro: Livraria José Olympio Editora, 1952.

101 ed. Rio de Janeiro: Livraria José Olympio Editora, 1936; 2 ed. Rio de Janeiro: Livraria José Olympio Editora, 1941; 3 ed. Rio de Janeiro: Livraria José Olympio Editora, 1947; 4 ed. Rio de Janeiro: Livraria José Olympio Editora, 1949; e 5 ed. Rio de Janeiro: Livraria José Olympio Editora, 1952.

111 ed. Rio de Janeiro: Livraria José Olympio Editora, 1938; 2 ed. Rio de Janeiro: Livraria José Olympio Editora, 1947; e 3 ed. Rio de Janeiro: Livraria José Olympio Editora, 1952.

121 ed. Rio de Janeiro: Livraria José Olympio Editora, 1945; e 2 ed. Rio de Janeiro: Livraria José Olympio Editora, 1952.

131 ed. Rio de Janeiro: Livraria José Olympio Editora, 1947; e 2 ed. Rio de Janeiro: Livraria José Olympio Editora, 1952.

${ }^{14}$ Ficavam de fora de tal edição conjunta, realizada pela José Olympio, A terra dos meninos pelados, publicado em 1939 pela Livraria do Globo, de Porto Alegre, e Histórias de Alexandre, saído em 1944 pela Editora Leitura, do Rio de Janeiro.

151 ed. Rio de Janeiro: Livraria José Olympio Editora, 1954.

${ }^{16}$ RAMOS, Ricardo. Retrato Fragmentado. São Paulo: Siciliano, 1992, p.209-210.
} 
Nesse momento, a família foi a Martins, a mesma editora que então publicava os romances de Jorge Amado e que em 1945 havia feito uma proposta vantajosa ao próprio Graciliano ${ }^{17}$, e firmou um contrato para a reedição de toda a obra do autor, “com uma tiragem mínima prevista de dez mil exemplares para cada título”"18. A partir daí, começaram a ser realizadas edições prefaciadas e ilustradas, atendendo, sobretudo, à demanda escolar. "Em pouco, Vidas Secas vendia 300 mil exemplares num ano. E os demais livros seguiam o padrão com desenvoltura"19.

No entanto, os volumes reeditados e amplamente divulgados e distribuídos apresentavam uma série de erros que comprometiam o texto do escritor, como atesta sua filha Clara Ramos:

\begin{abstract}
A partir dos anos 60 são despejados no mercado livreiro milhares de volumes destinados a satisfazer a demanda da faculdade. A faculdade arranca os cabelos no esforço de decifrá-los: a adulteração maciça do texto, não se restringindo aos pastéis tipográficos fáceis de identificar, capricha na dança surrealista das palavras, suprime, sádica, períodos inteiros; desloca os blocos de composição daqui para acolá, um final de capítulo debanda de seu lugar, vai se apertar no meio do capítulo seguinte ${ }^{20}$.
\end{abstract}

É nesse contexto de atendimento à larga demanda pela obra de Graciliano por meio de um trabalho editorial pouco cuidadoso, que a Martins lança os outros quatro livros supracitados; entre eles, Linhas Tortas e Viventes das Alagoas. A exemplo destes, as demais publicações póstumas, foram editadas por Heloísa Ramos, mulher do literato, juntamente com seu filho, Ricardo Ramos, e com seu genro, James Amado. Em entrevista concedida ao jornal Flan, em 29 de outubro de 1953, Ricardo destaca que a família teria contado ainda com a colaboração de alguns amigos, entre eles Aurélio Buarque de Holanda, Orígenes Lessa e Valdemar Cavalcanti.

Em 1975, em virtude, principalmente, do enxugamento do mercado para o livro literário no Brasil, a Martins enfrenta uma série de dificuldades financeiras que culminam no

${ }^{17}$ Como destaca Clara Ramos, José de Barros Martins propunha, em carta enviada ao escritor, tiragens numeradas de três mil exemplares para as reedições, de quatro mil para livros novos e o pagamento de direitos autorais, na base de $10 \%$ sobre o preço de capa de cada edição, da forma que melhor conviesse ao artista. Graciliano, mantendo-se fiel a José Olympio, recusa a oferta. (Ver: RAMOS, Clara. Mestre Graciliano confirmação humana de uma obra. Rio de Janeiro: Civilização Brasileira, 1979, p.263). As relações do autor alagoano com o editor paulista eram anteriores a tal proposta. Em 1942, em parceria com Jorge Amado, José Lins do Rego, Aníbal Machado e Rachel de Queiroz ele publica, pela Martins, o romance Brandão Entre o Mar e o Amor.

${ }^{18}$ Idem, p.264.

${ }^{19}$ RAMOS, Ricardo. op.cit. p.210.

${ }^{20}$ RAMOS, Clara. op.cit, p.264. 
encerramento de suas atividades e na rescisão do contrato firmado com a família do escritor. Antes disso, depois de pedir concordata, a editora paulista passa a publicar os livros de Graciliano em regime de co-edição com a Distribuidora Record S.A, do Rio de Janeiro, que, após a completa desativação da parceira, em contrato assinado com a família do romancista em $1^{0}$ de outubro de 1976, passa a ter o direito exclusivo de publicação das obras completas deste $^{21}$. Tal situação se mantém até o presente momento.

Linhas Tortas, que atualmente se encontra na $21^{\text {a }}$ edição, publicada em 2005, apresenta um caráter muito mais documental do que seletivo, propondo-se a abarcar o amplo período da produção do autor, que se estende de 1915 a 1952. O título da obra alude à suposta precariedade dos escritos que agrupa, retomando certa estratégia retórica conhecida como inania verba (palavras fúteis), recorrentemente utilizada na conceituação do gênero crônica. Em linhas gerais, ela prevê o rebaixamento desses textos jornalísticos (referidos como frivolidades sem maiores compromissos) e do próprio mister de cronista como meio de tornálos, em sentido contrário, ainda mais persuasivos. A suposta humildade reivindicada por tal procedimento ajudaria a dignificar a condição daqueles que escrevem “ao correr da pena”, bem como ampliaria as possibilidades de obtenção da benevolência do leitor, corroborando o êxito no intento comunicativo proposto. Graciliano, portanto, não se furta a essa tradição. O nome "Linhas Tortas” remete às noções de imprecisão, descaso e inferioridade, que se repetem nos títulos das seções "Garranchos”22, "Traços a esmo”23 e, novamente, "Linhas Tortas”24, comandadas pelo romancista ao longo de sua trajetória inicial como rabiscador de textos em prosa para a imprensa.

O volume se divide em duas partes. A primeira delas é composta por 28 textos, reunindo parte do trabalho cronístico inicial do autor, restrito ainda a jornais de circulação regional, e subdivide-se, por sua vez, em duas seções: “Linhas Tortas” e “Traços a Esmo”. A primeira delas agruparia crônicas escritas no ano de 1915, sob o pseudônimo R.O., para o Jornal de Alagoas de Maceió e para o Parayba do Sul, da cidade fluminense com o mesmo nome. No entanto, não é bem isso que acontece. A crônica que abre o livro, “A constituição da república tem um buraco...”, aparece como tendo sido publicada no Jornal de Alagoas, em março de

\footnotetext{
${ }^{21}$ BUMIGH, Nádia Regina. S. Bernanrdo de Graciliano Ramos: proposta para uma Edição Crítica. 1998. 341 f. Dissertação (Mestrado em Letras) - Faculdade de Filosofia Letras e Ciências Humanas, São Paulo.

${ }^{22}$ Nome de seção presente no jornal $O$ Índio, de Palmeira dos Índios, entre janeiro e maio de 1921.

${ }^{23}$ Título de seção encontrada tanto em $O$ Índio, no primeiro semestre de 1921, como no jornal fluminense Parayba do Sul, entre abril e agosto de 1915.

${ }^{24}$ Presente no Jornal de Alagoas, da capital Maceió, entre março e maio de 1915.
} 
1915, mas, na verdade, saiu, primeiramente, seis anos depois em O Índio, em abril de 1921. Além disso, o próprio nome da seção, “Linhas Tortas”, revela-se equivocado para designá-la, uma vez que 13 textos dos 16 que a compõem foram publicados no semanário Parayba do Sul, sob o título “Traços a Esmo”. Apenas quatro desses, foram estampados no Jornal de Alagoas, no ano de 1915, sob a rubrica "Linhas Tortas"25.

Outra incoerência, observada nesta primeira seção da primeira parte da obra, encontra-se no fato de as crônicas publicadas no citado jornal fluminense, Parayba do Sul, e assinadas com as iniciais R.O. do sobrenome do escritor, formam uma unidade à parte dentro dela. E, portanto, deveriam ser apresentadas como tal, de maneira semelhante à observada na segunda unidade dessa primeira parte, em que o editor agrupa apenas os textos redigidos sob o pseudônimo de J. Calisto, de uma nova série também nomeada como “Traços a Esmo", redigida para O Índio, de Palmeira dos Índios, em 1921. Nota-se, assim, que o critério oscila o que pode gerar equívocos interpretativos.

Essa segunda seção da primeira metade do livro, chamada “Traços a Esmo”, possui também alguns problemas. A seqüência de 12 textos que ela reúne não guarda a mesma ordem em que foi publicada em $O$ Índio. As crônicas II e VIII do pequeno jornal aparecem, respectivamente, como a quarta e a sexta crônica na ordem proposta pelo livro. Além disso, o texto IX está datado de abril, quando na verdade é de 27 de março de 1921. Vale ressaltar, porém, que originalmente Graciliano, sob o pseudônimo de J. Calisto, escreveu não 12, mas 14 crônicas para o semanário palmeirense. Das duas faltantes no livro Linhas Tortas, a XIII, conforme exposto acima, é aquela que abre equivocadamente o livro, sendo datada de 24 de abril de 1921; a XIV, de $1^{\circ}$ de maio de 1921, permanece desconhecida da maioria de seus leitores. Na verdade, uma versão modificada desta, foi publicada pelo escritor alagoano na revista Cultura Política, em agosto de 1941, e depois recolhida em Viventes das Alagoas ${ }^{26}$.

A segunda parte de Linhas Tortas não apresenta divisões e reuniria, a princípio, crônicas publicadas na imprensa carioca, durante a segunda permanência do escritor no Rio de Janeiro,

\footnotetext{
${ }^{25}$ AZEVEDO, Vivice. Apports inédits à l'oeuvre de Graciliano Ramos. In: Graciliano Ramos: Vidas Secas (séminaires de février et juin 1971). Poitiers: Centre de Recherches Latino-Américaines, da Universidade de Poitiers. 1977, p.138. Faz-se referência, aqui, aos seguintes textos, saídos no Jornal de Alagoas: "Linhas Tortas I”, de 18 mar. 1915; "Linhas Tortas II", de 20 mar. 1915; "Linhas Tortas IV”, 25 abr. 1915; e "Linhas Tortas V, de 7 maio 1915”.

${ }^{26}$ Trata-se do texto "Traços a esmo XIV", publicado com algumas modificações em Cultura Política, em agosto de 1941, com a designação de "Quadros e costumes do Nordeste VI" e depois recolhido em Viventes das Alagoas com o título "Habitação".
} 
depois de ele ter saído da prisão em janeiro 1937. Tais narrativas seriam assinadas com o nome pelo qual Graciliano se tornou literariamente conhecido. Na verdade, o texto que abre esta unidade, “Álvaro Paes”, revela o contrário. Foi publicado em 12 de junho de 1930 no Jornal de Alagoas, sob as siglas G.R. O mesmo se pode dizer da crônica "Milagres” que, mesmo com a rubrica “Graciliano Ramos”, saiu primeiramente na revista alagoana Novidade, em 11 de julho de 1931, e não em periódicos da então capital federal.

Até a $20^{\text {a }}$ edição do livro, nenhuma das narrativas trazia a indicação do veículo em que foi estampada e apenas uma minoria apresentava as datas da primeira publicação ${ }^{27}$, o que resulta num grande problema, pois o volume aparenta ter sido organizado seguindo uma ordem cronológica. Com a $21^{\circ}$ edição, supervisionada por Wander Melo Miranda, professor de Teoria da Literatura da Universidade Federal de Minas Gerais, que prometia rever alguns equívocos, a situação pouco mudou: apenas quatro das 71 crônicas da segunda parte do livro foram rigorosamente localizadas e datadas. São elas: “Jibóias”, “O Sr, Krause”, “Atribulações de Papai Noel” e “Um homem forte”.

Viventes das Alagoas, atualmente na 18 ${ }^{\mathrm{a}}$, saída em 2007 é uma grande miscelânea de textos de temática sertaneja, escritos, sobretudo, após a saída de Graciliano da prisão e de sua posterior fixação no Rio de Janeiro em $1937^{28}$. Originariamente, a obra reunia 36 crônicas. A partir da $15^{a}$ edição da Record, em 1992, foram acrescidas outras duas até então inéditas em livro: “Comandantes de Burros” e “Antônio Silvino”. Além dos textos jornalísticos, o volume contém ainda dois relatórios enviados por Graciliano ao governador do Estado de Alagoas nos anos de 1929 e 1930, quando o escritor era então prefeito da cidade de Palmeira dos Índios.

O título da obra indica o predomínio da descrição de figuras humanas, mas também sugere certa brutalização e animalização destas já que o termo “vivente” pode se referir a qualquer criatura viva e não a um indivíduo específico. Já o topônimo “Alagoas” localiza e restringe a

\footnotetext{
${ }^{27}$ A orelha da primeira edição de Linhas Tortas realizada pela Martins apresenta uma justificativa questionável para tais omissões. Segundo o texto o problema seria dos originais: "Sempre que foi possível localizar data e publicação, nós as transcrevemos - como também o fizemos em relação aos pseudônimos, abreviaturas ou iniciais, utilizados pelo autor. Os trabalhos que aparecem sem essas indicações, uns poucos, são os arrolados entre os originais, onde não existem informações precisas". Contudo, por meio da pesquisa em recortes de jornais, muitas lacunas poderiam ser esclarecidas.

${ }^{28}$ Pelo que se sabe, o livro reúne apenas três textos que são exceções a essa regra: "Lampião", escrito inicialmente para a revista alagoana Novidade; "Comandante dos Burros" e "D. Maria Amália" publicados no Jornal de Alagoas. Esta última crônica, no entanto, foi reaproveitada por Graciliano e relançada na revista Cultura Política em abril de 1941.
} 
origem dos seres representados. Na verdade, Graciliano não se limitou a seu estado de origem, como se poderia pensar a princípio; ele não se pautava por uma suposta correspondência geográfica entre a paisagem e os espaços ficcionalizados. Muitas das cidades e propriedades rurais apresentadas nas crônicas são designadas de maneira vaga como “espaços sertanejos”. Além disso, há textos que fazem referência a outras localidades como Pernambuco e Paraíba. Entretanto, o subtítulo do livro - “Quadros e Costumes do Nordeste” -, retirado da seção de mesmo nome da revista Cultura Política, amplia tanto o espaço como o assunto das crônicas. Estas tratariam não só de personagens, mas de práticas, situações e particularidades encontradas em toda a região nordestina.

Ao contrário de Linhas Tortas, volume organizado cronologicamente e dividido em seções que agrupam diferentes fases da produção do escritor, Viventes das Alagoas apenas reúne textos variados que se assemelham do ponto de vista temático sem nenhuma ordem aparente. Dessa maneira, o arranjo deles no livro não apresenta qualquer separação que leve em conta períodos e lugares de publicação distintos. Mesmo as crônicas de Cultura Política, que compõem a maioria da obra, não são apresentadas como um conjunto diferenciado (não se respeita a ordem de publicação dos textos na revista). Repete-se, portanto, uma falha já apontada na primeira parte do livro anteriormente analisado ${ }^{29}$. Em Viventes ocorre também a amplificação do problema de falta de exatidão bibliográfica de Linhas Tortas: em todas as crônicas são negligenciadas as datas e locais da primeira divulgação em periódico.

A última edição do livro (a 19a lançada pela Record em 2007), que também fez parte do mesmo projeto de reedição das obras do autor, supervisionado por Wander de Mello Miranda, procurou solucionar tais lacunas, mas as deficiências continuaram. A começar pela própria "Nota do editor” em que se afirma: "Esta nova edição de Viventes das Alagoas teve como

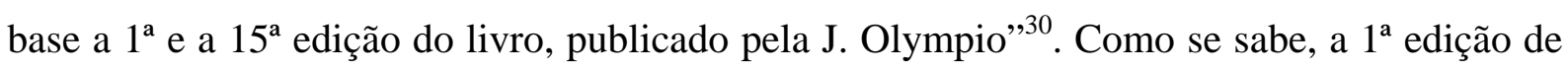
tal volume foi lançada em 1962 pela Martins, sem a participação da José Olympio. Além disso, foram recuperadas informações bibliográficas da primeira publicação em periódico dos textos de Cultura Política e de mais oito crônicas saídas em jornais cariocas e alagoanos, o que manteve o restante dos escritos sem a especificação dos locais e datas da veiculação

\footnotetext{
${ }^{29}$ Dos 38 textos que compõem o livro, 22 foram escritos originariamente para essa revista. Destes, 18 fizeram parte da seção do periódico chamada "Quadros e Costumes do Nordeste", três da seção "Quadros e Costumes Regionais” e um da seção nomeada apenas como "Quadros Regionais”. Vale salientar que Viventes das Alagoas não reúne toda a colaboração de Graciliano em Cultura Política. As crônicas "Booker Washington” e "A viúva Lacerda" foram publicadas em Linhas Tortas. O texto "Uma visita inconveniente" continua inédito em livro.

${ }^{30}$ NOTA do editor. In: RAMOS, Graciliano. Viventes das Alagoas. Rio de Janeiro: Record, 2007, p.5.
} 
inicial na imprensa. E mesmo entre tais colaborações identificadas há problemas. Diferentemente do que estabelece o editor, a crônica “Carnaval 1910”, que abre o volume, saíra na revista carioca O Cruzeiro, em fevereiro de 1942 e não no número inaugural de Cultura Política, em março de 1941. Na verdade, a narrativa que fora estampada na estréia da revista getulista chamava-se apenas “Carnaval”, o terceiro texto na seqüência da obra ${ }^{31}$.

Numa rápida comparação entre as versões das crônicas publicadas em Cultura Política e posteriormente reunidas no livro, observa-se algumas diferenças importantes em dois textos. “Quadros e costumes do Nordeste II” (“D. Maria Amália”), estampado no periódico estadonovista em abril de 1941, apresenta diferenças lexicais, acréscimos, cortes e um final todo modificado da sua correspondente em Viventes das Alagoas. Problema maior, contudo, é observado com a crônica "Carnaval”, que abre a série “Quadros e Costumes do Nordeste”. Cotejando as versões, foi observado que o segundo e terceiro parágrafos, encontrados a partir da segunda edição da obra, não constam nem na revista, nem na primeira edição do livro. Neste caso, parece que o texto-base do editor teria sido o manuscrito, como se pode constar conferindo-o no Arquivo Graciliano Ramos no $\mathrm{IEB}^{32}$. No entanto, no caso de "D. Maria Amália”, o mesmo editor se valeu de uma versão édita do texto, mais antiga, publicada, primeiramente, no Jornal de Alagoas em 18 de junho de 1933. Portanto, o critério varia o que pode levar a equívocos e imprecisões.

\subsection{Identificação e solução parcial dos problemas apontados}

Por meio de leituras da bibliografia referente ao escritor e do trabalho de campo realizado em acervos e bibliotecas paulistas e cariocas, notadamente o Centro de Documentação e Memória (CEDEM/ UNESP), o Arquivo Edgar Leuenroth (IFCH/UNICAMP), a Biblioteca do Instituto de Estudos Brasileiros e o Arquivo Graciliano Ramos (IEB/USP), em São Paulo, o Arquivo Público do Estado do Rio de Janeiro (APERJ) e a Biblioteca Nacional, na capital fluminense, parte dos problemas de ambos os volumes, arrolados acima, foi identificada ou solucionada.

\footnotetext{
${ }^{31}$ Outro ponto: o editor oferece apenas datas e locais de publicação póstuma dos textos "O fator econômico do cangaço", “Cabeças” e "Dois cangaços”, em 1953, no Diário de Notícias, quando na verdade, sabe-se que os dois primeiros foram estampados, primeira e respectivamente no Observador Econômico e Financeiro e no Diário de Notícias, em outubro de1938.

${ }^{32}$ RAMOS, Graciliano. O carnaval no interior. Manuscrito autógrafo. São Paulo: série manuscritos, título "Viventes das Alagoas", cota 9, pasta 1, Arquivo Graciliano Ramos, Instituto de Estudos Brasileiro, 31 jan. 1941.
} 
Além de aclarar as imprecisões editoriais da primeira parte de Linhas Tortas, foi possível encontrar a data e local da primeira publicação em periódico de 47 das 71 crônicas que compõem a segunda metade do livro. Dos 38 textos que constituem Viventes das Alagoas, foram localizadas informações bibliográficas de 33 delas. Apenas cinco não foram identificadas.

Nesse mesmo trabalho, como já fora apontado, localizou-se 58 textos do romancista alagoano ainda inéditos em livro. Em anexo, segue uma proposta de edição e organização de todo esse conjunto de produções. Tal trabalho incluiu a transcrição, o cotejo e a revisão de cada um desses escritos deixados de fora das obras completas de Graciliano e recolhidos ao longo das pesquisas de campo.

A maior parte de tais textos, desconhecidos do grande público e até mesmo dos estudiosos da obra do autor, foi publicada, com intervalos, no amplo período que vai de 1909 a 1935, em jornais e revistas alagoanas. O destaque maior fica para o semanário $O$ Índio, com 18 textos ${ }^{33}$, em que há toda uma série de 14 crônicas, chamada “Garranchos”, assinada por Graciliano com o pseudônimo " $\mathrm{X}$ ”34. Logo em seguida, aparece o Jornal de Alagoas, com 15 textos, concentrados ou na década de 1910 ou na de 1930. Há ainda um texto de 1911, estampado no Correio de Maceió, dois de 1931, saídos na revista alagoana Novidade, e mais um de 1935, redigido para a revista A Escola, de Maceió.

O restante, cerca de 20 textos, foi publicado, principalmente, depois de 1937, quando o artista estabelece residência definitiva no Rio de Janeiro ${ }^{35}$, em periódicos de diferentes estados, sobretudo revistas literárias e periódicos de orientação comunista, localizados na capital carioca. Nas páginas destes últimos, entre 1946 e 1952, foram estampados dez textos os quais só puderam ser recuperados mediante a consulta aos documentos da polícia política getulista, o chamado arquivo do Departamento de Ordem Política e Social (DOPS), sob a guarda do APERJ. Estes tornaram possível reconstituir parte do itinerário stalinista do escritor, com

\footnotetext{
${ }^{33}$ Tal número pode ser ampliado, tendo em vista que a colaboração do escritor para o pequeno jornal palmeirense foi realizada, na sua grande maioria, sem assinatura (ou com pseudônimos desconhecidos) e de maneira sistemática nas suas 14 primeiras edições, como atesta o próprio Graciliano em carta ao amigo Pinto de Mota Lima, em 4 de agosto de 1921 (Ver RAMOS, Graciliano. Cartas. Rio de Janeiro: Record: 1981, p.71). Mesmo sem a expressão clara da autoria, por meio de uma análise estilística e temática, seria possível identificar textos passíveis de serem atribuídos ao escritor alagoano.

${ }^{34} \mathrm{~A}$ correspondência entre tal pseudônimo e Graciliano encontra-se em GAMA, Maria Lúcia Palma. Projeto para Inéditos. Revista do Instituto de Estudos Brasileiros, São Paulo, n.35, 1993, p.201.

${ }^{35}$ Trata-se do período posterior a saída de Graciliano do cárcere, em janeiro de 1937.
} 
ênfase no período que vai de seu ingresso no Partido Comunista do Brasil (PCB), em 1945, até sua morte, em março de 1953.

Mais especificamente, em meio a essa vintena de textos, estão presentes crônicas, artigos, cartas, discursos e o trecho inicial de uma peça de teatro intitulada "Idéias Novas", estampada na Revista do Brasil, em julho de 1942. Em particular, tal escrito mostra-se relevante tanto para a obra do autor, pois pouco se sabia de sua incursão no gênero dramático ${ }^{36}$, quanto para a presente pesquisa, sobretudo se se considerar a afinidade temática entre a peça propriamente dita e as crônicas privilegiadas nesta análise, bem como o momento em que ela foi produzida. Além de ser ambientada no interior de Alagoas, destacando cenas de uma família sertaneja, foi redigida durante o período em que o autor de Vidas Secas era colaborador mensal de Cultura Política.

Paralelamente ao referido trabalho de pesquisa, concentrado na solução de problemas editoriais encontrados nos livros póstumos Linhas Tortas e Viventes das Alagoas e na localização e organização de textos gracilianos desconhecidos do grande público, foram catalogadas referências à publicação primeira na imprensa de contos e capítulos de romances que vieram a fazer parte das obras ficcionais e memorialísticas do escritor. São 89 notações que se estendem desde a veiculação de trechos de Caetés em jornais e revistas cariocas e nordestinos, entre 1933 e 1934, até a divulgação de páginas de Memórias do Cárcere, desde 1948 até depois de sua morte, sobretudo em folhas comunistas. Dessa maneira, torna-se possível acompanhar, de uma maneira mais completa, a carreira de Graciliano Ramos como produtor de textos para jornal e sua inserção nos meios jornalísticos e intelectuais ${ }^{37}$.

\subsection{Tentativa de sistematização das crônicas}

Tendo em vista a solução parcial das dificuldades encontradas com as edições de Linhas Tortas e Viventes das Alagoas e a ampliação do corpus de escritos do literato, pode-se dizer, em linhas gerais, que a produção cronística de Graciliano Ramos divide-se em três pólos

\footnotetext{
${ }^{36}$ Graciliano refere-se à composição de uma peça teatral, de passagem e sem entusiasmo, numa carta endereçada à mulher, em março de 1937. "Ontem insistiu comigo [a atriz Eugênia Álvaro Moreyra] para que escrevesse um drama ou comédia. Como não conheço técnicas de teatro, emprestou-me um livro, Teatro Social NorteAmericano, e disse que até maio eu lhe devia entregar a peça, o que não acontecerá” (RAMOS, Graciliano. Cartas. Rio de Janeiro: Record, 1981, p.183).

${ }^{37}$ A lista com tais referências também se encontra entre os anexos.
} 
temáticos principais, que, por sua vez, subdividem-se de acordo com condições específicas de produção, veiculação e recepção dos textos:

1) Textos que tratam da representação de alguns tipos e de certas práticas sociais, culturais e políticas nordestinas, traduzindo em discurso ficcional suas supostas vivências tanto no interior sertanejo, como na capital do Estado, Maceió. Esta categoria, por sua vez, subdividese em outras três, levando em conta diferentes circunstâncias de elaboração e publicação dos textos:

- Crônicas juvenis escritas entre 1909 e 1913 para veículos da capital alagoana notadamente, o Jornal de Alagoas e o Correio de Maceió - e toda produção do autor publicada nas quatorze primeiras edições do semanário palmeirense $O$ Índio, que começou a circular a partir de janeiro de 1921. Nesses dois momentos, Graciliano encontrava-se no interior alagoano e assinava seus textos com diferentes pseudônimos.

- Crônicas redigidas entre 1930 e 1933 para o Jornal de Alagoas e para a revista literária Novidade, quando o escritor residia em Maceió. A autoria dos textos publicados em 1930 ainda se encontra camuflada por pseudônimos, mas aqueles que vieram a público a partir de 1931 já são assinados com nome por meio do qual Graciliano ficou literariamente conhecido.

- Textos sobre a vida nordestina, publicados em Cultura Política: revista mensal de estudos brasileiros, entre 1941 e 1944. Em tal veículo estadonovista, suas narrativas foram estampadas, inicialmente, na seção “Quadros e costumes do Nordeste”, que depois seria renomeada como “Quadros e costumes Regionais” e, em seguida abreviada para “Quadros regionais” ${ }^{\text {38 }}$. Quem as assinava era a própria persona literária Graciliano Ramos. Como se verá ainda, três escritos desse conjunto foram republicados, alguns anos depois, no periódico comunista Revista do Povo - Cultura e Organização Popular, ao longo do ano de 1947.

\footnotetext{
${ }^{38}$ A partir do $19^{\circ}$ número de Cultura Política, os "Quadros e costumes do Nordeste” passaram a ser chamados de “Quadros e costumes regionais”. Depois da $25^{a}$ edição, reduziram-se a "Quadros regionais”. Tal processo de abreviatura do nome da seção pode ser tomado como índice da decadência do periódico, que, com o passar do tempo, vai perdendo a força e amplitude dos volumes inaugurais. Pode-se fazer, aqui, uma analogia entre a nova designação da seção e o encurtamento do nome do personagem Luís da Silva, de Angústia, cujo o avô, em escala descendente, chamava-se Trajano Pereira de Aquino Cavalcante e Silva e o pai Camilo Pereira da Silva (RAMOS, Graciliano. Angústia. 6 ed. Rio de Janeiro: Livraria Editora José Olympio, 1953, p.10).
} 
2) Textos que abordam diferentes aspectos do discurso cultural e artístico do país, que tinha seu epicentro no Rio de Janeiro, então capital federal. Graciliano participa desse diálogo cosmopolita e nacional, dedicando-se, sobretudo, ao tratamento de uma prática social específica: a literatura e a vida literária. Isso não quer dizer que aborde outras manifestações culturais ou tematize, vez por outra, certos elementos, usos, costumes e tipos do cotidiano carioca. Tal categoria subdivide-se em outros duas, em virtude também de distintas condições de produção e circulação dos textos a que se referem:

- Crônicas provincianas, escritas durante sua primeira permanência no Rio de Janeiro entre 1914 e 1915, antes da publicação de seus primeiros romances. Trata-se do conjunto de textos do autor veiculado pelo jornal Parayba do Sul, da cidade fluminense com o mesmo nome, sob a rubrica “Traços a Esmo”.

- Crônicas escritas entre 1934 e 1935, quando o escritor ainda vivia em Maceió, e entre 1937 e $1953^{39}$, período que se refere a sua segunda permanência no Rio de Janeiro, o qual se estende de sua saída da prisão até o ano de sua morte. Os textos reunidos nesse largo espaço de tempo representam a parte mais volumosa da produção do autor, destinada a diferentes publicações pernambucanas, mineiras e, sobretudo, cariocas, as quais possuíam uma maior projeção e destaque. A partir de 1934, com a publicação de seus dois primeiros romances - Caetés e S. Bernardo - Graciliano vai consolidando um perfil cultural e artístico bem definido e assina suas produções com o mesmo nome que está estampado na capa de seus romances.

3) Narrativas que tematizam figuras, aspectos e propostas associadas ao PCB, a partir de 1945, quando o escritor alagoano filia-se a tal entidade e escreve textos destinados, sobretudo, a publicações ligadas a ela.

Ao longo da trajetória de Graciliano como cronista, observa-se que na medida em que ele vai construindo e consolidando a imagem de grande literato nos meios intelectuais, não só deixa de lado o uso de pseudônimos, assinando os textos com o mesmo nome estampado na capa de Caetés, como toda a sua produção jornalística muda de orientação. O escritor deixa de lado o estilo debochado e sarcástico de seus primeiros narradores (R.O. e, principalmente, J. Calisto), sem, contudo, abdicar da ironia, para adotar uma postura mais séria, condizente com

\footnotetext{
${ }^{39}$ Com exceção da série de textos para Cultura Política, discriminada no item anterior.
} 
seu status de romancista celebrado pela crítica: gradualmente, o cronista subordina seu discurso aos parâmetros fornecidos pela entidade cultural chamada Graciliano Ramos. Dessa maneira, paralelamente à apresentação e à organização das crônicas faz-se necessária a observação do percurso do romancista, tendo em vista o intercâmbio entre as duas atividades.

Tais alterações na postura do cronista Graciliano podem ser observadas tanto nos textos de Cultura Política, nos quais ele aborda temas sertanejos, quanto em suas demais colaborações centradas no universo literário carioca, que ganham atenção especial, sobretudo, após sua saída da prisão. A crônica recorrentemente distancia-se das características associadas ao gênero desde o século XIX ${ }^{40}$ para se aproximar dos protocolos do artigo, do ensaio e também do conto.

Numa explicação de cunho predominantemente biográfico, Brito Broca, em prefácio à $17^{\mathrm{a}}$ edição de Linhas Tortas ${ }^{41}$, ressalta que, sobretudo, após a saída de Graciliano da prisão, em 1937, “o ficcionista teria absorvido o cronista”. Segundo ele, esta seria a razão da evolução pouco sensível entre os textos jornalísticos da segunda permanência do escritor no Rio de Janeiro e a colaboração deste, encoberta pelo pseudônimo J. Calisto, em $O$ Índio. "Na ficção ele concentraria toda sua energia depois de um período de hibernação: já não sobrava

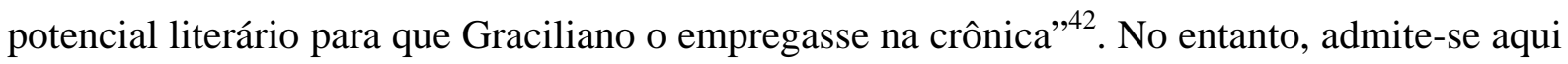
que o mais correto seria enxergar tal mudança não como uma queda de qualidade, mas apenas como uma mudança de orientação, como já fora sinalizados acima.

\subsection{As publicações dos “Quadros e costumes do Nordeste” na imprensa}

Do universo cronístico sistematizado acima, o foco da presente pesquisa recairá sobre os quadros nordestinos estampados por Graciliano em Cultura Política, na primeira metade da

\footnotetext{
${ }^{40}$ A noção moderna de crônica surgiu em meados do século XIX e se consolidou ao longo do século XX com a modernização da imprensa. Nessa nova perspectiva, crônica refere-se a um texto em prosa curto, publicado em jornais e revistas. Apesar de ser um gênero contingente e de consumo imediato, diferencia-se de outras modalidades jornalísticas. Reportagens, matérias e artigos apresentam um ponto de vista objetivo e distanciado, exigido pelas normas específicas de composição de tais narrativas que privilegiam certo recorte jornalístico dos assuntos tidos como mais importantes e urgentes. Já o cronista, sobretudo após o Modernismo, procura trabalhar com imagens prosaicas da vida cotidiana, imaginando um outro tipo de interlocutor mais afeito a uma leitura rápida e prazerosa, que, por sua vez, não deixa de ser séria e instrutiva. Ele pretende também construir uma relação próxima e íntima com tal leitor, com privilégio para o narrador participante e para o narrador testemunha, abdicando da posição da terceira pessoa. No quinto capítulo da presente pesquisa, tais características específicas do gênero serão examinadas com mais acuidade.

${ }^{41}$ BROCA, Brito. Prefácio. In: RAMOS, Graciliano. Linhas Tortas. Rio de Janeiro: Record, 1972.

${ }^{42}$ Idem, p.11.
} 
década de 1940, e parcialmente recolhidos em Viventes das Alagoas. Em linhas gerais, tal escolha se justifica em função tanto do mérito literário (segundo Ledo Ivo, tratam-se das melhores páginas de “jornalismo literário” produzidas pelo autor ${ }^{43}$ ), quanto do caráter polêmico e controverso desses textos, escritos para o principal veículo de propaganda ideológica do Departamento de Imprensa e Propaganda (DIP) do Estado Novo - regime que encarcerou o autor de Angústia, sem acusação prévia, de março de 1936 a janeiro de 1937. Nesse sentido, procurar-se-á examinar o efeito produzido por tais escritos na revista oficial, ou seja, privilegiar-se-á o estudo dos mesmos em seu ambiente primeiro de veiculação, resgatando-se os vínculos circunstanciais de momento que os orientavam e os debates culturais dos quais eles participavam naquele momento histórico específico.

Quando começa a colaborar com o periódico getulista, o artista alagoano já se apresentava como um escritor consagrado, assinando seus textos jornalísticos com o nome pelo qual se tornara literariamente conhecido. Não por acaso, até então, havia publicado Caetés (1933), duas edições de S. Bernardo (1934 e 1938), Angústia (1936), Vidas Secas (1938) e A terra dos meninos pelados (1939), além de um conjunto de mais de 130 crônicas, contos e artigos em jornais e revistas de todo o país, sobretudo, da capital federal.

Ao todo, entre 1941 e 1944, Graciliano publicou vinte e cinco textos em Cultura Política, sua participação mais intensa, sistemática e duradoura num único veículo: dezoito colaborações nos primeiros dezoito números quando a seção ainda se chamava "Quadros e costumes do Nordeste” e as narrativas eram identificadas, não por títulos individualizados, mas por numerais romanos em seqüência crescente; quatro no momento em que seus escritos passaram a ser enquadrados como "Quadros e costumes regionais”; outros dois após nova abreviatura do nome da seção, quando ela reduziu-se a "Quadros regionais"; e um no segmento "Literatura”, quando os quadros deixam de existir ${ }^{44}$. Abaixo segue a disposição das colaborações do escritor no periódico:

- “Quadros e costumes do Nordeste”45

o “Quadros e costumes do Nordeste I” (“Carnaval”), ano 1, n.1, mar. 1941.

\footnotetext{
${ }^{43}$ IVO, Ledo. O mundo concentracionário de Graciliano Ramos. In: Teoria e celebração. São Paulo: Livraria Duas Cidades, 1976, p.96-97.

${ }^{44}$ A partir do número 43, de agosto de 1944.

${ }^{45}$ Neste segmento “Quadros e costumes do Nordeste”, como os textos não apresentam títulos individualizados, cada referência vem acompanhada do nome da seção e do número romano correspondente entre aspas e, depois, entre parênteses, da designação que o texto recebera ao ser publicado em Viventes das Alagoas.
} 
Datiloescrito do $17^{\circ}$ texto dos "Quadros e costumes do Nordeste", de Graciliano Ramos, com alterações do próprio autor, publicado integralmente em Cultura Política (ano 2, n.17, jul.1942, p.348). Trata-se do único documento do gênero localizado no Arquivo Graciliano Ramos, no IEB.

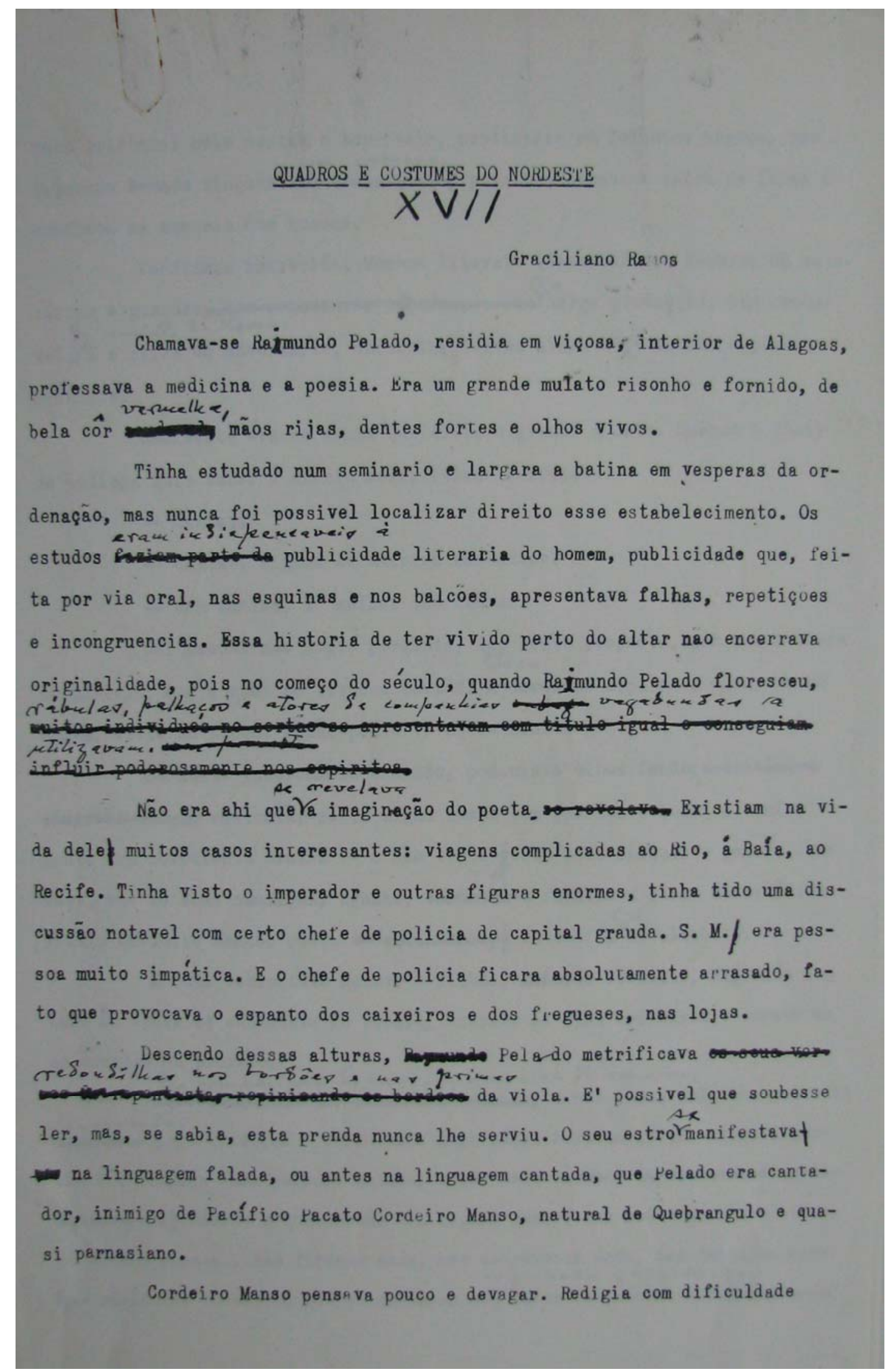


o “Quadros e costumes do Nordeste II” (“D. Maria Amália”), ano 1, n.2, abr. $1941^{46}$.

o “Quadros e costumes do Nordeste III” (“O moço da farmácia”), ano 1, n.3, maio. 1941.

o “Quadros e costumes do Nordeste IV” (“Casamentos”), ano 1, n.4, jun. 1941.

o “Quadros e costumes do Nordeste V” (“Ciríaco”), ano 1, n.5, jul. 1941.

o “Quadros e costumes do Nordeste VI” (“Habitação”), ano 1, n.6, ago. $1941^{47}$.

o “Quadros e costumes do Nordeste VII” (“Teatro I”), ano 1, n.7, set. 1941.

o “Quadros e costumes do Nordeste VIII” (“Teatro II”), ano 1, n.8, out. 1941.

o “Quadros e costumes do Nordeste IX” (“Bagunça”), ano 1, n.9, nov. 1941.

o “Quadros e costumes do Nordeste X” (“D. Maria”), ano 1, n.10, dez. 1941.

o “Quadros e costumes do Nordeste XI” (“Libório”), ano 2, n.11, jan. 1942.

o “Quadros e costumes do Nordeste XII” (“Desafio”), ano 2, n.12, fev. 1942.

o “Quadros e costumes do Nordeste XIII” (“Funcionário independente”), ano 2, n.13, mar. 1942.

o “Quadros e costumes do Nordeste XIV” (“Um antepassado”), ano 2, n.14, abr. 1942.

o “Quadros e costumes do Nordeste XV” (“Um homem de letras”), ano 2, n.15, maio 1942.

o “Quadros e costumes do Nordeste XVI” (“Um gramático”), ano 2, n.16, jun. 1942.

o “Quadros e costumes do Nordeste XVII” (“Dr. Pelado”), ano 2, n.17, jul. 1942.

o “Quadros e costumes do Nordeste XVIII” (“Transação de Cigano”), ano 2, n.18, ago. 1942 .

- “Quadros e costumes regionais”

o “A decadência de um senhor de engenho”, ano 2, n.19, set. 1942.

o "Recordações de uma indústria morta”, ano 2, n.20, out. 1942.

o “Uma visita inconveniente”, ano 2, n.22, dez. 1942.

o “Está aberta a sessão do júri”, ano 3, n.25, mar. 1943.

\footnotetext{
${ }^{46}$ Texto publicado originalmente, com algumas modificações, no Jornal de Alagoas, 18 de junho 1933.

${ }^{47}$ Texto publicado originalmente, com algumas modificações e sob o pseudônimo “J. Calisto”, em $O$ Índio, ano 1, n.14, $1^{\circ}$ maio 1921.
} 
- "Quadros regionais"

o “Um homem notável”, ano 3, n.27, maio. 1943.

o “A viúva Lacerda”, ano 4, n.42, jul. 1944.

- "Literatura"

o “Booker Washington”, ano 4, n.43, jul. 1944.

Desse conjunto, a presente análise deixará de lado apenas dois textos, justamente os dois últimos, que, ao contrário dos demais, fogem do escopo regionalista. Trata-se dos escritos “A viúva Lacerda” e “Booker Washington”, estampados, respectivamente, nos números 42 (julho de 1944) e 43 (agosto de 1944) do veículo. A primeira tematiza o nome de algumas ruas da capital carioca, entre elas a "Viúva Lacerda", que recebe uma atenção especial do cronista. Diante da indeterminação histórica da personagem que dava título ao logradouro, ele começa a especular, em tom jocoso, sobre quem teria sido o falecido marido da dita viúva Lacerda, chegando à conclusão de que se tratava do dicionarista português José Maria d'Almeida e Araújo Corrêa de Lacerda ${ }^{48}$. A segunda aborda a figura de Booker Washington, ex-escravo que se tornara um famoso educador nos EUA ${ }^{49}$.

A exclusão das duas últimas e o foco nas 23 primeiras colaborações do escritor em Cultura Política se justifica em função do caráter unitário e representativo deste conjunto mais amplo. Em todo ele predomina a tematização de diferentes aspectos da vida provinciana: personagens, cenas, práticas, usos e costumes sertanejos, conforme sinaliza o enquadramento regionalista conferido às narrativas pela revista getulista, interessada em compor um amplo painel do país mediante a incorporação simbólica das mais variadas regiões brasileiras ${ }^{50}$. Além disso, os textos iniciais, sobretudo os 18 textos primeiros, foram publicados no momento de auge da revista (antes da entrada do país na Segunda Guerra), quando, em

\footnotetext{
${ }^{48}$ Ele é o autor do Diccionário encyclopedico ou novo diccionário da língua portuguesa, publicado em Lisboa, por Francisco Arthur da Silva, em 1878. Além disso, aparece como colaborador de Eduardo Augusto de Faria na elaboração do Diccionario de língua portuguesa: para uso dos portugueses e brasileiros (1858).

${ }^{49}$ Anos antes, Graciliano fora o responsável pela tradução do livro Memórias de um negro, do mesmo Booker Washington, saído pela Companhia Editora Nacional, em 1940. Seu trabalho de verter para o português esta obra do educador norte-americano fora iniciada em 1938, conforme indica carta dirigida pelo escritor a Anísio Teixeira, em agosto de tal ano (correspondência presente no CPDCO, da FGV).

${ }^{50}$ Como se verá, além dos "Quadros e costumes do Nordeste", havia também os "Quadros e costumes do sul”, sob a responsabilidade de Marques Rebelo, e os "Quadros e costumes do Norte", escritos pelo jornalista Raimundo Pinheiro.
} 
analogia com o caráter disciplinador e orgânico do Estado autoritário, ela orientava e hierarquizava de maneira mais efetiva o conteúdo do material veiculado em suas páginas.

Antes de ganharem suporte livresco descrito acima, três desses quadros sobre a vida provinciana, saídos originariamente em Cultura Política, foram estampados no periódico comunista Revista do Povo - Cultura e Orientação Popular. Tal fato controverso chama ainda mais a atenção para esse conjunto de narrativas, que apesar de escritas para um órgão de direita, foram republicadas, alguns anos depois, num veículo de esquerda. Trata-se das seguintes colaborações:

- “Quadros e costumes do Nordeste - O Carnaval”, Revista do Povo - Cultura e Orientação Popular, Rio de Janeiro, ano 2, n.4, abr. 1946;

- "Quadros e costumes do Nordeste - O Casamento", Revista do Povo - Cultura e Orientação Popular, Rio de Janeiro, ano 2, n.5, maio/jun. 1946, p. 5 e 39;

- “Quadros e costumes do Nordeste - D. Maria”, Revista do Povo - Cultura e Orientação Popular, Rio de Janeiro, ano 2, n.6, jul. 1946, p.3-4.

O presente estudo não poderia se furtar ao exame de tal particularidade. Na medida em que se propõe a recuperar a especificidade da ambiência cultural de Cultura Política e os efeitos produzidos pelos textos do artista nesse espaço editorial, recobrará também os sentidos gerados pela republicação dos referidos “Quadros e costumes do Nordeste” no periódico comunista. Como se verá, a veiculação dos quadros regionalistas tanto na revista de direita e como na de esquerda diz muito a respeito do caráter ambivalente dos mesmos, bem como do ajuste semântico operado por ambos os suportes jornalísticos sobre as matérias que estampam.

\subsection{A recepção dos textos de Cultura Política}

Em geral, a reduzida tradição de leitura dos “Quadros e costumes do Nordeste” de Graciliano, saídos em Cultura Política, ou apenas cita de passagem o fato de tais escritos terem sido estampados na revista oficial, ou procura isolar essas narrativas do autor do conjunto do periódico, ou ainda pretende examinar aquelas em suas conexões com este, mas sem um grande aprofundamento. Além disso, não há nenhuma menção ao fato de os quadros 
nordestinos terem sido republicados, logo ao final do Estado Novo, no supracitado órgão comunista.

A partir da publicação de Viventes das Alagoas, tem início a trajetória de recepção dos “Quadros e costumes do Nordeste”. De começo, na grande imprensa, tomam corpo resenhas e rápidas observações críticas, dando conta do lançamento do livro, por volta de abril de 1962. Este é o caso de "Graciliano - Viventes e vivência”, de Barbosa Rolmes, texto saído na seção “A semana e os livros”, do Suplemento Literário do jornal O Estado de S. Paulo. Aludindo a um aparente contexto de crise do romance brasileiro, o articulista trata a obra como um “exemplo positivo”, a indicar o caminho a ser seguido pelos jovens ficcionistas:

[Em referência a Viventes das Alagoas]. Poderão objetar que se trata de série de páginas avulsas, escritas de 1941 a 1944, desenterradas de publicações esquecidas, constituindo uma coletânea de “Quadros e costumes do Nordeste”. Neste livro encontram-se, porém, já com todas as características da arte do grande escritor, uma galeria de esplêndidos tipos, alguns dos quais seriam desenvolvidos mais tarde, pelo criador de Angústia nos personagens de seus romances. Além disso muitas das situações de vários de seus livros já se encontram, aqui, em embrião. Daí a importância deste Viventes das Alagoas ${ }^{51}$.

Rolmes não só não faz referência ao fato de boa parte dos textos, originariamente, ter sido publicada em Cultura Política, como procura, de maneira equivocada, relacionar os citados quadros nordestinos ao restante da obra do autor. Segundo ele, em tais páginas avulsas, “desenterradas de publicações esquecidas”, encontrar-se iam, em germe, personagens e situações que seriam desenvolvidas posteriormente nos romances do escritor. Contudo, o resenhista se esquece de que em 1941, data em que começaram a ser escritos as crônicas as quais alude, Graciliano já havia publicado toda sua obra romanesca (Caetés, S. Bernardo, Angústia e Vidas Secas) e dedicava-se, sobretudo, a produção de contos e à escritura de suas memórias da infância e da cadeia.

As resenhas publicadas nos jornais Folha de S. Paulo ${ }^{52}$ e Última Hora, ${ }^{53}$ em abril de 1962, também não mencionam a publicação inicial dos textos de Viventes na revista getulista. No

\footnotetext{
${ }^{51}$ BARBOSA, Rolmes. Graciliano Ramos - Viventes e vivência. O Estado de S. Paulo, São Paulo, 28 abr. 1962. Suplemento literário.

52 ARROYO, Leonardo. Vida literária, Graciliano e as crianças. Folha de S. Paulo, São Paulo, 22 abr. 1962. Além de Viventes das Alagoas, trata também do volume Alexandre e Outros e Heróis, voltada preferencialmente para o público infantil, que também vinha de ser lançado naquele momento pela Martins Editora.

${ }^{53}$ PEREZ, Renard. Literatura - Graciliano: obra póstuma. Última Hora, Rio de Janeiro, 25 abr.1962.
} 
entanto, diferentemente do escrito anterior, ambas reforçam o caráter documental, sociológico e memorialístico dos quadros nordestinos do autor. Veja-se a segunda delas:

Em Viventes das Alagoas (Quadros e costumes do Nordeste) foram reunidas em livro, pela primeira vez, as crônicas publicadas por Graciliano na imprensa - em sua maioria, no período de 1941 a 1944. Aí o seu mundo sertanejo aparece na base do documentário. Tipos e festas populares de Alagoas e da Paraíba, apresentados em geral no tom de reminiscências, são fixados pelo escritor dando-nos o livro, em seu conjunto, um quadro expressivo e humano do Nordeste $^{54}$.

De maneira semelhante, Eneida, em artigo publicado no Diário de Notícias, também destaca que uma das constantes das crônicas do escritor seria "a fixação de costumes, tipos e aspectos da vida sertaneja” ${ }^{55}$. Porém, ao contrário dos demais resenhistas arrolados acima, não deixa de destacar que os textos reunidos em Viventes das Alagoas $^{56}$ teriam sido publicados inicialmente em Cultura Política, "uma "revista do DIP”57. Expressas tais informações, a escritora, em perspectiva biográfica, inicia o relato de suas experiências pessoais com o velho Graça. Para tanto, recupera trechos de uma matéria sobre este, escrita por ela mesma, em 1949, para a revista de orientação comunista Esfera.

Entre os episódios da vida de Graciliano presenciados por Eneida estava a passagem do artista alagoano pelo veículo getulista:

Fui visitá-lo algumas vezes na pensão do Catete onde pontificavam outros: o quarto era ruim, sujo, a pensão triste como todas as pensões familiares. O velho continuava a chamar de burro todo o mundo. Assistia sua revolta e seu nojo (sic) em colaborar na Cultura Política, aquela célebre realização do Estado Novo.

- Mas Graça, precisas viver, que diabo! Só sabes escrever que outra coisa poderias fazer?

- Mas é sujeira.

Os encargos da família crescendo, as meninas precisando estudar, Heloísa procura emprego, o velho Graça numa vida dura, roendo as unhas ${ }^{58}$.

\footnotetext{
${ }^{54}$ Idem, ibidem.

${ }^{55}$ ENEIDA. Graciliano Ramos: Viventes das Alagoas. Diário de Notícias, Rio de Janeiro, 15 abr. 1962.

${ }^{56}$ Mais de uma vez, a escritora grafa erroneamente o nome do referido volume como Viventes das Almas (Idem, ibidem).

${ }^{57}$ Idem, ibidem.

${ }^{58}$ Idem, ibidem.
} 
Como forma de afastar qualquer possibilidade de comprometimento de Graciliano com o regime de 1937, a escritora toma a vida do autor como fundamento para se determinar a significação das colaborações deste com a revista dipiana. Preterindo a análise dos textos propriamente ditos, tratados rapidamente como quadros sertanejos, vale-se de tal depoimento para destacar a distância do artista dos postulados estadonovistas. Dá a entender que se ele colaborava com o periódico oficial, isso ocorria tão somente em função das dificuldades financeiras enfrentadas por sua família, pois se enojava com a situação de manter-se vinculado a um órgão do DIP.

Adotando perspectiva diversa, Raul Antelo, nos anos de 1980, privilegiou a análise textual do conjunto das colaborações de Graciliano com Cultura Política, paralelamente ao exame da vinculação do artista a tal publicação dipiana. Segundo ele, haveria correspondência entre o ponto de vista assumido pelo narrador das crônicas e o lugar ocupado pelo escritor na máquina estatal:

Graciliano tende ao ponto de vista do forte e do fora. Narrador urbano, já distanciado desses viventes ora evocados, sua mediação se estabelece a partir de uma posição - no caso, claríssima - no aparelho de Estado. O romancista de prestígio "dentro" e entre os fracos é pago para fixar quadros e costumes do Nordeste, ou seja, congelar o mutável no marco de uma visão autoritária e exterior. A ironia e a saudade revelam o compromisso com o que ficou fora, a confiança na inevitabilidade e a necessidade do progresso, tal como está sendo construído, o que, em última análise é tributo do olhar do forte ${ }^{59}$.

Tendo como base tal análise empreendida por Antelo, bem como outros trabalhos sobre o regime de 1937, com destaque para o estudo de Cultura Política realizado por Mônica Pimenta Veloso ${ }^{60}$, Facioli ressalta os vínculos materiais do escritor alagoano e das colaborações deste com a revista getulista. No contexto da biografia intelectual produzida sobre Graciliano, o crítico destaca:

Graciliano escreve pois, na revista da elite e para a elite intelectual, sob a tutela do DIP, onde a ambigüidade e mesmo a oposição eram toleradas, o que permitia ao escritor, ao mesmo tempo, manter as ilusões de sua independência pessoal e receber vantajosa remuneração por seus textos, de vez que aquela revista era que melhor pagava (e em dia...) os seus colaboradores. Tudo no interior do mesmo

\footnotetext{
${ }^{59}$ ANTELO, Raul. Literatura em revista. São Paulo: Ática, 1984, p.34

60 VELLOSO, Mônica Pimenta. Cultura e poder político: uma configuração do campo intelectual. In: OLIVEIRA, Lúcia Lippi et al. Estado Novo: ideologia e poder. Rio de Janeiro: Zahar Editores, 1982.
} 
projeto ideológico evidentemente. Por isso é que os textos de Graciliano preenchem seções da revista previamente fixadas por seus responsáveis, homens do DIP, os “intelectuais orgânicos”. E os temas, em geral, enquadram-se no circuito de “descoberta e produção” do homem novo pretendido pelo Estado Novo, onde o aparelho de Estado aparecia como capaz de “traduzir a vocação popular”, através do estímulo ao conhecimento da realidade brasileira, em seus aspectos de “observação sociológica e investigação da psicologia nacional”61.

Tomando tal posicionamento como uma afronta a memória de seu pai, Ricardo Ramos rechaça qualquer aproximação entre o autor de Vidas Secas e o Estado Novo. Assim como Eneida, vale-se do "homem Graciliano Ramos” como categoria crítica para explicar a obra do “artista Graciliano Ramos”, preterindo a análise dos quadros nordestinos, propriamente ditos, ou mesmo o exame do papel desempenhado por tais produções na revista getulista ${ }^{62}$. Na verdade, ao tratar dessa questão, em meio ao ordenamento de suas reminiscências, seu principal objetivo parece ser o de desqualificar o trabalho de Facioli, ao qual se refere de maneira indireta, mas contundente:

A colaboração na revista Cultura Política vem a seguir. Com um agravante, ao que se pretende, a colaboração na revista luso-brasileira Atlântico, entre salazarista e estadonovista. Sim, não há nada a observar: Graciliano publicou nas duas crônicas e contos. Aquilo de, se não me censuram, publico até no Diário Oficial. Com maior ênfase estranha-se o seu trabalho de preparador de textos, revendo originais. Um capinar, escoimar, melhorar de escrita avulsa. Naturalmente remunerado, profissional. Não há porque sugerir um "bico no DIP, ou mais”. De certo a revista se subordinava ao Departamento de Imprensa e Propaganda. Mas ele nunca trabalhou lá, obviamente, escreveu e assinou suas crônicas na Cultura Política, emendou a prosa de colaboradores. Falar em DIP, insinuar entendimento maior, seria leviandade. Que significa esse “ou mais”? Além de leviana, a simples dúvida é desrespeitosa para com Graciliano $^{63}$.

Esse afastamento entre artista e Estado, enfaticamente repisado por Ricardo, ganha outros contornos no livro de memórias de Paulo Mercadante, amigo da família Ramos, que também se referiu às colaborações de Graciliano saídas em Cultura Política. Se Facioli considerava os quadros nordestinos do autor como partes ajustáveis ao projeto político-ideológico conduzido pelo Estado Novo, o trabalho de Mercadante procura, em sentido contrário, separá-los do

\footnotetext{
${ }^{61}$ FACIOLI, Valentim. Um homem bruto da terra (biografia intelectual). In: BOSI et al. Graciliano Ramos. São Paulo: Ática, 1987, p.68.

${ }^{62}$ Tal fato se justifica em função dos propósitos de seu livro Retrato Fragmentado, centrado não na análise de aspectos da obra de Graciliano, mas na exposição de memórias afetivas relacionadas ao seu falecido pai.

${ }^{63}$ RAMOS, Ricardo. Retrato fragmentado. São Paulo: Siciliano, 1992, p.217-218. A expressão "Bico no DIP (ou mais?)”, rejeitada por Ricardo, aparece como intertítulo da quarta parte da biografia intelectual de Graciliano escrita por Facioli.
} 
conjunto das produções dois demais autores estampadas em Cultura Política, como se o escritor alagoano, longe de servir ao regime realizasse uma crítica intersticial a este:

A colaboração de Graciliano na Cultura Política abrange o período de abril de 1941 a agosto de 1944. Não lhe parecerá contrária a seus pontos-de-vista, pois o que se devia levar em conta era o texto escrito e não a publicação. O que fizera foi relatar as condições de vida no Nordeste, denunciando a miséria e o atraso, o abandono do homem, a brutalidade da exploração agrária. Aceitar a sua literatura, postas nestes termos, seria uma incoerência do editor, jamais do autor, que não mentia em seu libelo, só contribuindo para que os governantes se alertassem quanto às injustiças sociais. Nesse ponto, no que dizia respeito a sua consciência, estava tranqüilo. Sua pena não se punha a serviço dos reacionários, quando a verdade da exploração era revelada. A revista, posto que feita com recursos oficiais, continha um protesto dos flagelados ${ }^{64}$.

Nos anos 2000, tal perspectiva que se, por um lado, não foge a análise dos "Quadros e costumes do Nordeste”, mas, por outro, procura estabelecer um lugar diferenciado para estes, isolando-os das demais colaborações veiculadas pela revista oficial, ganha espaço no meio universitário. Faz-se referência aqui, mais precisamente, aos trabalhos de Ana Amélia Melo e Nádia Regina Bumirgh. A primeira ressalta que, sorrateiramente, o artista alagoano valia-se do espaço ocupado no periódico getulista para criticar o regime de 1937, como se a única função de seus quadros nordestinos fosse conspirar contra a ordem estabelecida:

Escrevendo numa revista conhecida por um cunho ideológico claro, informado pelo discurso autoritário, Graciliano procura, nesse espaço destinado à recuperação do "verdadeiro" país, a fórmula de sua contraversão. Lendo-o ao reverso podemos compreender o alcance de sua visão crítica. A alternativa de recusar a oferta de trabalho estava fora de possibilidade, restava então o uso precioso da palavra. Da perspectiva tutelar da política getulista, de propagandear um movimento de cultura brasileira firmado na recuperação das raízes nacionais, de tom ufanista, era preciso escapar através da ironia, ou de um retrato cru dessa realidade. O tom acrimonioso desfaz os louros comemorativos da redescoberta do Brasil. Se a proposta de Graciliano era a de se firmar na realidade brasileira, esta aparecia sem meios tons e não era motivo de glória. Opondo o Brasil matuto, sertanejo, antiquado, ao litoral macaqueador das civilizações do outro mundo, sua crítica recai sobre o artificialismo bem pensante que, sob o fraque, esconde a tanga ${ }^{65}$.

\footnotetext{
${ }^{64}$ MERCADANTE, Paulo. Graciliano Ramos: o manifesto do trágico. Rio de Janeiro: Topbooks, 1994, p.123124.

${ }^{65}$ MELO, Ana Amélia M. C. Pensando o Brasil: os escritos de Graciliano no Estado Novo. In: ALMEIDA, Ângela Mendes de (org). De sertões, desertos e espaços incivilizados. Rio de Janeiro: Faperj; Mauad, 2001, p.69. Tal artigo é fruto da tese de doutorado De fraque e tanga: o impasse do moderno na literatura graciliana, defendida pela autora também no ano de 2001, na Universidade Federal Rural do Rio de Janeiro.
} 
Bumirgh adota viés semelhante, afirmando que Graciliano não poderia recusar o acesso a um meio de comunicação "para denunciar injustiças e misérias sociais"66 e revelar o "retrato cru” da realidade nacional ${ }^{67}$. No entanto, diferentemente de Melo, assume uma postura aberta de defesa do autor, como se a imagem dele tivesse sido maculada pelos estudos de Antelo e Facioli e precisasse ser reabilitada:

\footnotetext{
Sabendo-se que existe a insinuação por parte de alguns críticos literários de que o conjunto das crônicas produzidas por Graciliano, durante o Estado Novo, abraça o projeto cultural e político getulista, a pesquisa sobre a sua participação em Cultura Política tornou-se imprescindível para a defesa do não atrelamento do escritor alagoano aos ditames ideológicos estadonovistas ${ }^{68}$.
}

Além de propor tal abordagem interpretativa de cunho “salvacionista”, o objetivo final de Bumirgh é preparar uma edição crítica de Viventes das Alagoas. Valendo-se de procedimentos técnicos e científicos extraídos da crítica textual e genética, a pesquisadora recupera e examina detidamente manuscritos, recortes de periódicos e diferentes edições da obra, com o propósito e estabelecer o texto ideal do autor. De maneira geral, esse processo parece incidir sobre sua proposta analítica dos “Quadros e costumes do Nordeste”, pois por mais que leve em conta o suporte jornalístico de Cultura Política, a autora tem em mente o livro, ou melhor, uma imagem acabada e inteiriça do artista, que o processo de edição dos quadros nordestinos em livro ajuda a construir. Nesse sentido, levando em conta o perfil acabado e consolidado de Graciliano, volta-se contra o efeito de contradição e incoerência que tais escritos possam produzir.

\subsection{Enunciados-tipo e enunciados-ocorrência: proposta de análise}

Por fim, a retomada de alguns postulados da teoria da enunciação pode a ajudar a sistematizar melhor tal conjunto de leituras que, ao longo do tempo, abordaram os “Quadros e costumes do Nordeste”, de Graciliano. Pode-se considerar os textos de Graciliano, privilegiados na presente análise, como enunciados-tipo que se convertem em enunciados-ocorrência distintos seja na revista Cultura Política (tipo I), seja no periódico comunista Revista do Povo -

\footnotetext{
${ }^{66}$ BUMIRGH, Nádia Regina. Graciliano Ramos e a revista cultura política: pequena abordagem interpretativa na proposta de edição crítica de Viventes das Alagoas. São Paulo, 2003. Tese (Doutorado) - Faculdade de Filosofia Letras e Ciências Humanas, Universidade de São Paulo, p.55.

${ }^{67}$ Idem, p.78.

${ }^{68}$ Idem, p.11.
} 
Cultura e Organização Popular (tipo II), seja no livro Viventes das Alagoas (tipo III) ${ }^{69}$. Neste último caso, deixam de se portar como os "Quadros e costumes do Nordeste” da publicação oficial, na qual não apresentavam título individualizado (as narrativas eram apenas numeradas), para comporem outro tipo de unidade, expressa pelo nome da obra: como visto, enquanto o termo "viventes” remete à população sertaneja, tratada com certa bestialização, “quadros e costumes” recupera determinada dimensão etnográfica dos espaços nordestinos, não se restringindo a uma única localidade (“Alagoas”) ${ }^{70}$.

Conforme referido anteriormente, o livro pode ser tomado como uma grande miscelânea que agrupa diferentes textos de Graciliano e prevê outro tempo de leitura (reivindicado pelo próprio formato em questão), além de atribuir outra função primordial aos “Quadros e costumes do Nordeste”: ao retirar-los de seus espaços primeiros de veiculação e juntá-los a escritos saídos em momentos e espaços distintos, faz com que tais crônicas deixem de se vincular de maneira direta às finalidades estabelecidas pelos periódicos supracitados e passem a ser tomadas, preferencialmente, como textos periféricos aos romances centrais do autor. Nesse sentido, ajudariam não só a compor, adensar e iluminar as obras maiores de Graciliano, mas, sobretudo, a explicar a figura deste, na medida em que passariam a ser tratadas como suporte informativo para se apreender o pensamento e as diretrizes do artista, presentes, por exemplo, em S. Bernardo, Vidas Secas, Infância etc. ${ }^{71}$.

Portanto, desalojadas da revista oficial e agrupadas de maneira contígua em livro, as crônicas passavam a ser interpretadas segundo outros protocolos de leitura, requisitando, por sua vez, uma atenção diferenciada. Além disso, com a mudança de meio, prevêem um outro tipo de leitor (obviamente, não um sujeito de carne e osso, mas certa figura de destinatário construída pelo texto por meio de sua enunciação), que, por sua vez, terá um outro tipo de atitude diante dos mesmos. Em linhas gerais, os quadros nordestinos, editados no volume Viventes das

\footnotetext{
${ }^{69}$ Maingueneau destaca que os enunciados-ocorrência são aqueles produzidos por enunciações particulares e historicamente localizáveis, cujo sentido pode variar a cada situação enunciativa distinta, ao passo que os enunciados-tipo independem de qualquer enunciação e suporte específicos, revelando-se ser sempre o "mesmo" ao ser proferido em diferentes contextos comunicacionais. No entanto, o autor adverte que esta última categoria seria apenas uma abstração necessária: "no plano empírico só encontramos enunciados-ocorrência, produtos de atos singulares de enunciação" (MAINGUENEAU, Dominique. Elementos de lingüística para o texto literário. São Paulo: Martins Fontes, 1996, p.9).

${ }^{70}$ Vale lembrar que a obra apresenta de maneira discreta o subtítulo "Quadros e Costumes do Nordeste". Na folha de rosto da segunda edição, enquanto o nome "Viventes das Alagoas" é escrito em capitulares, no topo da página, a frase "Quadros e costumes do Nordeste" aparece com um tipo muito menor, entre parênteses, abaixo de uma ilustração que remete à crônica Dr. Jacarandá.

${ }^{71}$ Deve-se considerar, aqui, o fato de o livro ser lançado num contexto de publicação das obras completas do escritor pela Martins em 1962, tal como relato anteriormente.
} 
Alagoas, voltam-se preferencialmente aos conhecedores da obra de Graciliano, que, em regra, irão encontrar em tais escritos elementos para justificar a biografia do autor ou especificar passagens de seus romances, compondo um perfil mais unitário do mesmo.

Considerando-se as leituras dos "Quadros e costumes do Nordeste” arroladas acima, pode-se afirmar que a maior parte delas procura tomar os textos como enunciados-ocorrência do tipo III, ou seja, considera, sobretudo, a edição destes no suporte livresco, deixando de lado tanto a especificidade da veiculação jornalística como o caráter contraditório dos mesmos. Em geral, tais abordagens prevêem interpretações que levem em conta uma imagem mais bem acabada do escritor e de sua obra, sobretudo a perspectiva de um Graciliano artisticamente consagrado e independente, apesar do vínculo oficial com o PCB e das pressões do realismo socialista ${ }^{72}$. Dessa maneira, acabam deixando de lado a especificidade do momento histórico de publicação original dos quadros nordestinos, algo previsto pelas leituras de tipo I.

Tal procedimento está na base das resenhas de jornal sobre o lançamento do livro, bem como das leituras realizadas por Mercadante, Mello e Bumirgh. Ainda que tais autores retomem as propostas da revista (sobretudo os dois últimos), apóiam-se na idéia de um escritor herói, com um perfil estabelecido, como se o único propósito de Graciliano nas páginas da principal publicação do regime fosse combater o Estado Novo. Em sentido oposto, Antelo e Facioli consideram, prioritariamente, os textos como enunciados-ocorrência do tipo I, enfatizando uma interpretação crítica dos mesmos, em consonância com o exame geral do suporte jornalístico de Cultura Política. Apesar de certo viés acusatório, adotado em determinados momentos, ambos procuram recuperar o enquadramento histórico e as particularidades da veiculação inicial dos quadros nordestinos no periódico getulista.

Tomando também os “Quadros e costumes do Nordeste” como enunciados-ocorrência de tipo I, mas privilegiando-os como objetos centrais de análise $\mathrm{e}^{73}$, o presente trabalho procurará examinar de maneira detida os efeitos agregativos ou desagregativos produzidos por estes na ambiência jornalística da revista oficial. Ao mesmo tempo, levará em conta o fato até então

\footnotetext{
${ }^{72}$ Sobre essa questão ver o artigo "Roupa suja se lava em casa”, de Adriana Coelho Florent (In: RIDENTI et al. Intelectuais e Estado. Belo Horizonte: Editora UFMG, 2006), sobre as críticas internas dirigidas por Graciliano ao PCB, no que dizia respeito às orientações zhdanovistas sobre a criação literária, dominantes, a partir de certo momento, em tal agremiação partidária.

${ }^{73}$ Os trabalhos de Antelo e Facioli não se restringem ao exame da colaboração de Graciliano no periódico getulista. O primeiro aborda os "Quadros e costumes do Nordeste" ao longo de um estudo sobre diferentes revistas literárias (Cultura Política, Revista Acadêmica e Literatura). O segundo trata dos retratos nordestinos em meio à produção da biografia intelectual do artista alagoano.
} 
desconhecido de uma parte de tais escritos ter sido reproduzida no periódico comunista Revista do Povo - Cultura e Orientação Popular (tipo II). O estudo do papel desempenhado pelos textos no órgão de esquerda servirá para ressaltar as propriedades ambivalentes dos mesmos, ajudando, por fim, a compreender melhor o sentido por eles produzido no órgão de direita. Nesse processo não se tem a intenção de incriminar ou absolver o escritor. Ao invés de justificar suas ações, tentar-se-á compreendê-las, sem perder de vista o perfil de suas convicções e do período histórico em que ele viveu.

Porém, antes de analisar a especificidade da colaboração do autor em Cultura Política ou mesmo, em menor escala, na Revista do Povo - Cultura e Orientação Popular, cabe recuperar a trajetória jornalística de Graciliano como forma de especificar melhor o lugar ocupado pelos "Quadros e costumes do Nordeste” no conjunto de suas produções estampadas em jornais e revista. Nesse processo, partir-se-á do início de seu trabalho efetivo como rabiscador de textos em prosa para jornais - a série “Traços a Esmo” -, publicada jornal fluminense Parayba do Sul, prosseguindo-se até suas últimas produções dirigidas, sobretudo, a publicações vinculadas, oficialmente ou não, ao PCB. 


\section{Capítulo 2 - O percurso do cronista}

\subsection{O Parayba do Sul: da capital para a província}

Segundo o relato consagrado por sua biografia, em agosto de 1914, com o propósito de encontrar alguma atividade na imprensa, Graciliano viaja para o Rio de Janeiro. De início, torna-se suplente de revisor de o Correio da Manhã e de O Século. No início de 1915, é contratado como revisor de A Tarde. Entre março e junho deste mesmo ano, começa seu primeiro trabalho sistemático como cronista. Da capital do país, o jovem artista passa a colaborar com o semanário Parayba do Sul, da cidade fluminense com o mesmo nome, e a enviar crônicas para o Jornal de Alagoas. Em ambos os periódicos, está encoberto pelas iniciais R.O., referentes a seus dois últimos sobrenomes de batismo, Ramos de Oliveira ${ }^{74}$.

Para o Parayba do Sul, depois escrever uma crônica inicial em janeiro de 1915, assinada com seus sobrenomes por extenso (Ramos Oliveira) ${ }^{75}$, inicia uma série intitulada "Traços a Esmo" que engloba treze textos escritos entre 15 de abril e 05 de agosto de 1915 (com intervalos). Estes foram parcialmente transcritos no Jornal de Alagoas, sob as rubricas de "Linhas Tortas" ou “Coisas do Rio”. Além disso, o literato também redige algumas crônicas especificamente para tal jornal alagoano, como as de número II e III que foram agrupadas logo no início do volume Linhas Tortas.

Antes de entrar na análise específica desse conjunto de textos, produzidos durante a primeira permanência do escritor no Rio de Janeiro, tratar-se-á rapidamente de sua produção provinciana anterior, ainda em Alagoas, veiculada na imprensa.

A primeira crônica publicada por Graciliano Ramos, de que se tem notícia, foi "No campo das Letras”, em 20 de abril de 1909, no Jornal de Alagoas de Maceió ${ }^{76}$. O jovem cronista, na oportunidade com 17 anos incompletos e ainda estudante, em regime de internato, do Colégio Quinze de Maceió, assina o texto com o pseudônimo Lambda.

\footnotetext{
${ }^{74} \mathrm{O}$ nome completo do escritor era Graciliano Ferro Ramos de Oliveira.

75 Trata-se da crônica Na terra do Fogo as coisas estão frias..., publicada no Parayba do Sul em 07 de janeiro de 1915, que foi deixada de fora de Linhas Tortas e ainda permanece inédita em livro.

76 SANT’ANA, Moacir Medeiros. Graciliano Ramos antes de Caetés. Maceió: Arquivo Público de Alagoas, 1983, p.22.
} 
No início da década de 1910, continua colaborando esparsamente com a referida publicação sempre encoberto pelo véu do mesmo pseudônimo. Nela, despacha um texto em 1910, dois em 1911 e um em $1913^{77}$. Sabe-se ainda que em outubro de 1911 ele colaborara com outro jornal da capital do estado, o Correio de Maceió, com a crônica "Literatura”, usando, no entanto, o pseudônimo de Soeiro Lobato.

É de alguns anos antes a incursão de Graciliano pela poesia, que, diferentemente da prosa, não se restringiu à imprensa alagoana. Entre 1907 e 1913, o escritor publicou 41 poemas e sonetos na revista carioca $O$ Malho, sob os pseudônimos de Almeida Cunha, S. de Almeida Cunha, Soeiro Lobato, Feliciano de Olivença e Feliciano Olivença. Sua estréia como poeta, influenciado ainda por modelos parnasianos, ocorreu mediante a publicação do soneto "Incompreensível", estampado no referido veículo da então capital federal, em 29 de junho de 1907. O escritor assinou-o com o pseudônimo Feliciano Olivença.

Para a imprensa alagoana, entre 1909 e 1911 o autor também escreveu inúmeras poesias. Foram onze para o Jornal de Alagoas, cinco para o Correio de Maceió e duas para a revista literária Argos. Neste veículo, foram publicadas ainda duas cartas remetidas pelo jovem artista, encoberto pelo pseudônimo Manoel Maria Soeiro Lobato, aos editores ${ }^{78}$. Em resposta, estes exaltam o poeta e pedem para que ele revele seu verdadeiro nome.

Tais colaborações, seja na imprensa carioca ou alagoana gabaritaram-no a participar, em 18 de setembro de 1910, do inquérito "A arte e a literatura em Alagoas - O que são, o que pensam, o que lêem os nossos artistas e literatos - Qual a escola predominante entre nós - O Jornalismo", promovido pelo Jornal de Alagoas, num empreendimento análogo ao que fizera João do Rio em A Gazeta de Notícias da capital federal. Deixando o pseudônimo de lado, o então poeta assina o texto como G. Ramos de Oliveira e passa a discorrer, depois de valer-se de certa modéstia retórica, sobre academias de letras, escolas literárias, teatro, jornalismo e sobre suas atividades literárias desenvolvidas até então.

\footnotetext{
77 Os textos ainda inéditos em livro são os seguintes: "Estudante na roça”. Jornal de Alagoas, Maceió, 13 mar. 1910; "Pela mocidade”, Jornal de Alagoas, Maceió, 22 fev. 1911; "Zé Pereira”. Jornal de Alagoas, Maceió, 25 fev. 1911; "Professiomania”. Jornal de Alagoas, Maceió,26 set. 1913. Vale destacar que a partir de outubro de 1910, depois de deixar o internato em Maceió e voltar a viver com sua família, que havia se mudado para Palmeira dos Índios (até então seus familiares moravam em Viçosa), Graciliano passa a enviar suas colaborações do sertão alagoano para os periódicos da capital. Para consultar tais escritos na íntegra, favor consultar o segundo volume da presente pesquisa.

${ }^{78}$ SANT’ANA, Moacir Medeiros. A face oculta de Graciliano Ramos. Maceió: Arquivo Público de Alagoas, 1992, p.55-60.
} 
Nota-se, portanto, que antes de sua viagem para o Rio de Janeiro, em agosto de 1914, o jovem escritor já era reconhecido como artista pelo mais representativo jornal maceioense e, além disso, já havia colaborado, ainda que como poeta iniciante, com mais de quarenta poemas em O Malho, revista ilustrada da capital carioca de conteúdo humorístico, político, crítico e artístico, composta por uma equipe que reunia destacados escritores e caricaturistas da época ${ }^{79}$.

Voltando, agora, a tratar especificamente dos escritos de Graciliano para o Parayba do Sul, nota-se que por meio deles o cronista procurava participar, de maneira efetiva, do discurso cultural da capital da nação. No entanto, tratava-se ainda de uma inserção modesta e secundária em tal diálogo cosmopolita, tendo em vista tanto sua carreira como artista até aquele momento, limitada a certa projeção em Maceió e no próprio Rio, como a abrangência e a circulação restritas do periódico no qual começara a colaborar. Tal semanário, editado apenas às quintas-feiras, cujo redator era Ildefonso Falcão, tinha apenas quatro páginas (de tamanho standart), divididas em seis colunas. "Traços a Esmo", segmento sob a responsabilidade do jovem escritor, recorrentemente ocupava o espaço privilegiado da primeira página, ao lado de outra seção, chamada “Do Rio...”, e de algum editorial. O provincianismo do semanário ficava claro no destaque dado a tudo aquilo que vinha da cidade do Rio de Janeiro, centro em torno da qual o município de Paraíba do Sul gravitava ${ }^{80}$.

No entanto, por mais que nomeasse seus textos como "Traços a Esmo", o espaço por eles ocupado na modesta publicação e o fato de terem como matriz discursiva a representação do Rio de Janeiro, que ainda vivia sua bélle époque, já lhes conferia uma atenção especial. Na verdade, o suposto rebaixamento que o autor lhes atribui, consubstanciado no título da seção, apresentava-se como uma estratégia recorrente na prática de diferentes cronistas. Em geral, estes rebaixavam o próprio mister para retoricamente tornaram-se mais persuasivos: por meio

\footnotetext{
${ }^{79}$ Segundo Nelson Werneck Sodré, O Malho começou a circular em setembro de 1902, privilegiando o conteúdo humorístico. A partir de 1904, teria se tornado também um veículo político, passando a contar com a colaboração de Olavo Bilac, Guimarães Passos, Pedro Rabelo, Renato de Casto, e, principalmente, Bastos Tigre e Emílio de Meneses. Além disso, reunia em seus quadros, os "maiores caricaturistas da época” (SODRÉ, Nelson Werneck, História da Imprensa no Brasil, Rio de Janeiro: Civilização Brasileira, 1966).

${ }^{80}$ No restante do jornal predominavam notas, informações sobre a guerra na Europa, colunismo social e muitos anúncios, que ocupavam a segunda e toda a última página.
} 
do fingimento de uma suposta humildade, procuravam dignificar sua condição e ampliar as possibilidades de êxito em seu intento semiótico de sensibilizar e atingir o leitor ${ }^{81}$.

De maneira geral, sua coluna dividia o foco principal das atenções com a já citada "Do Rio...”, assinada por M.L., na verdade, Rodolfo Mota Lima, conterrâneo e amigo de Graciliano. M.L. procurava representar e condensar em seus textos diversos aspectos da capital, privilegiando, em regra, o relato daquilo que supostamente mais importante e urgente teria ocorrido na semana anterior à veiculação do periódico. Por outro lado, Graciliano tinha um objetivo diferente. Ao invés de propor um relato abrangente daquilo que de mais novo ocorrera, seu narrador R.O. procurava se deter na ficcionalização de certas práticas, tipos e objetos específicos, sobretudo àqueles relacionados ao universo cultural da cidade, tais como o cinema, o jornalismo, a figura do literato em esboço, e certas polêmicas literárias, entre outros tipos e manifestações culturais abordadas. Além disso, procurava se aproximar de maneira mais efetiva de seus leitores, ao passo que M.L. conferia maior importância objetiva a seu relato distanciado.

Escrevendo da capital do país para a folha do interior do estado, Graciliano se colocava como uma espécie de correspondente. Isto fica claro desde o primeiro texto que apresenta a estrutura de uma carta endereçada a seus interlocutores. A narrativa se inicia com o vocativo “Amável leitor” e termina com a data e o local de sua escritura: "Rio - abril - 1915”, elemento que não consta na edição de Linhas Tortas, mas que se mostra importante na consolidação do viés adequado de leitura do texto. Percebe-se, assim, que se trata de uma narrativa próxima do gênero epistolar, sobretudo, porque é pensada como um diálogo que aconteceria à distância entre duas pessoas, inicialmente desconhecidas, mas que manterão, logo depois, um contato semanal. Para que isso viesse a acontecer, o narrador constrói-se como um personagem, cujas crônicas simulam a vida de quem as escreve. Ao mesmo tempo, este procura definir e testar seus receptores que são, a todo o momento, evocados, tal como ocorre logo no início:

\footnotetext{
${ }^{81}$ Esta falsa modéstia, revestida da tópica inania verba (palavras fúteis), tem como objetivo chamar a atenção para a real importância da crônica, texto que cada vez mais ganhava importância nos jornais em que era publicado e dava prestígio a seu autor. Segundo Marlyse, o folhetim, ainda no século XIX, seria um "espaço mágico e tão rentável em termos de garantia de venda, que o 'folhetins', acaba sendo, no Brasil também, a viga mestra do jornal, como ensinaram os pais franceses do jornalismo moderno” (In: MEYER, Marlyse. Voláteis e versáteis, de variedades e folhetins se fez a chronica. Boletim Bibliográfico. Biblioteca Mário de Andrade, São Paulo, v.46, n.1-4, jan./dez. 1985, p.25).
} 
Amável leitor.

Não tenho o prazer de saber quem és. Não conheço teu nome, tua pátria, tua religião as complicadas disposições de teu espírito. Ignoro se tens a ventura de ser um pacato vendeiro enriquecido a custa de pequeninas e honestas trapaças, ou se és um celerado de figura sombria, calças rotas, botas sem salto e paletó ignobilmente descolorido com remendos nas costas e sonetos inéditos nas algibeiras. É possível até que sejas uma adorável criatura de tranças louras e dentes de porcelana e que agora, de volta da Igreja, onde ouviste uma detestável missa rezada por um velho padre fanhoso, abras este jornal para afugentar um bocado de tédio que encontraste escondido entre as páginas de teu manual encadernado a madrepérola ${ }^{82}$.

A “crônica-carta” guardava a aparente ambigüidade de ser, ao mesmo tempo, um documento público, estampado na página de um jornal, e íntimo, na medida em que fingia se destinar a cada leitor individualmente. Tendo em vista o aceno para a continuidade da relação entre remetente e destinatário, o primeiro procurava construir uma relação de proximidade e familiaridade com o segundo. Tal fenômeno ocorria mesmo quando este tematizava a distância entre ambos e a dificuldade da tarefa de aproximação, bem como quando adotava uma postura pseudo-agressiva, assim como na seguinte passagem:

Eu é que tenho necessidade de estudando teus gostos e fazendo completa abstração de minha individualidade, oferecer-te qualquer droga que te não repugne o paladar. Mas - que diabo! - eu não sei a quantidade e a cor da substância que acaso armazenas no crânio, rotundo burguês que candidamente transportas o suor de teu próximo para as profundidades de tua volumosa pança. Demais, sendo extremamente em geografia, devo confessar-te, ó miserável menestrel pálido, que nunca ouvi falar na cidade que habitas. Ignoro se há por lá estradas de ferro, automóveis, cinematógrafos, zonofones, outros tormentos inventados pela civilização ou se vives pacificamente entre duas tortuosas e infinitas lãs de casinhotes reles edificados à negra margem de um riacho triste ${ }^{83}$.

O trecho revela que além de espirituoso, o cronista procurava construir para si uma imagem de sinceridade e de humildade, de acordo com sua já referida estratégia retórica de persuasão frente a seu leitor desconhecido. Por mais que dissesse o contrário, e tendo em vista o propósito de manter o canal de comunicação, os temas e assuntos que extraía de fatos, práticas e tipos da capital ajustavam-se às expectativas dos destinatários provincianos. Dessa maneira, procurava compensar seu afastamento do universo regional em que circulava o periódico.

\footnotetext{
${ }^{82}$ RAMOS, Graciliano, Linhas Tortas. Rio de Janeiro: Record, 2005, p.26.

${ }^{83}$ Idem, p.26.
} 
Além de testar o leitor, esta primeira crônica procurava também avaliar o canal. O narrador indica que desconhecia a orientação política da folha e por isso desejava que seu texto não apresentasse "nem a sombra de uma idéia”. Em seguida, confidencia ao interlocutor sua condição de rabiscador que deve seguir as orientações do jornal e do público para o qual escreve, despindo-se de qualquer desejo aparente de liberdade ou de imparcialidade. A metalinguagem é usada aqui como mais um artifício para construir a imagem de um autor sincero e aumentar seu poder de sensibilizar os destinatários. Paralelamente, o gênero epistolar se prestaria à apresentação de um pseudodesabafo ao mesmo tempo jocoso e interessado. Em resumo, depois de estabelecido o contato e testados tanto o auditório quanto o próprio meio de comunicação, o cronista poderia agradar a ambos, de acordo com os limites oferecidos por este último.

No restante da série, continuava o esforço do cronista R.O. em criar uma identidade e um estilo bem definidos, que dessem unidade aos relatos, pois seu propósito continuava a ser o de se familiarizar com o destinatário com quem se correspondia semanalmente. Incorporando certos traços da tradição machadiana, adota o humor, o sarcasmo e o ceticismo ${ }^{84}$. Mediante tal procedimento, acentuava-se, assim, o fingimento poético já apontado desde o texto inicial: o narrador apresentava-se como uma personagem de ficção que ganhava relevo em meio aos assuntos tratados.

Outro procedimento que se mantinha ao longo dessa série de textos era a tentativa do narrador de construir para si um ethos de sinceridade, nem que para isso falsamente se rebaixasse perante o leitor. Na maioria das vezes, isso ocorria por meio da descrição de certas práticas e tipos pertencentes a seu universo imediato de cronista. Depois de tratar das engrenagens do jornalismo em outras três oportunidades, como fizera na já comentada crônica inicial, propõese a apresentar o funcionamento dos meios literários. O destaque principal recai sobre o texto XIV, de 8 de julho de 1915, no qual produziu a caricatura daquilo imaginava ser um literato em esboço. Nele, R.O. privilegiava o recorte de certas características que ridicularizam o retratado: além de apresentar modos excessivos, este seria vaidoso, egocêntrico, dogmático,

\footnotetext{
${ }^{84}$ BOSI, Alfredo et al. Graciliano Ramos. São Paulo: Ática, 1987, p.118.
} 
arrogante, agiria ao sabor de determinadas conveniências e se filiaria a certas igrejinhas literárias de elogio mútuo.

Em sentido oposto, orientando-se pelos pressupostos da escola realista européia, acredita que os homens de letras deveriam apresentar postura diversa. Caso desejassem conferir "verdade” (não só verossimilhança artística) aos seus textos, os escritores deveriam adotar uma postura crítica e debochada, deixando de lado elogios e encômios, que não passariam de fantasia romântica ou mesmo "safadeza” para conseguir notoriedade. Conforme se observa em outro escrito desse período, publicado no Jornal de Alagoas, em março de 1915, o principal modelo do escritor seria Eça de Queirós. Neste texto, posteriormente editado como o de número III da seção "Linhas Tortas", do livro de mesmo nome ${ }^{85}$, R.O., indignado com o relato da depredação da estátua do autor de Os Maias, exalta, contrariando seus procedimentos habituais de produzir o sentido como negatividade, a figura do romancista português:

Eça é grande em tudo - na forma própria, única, estupendamente original, de dizer as coisas; na maneira de descrever a sociedade, estudando de preferência os seus lados grotescos, ridicularizando-a, caricaturando-a (...) Eça era um ateu, um homem que não respeitava nada, que não tomava as coisas a sério. Pintou ministros estúpidos, padres devassos, jornalistas vendidos, condessas adúlteras; escarneceu a literatura de sua pátria, a política, as respeitáveis cinzas dos brutos e gloriosos antepassados dos vencedores dos mouros; troçou a burguesia, a religião, o hino da carta ${ }^{86}$.

A série de Graciliano para o Parayba do Sul se encerra em meio a um debate missivístico entre R.O. e M.L, responsável pela seção “Do Rio...”. A contenda teria sido iniciada com a crônica XV, na qual R.O. retoma certa polêmica sobre a rivalidade entre e o norte e o sul na literatura brasileira, travada na imprensa carioca pelos escritores Humberto de Campos (1886$1934)^{87}$ e Carlos Maul (1887-1974) ${ }^{88}$. M.L. critica o colega de jornal por ter contribuído, involuntariamente, com a prática nociva das “igrejinhas” ao dar destaque a "Karl von Maul”, um “campeão da cretinice, da falta de senso e da falta de preparo”. Logo em seguida, aconselha o amigo: "Não gastes mais o teu papel e a tua tinta com esses poseurs, que assim

\footnotetext{
${ }^{85}$ Na crônica XII, desta mesma unidade, a qual tem como assunto a representação dos criados em obras ficcionais, o cronista também sugere sua predileção pelas criações de Flaubert e Balzac.

${ }^{86}$ RAMOS, Graciliano. op.cit. p.23-24.

${ }^{87}$ Literato, jornalista, político, crítico maranhense.

${ }^{88}$ Jornalista, escritor e poeta originário de Petrópolis.
} 
lhes levas de presente o que eles justamente desejam - "notabilidade em letra de forma" mesmo em jornais da roça. E o papel e a tinta nas tuas mãos valem tanto...”89.

Para se defender das censuras, R.O. mantêm o mesmo expediente já observado ao longo dos seus "Traços a Esmo": adota a estratégia argumentativa de rebaixar-se, em períodos carregados de ironia e humor. Diz que, em seus textos anteriores, não teve a intenção de engrandecer nenhum dos dois contendedores. Sarcasticamente, indica que se errou dando espaço a Carlos Maul, mas M.L. teria incorrido no mesmo engano ao também colocar em evidência o nome do poeta petropolitano em sua carta. Termina a crônica, tripudiando do conselho do amigo: "N.B. Tenho meditado sobre o conselho que me deste de tomar um banho de água benta. Preciso de uma pia muito grande, principalmente agora, que somos dois ao banho: tu e eu" 90 .

Ao mesmo tempo em que fechava o movimento irônico do texto, R.O. parecia encenar também sua despedida das páginas do Paraíba do Sul, fechando a unidade formada pela série “Traços a Esmo”, que apesar de apresentar-se como tal não fora respeitada pela edição do volume Linhas Tortas ${ }^{91}$.

\subsection{O Índio: da província para a província}

Em junho de 1915, a Gazeta de Notícias do Rio de Janeiro, ainda um dos maiores jornais do país, havia se interessado em publicar as crônicas de Graciliano feitas para o Paraíba do Sul e ainda lhe oferecera uma vaga de revisor. Um amigo lhe pedira uma foto e algumas notas para a revista Concórdia, que também estamparia uma crônica sua ${ }^{92}$. Dessa forma, a capital carioca acenava-lhe com boas possibilidades para uma carreira de escriba. Contudo, em fins de agosto desse mesmo ano, recebe um telegrama do pai que lhe traz notícias funestas: três de seus irmãos haviam morrido em decorrência de uma epidemia de peste bubônica que assolava Palmeira dos Índios. Deveria partir do Rio de Janeiro e voltar para o sertão ${ }^{93}$.

\footnotetext{
${ }^{89}$ LIMA, Rodolfo Mota. (Carta aberta), Parayba do Sul, Paraíba do Sul, 29 jul. 1915.

${ }^{90}$ RAMOS, Graciliano. op.cit, p.69.

${ }^{91}$ Para mais informações sobre a deficiência editoriais de Linhas Tortas (1962), ver o capítulo anterior.

${ }^{92}$ RAMOS, Graciliano. Cartas. Rio de Janeiro: Record, 1981, p.57

${ }^{93}$ MORAES, Denis, O Velho Graça. Rio de Janeiro: José Olympio, 1992. p.35-36.
} 
Das crônicas do Paraíba do Sul às de O Índio, seu segundo trabalho jornalístico sistemático, há um intervalo de seis anos. Segundo relatos biográficos, nesse período, Graciliano deixara de colaborar com todos periódicos e dedicara-se a Loja Sincera, negócio de seu pai em Palmeira dos Índios. Todavia, em 1921, começara a trabalhar no pequeno jornal palmeirense do padre Macedo ( $O$ Índio). Tratava-se de uma publicação em tamanho tablóide, de quatro páginas divididas em quatro colunas. Nas duas primeiras, normalmente, constavam editoriais, pequenos textos, notas opinativas, epigramas e crônicas. A terceira era ocupada por telegramas, pequenas publicidades e pelas seções “Crônica Social” (com informações sobre eventos e figuras da elite municipal), "De Maceió” (com notas sobre a capital do Estado) e “A pedidos”. Na quarta, ganhavam espaço correspondências, pequenas notas e praticamente toda a publicidade e classificados.

De janeiro a maio de 1921, o escritor colaborou intensamente com as 14 edições iniciais da publicação ${ }^{94}$. Afora alguns textos eventuais ${ }^{95}$, Graciliano era responsável por três seções: “Factos e Fitas”, “Garranchos” e “Traços a Esmo” (a mesma rubrica de quando escrevia para o Parayba do Sul). A primeira era composta de epigramas ${ }^{96}$, assinados com o pseudônimo de Anastácio Anacleto. A segunda e a terceira eram espaços privilegiados para a veiculação de sua produção cronística. Em cada uma delas publicou séries de quatorze textos, mantendo-se oculto pelos pseudônimos “X” e “J. Calisto”, respectivamente. Como já indicado no capítulo anterior, Linhas Tortas reuniu apenas doze crônicas da coluna “Traços a Esmo”, deixando, portanto, uma parte significativa dos escritos literatos, estampados em tal jornal sertanejo, ainda inéditos em livro.

Com J. Calisto, Graciliano aprimora o narrador R.O., dando continuidade à criação daquele tipo irônico e sarcástico, que, recorrentemente, sobrepõe-se às personagens e aos fatos narrados, procurando sempre se aproximar do leitor e cativá-lo. Tratava-se de um tipo

\footnotetext{
${ }^{94}$ Em carta ao amigo Pinto Mota Lima, em agosto de 1927, Graciliano comenta sua atividade em O Índio, destacando que só participara das quatorze primeiras edições do periódico (RAMOS, Clara. Mestre Graciliano: confirmação humana de uma obra. Rio de Janeiro: Civilização Brasileira, 1979, p.51).

${ }^{95}$ As crônicas são as seguintes: "Judas”, de 27 de março de 1921, assinado com as iniciais J.C. (de J. Calisto); "Como se escreve", de 3 abril de 1921 e "Solidariedade", de 24 de abril de 1921, ambos rubricados com pseudônimo Lambda, já usado anteriormente pelo autor. Além disso, como indica Moacir Medeiros Sant’ana haveria uma série de outros textos sem assinatura, mas que numa rápida análise estilística e temática poderiam ser atribuídos a Graciliano. Cabe ainda fazer um trabalho mais acurado a fim de detectar aquelas narrativas passíveis de serem incluídas em suas obras completas.

${ }_{96}^{96}$ Textos breves e satíricos que expressam de forma incisiva, um pensamento ou um conceito malicioso.
} 
benevolente, astucioso e gaiato que opina sobre as questões que aborda, valendo-se, mais nitidamente, do humor machadiano.

J. Calisto preocupava-se mais com a captação das práticas sociais em seus aspectos mais corriqueiros, tais como alguns incidentes do cotidiano, a descrição de certos tipos culturais e o questionamento debochado de grandes instituições da sociedade (Igreja, Política, Justiça, Pátria). Isso não quer dizer que ele representasse o real, mas sim, que incorporava discursos sobre esse mesmo real. O narrador dessas crônicas instituiu uma sociedade imaginária - uma comunidade interiorana hipotética, referencia real, onde o narrador também inseria o leitor como personagem.

Desta condição de observador sócio-cultural, o cronista assumia uma postura superior aos que o liam, sem deixar de incorporar elementos de uso comum destes. Vivia constantemente essa relação ambivalente: ao mesmo tempo em que se distanciava, apresentava elementos do próprio cotidiano dos leitores para que estes se identificassem com o relato. O próprio uso de uma linguagem ágil marcada pela oralidade é mostra dessa aproximação. Sua sintaxe oscilava entre a descontração da fala, próxima da conversa entre duas pessoas, e a correção própria da norma culta. No entanto, praticava, ao mesmo tempo, o discurso irônico como forma de argumentação e reflexão, buscando a conivência do destinatário em novas leituras de velhos episódios. Tal opção causava dúvidas, gerava polêmicas, questionava outros discursos amplamente disseminados no corpo social como verdades incontestáveis, exigindo uma postura ativa dos receptores.

A crônica preâmbular do cronista, sob o pseudônimo de J. Calisto, para $O$ Índio esclarece alguns dos procedimentos narrativos identificados acima, ao mesmo tempo em que parecia jogar com as várias funções da linguagem ${ }^{97}$. Primeiramente, ganhava relevo o emissor (função emotiva). Na medida em que este agredia e afagava o leitor, e também se autodepreciava, acabava se apresentando como um personagem excêntrico que centralizava a crônica e buscava cativar seu auditório por meio da inversão irônica:

\footnotetext{
${ }^{97}$ Para definições sobre funções da linguagem, ver JAKOBSON, Roman. Lingüística e Comunicação. São Paulo: Cultrix, 1970. p. 119 a 162.
} 
Estou aqui de passagem. Sou hóspede nesta folha. Quando me der na telha, arrumo a trouxa e vou-me embora. Em minha rápida conversação contigo, meu interesse é muito limitado. Se tiveres paciência de ouvir-me, bem; se não, põe o teu chapéu e raspa-te ${ }^{98}$.

O narrador apresentava-se, na maioria das vezes, por meio de um monólogo na forma de um pseudodiálogo, em que ganhava destaque sua suposta despretensão. Nesse tipo de construção, por mais que o receptor fosse mencionado por meio de vocativos e da segunda pessoa (função conativa), o destaque continuava sendo o emissor:

Prefiro dizer-te francamente o que penso de ti, leitor amigo. Talvez seja assim melhor para nós ambos. Para ti, que procuráras corrigir-te; para mim que ficarei tranqüilo com a minha consciência. Podemos ser bons amigos. É até provável que assim aconteça. Se não acontecer, paciência ${ }^{99}$.

Contudo, no início do texto, há um momento em que o enunciador buscava definir o leitor, inserindo-o de forma direta, no interior da crônica, como um personagem. No entanto, percebe-se que ele adota uma estratégia levemente diferente daquela já observada com o narrador R.O. de O Parayba do Sul, visto acima. Enquanto, este último escrevia da capital do país para um destinatário provinciano, inicialmente desconhecido, procurando testá-lo e gradualmente vencer a distância que os separava, J. Calisto demonstrava, desde o princípio, estar mais próximo e ligado ao horizonte de expectativas da comunidade interiorana em que circulava o jornal $O$ Índio.

[Referindo-se ao leitor] Eu já sei quem tu és. Não é preciso que me digas teu nome, tua profissão, algumas mazelas que por acaso - quem não as possui? - te ornam o caráter. Mas, tu decerto, não queres palestrar com um desconhecido $^{100}$.

Como estratégia de aproximação, aparentemente ambígua, procurava ridicularizar jocosamente seu receptor, objetivando conquistar a atenção e o riso deste. Costumava referirse a ele, predominantemente como "Leitor amigo”, mas há outras menções - "pobre matuto desengonçado” e “rapariga bonita” (a quem se recusaria a fazer gentilezas) - que ajudavam a compor seu estilo, tom e preferências, sempre pautadas pela ironia e pela pseudo-agressão.

\footnotetext{
98 RAMOS, Graciliano, Linhas Tortas. Rio de Janeiro, Record, 2005 p.70. Em tal citação, nota-se uma certa semelhança textual com o "Prólogo ao Leitor” das Memórias Póstumas de Brás Cubas de Machado de Assis: “... se te agradar, fino leitor, pago-me da tarefa; se não te agradar pago-te com um piparote, e adeus ” (ASSIS, Machado de. Memórias Póstumas de Brás Cubas. Rio de Janeiro: Ediouro, 1997, p.12).

${ }^{99}$ RAMOS, Graciliano, op.cit. p.71.

${ }^{100}$ Idem, p.70.
} 
Ainda com relação ao texto de apresentação de J. Calisto, a função referencial, na qual prevalece o uso da terceira pessoa, não apresentaria tanto destaque. A centralização exercida pelo emissor rebaixava a importância do contexto, colocando em relevo a própria enunciação - o pseudodiálogo proferido por esse mesmo narrador.

Por outro lado, a função fática ganhava ênfase, sobretudo, quando J. Calisto, jocosamente, passava a ficcionalizar como fora sua escolha para trabalhar em $O$ Índio. Nesse processo, colocava em xeque o próprio canal, apesar de continuar referindo-se a si mesmo. Ao mesmo tempo, valia-se de uma suposta autodepreciação para caracterizar-se, perante o leitor, como um narrador sincero e autêntico. Tal artifício, já utilizado pelo cronista R.O. tem como objetivo, como já se pontuou, aumentar seu poder de aproximação e de persuasão:

\footnotetext{
No páreo que se fez, para escolher o pessoal desta casa, houve candidatos que se portaram lamentavelmente. Eu que fui o último a atingir a meta, cheguei cansado, deitando alma pela boca, positivamente estropiado. Não obstante, como os concorrentes eram poucos, necessário se fez conceder a todos prêmios de animação. Os que melhor correram estão ali pelo artigo de fundo e circunvizinhanças. Eu e alguns que venceram por uma pequena diferença de cabeças escondemo-nos bisonhamente por estes, recantos ${ }^{101}$.
}

Paralelamente, a metalinguagem marcava seu estilo. Encenava a própria redação dos textos que inventava, retomando aqui o recorrente lugar-comum, próprio do gênero cronístico, de que seus textos ficariam na superfície dos fatos: "Não esperes, pois, encontrar nestas crônicas coisas transcendentes. A profundidade assusta-me e é muito provável que assuste também a ti, leitor amigo. Fiquemos calmamente à superfície»"102

No que diz respeito à função poética, vale-se de uma metáfora dura que reforçava o tom de (pseudo-)agressão e de ironia de seu texto. Simultaneamente, ao comparar-se a alguns medicamentos, aos quais os leitores rotineiramente recorriam, o cronista procurava destacar sua utilidade. Tais elementos, integrantes da idéia de cotidiano da comunidade, corroboravam a estratégia ambivalente do cronista de, ao mesmo tempo, aproximar-se e de distanciar-se do auditório, arrogando-se uma condição superior:

\footnotetext{
${ }^{101}$ Idem, p.72-73.

${ }^{102}$ Idem, p.73
} 
Não desejo ser-te agradável; prefiro ser-te útil. Sou assim uma espécie de vendedor ambulante de sabão para a pele, de ungüento para as feridas, de pomada para calos. Talvez não encontre virtude em meus medicamentos. Pode ser que os calos de tua consciência continuem duros e não sintas melhora na sarna que porventura tenhas na alma, doenças que não te desejo. Em todo caso teu prejuízo será pequeno. O remédio nada te custa. Se a doença te mata tanto pior para ti e para teus credores, mas terás satisfação de dizer que recorreste a uma botica ${ }^{103}$.

Percebe-se nessa crônica, por meio dos recursos utilizados, o esforço do artista em criar uma identidade e um estilo. Nos outros textos, que completavam a seção, continuava a ênfase no próprio narrador: o personagem-cronista J. Calisto que se sobrepunha aos tipos e aos fatos apresentados. Contudo, observa-se aqui um apelo maior para o contexto imediato dos leitores. Ao mesmo tempo em que se apresentava como um ente superior, que observava as situações criticamente, o cronista introduzia elementos inerentes ao cotidiano dos interlocutores para que estes se identificassem, assim como já fora sinalizado acima, possibilitando, portanto, uma comunicação mais próxima e efetiva.

Tal procedimento pode ser observado com mais clareza no momento em que o cronista caracteriza alguns tipos sócio-culturais do universo da pequena cidade inventada em seus textos ${ }^{104}$. As crônicas VII ${ }^{105}$ e VIII ${ }^{106}$ trazem, respectivamente, a “vendedora de bilhetes” e a “mulher que pede esmolas para santos”. Nesses dois textos realiza uma descrição pormenorizada das personagens. A primeira é apresentada como uma mulher sedutora e cativante, que consegue sempre seus objetivos. A segunda, por outro lado, é velha, com uma verruga nas ventas, e exploradora.

Se se levar em conta o senso comum, realiza, portanto, uma inversão irônica. A personagem pagã (que vende bilhetes) é vista com condescendência ao passo que a religiosa (que pede esmolas) aparece como uma usurpadora. A alusão jocosa à religião e aos costumes salta para o primeiro plano ao se referir à “profissão rendosa” da carola:

\footnotetext{
${ }^{103}$ Idem, p. 72. Imagem semelhante fora utilizada anteriormente por Bilac: "Os cronistas são como bufarinheiros, que levam dentro das suas caixas rosários e alfinetes, fazendas e botões, sabonetes e sapatos, louças e agulhas, imagens de santos e baralhos de cartas, remédios para a alma e remédios para calos, breves e pomadas, elixires e dedais” (DIMAS, Antonio. Bilac, o Jornalista. São Paulo: EDUSP; Imprensa Oficial; Editora Unicamp, 2006. v.1, p.631).

${ }^{104}$ Tais tipos povoam a pequena cidade do interior criada pelo autor, que teria como referente imediato Palmeira dos Índios, ou seja, o espaço de circulação do jornal. Ao mesmo tempo, estariam presentes na farta tradição literária dedicada a representação da vida provinciana, da qual, por exemplo, o futuro romance Caetés (1933) do autor fará parte.

${ }^{105}$ J. CALISTO [Graciliano Ramos]. Traços a Esmo VII. O Índio, Palmeira dos Índios, 06 mar. 1921.

${ }^{106}$ J. CALISTO [Graciliano Ramos]. Traços a Esmo VIII. O Índio, Palmeira dos Índios, 13 mar. 1921.
} 
Entre os múltiplos retratos de personagens celestes que lhe enchem o altar, a mulher que pede esmolas possui sempre um santo de resistência, espécie de oráculo da vizinhança, hábil e conhecido fazedor de milagres, com uma grande autoridade que lhe dá a velhice. Muitas vezes vem de outra geração, pertenceu a uma avó ou bisavó da proprietária atual, que também explorava a indústria santeira, com algum êxito; já que naqueles temo se revelava um razoável milagreiro. Com os anos, naturalmente, crescem-lhe a virtude [...] As promessas cumprem-se, que ele quase nunca deixa de tomar em consideração a súplica dos crentes. Dor de dentes, engasgos, reumatismo, abscesso, feridas, torcicolos, mal de empalamados, doenças de olhos, dentições complicadas, tudo é motivo para importações ao orago e conseqüente paga à criatura que dele vive ${ }^{107}$.

Tal tratamento sarcástico e invertido de práticas e instituições consagradas, portadoras de forte apelo popular, repete-se na crônica $\mathrm{IX}^{108}$, na qual volta a abordar a religião. Aqui, discorre, com a pseudo-sinceridade habitual, sobre a conduta dos cristãos durante a Semana Santa. Contrariamente ao que se esperava do preceito religioso do jejum, conclui ironicamente que nessa época do ano ocorria uma larga indigestão entre os penitentes que devoravam tudo "com fé”:

'A carne é fraca.' É dos evangelhos. Pelo menos foi o que me disseram, e eu não tenho motivo para duvidar. Ora, é inegável que o estômago seja feito de carne. Como exigir, pois, da fraqueza deste pobre órgão, elasticidade bastante para transformar numa jibóia o mísero bípede religioso que nós somos ${ }^{109}$.

O cronista também se aproxima do universo do leitor quando particulariza temas nacionais. O futebol, o carnaval e hinos de louvor à pátria são observados por J. Calisto a partir de certa perspectiva sertaneja, com o mesmo rebaixamento irônico e humorístico que o caracteriza. Como é comum nos “Traços a Esmo”, ao tratar, por exemplo, da introdução do futebol no país, na crônica $\mathrm{XI}^{110}$, o cronista realiza uma pseudodissertação com finalidade humorística. Arrogando-se seriedade, profetiza que o esporte seria passageiro, visto que não passava de uma imposição externa. Ele seria o reverso da índole do povo brasileiro, sobretudo o do sertão nordestino, menos aberto a estrangeirismos, quando comparado com a população das cidades litorâneas. Para ressaltar a incompatibilidade entre o país e a nova prática, lança mão de palavras ásperas para descrever o interior nordestino, região marcada, segundo ele, pela inanição, pobreza e preguiça:

\footnotetext{
${ }^{107}$ Idem, p.98-99.

108 J. CALISTO [Graciliano Ramos]. Traços a Esmo IX. O Índio, Palmeira dos Índios, 27 mar. 1921.

109 Idem, p.103.

${ }^{110}$ J. CALISTO [Graciliano Ramos]. Traços a Esmo XI. O Índio, Palmeira dos Índios, 10 abr. 1921.
} 
Fisicamente falando, somos uma verdadeira miséria. Moles, bambos, murchos, tristes - uma lástima! Pálpebras caídas, beiços caídos, braços caídos, um caimento generalizado que faz de nós o ser desengonçado, bisonho, indolente, com ar de quem repete, desenxabido e encolhido a frase pulha que se tornou popular: 'Me deixa...'111.

J. Calisto, portanto, mantém o mesmo ideal de verossimilhança artística já manifestado anteriormente por R.O.: apenas imagens desabonadoras do mundo seriam "autênticas". Tal perspectiva ganha força ao tratar do sertão, pois assim como seus leitores, por mais que ironicamente procure se diferenciar destes, também seria um sertanejo. E invoca constantemente essa condição para melhor persuadir, pois sinaliza por meio dela, que conhece bem a matéria de que trata, valendo-se, inclusive, de termos lexicais específicos. Respaldado por essa ancoragem no real, porta-se como um narrador não confiável, um especialista, que descreve, seleciona e comenta de uma perspectiva favorável a seus interesses. Sua nãoconfiabilidade decorre do ato de dizer uma coisa para sugerir outra. Ainda a crônica XI, sobre o futebol, pode exemplificar tal postura. Nela, J. Calisto preconiza o retorno àquilo que imagina ser as fontes brasileiras. Para ele a rasteira seria o verdadeiro esporte nacional. Tal modalidade prevaleceria em todas as áreas. Nessa aproximação, carrega o tom de deboche e de ironia:

\footnotetext{
Todos nós vivemos mais ou menos a atirar rasteira nos outros. Logo na aula primária habituamo-nos a apelar para as pernas quando nos falta confiança no cérebro - e a rasteira nos salva. Na vida prática, é claro que aumenta a natural tendência que possuímos para nos utilizar eficientemente da canela. No comércio, na indústria, nas letras e nas artes, no jornalismo, no teatro, nas cavações, a rasteira triunfa. Cultivem a rasteira amigos ${ }^{112}$ !
}

Buscando uma forma mais visível de contato com os leitores, o narrador J. Calisto abre espaço para correspondências enviadas por estes. Utiliza tal procedimento em três crônicas. O recurso surge, por exemplo, como um meio para instaurar uma (falsa) polêmica na crônica $\mathrm{V}^{113}$. O cronista compila integralmente uma suposta missiva "de um jurado a um cavalheiro de importância", realizando apenas a seguinte interferência no final do texto: "Esta carta foi-

\footnotetext{
${ }^{111}$ Idem, p.111.

${ }^{112}$ Idem, p.114-115.

${ }^{113}$ J. CALISTO [Graciliano Ramos]. Traços a Esmo V. O Índio, Palmeira dos Índios, 27 fev. 1921.
} 
nos confiada por um cavalheiro de influência, que nos deu autorização para publicá-la. O original se encontra sob nosso poder"114.

Em tal carta anônima, um jurado vendido oferece seus serviços a uma pessoa também não nomeada, numa linguagem impostada, digna de um magistrado. De maneira geral, o missivista procurava justificar e atestar a eficiência dos meios de que se valia para inocentar qualquer réu. Segundo ele, por meio do discurso seria possível inverter a lógica de qualquer fato. O absurdo das considerações desse enunciador, apresentadas como coisa séria, levariam ao riso. Paralelamente, a repetição de tal tópica sobre o relativismo discursivo da verdade, comum ao longo da série “Traços a Esmo”, faz crer que a missiva seja uma invenção declarada do cronista, que buscaria discutir elementos associados à instituição judiciária com seus leitores. Ao mesmo tempo em que a introdução do suposto documento conferia mais "veracidade" ao texto, afastava J. Calisto da responsabilidade de autoria daquelas linhas. No entanto, por mais que a carta tenha realmente existido, a sua simples publicação no jornal já indica o peso da escolha do cronista ${ }^{115}$.

Na crônica $\mathrm{X}^{116}$, a mesma falsa polêmica é retomada e o diálogo continuado. J. Calisto declara ter recebido uma outra carta que o questionava por ter aberto espaço à missiva do jurado, que agora a assume como sendo de sua autoria. Dessa vez, o remetente, também anônimo, criticava-o por ter estimulado os cidadãos pacíficos de Palmeira dos Índios a se tornarem criminosos como o juiz de fato mencionado. De maneira irônica, o cronista se diz agradecido, pois seu crítico o julgara tão forte, a ponto de influir sobre a índole de seus compatriotas. Ele “agradece as verdades ditas”, e se diz “positivamente escangalhado”, rebaixando-se ironicamente diante de seu antagonista:

Declaro-me, com medo de nova investida, redondamente vencido e convencido para todos os efeitos. E se aqui exponho as razões que o meu desproporcionado antagonista superiormente joga contra as

\footnotetext{
${ }^{114}$ Idem, p.91.

${ }^{115}$ Em tal crônica, aparece uma referência a um suposto réu chamado Manuel Tavares. Este também seria o nome de um réu injustamente inocentado, presente no livro Caetés. Nesta obra, João Valério, narrador em primeira pessoa, comenta a redação de uma tira sobre a soltura do referido criminoso para o jornalzinho de padre Atanásio: “'Jurado amigo...' Carta a um juiz de fato, mofina contra o júri, que absolveu Manuel Tavares, assassino. Depois de muito esforço consegui descrever o tribual, o presidente magro e asmático, gente nos bancos, o advogado triste e com a barba crescida, o dr. Castro soletrando o libelo” (RAMOS, Graciliano. Caetés. 4. ed. Rio de Janeiro: Livraria José Olympio Editora, 1953, p.176-177).

${ }^{116}$ J. CALISTO [Graciliano Ramos]. Traços a Esmo X. O Índio, Palmeira dos Índios, 3 abr. 1921.
} 
desgraçadas linhas que inconsideradamente rabisquei, é que desejo penitenciar-me declarando com honestidade ao público que sou um jumento ${ }^{117}$.

Seu falso arrependimento reforça o tom de ironia. Logo em seguida, insinua que o papel do cronista seria revelar a crueza da vida sem idealizações, retomando certa noção de verossimilhança artística, esboçada anteriormente. Por meio desse diálogo efetivo estabelecido com um leitor (e que pode ser estendido a todos os outros), o narrador mais uma vez encena sua condição dual de simultaneamente aproximar-se e afastar-se de seu interlocutor.

\subsubsection{A série "Garranchos”}

Em sua relação com os destinatários, o cronista “ $X$ ”, da série “Garranchos”, adotava estratégia narrativa diferente. Ele procurava deixar de lado as alusões e ironias oblíquas de J. Calisto para construir um discurso mais direto e participativo, assumindo, muitas vezes, a condição de defensor da população palmeirense representada pelo jornal. Para tanto, recorrentemente, vale-se de um tom opinativo e mordaz de polemista, dispensando moderadamente as pseudo-grosserias jocosas vistas anteriormente.

Conseqüentemente, “X” desejava constituir-se como um narrador mais confiável, que deixava de lado a ênfase na interlocução e a tematização do espaço ficcional no interior da própria crônica. Diferentemente dos “Traços a Esmo” também, privilegiava a função didática em detrimento da estética, procurando acentuar o nível de redundância da narrativa.

Em três oportunidades, protagoniza uma campanha em defesa do incremento da instrução pública no município. Na primeira delas, a crônica de número de IV, de 20 de fevereiro de 1921, apela para o argumento da suposta relação entre a degradação moral da população, sobretudo das crianças, e o analfabetismo com intuito de sensibilizar seus interlocutores habituais e, ao fim, o próprio governo. Destaca que na cidade, criavam-se diariamente centros de diversões, mas não se abria nenhuma escola:

E a ignorância aumenta, e os crimes multiplicam-se! Temos (miséria!) escolas de vício, aprendizagem de crimes, escadas para a prostituição. É a casa de jogo, é o álcool, é a aluvião de mendigas, crianças à puberdade, que infestam a cidade, oferecendo-se quase.

${ }^{117}$ Idem, p.106. 
E não falarão essas misérias todas bastante alto para penetrar os ouvidos do governo? Não estarão ainda bem expostas à luz as pústulas que maculam a alma das multidões sertanejas?

Abri escolas, senhores do governo, esses 'viveiros da esperança', como lhes chamou Rosendo Muniz, e tereis prestado um grande bem a nossa pátria ${ }^{118}$.

Duas semanas depois, na crônica VI, de 6 de março de 1921, o cronista lança mão do mesmo argumento: "Voltamos a encarar de novo o grave mal que ameaça derruir a moral do povo: o analfabetismo. A ignorância arrasta, a passos gigantescos, a multidão sertaneja ao abismo tenebroso do crime!”119. No entanto, procurando ampliar o efeito de real de sua narrativa, lista uma série de relatos de crimes, ocorridos em diferentes lugares do sertão, que teriam como motivação a suposta ignorância do povo: uma criança morta por seu tio a golpes de enxada; um rapaz estrangulado por um policial em praça pública; um homem apunhalado por motivos fúteis. Seguindo a lógica do texto, tendo em vista a construção da relação causal supracitada, o cronista simplifica a resolução do problema:

Urge, pois, que se ponha termo a tamanhas misérias.

Como fazê-lo?

Projetando na treva que há na alma do analfabeto o clarão radioso que vem do livro! ${ }^{120}$.

Entre os dois últimos textos vistos acima, na crônica V, de 27 de fevereiro de 1921, X particulariza a precariedade da instrução fornecida ao povo, tematizando os supostos hábitos de leitura dos receptores do semanário em que escreve. Tal estratégia aproxima, deliberadamente, o tema do universo de seus destinatários:

Andamos, positivamente a passos de tartaruga em questões de letras. Toda a gente, quase, aqui assina jornais, e quase ninguém aqui lê os jornais que assina. Se lê não compreende. E, por não saberem ler e pela vaidade que tem os ignorantes de entenderem de tudo, indivíduos há que têm uma maneira muito original de julgar a obra pelo título e pelo nome que a subscreve, sem a ler, entretanto ${ }^{121}$.

\footnotetext{
${ }^{118}$ X [Graciliano Ramos]. IV, O Índio, Palmeira dos Índios, 20 fev. 1921.

${ }^{119}$ X [Graciliano Ramos]. VI, O Índio, Palmeira dos Índios, 6 mar. 1921.

${ }^{120}$ Idem, ibidem.

${ }^{121}$ X [Graciliano Ramos]. V, O Índio, Palmeira dos Índios, 27 fev. 1921.
} 
À medida que vai construindo seu discurso sobre a cidade, de acordo com tal perspectiva de orientador social, $\mathrm{X}$ continuava a privilegiar a tematização de supostos problemas que afligiam os munícipes, tais como a precariedade da iluminação pública, sobretudo a falta de eletricidade durante os sábados; as melhorias no abastecimento de água que custariam caro à população; a falta de um portão no cemitério, o que levava cães, porcos e galinhas a revirarem os túmulos; a ausência de árvores nas ruas; a precariedade do cinema local, incompatível com a modernidade da qual a cidade aspirava fazer parte, entre outros. Como dizia realizar a leitura mais adequada dos atos e práticas das diversas instituições e empresas locais, colocava-se na função de ecoar a opinião geral de que as dificuldades apontadas precisavam de rápida solução.

\subsubsection{O final de sua colaboração em $O$ Índio}

De acordo com o discurso de seus familiares, consta que Graciliano teria abandonado o jornal em função de uma indiscrição: o semanário teria emitido uma nota comemorativa pelo aniversário de seu pai, Sebastião Ramos, fazendo referência a sua atividade como colaborador. Essa atitude teria supostamente desmascarado seu pseudônimo, o que revelaria o valor dispensado pelo escritor ao anonimato ${ }^{122}$. Embora se desconheça as verdadeiras motivações da saída do cronista, Valentin Facioli afirma que essa explicação não seria convincente. Segundo ele, os pseudônimos utilizados pelo cronista, provavelmente, não seriam um grande segredo, “pois numa cidade como Palmeira dos Índios, em 1921 difícil imaginar que os leitores do jornalzinho não soubessem quem as escrevia [as crônicas]”"123. Além disso, padre Macedo, o editor, não teria se mostrado intransigente, mesmo com seu colaborador não revelando "qualquer compromisso com a ideologia católica, mesmo a mais liberal na época e lugar”,124.

O que se sabe é que duas edições após ter abandonado a publicação, Graciliano volta às páginas desta para responder à referida nota. Assinando agora G. Ramos, acaba lançando mão de uma falsa polêmica jocosa. Ele nega ter colaborado em $O$ Índio, ironizando que não sabia escrever e que não merecia tal honra ${ }^{125}$.

\footnotetext{
${ }^{122}$ RAMOS, Clara. op.cit. p.51.

${ }^{123}$ FACIOLI, Valentin. Um homem bruto da terra. In: BOSI, Alfredo et al. op.cit. p.39.

${ }^{124}$ Idem, ibidem.

125 Tal afirmativa não passava de pura ironia, pois como se sabe, mesmo no sertão Graciliano era considerado um homem de letras nesse momento: lecionava francês no Colégio Sagrado Coração, ensinava, sem formalidades
} 
Ora não tive a honra de trabalhar nesse semanário. Nunca juntei idéia para a fabricação de artigos, crônicas, notícias; nunca juntei tipos para a composição da prosa com que gente hábil enche linguados; nunca juntei os braços para puxar a alavanca do prelo que ali guincha e grita à noite, ao dar à luz o pensamento rabiscado em pedaços de papel com que se embrulha o público. Qualquer das três ocupações seria magnífica para mim, mas não quero receber o que me não pertence”126

Além disso, logo em seguida, divide a vida do jornal em duas fases: as quatorze primeiras edições e as duas últimas. O primeiro estágio, justamente o que colaborou, seria ruim. $\mathrm{O}$ segundo, por outro lado, seria brilhante:

Observei, com grande prazer, que esse hebdomadário passou por uma transformação radical. Encontrase agora muito melhorado, e não me posso esquivar a aqui lhes enviar as minhas mais calorosas felicitações. Até o número quatorze, esteve ele em estado de larva; hoje é a borboleta livre a esvoaçar com brilho e graça.

A qual das duas fases teria eu pertencido, na hipótese de deixar passar sem protesto a notícia que os senhores deram? Certamente à primeira, pois a segunda conta apenas duas semanas. (...)

O Índio tem apenas dois números bons - os últimos. Os outros, com exceção talvez de um artigo ou outro, estão perfeitamente desarranjados, cá em minha opinião ${ }^{127}$.

Assim, dissimuladamente, renega ao mesmo tempo em que debocha de seus próprios escritos, reforçando, por meio da ironia, a idéia de que seus pseudônimos eram conhecidos de todos ${ }^{128}$.

\subsection{Jornal de Alagoas e a revista Novidade: política e letras na capital alagoana}

escolares, português e gramática para grupos de pessoas, assinava vários jornais do Rio de Janeiro e solicitava livros pelos catálogos das editoras Alves, Garnier e Mercure de France (as duas primeiras da capital federal e a última de Paris).

${ }^{126}$ RAMOS, G. "Vi no último número desse jornal...”. O Índio, Palmeira dos Índios, 22 mai. 1921. Texto ainda inédito em livro.

${ }^{127}$ Idem, ibidem.

${ }^{128}$ Em carta, agora reservada, ao amigo Mota Lima, em agosto de 1921, torna a rebaixar seus textos de O Índio: “Censuras-me por não te haver mandado o jornal cá da terra. Foi um esquecimento muito natural. Não me passou que tivesses interesse em ver semelhante borracheira. É uma porcaria. Estará, talvez, um pouco menos mau depois de minha saída, mas ainda assim não presta. É, realmente, de admirar que eu tivesse trabalhado nele, de parceria com um padre (...) Tenho apenas os quatorze primeiros números, que foram os que fiz. Vou ver se consigo os outros. Mas sempre te aconselho a que não percas te tempo em ler semelhante maluqueira” (RAMOS, Graciliano. Cartas. Rio de Janeiro: Record, 1981, p.71-72). 
Como se sabe, entre janeiro de 1928 e março de 1930, Graciliano assume o cargo de prefeito de Palmeira dos Índios. Por meio de dois relatórios de prestação de contas que envia ao governador das Alagoas a época, Álvaro Paes, passa a ser reconhecido como homem público e escritor fora da província, alçando, inclusive, certa notoriedade em âmbito nacional. Ambos os documentos tornaram-se imediatamente públicos e conseguiram recepção extremamente favorável em diferentes órgãos de imprensa. O primeiro deles, depois de ganhar as páginas do Diário Oficial, em 1929, e de ser louvado pelo chefe do Estado ${ }^{129}$, é tomado pelo Jornal de Alagoas como um texto dos “dos mais expressivos e interessantes”130. Em seguida, numa reação em cadeia, outros periódicos alagoanos, O Semeador ${ }^{131}$ e o Correio da Pedra ${ }^{132}$, tratariam do mesmo. Trechos dele ainda seriam publicados no Rio de Janeiro no Jornal do Brasil e em A Esquerda, dirigido por Pedro Mota Lima ${ }^{133}$.

Contrariando o que se esperava de tais escritos burocráticos, marcados usualmente pela impessoalidade, pela redundância e pelo rigor formal pressuposto pelo uso do papel timbrado e pela configuração de um destinatário hierarquicamente superior, Graciliano Ramos vale-se do uso da primeira pessoa e de uma linguagem mais prosaica, em consonância com que se entendia como literatura moderna na época, sobretudo após o Modernismo. A realizar tal transgressão, o narrador procurava construir para si uma imagem pautada pela correção, pela austeridade e, principalmente, pela sinceridade, adotando muitas vezes um tom confessional. Ao mesmo tempo, valendo-se de estratégia semelhante a já observada com seus cronistas anteriores, (pseudo)rebaixa-se perante seu interlocutor a fim de melhor se aproximar dele e sensibilizá-lo:

\footnotetext{
${ }^{129}$ Em mensagem ao Congresso Legislativo, posteriormente publicada no Diário Oficial, em 1929, sob o título “Palmeira dos Índios”, Álvaro Paes destaca: “A administração de Palmeira dos Índios continua a oferecer um exemplo de trabalho e honestidade, que coloca o Município numa situação de destaque. /A ação do prefeito, forte e inteligente, se faz sentir nas iniciativas e realizações que têm concorrido para o engrandecimento do Município” (In: LIMA, Mário Hélio Gomes de. Relatórios. Rio de Janeiro: Record, 1994, p.78).

${ }^{130}$ JORNAL DE ALAGOAS, Maceió, 25 jan. 1929.

${ }^{131}$ Segundo Sant'ana, tal publicação católica, em série de artigos intitulada “A Prefeitura de Palmeira”, abordou os relatórios de Graciliano em três oportunidades: 25 de janeiro e 4 e 5 de fevereiro de 1929 (SANT’ANA, Moacir Medeiros de. História do romance Caetés. Maceió: Arquivo Público de Alagoas; SEC, 1983, p.13-14).

${ }^{132}$ PREFEITOS laboriosos. Correio da Pedra, Pedra, 15 set. 1929. Este mesmo jornal, em março de 1930, a propósito do segundo relatório do então prefeito Graciliano Ramos, publicara o editorial "Um administrador”, no qual defende tanto a diligência do escritor na condução dos negócios públicos quanto a linguagem irônica empregada pelo mesmo no documento oficial.

${ }^{133}$ SANT’ANA, Moacir Medeiros de. op.cit. p.14.
} 
Convenho em que o dinheiro do povo poderia ser mais útil se estivesse nas mãos, ou nos bolsos, de outros menos incompetentes do que eu; em todo o caso, transformando-o em pedra, cal, cimento etc., sempre procedo melhor que se o distribuísse com os meus parentes, que necessitam, coitados ${ }^{134}$.

O prefeito-escritor retoma ainda a ironia, o sarcasmo e a galhofa que também marcaram seus escritos enquanto R.O. e J. Calisto, injetando humor em meio à seriedade presumida pelo documento oficial:

Dos funcionários que encontrei em janeiro do ano passado restam poucos. Saíram os que faziam política e os que não faziam coisa nenhuma. Os atuais não se metem onde não são necessários, cumprem as suas obrigações e, sobretudo, não se enganam em contas. Devo muito a eles ${ }^{135}$.

O narrador vale-se também de inúmeros objetos e assuntos já tematizados em seus textos jornalísticos anteriores, sobretudo os de $O$ Índio, tais como a proliferação de pequenos prefeitos na administração municipal, a precariedade da instrução, problemas com a iluminação pública, entre outros.

Logo em seguida, depois de renunciar ao cargo de prefeito ${ }^{136}$, Graciliano assume a direção da Imprensa Oficial do Estado de Alagoas, a convite do governador Álvaro Paes, e se muda para Maceió. Lá, passa a conviver com o grupo de jovens intelectuais que se formara na cidade (José Lins do Rego, Rachel de Queirós, Jorge de Lima, Aurélio Buarque de Holanda, Alberto Passos Guimarães, Valdemar Cavalcanti, Santa Rosa, entre outros) e a colaborar com a imprensa da capital alagoana, chegando, inclusive, a se tornar sócio da Associação Alagoana de Imprensa no biênio 1931-1933 ${ }^{137}$.

\footnotetext{
${ }^{134}$ RAMOS, Graciliano. Viventes das Alagoas. Rio de Janeiro: Record, 2007, p.201.

${ }^{135}$ Idem, p.194.

${ }^{136}$ A 10 de abril de 1930, em telegrama lacônico, Graciliano comunicou ao chefe do governo estadual sua renúncia: Exmo. Governador do Estado. - Maceió - Comunico a V. Excia. que hoje renunciei ao cargo de Prefeito deste município. Saudações, Graciliano Ramos” (SANT’ANA, Moacir de Medeiros. Graciliano Ramos: vida e obra. Maceió: Secretaria de Comunicação Social, 1992, p.37).

${ }^{137}$ Ver RAMOS, Ricardo. Graciliano: retrato fragmentado. São Paulo: Siciliano, 1992.
} 
Colabora principalmente no Jornal de Alagoas $^{138}$, periódico governista, um dos mais importantes de Maceió, ora utilizando o pseudônimo "Lúcio Guedes”, ora assinando as crônicas com as iniciais G.R.. Residindo e escrevendo na capital, passa a privilegiar assuntos de abrangência estadual na medida em que procurava se aproximar e participar do diálogo com os habitantes da cidade litorânea, representados pelo jornal em questão. Nos seis textos que nele publica, ao longo do ano de 1930, detém-se quase que exclusivamente na tematização de certas práticas políticas alagoanas, procurando evocar, direta ou indiretamente, os avanços modernizadores da gestão do governador Álvaro Paes em contraposição ao que ocorria nas administrações anteriores. Tal conjunto de textos constituem uma unidade

Nas crônicas "Macobeba Pré-Histórico",139 e "Macobeba Antigo"140, feitas em seqüência, o narrador associa a trajetória de um candidato que perdera certa disputa eleitoral feita recentemente ao relato das origens de um ser fantástico e ameaçador chamado Macobeba. Tal figura mitológica fora imaginada por José Matias, no jornal A Província do Recife, em 1929, e logo depois, cantada em folhetos por poetas populares. Uma das cantigas dizia:

\author{
É um tal de Macobeba \\ Bicho feio e valentão \\ Tem quatro olhos enormes \\ Que parece ser o cão, \\ Tem as unhas tão compridas \\ Que nem mesmo um gavião (...) \\ Faz o diabo Macobeba; \\ Devasta tudo onde passa, \\ Derruba porta de engenho \\ Bebe toda cachaça, \\ 'E sai como um pé de vento
}

\footnotetext{
138 O Jornal de Alagoas é lançado em 1908. Em 1914, com o intuito de divulgar informações referentes ao conflito armado que se transformaria na I Guerra Mundial, passa a ter duas edições diárias. Em 20 de fevereiro de 1920, já apresentava um formato moderno, com oito páginas. Foi o primeiro periódico a oferecer, em suas edições dominicais, um suplemento semanal ilustrado que tratava, entre outras coisas, de literatura. Em 1926, estampava a primeira página exclusivamente literária da imprensa alagoana, sob a direção do poeta Lobão Filho. Em 08 de julho de 1936, é incorporado pela cadeia dos Diários Associados de Assis Chateaubriand (ver SANT’ANA, Moacir Medeiros. Historia da Imprensa Alagoana (1831-1981). Maceió: Arquivo Público de Alagoas, 1987).

139 GUEDES, Lúcio [Graciliano Ramos] Macobeba Pré-Histórico. Jornal de Alagoas, Maceió, 27 abr. 1930. Texto ainda inédito em livro.

${ }^{140}$ GUEDES, Lúcio [Graciliano Ramos] Macobeba Antigo. Jornal de Alagoas, Maceió, 29 abr. 1930. Texto ainda inédito em livro.
} 
Inda soltando fumaça ${ }^{141}$.

No primeiro dos textos de Graciliano, tal ente mitológico é apresentado como um salvador imaginário, criado pelo povo alagoano num período supostamente remoto. Como a população se sentia fraca para acabar com certas práticas coronelísticas vigentes, construiu a imagem de um "super-homem com atributos característicos das divindades grosseiras daquela época”, a qual lhes teria infundido a coragem necessária para vencer. Em pouco tempo, certos tipos bacharelescos, vinculados a estratos coronelísticos, assumiram o lugar de tal figura imaginada e passaram a se afirmar, perante todos, como "Macobebas", que passaram a povoar as Alagoas:

Houve talvez dois Macobebas. O primeiro, nascido numa idade heróica, tinha como todos os heróis que se respeitam, uma existência subjetiva; o segundo, atual e bacharel, é um ser de carne e osso, como qualquer um de nós. Julgo que este foi pouco a pouco tomando o lugar daquele, até confundir-se com ele e, de longe, parecerem formar os dois um todo indivisível ${ }^{142}$.

Ao chegarem ao poder, tais sujeitos de carne e osso, revestidos de caráter divino pelo consentimento e pela sujeição popular, deixaram de lado os desejos daqueles que os tinham engendrado e passaram a advogar em causa própria, adotando um comportamento destruidor. Práticas como nepotismo, clientelismo, violência, amizade com assassinos e ladrões de cavalos, entre outros vínculos espúrios, passam a dar o tom de seu mandonismo avassalador sobre o aparelho do Estado:

\footnotetext{
Alagoas macobebizou-se. Da capital aos mais remotos sertões fervilhavam bichos destruidores de incisivos aguçados e caninos enormes, que estragavam, sem cerimônia o que iam encontrando. Uns devoravam com avidez. Outros se contentavam roendo modestamente, mas coisa que lhes caísse entre as garras era coisa roída ${ }^{143}$.
}

Em certo sentido, tendo em vista o caráter alegórico da narrativa, o mostro salvador pode ser associado à República, mais especificamente a determinados bacharéis que se apossaram do aparelho do Estado a partir de então. O tom lastimoso, mas, sobretudo, irônico do texto

\footnotetext{
${ }^{141}$ AZEVEDO, Vivice. Apports inédits à l’oeuvre de Graciliano Ramos. In: Graciliano Ramos: Vidas Secas (séminaires de février et juin 1971). Poitiers: Centre de Recherches Latino-Américaines, da Universidade de Poitiers. 1977, p.119-120.

142 GUEDES, Lúcio [Graciliano Ramos]. Macobeba Pré-histórico. Jornal de Alagoas, Maceió, 27 abr. 1930 , p.3.

${ }^{143}$ GUEDES, Lúcio [Graciliano Ramos]. Macobeba Antigo. Jornal de Alagoas, Maceió, 29 abr. 1930, p.3.
} 
remete a certo sentimento de descontentamento com a nova classe dirigente, que tomou conta da intelectualidade após $1889^{144}$.

No entanto, como insinua o cronista logo em seguida, tal situação estaria mudando de rumos no Estado. Os bacharéis e coronéis farsantes, que se revestiam da aura mitológica do ser fantástico para amedrontarem a população e controlarem o aparelho do Estado de maneira autoritária e destruidora, gradualmente estavam sendo desmistificados e, dessa maneira, perdiam também parte de sua força vingadora. Ao final, fechando o movimento alegórico produzido pela narrativa, a aparente derrota e o sorriso desconfiado de Macobeba podem ser lidos como índices de que a velha política individualista e interesseira, corporificada por tais sujeitos que se faziam passar por monstros devoradores, estaria perdendo espaço para o governo modernizador e interessado pelo bem da coletividade de Álvaro Paes.

Adesão explícita de Graciliano à administração de Álvaro Paes, confirma-se em seu texto seguinte. Trata-se de uma crônica encomiástica, assinada com as iniciais G.R., que tinha como título o próprio nome do governador, objeto de louvor do artista ${ }^{145}$. Como estratégia retórica para disfarçar o elogio e criar a sensação de que dizia estritamente a "verdade”, o articulista destaca que deixaria de lado "excelências e adjetivos” e falaria não do político, mas do homem Álvaro Paes. Ao mesmo tempo em que o exaltava, procurava aproximá-lo dos cidadãos comuns do Estado. Seguindo tal perspectiva, o narrador valorizava, sobretudo, a iniciativa do governante de deixar o gabinete e viajar semanalmente por todo o sertão, com o objetivo de implantar suas idéias e de estimular, in loco, o desenvolvimento das Alagoas.

Apesar das ressalvas iniciais quanto à ausência de "excelências e adjetivos” na descrição do chefe do estado, o cronista acaba descrevendo-o como alguém bondoso, paciente, modesto, obstinado, generoso, delicado e brando: um rol de qualidades que procuram exaltar o trabalho e as atitudes sempre construtivas do governador:

\footnotetext{
${ }^{144}$ Tal como faz crer, por exemplo, Sevcenko, recuperando depoimentos de Euclides da Cunha do início do século XX: "A sociedade nascida com o novo regime passava por um processo turvo de "desencanto" - a "selva escura" - dando origem a uma "época de cerrado utilitarismo”, em que "a situação e dos espertos”. (...) As transformações sociais, políticas e econômicas, ao contrário do que se esperava, só trouxeram a exacerbação do egoísmo e do interesse na luta por cargos e comissões altamente remunerados, acompanhada pelo maior desprezo e indiferença pelos assuntos públicos. Existe apenas a determinação de atirar por terra tudo o que está feito; o desalojar as posições para realizarem um único ideal - ocupá-las” (SEVCENKO, Nicolau. Literatura como missão. São Paulo: Editora Brasiliense, 1983, p.146-147).

145 G.R. [Graciliano Ramos]. Álvaro Paes. Jornal de Alagoas, Maceió, 12 jun. 1930. Texto publicado posteriormente em Linhas Tortas.
} 


\begin{abstract}
Álvaro Paes tem prestado a Alagoas serviços que não prestaria se andasse de capacete e lança, vendo nas prefeituras do interior moinhos para desmantelar. Não desmantelou os moinhos. Aproveitou-os e, com habilidade sutil, convenceu-os de que eles eram excelentes máquinas, quando na realidade era ele que os impulsionava. E os moinhos entraram a bracejar com vigor, e cada um deles ficou certo de ser o melhor moinho do Estado (...) Álvaro Paes transformou-se num infatigável caixeiro-viajante. E, com pertinácia admirável, andou e anda a semear idéias novas, idéias que tem desenvolvido e preconizado em artigos, em livros, em discursos, em palestras, em cartas, em telegramas, em mensagens, em confidências ${ }^{146}$.
\end{abstract}

A criação desta imagem favorável do governador contrapõe-se diretamente ao destrutivo, assustador e terrível Macobeba, evocado nas crônicas anteriores. Enquanto o monstro mitológico encarnava a brutalidade e a malandragem na esfera política, exibindo superioridade e poder, Álvaro Paes, um sujeito de carne e osso, humildemente visitava os municípios sertanejos e entrava em contato direto com os "matutos". Por meio de tal oposição, o cronista procura valorizar o novo paradigma administrativo que teria sido instituído pelo chefe do Estado naquele momento. Paralelamente, ao explicitar tal posicionamento, Graciliano utilizava a literatura como instrumento político, participando do sistema de poder local, mediante a produção de textos que corroboram a administração do então chefe do Estado.

Para se ter uma idéia, o número do Jornal de Alagoas, de 12 de junho de 1930, no qual aparece estampada a crônica “Álvaro Paes”, de Graciliano, foi quase inteiramente dedicado à comemoração do segundo ano de mandato do governador. A publicação governista partia dessa efeméride para louvar, sem restrições, as realizações do chefe de Estado. Na primeira página, ao centro, estampava-se uma foto do político e, à esquerda, avultava o editorial "Um governo dinâmico”, que, em perspectiva semelhante àquela manifesta pelo artista alagoano, engrandecia as realizações do chefe do executivo estadual:

O preclaro político que nos governa não se deixa ficar no seu gabinete, dizendo por telegramas o que se deve fazer (...) Prefere, portanto, examinar de perto os que trabalham e os que deixam de fazer. Destarte viaja todas as semanas sozinho, sem avisos prévios, sendo recebido em todos os lugares, por onde passa como qualquer cidadão. (...) Alagoas, hoje, no meio do contentamento mais eloqüente e mais sincero,

${ }^{146}$ Idem, ibidem. 
saúda o seu preclaro governador, que lhe está impulsionando todas as energias, num ritmo permanente de beleza cívica, em busca de seu engrandecimento ${ }^{147}$.

Logo em seguida, com os dois textos da série "Prefeituras Municipais”, o Graciliano buscava, seja descrevendo certas medidas governamentais, seja analisando o desenvolvimento de diferentes cidades do Estado, iluminar com mais detalhes o aparente progresso alcançado por Alagoas na gestão Álvaro Paes. Para tanto, contrapõe-no à estagnação e ao atraso dos governos passados. Valendo-se de um tom predominantemente explicativo, o narrador adota como estratégia a exposição de dados específicos ao universo administrativo dos municípios sertanejos, aparentando ter como objetivo conferir maior enraizamento no real das narrativas. Cria a idéia de que estaria apresentando um quadro das municipalidades em toda a sua plenitude. Paralelamente, tais índices de referencialidade sugerem o domínio por parte do cronista da matéria de que trata ${ }^{148}$.

No primeiro artigo ${ }^{149}$, o escritor tomava como assunto a lei orgânica 1087, elaborada por Álvaro Paes. Segundo ele, tal dispositivo fazia com que a prestação de contas dos prefeitos, antes bienal, passasse a ser bimestral. Logo em seguida, os balancetes eram publicados no Diário Oficial para a devida conferência da população, o que aumentava a lisura do processo. A tais iniciativas o narrador acrescenta a fiscalização realizada in loco pelo próprio governador. Para isso, retoma a imagem de viajante incansável colada anteriormente a tal político, o qual visitava os diferentes lugarejos do interior, dava conselhos aos sertanejos e verificava o trabalho dos chefes políticos locais.

Depois de apresentar esse conjunto de medidas e práticas governamentais, destaca que as obras públicas teriam, a partir daquele momento, “existência real”: “Todos podem examinálas, medi-las, apalpá-las, saber quanto custaram, como foram construídas, a quem foram

${ }^{147}$ UM GOVERNO dinâmico. Jornal de Alagoas, Maceió, 12 jun. 1930, p.1. A primeira página desta edição do periódico ainda era ocupada por citações do próprio governador, recolhidas de seus discursos e pronunciamentos.

${ }^{148}$ O próprio Jornal de Alagoas fazia questão de ressaltar o caráter de especialista de Graciliano, quando assunto era a eficiência e lisura da gestão municipal. "A frente dos melhores prefeitos do atual triênio esteve há pouco o Sr. Graciliano Ramos, pela inteligência, pela atividade, pela energia, pela honestidade e pela felicidade de suas iniciativas. Todos sabem o que foi sua administração em Palmeira dos Índios (...). Entre as boas coisas instituídas pelo Sr. Graciliano Ramos na Prefeitura de Palmeira dos Índios conta-se a maneira porque são organizados os balancetes bimestrais, pela qual o leitor fica imediatamente senhor do que ali se vai passando (...). Esse sistema de publicar balancetes permite que a população saiba sempre o que se está fazendo e o que se pode fazer na administração de cada município (ADMINISTRAÇÕES municipais. Jornal de Alagoas, Maceió, 14 ago. 1930, p.3).

${ }_{149}$ GUEDES, Lúcio [Graciliano Ramos]. Prefeituras municipais I, Jornal de Alagoas, Maceió, 31 jul. 1930, p.3. Texto ainda inédito em livro. 
pagas”150. E, por fim, fechando o movimento laudatório e analítico proposto logo de saída, termina enfatizando que Alagoas se encontrava “em bom caminho”151.

Na continuação da série ${ }^{152}$, o articulista procurava esquadrinhar e categorizar as diferentes cidades alagoanas a fim de apontar aparentes melhorias que, em seu momento de enunciação, poderiam ser observadas nas mesmas. Continua, portanto, com o procedimento argumentativo de contrapor o governo de Álvaro Paes às administrações que o antecediam. Estas últimas são tomadas uniformemente como um bloco indiferenciado, sugerindo que as ações do atual chefe de Estado se constituiriam num marco divisório na política do local: haveria um antes e um depois da chegada de Álvaro Paes ao poder. Em regra, ele representaria a modernidade e a prosperidade das Alagoas em oposição ao atraso do passado. Segundo Graciliano, tal afirmação poderia ser atestada pelo fato de que, sob a gestão desse governante, quase todos os municípios passaram a consignar mais dinheiro a "obras de utilidade” do que a gastos com pessoal. Antes dele, conforme sublinha o articulista, ocorreria exatamente o contrário.

Depois de uma abordagem geral, o autor define e analisa especificamente três classes de municípios: os mirins, os intermediários e os prósperos. Ao esboçar as especificidades de cada uma dessas categorias, busca atestar discursivamente seu conhecimento da "realidade" administrativa do Estado. Ele afirma que à medida que aumentava a arrecadação das cidades, maiores eram as realizações dos prefeitos dignas de encômio. Mesmo nos lugarejos mais pobres, em função das dificuldades financeiras, qualquer obra como uma "calçada de pedras toscas”, poderia ser vista como um trabalho hercúleo. Assim, proporcionalmente, exalta os esforços das diferentes municipalidades. Ao se referir às mais ricas, com o intuito de enfatizar o novo viés de trabalho e progresso capitaneado por Álvaro Paes, assevera: "Estão hoje no galarim umas que por aí se arrastavam, bisonhas e em pasmaceira, entregues a cidadãos resignados que diziam com displicência: - ‘Encontrei mole, e mole deixo’. Tudo mudado”153.

Em de abril de 1931, já depois da deposição de Álvaro Paes e da nomeação de interventores federal para Alagoas, em decorrência da vitória do movimento revolucionário de $1930^{154}$,

\footnotetext{
${ }^{150}$ Idem, ibidem.

${ }^{151}$ Idem, ibidem.

152 GUEDES, Lúcio [Graciliano Ramos]. Prefeituras municipais II, Jornal de Alagoas, Maceió, 8 ago. 1930, p.3. Texto ainda inédito em livro.

153 Idem, ibidem.

154 Apesar das críticas pessoais à Revolução e das evidências de fidelidade ao governo caído, como se pode depreender de sua tentativa de organizar, em Palmeira dos Índios, um foco de resistência à tomada do poder
} 
Graciliano passa a ser colaborador especial da revista literária Novidade, dirigida por Valdemar Cavalcanti e Alberto Passos Guimarães. A publicação, que circulou por pouco mais de seis meses, até setembro de 1931, colocava-se como porta-voz de uma nova geração de artistas nordestinos. Congregava nomes de importância local que logo depois viriam a ser conhecidos nacionalmente tais como os de Jorge de Lima, Lima Junior, José Lins do Rego, Aloysio Branco, Carlos Paurilio, Raul Lima, Aurélio Buarque de Holanda, Santa Rosa, entre outros. Além disso, já no final de sua existência, o veículo passou a estampar textos de Álvaro Lins e Tristão de Athayde, críticos representativos da capital federal.

O periódico adotava um discurso de inovação e de ruptura com certos procedimentos culturais tidos como tradicionais, ecoando propostas de determinada parcela da elite intelectual alagoana que procurava se afirmar ao deixar de lado os princípios e noções do movimento artístico anterior. Valdemar Cavalcanti, no editorial do primeiro número, em tom de manifesto, destaca que a revista abandonaria um "romantismo molengo" para privilegiar as "realidades da vida" 155 . Tal estratégia tinha como objetivo mostrar que os novos seriam mais “verdadeiros” e “fiéis” à representação do real do que os integrantes das escolas do passado. Em linhas gerais, essa reivindicação de uma maior verossimilhança artística por parte da mocidade se ancoraria, sobretudo, no privilégio para a representação de certas particularidades locais.

De acordo com tal perspectiva, Novidade reservava boa parte de seu espaço para contos, poesias, crônicas e artigos com reflexões sobre temas associados, principalmente, ao Nordeste. Nela ainda se observava a presença marcante da fotografia. A seção “Arte fotográfica”, que ocupava o centro da revista, trazia fotos de página inteira. Informações sobre produções cinematográficas locais e sobre os filmes em cartaz também possuíam um lugar específico. Observa-se que o peso atribuído às artes visuais (foto e cinema), tidas como índices de modernidade, estaria atrelado à proposta original da publicação de se mostrar mais atual e “fiel” à representação do real aos olhos do público.

pelos revolucionários (tal caso fora relato, posteriormente em suas Memórias do Cárcere), Graciliano é mantido no cargo de diretor da Imprensa Oficial pelos sucessivos interventores nomeados pelo governo provisório de Vargas até dezembro de 1931. Em tal período, fora ainda alvo de investigação por parte da Junta Estadual de Sanção, organismo criado a partir do decreto federal de número 19.811, de 28 de março de 1931, com o objetivo de julgar crimes políticos e funcionais, mas que se constituía, de fato, em instrumento de perseguição de desafetos vencidos, depois de 1930 (FACIOLI, Valentim. op.cit. p.47). O escritor recebera denúncia de uso indevido de um conto e vinte mil-réis, referente ao período em que fora prefeito de Palmeira dos Índios. Apresentada a defesa, consegue a absolvição e o processo é arquivado (Idem, ibidem).

${ }^{155}$ CAVALCANTI, Valdemar. Cartão de Visitas. Novidade, Maceió, n.1, 11 abr. 1931. 
A partir de sua colaboração em Novidade, Graciliano passará a assinar suas crônicas com o nome com que se tornou literariamente conhecido. Coincidentemente, é nas páginas da revista que o escritor publica pela primeira vez um trecho de romance. Trata-se do capítulo XXIV de seu livro ainda inédito a época, Caetés ${ }^{156}$. Nesse momento, o romancista gozava de prestígio não só Maceió, mas também na capital federal. Ainda em 1930, ele fora contatado pelo poeta e editor Augusto Frederico Schmidt, que ficara sabendo da existência dos Caetés e pedia os originais para editá-los. Em novembro de 1931, o Jornal de Alagoas já anunciava que tal romance seria lançado antes do final do ano ${ }^{157}$. No entanto, como se sabe, o volume só veio a público três anos depois, em 1934, pela Schmidt Editora.

Segundo o biógrafo Denis de Moraes, a versão mais plausível para que Graciliano, escritor, passasse a ser conhecido nos meios literários cariocas, teria sido não só a publicação de trechos dos famosos relatórios na imprensa da capital federal, mas principalmente a interferência de Santa Rosa que, morando no Rio, divulgara os referidos documentos nas rodas de intelectuais da cidade. Em seguida, José Américo de Almeida, revelaria a existência de originais de um livro do ex-prefeito sertanejo. Ciente da existência do romance inédito Schmidt escrevera a Graciliano.

Além do já citado trecho de Caetés, Graciliano Ramos publica ainda quatro crônicas em Novidade. Deixando parcialmente de lado a galhofa, a pseudo-agressão e a obsessão pela interlocução de seus primeiros narradores, R.O. e J. Calisto, Graciliano, por mais que mantenha o sarcasmo e a ironia, adota um posicionamento que procura ser mais sério e equilibrado, condizente com sua imagem de literato em vias de publicar um livro que, segundo carta de Rômulo de Castro, secretário de Schmidt, seria com certeza um sucesso, podendo, inclusive, lograr êxito semelhante ao de A bagaceira de José Américo de Almeida, obra que é tomada como precursora do romance nordestino de $1930^{158}$.

\footnotetext{
${ }^{156}$ RAMOS, Graciliano. Capítulo XXIV. Novidade, Maceió, n.9, 6 jun. 1931.

157 Também no Jornal de Alagoas, alguns anos depois, Aloysio Branco, afirmaria: “É, incontestavelmente, no sr. Graciliano Ramos que Alagoas possui o seu maior romancista ainda inédito, é verdade, mas como esses avarentos, cuja enorme fortuna custa muito a entrar em circulação, embora tenham certeza que depende deles a salvação da crise. São dois os seus romances inéditos: Caetés e S. Bernardo” (BRANCO, Aloysio. Alguns aspectos da prosa alagoana. Jornal de Alagoas, Maceió, 31 maio. 1933, p.3).

${ }^{158}$ MORAES, Denis. O velho Graça. Rio de Janeiro: José Olympio, p.74.
} 
Na crônica “Sertanejos”"159, publicada no primeiro número de Novidade, Graciliano, em oposição ao tratamento idealizado conferido ao homem interiorano tanto pela literatura quanto pelo jornalismo produzidos sobre o sertão, apresenta os “matutos” como seres vulgares, tipos existentes em qualquer lugar. Nesse processo, procura, indiretamente, aproximá-los dos habitantes do litoral, surpreendendo e despertando a atenção destes últimos, que, aparentemente, constituíam-se nos destinatários preferenciais de sua mensagem. Por outro lado, quando atribui especificidade aos "caboclos”, em regra, o autor adota certo viés negativo e crítico, acabando por rebaixá-los:

Trabalham pouco, pensam pouco. Mas querem progresso, o progresso que vêem, encantados nas fitas americanas. E progridem sem tomar fôlego. Numa casa velha de taipa, arranjam uma sala bonita e metem dentro quadros, cortinas e penduricalhos. ${ }^{160}$.

Como estratégia para conferir maior autenticidade a seu relato, o cronista continua a adotar determinado tom de problematização, que pressupõe, como se vê, não o elogio do sertanejo como um "homem forte", mas sim um retrato deste último sem cores ou adornos. Assim, ao deixar de lado possíveis idealizações, mostrar-se-ia, supostamente, mais fiel ao "real", distanciando-se, segundo o artista, da representação literária e pitoresca do matuto, muito comum no Romantismo ${ }^{161}$. Para tanto, detêm-se, principalmente, na exposição da incongruência de uma prática comum no sertão (e também nas capitais litorâneas): a adoção de hábitos e modos importados por seus moradores que, por sua vez, eram incompatíveis com o meio precário e atrasado em que viviam. Diagnostica que seria melhor abandonar os estrangeirismos, o progresso ilusório propagado pelas fitas americanas, e retornar às práticas e costumes regionais, os quais melhor se ajustariam à conjuntura pobre e tacanha retratada.

Em sua crônica seguinte ${ }^{162}$, Graciliano, metonimicamente, propõe-se a tratar do banditismo a partir da figura de Lampião. O cronista defende a tese de que o "salteador cafuzo" entrara para o crime não por ignorância ou devido às injustiças que sofrera, mas sim em função da miséria que assolava o sertão. Partindo de tal premissa, imagina a vida pregressa do bandoleiro como meio para compreender as ações recentes deste. Em seguida, procura

\footnotetext{
${ }^{159}$ RAMOS, Graciliano. Sertanejos. Novidade, Maceió, n.1, 11 abr. 1931. Texto ainda inédito em livro. 160 Idem, ibidem.

${ }^{161}$ No capítulo seguinte, tal crônica será retomada com o objetivo de se examinar melhor a recusa de Graciliano ao protocolo romântico, apresentado como falso e ficcional, e a defesa de um registro dito "realista", considerado verdadeiro e documental.

${ }^{162}$ RAMOS, Graciliano. Lampião. Novidade, Maceió, n.3, 35 abr.1931. Texto posteriormente reunido no volume Viventes das Alagoas.
} 
contrapô-lo aos moradores das cidades, valendo-se de artifício semelhante ao que utilizara na crônica anterior como estratégia para aproximar o relato de seus leitores da capital litorânea. Ao fazer tal comparação, deixa de lado a crueldade e a brutalidade usualmente associadas a Lampião para valorizar sua coragem e sua força. Dessa maneira, acaba compondo um retrato inusitado do personagem. Tal imagem nova parece servir para rebaixar e questionar seus receptores “civilizados”, entre os quais ele próprio se incluiria:

Como somos diferentes dele! Perdemos a coragem e perdemos a confiança que tínhamos em nós. Trememos diante os professores, diante dos chefes e diante dos jornais; e se professores, chefes e jornais adoecem do fígado, não dormimos. Marcamos passo e depois ficamos em posição de sentido. Sabemos regularmente: temos o francês para os romances, umas palavras inglesas para o cinema, outras coisas emprestadas ${ }^{163}$.

A suposta bravura e ousadia do lampionismo servem de argumento para que o cronista critique, indiretamente, tanto o aparente descaso em relação ao sertão miserável como uma literatura “civilizada” e oficial, marcada pela adoção de estrangeirismos e pelo uso de “adjetivos idiotas”. De acordo com seu estatuto de verossimilhança, a arte literária, pelo contrário, deveria olhar para os problemas regionais, deixando de lado determinadas fórmulas aparentemente artificiais cultivadas pelo cânone. De maneira indireta, aqui, Graciliano já esboçava a defesa do romance nordestino de 1930, que começava a ser produzido por seus companheiros de geração. Como se verá mais a frente, tal atitude se repetirá ao longo de suas produções futuras, tanto antes como depois de sua prisão em 1936.

Em consonância com essa perspectiva, na sua crônica seguinte, intitulada “Chavões”164, realiza um pseudo-manifesto irônico em defesa do lugar-comum. Na verdade, suas intenções semiótica mostram o contrário: mediante um desacordo entre enunciado e enunciação, próprio da antífrase, o artista diz “x”, para que seu texto seja interpretado como "não-x”. Em linhas gerais, ele afirma que os autores que se valem de tal tipo de construção seriam, em geral, cidadãos inofensivos, tais quais os sujeitos comparados com Lampião na crônica anterior. Ao mesmo tempo, afirma que os clichês predominariam no gosto do público uma vez que poderiam ser lidos rapidamente, sem a necessidade de serem entendidos de maneira efetiva. Associa-os, metaforicamente, a uma rodovia bem conservada (plana, batida, reta e extensa) por onde se viajaria sem dificuldades. Em sentido oposto, assinala também a existência de

\footnotetext{
163 Idem, ibidem.

${ }^{164}$ RAMOS, Graciliano. Chavões. Novidade, Maceió, n.8, 30 maio 1931. Texto ainda inédito em livro.
} 
uma "literatura encrencada dos homens de talento". Esta, por sua vez, era comparada aos “caminhos sertanejos cheios de surpresas de espinho rasga-beiço”.

Metonimicamente, o chavão figurava como índice da literatura oficial e conservadora, feita por sujeitos sem energia e coragem e que deveria ser combatida, segundo o ponto de vista do autor (há no texto referências irônicas à Academia Brasileira de Letras e à morte de Graça Aranha; tanto a entidade como o autor de Canaã poderiam ser tomados, indiretamente, como representantes desta literatura institucionalizada à qual Graciliano criticava). Em contrapartida, a dita "literatura encrencada” poderia ser tomada como manifestação do "lampionismo literário", sugerido no último texto. Este deveria ser valorizado uma vez que tiraria o leitor de sua passividade habitual, levando-o a "abalos e interrupçõe freqüentes” em meio ao passeio desagradável, e por isso mais real, segundo a lógica do cronista, pelas ásperas paisagens sertanejas representadas.

Numa entrevista imaginária realizada com Lampião, que aparece no número 6 de Novidade, de 16 de maio de 1931, sem assinatura, já há uma menção a tal “lampionismo literário” supracitado. Apesar de o texto não apresentar assinatura, tem-se a convicção de que ele seria de autoria de Graciliano. Observam-se na narrativa recorrências estilísticas e temáticas, presentes em outras crônicas do escritor estampadas no mesmo periódico. O trecho selecionado abaixo, por exemplo, retoma ironicamente a aproximação premeditada da literatura e do jornalismo ao cangaço como forma de conferir aos dois primeiros firmeza, coragem e estatuto de realidade. Para tanto, estes deveriam se pautar por certa idéia de hostilidade e rudeza na composição de quadros hipoteticamente mais “fiéis" e "verdadeiros" do Nordeste:

- Deixe disso, capitão, não se afobe. Novidade é um jornal.

- Um jornal?

- Sim, senhor um papel com letras para embromar os trouxas. Mas o nosso é um jornal sério, um jornal de bandidos. É por isso que estou aqui. Um jornal sisudo. Temos colaboradores entre as principais figuras do cangaço alagoano, temos correspondentes...

Lampeão mostrou a dentuça e grunhiu:

- Uhn! Anda procurando um chefe.

- Ah! Não! Protestamos. Já temos. O lampionismo em literatura é diferente do seu. O que eu quero é entrevista-lo, entende ${ }^{165}$ ?

${ }^{165}$ LAMPEÃO entrevistado por Novidade, Novidade, Maceió, n.6, 16 maio 1931, p.8. 
Em dezembro de 1931, com o governo alagoano nas mãos do interventor Tasso de Oliveira Tinoco, o terceiro a passar pelo cargo desde a vitória revolucionária ${ }^{166}$, o escritor renúncia à chefia do Diário Oficial do Estado e retorna para Palmeira dos Índios. No entanto, dois anos depois, é nomeado diretor da Instrução Pública, cargo correspondente a Secretário Estadual de Educação, e se vê obrigado a voltar para Maceió. Em sua nova permanência na capital, volta a publicar crônicas no Jornal de Alagoas e, assim como em Novidade, torna a assinálas com nome artístico que o consagrou.

Todos esses textos se concentram no ano de 1933 e, em comum, procuram apresentar aos leitores maceioenses diferentes tipos sertanejos. Para realizar tal intento, adota dois estratagemas diferentes (que, no entanto, se entrecruzam): 1) propõe-se a enfocar personagens aparentemente desconhecidas de seu público, particularizando o argumento já utilizado de que o sertão era um espaço desconhecido e idealizado, que precisava de um retrato mais aproximado; 2) compara certas figuras interioranas a suas correspondentes na cidade litorânea, observando dessemelhanças que ocorreriam em função de certas particularidades inerentes a cada lugar. Em ambos os casos, abraça a postura de revelar algo novo e curioso a seus receptores, o que despertaria a atenção destes para suas produções. Ao mesmo tempo, tais narrativas estariam ancoradas na ficcionalização de sua experiência de sertanejo, recorrentemente invocada, o que, como já sinalizado, procura lhes conferir maior estatuto de verdade, aumentando seu efeito persuasivo.

Em "Mulheres”167, seu primeiro texto neste retorno a Maceió, o cronista aborda o feminismo caboclo, destacando a condição de superioridade da mulher sertaneja se comparada ao matuto do sexo oposto. Mesmo quando ainda não votavam, elas já dominavam à socapa alguns municípios interioranos. Novamente, aqui, o narrador procurava apresentar a faceta sertaneja de um assunto que vinha ganhando destaque na capital, sobretudo no próprio Jornal de Alagoas. No momento da redação da narrativa, havia uma preocupação, expressa pelo periódico, quanto à educação política do novo eleitorado feminino e de quais seriam as representantes deste na Assembléia Constituinte de maio de 1933. Tais considerações podem

\footnotetext{
${ }^{166}$ Tinoco ficou na chefia do executivo estadual por quase um ano, de 31 de outubro de 1931 a 25 de outubro de 1932. Antes dele, passaram pelo cargo Hermilo de Freitas Melro (de 14/10/1930 a 9/8/1931) e o tenente-coronel Luís de França Albuquerque, interino (de 9/08/1931 a 31/10/1931) (In: BARROS, Francisco Reinaldo Amorim de. $A B C$ das Alagoas: dicionário, histórico e geográfico das Alagoas. Brasília: Senado Federal, Conselho Editorial, 2005, v.2, p.35).

${ }^{167}$ RAMOS, Graciliano. Mulheres. Jornal de Alagoas, Maceió, 20 mai. 1933.
} 
ser observadas, por exemplo, nos textos “A mulher e a política”, “A presença da mulher na ante-sala da constituinte” e "Quem deverá representar a mulher alagoana na futura constituinte”, publicados no citado veículo, respectivamente em 4 de agosto de 1932, 25 de novembro de 1932 e 2 de março de $1933^{168}$.

Logo depois, aparece o texto "D. Maria Amália”169 , uma espécie de suíte da crônica anterior. Agora, o narrador detém-se, mais especificamente, no retrato da esposa de um chefe político do interior que assumira o poder local de maneira encoberta, no lugar do marido. Tal tipo feminino é descrito como um coronel de saias que apoiava políticos em troca de favores. O fato de a personagem pertencer ao sexo “frágil” não alterava em nada a execução de certas práticas reprováveis, comuns à administração municipal, que se manteriam as mesmas, com destaque para tríade parasitismo, nepotismo e clientelismo. Segundo o artista, D. Maria Amália era a figura que mais atormentava o governador do Estado, sempre a cobrar deste a prestação de favores a seus amigos e a prática de sanções e castigos contra seus opositores. A mulher aparecia como um ser onipresente que crescera tanto a ponto de se tornar, na ótica do cronista, em símbolo do fiasco econômico, político e social do país.

Há aqui uma nítida mudança de postura de Graciliano em relação a suas crônicas sobre a política estadual, escritas em 1930 e assinadas com pseudônimos. A esperança no desenvolvimento alagoano, cristalizado na administração Álvaro Paes, sempre digna de encômios, dá lugar a perspectiva de manutenção daquilo que identifica como atraso e estagnação. O ex-governado, facilmente identificado no texto acima como o político que sofre as pressões de D. Maria Amália, não consegue vencê-la. Depois de resistir a todas as comissões de sindicância, a matrona se manteria "forte, gorda e bonita".

Uma de suas últimas colaborações publicadas no Jornal de Alagoas é o texto “Doutores”170. Nele Graciliano tematiza a diferença entre as pessoas detentoras do título de doutor na capital e no interior. Enquanto as primeiras apresentavam-se como sujeitos “razoáveis”, não

\footnotetext{
${ }^{168}$ Segundo Vivice Azevedo, a defesa do voto feminino, instituído pelo Código Eleitoral em 1932, já havia ganhado as páginas do Jornal de Alagoas durante o ano de 1931 em três oportunidades: "Voto feminino" (3 de maio) "O direito de voto à mulher" (1 $1^{\circ}$ de outubro) e "A reforma eleitoral” (2 de outubro). Ver AZEVEDO, Vivice, op.cit. p.132.

${ }^{169}$ RAMOS, Graciliano. D. Maria Amália. Jornal de Alagoas, Maceió, 18 jun. 1933. Texto posteriormente publicado com algumas modificações em Cultura Política, em abril de 1941, e depois reunido em Viventes das Alagoas.

${ }^{170}$ RAMOS, Graciliano. Doutores. Jornal de Alagoas, Maceió, 11 jun. 1933. Texto ainda inédito em livro.
} 
se diferenciando, a princípio, dos demais, as segundas mostravam-se dogmáticas, pernósticas e superiores. Segundo o narrador, as principais razões para o fato diriam respeito aos ambientes distintos encontrados nos dois lugares. Nas cidades litorâneas, haveria o favorecimento ao convívio intelectual. Já no sertão, em sentido oposto, ocorreria o contrário.

Diante do amesquinhamento do meio, o dito “doutor” precisaria reafirmar seu título perante os matutos "ignorantes” a todo o momento, realizando para isso inúmeras tarefas para as quais não teria a devida habilitação. Segundo o narrador, tornar-se-ia, devido a tal procedimento um charlatão.

\subsection{A consolidação do escritor e o cronista-articulista}

Ainda em 1933, um trecho de Caetés, intitulado "Luiza” foi veiculado na prestigiosa revista literária Boletim de Ariel do Rio de Janeiro ${ }^{171}$. No início de 1934, outra parte do que viria a ser seu primeiro romance ganhava as páginas de A Noite Ilustrada, periódico também da capital carioca. Em 20 de fevereiro de 1934, uma foto de Graciliano seria estampada na capa do jornal Literatura, dirigido por Augusto Frederico Schmidt, Sabóia Medeiros e Manuel Bandeira, com a seguinte legenda: “Graciliano Ramos - romancista de Caetés”"172.

Na página seguinte desse mesmo número de Literatura, são arroladas uma série opiniões elogiosas, conferidas por diferentes críticos, ao primeiro livro do escritor alagoano que viera de ser lançado pela editora Schmidt (a mesma responsável pela confecção do referido periódico). Tais afirmações, que em conjunto ganhavam um caráter publicitário, indiciavam como havia sido amplamente favorável a recepção de Caetés nos meios intelectuais. Abaixo, listam-se apenas algumas delas com o objetivo de se apresentar, mesmo que ainda sumariamente, o lugar de destaque que Graciliano foi ocupando nas letras nacionais desde a publicação de seu romance de estréia:

\footnotetext{
${ }^{171}$ Tal colaboração abarcava o capítulo 18 e parte do 19 da versão de Caetés que fora lançada logo depois pela Schmidt e depois republicada pela José Olympio (RAMOS, Graciliano. Caetés. Rio de Janeiro: Livraria José Olympio Editora, 1953, p.143-149).

${ }^{172}$ Em editorial presente no segundo número do periódico, Augusto Frederico Schmidt assim o definia: “... Estas poucas folhas de jornal, são mais do que movimento interessado de cultura, são mais do que um trabalho em favor dos nossos ideais - mas antes de tudo um dever a cumprir, e mais a ingênua esperança de fabricarmos uma ambiente para nós literatos podermos viver. No Brasil não há realmente um lugar para nós. Vivemos, numa pequena colônia, com as nossas lutas, as nossas rivalidades, os nossos diferentes pontos de vista, tudo em lugar estreito” (SCHMIDT, Augusto Frederico. Nós literatos. Literatura, Rio de Janeiro, ano 1, n.2, 20 jul. 1933).
} 
Com ele (Caetés) o sr. Graciliano Ramos pode, sem favor, formar na fileira dos melhores romancistas do Brasil. E dentro de poucos meses - anuncio com o maior prazer aos leitores do Boletim - a publicação de São Bernardo, que já conheço, revelará ao país um de seus grandes, dos seus maiores romancistas de todos os tempo” (HOLANDA, Aurélio Buarque, Boletim de Airel, Rio de Janeiro, fev. 1934).

Caetés há de marcar entre os bons romances do ano e mesmo desta época. Parece-me que sinto prenúncios, em Graciliano Ramos, de um grande romancista que chega (...) Entre os livros que enxameam a mesa do crítico, nenhum, há muito tempo, mostrou mais seguras promessas (VIEIRA, José Geraldo. A Nação, Rio de Janeiro, 4 fev. 1934).

Caetés é um belíssimo trabalho, dos que mais me têm deliciado nestes Brasis, em qualquer tempo. Esse homem sequíssimo para o número [um] da 'minha gente', na minha biblioteca. Romance bem pensado, bem sentido, bem escrito e com o mínimo de romance possível (...) A galeria de esquisitões é aqui das mais impressionantes, igualando em mérito a de certas páginas de Lima Barreto. Essas almas empoeiradas, enferrujadas, são da província, mas poderiam ser também de nossos subúrbios (GRIECO, Agripino. O Jornal, Rio de Janeiro, 4 fev. 1934).

A vida monótona da cidadezinha - Palmeira dos Índios, que serve maravilhosamente de décor ao romance de Graciliano Ramos - fixa-se fortemente em Caetés, com alguma coisa de grande, de real, de densamente humano (CAVALCANTI, Valdemar. Boletim de Ariel, Rio de Janeiro, dez. 1933).

Em números anteriores de Literatura, Jorge Amado e José Lins do Rego já haviam se manifestado a favor de Graciliano, ressaltando a grandeza da obra inicial deste:

Conheci Graciliano Ramos numa viagem que fiz a Alagoas no meado desse ano. Já lera os originais de Caetés, mas parece-me que compreendi melhor esse romance depois de conhecer o autor.

Realmente me assombrava no livro a secura, a sua justeza de construção, volume onde não há uma palavra inútil. Nenhum derramamento de linguagem e lirismo. Nenhum enfeita. Mas romance como o diabo (AMADO, Jorge. Nota sobre Graciliano Ramos. Literatura, Rio de Janeiro, dez. 1933).

Caetés não é só um romance que firmou um escritor em plano alto; é o que há de mais real e amargo sobre as nossas gentes de cidades pequenas, uma crônica intensa e miúda sobre o brasileiro que não anda em automóvel e não veste casaca. (...) é um depoimento dos maiores que nos tem vindo da nossa literatura, tão chegada ao convencional e á moda” (REGO, José Lins. Caetés. Literatura, Rio de Janeiro, 5 fev. 1934). 
Com o lançamento de $S$. Bernardo poucos meses depois pela editora Ariel, a imagem de grande romancista associada a Graciliano consolida-se. No Arquivo Graciliano Ramos, pertencente ao IEB, entre pequenas notas e críticas mais extensas, contemporâneas à aparição de seu segundo romance, foram contabilizadas 26 ocorrências dando conta do aparecimento do livro. Dessa considerável fortuna crítica de S. Bernardo, destoam apenas as observações feitas por Agripino Grieco e Augusto Frederico Schmidt. Os dois articulistas cariocas apontavam para a possível inverossimilhança do narrador-personagem Paulo Honório, tendo em vista a incompatibilidade entre a sofisticação de seu relato e a rusticidade de sua figura. No entanto, o restante dos críticos, na grande maioria das vezes, tece elogios incondicionais à obra ou ao encaminhamento da produção romanesca do escritor. Na revista Careta, em 14 de setembro de 1935, por exemplo, Peregrino Júnior destacava:

\begin{abstract}
O autor admirável dos Caetés e do S. Bernardo é um romancista autêntico, que, longe do Rio, sem fazer parte de igrejinhas literárias e sem ter camaradas na imprensa, conseguiu uma situação de prestígio, de admiração e de respeito nos melhores círculos intelectuais (...) é considerado uma das figuras centrais da jovem literatura (...) Graciliano Ramos, que longe dos ruídos da cabotinagem e dos charlatanismos metropolitanos, vive silenciosamente em sua província, trabalhando com o ritmo e a serenidade de um verdadeiro artista $^{173}$.
\end{abstract}

Na medida em que vai adquirindo tal status artístico, ainda antes de sua prisão em março de 1936, observa-se que a produção cronística de Graciliano sofre uma nova inflexão. Em regra, o autor vai deixando de lado assuntos relacionados à vida sertaneja para tratar basicamente de literatura. Nesse sentido, aborda de maneira mais detida as produções nordestinas de seus jovens companheiros de geração. Em linhas gerais, procura valorizá-las atribuindo-lhes maior verossimilhança artística do que aos demais romances brasileiros escritos até então, sobretudos aqueles feitos por literatos “oficias” da Academia.

Em “O romance do Nordeste”, publicado no Diário de Pernambuco, em março de 1935, o escritor, em tom de manifesto, procura opor aquilo que chama de literatura artificial e importada do passado à literatura "autêntica e verdadeiramente brasileira” de seu momento presente, feita, sobretudo, por nordestinos:

Os romancistas atuais compreenderam que para a execução da obra razoável não bastam retalhos de coisas velhas e novas importadas da França, da Inglaterra e da Rússia. E como deixaram de ser

173 JUNIOR, Peregrino. Sobre Graciliano Ramos e Gilberto Freyre. Careta, Rio de Janeiro, 14 set. 1935. 
obrigatórias as exibições da porta do Garnier, os provincianos conservaram-se em suas cidadezinhas, acumulando documentos, realizando uma honesta reportagem sobre a vida no inteiror.

O trabalho que há no Nordeste é mais intenso do que em qualquer outra parte do Brasil, tão intenso que um crítico, visivelmente alarmado com as produções daqui, disse ultimamente que não é só no Norte que se faz literatura. De certo. Era indispensável, porém, que nossos romances não fossem escritos no Rio, por pessoas bem intencionadas, sem dúvida, mas que nos desconheciam inteiramente ${ }^{174}$.

No texto "Suor", saído na Folha de Minas de Belo Horizonte, em fevereiro de 1935, o cronista adota procedimento semelhante ao tratar do terceiro romance de Jorge Amado. Ele contrapõe uma "literatura antipática e insincera que só usa expressões corretas, só se ocupa de coisas agradáveis” às produções dos romancistas de seu momento de enunciação que "resignaram-se a abandonar o asfalto e o café, viram de perto muita porcaria, tiveram a coragem de falar errado como toda a gente, sem dicionário, sem gramática, sem manual de retórica”175. O escritor baiano, obviamente, faria parte deste segundo grupo o qual seria pautado, segundo Graciliano, pelo “amor à verdade” em detrimento da imaginação.

Nesses dois textos indicados acima, nota-se também que o escritor alagoano, mais uma vez, opta por deixar de lado o estilo debochado e sarcástico de seus primeiros narradores (R.O. e, principalmente, J. Calisto), sem, contudo, abdicar da ironia, para adotar uma postura mais séria, condizente com sua nova situação nos meios intelectuais. Dessa maneira, suas crônicas ganham o aspecto de artigos, detendo-se num assunto específico (o romance nordestino). Nelas, Graciliano procura demarca sua opinião por meio de leituras e análises das produções romanescas de seu momento de enunciação e da comparação interessada destas com aquilo que era feito no passado, com o objetivo de demarcar, defender e consolidar uma posição.

Diante dessas novas atribuições, o escritor procura também mostrar erudição. Esta, por sua vez, é utilizada como estratégia retórica para valorizar os romances e escritores nordestinos que recorrentemente Graciliano tematizava em suas narrativas. Em crônica intitulada "Um romancista do Nordeste”, estampada na revista Literatura em 20 de junho de 1934, ao

\footnotetext{
${ }^{174}$ RAMOS, Graciliano. O romance do Nordeste. Diário de Pernambuco, Recife, 10 mar. 1935. Texto ainda inédito em livro.

${ }^{175}$ RAMOS, Graciliano. Suor. Folha de Minas, Belo Horizonte, 17 fev. 1935. Texto publicado em Linhas Tortas com o título "O romance de Jorge Amado". No próximo capítulo, a análise deste texto será retomada, tendo em vista o propósito de se conceituar melhor os pressupostos poéticos de Graciliano.
} 
analisar o conjunto da produção romanesca de José Lins do Rego até aquele momento, o romancista aponta que ela seria mais coesa do que certos livros de escritores consagrados:

\begin{abstract}
A obra do Sr. Lins do Rego tem coesão. Às vezes a de escritores grandes demais não tem. Os livros do velho Hugo, os de Anatole France, os de Machado de Assis, estão cheios de soluções de continuidade, intercalações, enxertos. Vendo esses parêntesis, somos levados a pensar que certos autores ou trabalham com interrupções ou escrevem nas horas vagas folhas avulsas que entremeiam nas suas narrações com mais ou menos habilidade. Entre nós o comum é encontrarem-se romances arranjados com pedaços desconexos. Lemos uma página boa, em seguida vinte páginas que não são boas nem ruins, adiante uma péssima, depois uma sofrível - e o leitor tem a impressão de estar vendo um desses gráficos do serviço de estatística em que as linhas descem ou sobem desesperadamente"176
\end{abstract}

No entanto, o autor de Doidinho destacava-se não só pelo arranjo formal da obra, mas principalmente por se ajustar ao ideal de verossimilhança artística esboçado por Graciliano: José Lins encontrava-se discursivamente próximo da realidade que se propunha a tratar, trabalhando com certas tópicas sugeridas por fatos e cenas nordestinas, sem com isso realizar uma representação aparentemente estereotipada e artificial da região. Além disso, buscaria incorporar a língua "bronca, incerta, de vocabulário minguado” do Nordeste como estratégia para conferir uma suposta fidelidade representativa a seus textos ${ }^{177}$.

\title{
2.5. Saída da prisão e o trabalho na imprensa carioca
}

Como se sabe, Graciliano foi preso em 1936, em Maceió, sem acusação formal ${ }^{178}$. Em seguida, o escritor foi levado para o Rio de Janeiro, onde ficou preso até janeiro de 1937. Após sua libertação, ele decide fixar-se na capital carioca e se dedicar, sobretudo, à carreira literária. Logo no princípio dessa nova vida posterior ao cárcere, passa escrever para Imprensa Brasileira Reunida Limitada (I.B.R. Ltda) ${ }^{179}$, uma agência de notícias de São Paulo, que

\footnotetext{
${ }^{176}$ RAMOS, Graciliano. Um romancista do Nordeste. Literatura, Rio de Janeiro, ano 1, n.18, 20 jun. 1934.

${ }^{177}$ Idem, ibidem.

178 Tal seria a versão consagrada pelos relatos biográficos em torno da vida do autor (ver FACIOLI, Valentim, op.cit. p.59 e MORAES, Dênis de. op.cit. p.113). No entanto, segundo o prontuário de Graciliano na Polícia Política, documento de número 11.473, presente no Arquivo Público do Estado do Rio de Janeiro, o escritor teria sido demitido de seu cargo de Diretor de Instrução Pública do Estado de Alagoas, "em virtude de suas atividades subversivas”, em março de 1936. Ainda neste mesmo mês fora preso, sob acusação de ter participado “do movimento comunista irrompido no Nordeste do país, em 23/11/1935”. No entanto, como sublinha Moraes “jamais seria processado ou acusado publicamente de algum deslize” (Idem, ibidem).

${ }^{179}$ Em correspondência endereçada à mulher em fevereiro de 1937, Graciliano comunica-lhe uma viagem a São Paulo na qual travara contato "com uns cidadãos importantes, donos duma dessas companhias que distribuem artigos para a imprensa” (RAMOS, Graciliano. Cartas. Rio de Janeiro: Record, 1981, p.174). Em seguida, referindo-se aos funcionários da I.B.R., que financiaram sua vinda para a capital paulista, pontua: "Creio que vou
} 
distribuía matérias de diferentes colaboradores ${ }^{180}$ para uma cadeia de mais de duzentos jornais de todo país, entre eles o Diário de Notícias do Rio de Janeiro, o qual recebia os textos do escritor alagoano com exclusividade na capital federal ${ }^{181}$. Além disso, sem intermediários, colaborara ainda com vários periódicos cariocas, tais como: O Cruzeiro, Vamos Ler!, Dom Casmurro, Revista do Brasil, Diretrizes, Observador Econômico e Financeiro, Diário de Notícias, Diário Carioca, Folha Carioca, O Jornal, A Tarde, entre outros ${ }^{182}$. "Era uma atividade voltada principalmente para a obtenção de recursos que completassem o magro orçamento formado por direitos autorais de livros e por parcos ordenados de inspetor federal de ensino e revisor do Correio da Manhã ${ }^{\text {,183. }}$.

Do total de textos coligidos na segunda parte de Linhas Tortas e posteriormente localizados por esta pesquisa (uma vez que a primeira edição do livro, como se viu, deixou de lado informações bibliográficas mínimas, como data e local da primeira veiculação na imprensa dos mesmos), notou-se que a maior parte deles, 16 ao todo, saiu estampada no $1^{\circ}$ Suplemento do Diário de Notícias, que circulava aos domingos na capital federal. Como se sabe, tal caderno configurava-se como um espaço nobre, pois nele escreviam apenas figuras de destaque no cenário intelectual brasileiro, tais como José Lins do Rego, Lúcia Miguel Pereira, Rubem Braga, Guilherme de Almeida, Jorge de Lima, Lúcio Cardoso, Mário de Andrade, que em 1939 assume a seção “Vida Literária” do mesmo jornal, Tasso da Silveira, entre outros ${ }^{184}$.

escrever qualquer coisa para os rapazes que nos tem obsequiado mas eles só dão cinqüenta mil-réis por artigo” (Idem, p.176). Apesar do preço baixo, o artista entra em contato com os representantes comerciais da empresa no Rio de Janeiro e, depois de combinar o pagamento e número de artigos a serem produzidos, começa a trabalhar. De início, como indica outra carta de março do mesmo ano, recebe a incumbência de escrever seis artigos em um único mês. Mais especificamente, em pesquisa realizada na Junta Comercial de São Paulo (Jucesp), descobriu-se que a I.B.R. Ltda começou a funcionar em 12/11/1935 e que, em 1939, transformou-se em sociedade anônima. Entre seus diretores estava Angelo Franchini que é citado pelo romancista na segunda missiva, referida acima.

${ }^{180}$ Conforme sublinha o próprio Graciliano, entre os colaboradores da agência de notícias estavam José Lins do Rego e Gilberto Freyre, o que para os diretores da empresa era um motivo de honra (RAMOS, Graciliano. op.cit. p.180).

${ }^{181}$ O Diário de Notícias do Rio de Janeiro, fundado por Orlando Dantas, circula de 1930 a 29 de outubro de 1976. "Por pouco mais de três décadas, na gestão de seu fundador e diretor [...] o Diário de Notícias é um dos mais importantes jornais do país” (BAHIA, Juarez, Jornal, História e Técnica, p.180). Durante o Estado Novo, a publicação recusou-se a receber subvenção do Departamento de Imprensa e Propaganda (DIP). Sua posição liberal-democrata, com apelo nacionalista, faz do veículo "uma trincheira onde atuam antifascistas, liberais, conservadores e socialistas” (Idem, ibidem). Além da produção cronística recolhida em Linhas Tortas, Graciliano publicou outros quatorze textos em tal periódico, sobretudo, entre 1938 e 1939, que viriam a fazer parte de suas obras ficcionais ou memorialísticas. Trata-se de capítulos de Vidas Secas, Histórias de Alexandre, Insônia e Infância. Para mais informações ver anexos.

${ }^{182}$ Além dos periódicos cariocas, Graciliano começou a assinar, a partir de dezembro de 1945, artigos e contos em A Tribuna de Santos, São Paulo.

${ }^{183}$ BOSI, Alfredo, et al. op.cit. p.118.

${ }^{184}$ A primeira crônica de Graciliano estampada no Diário de Notícias, "Norte e Sul”, data de 25 de abril de 1937. Até abril do ano seguinte, seus textos aparecem com o copyright da I.B.R. Ltda,. Isso não é mais notado a partir da crônica "Sociedade de Amigos", veiculada pelo mesmo jornal em 26 de junho de 1938. Como se vê, 
Em geral, os textos de Graciliano, escritos em sua segunda permanência no Rio, tratam basicamente de literatura e da vida literária nacional e são assinados com o nome artístico do autor, agora uma renomado romancista, que além de Caetés e São Bernardo, viu seu livro Angústia, escrito em Maceió, ser publicado pela editora José Olympio, em 1936, quando ainda se encontrava na cadeia. Em 1937, essa obra recebe o Prêmio Lima Barreto, concedido pela Revista Acadêmica que também lhe dedica um número especial com treze artigos sobre sua obra, escritos por, entre outros, Mário de Andrade, Oswald de Andrade, Jorge Amado e Rubem Braga. À figura do grande romancista, já parcialmente consolidada pela crítica antes de sua prisão, será agregada a imagem do homem íntegro que passara pela violenta experiência do cárcere. A soma de tais elementos será preponderante na composição do perfil cultural e artístico de Graciliano que se convencionou ao longo do século, principalmente, em função de certos estudos críticos que enfatizaram essa associação entre cidadão e artista, cujo maior exemplo, é o volume Ficção e confissão de Antônio Cândido ${ }^{185}$.

Em função, sobretudo, desse respaldo da intelectualidade da capital federal, o escritor alagoano começa a participar com mais constância e efetividade do discurso cosmopolita; o grande diálogo nacional em que se discutia literatura intensamente. Trata-se de um momento de polarização política e literária em que se percebe o esgotamento do romance social ${ }^{186}$. Sua fala intervém nessa massa discursiva e seu referente passa a ser, sobretudo, a produção cultural (literária) do momento em que vivia. Essa situação estende-se até o momento de sua morte em 1953.

As crônicas, publicadas nos grandes jornais formadores de opinião, eram o canal direto para a entidade literária e cultural Graciliano Ramos manifestar seus posicionamentos. De maneira geral, seus textos buscavam ser condizentes com sua posição consolidada de romancista; visavam, assim, manter a seriedade e o compromisso. Em sua maioria, esses artigos colocavam-se como documentos de crítica e propunham-se a revelar, segundo a ótica do

\footnotetext{
sua colaboração mais efetiva para tal jornal se concentra nos anos de 1937 e 1938 que parecem ser os anos em que o autor alagoano se encontrava vinculado a tal agência de conteúdo.

${ }^{185}$ Segundo relato do próprio Cândido, Graciliano pedira a José Olympio que o autor de Formação da Literatura Brasileira escrevesse a introdução às suas obras completas. De 1955 a 1969, o texto foi situado no primeiro volume destas, Caetés. Em 1969, a editora Martins o desloca para S. Bernardo e, em 1974, resolve aposentá-lo. CANDIDO, Antonio. Ficção e confissão. São Paulo: Editora 34, 1992, p.10.

${ }^{186}$ Para mais informações sobre contexto literário da época, ver BUENO, Luís. Uma História do Romance Brasileiro de 30. São Paulo: Edusp; Campinas: Editora da Unicamp Campinas, 2006.
} 
romancista alagoano, a "verdade literária” da primeira metade do século XX no Brasil. O escritor parece continuar e incrementar o movimento já iniciado, ainda em Alagoas, quando por volta de 1933, começa a publicar suas produções em periódicos de fora de seu estado natal. Nesse sentido, ao escrever sobre literatura, examinando diferentes autores, posturas, estilos e opções temáticas, Graciliano imita a estrutura da crítica literária, tendo em vista o propósito de legitimar os próprios caminhos e os de seus parceiros de geração.

Seus textos, portanto, estão mais enraizados em fait divers de natureza artística. O estilo descritivo e analítico procura reforçar o ideal de verossimilhança artística defendido pelo autor. Das 71 crônicas que compõem a segunda parte do livro Linhas Tortas, 40 tratam, exclusivamente, de literatura e da vida literária nacional. Há críticas a inúmeros livros, descrição dos concursos literários promovidos por revistas, livrarias e pelo governo federal e considerações sobre literatura, que deixam claro o projeto literário explicitado pela persona Graciliano Ramos. Os outros 31 textos versam sobre temas diversos, abordando o cinema, o teatro, a música, cenas cariocas e a Segunda Guerra. Contudo, mesmo quanto trata do conflito mundial, por exemplo, o escritor destaca aspectos literários. Na maioria das vezes, os fatos são utilizados para se discutir literatura.

Nesse momento, num contexto de acirramento das disputas no campo das letras, artista alagoano elege outro adversário: a chamada literatura intimista, de orientação católica, que ganhara vulto, sobretudo, depois de 1935, e cujo principal expoente era o católico Octávio de Faria (com destaque também para, entre outros, José Geraldo Vieira, Jorge de Lima e Lúcio Cardoso) ${ }^{187}$. Em oposição à narração pretensamente documentária dos nordestinos, os chamados romances psicológicos radicalizavam o interesse pelo indivíduo, com destaque para produção de dramas centrados em personagens pertencentes à burguesia urbana. Nesse sentido, deixavam de lado a menção às massas, às questões sociais e às mazelas do interior do país, enfim, tudo aquilo que o realismo crítico de 1930 pregava como receita literária até então.

\footnotetext{
187 Segundo Bueno, trata-se do momento em que a "outra via”, representada pelos romances intimistas, em oposição aos romances proletários em fase de esgotamento, começara a ser percebida enquanto tal e ganhara força, mediante a publicação de uma série de livros representativos: O anjo (1934) e A mulher obscura (1939), de Jorge de Lima, Território humano (1936), de José Geraldo Vieira, e A luz do subsolo, de Lúcio Cardoso (1936) (BUENO, Luís. Os três tempos do romance de 30. Teresa, São Paulo: Editora 34, n.3, 2003, p.271).
} 
Logo depois de sua saída da prisão, nas crônicas "Norte e sul”"188 e "O fator econômico no romance brasileiro”"189, ambas publicadas em abril de 1937, Graciliano volta sua artilharia contra os ataques sofridos pelo romance social (sobretudo aquele produzido por autores nordestinos), protagonizados por críticos afeitos ao romance intimista. Na tentativa de defender a posição alcançada pelo primeiro, revida:

\footnotetext{
Ora, nestes últimos tempos surgiram referências pouco lisonjeiras às vitrinas onde os autores nordestinos arrumam facas de ponta, chapéus de couro, cenas espalhafatosas, religião negra, o cangaço e o eito, coisas que existem realmente e são recebidas com satisfação pelas criaturas vivas.
}

As mortas, empalhadas em bibliotecas, naturalmente se aborrecem disso, detestam o sr. Lins do Rego, que descobriu muitas verdades há séculos, escondidas no fundo dos canaviais, o sr. Jorge Amado, responsável por aqueles horrores da ladeira do Pelourinho, a sra. Rachel de Queiros, mulher que se tornou indiscreta depois do João Miguel $^{190}$.

Em linhas gerais, Graciliano faz uma oposição entre os “realistas” nordestinos, interessados na representação das mazelas existentes no interior do país (com destaque para José Lins do Rego, Jorge Amado e Rachel de Queirós) e os “intimistas” citadinos, produtores de dramas burgueses edulcorados. Como não poderia deixar de ser, louva os primeiros e rebaixa os segundos. Enquanto estes, sujeitos “refinados”, prender-se-iam “à torturas interiores, sem causa” e não tolerariam “a imagem da fome e o palavrão obsceno”, aqueles, de maneira aguerrida, aludiriam à "miséria das bagaceiras, das prisões, dos bairros operários, das casas de cômodos”191. No capítulo seguinte, tal oposição será examinada mais detidamente com fito de se especificar melhor as diretrizes poéticas do autor de Vidas Secas.

\subsubsection{A polêmica envolvendo Mário de Andrade, Jorge Amado e Joel Silveira}

Paralelamente à defesa dos escritores nordestinos, outras tópicas recorrentes nos escritos de Graciliano sobre literatura, após sua saída do cárcere, são a valorização do apuro formal e a crítica a certas facilidades advindas do Modernismo, especialmente aquilo que se referia à “Gramatiquinha da fala brasileira”. Nesse sentido, Graciliano participa em duas oportunidades

\footnotetext{
${ }^{188}$ RAMOS, Graciliano. Norte e Sul, Diário de Notícias, Rio de Janeiro, 25 abr. 1937 (Copyright de I.B.R exclusividade no Distrito Federal para o Diário de Notícias).

${ }^{189}$ RAMOS, Graciliano. O fator econômico no romance brasileiro, Observador Econômico e Financeiro, Rio de janeiro, ano II, n.15, abr. 1937.

${ }_{190}$ RAMOS, Graciliano. Linhas Tortas. Rio de Janeiro: Record, 2005, p.192.

${ }^{191}$ Idem, p. 191 e 192.
} 
de certa polêmica discursiva instaurada pelo texto "A palavra em falso", de Mário de Andrade. Com as crônicas “Os sapateiros da literatura” e "Os tostões do Sr. Mário de Andrade”, o autor alagoano entra no debate procurando defender os romancistas nordestinos de sua geração, especificamente os contendedores Jorge Amado e Joel Silveira, mas, ao mesmo tempo, compactua com o crítico paulista no que diz respeito à valorização da técnica na composição dos romances.

Mário, ao assumir a coluna "Vida Literária” do Diário de Notícias, em 1939, irá se colocar na defesa das conquistas modernistas que se banalizavam em função do mau uso das mesmas pelos autores, tomando como bandeira a valorização do apuro formal, a qual teria sido colocada em segundo plano em função tanto do engajamento político dos escritores como da expansão do mercado literário. O autor de Paulicéia Desvairada argumenta que o experimentalismo modernista estava se confundindo com ignorância. Basta ver o paralelo que traça entre o mau uso do verso livre, associado principalmente à poética modernista, e a vontade de retratar apenas a realidade (pura e simples) dos romances documentais. Ambos representavam o perigo do "abandono das preocupações técnicas, o se entregar à superficialidade das observações sem sublimação nem trabalho"192.

Na crônica "A palavra em falso”, em meio aos elogios com que recebe o primeiro livro de contos de Joel Silveira, Onda Raivosa, Mário não deixa de perceber o que julgava um equívoco. Ele aponta o trocadilho de mau gosto "perdida” usado para descrever os soluços de uma personagem ${ }^{193}$. “Ao ler está última palavra tive um sobressalto desagradável. Como é que o escritor delicado deixara escapar essa alusão grosseira ao que era a pobre da Margarida! A palavra soara totalmente em falso[...] Um cochilo"194.

Na semana seguinte, na revista Dom Casmurro, Jorge Amado revela toda sua insatisfação com o rodapé domingueiro de Mário de Andrade. O escritor baiano começa seu texto afirmando, indiretamente, que o desapontamento com o crítico paulista seria geral:

\footnotetext{
${ }^{192}$ ANDRADE, Mário de. Vida Literária. São Paulo: HUCITEC; EDUSP, 1993, p. 83.

${ }^{193}$ Segue o trecho do conto "Natal com Margarida” de Joel Silveira em que Mário detectara a construção que lhe soara como um equívoco: “- Não tenho mais jeito. No dia em que eu estiver velha o que vai ser? Tenho que pedir esmola. Sair de mochila pela rua pedindo esmola. - Soluçava como uma perdida” (SILVEIRA, Joel. Onda Raivosa. 1.ed. São Paulo: Editora Rumo Limitada, 1939 p.56).

${ }^{194}$ ANDRADE, Mário de. op.cit. p. 90.
} 
'Tristeza de ler Mário de Andrade nas manhãs de domingo’, disse um literato outro dia na porta da José Olympio. Disse sem maldade, disse mesmo com uma voz melancólica de quem tinha perdido um amigo precioso. E os do grupo, que pertenciam a vários grupos literários, baixaram a cabeça num triste assentimento $^{195}$.

Depois de enaltecer a figura de Mário, destacando que ele conseguiu com méritos o título de “mestre” entre a intelectualidade brasileira, continua a crítica indireta. Refere-se, agora, aos moços. Estes estariam desiludidos com o "ex-aguerrido” autor de Paulicéia Desvairada e zombariam apressadamente dele. Aqui Jorge Amado ataca uma das bases da proposta crítica mariodeandradina, nesse momento: o desejo de posar como alguém útil, sobretudo, para a mocidade.

Fundamentado o desânimo generalizado, o autor de Suor explicará porque julga a colaboração do “mestre” no Diário de Notícias um fracasso:

\begin{abstract}
No artigo do último domingo, sobre vários contistas, Mário de Andrade na sua crítica não foi procurar neles a mensagem que nos seus livros traziam para os homens. Delicado e detalhista ficou atrás das palavras 'falsas', dos termos que soaram falso aos seus ouvidos de esteta e professor de música. Ouvido gran-fino e educadíssimo ${ }^{196}$.
\end{abstract}

Percebe-se que a crítica se detém no excesso de esteticismo de Mário que deveria usar a sensibilidade para compreender a mensagem e não o ouvido para fazer crítica.

Duas semanas depois vem a resposta em “A Raposa e o Tostão”. Mário adota procedimento discursivo comum em seus textos: elogia pra depois criticar. Começa a crônica mencionando a fartura literária do momento em que vivia para daí empregar a metáfora monetária que norteará sua argumentação em torno da falta de apuro formal. Segundo ele, toda riqueza pressupõe o troco miúdo. “... nem tudo são cheques de cinqüenta contos, mas há notas de cem mil-réis, dez mil-réis e até moedinhas de tostão”197. Havia ainda as notas falsas.

Em seu raciocínio, caberia chamar por tostão todos aqueles que substituíam a técnica por intenções sociais vagas e interesses escusos em busca de sucesso editorial fácil. Não seria

195 AMADO, Jorge. O Tempo que Vai. Dom Casmurro, Rio de Janeiro, 12 ago. 1939.
196 Idem, ibidem.
${ }^{197}$ ANDRADE, Mário de. Empalhador de Passarinhos. São Paulo: Livraria Martins Editora, 1972, p. 101. 
aparentemente o caso de Jorge Amado, a quem Mário continuava a admirar como romancista, citando, inclusive, “a força comunicativa de um Jubiabá”,198.

Sua preocupação parecia recair sobre o que os tostões (e notas falsas) representavam de ruim em meio às engrenagens do mercado literário que se expandia: demagogia, repetição de processos bem sucedidos, malabarismos sentimentais, concessões fáceis ao público, vontade de se tornar célebre de antemão. Da condição de crítico abalizado e reconhecido, afirma que as "palavras em falso" que tirava das obras analisadas serviam para ilustrar as falhas do tempo em que vivia.

Mário quer se defender também da pecha de formalista. Diz categoricamente que não estava pregando o retorno ao Parnasianismo, tão duramente criticado no passado por confundir forma e fôrma. Faz a mea-culpa dos modernistas para dizer que as liberdades conquistadas não significavam dissolução total e libertinagem artística. Nesse momento, critica asperamente o mau realismo que se detinha apenas no núcleo da mensagem, aludindo ao que Jorge Amado dissera:

Jamais exigi de ninguém a forma rija do ditirambo, mas repudio e hei de profligar o amorfo, as confusões do prosaico com o verso-livre, a troca da técnica por um magro catecismo de receitas, o monótono realismo escamoteado em sua estupidez moluscóide aquela transposição para o mundo da arte, em que o mal de um se converte em mal de muitos. Tanto a arte convence... ${ }^{199}$.

Já no final do texto, quando adentra propriamente na descrição do mercado editorial, o termo “tostão” associado a interesses econômicos ganha mais relevo. O mercado crescia assim como o número de leitores o que despertava o ânimo dos romancistas. Na opinião do crítico, em meio a esse assanhamento, era seu papel separar "as imitações, as falsificações, as mistificações, ou apenas as pressas” que ameaçavam “confundir tudo”200.

A raposa do título reaparece no último parágrafo em citação literária de Lady into fox de David Garnett. Tal menção sugere uma crítica indireta a Jorge Amado que estava adquirindo os maus hábitos de seus admiradores: as raposas tostões.

\footnotetext{
198 Idem, p.102.

${ }^{199}$ Idem, p.105.

${ }^{200}$ Idem, p.106.
} 
Por outro lado, Mário também parece se defender, referindo-se indiretamente à citada crônica de seu opositor. Como foi visto, nela o escritor baiano, ao textualizar sua decepção com o rodapé literário mariodeandradino, tinha em mente o “mestre” do modernismo violento e destrutivo de Paulicéia Desvairada, ao qual todos admiravam, e não um articulista tão atento a problemas técnicos e formais num momento de ebulição política. Diante dessa incompatibilidade entre a própria imagem e o retrato feito pelos admiradores, Mário advoga em favor de certo ideal de "lealdade interior", correndo o risco de ser abandonado pela multidão que partiria “em busca de outras adorações”. Termina o texto em tom profético: “só na solidão encontraremos o caminho de nós mesmo" ${ }^{201}$. A frase enfatiza e fecha a discussão em torno da defesa do apuro formal ao sugerir o ato de cultivar-se.

Não por acaso, Jorge Amado responde com uma crônica intitulada "A Solidão é Triste”. Colocando-se na condição de grande injustiçado, ele redobra a carga de ataques sobre o formalismo de seu opositor. Defende também com todo vigor a poética do realismo crítico da qual partilhava. Para isso, vale-se de uma imagem que refletiria o isolamento e a mesquinhez do autor de Macunaíma:

\footnotetext{
O crítico nessa sua última fase tenta uma volta desesperada à torre de marfim. O espetáculo tão triste do mundo guerreiro horroriza a fina sensibilidade de esteta e ele não pensa que talvez sua inteligência pudesse ser útil para melhorar os homens enlouquecidos. Foge para a sua torre de marfim [...]Um sujeito da importância e da projeção desse escritor não tinha direito a essa atitude ${ }^{202}$.
}

Jorge considerava a técnica importante, mas naquele momento não a julgava primordial. A Segunda Guerra Mundial começara no dia anterior ao texto que escrevia ( $1^{\circ}$ de setembro): “É claro que é importante e em determinados momentos do mundo, momentos calmos e felizes, pode até ser estudado como a mais importante. Mas nesse momento terrível ela passa para um palco absolutamente secundário ${ }^{203}$.

Joel da Silveira, ao entrar na briga, faz pergunta semelhante à de Jorge Amado: "Mário de Andrade de ontem, onde estás que não respondes?”204. Em seguida, retomando a metáfora

\footnotetext{
${ }^{201}$ Idem, p.107.

${ }^{202}$ AMADO, Jorge. A Solidão é triste. Dom Casmurro, Rio de Janeiro, n. 116, 02 set. 1939.

203 Idem, ibidem.

${ }^{204}$ Vale destacar que na já citada primeira edição de Onda Raivosa há o recorte de uma crítica favorável de Jorge Amado a Joel Silveira: “... Além disso tem muito talento e de repente se colocou entre os nosso melhores cronistas. O futuro está deante dêle e creio que Joel Silveira está fadado a uma brilhante carreira intelectual”.
} 
monetária mariodeandradina, exemplifica quem seriam os tostões e os cinqüenta contos de réis. Traz a discussão para o terreno da luta de classes:

\begin{abstract}
...o sr. Mário de Andrade com óculos, cultura, espírito e tudo, inclusive fichário e biblioteca representa a gordíssima soma de cincoenta contos de réis em cédulas novinhas do Banco do Brasil. Eu, com toda a malidez, com todos os intestinos arruinados por uma alimentação deficiente com toda a ignorância, ousadia e burrice, valho simplesmente um tostão, um microscópico tostão sem utilidade ${ }^{205}$.
\end{abstract}

Enfim, Graciliano Ramos entra em cena para finalizar e trazer à tona a importante discussão (que ia sendo silenciada pelos telegramas que vinham da Europa em guerra). Para ilustrar a verdade laplaciana de que todo o escritor deve saber escrever, Graciliano, em "Os sapateiros da literatura”, associa o fazer do "verdadeiro" homem de letras ao trabalho de um sapateiro honesto. Da mesma maneira que este dominava manuseio de seus instrumentos, aquele deveria conhecer os meandros da arte da escrita. Nesse sentido, constrói uma série de analogias entre o romance e o sapato e entre a própria composição destes:

Dificilmente podemos coser idéias e sentimentos, apresentá-los ao público, se nos falta a habilidade indispensável à tarefa, da mesma forma que não podemos juntar pedaços de couro e razoavelmente compor um par de sapatos, se os nossos dedos bisonhos não conseguem manejar a faca, a sovela, o cordel e as ilhós ${ }^{206}$.

Ao mesmo tempo em que tal comparação aproxima-o de Mário, também o distancia deste. Graciliano sugere que os escritores que dependiam da literatura para sobreviver não estariam tão longe de um pequeno operário. Apresenta uma percepção materialista (e classista) do fazer artístico, retomando parcialmente o argumento de Joel Silveira.

Nesse sentido, separa os "sapateiros da literatura” dos "literatos por nomeação”. Na primeira categoria, estariam os rapazes da Dom Casmurro (entre eles Joel Silveira) - os escritores flagelados vindos do nordeste miserável. Por serem tomados como "desgraçados” e "pobresdiabos", e dependerem da literatura para ganhar os citados "tostões" (tomados em sentido estrito), são vistos por Graciliano como artistas mais verdadeiros e autênticos. Pela lógica do texto, o autor alagoano inclui-se nesse grupo que trabalhava como os sapateiros: "ficamos na tripeça, cosendo, batendo e grudando”. Já o segundo conjunto englobaria os literatos ditos de

\footnotetext{
${ }^{205}$ SILVEIRA, Joel. Fala um Tostão. Dom Casmurro, Rio de Janeiro, 12 set. 1939.

${ }^{206}$ RAMOS, Graciliano. op.cit. p. 268.
} 
fachada: "um certo número de indivíduos que se vestem bem, comem direito, gargarejam discursos, dançam e conversam besteira com muita facilidade” ${ }^{207}$. A referência não parece ser feita diretamente a Mário, mas aos membros da Academia Brasileira de Letras, insistentemente criticados pelo autor de Vidas Secas em outros textos ${ }^{208}$.

A própria maneira pela qual Graciliano se identifica com os "operários do texto", torna evidente a defesa do tipo literatura de que partilhava: o romance nordestino que procurava representar certos problemas sociais, principalmente, aqueles associados ao interior do país. Segundo o autor, por mais precários que fossem seus instrumentos de ação (a sovela e a faca miúda), bem usados, eles seriam armas para cortar o "couro da realidade”. Nota-se aqui a reutilização, por parte do escritor, do pseudo-rebaixamento de seus objetos de trabalho como forma de elevar os resultados obtidos com estes, ou seja, os romances nordestinos que vinham sendo confeccionados.

Já em “Os tostões do sr. Mário de Andrade”, Graciliano adota abertamente um tom conciliador, deixando mais claro o que esboçara na crônica anterior: ao mesmo tempo em que defende o chamado realismo nordestino crítico (de Jorge Amado e Joel Silveira), manifesta preocupação excessiva com arte de escrever ${ }^{209}$. Na verdade, essas duas perspectivas parecem caminhar juntas. Apegar-se ao argumento da valorização do apuro formal seria um meio também de separar o joio do trigo e de amparar as produções nordestinas que naquele momento eram alvos constantes de críticas, tais como as de Octávio Faria, que afirmava que certos escritores do Norte estariam "renegando o romance por um sem número de deuses em moda, sacrificando-o ao sucesso imediato ou ás possibilidades políticas de uma vitória esquerdista”210.

Graciliano, portanto, procura sanar o mal-entendido causado pela metáfora monetária empregada por Mário e pelo posterior paradoxo sustentado por Joel Silveira. O primeiro ao “colar em alguns escritores etiquetas com preços muito elevados, rebaixando o valor de

\footnotetext{
${ }^{207}$ Idem, p. 269.

208 Basta ver a crônica “Uma eleição” também de Linhas Tortas em que cita a ABL como uma “casa onde existem numerosos médicos e alguns literatos” (p.255). A ironia continua ao criticar abertamente a instituição, afirmando que ela daria preferência a escritores inofensivos, visando sua autopreservação.

${ }^{209}$ Como já indicara em outros textos de Linhas Tortas, Graciliano considera o fazer literário como uma empreitada áspera. Para ele, o estalo criativo (proveniente de alguma emanação divina) daria lugar à paciência e à consulta ao dicionário. Manifesta, assim, a tópica da busca por um constante aprimoramento do estilo. Além das crônicas, sua produção romanesca e memorialística revelam a premência e a tensão dessas questões.

${ }^{210}$ FARIA, Octávio. O defunto se levanta. O Jornal, Rio de Janeiro, maio 1937.
} 
outros”211 tornava antipática a boa causa que defendia. Nesse sentido, o cronista reafirmava a importância da técnica, tendo em vista "o mau gosto e a imperícia que atualmente reinam e desembestam na literatura nacional"212.

O contra-senso seria Joel Silveira que “não é tostão, nunca foi”, assumir-se como tal. "Escreveu um excelente artigo para mostrar que não sabe escrever”. Essa atitude poderia atiçar vaidade dos verdadeiros “tostões”, na medida em que poderiam se identificar com Joel e pensar coisas do tipo: "Ora se Joel, tão arrastado, tão amarelo, tão barato, faz contos, crônicas interessantes, porque não faremos nós coisa igual? Mexamo-nos, fundemos sociedades e pinguemos em revistas os nossos cinco vinténs de literatura” ${ }^{213}$. Um desastre, na argumentação de Graciliano.

\subsubsection{O concurso da José Olympio e a tematização de seus romances nas crônicas}

No discurso do cronista sobre a vida e a produção literária carioca que lhe eram contemporâneas, destaca-se um episódio, colocado em relevo em duas oportunidades: a polêmica em torno do concurso Humberto de Campos, organizado pela livraria José Olympio. Nele chegaram ao último escrutínio Luís Jardim e Viator, pseudônimo que, depois se soube, pertencia a Guimarães Rosa. Trata-se da representação de um fato específico, mas que ganha magnitude por se tratar da relação entre dois dos romancistas brasileiros mais celebrados pelo discurso da crítica no século XX. A descrição pormenorizada do acontecimento dá aos textos status de supostos documentos de interesse histórico e literário. Paralelamente, a opção de retratar os bastidores da premiação cria o efeito de desocultação dos mecanismos de funcionamento do meio artístico, revelando, aparentemente, os autores além de seus textos.

Enquanto membro integrante comissão julgadora do concurso, Graciliano considerou o livro de Viator "terrivelmente desigual”, o qual apresentaria momentos grandiosos e ordinários, e por isso colocou-se contra ele. Na primeira crônica sobre o assunto, “Um livro inédito”, o narrador destaca que, mesmo tendo votado contra Viator, considerava-o um escritor de grande valia, apesar “dos contos ruins e de várias passagens de mau gosto”²14. Questionava o desaparecimento deste após a derrota e afirmava que seus contos deveriam ser publicados,

\footnotetext{
${ }^{211}$ RAMOS, Graciliano. op.cit. p.271.

${ }^{212}$ Idem, p.273.

${ }^{213}$ Idem. ibidem.

${ }^{214}$ Idem, p.155.
} 
mesmo com as passagens ruins para justificar os votos do júri Humberto de Campos. Já na segunda crônica, “Conversa de bastidores”215, Graciliano retoma o episódio do concurso sete anos depois, quando Rosa acabara de lançar seu primeiro livro, Sagarana, que reunia boa parte das narrativas apresentadas ao referido júri. Nesse texto, Graciliano tenta explicar a situação, adotando certo tom de remorso, pois teria vacilado na escolha. Relata o seu encontro com Rosa em 1944, recriando um suposto diálogo com este:

- O senhor figurou num júri que julgou um livro meu em 1938

- Como era seu pseudônimo?

- Viator.

- Ah! O senhor é o médico mineiro que andei procurando. [...]

- Sabe que votei contra seu livro?

- Sei, respondeu-me sem nenhum ressentimento ${ }^{216}$.

Logo em seguida, o narrador afirma que reiterou ao romancista mineiro as críticas que fizera ainda durante o concurso de 1938. Rosa teria concordado com ele, suprimindo os contos mais fracos. De maneira geral, essa ressalva tem a função de legitimar a aparente falha do crítico Graciliano, preservando sua posição.

Se, em suas crônicas provincianas, os diferentes narradores, R.O. e J. Calisto, valiam-se da metalinguagem para comentar os textos que escreviam, encenando a redação dos mesmos, em sua segunda permanência no Rio de Janeiro, o cronista Graciliano Ramos usará tal expediente para discutir elementos concernentes a sua própria produção como romancista. Dessa maneira, procura desmistificar alguns aspectos de sua criação literária, adotando a estratégia de supostamente humanizar-se diante do leitor. Tais afirmações, portanto, deveriam ser vistas como componentes da ficção de Graciliano e não como recursos absolutos para se compreender sua obra. Elas integram seu projeto geral de fingimento artístico e de composição de sua persona literária.

No texto “Alguns tipos sem importância”, feito a pedido do crítico Brito Broca, que gostaria de saber como teriam sido criados os personagens de seus romances, Graciliano debruça-se sobre sua própria obra literária por meio da crônica. O próprio título já demonstra

\footnotetext{
215 Tal crônica saiu publicada pela primeira vez na revista A Casa, número de junho de 1946 e depois reproduzida em vários jornais do país, inclusive em A Tribuna, de Santos, em 06 de outubro de 1946. (Em MEMÓRIA de Guimarães Rosa, Rio de Janeiro: Livraria José Olympio Editora, 1968).

${ }^{216}$ RAMOS, Graciliano. op.cit. p.353.
} 
autodepreciação retórica, que serve de justificativa para falar de si mesmo num texto de jornal. O cronista diz que as obras depois de publicadas ganhariam vida, além de qualquer intencionalidade pensada:

(...) - os leitores vêem o que não tive a intenção de criar, aumentam ou reduzem as minhas figuras, e isto prova que nunca realizei o que pretendi. Referindo-me, portanto, a essa cambada não penso no que ela é hoje multiforme, incongruente, modificada pelo público, mas nos tipos que imaginei e tentei compor inutilmente. Falharam todos. Esta declaração é necessária: talvez não anule, mas pelo menos atenuará uns toques de vaidade que por acaso apareçam nas linhas que se seguem ${ }^{217}$.

Em seguida, relata seu começo supostamente ocasional como literato redigindo “contos ordinários”, dos quais teriam partido suas três obras iniciais - Caetés, S. Bernardo e Angústia. Em seguida, trata de Vidas Secas que apareceu, inicialmente, com o conto "Baleia” e depois foi se expandindo de forma fragmentada; cada nova narrativa poderia ser lida separadamente ou como um capítulo do livro.

\subsection{A produção comunista}

Em agosto de 1945, Graciliano filia-se ao Partido Comunista do Brasil (PCB). Nesse momento, a organização voltava a funcionar legalmente e se aproximava do já decadente ditador Getúlio Vargas no contexto do final da Segunda Guerra Mundial (1939-1945). O romancista alagoano torna-se um militante disciplinado. Participava de células, encontros e reuniões partidárias, pronunciava e redigia discursos, além de colaborar, sem regularidade, com veículos da imprensa comunista.

No entanto, antes mesmo de entrar oficialmente no partido, ainda no final da década de 1930, Graciliano colaborara com dois veículos de orientação comunista, voltados, sobretudo, para o campo cultural: o periódico paulista Cultura: Mensário Democrático e a carioca Esfera: revista de letras, artes e ciências. O primeiro é lançado em outubro de 1938, num contexto de disputas no interior do próprio Partidão. Naquele momento, o grupo carioca, liderado por Lauro Reginaldo da Rocha, o Bangu, tomava o controle do PCB, defendendo a tese de "União Nacional”218 e a conseqüente aproximação do ditador Getúlio Vargas, depois de

\footnotetext{
${ }^{217}$ RAMOS, Graciliano. Linhas Tortas. p.278.

${ }^{218}$ Depois de denunciar em seu jornal oficial, A Classe Operária, em agosto e novembro de 1936, as manobras golpistas de Getúlio, o PCB, a partir de 1938, influenciado pelas decisões adotadas no VII Congresso da Internacional Comunista (entre elas a formação de Frentes Populares) e pela ascensão de Hitler na Alemanha, começou a defender a bandeira da "União Nacional”, embora ela só tenha sido adotada oficialmente a partir da Conferência da Mantiqueira, realizada em 1943. Como se sabe esta consagrou, a visão de que havia uma
} 
travar uma luta "subterrânea” contra o Comitê Central Provisório (CCP) de São Paulo, chefiado por Hermínio Sacchetta e Heitor Ferreira Lima ${ }^{219}$. Em tal cenário, Cultura: Mensário Democrático aparece com a finalidade de reduzir a influência de Problemas, revista de sucesso, comandada pelos comunistas da capital paulista ${ }^{220}$.

Adotando uma linha antifascista e nacionalista, Cultura atrai boa parte da intelectualidade de esquerda $^{221}$. De maneira geral, em suas quarenta páginas mensais, a revista tratava de letras, artes em geral (sobretudo cinema), ciências, história, filosofia, moda, além de enfatizar a luta contra o fascismo e a defesa da política de "união nacional” ${ }^{\text {222 }}$. Seu conselho editorial era formado por Affonso Schmidt, Álvaro Moreyra, Edgar Monteiro Lobato, Oswald de Andrade, Sérgio Milliet e Graciliano Ramos. Além de exercer tal função, o escritor alagoano também publica no quinto número do periódico, de fevereiro/março de 1939, o texto "Uma personagem curiosa”, no qual detém-se na análise do livro Amanhecer (1938), de Lúcia Miguel Pereira.

Tendo como redatora-chefe Silvia de Leon Chalreo, Esfera: revista de letras, artes $e$ ciências, como não poderia deixar de ser, privilegiava os assuntos descritos em seu próprio subtítulo, na ordem que os mesmos eram apresentados: literatura (crítica e material ficcional inédito), artes em geral (cinema, pintura, teatro etc.), além de textos sobre história, folclore e saúde, entre outros ${ }^{223}$. Além de figurar como redator da publicação, ao lado de nomes como Dias da Costa, Eneida, José Lins do Rego e Jorge Amado, Graciliano publica também apenas um texto na mesma. Trata-se da crônica “Um anúncio”, ainda inédita em livro. Nesse

burguesia progressista no Brasil e que ela seria aliada do proletariado na execução da revolução brasileira (OLIVEIRA, José Eduardo. O discurso democrático no pós-guerra: a voz do PCB. 2003, 338f. Tese (Doutorado) - Faculdade de Filosofia Letras e Ciências Humanas. Universidade de São Paulo, São Paulo, 2003). ${ }^{219}$ Conflito minuciosamente descrito por Dainis Karepovs em Luta subterrânea, O PCB em 1937-1938 (São Paulo, Hucitec, UNESP, 2003).

${ }^{220}$ DULLES, John. W.F. O comunismo no Brasil. Rio de Janeiro: Nova Fronteira, 1985, p.170. Ao se referir a Cultura: Mensário Democrático, o autor destaca: “Um dos membros do seu conselho diretor era Graciliano Ramos, que fora preso sem dar grande motivo para isso ou, até, sem dar motivo algum, em seguida aos levantes de 1935 (e que entraria para o PCB em 1945)” (Idem, ibidem).

${ }^{221}$ Cultura circulou até setembro de 1940, totalizando 18 números.

${ }^{222}$ Com a relação a este último ponto, ver, por exemplo, o artigo “O sentido da União Nacional”, de Rubens F. Netto, no qual se destacam as palavras de Getúlio: ‘NENHUM SACRIFÍCIO, NESTA HORA GRAVE, SERÁ BASTANTE, NENHUMA VIGILÂNCIA EXCESSIVA PARA A DEFESA DE NOSSA BANDEIRA, DE NOSSO IDIOMA, DAS NOSSAS TRADIÇÕES’ (Cultura, ano 1, n.2, São Paulo, nov. 1938, p.34).

223 De acordo com os números remanescentes de Esfera no Instituto de Estudos Brasileiros e na seção de periódicos da Biblioteca Nacional observa-se que a revista circulou mensalmente em seus quatro primeiros números, de maio a agosto de 1938. Em seguida, há um grande salto. O próximo número encontrado é apenas de março de 1944 (ano 3, n.9). Nesse momento, Graciliano ainda figura entre os redatores, apesar de não ser detectada a publicação de nenhum texto de sua autoria. A publicação segue, com grandes intervalos e mudanças, até outubro 1949. 
trabalho, o artista alagoano analisa a atitude inusitada de Amadeu Amaral Júnior, escritor que anunciara num jornal que se encontrava desempregado e oferecia seus serviços literários. O caso é utilizado pelo autor de Caetés para discutir, de maneira irônica, a precariedade em que se encontravam os homens de letras no país.

Ainda antes de sua entrada no PCB, Graciliano também colabora com dois importantes periódicos, que, se não estavam vinculados diretamente ao Partidão, sofriam forte influência deste. Tratava-se de Dom Casmurro e da revista Diretrizes. O primeiro começou a circular ainda em 1937, sob direção de Brício de Abreu. Ao longo de sua vida teve como diretores Álvaro Moreyra, Marques Rebelo e Jorge Amado, dedicando-se, basicamente à literatura nacional $^{224}$. Quanto ao segundo, lançado por Samuel Wainer e Azevedo Amaral, em março de 1938, dedicava-se, basicamente, à política (com destaque para o noticiário internacional) e às letras, dispondo, inclusive de um suplemento literário ${ }^{225}$. Depois da saída de Amaral, sobretudo, o periódico passa a adotar uma linha abertamente antifascista, já sob forte ingerência dos comunistas.

A censura getulista acompanhava de perto o trabalho realizado por essas duas publicações. Ambas eram alvos de sindicâncias. Um relatório interno, datado de 3 de novembro de 1939 e endereçado ao chefe de política, assim se referia a elas de maneira conclusiva:

\footnotetext{
Essas revistas não defendem francamente os pontos de vista marxistas, porque tal atitude ser-lhes-ia vedada pela polícia, mas quase toda a sua literatura é orientada no sentido de criação de uma tendência claramente esquerdista.

Sabemos, aliás, que o PCB recomenda a leitura de ambas e de tal fato já demos conhecimento a V. Exa. e a circunstância de terem sido encontrados inúmeros exemplares dessas publicidades nas buscas ultimamente efetuadas pela Delegacia na sede do Comitê Regional do Partido e em diversas células vem confirmar esta informação e demonstrar que se tratam de órgãos tendenciosos e prejudiciais ao interesse
}

\footnotetext{
224 Álvaro Moreyra sublinhava no primeiro número de Dom Casmurro, que o periódico “foi fundado por escritores e jornalistas, e é dirigido por eles” (MOREYRA, Álvaro. Dom Casmurro, ano 1, n.1, 13 maio 1937, p.1).

${ }^{225}$ Com relação ainda à divulgação literária, Diretrizes publicou, em forma de folhetim, a novela Brandão entre o mar e amor, escrito por Graciliano Ramos, José Lins do Rego, Jorge Amado, Rachel de Queiroz e Aníbal Machado, a qual viria a ser publicada pela Martins em 1942. Além disso, editou, também de modo folhetinesco, o ABC de Castro Alves, escrito pelo autor de Jubiabá.
} 
público, porquanto sob a capa de veiculadores da cultura universal, propagam, veladamente, doutrinas que colidem com a organização política e social do país ${ }^{226}$.

Apesar da perseguição política, Graciliano publicou cinco textos em cada um destes veículos. Em Dom Casmurro, entre agosto de 1939 e julho de 1940, o autor alagoano estampou crônicas sobre a vida cultural brasileira, seguindo diretriz assumida por sua produção jornalística depois de sua saída da prisão ${ }^{227}$. Já para Diretrizes, no intervalo entre março de 1941 e dezembro de 1923, o artista destinou capítulos de Infância (1945), que vieram a público, primeiramente em tal periódico ${ }^{228}$. Tais textos, editados parcialmente como contos isolados, eram quase sempre acompanhados por ilustrações de artistas famosos (entre eles, Santa Rosa, Percy Deane e Augusto Rodrigues), o que indicia importância conferia aos mesmos. Ao mesmo tempo, o escritor figurava no conselho diretor da revista, ao lado de, entre outros, Astrogildo Pereira ${ }^{229}$.

Nas vésperas de entrar para os quadros do PCB, ainda em julho de 1945, o escritor republica, agora no jornal comunista Tribuna Popular, o artigo "O fator econômico no romance brasileiro”. Como conseqüência imediata da anistia decretada por Getúlio Vargas, tal periódico começou a circular em maio daquele ano, tendo como diretores Pedro Mota Lima, Dalcídio Jurandir, Álvaro Moreyra e Carlos Drummond de Andrade ${ }^{230}$. Além de defender a luta popular, promover o ideal de "união nacional” e combater os remanescentes do fascismo, o jornal engaja-se na propaganda ideológica do partido, bem como na campanha eleitoral para a presidência e eleição da Assembléia Constituinte ${ }^{231}$. Paralelamente, confere grande espaço

226 TEIXEIRA, Baptista (Cap. Delegado Especial). Relatório ao Exmo. Sr. Dr. Chefe de Polícia. Arquivo Público Estado do Rio de Janeiro, Fundo Polícias Política no Rio de Janeiro, Setor Comunismo, Pasta 4D, Anexo 174, 3 nov. 1939.

${ }^{227}$ Trata-se das crônicas, todas elas reunidas em Linhas Tortas: “Alguns tipos sem importância” (ano 3, n.114, 19 ago. 1939); "Um velho cartão postal” (ano 3, n.119, 23 set. 1939); “O teatro de Oswald de Andrade” (ano 3, n.127, 2 dez. 1939); “Uma justificação de voto” (ano 4, n.157, 13 jul. 1940); e “A poesia de Beatrix Reynal” (ano 5, n.202, 31 maio 1941).

${ }^{228}$ São eles “Chegada à vila” (Il. Santa Rosa, 6 mar. 1941); “José da Luz” (Il. Percy Deane, 12 ago. 1943, p.13 e 23); “Escola” (Il. Percy Deane, 21 out. 1943); “Chico Brabo” (23 dez. 1943); e “Manhã” (Il. Augusto Rodrigues, p.1 e 8.).

${ }^{229}$ Em outro documento da Polícia Política, um boletim de abril de 1941, o nome de Graciliano aparece entre os redatores de Diretrizes, os quais são descritos como “elementos que combatem o governo" e ainda "sujeitos fichados como participantes de atividades subversivas” (DIRETRIZES (revista), S-1. - Boletim n. 88 (pag.XXI). Arquivo Público Estado do Rio de Janeiro, Fundo Polícias Política no Rio de Janeiro, Setor Comunismo, Pasta 4D, Folha 00012 - (21), 12/13 abr. 1941).

${ }^{230}$ Pouco tempo depois, este último solicita a retirada de seu nome ao "constatar que alguns eram mais diretores que outros e que estava difícil participar da direção e do trabalho do jornal” (RUBIM, Antônio Canelas. Partido Comunista, Cultura e Política Cultural. 1986. 415fl. Tese (Doutorado) - Faculdade de Filosofia Letras e Ciências Humanas. Universidade de São Paulo, São Paulo, 1986, p.41).

${ }^{231}$ Idem, p.40-41. 
às atividades culturais, congregando inúmeros intelectuais ${ }^{232}$. De maneira geral, nessa nova ambiência discursiva esquerdista, a idéia de uma literatura ancorada em análises econômicas e na representação de certos problemas nacionais, veiculada pelo texto no autor alagoano, parece ajustar-se perfeitamente às perspectivas culturais da agremiação partidária naquele momento.

Logo depois de sua entrada efeitva no PCB, abonada pelo próprio Prestes em 18 de agosto de $1945^{233}$, o romancista alagoano concedera uma entrevista de página inteira a Ruy Facó, de a Tribuna Popular. Em linhas gerais, tal jornalista procura estabelecer uma conexão entre a obra pregressa do escritor, as experiências de vida deste nos cárceres getulistas e a decisão do mesmo de entrar no "partido do povo”. Haveria uma suposta consonância entre as opções políticas do artista e do homem Graciliano Ramos:

Seu vigoroso romance Vidas Secas, posterior à prisão, é um grito do povo do Nordeste brasileiro, contra as condições semi-feudais em que tem vivido. A prisão abriu mais os olhos de Graciliano Ramos, trouxe-o mais para perto da vida, fazendo-o enxergar a vida por ângulos até então imperceptíveis.

Era o caminho aberto para sua última resolução, resolução mais importante de sua vida: o ingresso no Partido Comunista. Lembremo-nos que na prisão, intimidado pela polícia-política a assinar um documento pelo qual se 'obrigaria a abandonar suas atividades comunistas', Graciliano recusou-se terminantemente a fazê-lo, mesmo não sendo comunista, como de fato não o era, então. Preferiu as torturas da prisão que o puseram gravemente enfermo, a submeter-se a obrigação semelhante.

(...) Graciliano Ramos abriu caminho para muitos outros intelectuais honestos, mesmo para aqueles que só tem vivido em torres de marfim, mas que finalmente serão chamados pelos próprios acontecimentos a cumprir sua missão de escritores, a ligar-se à corrente política que representa o proletariado e o povo: o PCB. ${ }^{234}$.

A partir de então, cumprindo o compromisso que fora anunciado na entrevista, a grande maioria das colaborações de Graciliano, publicadas em diferentes veículos do PCB, procurará defender abertamente as diretrizes partidárias. Nesse sentido, no dia 10 de outubro de 1945, a Tribuna Popular transcreve integralmente um discurso do artista alagoano intitulado "A tarefa principal: Constituinte!”. Nele, o escritor parece se enquadrar na política do partido, assentada no “queremismo” que defendia uma constituinte com Getúlio no poder. Nesse momento, o

\footnotetext{
${ }^{232}$ Idem, p.41.

${ }^{233}$ MORAES, Dênis de. op.cit. p.210.

${ }^{234}$ FACÓ, Ruy. Graciliano Ramos, escritor do povo e militante do PC. Fotos Ruy Santos, Tribuna Popular, Suplemento de Literatura e Arte, Rio de Janeiro, 26 ago. 1945.
} 
ditador passa a ser visto pelo Partidão como um líder progressista, pois além de ter entrado na guerra ao lado de Stálin, ainda em 1945 havia estabelecido relações diplomáticas com a URSS e assinado uma lei antitruste ${ }^{235}$.

Em setembro do mesmo ano, o literato alagoano estampa, ainda nessa mesma folha, o texto “Os amigos do povo”, no qual rebate determinadas críticas feitas ao PCB por José Lins do Rego $^{236}$. Como se deslegitimasse a atuação do Partidão, tal autor propunha a criação de um partido que fosse "o verdadeiro amigo do povo, um complexo de idéias generosas, de compromissos com a dignidade humana" ${ }^{\text {237 }}$. Com o intuito de defender os interesses do órgão comunista e ao mesmo tempo ser cordial com o velho amigo, Graciliano procurava apontar incongruências e contradições no discurso deste. Nesse sentido, argumenta que agremiação reivindicada pelo escritor paraibano já existia, pois o PCB atuava de maneira organizada em todo o território nacional na luta pelas causas populares. Paralelamente, se discordava do homem Zé Lins, preferia pensar como o quixotesco personagem de Fogo Morto, Vitorino papa-rabo, o qual imagina ter ganhado vida, saído das páginas do livro e se tornado militante de uma das células do partido. Indiretamente, portanto, sugere que autor de Doidinho, com esse posicionamento crítico, estaria em desacordo com sua própria obra.

Nessa mesma linha, meses depois, Graciliano publica o desconhecido artigo "O Partido Comunista e a criação literária”, também na Tribuna Popular do Rio de Janeiro ${ }^{238}$. Como se sabe, a agremiação, nesse momento, estava em franca campanha para ampliar sua ação política. Com o referido texto, Graciliano parece se ajustar a tal projeto expansionista na medida em que procura defender a idéia de que não haveria ingerência do partido nas

\footnotetext{
${ }^{235}$ FAUSTO, Boris. História do Brasil. São Paulo: Edusp, 2003, p.386-387.

${ }^{236}$ Quando da entrada oficial de Graciliano no PCB, José Lins comentara o fato de maneira crítica: “Graciliano Ramos pretende agora deixar o plano da ação interior, da criação de personagens para tomar parte na reforma geral da sociedade. O mundo que ele concebeu era um mundo de escuridão, de erros terríveis, de mutilações e de rancores. O romancista que mergulhara nos mistérios da natureza humana seviciada, volta às raízes de sua própria vida em livro de memórias de infância. E no dia que entrega ao público este seu documento impressionante volta-se para uma solução de reforma que lhe parece a aurora da humanidade que renasce. $\mathrm{E}$ ele tanto acredita nesta aurora, que não vacila em afirmar que o "comunismo é a juventude do mundo" (REGO, José Lins. O comunista Graciliano Ramos. [?], [Rio de Janeiro?], 1945. Arquivo Graciliano Ramos, Instituto de Estudos Brasileiros, Série Recorte, Pasta 16, Documento 30).

${ }^{237}$ REGO, José Lins. apud RAMOS, Graciliano. Linhas Tortas. Rio de Janeiro: Record, 2005, p.372. Segundo Moraes, em tal artigo, o autor paraibano pediria a criação de um partido que fosse "verdadeiro amigo do povo", pois seu candidato às eleições presidenciais, o brigadeiro Eduardo Gomes, fora derrotado por Eurico Dutra no pleito realizado naquele momento (MORAES, Denis de. op.cit. p.216).

${ }^{238}$ Neste momento, o periódico já se consolidara como o órgão mais importante de uma cadeia de jornais editados pelo PCB nas grandes cidades do país. A publicação tinha uma tiragem média de 30 mil exemplares diários e chegou a atingir, em 1946, cerca de 50 mil, igualando-se aos jornais mais vendidos no período (RUBIM, Antônio Canelas. op.cit., p.41).
} 
produções artísticas de seus filiados. Seu depoimento serve de estímulo e de convite a intelectuais receosos de fazerem parte das fileiras do $\mathrm{PCB}^{239}$ :

É desnecessário asseverarmos que o Partido Comunista nenhum dano causa à produção literária (...) Tolice imaginar que lhes vão torcer as idéias, impor o trabalho desta ou daquela maneira. Foram as idéias que os trouxeram, todos vieram de olhos muito abertos, conhecendo perfeitamente o caminho. Ninguém está aqui por sentimento ou religião (...) E é claro que não haveria conveniência em fabricar normas estéticas, conceber receitas para a obra de arte. Cada qual tem a sua técnica, o seu jeito de matar as pulgas, como se diz em linguagem vulgar ${ }^{240}$.

Em seguida, aproxima aquilo que imagina ser o projeto literário da instituição da concepção que ele próprio fazia de literatura, conforme próprio escritor já havia exposto em "O fator econômico no romance brasileiro": a construção do efeito de real por meio da ficcionalização das mazelas do país:

Afinal para expormos as misérias desta sociedade meio decomposta não precisamos de longo esforço nem talento extraordinário: abrimos os olhos e ouvimos, jogamos no papel honestamente os fatos.

Difícil seria defendê-la. Por isso nossos inimigos se desesperam. E afastam-se da terra. E vivem a descobrir mundos imaginários ${ }^{241}$.

Percebe-se que indiretamente Graciliano continua a se contrapor aos romancistas tachados de intimistas, os quais deixariam de lado a representação de problemas sociais para privilegiar certos dramas e situações que diriam respeito ao universo temático das classes mais abastadas da população.

Em setembro de 1946, depois do retorno de Astrojildo Pereira ao PCB, começa a circular a revista Literatura. O veículo tinha a proposta de ser o porta-voz oficioso do partido na área cultural $^{242}$. A publicação, dirigida pelo próprio Astrojildo, apresentava em seu conselho editorial o próprio Graciliano ao lado de Álvaro Moreyra, Aníbal Machado, Arthur Ramos,

\footnotetext{
${ }^{239}$ O articulista acaba ecoando a iniciativa de Pedro Pomar, Jorge Amado e Pablo Neruda que, também em 1946, lançaram, pela editora Horizonte do Rio de Janeiro, o livro O Partido Comunista e a liberdade de criação.

240 RAMOS, Graciliano. O partido comunista e a criação literária. Tribuna Popular, Rio de Janeiro, 22 maio 1946. Texto ainda inédito em livro.

${ }^{241}$ Idem, ibidem.

${ }^{242}$ No entanto, Literatura acabou não sendo assumida devidamente pelo PCB, "mas considerada como algo de Astrogildo Pereira e só, por vezes ajudada financeiramente” (RUBIM, Antônio Canelas. op.cit, p.49).
} 
Manuel Bandeira e Orígenes Lessa. Portanto, apesar de diretamente vinculada à entidade, possuía colaboradores variados ${ }^{243}$.

No editorial de apresentação do periódico, há a preocupação de seus editores em explicar o significado que a palavra "Literatura" teria para eles: o termo seria empregado "no seu sentido autêntico, ativo e militante, ou seja, no sentido oposto a tudo que signifique passatempo, divertimento, jogo, esporte, luxo, bibelô bibliográfico”244. Fica evidente o privilégio àquilo que se entende como "literatura engajada”, a qual deveria se pautar pela representação de certas feridas sociais tendo como objetivo a conscientização e a "elevação do nível cultural das massas”.

De acordo com estes princípios, logo no primeiro número da revista, Graciliano assina o texto "Decadência do romance brasileiro". Nessa colaboração, o escritor alagoano procura realizar um reexame severo das produções de seus companheiros de geração. Considera que desde a Intentona Comunista de 1935, as obras dos principais expoentes do romance nordestino (Rachel de Queirós, Jorge Amado, José Lins do Rego e Amando Fontes) estariam em franco declínio. Segundo o crítico, isso teria acontecido, pois tais romancistas teriam deixado de lado a ficcionalização de suas experiências interioranas para tratarem da representação sofisticada de cenas e situações que lhes seriam estranhas e distantes. Acaba indiretamente aproximando-os dos adeptos do romance intimista, os quais eram descritos por Graciliano como sujeitos refinados, em suma "burgueses”, realizadores de uma espécie de “espiritismo literário":

[Referindo-se aos expoentes do romance nordestino] Criaturas inteligentes e inquietas, não confiaram nos seus sentidos e entraram resolutamente a delirar. As suas personagens, vagas, absurdas, não comem, não bebem não sentem as necessidades comuns dos viventes ordinários: mexem-se, ou, antes, estão paradas num ambiente de sonho, procedem como os loucos, falam como os loucos. E há dezenas de imitadores, simples copistas (...)

Os nossos melhores romancistas viviam na província, miúdos e isentos de ambição. Contaram o que viram, o que ouviram, sem imaginar êxitos excessivos. Subiram muito - e devem sentir-se vexados por terem tão sinceros. Não voltarão a tratar daquelas coisas simples. Não poderiam recordá-las. Estão longe delas, constrangidos, limitados por numerosas conveniências. Para bem dizer, estão amarrados.

\footnotetext{
${ }^{243}$ No entanto, a partir de 1947, a revista se tornara menos literária e mais propangandística do PCB, passando a contar apenas com simpatizantes do partido. Deixa de circular em outubro de 1948.

${ }^{244}$ APRESENTAÇÃO. Literatura, Rio de Janeiro, ano 1, n.1, set. 1946.
} 
Certamente ninguém lhes vai mandar que escrevam de uma forma ou de outra. Ou que não escrevam. Não senhor. Podem manifestar-se. Mas não se manifestam. Não conseguem recobrar a pureza e a coragem primitivas. Transformaram-se. Foram transformados. Sabem que a linguagem que adotavam não convém. Calam-se. Não tinham nenhuma disciplina, nem na gramática, nem na política. Diziam às vezes coisas absurdas - e excelentes. Já não fazem isso. Pensam no que é necessário dizer. No que é vantajoso dizer. No que é possível $\operatorname{dizer}^{245}$.

Sua próxima colaboração, estampada em veículo comunista, acontece apenas quase três anos depois quando publica o texto "Prestes”, em janeiro de 1949, no jornal Classe Operária, órgão oficial do Comitê Nacional do $\mathrm{PCB}^{246}$. Trata-se de uma narrativa encomiástica, em comemoração ao aniversário do líder do partido ${ }^{247}$. O escritor alagoano, reproduzindo estratégia comum em sua produção cronística, sinaliza que deixaria de lado o mito, resultado da força criadora da multidão, para tratar do homem Luís Carlos Prestes: “Certo não concedemos auréola a Prestes: o que nos atrai nele é a parte humana, de ordinário deixada na sombra”248. Mediante tal procedimento, seu objetivo parece ser o de se mostrar mais sincero e verdadeiro ao propor a descrição de uma figura de carne e osso. Paralelamente, procura também dissimular o panegírico. No entanto, em seguida, atribui-lhe um rol de características enobrecedoras, extraídas de diferentes cenas e situações, que elevariam a figura supostamente comum do líder partidário: paciência, polidez, acessibilidade, franqueza, entre outras.

Logo depois, argumenta que Prestes seria uma figura marcada por contrastes. Com tal argumento, o narrador aparenta ter o objetivo de realizar releituras abonadoras de supostos defeitos comumente atribuídos ao “cavalheiro da esperança”. O aspecto frio e insensível deste teria como contraponto seu calor e vigor internos. A aparente "firmeza de um compressor"

\footnotetext{
${ }^{245}$ RAMOS, Graciliano. Decadência do romance brasileiro. Literatura, Rio de Janeiro, ano 1, n.1, set. 1946.

${ }^{246}$ De certa maneira, tal trabalho já havia sido anunciado anteriormente, na entrevista concedida por Graciliano, quando de sua entrada oficial no PCB: "Iniciou-se para Graciliano Ramos uma nova fase na sua vida: ao lado da literatura, ele se [dedicará] também ao PCB em trabalhos de ordem prática que faz questão de realizar como tarefas. Assim é que já tomou a seu cargo uma pequena biografia de Luís Carlos Prestes, bem como a revisão de livros que serão editados sob orientação do partido” (FACÓ, Ruy. op.cit.).

${ }^{247}$ Tal escrito faz parte de um caderno dedicado à celebração do $51^{\circ}$ aniversário de Prestes no qual há colaborações de boa parte da intelligentsia do PCB. Este número de Classe Operária conta com textos de Maurício Grabois ("Prestes como Secretário Geral do PCB”), Aydano Couto Ferraz ("Primeiro encontro com Prestes”), Zuleika Alambert (“As mulheres também saúdam Prestes”), Candido Portinari ("Prestes está no coração do povo”), Moacir Werneck Castro (“Herói e Líder do Povo”), Afonso Schmidt (“O Sobretudo”), Jacob Gorender ("A solução revolucionária para o problema da terra”), Dalcídio Jurandir ("Fraternal, Compreensivo, Humano"), Astrogildo Pereira ("Meu primeiro encontro com Prestes”), Pedro Pomar ("Prestes campeão da luta antiimperialista”), Carlos Mariguella ("Prestes - chefe revolucionário e líder parlamentar”), Diógenes Arruda (“O Camarada Prestes - Exemplo de Firmeza Revolucionária”), Heloísa Prestes ("Quando Carlos se tornou comunista”), Mário Lago (“Prestes da Música Popular”), Oscar Niemayer (“São raros os homens como Prestes"), Jorge Amado (“Mensagem de Natal para Prestes”), entre outros.

${ }^{248}$ RAMOS, Graciliano. Prestes. Classe Operária, Rio de Janeiro, $1^{\circ}$ jan. 1949.
} 
esconderia sua “delicadeza interior de pureza quase infantil”. A timidez e a dedicação corajosa e completa a uma empresa também se mesclariam simbioticamente na composição de sua personalidade. O líder teria ainda uma outra dualidade, digna de um semideus onipotente:

... afigura-se-nos que a singular personagem [Prestes] apreende com igual nitidez os objetos próximos e os distantes, graúdos e miúdos, o panorama e o pormenor, os mais graves acontecimentos internacionais e os efeitos de ligeiras desavenças existentes nas brenhas de um território deserto ${ }^{249}$.

Concluindo o procedimento dialético esboçado anteriormente, termina o texto sintetizando que a dignidade e austeridade de Prestes estariam acima de qualquer oposição. Fica mais claro o intuito do narrador de glorificar a missão do chefe do PCB:

Chegamos agora a um ponto em que não distinguimos nenhum sinal de oposição: há em Prestes uma dignidade fundamental, incontestável. É a essência do seu caráter. Admiram-no com exaltação, odeiam-no com fúria, glorificam-no e caluniam-no. Seria difícil achar quem lhe negasse respeito à austeridade imutável, maciça, que o leva a afrontar serenamente duras fadigas e sacrifícios horríveis coisas previstas e necessárias ${ }^{250}$.

Os outros quatro escritos do cronista alagoano, veiculados em publicações comunistas, tiveram como destino o jornal Imprensa Popular, que substituiu a Tribuna Popular, proibida de circular pelo governo, num contexto posterior ao retorno do PCB à ilegalidade em 1947 e a cassação do mandato de seus parlamentares em $1948^{251}$. No primeiro deles, intitulado “Álvaro Moreyra”, saído em 21 de maio de 1950, Graciliano, adotando novamente o protocolo do depoimento pessoal com função encomiástica, exalta a figura do amigo que dá nome ao texto $^{252}$. A tematização de suas experiências com o colega comunista parece ter a função de vivificar certas qualidades que atribui a este, tais como bondade, simplicidade, honestidade, coerência e coragem. Outra estratégia para enobrecer a imagem do companheiro de partido é a diferenciação deste do meio literário brasileiro, marcado, segundo o escritor alagoano, pelo cabotinismo e pelo oportunismo.

\footnotetext{
${ }^{249}$ Idem, ibidem.

${ }^{250}$ Idem, ibidem.

${ }^{251}$ RUBIM, Antonio Canelas. Marxismo, cultura e intelectuais no Brasil. Salvador: Centro editorial e didático da UFBA, 1995, p.31.

252 Este fora o antecessor de Graciliano na presidência da Associação Brasileira de Escritores (ABDE).
} 
Pouco depois de se tornar presidente da Associação Brasileira de Escritores (ABDE), publica o texto “O último romance de Alina Paim”, em 10 de abril de $1951^{253}$. Nesse artigo, Graciliano, na qualidade de dirigente eleito da entidade (mas ainda não empossado) ${ }^{254}$, coloca-se em defesa da escritora que tivera mandado de prisão decretado por um juiz da cidade de Cruzeiro. Alina viajara para tal localidade, na qual ocorria uma greve de ferroviários, com o intuito de colher material para elaboração de um romance. No entanto, o magistrado teria julgado que o projeto do livro seria um atentado à ordem e por isso mandou prendê-la. O autor de Vidas Secas, depois de elogiar a romancista, lembra que nem nos piores dias de repressão um livro fora proibido antes mesmo de ser escrito. Em seguida, o articulista, fechando de maneira irônica o movimento metonímico do texto (no qual defender Alina seria defender a liberdade de criação em geral), argumenta de maneira irônica:

\begin{abstract}
Possivelmente, no juízo dele [do referido magistrado], greve não é matéria digna de ficção. Numerosas criaturas aí pensam do mesmo jeito; contudo é a primeira vez que uma se revela com tanta clareza e falta de cerimônia. Se a moda pega, seremos forçados, antes de começar um romance, a pedir licença ao rigoroso censor de Cruzeiro ${ }^{255}$.
\end{abstract}

No ano seguinte, o jornal Imprensa Popular publica uma nota enviada por Graciliano, agora presidente reeleito da $\mathrm{ABDE}$, na qual este repudiava a criação da Sociedade Carioca de Escritores (SOCE). Como se sabe, a ABDE, depois de 1949, começara a se esvaziar, sobretudo em função da nova orientação zhdanovista ${ }^{256}$ do PCB que tomara unilateralmente o comando da entidade das mãos de literatos não alinhados ao partido ${ }^{257}$. Procurando defender a abrangência e a legitimidade da instituição, mas sem se afastar das diretrizes comunistas

\footnotetext{
${ }^{253}$ Este texto de Graciliano ocupava um espaço delimitado e marcado no topo da página 2 do referido periódico, no qual escreviam, sobretudo, eméritos intelectuais do PCB, tais como Dalcídio Jurandir, Paulo Motta Lima, Astrogildo Pereira, Moacir Werneck Castro e outros colaboradores menos destacados como o próprio filho de Graciliano, Ricardo Ramos. O artigo do escritor alagoano pode ser visto como uma contribuição pontual. Folheando a publicação no ano de 1951, pude notar recorrentes colaborações de Ricardo nesta coluna e apenas tal narrativa de Graciliano sobre a mandado de prisão da escritora Alina Paim.

${ }^{254}$ Graciliano toma posse do cargo apenas em 15 de maio de 1951 (Moraes, Denis de. op.cit. p.278).

${ }^{255}$ RAMOS, Graciliano. O último romance de Alina Paim. Imprensa Popular, Rio de Janeiro, 10 abr.1951.

${ }^{256}$ O Zhdanovismo refere-se ao período, entre 1947e 1948, em que Andrei Zhdânov assume o posto de censor das artes e da literatura, exercendo forte controle sobre a produção intelectual soviética. Tal atitude repercutiria mundialmente nos partidos comunistas de orientação stalinista. No Brasil, o PCB deixaria de lado a construção de uma frente de ação comum com as demais forças democráticas para pregar sectária e doutrinariamente seus ideais. "Em lugar da cultura burguesa 'decadente e degenerada', escritores e artistas [segundo o zhdanovismo] se empenhariam em edificar a 'cultura proletária', a única capaz de desmistificar os valores morais da classe dominante e sustentar o caráter revolucionário da obra de arte. As inovações estéticas passariam a ser condenadas como anti-soviéticas e contra-revolucionárias” (In: MORAES, Denis. op.cit. p.259).

${ }^{257}$ Tais intelectuais, com destaque para Carlos Drummond de Andrade, Afonso Arinos, Otto Maria Carpeaux, entre outros, publicaram um violento manifesto de condenação e de ruptura com os comunistas e sua área de influência (In: BOSI et al. op.cit, p.81)
} 
impostas a esta, o romancista alagoano sinaliza que a criação da SOCE consistiria num ato discriminatório e de cerceamento da liberdade de criação, visto que comprometeria o entendimento entre os intelectuais. Segundo ele, não deveria haver cisões nos meios políticoliterários. A fim de se mostrar mais persuasivo em seu intento semiótico de desprestigiar a nova sociedade de escritores que acabava de ser formada na capital federal, Graciliano busca também construir a imagem de uma ABDE plural e apartidária:

\begin{abstract}
A ABDE, cujas portas estão abertas a todos os escritores brasileiros, quaisquer que sejam os setores de sua especialidade, sem indagar sua orientação estética ou sua filiação político-partidária, manifesta-se contrária às discriminações e lança apelo aos homens de cultura de nosso país, a fim de [que] ponham acima dos interesses pessoais, de grupo ou partido, os interesses comuns a todos os que se dedicam ao trabalho intelectual ${ }^{258}$.
\end{abstract}

Também em 1952, Graciliano fez parte de uma delegação de intelectuais brasileiros que visitou a União Soviética. De lá envia um artigo na forma de carta, intitulado “O Kolkhoze Kheivani”259, que sai estampado no jornal Imprensa Popular, em julho do referido ano, e fora posteriormente recolhido no livro Viagem $(1954)^{260}$. Em tal texto, relata uma série de números e impressões de uma visita a um kolkhoze com o intuito de atestar a produtividade destas fazendas coletivas soviéticas e a expansão demográfica das populações residentes nelas. Ao final, fechando o movimento comparativo da narrativa entre o progresso da URSS e o implícito atraso nacional, lamenta em nome dos brasileiros: “Quando possuiremos kolkozes como este? Quando, entre nós, terão prosperidade e terra fértil e as mulheres férteis? „261.

Da mesma maneira, desde 1948 até pouco antes de sua morte, ocorrida em março de 1953, Graciliano publicou trechos de Memórias do Cárcere em diferentes periódicos comunistas ou apenas vinculados ao partido. Duas passagens de tal livro foram estampadas em Fundamentos, um deles, inclusive recebera todo destaque no primeiro número de tal revista paulista, em junho de 1948; uma no periódico Para Todos, veículo dirigido por Álvaro

\footnotetext{
${ }^{258}$ RAMOS, Graciliano. Unidade em defesa dos direitos do escritor. Imprensa Popular, Rio de Janeiro, 30 ago. 1952.

${ }^{259}$ Tal texto foi publicado com algumas modificações no livro póstumo Viagem, cuja primeira edição é de 1954. Nele, Graciliano, de acordo com certa imagem de sinceridade e de verdade que procura construir para si (e para seus narradores) em todos os seus relatos memorialísticos (e romances), diz que não irá cantar loas ao governo Soviético: "Pretendo ser objetivo, não derramar-me em elogios, não insinuar que, em trinta e cinco anos, a revolução de outubro haja criado um paraíso, com as melhores navalhas de barba, as melhores fechaduras e o melhor mata-borrão” (RAMOS, Graciliano. Viagem. 2 ed. Rio de Janeiro: Livraria José Olympio Editora, 1955 p.11).

${ }^{260}$ Trata-se de uma espécie de primeira versão do capítulo 27 do referido.

${ }^{261}$ RAMOS, Graciliano, O Kolkhoze Kheivani. Imprensa Popular, Rio de Janeiro, jul. 1952.
} 
Moreyra e voltado, basicamente para as letras nacionais; e mais uma no Jornal do IV Congresso, produzido pela $\mathrm{ABDE}^{262}$. Nesta última folha, o artista também estampou o artigo “Convocação”, no qual convidava todos os escritores do país, fossem eles partidários de quaisquer tendências políticas e artísticas, a participarem do encontro da entidade que seria realizado em Porto Alegre, entre 25 e 30 de setembro de 1951. Mais uma vez, seu discurso conciliador procura contornar o aparelhamento da instituição realizado pelo PCB.

Em síntese, observando em conjunto os discursos e artigos de autoria de Graciliano publicados em veículos comunistas depois de sua entrada oficial no Partidão, pode-se inferir que se tratam de colaborações pontuais: apesar de militante disciplinado, o escritor alagoano não participava da rotina diária dos veículos. No entanto, todas elas procuram de alguma maneira seguir e defender publicamente certas orientações partidárias ${ }^{263}$. Isso fica mais evidente quando, em duas oportunidades, como se viu acima, o romancista procurou desmentir que haveria cerceamento da liberdade de criação de artistas filiados ao PCB.

Além de escrever para as publicações comunistas arroladas acima, Graciliano foi legalmente dono e editor responsável do jornal Partidários da Paz, do final de 1950 a fevereiro de 1953. Tratava-se de uma publicação monotemática, que começou como um jornal de formato standart e depois se tornou numa revista. Ela procurava propagar a "campanha pela paz", uma iniciativa mundial conjunta de todos os partidos ligados ao Kremlin, no contexto da Guerra Fria. O cumprimento disciplinado de tal tarefa serve também de índice para se reafirmar, pelo menos publicamente, a vinculação do autor alagoano às orientações do $\mathrm{PCB}^{264}$.

\footnotetext{
${ }^{262}$ As referências bibliográficas de tais textos, seguindo a ordem cronológica em que foram publicados, são as seguintes:"Página inédita de Memórias da Cadeia”, Fundamentos, São Paulo, n.1, jun. 1948, p.26 e 27; "Capítulo XVII", Para Todos, Rio de Janeiro, 20 out. 1949, n.1, ano 1 (nova fase); “O Porão do Manaus”. Jornal do IV Congresso, Rio de Janeiro, 1 set. 1951, n.1, p.4 e 7; “Birinyi”, Fundamentos, São Paulo, n.31, jan. 1953, p.4 (o texto é acompanhado de uma ilustração da reprodução fac-similar de um trecho do manuscrito de "Birinyi”. Na capa da revista, há um desenho de Graciliano feito por Virgínia Artigas).

${ }^{263}$ Florent, ao analisar dois discursos de Graciliano, feitos internamente a células do PCB, destaca as críticas intestinas dirigidas pelo escritor à política cultural levada a termo pelo partido. Seus alvos preferenciais seriam seus alvos seriam o obreirismo e o zhdanovismo. Por outro lado, ressalta a imagem pública do artista como um "escritor comunista disciplinado", a mesma que é respaldada pela trajetória graciliana na imprensa do Partidão, ora apresentada (Ver FLORENT, Adriana. Roupa suja se lava em casa - Graciliano Ramos, escritor e comunista na era Vargas. In: RIDENTI et. al. Intelectuais e Estado. Belo Horizonte: Editora UFMG, 2006, p.143-162).

${ }^{264}$ Além de figurar como proprietário e editor do jornal "Partidários da Paz", Graciliano foi ainda jurado dos "Prêmios da Paz", fundador e conselheiro do "Movimento Brasileiro dos Partidários da Paz", diretor da "Organização Nacional de Defesa da Paz e da Cultura", participante do Congresso dos Partidários da Paz, em São Paulo, e delegado eleito para o $2^{\circ}$ Congresso Mundial dos Partidários da Paz. Como presidente da ABDE, fez dela uma das entidades mais empenhadas no "combate pela paz". Em todas as frentes, graças ao prestígio como escritor e à missão determinada pelo PCB, ocupou lugar de destaque. Para mais informações ver a matéria "Memórias de um militante stalinista” de Mário Magalhães, publicada em 9 de março de 2003, no Caderno Mais!, da Folha de S. Paulo.
} 
PARTE II - Debates culturais dos anos de 1930 e 1940 e a mediação editorial de Cultura Política 


\section{Capítulo 3 - A poética de Graciliano pari passu às diretrizes estadonovistas}

\subsection{Introdução}

Com o objetivo de reunir mais subsídios que orientarão a análise dos textos publicados por Graciliano Ramos na revista Cultura Política, convém investigar melhor os princípios poéticos norteadores da produção artística do escritor alagoano, apenas passados em revista no capítulo anterior. Como se sabe, tais posicionamentos foram expressos, de maneira difusa e genérica, em suas cartas, romances, mas, sobretudo, ao longo do trabalho que exercera como cronista e crítico literário, durante toda a vida, em diferentes periódicos brasileiros. Entre os preceitos formadores de seu metatexto, ora examinados, o destaque principal recai sobre aqueles que tratam das matérias a serem privilegiadas pelos artistas, bem como do ethos que estes deveriam apresentar, caso desejassem compor uma obra, a um só tempo, “realista” e “autenticamente” brasileira.

Nos diferentes momentos em que explicitou seus postulados literários, Graciliano, quase sempre, tinha em vista um adversário no campo das letras. Nesse sentido, suas crônicas podem ser tomadas como pequenos manifestos em favor da arte que ele e seus companheiros de geração produziam. Se inicialmente, o artista alagoano voltou sua artilharia contra a tradição romântica, consagrada à representação do espaço e do homem sertanejos, num contexto ainda de afirmação regional do romance de 30, isso vai mudando de figura ao longo da segunda metade da década de 1930. Como se viu de maneira breve no capítulo anterior, a partir daí, tal produção artística de matiz regionalista, vai ganhando o estatuto de “representante da brasilidade" e adquire um novo oponente: certo tipo de literatura dita intimista ou psicológica, feita, sobretudo por romancistas identificados com a Igreja Católica, tais como Otávio de Faria, José Geraldo Vieira, Lúcio Cardoso, entre outros. Na opinião do autor de Angústia, estes praticariam uma espécie de “espiritismo literário”, uma vez que deixariam de lado a tematização do que se supunham ser os problemas nacionais, sobretudo os do interior do país, para se focarem em dramas introspectivos e burgueses.

De acordo com o estatuto de verossimilhança referendado por Graciliano, sobretudo em suas crônicas, antes de colaborar para a construção de uma nacionalidade idealizada, a arte literária 
deveria olhar os problemas regionais de perto, deixando de lado determinadas fórmulas supostamente "artificiais" cultivadas pela tradição textual que se construiu em torno dos espaços interioranos. Ao mesmo tempo, pressupunha que os escritores deveriam travar um contato sensorial, inscrito em suas próprias biografias, com as matérias sertanejas que se propunham a narrar. Mas não parava por aí. Além de se colocarem tal como testemunhas ante os fatos a serem ficcionalizados, considerava que os homens de letras tinham a missão de realizar o estudo objetivo da "realidade" do país e corroborar o conhecimento e a transformação desta última.

Em certo sentido, tais diretrizes já estavam presentes nas propostas do romancista Franklin Távora, ainda no século XIX. Dessa maneira, procurar-se-á mostrar em que medida as orientações da poética graciliânica se inscrevem na tradição crítica do autor de O Cabeleira, principalmente, no que diz respeito à valorização da idéia de observação “direta” do mundo (em detrimento daquilo que se taxava como imaginação e fantasia); à crítica ao protocolo romântico (consubstanciada, em nível nacional, na figura de Alencar); e à primazia conferida à abordagem do Norte (Nordeste), como índice de brasilidade, pois se supunha que esta região ainda guardava as raízes nacionais, enquanto o Sul teria se “internacionalizado”.

Além desse rápido recuo ao século XIX brasileiro, convém ainda recuperar, em perspectiva arqueológica, o conjunto das normas, regras e convicções poéticas de Graciliano, em consonância com os posicionamentos de seus companheiros de geração (em geral, romancistas nordestinos; entre eles José Lins do Rego, Rachel de Queirós, Jorge Amado), bem como apresentar as semelhanças entre tais princípios com certas orientações presentes no discurso estadonovista, sobretudo, aquelas voltadas para o campo das letras, com destaque para os seguintes itens ${ }^{265}$ : a conceituação do Modernismo de 1922; o rebaixamento do individualismo, tendo em vista o pressuposto do caráter "social” da obra de arte; a valorização da noção de "documento"; a reivindicação de que o discurso sociológico se sobrepunha ao literário; o privilégio para o tratamento da matéria regional; a apresentação do romance de 1930 como o ponto culminante da literatura brasileira; a defesa de um ethos testemunhal de escritor em oposição aos ditos “autores de gabinete”, presos em suas “torres de marfim”, entre outros elementos.

\footnotetext{
${ }^{265}$ Vale destacar que o termo "semelhança” sempre implica a idéia de diferença, nunca a de identidade. Na aproximação entre discursos de emissores distintos, aqui sugerida, pressupõe-se que as diretrizes poéticas de Graciliano, explicitadas em seus metatextos críticos, seriam apenas análogas e não iguais às de seus companheiros de geração e às do Estado Novo.
} 
Tal proposta de comparação entre discursos de atores tão diversos - Graciliano, romancistas nordestinos e Estado Novo - tem como objetivo principal ressaltar os elos conceituais que, em certo sentido, aproximavam autores e regime, enquanto participantes do mesmo enquadramento histórico, ou seja, enquanto agentes que partilhavam da mesma poética cultural $^{266}$. Como afirma Teixeira, este conceito, associado à noção de episteme de Foucault ${ }^{267}$, pressupõe que não seria a "realidade" que se imporia aos artistas, mas sim certa idéia de realidade, de base interdiscursiva e dialógica, integrante da dinâmica cultural da época em que tais sujeitos produziram suas obras ${ }^{268}$.

Por essa perspectiva, mais especificamente, afirma-se que os escritores não trabalhariam com os acontecimentos propriamente ditos, mas sim com a poética dos acontecimentos, ou seja, com determinadas imagens do mundo exterior incorporadas pelo discurso geral e convertidas em tópicas artísticas ${ }^{269}$. Portanto, tal categoria englobaria o conjunto de noções, técnicas, protocolos, expectativas de leitores, normas e saberes, regidos por contingências históricas, que delimitariam as coordenadas de produção e de recepção de uma obra, ou seja, o diálogo desta com o repertório da época em foi gestada e a história de sua leitura. Em resumo, ao reger diferentes áreas do saber e da prática social, unificaria o diverso e daria inteligibilidade ao "mistério da arte e da vida em geral”"270.

\footnotetext{
${ }^{266}$ As bases para tal conceito encontram-se no livro The New Historicism, editado em 1989 por H. Aram Veeser. Aí, encontram-se dois textos particularmente importantes: "Towards a Poetics of Culture", de Stephen Greenblatt, criador do termo "poética cultural"; e "Professing the Renaissance: The Poetics and Polictics of Culture”, de Louis A. Montrose. No Brasil, Ivan Teixeira tem procurado discutir e delimitar esta noção, bem como aplicá-la em diferentes estudos, como se depreende dos artigos "Literatura como Imaginário: Introdução ao Conceito de Poética Cultural” (2003) e "Poética Cultural: Literatura e História” (2006), além da tese de Livredocência "Irônica invenção do mundo: leitura histórica de O Alienista" (2009). Para mais informações, ver bibliografia.

${ }^{267}$ Trata-se do paradigma de determinada época, ou seja, do conjunto de noções e procedimentos discursivos que permitiriam o acesso ao conhecimento (a constituição da epistemologia) num dado momento histórico. Tal noção estruturaria os múltiplos saberes, que apesar de suas especificidades, diferenças de objetos e abordagens teóricas, compartilhariam de certas formas e características gerais. Sua descrição se encontra presente, sobretudo, nas obras foucaultianas As palavras e as coisas (São Paulo: Martins Fontes, 2002), Arqueologia do Saber (Rio de Janeiro: Forense Universitária, 2007) e Ordem do Discurso (São Paulo: Edições Loyola, 1996).

${ }^{268}$ TEIXEIRA, Ivan. Semiosfera e invenção do autor. In: FILHO, Plínio Martins; TENÓRIO,Waldecy (Orgs). João Alexandre Barbosa: o leitor insone. São Paulo: Edusp, 2007.

${ }^{269}$ De certa maneira, o conceito de poética cultural atualiza os pressupostos da poética aristotélica, sobretudo, ao considerar que o artista não trabalharia com a noção de verdade, mas sim com o conceito de verossimilhança, na medida em que procuraria tornar seu discurso semelhante aos discursos sociais que transforma por meio de sua prática. “...pelas precedentes considerações se manifesta que não é ofício do poeta narrar o que aconteceu; é, sim, o de representar o que poderia acontecer, quer dizer: o que é possível segundo a verossimilhança e a necessidade” (ARISTÓTELES. Poética. Lisboa: Nacional/Casa da Moeda, 1992, p.115).

270 TEXEIRA, Ivan. Literatura como imaginário: introdução ao conceito de poética cultural. Revista da Academia Brasileira de Letras, Rio de Janeiro, fase VII, ano IX, n. 37, out./nov./dez. 2003, p.49.
} 
No entanto, se se ressaltam afinidades e interdependências entre artistas e governo, no que diz respeito às opiniões emitidas e à estruturação discursiva destas, de acordo com o protocolo da época, convém ressaltar que o Estado Novo acabara se apropriando, mesmo que à revelia dos múltiplos pontos de vista de Graciliano e dos romancistas de 1930, de certas noções por eles veiculadas $^{271}$. Em seguida, traduziu-as em termos políticos, como forma de legitimar suas ações e pronunciamentos. De acordo com tal perspectiva, a justificação ideológica do regime, que não estava originalmente presente nas falas dos artistas, emerge pela leitura, enquadramento e direcionamento específico dado a elas pela retórica estatal.

Nesse sentido, a proposta de individuação e de associação de posicionamentos literários e políticos de tais entidades (escritor e regime), ao longo dos anos de 1930 e 1940, obviamente, não deixará de lado a especificidade desse intercâmbio entre governo e intelectualidade. Como se sabe, sobretudo, após a Revolução de Outubro $^{272}$, o estudo da realidade nacional figurava quase que como tema obrigatório, lema político e literário, uma espécie de fonte de todos os sentidos ${ }^{273}$. De qualquer maneira, apesar dos diferentes projetos em curso no campo cultural, que pretendiam falar em nome da nação, incluindo aí a perspectiva de Graciliano, o regime procurava agenciar tal estado de coisas. Dirigindo o horizonte de leitura e a interpretação da "brasilidade”, o Estado, por meio de seus diferentes atores e canais de

\footnotetext{
${ }^{271}$ Tal processo de apropriação dos lugares-comuns da intelectualidade não foi unilateral. Num momento de construção e aparelhamento do Estado-Nação no país, os intelectuais desejavam ver suas demandas atendidas pelo governo. E, segundo Bomeny, a montagem desse aparato estatal nos anos de 1930 e 1940 "justificou a demanda de especialistas, envolveu intelectuais de várias áreas e deu chance a homens ilustrados e propositivos" (BOMENY, Helena. Infidelidades eletivas: intelectuais e política. In: BOMENY, Helena (org). Constelação Capanema: intelectuais e política. Rio de Janeiro: Editora FGV; Universidade São Francisco, 2001p. 17.) Eles teriam sido atraídos, sobretudo, pelo projeto intervencionista do governo getulista, na medida em que este se mostrava pautado por "racionalidade, planejamento, combate ao regionalismo, às oligarquias e ao mandonismo local” (Idem, p.21). De maneira geral, o discurso reinante era de que o país pedia uma política nacional de Estado que levasse a modernidade a setores importantes da vida social como saúde, educação, cultura, artes, patrimônio histórico etc. Nesse sentido, os "homens de pensamento" tomaram a frente de tal processo político e cultural, pois, conforme sublinha Pécault, arrogavam-se a condição de intérpretes dos "sinais que demonstravam que já existia uma nação inscrita na realidade, mesmo que ainda desprovida de expressão cultural e política: do implícito vangloriavam-se de produzir o explícito" (PÉCAUT, Daniel. Intelectuais e a política no Brasil: entre o povo e a nação. São Paulo: Ática, 1990, p.38).

${ }^{272}$ Ao longo do texto, a expressão "Revolução de Outubro" refere-se ao movimento armado que depôs o então Presidente da República, Washington Luís, e impediu a posse do novo chefe da nação, Júlio Prestes, eleito em 1930. Não se faz menção à "Revolução Vermelha” ou à "Revolução Bolchevique”, liderada por Vladmir Lenin em outubro de 1917.

${ }^{273}$ O próprio Graciliano, de maneira irônica, explicita essa idéia em a Pequena História da República. "Os homens de 1930 não tinham um programa. E justificaram-se. Como poderiam arranjar isso? Importar? Que é que deviam importar? Vivíamos num país onde os lugares se diferençavam muito uns dos outros. O Nordeste era superpovoado, o Amazonas era quase deserto. Tínhamos criaturas civilizadíssimas em Copacabana e selvagens de beiço furado no Mato Grosso. Que sabia disto lá fora? / Assim, os revolucionários deram uma explicação razoável ao público: tencionavam firmar-se na realidade brasileira. E como essa realidade tudo podia comportar, houve aqui um saco de gatos: inimigos ferozes se juntaram, idéias contraditórias tentaram harmonizar-se" (RAMOS, Graciliano. Alexandre e outros heróis, Rio de Janeiro: Record, 2003, p.188).
} 
comunicação, apresentava-se tanto como regulador como quanto autenticador das propostas colocadas em jogo, pois, como, se verá no capítulo seguinte, auto-imputava-se a condição de representante supremo do “espírito nacional” e, por conseguinte, da cultura popular.

A própria leitura da produção literária de Graciliano Ramos (como a de outros artistas), realizada pelo regime, pode ser tomada como exemplo. Ao invés de censurar suas obras, passava-se a procurar nelas apenas a parcela de realidade que lhes coubesse ${ }^{274}$ (e que conviesse ao poder). Nesse cenário, abordar o sertão miserável, tal como realizado pelo escritor em Vidas Secas, ou mesmo nas crônicas de Cultura Política, não se constituía numa ameaça, muito pelo contrário, pois o próprio Estado se colocava como o suposto iniciador do movimento de descida aos "porões da realidade nacional”, num processo de tomada de “consciência” do país. O mesmo ocorreria com o tratamento do autoritarismo em S. Bernardo. Ao tratar do tema, o romancista teria descrito um problema social e político, que tinha suas origens no caráter antidemocrático das oligarquias liberais, em fase de superação, tendo em vista a atuação do regime, pautada pelo combate ao liberalismo da Primeira República ${ }^{275}$.

\section{2. "Realismo" 276 na tematização do sertão}

Feitas tais considerações preliminares, cabe, agora, tratar detidamente da poética graciliana, focando, sobretudo, os juízos críticos emitidos pelo próprio autor ao longo da vida. De maneira geral, o privilégio concedido à observação, na tessitura de uma nova dizibilidade sobre o espaço sertanejo, bem como ao caráter testemunhal do artista, são constantes nas diretrizes literárias de Graciliano Ramos. Sobretudo ao longo da década de 1930, o escritor alagoano começa a tornar explícita tal postura em textos nos quais discute as imagens literárias produzidas sobre sua terra e eleva o trabalho artístico de seus companheiros de geração, com destaque para José Lins do Rego, Rachel de Queirós e Jorge Amado. Trata-se de um período no qual o autor de Caetés vai se tornando um homem de letras reconhecido,

\footnotetext{
274 Tal formulação encontra-se presente no instigante artigo "Realidade e consciência nacional. O sentido político do Modernismo”, do pós-doutorando pela Unicamp, Daniel Faria, publicado em História, São Paulo, v. 26, n. 2, 2007, p. 385-405.

${ }^{275}$ Idem, p.398.

${ }^{276} \mathrm{Na}$ presente pesquisa, ao invés de se tomar o termo como sinônimo de reprodução "fiel do real”, procura-se, na verdade, ressaltar o caráter convencional e limitado do mesmo, enquanto conceito produtor não da "realidade" do "efeito de real”. Segundo Jakobson, tal noção seria regida por valores e princípios historicamente datados, pois não haveria uma versão única e total de realismo (JAKOBSON, Roman. Do realismo artístico. In: TOLEDO, Dionísio de Oliveira. Teoria da literatura - formalistas russos. Porto Alegre: Globo, 1973).
} 
primeiro em nível local, depois nacional ${ }^{277}$, passando a participar com mais intensidade do debate sócio-cultural de seu tempo ${ }^{278}$.

No entanto, antes de entrar especificamente no exame de tais produções e tendo em vista o propósito de recuperar uma das matrizes do discurso analítico de Graciliano, cabe realizar uma incursão inicial, ainda que sumária, pela perspectiva crítica de Franklin Távora. Como se sabe, os posicionamentos do autor de O Cabeleira foram reunidos, sobretudo, em Cartas a Cincinato, livro em que procurou debater e polemizar determinados aspectos da obra de José de Alencar ${ }^{279}$. Em tal volume, o missivista promove o rebaixamento sistemático do romancista de $O$ Guarani, taxando-o como um literato de gabinete que, como não tivera contato direto e efetivo com os lugares sobre os quais escreveu, teve de se valer estritamente da imaginação para compor seus relatos e por isso teria incorrido em inúmeros “erros”280.

Em linhas gerais, para Távora, o conceito de imaginação não se confundiria com a criação de elementos novos, mas, na verdade, diria respeito à elaboração de novas imagens a partir de dados captados pelos sentidos e armazenados pela memória. Nesse sentido, ela teria por função reproduzir e retratar com vivacidade algo já dado e percebido. Na concepção do escritor cearense, tratava-se da produção de uma narrativa lastreada por fenômenos observáveis. Ao propor tal diretriz, ele acaba impondo uma restrição à perspectiva imaginativa romântica. Segundo ele, um dos principais erros de Alencar foi o desejo de

\footnotetext{
277 Primeiramente, com a publicização de seus relatórios endereçados ao governador do Estado, Álvaro Paes, quando ainda era prefeito de Palmeira dos Índios (cidade do agreste alagoano) e logo depois com a publicação de seus quatro primeiros romances Caetés (1933), S. Bernardo (1934), Angústia (1936) e Vidas Secas (1938).

${ }^{278}$ Como se viu no capítulo anterior, nesse momento, sua produção cronística sofre uma inflexão: o escritor começa a deixar de lado a galhofa, a pseudo-agressão e a obsessão pela interlocução, marcas de seus primeiros textos, veiculados em jornais provincianos e encobertos por diferentes pseudônimos, para adotar uma postura pautada pela seriedade analítica, sem abdicar, contudo, do uso do sarcasmo e da ironia. A partir daí, passa a veicular seus textos em publicações de maior expressão e a assiná-los com nome pelo qual se tornou literariamente reconhecido.

${ }^{279}$ Tal conjunto de textos foi publicado inicialmente no jornal carioca Questões do Dia, editado por José Feliciano de Castilho, em dois momentos diferentes: as cartas que tinham como alvo o romance $O$ Gaúcho saíram em setembro e outubro de 1871. Aquelas destinadas a analisar Iracema, foram publicadas dois meses depois, entre dezembro de 1871 e fevereiro de 1872.

${ }^{280}$ Apesar de nutrir-se de motivos diferentes, Nabuco se valia de questionamentos semelhantes para criticar Alencar. "A natureza americana ele estudou-a nos livros; as flores na botânica (...) Quem lê os romances do sr. José de Alencar, vê que ele nunca saiu do seu gabinete e nunca deixou os óculos” (COUTINHO, Afrânio [org.]. A polêmica Alencar-Nabuco. Rio de Janeiro: Edições Tempo Brasileiro, 1965, p.209). Outro detalhe é que o próprio autor de $O$ Guarani, anos antes, valera-se de argumentos semelhantes para diminuir a Confederação dos Tamoios, taxando o poema de "artificial" e preso a modelos externos, em controvérsia com Gonçalves de Magalhães. "Digo-o por mim: se algum dia fosse poeta, e quisesse cantar a minha terra e as suas belezas, se quisesse compor um poema nacional, pediria a Deus que me fizesse esquecer por um momento as minhas idéias de homem civilizado. Filho da natureza, embrear-me-ia por essas matas seculares, contemplaria as maravilhas de Deus...” (ALENCAR, José de. Obra completa, vol. IV. Rio de Janeiro: Nova Aguilar, 1959, p.865).
} 
originalidade. A vontade de inovar teria feito com que o romancista de Iracema criasse uma língua e uma paisagem fictícias:

\begin{abstract}
Ao passo que Cooper daguerreotypa a natureza, Sênio [Alencar], à força de querer passar por original, sacrifica a realidade ao sonho da caprichosa imaginação, despreza a fonte, onde muita gente tem bebido, mas que é inesgotável, e onde há muito licor intacto. Para Sênio a verdade, dita por muitos, perde o encanto. Ele não há de escrever pelo ramerrão; fora rebaixar-se. É preciso dar cousa nova, e eis que surge o mostro repugnante e desprezível ${ }^{281}$.
\end{abstract}

Ao mesmo tempo em que recusa a condição de gênio criador, um dos principais pilares do Romantismo, Távora toma a arte literária como um tipo de imitação passível de ser realizada, principalmente, de duas maneiras: 1) pela observação direta dos modelos ou pelo estudo de historiadores conceituados, incluindo também fontes populares, como os cancioneiros; e 2) pelo concurso da verdadeira imaginação, ou seja, pelo uso de imagens lastreadas pela memória, com o privilégio para a observação “direta” e para a busca da “exatidão daguerreotípica”282. Nas Cartas a Cincinato, sobretudo nos textos que se referem ao romance O Gaúcho, esse último ponto parece ser seu enfoque principal. Ele questiona Alencar por não ter ido ao Rio Grande do Sul para fazer tal obra. "Isto o faz cahir em freqüentes inexactidões, quer se propunha a reproduzir, quer a divagar na tela”283.

Por outro lado, considera que a finalidade da arte não seria inventariar ou imitar servilmente as coisas do mundo, mas sim procurar separar o belo do grotesco. Nesse sentido, o poeta deveria depurar os dados colhidos pela observação; seu daguerreótipo seria seletivo, devendo privilegiar a expressão de uma natureza ideal. Por outro lado, enquanto para Alencar a verossimilhança estaria na coerência interna da obra, para Távora esta só se daria a partir da conformação do autor à dita realidade externa ou aos relatos históricos abalizados, ou seja, a mediações discursivas pautadas pela verdicção, por ele selecionadas.

\title{
3.3. Graciliano e a representação do sertão
}

O primeiro momento em que o autor de Caetés tematizou de maneira clara e efetiva a desconstrução da imagem que, rotineiramente, fazia-se sobre o sertão, nos relatos românticos,

${ }^{281}$ TÁVORA, Franklin. Cartas a Cincinato. Estudos críticos de Semprônio. Pernambuco: J. W. Medeiros, 1872, p.14.

${ }^{282}$ Ele destaca que tal imitação também seria possível pelo conhecimento da tradição literária.

${ }^{283}$ Idem, p.15. 
foi na crônica "Sertanejos”, publicada no primeiro número da revista alagoana Novidade, em abril de 1931. Neste texto, Graciliano contrapõe a imagem do interiorano, difundida nas cidades litorâneas por jornalistas e literatos “que nunca estiveram no interior”, àquela que seria a verdadeira representação do matuto, “sem nenhum pitoresco”, dada por ele. Para construir tal retrato supostamente fiel, o narrador invoca suas origens sertanejas, reforçando o efeito de real. Trataria de criaturas comuns e se distanciaria do "produto literário", estereotipado e ficcionalizado, construído na capital:

Essa mistura de retirante, beato e cangaceiro, enfeitada com patuá, duas alpercatas e muitas figuras de retórica, torna-se rara. Os homens de minha terra podem ter por dentro a cartucheira e os molambos, mas exteriormente são criaturas vulgares sem nenhum pitoresco ${ }^{284}$.

O seu relato, portanto, pretende afirmar-se quase como um documento em contraposição ao conhecimento "falso" que se produzia sobre o sertão e que era veiculado em livros e jornais. Para tanto, sem abdicar da ironia e do deboche, adota certa perspectiva sociológica que procura enquadrar e tipificar os habitantes daquele espaço. Inicialmente, retoma de maneira breve e genérica o passado destes para, em seguida, deter-se em imagens e situações que transmitiam a sensação de contemporaneidade:

\begin{abstract}
Os sertanejos dos campos estiveram no Amazonas, em São Paulo e no Espírito Santo; tiraram borracha, plantaram café, voltaram com maços de notas e dispostos a esbanjá-las depressa. Alguns, incapazes de exercícios pesados, meteram-se no exército e na marinha, e os que haviam ido à cadeia e levado pancada, entraram na polícia e vingaram-se.
\end{abstract}

Todos esses sujeitos regressaram muito sabidos, estranhando tudo, falando difícil, desconhecendo os amigos, ignorando os nomes dos objetos mais corriqueiros, confundindo bode com onça. Naturalmente não quiseram mais criar bodes. Tornaram-se negociantes ambulantes ou adquiriram um pedaço de terra e foram explorar o trabalho dos outros ${ }^{285}$.

Se ao apresentar os sertanejos como seres vulgares, figuras existentes em qualquer lugar, Graciliano procurava retirar-lhes as camadas discursivas de "pitoresco" que os recobriam e, indiretamente, aproximá-los dos habitantes do litoral, em sentido oposto, não deixa também de se reportar a eles mediante um viés crítico e depreciativo:

\footnotetext{
${ }^{284}$ RAMOS, Graciliano. Sertanejos. Novidade, Maceió, n.1, 11 abr. 1931. Texto ainda inédito em livro.

${ }^{285}$ Idem, ibidem.
} 
Falam demais não ganham quase nada e começam a sentir necessidades exorbitantes. Têm rodovias, estradas de ferro, luz elétrica, cinema, praças com jardins, filarmônicas, máquinas de escrever e pianos. Só faltam escolas e hospitais. Por isso os sertanejos andam carregados de muita verminose e muita ignorância ${ }^{286}$.

Dessa maneira, o articulista parece orientar-se por certa perspectiva da escola realista européia (seu maior modelo seria Eça de Queirós), acreditando que apenas certo viés “pessimista” de representação do mundo seria autêntico ${ }^{287}$. Daí privilegiar certas tópicas de desacerto como índices de aderência a uma suposta representação "verdadeira” do real. Por essa lógica, ao mesmo tempo em que valorizava a experiência “concreta”, deveria adotar uma postura crítica, caso quisesse conferir verossimilhança artística a seu texto e distanciar-se do produto literário, aludido anteriormente. Para tanto, detêm-se, principalmente, na exposição da incongruência de uma prática comum no sertão (e também nas capitais litorâneas): a adoção de hábitos e modos importados por seus moradores que, por sua vez, seriam incompatíveis com o meio precário e atrasado em que viviam. Diagnostica que seria melhor abandonar os estrangeirismos, o progresso ilusório propagado pelas fitas americanas, e retornar às práticas e costumes regionais, os quais melhor se ajustariam à conjuntura pobre e tacanha retratada.

No que diz respeito a esse último o aspecto, Graciliano parece distanciar-se dos posicionamentos estéticos de Távora. Por mais que promovesse a observação, em detrimento da imaginação e do gênio criativo, o autor de $O$ matuto ainda apresentava uma visão idealizada do belo literário, como pode ser observado no trecho abaixo:

\footnotetext{
${ }^{286}$ Idem, ibidem.

${ }^{287}$ A ascendência de Eça sobre Graciliano era manifesta de maneira aberta por este último. Conforme visto no capítulo anterior, o autor alagoano, no início de seu trabalho cronístico, chegou escrever uma crônica condenando a depredação da estátua do romancista português. Por outro lado, tal influência da escola autointitulada realista, do século XIX, mais intensa e declarada, sobretudo, no começo da trajetória literária do escritor, não ocorrera de maneira irrestrita. Graciliano repudiava certos pormenores descritivos, largamente utilizados pelos próprios escritores nordestinos como estratégia discursiva para conferir maior "fidelidade” a seus relatos (RAMOS, Graciliano. O romance do Nordeste, Diário de Pernambuco, Recife, 10 mar. 1935, $2^{\text {a }}$ seção, ano 110). Ao mesmo tempo, a retomada do Realismo/Naturalismo pelo autor de Vidas Secas, no contexto do romance regionalista de 1930, orientou-se por outros pressupostos (apesar de ter mantido certos procedimentos técnicos). Se no século XIX, predominava uma interpretação biológica e determinista dos fenômenos, nos anos de 1930, passava a prevalecer uma leitura dos problemas do país focada em dados econômicos, históricos e sociológicos (SUSSEKIND, Flora. Tal Brasil, qual romance?. Rio de Janeiro: Achiamé, 1984, p.86). O capítulo 21 de S. Bernardo alegoriza muito bem a oposição entre essas duas vertentes interpretativas. Enquanto Paulo Honório não via problemas em agredir Marciano, funcionário de sua fazenda, pois considerava que ele não passava de um "molambo", que nascera e ia morrer em tal condição subumana, Madalena indignava-se diante da atitude do marido, procurando explicar a situação degradada do serviçal como decorrente das violências, humilhações e explorações que este sofrera ao longo da vida (RAMOS, Graciliano. $S$. Bernardo. 5. ed. Rio de Janeiro: Livraria Editora José Olympio, 1953, p.108-112). Portanto, a perspectiva humana e materialista da mulher, fundada nas ciências sociais, contrapunha-se à violência do fazendeiro, que tinha como base, por sua vez, o imobilismo e o determinismo das leis naturais.
} 
Segundo penso, meu amigo, e me parece recomendar a estética, o artista não tem o direito de perder de vista o belo ou o ideal, posto que combinando-o sempre com a natureza (...) Li um precioso livro, intitulado - A ciência do belo - por Lévêque (...) Nunca mais me esqueci de um pedacito que lá vem, concebido nestes termos: "Se o artista não é senão o arrolador da vida de todos os dias, quero antes a vida em si mesma, que é viva, e onde não me demorarei com a vista senão sobre o que me interessar"288.

Portanto, ao mesmo tempo em que crítica, de maneira metonímica, certos pilares do Romantismo, presentes nas obras de Alencar, ainda estaria influenciado pela crítica romântica e por certa visada oriunda da filosofia idealista.

\subsection{A especificação da crítica ao Romantismo}

Se em "Sertanejos”, Graciliano questiona a imagem construída pela tradição sobre os espaços interioranos, sem especificar o alvo de sua crítica, isso muda de figura com o texto "O romance do Nordeste”, publicado no Diário de Pernambuco, de Recife, em março de 1935. Nele o escritor ataca frontalmente a tradição romântica. Esta, ao tratar da matéria sertaneja, teria se afastado daquilo que ele nomeia como o caráter brasileiro:

Em geral os nossos escritores mostraram uma admirável ignorância das coisas que estavam perto deles. Tivemos caboclos brutos semelhantes aos heróis cristãos e bem falantes em excesso. Os [patriotas] do século passado, em vez de estudar os índios, estudaram tupi nos livros e leram Walter Scott. Tivemos Damas das Camélias de segunda mão. Tivemos paisagens inúteis em linguagem campanuda, pores-dosol difíceis, queimadas enormes, secas cheias de adjetivos. Descrições. José Veríssimo construiu um [candieiro] em não sei quantas páginas.

Muito pouco - rios, poentes cor de sangue, incêndios, candieiros ${ }^{289}$.

Pela citação, percebe-se que o autor alagoano coloca lado a lado tanto o romance histórico romântico, como aquele de caráter folhetinesco. Ambos teriam servido de parâmetros equivocados para que os artistas nacionais do passado compusessem "paisagens inúteis”, em "linguagem campanuda”. Segundo o autor, o motivo principal desse aparente equívoco na

\footnotetext{
288 TÁVORA, Franklin. op.cit, p.215.

289 RAMOS, Graciliano. O romance do Nordeste, Diário de Pernambuco, Recife, 10 mar. 1935, $2^{\mathrm{a}}$ seção, ano 110. Texto ainda inédito em livro.
} 
representação do espaço sertanejo estaria no fato de os literatos antigos darem preferência a modelos importados ao invés de procurarem se ater à observação do mundo que os rodeava.

Retomando o possível paralelo entre Graciliano e Távora, há aqui outro ponto de divergência. O escritor cearense, apesar de defender a primazia da observação nas Cartas a Cincinato, ao escrever seus romances acabou dando preferência a personagens e episódios tomados da história como melhor caução para conferir autenticidade estética a suas obras. Dessa maneira, "situando suas narrativas no século XVIII, o autor de O Cabeleira se privava da possibilidade de uma observação efetiva da realidade social que lhe servia de matéria, devendo contentar-se com pesquisar as fontes históricas” ${ }^{\text {} 290}$. Portanto, por meio de sua prática como romancista, é possível depreender que quando revela predileção por certo romance "verossímil possível”, estaria tomando a verossimilhança mais como uma adequação a um conjunto de verdades documentado pela tradição ${ }^{291}$. Nesse sentido, acaba optando por um modelo extraído da crônica histórica romanceada.

Para o autor de Vidas Secas, tal procedimento de recuperar "retalhos de coisas velhas e novas importadas da França, da Inglaterra e da Rússia” era coisa do passado. Os escritores de seu momento de enunciação teriam passado a se fiar apenas em seus sentidos, ao mesmo tempo em que não precisavam mais exibir-se às portas da Garnier; assim, podiam ficar em suas cidades sertanejas, realizando uma "honesta reportagem" da vida do interior. Na sua opinião, tal iniciativa teria contribuído para o desaparecimento dos "processos de pura composição literária” nas obras que tematizavam o Nordeste. Por essa diretriz, subentende-se que seu conceito de verossimilhança colocava em primeiro plano a perspectiva de não se afastar do ambiente que se conhecia e observar atentamente a conformação deste (com ênfase na contemporaneidade). Outro ponto fundamental era não confiar demais na imaginação, o que sempre levava à criação de produtos fantasiosos.

No decorrer do texto, Graciliano particulariza seu argumento tomando como exemplos as produções de seus companheiros de geração Raquel de Queirós, Jorge Amado e José Lins do Rego. Sobre este último, chega a destacar:

\footnotetext{
${ }^{290}$ ALMEIDA, José Maurício Gomes de. A tradição regionalista no romance brasileira. Rio de Janeiro: Topbooks, 1999.

${ }^{291}$ Idem, ibidem.
} 
O sr. Lins do Rego criou-se na bagaceira de uma engenho, e julgo que nem sabe que é bacharel. Conservou-se garoto de bagaceira, o que não the teria acontecido se morasse no Rio, freqüentando teatros e metendo artigos nos jornais. Aqui está bem. Quando o cheiro das tachas vai esmorecendo, dá um salto a uma engenhoca, escuta Zé Guedes, seu Lula, a velha Sinhazinha ${ }^{292}$.

O autor de Doidinho merece destaque por encontrar-se discursiva e afetivamente próximo da realidade que se propunha a tratar, trabalhando com certas tópicas sugeridas por fatos e cenas nordestinas, deixando de lado, na opinião do articulista, uma representação estereotipada e artificial da região. Para que esta última não tornasse a ocorrer colaborava muito a relativa proximidade física daquele que escreve com o mundo figurado em seus romances. Trata-se de um momento em que os principais expoentes da chamada geração de 1930 ainda se encontravam no Nordeste e se valiam dessa condição como argumento para reforçar a força e a “verdade” do romance de caráter regional que produziam.

Em “Suor”, texto saído na Folha de Minas de Belo Horizonte, em fevereiro de 1935, essa posição fica ainda mais destacada:

\footnotetext{
O escritores atuais foram estudar o subúrbio, a fábrica, o engenho, a prisão da roça, o colégio do professor cambembe. Para isso resignaram-se a abandonar o asfalto e o café, viram de perto muita porcaria, tiveram a coragem de falar errado como toda a gente, sem dicionário, sem gramática, sem manual de retórica. Ouviram gritos, pragas, palavrões, e meteram tudo nos livros que escreveram. Podiam ter mudado os gritos em suspiros, as pragas em orações. Podiam, mas acharam melhor pôr os pontos nos $\mathrm{ii}^{293}$.
}

Além de ver de perto, estudando as paisagens a serem representadas, quase como repórteres, os romancistas, se quisessem construir obras verossímeis, deveriam trazer para o discurso artístico o modo de falar das pessoas que viviam nesses espaços. A noção de verossimilhança do autor, insistentemente, destaca tal exigência formal. Ele repudia os diálogos antigos, marcados por tabaréus bem falantes, por "pedantismos” colocados na boca dos matutos. Era preciso que o escritor fizesse com que seus personagens falassem "como toda a gente”. Essa preocupação, por sua vez, já aparecia nas Cartas a Cinicinato, sobretudo quando Távora se refere ao romance Iracema, de Alencar:

\footnotetext{
${ }^{292}$ RAMOS, Graciliano. op.cit.

293 RAMOS, Graciliano. Suor. Folha de Minas, Belo Horizonte, 17 fev. 1935. Texto também publicado em Linhas Tortas (São Paulo: Martins, 2005) com o título “O romance de Jorge Amado”, p.129.
} 
Há um grande erro de forma na obra do Sr. Alencar: essa linguagem sempre figurada, que ele põe a cada instante na boca dos bárbaros, como se fossem todos poetas.

Está enganado; o uso, que faziam dos tropos, era determinado tão somente pela necessidade, quando tinham de exprimir as idéias abstratas, para as quais lhes faltavam termos. Fora disso, o seu modo de exprimir havia de ser grosseiro, rústico e simples, porque a mais lhes não permitia subir o estado de embrutecimento intelectual e moral, em que seu espírito jazia imerso. É o que dizem todos os autores ${ }^{294}$.

Tal afirmação de Távora parece antes ancorada em autoridades estabelecidas (“dizem todos os autores”), do que na aparente observação efetiva do modo de falar do sertanejo, reivindicada pelo autor de Angústia. Em outro sentido, relaciona-se mais a retomada de um lugar-comum consolidado sobre os espaços interioranos: a idéia de se tratarem de regiões de hábitos bárbaros e licenciosos, de população embrutecida, que, portanto, deveria falar e agir segundo estas coordenadas. Graciliano também tem essa tópica em seu horizonte, mas enfatiza que ela seria melhor respaldada pelo contato "efetivo" do escritor com os habitantes de tais lugares incultos.

No prefácio de O Cabeleira, Távora volta a tratar das letras nacionais, focando sua atenção, sobretudo, no que nomeia como "literatura do Norte". Nesse movimento, acaba lançando as sementes de um programa regionalista. Na sua opinião, as obras literárias produzidas na parte setentrional do país tinham mais elementos para se apresentarem como autenticamente brasileiras, filhas da terra, quando comparada às produções do Sul. Isso ocorreria porque a região nortista manteria seus costumes e tradições de forma mais intacta, uma vez que fora menos exposta ao influxo de estrangeiros, tal como acontecera com a porção mais meridional do país, sobretudo quando se pensava na Corte. Diante das condições latentes naquele espaço tradicional, o escritor cearense vaticina:

Por infelicidade do Norte, porém, dentre os muitos filhos seus que figuram com grande brilho nas letras pátrias, poucos têm seriamente cuidado de construir o edifício literário dessa parte do império que, por sua natureza magnificente e primorosa, por sua história tão rica de feitos heróicos, por seus usos, tradições e poesia popular há de ter cedo ou tarde uma biblioteca especialmente sua ${ }^{295}$.

Essa profecia parece de ter sido atendia nos anos que se sucederam. Referindo-se especificamente à produção que se fazia no Nordeste (nesse momento, já uma região

${ }^{294}$ TÁVORA, Franklin. op.cit, p.250.

295 TÁVORA, Franklin. O Cabeleira. São Paulo: Ática, 1977, p.11. 
autônoma, desmembrada do “Norte”, antiga divisão administrativa) ${ }^{296}$, Graciliano parece confirmar a realização de tal prognóstico, lançado por Távora:

\begin{abstract}
O trabalho que há no Nordeste é mais intenso do que em qualquer outra parte do Brasil, tão intenso que um crítico, visivelmente alarmado com as produções daqui, disse ultimamente que não é só no Norte que se faz literatura. De certo. Era indispensável, porém, que nossos romances não fossem escritos no Rio, por pessoas bem intencionadas, sem dúvida, mas que nos desconheciam inteiramente ${ }^{297}$.
\end{abstract}

No entanto, ao exaltar a literatura de sua região natal, o escritor alagoano não se detém naquilo que ela apresentava de pitoresco. Muito pelo contrário. Para ele, o principal motivo de sucesso dos livros nordestinos seria a suposta "fidelidade ao real” de seus realizadores. No momento em que Graciliano enuncia tal posicionamento o chamado “romance de trinta” já desfrutava de destaque nos meios intelectuais. Deixava de ser taxado como puramente regionalista, para ser alçado à condição de representante da nacionalidade. Trata-se de um momento em que ganha ênfase a análise sociológica do homem brasileiro, num contexto de institucionalização pelo Estado da cultura popular, o que confere às produções de Jorge Amado, José Lins do Rego, Raquel de Queirós, entre outros, o estatuto de obras preocupadas com a nação e com seu povo, mestiço, pobre, inculto em suas manifestações sociais. “A literatura passa a ser vista como destinada a oferecer sentido às várias realidades do país; a desvendar a essência do Brasil real”298.

Em “Um romancista do Nordeste”, crítica estampada na revista carioca Literatura, em junho de 1934, Graciliano se dedica a examinar a obra de José Lins do Rego, que naquele momento vinha de lançar Doidinho. Depois de exaltar a produção do romancista paraibano, chegando, inclusive, a afirmar que a obra dele tinha mais coesão que a de Vitor Hugo, Anatole France, e Machado de Assis, o articulista repudia justamente as passagens mais “pitorescas” de Menino de Engenho: as descrições de uma seca e de uma queimada. Na sua opinião, esses trechos poderiam desaparecer sem desvantagem para o conjunto, uma vez que, apesar de bem feitos,

\footnotetext{
${ }^{296}$ Termo utilizado pela primeira vez, em 1919, para designar a área de atuação da Inspetoria Federal de Obras contra as Secas (IFOCS); tal região seria uma parte do antigo Norte, caracterizada por longos períodos de estiagem. Em função disso, requisitava uma atenção maior do poder público federal. "O Nordeste é, em grande medida, filho das secas; produto imagético-discursivo de toda uma série de imagens e textos, produzidos a respeito desse fenômeno, desde que a grande seca de 1877 veio colocá-la como problema importante para esta área” (ALBUQUERQUE, Durval Muniz de. A invenção do Nordeste e outras artes. Recife: Fundação Joaquim Nabuco, Editora Massangana; São Paulo: Cortez, 1999, p.68).

${ }^{297}$ RAMOS, Graciliano. O romance do Nordeste, Diário de Pernambuco, Recife, 10 mar. 1935, 2a seção, ano 110.

${ }^{298}$ ABUQUERQUE, Durval Muniz de. op.cit, p.107.
} 
já haviam sido explorados por literatos de outras épocas, entre eles José de Alencar e Graça Aranha.

Graciliano, portanto, considerava o “excesso de tintas” prejudicial, sobretudo, na abordagem dramática de tais lugares-comuns sertanejos, fundados em certa idéia de que a vida nos espaços interioranos seria guiada pelos ciclos da natureza. Ao mesmo tempo, para o romancista, os escritores precisavam deixar de lado também os pormenores “inúteis”, cultivados pela escola realista, e mostrar os personagens por dentro, "vivos” e "inteiros”. Tais pontos de vista se consubstanciaram, sobretudo, em seu romance Vidas Secas (1938). Em carta, na qual trata da obra, o autor comenta:

Fiz um livrinho sem paisagens, sem diálogos. E sem amor. Nisso, pelo menos, ele teve alguma originalidade. Ausência de tabaréus bem falantes, queimadas, cheias e poentes vermelhos, namoros de caboclos. A minha gente, quase muda, vive numa casa velha de fazenda. As pessoas adultas, preocupadas com o estômago não têm tempo de abraçar-se. Até a cachorra é uma criatura decente, porque na vizinhança não existem galãs $\operatorname{caninos}^{299}$.

Portanto, nada de tragédias hiper-dimensionadas pela apresentação dramática do espaço ressequido e castigado pela seca, nada de namoros romanceados, nada de heroísmos, com o propósito de exaltar os sertanejos. O pressuposto do autor, de acordo com as coordenadas apresentadas até aqui, parece ser o de atribuir uma vida ordinária aos retirantes, procurando simultaneamente articular o espaço (físico e social), a ação, os personagens e a linguagem utilizada por estes. Nesse processo, acaba enfeixando uma trama sem grandes peripécias, em que se destaca a pobreza da fala dos tipos colocados em cena. Tais aspectos parecem mimetizar e vivificar as tópicas da monotonia associada ao sertão, bem como do embrutecimento dos habitantes que lá habitavam, destituídos de subsídios lingüísticos para compreenderem o mundo em que viviam.

Se em Távora há a perspectiva de exaltação e mitificação do dado regional (especificamente a natureza “magnificente e primorosa”, a história de feitos heróicos, usos e tradições) ${ }^{300}$, em

\footnotetext{
299 RAMOS, Clara. Mestre Graciliano - confirmação humana de uma obra. Rio de Janeiro: Civilização Brasileira, 1979, p.129.

${ }^{300}$ No que diz respeito ao sertão e a seus habitantes, é com O sertanejo (1875), de José de Alencar, que essa perspectiva de engrandecimento ganhara maior destaque. Nessa obra, por mais que procurasse conferir estatuto de real ao relato, localizando a ação num meio sociocultural que lhe era próximo (sua terra natal), o autor imprime tanto ao herói como ao espaço representados dimensão épica e um tratamento mítico. Dessa maneira,
} 
Graciliano o propósito é muito mais de exposição (denúncia) dos problemas (econômicos, políticos e sociais) enfrentados por aquele espaço e por seus viventes ${ }^{301}$, norteando-se por um protocolo analítico que mesclava doses de sociologia e psicologia em meio ao tratamento da matéria ficcional. Portanto, não há a perspectiva encomiástica ou saudosa dirigida aos personagens ou ao próprio lugar representado. Seu objetivo seria dar a conhecer aquele espaço arruinado, bem como os habitantes deste, norteando-se pela necessidade maior de estudo da "realidade do país". O autor de S.Bernardo, portanto, adota uma perspectiva nacionalista crítica, sem rasgos de nostalgia pelo passado ou de euforia pelas mudanças futuras. Parece defender a hipótese de que só se conhecendo as ruínas nacionais se poderia construir algo novo: as feridas só seriam curadas se se convivesse com elas.

Vale ressaltar que nesse processo a sempre aludida “realidade da região Nordeste” seria tomada por Graciliano como algo pré-existente, como uma espacialidade natural que deveria ser captada "fielmente” pelo discurso literário. No entanto, como se sabe, longe de apenas representar esse mundo, seus romances, bem como os de seus companheiros da geração de 1930, participaram ativamente do processo de invenção da própria região. Ao proporem uma nova visibilidade e dizibilidade para o sertão pressupunham a emergência ou a resignificação de conceitos, temas, objetos, figuras, imagens que permitiriam ver e falar de forma diferenciada. Quando o escritor alagoano rebaixa o protocolo romântico e reivindica uma outra maneira de produzir sentido sobre aquele espaço, mostra ter tal perspectiva em seu horizonte.

No entanto, por mais que Graciliano aparente ter consciência de que o espaço é uma construção discursiva, reconhecendo as relações de poder e saber que o instituíam historicamente ${ }^{302}$, o escritor se coloca como detentor de uma verdade transcendente sobre região nordestina, a qual deveria ser por ele revelada. Nesse sentido, sua estratégia seria a de culpabilizar e diminuir o modelo romanesco anterior e, paralelamente, afirmar a superioridade realística da produção de Jorge Amado, José Lins do Rego, Raquel de Queirós e de outros artistas que naquele momento se dedicavam a escrever sobre o Nordeste. Tal procedimento,

continua considerando a arte literária como uma forma de afirmação e glorificação da nacionalidade ao tratar do homem e da paisagem sertaneja.

${ }^{301}$ Em sua produção cronística e ficcional é comum o escritor se referir à população sertaneja por meio do termo "viventes", o que atribuía a esta certa brutalização e animalização. A palavra, inclusive, está no título do livro póstumo Viventes das Alagoas. Segundo Ricardo Ramos, filho de Graciliano, a sugestão de nome desta obra fora dada por Jorge Amado (RAMOS, Ricardo. Retrato Fragmentado. São Paulo: Editora Siciliano, 1992, p.35).

${ }^{302}$ Noção extraída, sobretudo, dos capítulos "O olho do poder" e "Sobre a Geografia" do livro Microfísica do Poder (Rio de Janeiro: Graal, 1999), de Michel Foucault. 
como se verá a frente, deve ser enquadrado num contexto específico de disputas no campo literário.

\subsection{A visada “classista” no tratamento do sertanejo}

Na crônica “Natal”, saída na revista O Cruzeiro, em 21 de dezembro de 1940 303 , Graciliano faz uma oposição entre os cantadores (“poetas que se esgoelam repenicando as primas”, os quais têm sua produção recolhida nos folhetos de cordel) e determinado grupo de literatos, autores de contos regionais. Enquanto, os primeiros procederiam com relativa honestidade e autenticidade na abordagem da matéria sertaneja, os segundos teriam observação nula, realizando obras uniformes, piegas, “encharcadas na garapa do romantismo”. Dessa maneira, os primeiros são valorizados por se fiarem a seus sentidos, pois cantariam aquilo que apreenderiam diretamente do espaço onde viviam. Os segundos, por outro lado, abdicariam da empiria para se escorarem em alguma autoridade literária reconhecida. Ao adotarem este procedimento deixariam de lado, por exemplo, certos costumes indecentes e o fato de que os habitantes do interior seriam pagãos. O cronista imagina que tais dados não serviriam a semelhante tipo de literatura idealista e, por esse motivo, continuariam em segredo como se não existissem.

Pelo que foi visto até aqui, nada de novo nas concepções artísticas defendidas pelo escritor desde os anos 1930: ao abordar a festa natalina, Graciliano continua com o intento retórico explícito de rebaixar o protocolo romântico, a maneira que no passado se construíam as verdades sobre o sertão, e elevar um outro, documental, que atualizava certos pressupostos do realismo literário do século XIX. Este último, do qual partilha, seria superior por reivindicar certa correspondência imediata entre o mundo e o texto (como se não houvesse a intermediação sígnica).

No entanto, fica claro que as duas formas de tratar artisticamente a matéria regional supracitadas (a realista dos cantadores e a romântica dos literatos), seriam realizadas por classes sociais opostas. Nas camadas mais altas da sociedade sertaneja haveria alarmada pudicícia e rubores, em função da tradição das famílias. Para elas, "a virtude é coisa útil, respeitável, e não convém estragá-la assim de chofre”. Todos se conhecem e todos se

\footnotetext{
${ }^{303}$ Texto reunido no livro póstumo do autor Viventes das Alagoas (São Paulo: Martins, 1962).
} 
policiam. Já para a “cambada mesquinha e suarenta”, “as instâncias do coração” não achariam obstáculos sociais para se manifestarem. Entre tais extratos menos favorecidos, não haveria espaço para formalidades ou pudores; os desejos amorosos se processavam rapidamente por meio de “diálogos curtos, vivos, sem rodeios, sem metáforas”304. Essa oposição entre comportamentos de ricos e pobres, revelava-se interessada e servia de argumento para o autor defender sua perspectiva retórico-poética no trato do sertão: enquanto a literatura de feição romântica seria pudica, palavrosa e dominante (pois predominaria nos escritos e nas verdades construídas sobre o lugar), a outra, realista, que procurava consolidar seu espaço no cenário cultural brasileiro, não se furtaria a apresentar aparentes indecências de maneira rápida e direta, em linguagem usualmente tida como baixa.

Por esse aspecto, no qual o cronista combate frontalmente certa visão dominante que se fazia sobre o sertão, ele acaba construindo para si o lugar de uma figura iluminada, que vai tirar da sombra ou reorientar as verdades que se produziam sobre o lugar. Acredita que assim colaboraria para que determinadas práticas, costumes e personagens sertanejas passassem a ter existência ou mesmo ganhassem uma forma que supunha mais adequada, seja porque eram preteridos pelo modelo literário anterior, seja por que eram idealmente formulados por este.

A tal papel, o cronista acrescenta ainda a função de atuar diretamente sobre as matérias apresentadas. Nesse sentido, caberia a ele não só apresentá-las e explicá-las, sem concessões ou meios-termos, como também corrigir certos elementos delas julgados improcedentes. O narrador do texto, portanto, ao tratar dos assuntos, pretende colaborar para transformá-los. Melhor dizendo, dentro das premissas do raciocínio marxista, ao formular antíteses, ele trabalharia para construir uma síntese, a qual implicava a destruição do modelo dominante. Essa postura “revolucionária” tinha sua matriz na escolha da própria diretriz literária adotada pelo escritor: enquanto sua literatura se identificava com a “canalha” ${ }^{305}$, com aqueles que seriam, supostamente, os sujeitos históricos da mudança, as convenções idealistas e

\footnotetext{
${ }^{304}$ RAMOS, Graciliano. Natal. O Cruzeiro, Rio de Janeiro, 21 dez. 1940. In: Viventes das Alagoas. São Paulo: Martins, 1962, p.13.

${ }^{305}$ De certa maneira, Távora, em $O$ cabeleira, ao selecionar, da história de Pernambuco, não exemplos de grandeza moral, mas "vultos infelizes", pertencentes a uma classe social menos nobre, parece se ajustar a essa perspectiva (além disso, José Gomes fora cantador ao mesmo tempo em que figurava como tema recorrente nos versos dos trovadores, outro indício de seu aspecto popular). No entanto, enquanto tal autor adotara uma perspectiva moralizante (do homem naturalmente bom que se corrompe e depois se regenera), Graciliano vale-se de um tom de denúncia, dando privilégio para aspectos econômicos, políticos e sociais no trato do espaço e do homem sertanejos.
} 
românticas diriam respeitos à classe dominante, que, até então, controlava o poder econômico e a produção das verdades sobre o espaço.

Subentende-se que os rebaixados socialmente, as vítimas de exploração, seriam mais autênticos, pois não estariam presos às convenções e artificialismos da classe dominante. Dessa maneira, o procedimento do cronista de identificar sua literatura ao grupo social menos privilegiado seria uma forma de validá-la e de conferir-lhe maior estatuto de real.

Tal perspectiva já poderia ser vista na crônica "Suor”, apresentada anteriormente. Nela, Graciliano se vale de uma oposição binária semelhante, contrapondo, de maneira direta, os literatos passadistas bem colocados socialmente (que se ufanavam com seu país) aos escritores atuais (que não achavam que as coisas iam tão bem, assim):

\begin{abstract}
Há uma literatura antipática e insincera que só usa expressões corretas, só se ocupa de coisas agradáveis, não se molha em dias de inverno e por isso ignora que há pessoas que não podem comprar capas de borracha. Quando a chuva aparece, essa literatura fica em casa, bem aquecida, com as portas fechadas. E se é obrigada a sair, embrulha-se, enrola o pescoço e levanta os olhos , para não ver a lama nos sapatos. Acha que tudo esta direito, que o Brasil é um mundo e que somos felizes. (...)
\end{abstract}

\begin{abstract}
Ora, não é verdade que tudo vá assim tão bem. Umas coisas vão admiravelmente, porque há literatos com ordenados razoáveis; outras vão mal, porque os vagabundos que dormem nos bancos dos passeios não são literatos nem capitalistas. Nos algodoais e nos canaviais no Nordeste, nas plantações de cacau e de café, nas cidadezinhas decadentes do interior, nas fábricas, nas casas de cômodos, nos prostíbulos, há milhões de criaturas que andam aperreadas. (...) É natural que a literatura nova que por aí andam construindo se ocupe ${ }^{306}$.
\end{abstract}

Portanto, ao reivindicar um contato “íntimo” entre escritores e matérias narradas, pressupondo que os primeiros, além de se identificarem à “canalha da roça”, deveriam ter vivido no sertão, para então produzirem textos “sinceros”, Graciliano não tem em mente apenas a imagem que, intradiscursivamente, constrói-se de determinado escritor (a partir da leitura dos livros dele), mas sim representações preliminares e exteriores de tais sujeitos. Em outras palavras, dava a entender, em seus textos críticos (não em seus romances, contos e memórias), que o homem deveria se sobrepor ao artista. Assim, como se recusasse o fato de que as próprias histórias de

\footnotetext{
${ }^{306}$ RAMOS, Graciliano. Linhas Tortas, São Paulo: Martins, 1962, p.127-128.
} 
vida dos autores seriam mediadas pela ficção, acabava privilegiando, neste caso, uma interpretação predominantemente biográfica da obra literária ${ }^{307}$.

Tendo em vista a pressuposição dessa aparente correspondência entre obra e mundo, como visto até aqui, o romancista alagoano julgava que a história de vida de um escritor era determinante para conferir "verdade" aos textos por ele produzidos. Para se ter uma idéia melhor do peso deste quesito no horizonte crítico do autor de Angústia, ele afirmou que a produção romanesca de seu colega José Lins do Rego entrara em franco declínio a partir do momento em que este se esquecera de suas “origens”. Na opinião de Graciliano, o autor paraibano, após o Ciclo da cana-de-açúcar, terminado com o volume Usina, de 1936, deixara de lidar com lugares e acontecimentos conhecidos, referentes à zona da indústria açucareira, onde fora criado, para tratar de assuntos que ele não conhecia bem:

Pureza (1937) é uma pequena estação que ele viu de longe, da janela do trem. Em Pedra Bonita (1938) desejou estudar a epidemia religiosa que houve em Pernambuco no século passado, mas teve preguiça e inventou beatos e cangaceiros. Sacrificou até a geografia: pôs sua gente numa vila do Anum, que não existe. A primeira parte de Riacho Doce (1940) passa-se toda na Suécia. Embreando-se nessas regiões desconhecidas, José Lins do Rego repetiu muito do que já havia dito ${ }^{308}$.

Graciliano trata a fidelidade à própria trajetória como condição fundamental para a produção literária, pois somente dessa maneira um artista conseguiria manter-se fiel à “realidade” que desejava representar. Enquanto ficcionalizou suas experiências pessoais, Zé Lins teria produzido livros “cheios de vida”, escritos na arcaica “língua dos descobridores”, mantida em certas paragens do interior nordestino. Ao adotar perspectiva diversa, arriscou-se em “digressões perigosas”.

\footnotetext{
${ }^{307}$ Como complemento interpretativo, se levarmos em conta certos pressupostos oriundos da sociologia da literatura, pode-se considerar que Graciliano escreve num momento de desterritorialização pessoal e social, num contexto de decadência da sociedade nordestina patriarcal e de substituição desta por uma outra de caráter mais urbano-industrial (MICELI, Sérgio. A expansão do mercado do livro e a gênese de um grupo de romancistas profissionais. In:__. Os Intelectuais à brasileira. São Paulo: Companhia das Letras, 2001, p.141-194). Esse é o tema que, de uma maneira geral, predomina no "romance de trinta". Os autores dessa geração, em sua maioria descendentes de famílias tradicionais e decadentes, vivendo um processo de marginalização, deixavam de ter um compromisso direto com os grupos dominantes aos quais estavam ligados originariamente. Em contrapartida, procuravam se aproximar da "arraia miúda", adotando temas e formas de expressão de matriz popular como forma, sobretudo, de denunciar as condições sociais em que se vivia.

${ }^{308}$ RAMOS, Graciliano. A decadência do romance brasileiro. Literatura, Rio de Janeiro, ano 1, n.1, set. 1946, p.23.
} 
Ao propor tal conceituação estrita, Graciliano deixava em segundo plano a análise dos modelos literários e dos protocolos discursivos de que os artistas se valiam para construir suas obras e produzir o efeito de real sobre o auditório. Não que o escritor alagoano recusasse a importância da técnica na fatura de um livro, muito pelo contrário, como revela sua própria produção romanesca, mas seus textos críticos concedem privilégio a certa noção de autenticidade da experiência, a qual orientava suas análises e interpretações.

Guiado por essa convicção, separa os escritores dispostos a "abandonar o café e o asfalto" para verem de perto as misérias sertanejas, daqueles, que sem saírem do conforto de seus gabinetes, "sem se molharem nos dias de inverno", tratavam das paragens interioranas em suas obras. Como se verá, o presidente Getúlio Vargas utilizava categorização semelhante para se referir aos homens de letras.

\subsection{O caráter do escritor e o Estado Novo}

Em seu discurso de posse na Academia Brasileira de Letras (ABL), em 1943, Getúlio Vargas sinalizava para a deformação lógica que governou o pensamento brasileiro até 1930, quando administradores e intelectuais encontravam-se divorciados. Para o presidente, como decorrência desse cenário, a instituição fundada pelo autor de Dom Casmurro reservava suas cadeiras apenas àqueles que tratassem, de forma desinteressada, das “coisas do espírito”. Nesse sentido, mantinha-se distante dos problemas nacionais:

A Casa de Machado de Assis parecia reservada, nas minhas reflexões, aos homens votados à criação artística e ao estudo desinteressado dos problemas culturais. Não a considerava gleba apropriada ao rude amanho dos agricultores, mas terreno escolhido e tratado, onde os jardineiros operam milagres de beleza e colorido ${ }^{309}$.

De acordo com as metáforas utilizadas pelo presidente, os “jardineiros” corresponderiam aos chamados "homens de pensamento", às inteligências cultas, que olhariam para a vida de forma fria e distanciada, em termos de "categoria filosófica”, procurando beleza e colorido, ao mesmo tempo em que recusavam o contato direto com a terra, com a "gleba” nacional. Os agricultores, pelo contrário, seriam os "homens de ação”, ou seja, aqueles voltados para o estudo da realidade do país por meio das artes e de atividades práticas. Portanto, não se

${ }^{309}$ VARGAS, Getúlio. A nova política do Brasil. Rio de Janeiro: Livraria José Olympio Editora, vol.X, 1943, p.221. 
furtavam a revolver o solo, em seu rude amanho, com o objetivo de produzirem obras destinadas à recuperação das raízes brasileiras.

Segundo Getúlio, a separação, aparentemente irreconciliável, entre essas duas categorias resultava em prejuízos para ambas e, por conseguinte, para o país. Os intelectuais reclamavam isolamento e reclusão em sua "torre de marfim", tendo em vista a ausência de amparo governamental e o desprezo que dispensavam a seus antagonistas. Por outro lado, os "homens de ação”, dedicados a tarefas de ordem prática, desprezavam as possibilidades imaginativas dos que sabiam pensar e dizer com sofisticação. Para o presidente somente após a Revolução de Outubro operou-se a simbiose necessária entre os dois grupos:

\footnotetext{
Hoje vemos em vosso meio, compartilhando a imortalidade com poetas e romancistas, representantes das profissões liberais, juristas, historiadores, políticos e até industriais. É admirável que isso aconteça. Os valores da inteligência são multiformes, resultam de múltiplas e fecundas aplicações. Os modernos processos de integração social não podem malbaratá-los e a todos disciplinam, num sentido útil, para maior bem da coletividade ${ }^{310}$.
}

A própria posse de Getúlio na Academia, eleito para a Cadeira 37, sucedendo a Alcântara Machado, seria o maior exemplo dos novos tempos anunciados pelo presidente.

Diante do anúncio de tal reconfiguração do campo intelectual, a Academia não poderia se manter alheia à vida nacional. Aos olhos do chefe do governo, ela adquirira, sobretudo durante o decênio de 1930, um papel mais ativo sobre o conjunto da realidade brasileira, em seus múltiplos aspectos. Seu objetivo passara a ser o de coordenar tendências, idéias e valores, além de "elevar a vida intelectual do país a um plano superior, imprimindo-lhe direção

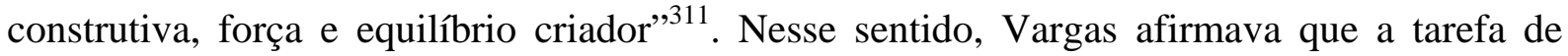
elevação da cultura, a cargo da instituição, passava, inevitavelmente, pelo estudo e pela solução dos grandes problemas da nacionalidade. Por tal perspectiva, entendia-se que os atributos e qualidades dos "homens de pensamento", deveriam ser utilizados para o enfrentamento e a solvência das tarefas desempenhadas pelos aludidos "homens de ação", sobretudo aqueles pertencentes ao aparelho do Estado. Ao mesmo tempo, atrelava-se a arte a certo propósito nacionalista e o escritor, tal como o agricultor aludido anteriormente, deveria

\footnotetext{
${ }^{310}$ Idem, p.223.

${ }^{311}$ Idem, p.223-224.
} 
se dedicar ao Brasil, revolvendo o solo pátrio e colhendo os frutos (obras) a partir deste trabalho. A literatura, portanto, passava a ser sinônimo de nação.

Diante da ênfase concedida a tais argumentos, pode-se entender que Getúlio realiza uma crítica indireta à postura do fundador da $\mathrm{ABL}$, sobretudo no que diz respeito ao tratamento dispensado por Machado de Assis às matérias brasileiras. Conforme explica o presidente da República, a instituição fundada pelo autor de Quincas Borba nascera sob a invocação da Academia Francesa, ou seja, submissa a influências externas. Além disso, colocava-se preferencialmente como "refúgio” e "repouso amável” a “espíritos serenos”, que apenas observavam com "imparcial frieza” os acontecimentos atuais. Em sentido oposto, Vargas reivindicava um contato “íntimo" e “direto" entre a intelectualidade e os problemas brasileiros, sem fugas contemplativas ou retiros em asilos seguros. Por sua perspectiva, era preciso que os homens de letras deixassem o isolamento e participassem de maneira viva e intensa da construção da nacionalidade.

Se Machado figurava como um romancista afeito, preferencialmente, às coisas do espírito, olhando para as matérias nacionais com distância e desinteresse, Euclides da Cunha, por outro lado, seria tomado como seu contraponto. Para o presidente, o autor de Os sertões colocava-se como uma espécie de síntese entre as categorias "homens de pensamento" e "homens de ação”. Numa entrevista compilada em A nova política do Brasil, Getúlio se refere a este último como "escritor da terra”, artista em cuja obra os contemporâneos e os vindouros recolheriam "a mensagem da raça ou da Pátria, como testemunho da sua inquietação, dos seus anseios ou esperanças”312. Em outras palavras, a literatura euclidiana destacava-se aos olhos de Vargas por sua aparente função social e política, dentro de certa perspectiva a um só tempo utilitarista e nacionalista.

A oposição entre Euclides e Machado, como personificações de duas vertentes antagônicas da literatura nacional, torna-se, mais explícita no pensamento de Cassiano Ricardo. Em Marcha para oeste, depois de alertar para o perigo de os escritores nacionais adquirirem certa doença chamada de “infecção cultural”, contraída a partir do distanciamento das raízes brasileiras,

\footnotetext{
${ }^{312}$ Ao responder à questão "Dos escritores nacionais, a quem V. Exa. confere o caráter mais representativo?”, Getúlio, além de Euclides, destaca a figura de Gonçalves Dias, descrito como o poeta da raça. VARGAS, Getúlio. A nova política do Brasil. Rio de Janeiro: Livraria José Olympio Editora, vol. VI, [1938-1941], p.239.
} 
sob o pretexto de que o "espírito” não teria pátria, o poeta de Martim Cererê cita o fundador da ABL, como um dos portadores-símbolos desta degenerescência:

\begin{abstract}
Sua prosa não é apenas anti-brasileira no apuro clássico de um português que se escorrega já se limpa bem de todas as manchas da terra que marcam a raiz dos nossos vocábulos mais toscos e amorosos. Faltam-lhe a cor, a imagem e o ritmo que são sinais psicológicos de toda a linguagem brasileira identificando o homem cheio de rumor primitivo em ligação com a natureza tropical. Sobram-lhe harmonia, polidez, segunda intenção: falta-lhe a seiva gostosa do sentimento. Substituiu ele a desconfiança pela dúvida, pelo ceticismo. A dor brasileira é substituída , também, nos seus livros, por um dor intelectual sem calor humano e sem sangue ${ }^{313}$.
\end{abstract}

Se Machado de Assis, apegado a “abstrações” e a modelos importados, não refletiria na língua em que escrevia a “marca psicológica, telúrica, bio-democrática de seu meio”, fugindo assim ao "compromisso de sangue" para com a pátria, outra teria sido a atitude de Euclides da Cunha. Por oposição, Cassiano Ricardo enfatiza que este pensava "brasileiramente”, pois teria deixado de lado o "cosmopolitismo dissolvente”, presente nas obras daquele, em proveito da representação de algo novo, a "força original da terra". Ao particularizar seu argumento, o poeta modernista ressalta ainda a perspectiva sociológica empregada pelo autor de Os sertões, bem como a postura nacionalista dele, que, enquanto escritor, não renegara sua missão, mas, pelo contrário, ter-lhe-ia encarado sem vacilações, ao deslocar-se ao interior do país e ao eleger tal espaço como tema preferencial de suas obras:

\footnotetext{
O estudo do homem brasileiro, tema predileto da campanha nacionalista, ele [Euclides] o tinha realizado a golpes geniais de desbravador, ao fixar as populações sertanejas e o que elas significam para a formação da nacionalidade. Coube-lhe a glória decisiva de chamar a atenção dos nossos estadista e sociólogos-políticos para um material humano que não teria sido aproveitado, nem compreendido sequer. Chamou ele, contra semelhante injustiça, retratando o drama de Canudos como "crime coletivo de uma civilização incapaz", como diria Afrânio Peixoto ${ }^{314}$.
}

Retomando a conceituação da prosa machadiana por um viés negativo, mas comparando-a agora, com a linguagem empregada por Euclides, Cassiano Ricardo atribui à primeira certa obliqüidade e dissimulação e à segunda, em sentido oposto, transparência e clareza, como se neste último caso, ela perdesse seu estatuto de signo e passasse a tratar das coisas

\footnotetext{
${ }^{313}$ RICARDO, Cassiano. Marcha para Oeste. Rio de Janeiro: Livraria José Olympio Editora, 1940, p.549.

${ }^{314}$ Idem, ibidem.
} 
propriamente ditas. Nesse sentido, enquanto o estilo "falso" de Machado seria imitável, o mesmo não ocorreria com a arte "brutal” de Euclides:

\footnotetext{
Para imitar Euclides é preciso que o imitador use de meios “confessáveis”, porque visíveis. Para imitar Machado de Assis bastará um pouco de perfídia, de finura intelectual. A meia sombra é o melhor disfarce e a segunda intenção é um processo de ambigüidade indispensável ao imitador dotado daquela sagacidade sorridente para as meias tintas, para as atitudes neutras e para os torneios de composição clássica. (...) A claridade do nosso linguajar típico e ensolarado é substituída pela clareza de uma pseudo-lógica, que é a das idéias claras. A arte de Machado admite o mimetismo; instiga a qualidade que desfrutam alguns imitadores, por certo amáveis, de se adaptar ao ambiente, sob o pretexto de adotar um modelo ilustre. A de Euclides é claridade e violência. Quem o imitasse seria ridículo. Teria que agir no claro e não na sombra, confessando-se imitador ${ }^{315}$.
}

Assim, se Machado escondia-se "por de trás das palavras”, valendo-se de uma linguagem dotada de uma série de artifícios retóricos, que o distanciavam do seu dever "para com o seu meio e para com a sua gente”, Euclides, supostamente, não se apegaria a modelos, expondo de maneira "clara” e "sem intermediários” seus posicionamentos em relação aos problemas brasileiros. Paralelamente a tais colocações, Ricardo destaca ainda que este último obtinha destaque não só por privilegiar temas nacionais, mas também por operar com maestria certo protocolo testemunhal de base científica, no qual se destaca a força e a inteligibilidade da linguagem empregada. Para o autor de Macha para Oeste, os posicionamentos euclidianos seriam evidentes e visceralmente conectados às raízes do país. Segundo sua perspectiva, enquanto Machado procurava atingir o universal a partir de uma concepção internacionalista e cosmopolita, ou seja, por meio da cópia da cópia de modelos, o autor de Os sertões alcançava esse objetivo tornando-se o mais brasileiro possível, ao lidar "diretamente” com a temática regional sem deformações ou obscuridades.

Tendo em vista tais posicionamentos, pode-se estabelecer uma aproximação entre o que Cassiano Ricardo diz sobre os dois escritores abordados até aqui e o conceito de mimesis, exposto por Platão no décimo livro da República. Neste trecho, o filósofo grego destaca que todas as coisas do mundo seriam signos derivados de uma emanação divina superior. Tal perspectiva tacha a poesia como essencialmente falsa, definindo-a como uma cópia da cópia. Considera que ela estaria mais distante da idéia primeira de verdade do que um simples objeto palpável. Por exemplo, uma cama representada num texto poético, já seria uma reprodução do

${ }^{315}$ Idem, p.550. 
conceito de cama colocada em prática por um marceneiro ${ }^{316}$. Nesse sentido, para Cassiano Ricardo, enquanto Machado se aproximaria do literato que realizaria imitações de imitações, Euclides seria uma espécie de artesão (artífice), pois trabalharia de maneira mais próxima e imediata com os materiais que se punha a representar. Em outras palavras, se o primeiro lidava apenas com modelos literários importados, o segundo travava um suposto contato “direto” com “espírito da nação”, sendo capaz de manter-se mais fiel à essência deste.

Em certo sentido, ao colocar os dois artistas como antípodas, o poeta de Martin Cererê apresentava, analogamente, uma nacionalidade cindida entre litoral e sertão ${ }^{317}$. Machado, sinônimo de falsidade e artificialismo, representaria o primeiro espaço; Euclides, considerado o reanimador da “força original da terra", metonimicamente, seria tomado pelo próprio interior do país. Ao mesmo tempo, o contraste entre os dois escritores correspondia à oposição entre dois saberes, respectivamente, literatura e sociologia. De acordo com uma categorização estanque e enviesada, entendia-se que Machado mantinha-se preso ao universo literário e Euclides, por outro lado, privilegiava o exame “objetivo" do meio e do homem brasileiros. Assim, num contexto de valorização do cientificismo, no qual a literatura deveria se voltar para a construção da brasilidade, o romancista de Quincas Borba deveria ser rebaixado, pois negligenciava as raízes rurais do país e adotava um estilo avesso ao "sentimento mais profundo de simpatia humana, de amor à terra, à sua paisagem e à sua gente”318; ao passo que o autor de Os sertões se mostrava conectado com uma suposta essência da brasilidade, ao particularizar temas de caráter regional e não urbano.

Como visto anteriormente, para Graciliano o sertão apresentava estatuto semelhante. De acordo com sua concepção de verossimilhança artística, a atitude de deixar de lado a temática sertaneja, mais especificamente as mazelas do interior do país, para tratar de "sutilezas e

\footnotetext{
316 PLATÃO. A República. Tradução de Maria Helena da Rocha Pereira. Lisboa: Fundação Calouste Gulbenkian, 1990.

${ }^{317}$ Curiosamente, em "Notícia da atual literatura brasileira - instinto de nacionalidade", artigo de 1873, o próprio Machado reconhecia a oposição geográfica entre litoral e sertão, marcante desde os primórdios da ocupação do solo brasileiro pelos colonizadores portugueses. Segundo ele, os romances de seu tempo não se furtavam a buscar a cor local - a representação da vida brasileira em seus diferentes aspectos e situações. Nesse sentido, faz referência às diferenças entre a descrição dos quadros e hábitos sertanejos e aqueles encontrados, sobretudo, na corte instalada no Rio de Janeiro: "Naturalmente os costumes do interior são os que conservam melhor a tradição nacional; os da capital do país, em parte, os de algumas cidades, muito mais chegados à influência européia, trazem já uma feição mista e ademanes diferente”(ASSIS, Machado de. Obras Completas, vol 3, Rio de Janeiro: Aguilar, 1994, p.804). Apesar de reconhecer tal situação, ponderando que nossa literatura nascente deveria alimentar-se dos assuntos regionais, o autor de Dom Casmurro não absolutiza tal ponto de vista, pois considera tal atitude empobrecedora.

${ }^{318}$ Idem, p.549.
} 
complicações” existentes no “cassino da Urca e nos banhos de Copacabana” correspondia ao artificialismo e ao desprezo pela "realidade” do país:

\begin{abstract}
Desapareceram os mocambos, os sobradões onde se alojavam trabalhadores e vagabundos, as cadeias sujas, as bagaceiras e os canaviais, as fábricas, os saveiros, a escola da vila. E a nossa literatura começou a comportar-se, na moral e na sintaxe, como as mulheres da Rua do Siriri. Baniu-se o palavrão, verdadeiro e bíblico. Afastou-se o negro. As personagens branquearam. E, timidamente, aproximam-se da Academia ${ }^{319}$.
\end{abstract}

Dessa maneira, os “deslizes” no plano do conteúdo correspondiam a inadequações no plano da expressão, já que o abandono das “coisas simples” da província corresponderia à utilização de uma linguagem e de uma sintaxe adequadas à moral dos espaços urbanos do litoral. Nesse sentido, o palavrão, índice de realidade anterior, teria sido abolido.

A sobrevalorização do espaço e do homem sertanejos, como matérias preferenciais da literatura, torna a ficar clara em entrevista, dada por Graciliano, ao jornalista Homero Senna. Nela, o escritor alagoano, ao estabelecer constantes paralelos entre o fazer literário e sua história pessoal, ressalta que preferia viver no interior, pois ali "poderia entrar em contato íntimo com a terra e com o povo" ${ }^{320}$. E continua: "É, por exemplo, de onde vem a força de um José Lins do Rego, de uma Rachel de Queirós, de um Jorge Amado”321 . Ao mesmo tempo, recusa as grandes cidades. Seu alvo são as capitais nordestinas, vistas como lugares tomados por “mexericos”, “grupinhos”, “academiazinhas”, “institutos históricos”. Portanto, ele toma as instituições literárias, situadas nos espaços urbanos, como índices do artificialismo da vida em tais localidades, ao passo que o sertão, com toda a sua rusticidade, seria, por oposição, visceralmente "autêntico".

Voltando à Marcha para Oeste, os posicionamentos críticos de Cassiano acabavam reforçando certa perspectiva que reduzia o escritor ao homem, bem como subordinava a literatura à certa idéia de verdade testemunhal. Euclides da Cunha era valorizado, sobretudo, por ter saído da "torre de marfim”, deslocar-se até o interior do país e presenciar a batalha entre sertanejos e forças republicanas. Segundo tal orientação, Machado seguira caminho inverso: continuava distante da "realidade brasileira”, a um só tempo preso a vida da capital

\footnotetext{
${ }^{319}$ RAMOS, Graciliano. A decadência do romance brasileiro. Literatura, Rio de Janeiro, ano 1, n.1, set. 1946, p.23.

${ }^{320}$ SENNA, Homero. República das letras. Rio de Janeiro: Gráfica Olímpica Editora Ltda, 1968, p.188.

${ }^{321}$ Idem, ibidem.
} 
federal e alheio à missão atribuída aos escritores de compreender o drama brasileiro e intervir sobre ele.

Essa perspectiva de interpretação biográfica da obra de arte, recorrente nos textos críticos de Graciliano, era moeda corrente no discurso estadonovista. Um de seus maiores pólos de produção e divulgação era o suplemento “Autores e Livros”, do jornal A Manhã, comandado à época pelo acadêmico Múcio Leão. Tendo em vista a importância concedida pelo regime à literatura, no processo de construção e consolidação da identidade nacional, este caderno dominical procurava recontar a história das letras brasileiras a partir da celebração de uma galeria de vultos do passado, homens representativos das artes e do pensamento do país ${ }^{322}$. A cada número, uma figura era homenageada. Tal iniciativa incluía a publicação de textos e documentos de autoria desta, bem como artigos biobibliográficos sobre ela, escritos por nomes de destaque no meio intelectual. Entre os festejados, estavam José de Alencar, Machado de Assis, Aluísio Azevedo, Euclides da Cunha, Augusto dos Anjos, Visconde de Taunay, Joaquim Manuel de Macedo, Franklin Távora, Eduardo Prado, Jackson Figueiredo, além de outros autores.

Como indica Velloso, o próprio nome do suplemento já sinalizava para uma concepção de literatura fundada na premência do homem sobre a obra ${ }^{323}$. A justaposição das palavras “autores” e "livros”, com a precedência da primeira sobre a segunda, aponta para a idéia de que as histórias de vida dos escritores conferiam sentido a suas produções, pressupondo uma correspondência imediata entre umas e outras. Nesse sentido, os números eram introduzidos por uma seção intitulada “Notícia”, uma espécie de nota histórica, que procurava dar conta do perfil do literato enfocado, privilegiando dados sobre seu nascimento, morte, relações familiares, amizades, trajetória estudantil, entre outras informações. Em seguida, depois da apresentação de uma antologia de escritos da figura homenageada (nos mais variados gêneros - poesia, carta, ensaio, discurso etc.), ganhavam espaço textos de críticos. Estes, na sua grande

\footnotetext{
322 Como indica o próprio editor do suplemento, Múcio Leão, o plano que "Autores e Livros” adotou foi o de "uma história literária brasileira, organizada em duas partes: uma consistindo em uma antologia da obra de um determinado escritor; a outra, numa seleção crítica referente a este mesmo autor. Publicando semanalmente fascículos que em geral têm 16 páginas, mas que não raro chegam a ter 24 e até 32 páginas - damos por mês três ou quatro capítulos de nossa história literária, com uma amplitude que nenhum tratado sobre o assunto até agora teve" (RELAÇÃO dos artigos publicados até hoje. A Manhã, Rio de Janeiro, ano III, 27 jun. 1943, Autores e Livros, p.305).

${ }^{323}$ VELLOSO, Mônica Pimenta. Literatura como espelho da nação. Estudos Históricos, Rio de Janeiro, vol. 1, n.2, 1988, p.251.
} 
maioria, eram redigidos por companheiros de vida do artista, o que ressaltava o privilégio concedido à sociabilidade intelectual da qual ele participava.

Se levarmos em conta o extenso rol de homenageados, mais de oitenta ao todo, Euclides da Cunha foi o único autor a ser tema de duas edições, sendo que uma delas tratava, exclusivamente, do volume Os sertões. Na primeira, o escritor era apresentado, logo no texto introdutório, como aquele que, por uma "tácita eleição da alma nacional”, era o "gênio por excelência representativo da nossa terra, da nossa gente, das nossas altas e puras aspirações de heroísmo, de beleza e de verdade” ${ }^{\text {324 }}$. Já a segunda, dedicada à saga de Canudos, tinha sua especificidade justificada no fato de destinar-se à comemoração de "uma das obras máximas da cultura brasileira de todos os tempos - um livro que sem nenhum favor, representa um dos cimos do pensamento humano do século XX” ${ }^{325}$. Nesse sentido, ela seria um "símbolo da vida e da alma de nosso povo"326.

O tratamento conferido a Machado, em “Autores e Livros”, é de outra ordem. Para além da retórica laudatória habitual, o suplemento reunia artigos com questionamentos sobre a suposta falta de aderência do artista às suas origens pessoais e, coextensivamente, ao protocolo documental, reivindicado pelo Estado no processo de construção da nacionalidade. O fascículo dedicado ao escritor seria um dos únicos, em toda a coleção, a não trazer um relato biográfico introdutório. Referia-se a ele apenas como um "homem estranho, singular, misterioso e perturbador”327. Em certo sentido, este fato pode ser tomado como índice de uma aparente defasagem entre autor e obra, atribuída ao romancista pelos editores da publicação $^{328}$. A corroborar tal hipótese, os textos críticos, presentes no volume, procuravam

\footnotetext{
${ }^{324}$ NOTÍCIA sobre Euclides da Cunha. A Manhã, Rio de Janeiro, ano II, 16 ago. 1942, Autores e Livros, p.75.

${ }^{325}$ EXPLICAÇÃO do suplemento. A Manhã, Rio de Janeiro, ano II, 23 ago. 1942 Autores e Livros, p.81. Apesar de tratar especificamente de um livro, este número do suplemento procurava personificá-lo e traçar-lhe a "biografia", com destaque para o no texto "Biografia de Os Sertões", de Francisco Venâncio Filho (Idem, p.84).

${ }^{326}$ UMA HOMENAGEM a Euclides. A Manhã, Rio de Janeiro, ano I, n.7, 23 ago. 1942, Autores e Livros, p.97.

${ }^{327}$ MACHADO de Assis. A Manhã, Rio de Janeiro, ano II, 28 set. 1941 Autores e Livros, p.91.

${ }^{328}$ Em “A iconografia de Machado de Assis", também presente neste número de “Autores e Livros", Peregrino Júnior, na falta de materiais escritos que esclarecessem a trajetória do fundador da ABL, procurou reconstituirlhe a história pessoal por meio do exame imaginativo de uma coleção de imagens. Ancorado em dados extraídos da biologia, o crítico afirmava que o exame da "morfologia corporal" dos indivíduos, variante ao longo dos anos, poderia ser captada e estudada por meio das fotografias. Segundo o acadêmico, o exame delas permitiria recompor tanto a vida quanto a personalidade de uma pessoa. Por detrás de tal iniciativa fantasiosa, subjaz a importância conferida aos dados biográficos, como forma de compreender e justificar a sensibilidade do artista e, por sua vez, o significado de sua obra. Prosseguindo por tal caminho, Peregrino aponta que o sentido da "evolução" tanto física quanto espiritual do obscuro Machado seria o da progressiva aristocratização e braqueamento: "Todas as influências que estavam na raiz de sua vida - a cor, a pobreza, a feiúra - todas elas ele as domina, recalca e vence”. Sem rebaixar o romancista de Quincas Borba, o crítico destaca que a glória pessoal deste incluiu a superação de suas origens étnicas e sociais.
} 
ressaltar a suposta alienação de Machado tanto em relação aos problemas de seu tempo, quanto a sua própria história pessoal, posturas estas que redundariam numa dupla traição: à pátria e a si mesmo ${ }^{329}$.

José Lins do Rego é um deles. No texto “Um escritor sem raízes”, o romancista paraibano, apesar de realçar os dotes imaginativos de Machado, apresenta-o como um escritor aristocrático, desconectado de sua própria história, bem como das aspirações populares. Diante deste aparente problema, afirma que ele ocuparia um lugar à parte em nossas letras:

Machado de Assis ficará sempre à margem de nossa copiosa literatura. Não serviria nunca de modelo, se se quisesse tirar um retrato de seu povo, e mesmo da elite de sua gente. No entanto, há muito do Brasil em sua obra, da boa sociedade dos tempos do segundo império, daquela vida sem estrépitos, daquela mansa e deliciosa vida de família dos educados salões da corte. Mas tudo isto é visto por um inglês cheio do gênio da observação, que ficasse no Brasil pelo gosto de observar ${ }^{330}$.

Portanto, considera que Machado não poderia ser tomado como um exemplo a ser seguido em nosso universo literário, pois, além de realizar um retrato distorcido da vida nacional, orientara-se por uma perspectiva importada, de matriz inglesa. Nesse sentido, não só privilegiava o "artificialismo" da vida aristocrática, dos salões cariocas, como adotava modelos estranhos para tratar dessa temática. No entanto, além de observar falhas de ordem conteudística, tanto na eleição dos temas como na forma de abordá-los, José Lins destacava que o autor de Dom Casmurro fora ainda um martirizado prisioneiro dos mestres do vernáculo. Logo, contrapõe o alegado conservadorismo lingüístico do romancista à atitude "libertária” de Eça de Queirós. Aquele não tivera a coragem deste, “de por-se de encontro a todos os Castilhos que tomassem dores pela gramática”. "E violando a sua língua com a força de um fauno, Eça fecundou-a de uma boa porção de impurezas que fizeram um bem sem tamanho 'ao mui rico idioma de Camões',331.

\footnotetext{
${ }^{329}$ No que diz respeito aos questionamentos a Machado, estampados em "Autores e Livros", as principais exceções, entre os articulistas que não foram contemporâneos do escritor, são Monteiro Lobato e Astrogildo Pereira. Ambos destacavam o valor do romancista, preterindo argumentos que o acusavam de não-assumir sua própria biografia e a representação do país. O primeiro destacava que ele teria se voltado contra a "superidiotia" do patriotismo então vigente. Já o segundo colocava-o não só como o mais universal de nossos escritores, mas também como o mais nacional, pois julgava que estas categorias estavam intimamente vinculadas.

${ }^{330}$ REGO. José Lins. Um escritor sem raízes. A Manhã, Rio de Janeiro, ano II, 28 set. 1941 Autores e Livros, p.99.

${ }^{331}$ Idem, ibidem.
} 
Os supostos isolamento e absenteísmo de Machado de Assis foram também referidos com outras cores ao longo da publicação. Barbosa Lima Sobrinho, num texto de caráter predominantemente apologético, não deixou de expor tais restrições ao tratar, não da obra, mas do próprio autor que estampava seu nome na capa dos livros:

\begin{abstract}
Toda vez que o mundo lá fora é tumultuoso e violento, ele pega em si mesmo e mete-se no cantinho do gabinete de trabalho, entre os livros de sua afeição. Em todo o vigor de sua juventude, pode ter os olhos fechados para a Guerra do Paraguai; a abolição, que desvairou toda a gente, encontra a sua alma resguardada dos furacões, com que ela atravessou o país de Norte a Sul (...) O 15 de novembro também não o interessou. A epopéia dos jagunços, que havia de arrancar de Euclides uma sinfonia wagneriana, não consegue, nos registros de A Semana, mais que algumas observações irônicas, amesquinhadoras da tragédia sertaneja ${ }^{332}$.
\end{abstract}

Para o articulista, o fundador da ABL viveria numa espécie de "região de neves perpétuas”, onde se encontrava a "suprema inteligência". Deste ponto alvo, gélido e afastado, o romancista, examinaria com "exatidão e impessoalidade” o "torvelinho humano”, sem se entregar às paixões de seu tempo. Com outros propósitos, Sobrinho retoma aqui a oposição entre Euclides da Cunha e Machado, exposta anteriormente por Cassiano Ricardo: enquanto o primeiro se deslocara até o campo de batalha sertanejo e compusera uma verdadeira "sinfonia wagneriana”, a partir dos acontecimentos ali vivenciados, o segundo preferia colocar-se como uma espécie de retratista, minucioso e sutil, das “contradições da alma humana”, preterindo “paisagens, descrições e até mesmo ambientes em suas obras”333.

Em artigo presente no mesmo número de “Autores e Livros”, Jorge de Lima lamenta o fato de Machado nunca ter saído da "penumbra em que vivia”, ocultando obstinadamente suas origens raciais. “A humildade de sua filiação de certo traria o mais surpreendente realce, se ele o confessasse, à glória que o escritor já tinha em vida. Recalcou o pitoresco destas origens coloridas com o sangue que nunca desejou expor como ornato ao seu renome» ${ }^{\text {334 }}$. Além disso, se tivesse realizado a biografia de sua infância, poderia ter escrito as "melhores páginas de nossa literatura sobre o assunto”, de modo semelhante ao que fizera Marcel Proust.

\footnotetext{
${ }^{332}$ LIMA SOBRINHO, Barbosa. Na região das neves perpétuas, A Manhã, Rio de Janeiro, ano II, 28 set. 1941 Autores e Livros, p.106.

333 Idem, ibidem.

${ }^{334}$ LIMA, Jorge, A propósito de Machado de Assis. A Manhã, Rio de Janeiro, ano II, 28 set. 1941 Autores e Livros, p.98.
} 
Aurélio Buarque de Holanda é menos condescendente com este comportamento machadiano. Em artigo saído na Revista do Brasil, no qual analisa detidamente o estilo e a linguagem do escritor, o crítico pontua:

\begin{abstract}
O espírito brasileiro, o instinto de nacionalidade - para usar de expressão sua - não era bastante vivo em Machado, em tão alto grau como se afigura a alguns dos seus críticos. Não o era por condições resultantes do próprio temperamento do escritor: Faltava-lhe, para tanto, como já se observou, um sentimento mais profundo de simpatia humana, de amor à terra, à sua paisagem e à sua gente, mais força de poesia e impulso mais forte de solidariedade com o povo humilde, de onde se originou ${ }^{335}$.
\end{abstract}

Apesar de valorizar a maestria da escrita de Machado, (romancista, segundo ele, capaz de conciliar harmonicamente as atribuições de escritor e gramático na composição de suas obras), Holanda atenta para a frieza e artificialidade das produções deste. Sem expandir sua argumentação, o crítico sugere que uma leitura contrastiva da obra do escritor das Memórias Póstumas com a de Manuel Antônio de Almeida e de Lima Barreto seria capaz de confirmar a veracidade de seu argumento, ao pressupor mais vida e espontaneidade nos livros destes últimos, no que dizia respeito à representação de cenas da vida carioca.

Em crônica de 1939, estampada no Diário de Notícias, Mário de Andrade afirmava que Machado seria um escritor digno de culto, tendo em vista sua obra magistral, mas não de amor. O crítico encontrava as justificativas para tal restrição no fato de faltarem ao artista das Memórias Póstumas “dons de generosidade, a confiança na vida e no homem, a esperança”. No entanto, a distância que o separava do romancista carioca não seria apenas afetiva, mas também intelectual, sobretudo, quando levava em conta dados da trajetória do homem Machado:

\begin{abstract}
Venceu as próprias origens, venceu a língua, venceu as tendências gerais da nacionalidade, venceu o mestiço. É certo que para tantas vitórias, ele traiu bastante a sua e a nossa realidade. Foi o anti-mulato, no conceito que então se fazia do mulatismo. Foi intelectualmente o anti-proletário, no sentido em que principalmente hoje concebemos o intelectual. Uma ausência de si mesmo, um meticuloso ocultamento de tudo quanto podia ocultar conscientemente. E na vitória contra isso tudo, Machado de Assis se fez o mais perfeito exemplo de “arianização” e de civilização da nossa gente. Na língua. No estilo. E na sua concepção estético-filosófica escolhendo o tipo literário inglês ${ }^{336}$.
\end{abstract}

\footnotetext{
335 HOLANDA, Aurélio Buarque de. Linguagem e estilo de Machado de Assis. Revista do Brasil, Rio de Janeiro, $3^{\text {a }}$ fase, ano II, n.13, p.55.

${ }^{336}$ ANDRADE, Mário. Aspectos da literatura brasileira. Belo Horizonte: Itatiaia, 2002, p.124.
} 
Mário lia a obra e a biografia de Machado segundo o protocolo do realismo nacionalista de matriz modernista, o qual tomava para si a missão de conferir uma "alma” ao país e recusava, de certa maneira, absenteísmos individualistas. Nesse sentido, o autor de Quincas Borba, aos olhos do crítico, não poderia ser tomado como um ser representativo do "Homo brasileiro", pois teria renegado sua classe, sua cor e adotado modelos importados para representar o país, ou seja, fora infiel tanto a si mesmo como a sua pátria. Só não naufragara totalmente, velejando por águas tão turvas e perigosas, em virtude de sua genialidade, produzindo, apesar de tudo, um rol "obras-primas de caráter acadêmico"337.

O tratamento dispensado a Machado de Assis em Cultura Política não se mostrou diferente daquele observado até aqui. Em editorial “A ordem política e a evolução intelectual”, presente na subseção “Evolução Intelectual”, o suposto absenteísmo do escritor é utilizado para exemplificar a separação que existia entre atividades políticas e intelectuais antes de 1930 (tal como o Estado Novo gostava de enfatizar e Getúlio já fizera referência em seu discurso de posse na $\mathrm{ABL})$ :

\footnotetext{
Machado de Assis, a acreditarmos no depoimento de seus biógrafos e críticos, fazia questão de proclamar-se indiferente aos interesses políticos de sua terra. E, realmente, em toda a sua obra considerável, em quantidade e qualidade não há a menor referência expressa, direta encontrável em tantos autores de seu tempo) à sociedade que descrevia, considerada como um derivado político da época ${ }^{338}$.
}

Não por acaso, os textos do autor de Dom Casmurro, em nenhum momento, estiveram presentes na seção "Páginas do passado brasileiro”. Este segmento da publicação, a partir da seleção de trechos de romances de época, crônicas e livros de memória, pretendia fazer uma espécie de inventário do cotidiano do país ao longo da história. Seu objetivo, portanto, era o de conectar a vida social do presente estadonovista ao ritmo secular das tradições nacionais que vinham desde o período colonial. São abordadas práticas religiosas, artísticas, econômicas, costumes, lendas, mitos entre outros elementos que procuravam recompor vivências tanto do campo como da cidade.

No texto de introdução desta parte da revista, os editores anunciavam:

\footnotetext{
${ }^{337}$ Idem, p.127.

${ }^{338}$ A ORDEM política e a evolução intelectual. Cultura Política, Rio de Janeiro, ano 1, n.1, mar. 1941, p.250.
} 
O Brasil de ontem - da Colônia, do Império, da Primeira República, deve conservar-se bem vivo em nossa memória. Não podemos, nem devemos nos desligar dele. Porque só ele explicara o que somos hoje e o que seremos amanhã. - Páginas escolhidas de escritores de ontem, brasileiros ou estrangeiros que viram e amaram o Brasil - serão o conteúdo desta seção Elas nos reconduzirão, através de testemunhos autênticos, ao que há de mais vivo e de mais puro em nosso passado social ${ }^{339}$.

Entre os autores presentes em “Páginas do passado brasileiro” estão os cronistas França Júnior e João do Rio, além de romancistas, ensaístas e memorialistas, tais como Manuel Antônio de Almeida, Raul Pompéia, Alcântara Machado, Afonso Arinos, Eduardo Prado, Joaquim Nabuco, entre outros. Subentende-se, dessa maneira, que Machado não seria uma das opções nessa empreitada de retomar e conferir sentido à vida pregressa da nacionalidade, a partir da perspectiva vencedora do governo autoritário.

Da mesma forma que não figurava em "Páginas do passado brasileiro", Machado não se encontrava também entre os escritores tematizados pela seção "Intérpretes da vida social brasileira”. Em consonância com a primeira, esta tinha como objetivo reconectar passado e presente, mas ao invés de privilegiar costumes e tradições, voltava-se para o estudo das biografias de brasileiros ilustres, os quais teriam procurado examinar e traduzir o imutável “espírito nacional”. De certa maneira, eles resumiam em si as qualidade e atribuições dessa entidade abstrata. O escolhido para o primeiro número é Manuel Antônio de Almeida, pois num contexto dominado pela literatura romântica e sentimental, ele teria se voltado para "nossa vida social”, procurando "fixar tipos e quadros de costumes, pintar o ambiente brasileiro do seu tempo, com sinceridade e realismo"340.

Graciliano Ramos vale-se de argumentos semelhantes aos empregados por seus companheiros de geração José Lins do Rego, Jorge de Lima, Aurélio Buarque de Holanda, pelo modernista Mário de Andrade, bem como pelos intelectuais e publicações do regime, para questionar o

\footnotetext{
${ }^{339}$ PÁGINAS do passado brasileiro. Cultura Política, Rio de Janeiro, ano 1, n.1, mar. 1941, p.245.

${ }^{340}$ INTÉRPRETES da vida social brasileira. Cultura Política, Rio de Janeiro, ano 1, n.1, mar. 1941, p.242. Se Machado era preterido pela publicação, já o autor de Os sertões fora objeto de uma série de textos, intitulada "Euclides - o estilizador de nossa história”, que se estendera por quatro volumes. De autoria de Ataíde Miranda, os artigos procuravam ressaltar o papel do escritor na construção de uma nova forma de pensar e sentir o país, pautada não por doutrinas importadas, mas pela "pressão dos dados objetivos". Ao mesmo tempo, ele era apresentado como um sujeito predestinado: "Sua participação na marcha contra o sertão amotinado tinha, como se vê, o sentido de um chamamento do Destino, - que é afinal, uma coincidência entre a missão de um povo e a missão de um homem. Euclides não era um simples cidadão...” (MIRANDA, Ataíde. Euclides - o estilizador de nossa história. Cultura Política, Rio de Janeiro, ano IV, n.42, jul. 1944). Por reunir tais atributos, consubstancializados em sua obra, ele teria dado o primeiro passo na elaboração de um estilo "autenticamente" nacional.
} 
lugar de Machado de Assis nas letras nacionais. Perguntado se o considerava um caso de genialidade, em entrevista concedida ao periódico Dom Casmurro, o escritor alagoano renega enfaticamente:

\footnotetext{
Certamente que não. Justifica-se esse meu ponto de vista por uma questão de educação literária, quando não fosse por um imperativo do temperamento. Meu espírito se formou numa ambiência de riso claro e vivo, como o de Anatole France. Ademais, o que mais me distancia de Machado de Assis é o seu modo de definir-se, a ausência completa da coragem de uma atitude. O escritor tem o dever de refletir a sua época e iluminá-la ao mesmo tempo. Machado de Assis não foi assim. Trabalhando a língua como nenhum, poderia ter feito uma obra transitável às idéias.
}

Pela perspectiva expressa por Graciliano, a “transitabilidade às idéias” de uma obra literária dependia não só da eficiência técnica no “manejo da língua”, mas, sobretudo, do próprio caráter do sujeito que estampava o nome na capa de um livro. Nesse sentido, para o autor de Angústia, o ethos do homem de letras não seria apreendido intradiscursivamente, mas a partir dos posicionamentos manifestos por ele sobre as questões da época em que vivera. E não apenas isso. Segundo o romancista alagoano, era preciso que o escritor não só refletisse seu momento presente, mas o iluminasse, ou seja, atuasse de forma direta sobre ele, como agente transformador, na construção de um outro devir.

Levando em conta tais orientações, discorda da maioria dos homens cultos do país e afirma não amar Machado de Assis. Se Alencar pecava pelo “excesso imaginativo”, na construção de um Brasil mítico, este, além de absenteísta, desprovido de “coragem” para tomar uma atitude frente aos problemas nacionais, não apresentava o "riso claro e vivo" de Anatole France. Mediante a tal citação, Graciliano se refere criticamente à obliqüidade e à dissimulação, características da prosa machadiana, de modo semelhante ao que fizera Cassiano Ricardo. Além disso, a utilização do nome do escritor francês serve para reforçar, por meio do contraste estabelecido, a suposta distância entre o autor de Dom Casmurro e os assuntos nacionais. Como se sabe, o romancista de O crime de Sylvestre Bonnard colocara-se ao lado de Émile Zola na defesa do capitão Dreyfuss, bem como, logo depois, aderira à esquerda socialista $^{341}$.

${ }^{341}$ CHASTENET, Jacques. Vida e obra de Anatole France. In: FRANCE, Anatole. O crime de Sylvestre Bonnard. Tradução de Álvaro Moreyra. Rio de Janeiro: Editora Delta, 1963. 
Paralelamente a tais restrições à figura de Machado de Assis, Graciliano também rejeita a tentativa de transformá-lo em símbolo nacional por parte da intelectualidade. Na crônica "Os amigos de Machado de Assis”, escrita em 1939, ano no qual se comemorara o centenário de nascimento do fundador da ABL, Graciliano se indispõe contra aqueles que tornavam o romancista carioca em objeto de culto:

\begin{abstract}
Nas homenagens que hoje tributam a Machado de Assis há com certeza, junto à admiração dos que o leram cuidadosamente, muito de respeito supersticioso, respeito devido às coisas ignoradas. Visto à distância, desumanizado, o velho mestre se torna um símbolo, uma espécie de mito nacional. Com estátuas e placas nas ruas, citado a torto e a direito, passará definitivamente à categoria dos santos e heróis $^{342}$.
\end{abstract}

Antes que parte da crítica impusesse a genialidade de Machado como um dado incontestável, tal como um dogma, o escritor alagoano reivindicava a necessidade de “humanizá-lo”, ou seja, de interpretar criticamente tanto sua obra como suas ações. Ao mesmo tempo, subjaz no discurso graciliânico, a parte sua postura sabidamente iconoclasta e materialista, de recusa generalizada à divinização de qualquer vulto pátrio, a censura ao nacionalismo estreito da crítica, que procurava, a todo custo e sem o devido exame, eleger aquele que seria o parâmetro e modelo maior da literatura brasileira, digno de exportação. Segundo ele, tal empreendimento, além de equivocado, seria um tanto quanto vazio, pois seu único objetivo seria o de infundir no povo a idéia abstrata de grandeza, da mesma forma que este precisava de “imagens para segurar as noções de justiça, bondade, santidade”343.

No caso de Euclides, as referências graciliânicas são menos explícitas. No texto "Uma viagem de bonde”, em meio a uma descrição de caráter expressionista, na qual determinados espaços da cidade do Rio de Janeiro aparecem mesclados a reminiscências e fatos contemporâneos à narração, o cronista faz menção, de passagem, ao autor de Os sertões:

\footnotetext{
Numa praça miúda, com folhas de papel na mão, José de Alencar está sentado em posição ridícula. Muito grande José de Alencar. Necessário melhorar-lhe a estátua. O Guarani, que poucos leram e todos admiram, há de tornar-se um livro fundamental, maior que Os sertões. Falta uma estátua de Euclides da Cunha: cidadão deste século ainda não amadureceu convenientemente ${ }^{344}$.
}

\footnotetext{
342 RAMOS, Graciliano. Os amigos de Machado de Assis, Revista do Brasil ( $3^{\circ}$ fase), ano II, n.12, Rio de Janeiro, jun. 1939. In: RAMOS, Graciliano. Linhas Tortas. Rio de Janeiro: Record, 2005, p.148.

343 Idem, p.151.

${ }^{344}$ Idem, p.359.
} 
Ressalta-se aqui o tom apologético: Euclides merecia uma estátua em sua homenagem. No entanto, isso ainda não teria acontecido, não pelo desprezo a sua obra "fundamental”, mas pelo fato de ele ter vivido no século $\mathrm{XX}^{345}$ e, de maneira diferente do oitocentista Alencar, encontrar-se mais próximo do momento de enunciação do qual fala o cronista. Paralelamente, percebem-se traços de ironia nessa passagem. Mais uma vez, Graciliano aparenta questionar a necessidade de se elegerem figuras representativas, como meio de afirmação das letras nacionais e como mostra de nossa projeção literária frente a outros países. Na sua opinião, quase sempre, este processo de endeusamento era feito sem o devido conhecimento da obra dos escritores glorificados, coisa que acontecia, de certa maneira, com Machado de Assis, como visto acima.

No artigo "Os avatares do naturalismo”, Bernucci estabelece o cotejo entre trechos de Vidas Secas e de Os sertões (mais especificamente do segundo capítulo da obra euclidiana) como forma de apontar coincidências temáticas, estilísticas e lingüísticas entre os dois livros. Segundo ele, se não fosse o conjunto de imitações textuais observadas nesse processo, não seria possível explicar a estima de Graciliano por Euclides ${ }^{346}$. Ao mesmo tempo, afirma que seria admissível que o primeiro impusesse restrições ao segundo, pois este teria narrado cenas não vistas, a partir de fontes livrescas, consultadas antes de sua ida ao arraial de Canudos. E, como se sabe, o autor de S.Bernardo destacava em seu discurso crítico que o "ver” importaria mais que o "inventar" 347 .

Apesar desta ressalva apontada pelo especialista, quando Graciliano apontava sua aversão "às combinações pacientes e caprichosas de vocábulos sonoros, infelizes quebra-cabeças do tempo em que um sujeito, sem nunca sair do Rio de Janeiro, descrevia sertões absolutamente desconhecidos”348, ele se referia não a Euclides, mas, sobretudo, a autores românticos. Para tanto, valia-se de postulados críticos semelhantes aos empregados por Franklin Távora, como abordado anteriormente.

\footnotetext{
${ }^{345}$ Euclides da Cunha morrera apenas em 1909.

${ }^{346}$ BERNUCCI, Leopoldo. Os avatares do naturalismo. In: Boulder: University of Colorado, 1995, p.106.

${ }^{347}$ Idem, p.107.

${ }^{348}$ RAMOS, Graciliano. op.cit. p.364. . A imitação dos sentidos. São Paulo: Edusp;
} 
De qualquer maneira, o questionamento à factibilidade das descrições do sertão apresentadas por Euclides, estavam presentes nas considerações dos autores nordestinos de 1930, entre eles José Lins do Rego:

\begin{abstract}
Euclides falara do homem "desengonçado e torto", de um homem feio e triste. Euclides tinha para tudo que via um olho de Goya. O seu sertanejo parecia um aleijão humano. Aqueles homens belos e elegantes de Koster, verdadeiros apolos que as gravuras do inglês nos legaram, através da página clássica dos Sertões se reduziam a um "hércules-quasímodo", “de andar sem firmeza e sem aprumo”, e sem “o desempeno, a estrutura corretíssima das organizações atléticas”. No fim, um monstro, refletindo a "a preguiça invencível”, a atonia muscular perene, em tudo: na palavra remorada, no gesto contrafeito, no andar desaprumado. Não era "possível idear cavaleiro mais chucro e deselegante”. Esse exagero de traços, essa deformação de linhas ganhara fama de retrato fiel. E, no entanto, este sertanejo de Euclides era mais uma ficção do gênio do criador, era mais o homem da imaginação do poeta que o homem verdadeiro dos nossos sertões nordestinos ${ }^{349}$.
\end{abstract}

Como contraponto, o autor de Doidinho vale-se de sua experiência pessoal para afirmar que a perspectiva euclidiana seria falsa. Ele relembra a figura de um cangaceiro do bando de Antonio Silvino, um sujeito loiro e bem aprumado, que conhecera anos atrás. Segundo o escritor, este tipo de “cavaleiro” seria mais comum no sertão, na lida com os bois, ao passo que o "hércules-quasímodo" de Euclides poderia ser encontrado com mais facilidade nas bagaceiras da Zona da Mata. Logo conclui que ao se valer do “olho de Goya” e não de sua própria visão, Euclides deformara a realidade e traçara um retrato infiel do homem dos rincões interioranos.

\title{
3.7. A crítica generalizada ao Modernismo
}

Se pairam dúvidas sobre os posicionamentos que Graciliano dispensou à figura e à obra de Euclides da Cunha, o mesmo não ocorre em relação ao Modernismo. Apesar de não apontar nomes, o escritor é muito mais explícito ao se referir ao movimento. E, via de regra, de maneira crítica. Em diversas ocasiões, voltou-se, sobretudo, contra a leitura do cânone proposta pelos artistas do grupo. Segundo o autor alagoano, tais literatos “cabotinos” passaram a condenar, de forma apressada e sem o devido exame, determinadas obras, simplesmente pelo fato de terem sido escritas em "português direito", promovendo a idéia de que sintaxe e bom gosto seriam incompatíveis. "Liberdade. Carta de alforria. Abaixo o

${ }^{349}$ REGO, José Lins. Eu não vi o sertanejo de Euclides. In: . Gordos e magros: ensaios. Rio de Janeiro: C.E.B., 1942, p.216-217. 
galego. Os direitos do homem. Caímos no exagero. Desejando libertar-nos reforçamos a dependência escrevendo regularmente contra as normas”350. Em entrevista a Homero Senna, Graciliano incluía no rol de censuras ao processo de reinterpretação do passado empreendido pelos modernistas a idéia de que eles teriam se valido de má-fé e desonestidade ao definirem, de maneira arbitrária e interessada, as obras e escritores nacionais que mereciam ser esquecidos:

\begin{abstract}
Os modernistas brasileiros, confundindo o ambiente literário do país com a Academia, traçaram linhas divisórias rígidas (mas arbitrárias) entre o bom e o mau. E, querendo destruir tudo que ficara para trás, condenaram, por ignorância ou safadeza, muita coisa que merecia ser salva. Vendo em Coelho Neto a encarnação da literatura brasileira - o que era um erro - fingiram esquecer tudo quanto havia antes, e nessa condenação maciça cometeram injustiças tremendas ${ }^{351}$.
\end{abstract}

Ao mesmo tempo em que Graciliano criticava as mutilações perpetradas pelo Modernismo auto-afirmativo e “intencional” dos anos de 1920, na releitura que este promovera da história literária do país, também descarregava sua artilharia contra as próprias produções dos artistas de 1922. Seu principal alvo são as inovações lingüísticas propostas por tais escritores. Para o autor de Caetés, as mudanças que eles procuraram “enxertar” na língua, tal como a colocação pronominal “as avessas”, não raro, estavam em desarmonia com a linguagem popular, invocada por eles mesmos, contraditoriamente, como “autoridade suprema"352 em qualquer discussão sobre a "realidade nacional”. Nesse sentido, considera que os modernistas teriam se afastado do país, pois “enquanto alguns procuravam estudar alguma coisa, ver, sentir, eles importavam Marinetti”353.

Em virtude de tal ruptura com a "imperiosa" cultura do povo, sobretudo, no que diz respeito à linguagem empregada no discurso artístico, Graciliano acrescentava que os modernistas pecavam pela falta de clareza. Para o escritor alagoano, as composições destes seriam marcadas por cacofonias e solecismos, os quais fariam com que os leitores precisassem adivinhar o sentido das construções, “como se decifrassem charadas”, tendo em vista a anfibologia decorrente da ruptura forçada com as normas. Esses procedimentos, assim como, anteriormente, o tratamento conferido ao cânone pelo Modernismo, são apontados como produtos do embuste e da perfídia de “indivíduos sagazes, de escrúpulos medianos” que

\footnotetext{
${ }^{350}$ Idem, p.388.

${ }^{351}$ SENNA, Homero. op.cit. p.185.

${ }^{352}$ RAMOS, Graciliano. op.cit. p.388.

353 SENNA, Homero. op.cit. p.184.
} 
resolveram ganhar notoriedade de forma rápida, “criando uma língua nova do pé para a mão, uma espécie de esperanto, com pronomes e infinito em greve, oposicionistas em demasia, e preposições no fim dos períodos”354. Em outras palavras, toma as novidades como “tapeações badaladas por moços dispostos a encoivarar duas dúzias de poemas em vinte e quatro horas e manufaturar romances com o vocabulário de um vendeiro”355. Nesse sentido, toma a Gramatiquinha da fala brasileira, anunciada por Mário de Andrade, como uma "frescura”, índice maior da artificialidade das propostas do grupo "revolucionário”.

Apesar de rebaixar as produções modernistas, Graciliano não deixava de reconhecer o papel destas na abertura de novos caminhos artísticos e na soltura das amarras que ainda prendiam a estagnada literatura nacional entre o final do século XIX e início do XX. Conforme explica Graciliano, o grande mérito do movimento de 1922 teria sido usar a picareta e espalhar o terror entre os antigos cultores da língua, deixando o terreno mais ou menos desobstruído para geração de 1930. Nesse sentido, reduz a importância do Modernismo apenas à condição de preparador de algo maior, que o sucederia:

Foi aí que de vários pontos surgiram desconhecidos que se afastavam dos preceitos rudimentares da nobre arte da escrita e, embreando-se pela sociologia e pela economia, lançavam no mercado, em horrorosas edições provincianas, romances causadores de enxaqueca ao mais tolerante dos gramáticos. Um escândalo. As produções de sintaxe presumivelmente correta encalharam. E as barbaridades foram aceitas, lidas, relidas, multiplicadas, traduzidas e aduladas. Estavam ali pedaços do Brasil - Pilar, a ladeira do Pelourinho, Fortaleza, Aracaju ${ }^{356}$.

Graciliano refere-se aqui, diretamente, à perspectiva sociológica do romance de 1930, que concedia privilégio à observação em detrimento da invenção no tratamento literário de “pedaços do Brasil”, matéria até então preterida pelos escritores pátrios. Para o artista alagoano, as produções anteriores à Semana de 1922 e à Revolução de Outubro, seriam marcadas pelo artificialismo e pelo academicismo estéril, decorrente da utilização de modelos importados e do desprezo pela "realidade” brasileira. Segundo Graciliano, nessa fase de “estagnação”, em que o país permanecia desconhecido, quem dava as cartas na literatura nacional eram “sujeitos pedantes” que

\footnotetext{
${ }^{354}$ RAMOS, Graciliano. op.cit. p.393.

355 Idem, p.395.

356 RAMOS, Graciliano. A decadência do romance brasileiro. Literatura, Rio de Janeiro, ano 1, n.1, set. 1946, p.20-21.
} 
alheavam-se dos fatos nacionais, satisfaziam-se com o artifício, a imitação, o brilho do plaquê. Escreviam numa língua estranha, importavam idéias, reduzidas. As novelas que apareceram no começo do século, medíocres, falsas, sumiram-se completamente. Uma delas Canaã, que obteve enorme êxito, dá engulhos, é pavorosa ${ }^{357}$.

O rebaixamento da figura de Graça Aranha, algo recorrente ao longo da produção cronística de Graciliano ${ }^{358}$, pode ser lido, aqui, como mais uma forma utilizada pelo escritor para alfinetar o Modernismo. Apesar de considerado, na maioria das vezes, como um romancista que apenas teria emprestado seu prestígio artístico aos jovens protagonistas da Semana de 1922, o autor de Canaã, ainda nos anos de 1940, era tido como um dos líderes do movimento e seu gesto de rompimento com a ABL apresentava um "significado muito maior do que hoje se atribui a ele" ${ }^{359}$. Nesse sentido, o ataque a tal literato, escolhido a dedo entre o conjunto de homens de letras que se "alheavam da matéria nacional” e praticavam um "academicismo estéril”, no início do século XX, não seria gratuito: servia para questionar as próprias raízes do grupo modernista e, em sentido oposto, ressaltar que o “novo” somente começara a ser produzido, de maneira efetiva, depois de 1930.

Em novembro de 1936, com o propósito de realizar um balanço do Modernismo, Tristão de Athayde organizou o quarto número da revista Lanterna Verde, publicação direitista vinculada a Sociedade Felippe d'Oliveira. De maneira geral, o volume foi marcado pela recusa ao movimento. No artigo que o fechava, o crítico, um dos mais influentes do país na primeira metade do século XX, chegava às seguintes conclusões: 1) o Modernismo não só existiu, mas viveu; 2) o Modernismo morreu; 3) a herança literária modernista foi maior em espírito que em obras; e 4) o Modernismo preparou o renascimento literário pós-modernista. Referindo-se ao segundo aspecto, Athayde estabelecia uma separação entre as produções feitas antes e depois de 1930:

\footnotetext{
A fase modernista não se confunde com a fase moderna de nossas letras. (...) O movimento modernista nasceu, no Brasil, durante a guerra européia, tendo em S. Paulo o seu quartel general; generalisou-se em 1925, com a adesão dos elementos cariocas e a Semana de Arte Moderna; dividiu-se em várias correntes, radicalmente separadas entre si, em convicções filosóficas, em idéias estéticas e em posições

${ }^{357}$ Idem, p.20.

${ }^{358}$ Na crônica “Chavões”, publicada em Novidade, em 1931, Graciliano se refere ao autor de Canaã em tom de deboche: “Ora vejam. Coberto de Glória, o sr. Graça Aranha resolve morrer, o que é uma perda irreparável para a sua excelentíssima família e para a Academia Brasileira de Letras”.

359 BUENO, Luís. Uma história do romance de 30. São Paulo: Editora da Universidade de São Paulo; Campinas: Editora da Unicamp, 2006, p.47.
} 
políticas e dissolveu-se espontaneamente por volta de 1930, quando o interesse nacional deslocou-se do terreno literário para o político e a literatura veio assumir uma feição inteiramente diversa da que vinha tendo no decênio anterior ${ }^{360}$.

Assim como Graciliano, o crítico carioca asseverava que o Modernismo ficara para trás, dando lugar a uma nova fase, muito mais viva e criadora, das letras nacionais. E eles não estavam sozinhos; postulações como esta encontravam grande acolhida e ressonância entre estudiosos e escritores de 1930. Conforme sublinha Bueno, nesse momento, repetia-se “à náusea” a idéia de que o movimento de 1922 tivera apenas um caráter destruidor e mostrarase "incapaz de construir o que quer que fosse”. O propósito geral destas afirmações era semelhante ao exposto pelo autor de Angústia: elevar os romancistas surgidos após a Revolução de Outubro, que figuravam como "verdadeiros construtores da arte nova, capazes de afrontar os preceitos da 'nobre arte da escrita',361.

Jorge Amado é um dos autores nordestinos que enfatizava o papel essencialmente crítico, mas “improdutivo" e "artificial” do Modernismo. Conforme destacava, a única utilidade do movimento de 1922 teria sido proporcionar certa libertação das fórmulas até então vigentes no cenário literário brasileiro, o que, por sua vez, teria preparado os leitores para as novidades surgidas depois de 1930. No mais, somente "tapeações”, sobretudo, no que dizia respeito à língua e ao estilo empregados, quando não a simples "paralisia”:

O Modernismo sempre me dá essa impressão: um grupo de fortíssimos gigantes, empunhado picaretas, afiados facões, pás, o diabo, para destruir uma casa de papelão. Destruíram-na a cusparadas, cruzaram os braços, ficaram preocupadíssimos porque não tinham mais nada que fazer ${ }^{362}$.

Como justificativa para o caráter não-fecundo do Modernismo, o autor de Jubiabá afirmava que os artistas vinculados ao movimento eram brutalmente inconformistas quanto à forma, mas inteiramente conformistas quanto ao conteúdo, o que os teria impedido de produzir “obras de criação”, nas quais, segundo ele, este último aspecto seria fundamental. Desdobrando seu raciocínio, Jorge Amado encontrava explicação para tal estado de coisas na filiação dos artistas de 1922 à aristocracia cafeeira. Para ele a rebelião literária modernista correspondeu à criação de novas fórmulas artísticas, adequadas aos princípios da alta

\footnotetext{
${ }^{360}$ ATHAYDE, Tristão de. Síntese. Lanterna Verde, Rio de Janeiro, n.4, nov. 1936, p.89.

${ }^{361}$ BUENO, Luís. op.cit, p.47-48.

${ }^{362}$ AMADO, Jorge. Resposta de Jorge Amado. Revista do Brasil, Rio de Janeiro, ano III, $3^{\text {a }}$ fase, n.22, abr. 1940, p.109.
} 
burguesia paulista, enriquecida com o café. “Os seus grandes nomes não passavam, de certa maneira, de palhaços para uma claque refinada e esnobe”363.

Ao mesmo tempo em que rebaixava o Modernismo, Jorge Amado ressaltava a influência “brutal” dos acontecimentos políticos do decênio de 1930 sobre a literatura brasileira. Para ele, do bojo da Revolução de Outubro não teriam saído apenas transformações na administração do país, mas sim os novos ensaístas e romancistas do Brasil ${ }^{364}$. Nesse cenário, o interesse pelos problemas nacionais teria saltado para o primeiro plano, paralelamente ao enfraquecimento das influências estrangeiras, ainda determinantes no movimento de 1922.

Tal interpretação do Modernismo, recorrente no cenário intelectual brasileiro ao longo dos anos de 1930 e 1940, também foi a adotada pelo Estado Novo ${ }^{365}$. Assim como Graciliano atribuía ao movimento apenas o papel de libertador das “cadeias do espírito” e de preparador do terreno paras as gerações vindouras, o regime tomava a Semana de 1922 como marco inicial de um processo de recuperação da brasilidade e de despertar da literatura para uma “vida nova”, que somente seria concretizado pela Revolução de Outubro. O próprio Getúlio Vargas, em discurso pronunciado na Universidade do Brasil, em 28 de julho de 1951, estabelece tal relação de continuidade, na qual as propostas modernistas valeriam tão somente enquanto prenunciadoras das conquistas a serem efetivadas pelo governo:

As forças coletivas que provocaram o movimento revolucionário do Modernismo na literatura brasileira, que se iniciou com a Semana da Arte Moderna de 1922, em São Paulo, foram as mesmas que precipitaram, no campo social e político, a Revolução de 1930. A inquietação brasileira, fatigada do velho regime e das velhas fórmulas, que a rotina transformaram em lugar-comum, buscava algo de

\footnotetext{
${ }^{363}$ Idem, ibidem.

${ }^{364}$ Idem, ibidem.

365 De maneira geral, tanto para direita quanto para a esquerda, o período em questão configurava-se como um momento de recusa ao Modernismo. Como se sabe, em julho de 1937, o regime nazista organizou, em Munique (e depois em mais treze cidades alemãs), uma exposição de "arte degenerada”, rótulo que compreendia a produção artística dita de vanguarda, produzida, sobretudo, desde o início do século XX. Ao colocar as obras de artistas modernos lado a lado a trabalhos feitos por internos de manicômios, o objetivo do evento era mostrar que a arte vanguardista, ao invés de exaltar a grandiosidade do povo, pelo contrário, mostrava o caráter doentio e degenerativo do mesmo, e por isso precisava ser expurgada pelo Estado (GAY, Peter. Modernism: the lure of heresy. New York: W.W. Norton, 2008, p.423). Em sentido oposto, o governo hitlerista valorizava os padrões de beleza clássicos da Antiguidade e do Renascimento, mais adequados, segundo a retórica oficial, a representar a “supremacia da raça ariana” (BORTULUCCE, Vanessa Beatriz. A arte dos regimes totalitários do século XX: Rússia e Alemanha. São Paulo: Annablume; Fapesp. 2008, p.66). Na União Soviética stalinista, por sua vez, após o Congresso de Escritores de 1934, o realismo socialista impôs-se como doutrina oficial a reger todas as manifestações culturais. Como pregava o engajamento da arte na educação dos trabalhadores e na representação de uma realidade monolítica, tutelada pelo governo, tal perspectiva entrou em rota de colisão com a pluralidade da arte vanguardista e acabou por eliminá-la da URSS (Idem, p.94).
} 
novo, sinceramente nosso, mas visceralmente brasileiro. Por outro lado, a revolução econômica do mundo, o progresso técnico industrial, a ascensão do proletariado urbano como força ponderável na decisão dos fatos políticos estavam a exigir nova estruturação da sociedade e novas leis, capazes de atender com eficiências a essas necessidades ${ }^{366}$.

Ao eleger tais marcos temporais como representativos e depois concatená-los numa seqüência linear (e aparentemente irreversível), o presidente construía uma relação necessária entre momentos distintos a partir de uma perspectiva teleológica e legitmadora. Nesse processo de construção de inteligibilidade, o Modernismo perdia sua autonomia e força, passando a ser visto apenas como iniciativa inacabada e incompleta, que viria a ser concretizada posteriormente, em etapas distintas, durante a permanência de Vargas no poder. A partir de 1930, o chefe da nação faz referência a uma suposta convergência entre as iniciativas literárias e políticas, na qual o potencial destrutivo dos revoltosos da Semana de Arte Moderna teria sido limado em prol de propostas mais construtivas e conciliatórias:

“... passados os primeiros instantes e obtidas as primeiras conquistas, um e outro se fundiram num movimento mais amplo, mais geral, mais completo, simultaneamente reformador e conservador, onde foram limitados excessos, polidos os extremos sempre cheios de asperezas e harmonizadas as tendências mais radicais e divergentes”367.

Para Vargas, política e cultura formavam um todo inseparável e interdependente. Partindo de tal premissa, o presidente procurava tanto explicar como justificar o "magnífico surto nas letras brasileiras" durante a década de 1930, no qual "uma plêiade numerosa de valores novos trouxe a sua colaboração e entusiasmo criador e renovador a todos os departamentos da cultura”. Segundo o autor de A nova política do Brasil nunca a vida intelectual brasileira assistira a um período tão fértil e pujante, graças, sobretudo, a ação de seu governo que teria dispensado "simpatia, compreensão, apoio cotidiano, estímulo e liberdade" à cultura nacional $^{368}$. Portanto, ao se referir a produção artística feita depois de 1930, sua abordagem deixava de lado, voluntariamente, a censura praticada pelo Estado Novo. Ao mesmo tempo, concentrava-se em dados quantitativos, esquecendo-se também que grande parcela das obras lançadas no período obedecia a certo caráter pedagógico, condizente com as diretrizes da propaganda estatal. Esta, por sua vez, procurava controlar e enquadrar as versões possíveis e

\footnotetext{
${ }^{366}$ VARGAS, Getúlio. O governo trabalhista do Brasil. Rio de Janeiro: José Olympio, 1952, p.382.

${ }^{367}$ Idem, p.383.

${ }^{368}$ Idem, p.384.
} 
toleradas da "realidade” brasileira a serem veiculadas pelos diferentes discursos, cerceando o pluralismo das manifestações.

Tal perspectiva varguista que procurava estabelecer um elo de continuidade entre os marcos temporais de 1922 e 1930, transformados de simples datas em eventos acabados, bem como subordinar o primeiro momento ao segundo, já se encontrava presente nos textos dos diferentes ideólogos estadonovista. No livro Política e Letras, Rosário Fusco destacava que, se por um lado, o Modernismo teria imposto a necessidade de se conhecer a vida nacional, por outro, para atingir esse objetivo, o movimento valera-se de uma atitude excessivamente destrutiva e iconoclasta, voltando-se, de maneira imoderada, contra tudo aquilo considerado passadista e tradicional. Com a chegada de Getúlio ao Catete, tal postura desmedida e irrefletida fora corrigida e substituída por outra mais construtiva e pacificadora:

O fato é que, ajustados os quadros políticos aos quadros sociais, a construção começou também no campo das letras. E logo após a vitória do movimento revolucionário de 1930, passamos a constatar o seguinte fenômeno: assim como a revolução política progredia, em espírito, recriando a alma do país, que anima as cidades e os campos, a revolução literária prolongava-se num silencioso, mas seguro, processus de evolução $^{369}$.

Nesse sentido, o poeta de Cataguazes destaca que teria cabido à Revolução de Outubro a tarefa de garantir uma trégua na revolução literária iniciada em 1922. Conforme explica, a ação do Estado permitira que o país, enfim, reencontrasse seu caminho de equilíbrio, conscientização e valorização efetiva das matérias brasileiras, tanto em termos políticos quanto literários. Para Fusco, politicamente, o governo vitorioso procurara associar presente e passado num processo de "nacionalização de todas as nossas reservas"; e literariamente, valorizar a busca do universal a partir do regional. Portanto, segundo tal perspectiva, o Modernismo fora não só territorializado (com suas arestas devidamente aparadas) como também complementado pela obra de Getúlio.

Em inquérito sobre a produção literária brasileira, com destaque para o papel exercido pelo Modernismo, realizado pela Revista do Brasil, nos anos 1940, Almir de Andrade adotava posicionamento semelhante. Segundo ele, o movimento teria sido essencialmente crítico, pois objetivara fazer uma revisão de valores e libertar a literatura de velhos esquemas. Contudo,

\footnotetext{
${ }^{369}$ FUSCO, Rosário. Política e letras. Rio de Janeiro: Livraria José Olympio Editora, 1940, p.75.
} 
nada produzira de grande ou duradouro. Sua marca teria sido a agitação, a efemeridade e a preparação do terreno para os autores posteriores, estes sim passíveis de serem chamados de criadores, na sua opinião. O futuro diretor de Cultura Política faz uma analogia entre o mundo natural e o universo literário para explicar seu argumento:

\begin{abstract}
Na evolução das artes, como na evolução as espécies biológicas, há movimentos dessa natureza: surgem tão somente para preparar o terreno aos movimentos seguintes, morrendo eles próprios sem deixar descendentes. Não perduram; entretanto, seria difícil compreender o aparecimento de muitas tendências posteriores, sem o trabalho de desbravamento e preparação por eles efetuado ${ }^{370}$.
\end{abstract}

Apesar de reconhecer o papel crítico e desbravador do movimento, frente ao "torpor” e à “inconsciência” da literatura do início do século, sobretudo no que dizia respeito ao tratamento das matérias tidas como brasileiras, sua postura é essencialmente questionadora da influência e da permanência do “espírito modernista” nas obras produzidas depois de 1930:

\begin{abstract}
Nada mais falso do que julgar que o movimento modernista abriu uma era realmente nova em nossa literatura; nada mais artificial do que tomá-lo como marco divisório entre o presente e o passado. Do Modernismo surgiram muitas tendências novas; mas depois do Modernismo muitas outras tendências se estão formando em sentido contrário a ele, procurando reviver antigas tradições literárias ou se aproximando insensivelmente do equilíbrio e da disciplina dos modelos clássicos ${ }^{371}$.
\end{abstract}

Se retira do Modernismo qualquer influência determinante, a não ser deixar o caminho livre para os romancistas e poetas de 1930, Almir destaca que coube aos acontecimentos políticos, iniciados com a Revolução de Outubro, a maior ascendência sobre a cultura nacional. Segundo ele, a ação estatal teria conferido uma tendência mais humana e nacional à produção artística, com ênfase na recuperação de aspectos históricos e sociológicos da vida brasileira.

Com relação ao referido caráter inacabado do Modernismo, Wilson Lousada, responsável pela seção "Literatura de Ficção”, da revista Cultura Política, destacava que o movimento, obedecendo a certas circunstâncias dominantes no período posterior à Primeira Guerra Mundial, voltara-se para as tradições nacionais, em processo análogo ao realizado por outros povos naquele momento. Contudo, tratava-se de uma visada nacionalista imposta, sobretudo, pela conjuntura internacional, marcada ainda por um caráter "sentimental” e "livresco", que a

${ }^{370}$ ANDRADE, Almir de. Resposta de Almir de Andrade. Revista do Brasil, Rio de Janeiro, ano III, $3^{\text {a }}$ fase, n.22, abr. 1940, p.103.

${ }^{371}$ Idem, p.106. 
distanciava da dita "realidade” brasileira. Conforme explica o articulista, tal cenário mudaria após 1930, quando teria surgido, “espontaneamente”, outro nacionalismo mais “objetivo e realístico”, condizente com as propostas da Revolução de Outubro:

\begin{abstract}
Desta vez, é claro, influenciado por motivos de ordem interna, e bem mais nosso que o anterior, por isso que menos preso às escolas literárias estrangeiras, e menos intencional também. Surgiu espontaneamente, sem o ar de conspiração secreta tramada aos cochichos entre meia dúzia de escritores.
\end{abstract}

Foi para nós uma espécie de libertação espiritual sem os inconvenientes da que se realizou em 1922. Sem a necessidade imperiosa de escolher para acompanhar o ritmo exterior. Definimos nossa atitude perante nós mesmos, perante nossa consciência alertada e possivelmente justificada ${ }^{372}$.

Nesse sentido, o Modernismo brasileiro é rebaixado tanto por partilhar de modelos importados (em outro texto Lousada destaca que ele seria tributário do Modernismo francês e do pansexualismo de Freud $^{373}$ ), bem como por preterir uma abordagem sociológica e documental do país, a qual seria levada a termo, em contrapartida, pelos romances regionalistas de 1930. Portanto, o movimento de 1922 renegava aquilo que o autor chamava de "sensibilidade literária realista”, em favor de certas "aventuras freudianas e pagãs”, de experimentalismos “sem raízes profundas” e da ênfase no "esteticismo”. Segundo ele, ainda, os empreendimentos modernistas teriam realizado apenas uma incursão pela superfície da vida nacional, restringindo-se ao folclore e ao primitivismo, mas divorciando-se da terra e do povo.

Ao mesmo tempo, conforme ressalta Lousada, se o Modernismo fora mais "subjetivo, cerebral e literário”, a nova fase das letras nacionais, inaugurada pela Revolução de 1930, destacava-se pela objetividade e pelo privilégio concedido ao tratamento das matérias nacionais. Para o articulista, ela teria revelado aspectos da “evolução social” do país até então

\footnotetext{
${ }^{372}$ LOUSADA, Wilson. Literatura de Ficção (XVI). Cultura Política, Rio de Janeiro, n.16, jun. 1942, p.237.

${ }^{373}$ Tal referência a Freud já estava presente na crítica feita por Tristão de Athayde à rapsódia Macunaíma, de Mário de Andrade, quando do lançamento da obra em 1928: "Realmente, há em todo o livro mais que obscenidade, pornografia. Esse é um caráter conhecido de todas as lendas de primitivos. Na introdução aos mitos taulipangues e arecunas, Koch-Grünberg avisa logo que há algumas passagens tão obscenas que ele não as reproduz. O que deve fazer arregalar os olhos a todos os freudianos à cata de complexos... O sr. Mário de Andrade conservou em seu herói esse instintivismo, tão adaptado à mentalidade e às inclinações de nossos dias, em que os homens ingenuamente viraram - ‘a bengala com castão pra baixo e a ponta pra cima' - como dizia um orador de comício. / Conservando esse traço típico de um herói primitivo, viu nele o senhor Mário de Andrade um caráter bem brasileiro" [THAYDE, Tristão de (Alceu Amoroso Lima). Macunaíma. O Jornal, Rio de Janeiro, 9 set. 1928. In: RAMOS JÚNIOR, José de Paula. A fortuna crítica de Macunaíma: primeira onda (1928-1936). 2006. 2 v. Tese (Doutorado em Literatura Brasileira) - Faculdade de Filosofia Letras e Ciências Humanas, Universidade de São Paulo, 2006, v.2, p.16].
} 
desconhecidos, focando-se tanto no homem, como no ambiente pátrio, sem preterir os problemas tipicamente brasileiros, numa atitude marcada pela substituição do "conformismo" pela “ação”. Portanto, as obras passavam, muitas vezes, a ser consideradas apenas enquanto documentos e instrumentos de intervenção em dada realidade ou, conforme sublinham as linhas que antecedem o segundo texto da seção "Literatura de Ficção", "a literatura deixou de valer apenas como literatura e passou a procurar uma base social definida”,374.

Voltando a Graciliano, o escritor utilizava argumentos análogos tanto para rebaixar a importância do movimento de 1922, como para, por contraste, enaltecer, individualizar e potencializar as produções de seus companheiros de geração. Para ele, o dito romance nordestino de 1930 seria a vertente mais autêntica e "realista” da literatura brasileira, que viera se sobrepor ao “choque libertador”, efêmero e estéril, das iniciativas modernistas. Como visto, o artista alagoano apegava-se a outros critérios, que não o experimentalismo lingüístico, o cosmopolitismo e o deboche, entre outras preceptivas colocadas em destaque pela Semana de Arte Moderna, para determinar o valor das obras. Em sentido oposto, enfatizava a necessidade de os autores privilegiarem a abordagem e o estudo de dados sociológicos e econômicos, bem como se restringirem ao tratamento de matérias regionais, como forma de conferirem "verdade” a seus escritos literários.

Para Graciliano, no momento histórico em que vivia, a palavra literatura apresentava um significado “acanalhado”: era sinônimo de fraude, de impostura, de emprego de artifícios retóricos e, consequentemente, de desconexão com a vida brasileira. Em sentido oposto, afirmava que o estudo “objetivo” das relações sociais e econômicas do mundo sertanejo, correspondia tanto à descoberta “autêntica”, como à ação “direta” sobre a realidade nacional. A mesma postura era defendida por seus colegas de geração. Jorge Amado, em nota introdutória ao romance Cacau (1934), escreveu que seu objetivo era tratar da vida dos trabalhadores das fazendas cacaueiras do sul da Bahia com um "mínimo de literatura para um máximo de honestidade”. José Lins do Rego, em texto saído no primeiro número do periódico Dom Casmurro, declarara que a "imaginação criava somente aquilo que a realidade lhe inspira” e que fugir dessa orientação significava, necessariamente, “cair na fantasia, no devaneio retórico, que tanto pode ser cívico, religioso ou proletário”375.

\footnotetext{
${ }^{374}$ LOUSADA, Wilson. Literatura de Fiç̧ão (II). Cultura Política, Rio de Janeiro, n.2, abr. 1942, p.261.

${ }^{375}$ REGO, José Lins. A Literatura Proletária. Dom Casmurro, Rio de Janeiro, ano 1, n.3, maio 1937, p. 6.
} 
Nesse ponto, continuam a avultar semelhanças entre o discurso combativo do autor de Vidas Secas e aquele construído pela ditadura varguista no campo das letras. Tendo em vista, sobretudo, a defesa do referido protocolo “sociológico-regional” ${ }^{376}$, recorrentemente invocado por Graciliano, não por acaso, os romances regionalistas ocupavam um lugar de destaque nas formulações dos ideólogos estadonovistas. Na opinião deles, tal vertente da literatura brasileira ajustava-se perfeitamente aos novos tempos anunciados pela Revolução de Outubro e, em seguida, pelo Estado Novo. Segundo o discurso oficial, enquanto os modernistas teriam adotado uma perspectiva "falsa", tachada de excessivamente "literária” (apesar da atenção dedicada a matérias brasileiras), os romancistas surgidos depois de 1930, mais apegados ao povo e à terra, não teriam fugido às demandas do real e, consequentemente, a suas funções frente à pátria, com destaque para a construção da unidade nacional a partir do tratamento de matérias regionais (sobretudo de matriz rural), num processo de incorporação simbólica de diferentes partes e tipos do país.

Referindo-se à produção cultural pós-1930, Rosário Fusco destaca que o enfrentamento da “realidade”, por diferentes artistas e pesquisadores, constituíra-se no fator mais representativo da produção intelectual brasileira desse momento, em oposição ao “Modernismo intencional”, “exibicionista” e de “convenção” da fase anterior:

Sociólogos e romancistas passam a valorizar o documento, contrapondo-o, à imaginação pura e simples. Fase de estudos objetivos, todos querem contribuir para o maior e melhor conhecimento de nossas realidades. E se Gilberto Freyre confirma, em forte ensaios de interpretação social, o nordeste que José Lins do Rego descreve nos seus apreciados romances, com a decadência do bangüê e o conseqüente esfacelamento da nobreza rural nascida à sombra do engenho, o próprio presidente da República se faz novo bandeirante para recomendar, como sociólogo e como homem de governo, a marcha para o oeste, numa primeira tentativa para o aniquilamento do latifúndio e a disseminação da pequena propriedade; incrementando o plantio de novos centros de vida rural, fomentando o intercâmbio entre o sertão e o centro, o comércio das populações meridionais com os agregados sociais dos desertos geográficos, que morrem de fome demográfica; ajudando a produção agrícola, rasgando estradas, fundando escolas, revolvendo o solo ${ }^{377}$.

Novamente, o poeta de Cataguazes pretende apresentar os rumos da vida literária do país, pós-Revolução de Outubro, como uma conseqüência da política getulista, algo que já estaria

\footnotetext{
${ }^{376}$ VELLOSO, Mônica Pimenta. Literatura como espelho da nação, Estudos Históricos, Rio de Janeiro, v.1, n.2, 1988, p.245.

${ }^{377}$ FUSCO, Rosário. op.cit. p.78-79.
} 
presente na própria eleição do marco temporal de 1930, como ponto de inflexão das letras nacionais. Segundo ele, o governo Vargas teria conferido um "sentido objetivo" ao estudo da realidade brasileira, do qual os escritores, sobretudo os nordestinos, teriam se aproveitado para compor livros voltados para o social, em que a "imaginação contava pouco". Nessa atitude de vinculação entre política e artes, Fusco não deixava de ressaltar a perspectiva regionalista e o apego à terra, presentes nas obras de tais escritores, como componentes de um movimento maior de recuperação e valorização da nacionalidade.

Em Aspectos da Cultura Brasileira, Almir de Andrade parte de uma concepção binária para afirmar que a literatura poderia alcançar o "humano" por meio de duas perspectivas distintas: a individual e a social. A primeira remeteria ao universo subjetivo (dramas, problemas e conflitos interiores), que se "armazenam nas profundidades do ser" ${ }^{378}$. A segunda, por outro lado, dizia respeito à observação e análise detalhada da realidade objetiva, procurando sua força no exame do homem em sociedade. Apesar de considerar a validade das duas abordagens e afirmar que ambas progrediriam na mesma intensidade, confere maior destaque à segunda. Depois de fazer referência à fecundidade do “romance social”, como forma de acessar aos problemas mais profundos da vida, o futuro diretor de Cultura Política declara:

\footnotetext{
Não há homem isolado do meio, nem homem sem uma definida formação social. Assim pode a literatura chegar a um grau bem forte de vitalidade, quando une à expressão do homem como ser a expressão do meio onde, em cada época, se concretizam as suas aspirações. Não esqueçamos que Tolstoi e Dostoievski não seriam tão grandes, se não fosse tão visceralmente 'russos' nos seus motivos"379.
}

Em sua opinião, tal abordagem de cunho social apresentava finalidades mais marcadamente brasileiras, pois partiria de uma matriz regional, fundada no conhecimento supostamente objetivo do meio nacional, para então propor uma visada de orientação universalista (além de qualquer especificidade geográfica). Por analogia, assim como em Tolstoi e Dostoievski, a magnitude de José Lins do Rego, Graciliano Ramos, Marques Rebelo, Amando Fontes, Rachel de Queirós, Jorge Amado, entre outros, encontrava-se no fato de tratarem dos grandes dramas humanos a partir de um enquadramento localista, privilegiando o conhecimento e o estudo do país.

\footnotetext{
${ }^{378}$ No que diz respeito ao tratamento do homem em sua intimidade subjetiva, apontava como destaques Vinícius de Morais e Augusto Frederico Schimdt, na poesia, e Lúcio Cardoso e Otávio de Faria, no romance.

${ }^{379}$ ANDRADE, Almir. Aspectos da literatura brasileira. Rio de Janeiro: Schmidt, 1939, p.86.
} 
O já citado Wilson Lousada adotava perspectiva semelhante. Depois de afirmar que o movimento revolucionário de 1930 fora o fator “mais considerável na transformação sofrida pelas nossas letras”, ele alçava os romances Menino de Engenho, Os Corumbas, S. Bernardo e $O$ Quinze à condição de espelhos de "uma realidade que, nos anos anteriores por falta de ambiente espiritual receptivo, nunca poderia ser entendida em seu verdadeiro alcance” ${ }^{\text {,30 }}$. Segundo ele, tais autores teriam passado a se apoiar em aspectos físicos, humanos e sociológicos da vida brasileira, tendo em vista o estabelecimento de um contato "profundo" entre “forças intelectuais e sociais”. Nem mesmo o "realismo cru” e o pessimismo acentuado de alguns escritores seriam vistos como problemas. Tais opções se justificariam enquanto componentes de certa busca nacionalista que reivindicava a procura "em nós mesmos das causas e finalidade de todas as dúvidas, erros e inquietações”381 . Logo, seria um sinal de vida, de "pesquisa consciente da realidade nacional” e de "vontade construtiva”.

Paralelamente, Lousada enfatiza que tal recuperação e estudo da vida nacional passavam antes pela abordagem das matérias típicas das diferentes regiões brasileiras, item, como visto, fortemente presente nas orientações de cunho localista de Graciliano. O articulista de Cultura Política afirmava, por exemplo, que

\footnotetext{
Um romancista mineiro, por exemplo, não tem argumentos para resumir, na sua gente, toda a alma coletiva do Brasil, tão rica e expressiva nas suas diversas manifestações de caráter regional. Nem o romancista gaúcho, amazonense, pernambucano ou paulista. Cada um deles, portanto, terá de conservar suas raízes características, próprias, sua fisionomia peculiar, sua tradição incorporada ao meio social que trabalhou e moldou ${ }^{382}$.
}

Segundo ele, tendo como base o pensamento de Oliveira Viana, o Brasil não formava um bloco único e indiviso. Na composição heterogênea da nação, pesavam questões específicas, referentes às variações do meio físico, social, da história de constituição dos diferentes grupos populacionais, bem como do “caldeamento dos elementos étnicos”. Nesse sentido, para o articulista, seria inútil falar em escritores nacionais (em sentido geográfico), pois considerava que eles só poderiam se realizar, brasileiramente, por meio do regionalismo.

\footnotetext{
${ }^{380}$ Idem, p.262.

${ }^{381}$ LOUSADA, Wilson. Literatura de ficção II. Cultura Política, Rio de Janeiro, n.2, abr. 1941, p.263.

${ }^{382}$ LOUSADA, Wilson. Literatura de ficção VII. Cultura Política, Rio de Janeiro, n.7, set. 1941, p.292.
} 
Sabendo-se do caráter autoritário e centralizador do Estado Novo pode soar estranha a defesa desta perspectiva localista nas páginas de Cultura Política. No entanto, conforme explica José Lins do Rego, em artigo sobre Gilberto Freyre, tal orientação, formulada, sobretudo, pelo movimento regionalista do Recife, incidia apenas sobre o plano artístico. No plano político, ela respeitava a concentração de poder nas mãos do presidente imposta pela ditadura varguista, mostrando-se contrária ao estadualismo que vigorara durante a Primeira República e fora tão combatido pelo regime ${ }^{383}$ :

Ser da sua região, de seu canto de terra, para ser-se mais uma pessoa, uma criatura viva, mais ligada à realidade. Ser de sua casa para ser intensamente da humanidade. Nesse sentido o regionalismo do Congresso do Recife merecia que se propagasse por todo o Brasil porque é essencialmente revelador e vitalizador do caráter brasileiro e da personalidade humana. Com um regionalismo desses é que poderemos fortalecer ainda mais a unidade brasileira. Porque cultivando o que cada um tem de mais pessoal, de mais próprio, vamos dando mais vida ao grupo político, formando um povo que não será uma massa uniforme e sem cor $^{384}$.

Diante de tal argumentação, subentende-se que uma experiência como Macunaíma (1928), de Mário de Andrade, seria vista como uma tentativa falhada. Lousada tomava o livro não como um romance, mas sim como uma "alegoria”, fundada no folclore e, portanto, desconectada da reivindicada empiria dos fatos do país. Em certo sentido, o autor de Paulicéia Desvairada era acusado de transformar “inspirações” retiradas da cultura regional em “fórmulas de invenção pessoal”385, deixando de lado uma abordagem pretensamente objetiva e sociológica da nacionalidade.

Bueno refere-se à vigência de certo espírito “anti-Macunaíma” na década de $1930^{386}$. Como exemplo, recupera um artigo de José Lins do Rego, no qual o escritor paraibano volta-se contra a linguagem “artificial” empregada pelo “esteta” Mário de Andrade, dentro da briga entre modernistas e regionalistas de Recife:

A língua de Mário de Andrade em Macunaíma nos pareceu tão arrevesada quanto a dos sonetos de Alberto Oliveira. A língua que Mário de Andrade quis introduzir com o seu livro é uma língua de fabricação; mais um arranjo de filólogo erudito do que um instrumento de comunicação oral ou escrito. O livro de Mário de Andrade só foi bem entendido por estetas, por eruditos, e o seu herói é tão pouco

\footnotetext{
${ }^{383}$ Como se sabe, o Estado Novo substituiu os antigos governadores por interventores federais.

${ }^{384}$ REGO, José Lins. Gordos e magros: ensaios. Rio de Janeiro: C.E.B., 1942, p.130-131.

${ }^{385}$ VELLOSO, Mônica Pimenta. op.cit. p.245.

${ }^{386}$ BUENO, Luís. op.cit. p.61.
} 
humano e tão artificial quanto o boníssimo Peri, de Alencar. (...) Este livro de Mário de Andrade é um repositório de folclore, o livro mais cerebral que já se escreveu entre nós ${ }^{387}$.

Portanto, José Lins considerava que Mário, por motivos e escolhas diferentes, teria se valido de recursos formais semelhantes aos utilizados pelos execrados parnasianos, o que fazia com que sua obra só pudesse ser compreendida por um circulo restrito de eruditos ${ }^{388}$. Paralelamente, ao afirmar que o referido livro seria incapaz de uma interlocução efetiva com o grande público, tal como acontecia com seu Ciclo da Cana de Açúcar, o romancista paraibano dizia, por outras vias, que era ele quem utilizava uma língua "natural”, pois deixara de lado os adornos e rebuscamentos modernistas. Ela lhe possibilitaria uma comunicação "franca” e “direta” com o povo. Os números favoreceriam os juízos do autor de Fogo Morto. Enquanto ele vendia milhares de exemplares em sucessivas edições, Macunaíma, depois da publicação de 800 volumes em 1928, só teria alcançado sua segunda edição, pela José Olympio, em $1937^{389}$.

No processo de valoração das propostas e diretrizes dos escritores nordestinos, entre elas a visada regionalista privilegiada por estes, José Lins e Graciliano ocupavam lugar de destaque. Rosário Fusco, por exemplo, trata o primeiro como "a maior e a mais expressiva revelação do romance brasileiro moderno”. Já o segundo é apresentado como o mais seguro dos “autores do Norte”. "Seu estilo é de uma força invulgar, sua arte de compor esplêndida e sua capacidade de romancear surpreendente. S. Bernardo é, com certeza, uma positiva obra-prima e um dos raros livros da literatura brasileira que merecem uma divulgação inteligente no exterior"390.

Para Wilson Lousada, Graciliano seria um raro exemplo de romancista que estabelecera um equilíbrio perfeito entre homem e meio, pois conseguira dosar o “império da paisagem”,

\footnotetext{
${ }^{387}$ REGO, José Lins do Rego. Espécie de história literária. Lanterna Verde, Rio de Janeiro, n.6, abr. 1938, p.95. In: BUENO, Luís. op.cit. p.62.

${ }^{388}$ De acordo com o referido clima anti-Macunaíma nos anos de 1930, Rubem Braga publica crítica análoga ao se referir ao romance e a postura do autor paulista. "Mário pegou um jeito de escrever que seria popular se não fosse tão precioso. Ele faz parte de um pequeno clube fechado de gastrônomos que há em São Paulo. E faz gastronomia na linguagem também (...). O paladar do povo é simples. Se Mário de Andrade fosse preparar um vatapá, ele faria um vatapá tão bem feito, tão em regra, tão profundamente baiano, segundo tantas recomendações de regras de especialistas que nenhum baiano gostaria do vatapá dele. Foi para a extrema esquerda da língua. Reagindo contra a aristocracia do fraseado solene e da hierarquia dos pronomes, ele caiu no populismo mais difícil e precioso" (BRAGA, Rubem. Os defeitos de Macunaíma. Diário de Notícias, Rio de Janeiro, 18 jul. 1937).

${ }_{389}$ BUENO, Luís. op.cit. p.62.

${ }^{390}$ FUSCO, Rosário. op.cit. p.149-150.
} 
observado na região das secas, com a fixação de personagens bem-acabados, tanto humana quanto psicologicamente:

\begin{abstract}
No grupo de ficcionistas que deu ao romance brasileiro, depois de 1930, um impulso verdadeiramente notável, e onde estão José Lins do Rego, Amando Fontes, Rachel de Queirós, Jorge de Lima, Jorge Amado e outros, Graciliano Ramos adquire relevo excepcional pelas suas qualidades inatas de bom psicólogo sem prejuízo do espírito regionalista. Mais do que nenhum outro, ele representa o artista equilibrado entre a paisagem e o personagem ${ }^{391}$.
\end{abstract}

A região Nordeste era tratada pelo articulista como um espaço em que, obrigatoriamente, a “realidade” se imporia a seus habitantes, fossem eles homens comuns na luta diária pela sobrevivência, fossem eles romancistas na escritura de seus livros de matiz regionalista. Para estes últimos, o "realismo da terra" apresentava-se tanto como um leitmotiv, quanto como uma necessidade física. Portanto, fugir dele seria impossível. O grande problema surgia quando os autores conferiam-lhe caráter exclusivo, o que redundava em obras excessivamente descritivas e exteriorizadas, mas pobres em aspectos humanos de matriz “universal”. Nesse sentido, Graciliano se sobressaía aos olhos de Lousada como um legítimo criador; escritor de um "regionalismo justo", pois conseguira fixar suas criaturas dentro da paisagem, sabendo ao mesmo tempo ser “localista” e projetar-se além dos limites sertanejos ${ }^{392}$.

Em outro sentido, pensando na própria estruturação do texto, Almir de Andrade refere-se a certo equilíbrio entre o clássico e o moderno na obra de Graciliano. Ele considera o fazer artístico do autor alagoano, como resultado de um processo de lenta depuração e aperfeiçoamento, que o colocava além da perspectiva simplesmente "libertadora" e “destrutiva” do Modernismo:

\footnotetext{
Graciliano Ramos, por exemplo, traz a marca indiscutível da influência modernista - como José Lins do Rego, como José Américo de Almeida, como Jorge Amado, como muitos outros. Entretanto, há no romance de Graciliano um esforço de cristalização nitidamente 'contrário' ao do movimento modernista: seu estilo castigado, burilado, expurgado está bem distante da liberdade de expressão, do primitivismo, do naturalismo, do 'brasileirismo' dos escritores modernistas; seus capítulos, cimentados e estruturados, revelam uma disciplina espiritual, uma disciplina de forma, de estilo, de concepção, que é, em si mesma, a negação do espírito do Modernismo ${ }^{393}$.
}

\footnotetext{
${ }^{391}$ LOUSADA, Wilson. Literatura de Ficção IV. Cultura Política, Rio de Janeiro, ano 1, n.4, jun. 1941, p.236. ${ }^{392}$ Idem, p.235.

${ }^{393}$ ANDRADE, Almir de. Resposta de Almir de Andrade. Revista do Brasil, Rio de Janeiro, ano III, $3^{\text {a }}$ fase, n.22, abr. 1940, p.106.
} 
Dessa maneira, ao mesmo tempo em que não empreendera uma volta aos modelos clássicos, Graciliano teria se afastado das propostas do movimento de 1922, que, segundo Almir, terlhe-iam inspirado apenas os temas de seus livros e, mais especificamente, favorecido alguns aspectos elocucionais de sua prosa. Na opinião do crítico, em suma, as obra do escritor alagoano poderia ser tomada como uma "contra-reação individual anti-modernista”, das mais significativas da literatura brasileira, pós-1930 ${ }^{394}$.

\subsection{O repúdio ao individualismo e a defesa da idéia de "romance social"}

Diferentemente do que costumava expressar em seu metatexto, quando em vários momentos adotava uma postura combativa e passava a questionar o suposto artificialismo de seus “adversários” (fossem eles românticos, vanguardistas paulistas ou idealistas católicos, como se verá), Graciliano, não mais o crítico, mas sim o artista investido da condição de escritor consagrado, era também um homem do artifício. Além disso, conhecia muito bem a tradição literária brasileira e internacional, manejando-a com destreza tanto na confecção de suas obras, como no próprio processo de afirmação da relevância cultural, da vertente de romances nordestinos a que se filiava. A própria defesa que realizava da correção gramatical, de uma linguagem seca (de períodos curtos e densos) e da necessidade de os homens de letras dominarem a técnica necessária para desempenharem seu ofício (da mesma maneira que um sapateiro deveria saber manusear seus instrumentos para compor um par de sapatos) podem ser tomadas como provas disso.

No prefácio do livro de contos Neblina, de José Carlos Borges, Graciliano, referindo-se especificamente à composição do texto “Coração de D. Iaiá”, presente em tal obra, afirma que o jovem escritor exprimira-se "direito", "sem penduricalhos”, o que teria conferido a sua prosa uma aparência de naturalidade. Tal ardil enganaria os leitores desprevenidos; eles não perceberiam o artifício e teriam a impressão de que aquilo era espontâneo e fora arranjado sem nenhum esforço. O romancista alagoano está interessado na verossimilhança artística da narrativa:

D. Iaiá é matuta, honesta, duma honestidade rigorosa e de pedra. O sr. José Carlos Borges compreende-

lhe a moral e a dureza. E fixa-a em cartas que D. Iaiá faria se soubesse escrever. Se ele nos exibisse os

${ }^{394}$ Idem, ibidem. 
bilhetes dessa criatura, com a sua ortografia e a sua pontuação, a história seria horrorosa. A redação não é da velha, mas parece-nos que é. A correspondência tem, portanto, verossimilhança, uma verossimilhança obtida à custa de repetições oportunas e dum vocabulário pequeno, presumivelmente o que adotam as senhoras de escassos recursos intelectuais e muita devoção ${ }^{395}$.

Logo, o que estaria em jogo não seria a verdade, mas a construção da idéia de verdade. Se Borges tivesse apresentado os supostos bilhetes, escritos pela própria D. Iaiá, a história seria “horrorosa”. No entanto, como produzira o efeito refinado de que fora a velha que os escrevera, sem ter sido, tornava seu relato literariamente atraente, colocando-o além de uma mera reportagem ou da simples compilação de missivas.

Para Graciliano ainda, o contista, ao mesmo tempo em que compusera tal personagem verossímil, não teria deixado de apresentar “alguns pedaços da vida no interior”: “as relações do coronel com a política dominante, os progressos do rapaz que toca bombardino na filarmônica, as esperanças da moça que se candidata a professora municipal e é barradas pelas parentas do juiz e do prefeito" ${ }^{396}$. Nota-se, portanto, que quando a utilização de artifícios se ajustava a perspectiva literária do escritor, ela deixava de figurar como algo condenável ou desabonador. Em sentido oposto, a produção efeitos, mediante o emprego de recursos expressivos, tornava-se o ingrediente central na representação (que supunha) “realista” dos espaços sertanejos.

Contudo, mesmo no que dizia respeito à recorrente defesa da obsessão especular do romance de trinta, há também uma diferença entre o que Graciliano afirmava em seus textos críticos, de caráter combativo, e aquilo que se depreende de seus romances. Em S. Bernardo, por exemplo, Paulo Honório chega a destacar:

\footnotetext{
Uma coisa que omiti e produziria bom efeito foi a paisagem. Andei mal. Efetivamente a minha narrativa dá idéia de uma palestra realizada fora da terra. Eu me explico: ali, com a portinhola fechada, apenas via de relance, pelas outras janelas, pedaços de estações, pedaços de mata, usinas e canaviais ${ }^{397}$.
}

O trecho trata, de maneira explícita, do trabalho com a linguagem inerente à produção romanesca, discorrendo sobre as próprias estratégias textuais empregadas pelo narrador. Além

\footnotetext{
395 RAMOS, Graciliano. Uma justificação de voto. In: BORGES, José Carlos. Neblina. Curitiba: Ed. Guaíra Ltda, [1940 ?]. Texto também presente em Linhas Tortas (Rio de Janeiro: Record, 2005), p.213.

${ }^{396}$ Idem, p.214.

${ }^{397}$ RAMOS, Graciliano. S. Bernardo. Rio de Janeiro: Livraria José Olympio Editora, 1953, p.79.
} 
disso, retoma com certa ironia o imperativo de se enfocar a sempre referida "cor local". Contrariamente aos narradores de Jorge Amado e José Lins do Rego, Paulo Honório via a paisagem de "relance" 398.

De qualquer maneira, a produção crítica de Graciliano, com algumas exceções, parecia apontar para um caminho contrário. Sobretudo a partir de 1937, o escritor passara a adotar outra estratégia a fim de valorizar e consolidar a vertente nordestina de romance da qual partilhava. Em linhas gerais, ele deixa de fazer comparações entre seus contemporâneos de geração e literatos do passado, com o intuito de rebaixar o protocolo romântico, bem como criticar os modernistas de 1922 com o propósito de afirmar-se. Seu objetivo torna-se outro: contrapor os escritores com os quais construíra afinidades (José Lins do Rego, Jorge Amado e Rachel de Queirós, principalmente) aos adeptos do dito romance intimista, de influência católica, que ganhavam destaque no meio literário, naquele momento. Obviamente, realizará a defesa dos primeiros e rebaixará os segundos. Estes praticariam, conforme diz, uma espécie de “espiritismo literário”, uma vez que deixariam de lado a tematização do que se supunha ser a "realidade" do país (a referida “cor local”), sobretudo aquela encontrada nos sertões brasileiros, para se focarem em dramas introspectivos, burgueses e citadinos ${ }^{399}$.

Tal julgamento já aparecia em “O fator econômico no romance brasileiro”, um de seus primeiros textos publicados após sua saída da prisão, na revista carioca Observador Econômico e Financeiro, em abril de 1937. Nele, o cronista desenvolve uma leitura crítica da produção dos romancistas nacionais, destacando que boa parte desta seria marcada tanto pela ausência de uma observação cuidadosa dos acontecimentos como pelo desprezo por dados econômicos. Mais especificamente questiona a preferência crescente por dramas individuais, considerados abstratos e arbitrários, bem como distantes do que supunha ser os reais interesses e anseios da coletividade. “Acontece que alguns escritores se habituam a utilizar em romance apenas coisas de natureza subjetiva. Provavelmente há o receio de que, sendo comércio e indústria, oferta e procura, etc. vistos muito de perto, a questão social venha à baila”. Particularizando seu argumento, repudia o que chama de lirismo “vazio” e "fantasmagórico" de tais autores intimistas, que por deixar de lado a suposta concretude dos

\footnotetext{
${ }^{398}$ SUSSEKIND, Flora. op.cit. p.171.

${ }^{399}$ Como visto no capítulo anterior, tais produções ganharam força, sobretudo, depois de 1935. Nelas, o interesse pelo indivíduo é radicalizado com destaque para personagens ficcionais pertencentes aos estratos mais abastados da sociedade. Paralelamente, deixa-se de lado a menção às massas. Destaque para Jorge de Lima, José Geraldo Vieira, Lúcio Cardoso e Octávio de Faria.
} 
fatos acabaria resultando numa análise de cima para baixo da sociedade. Para o narrador, tais omissões afetariam a "verdade" e "autenticidade" dos textos:

\begin{abstract}
Os romancistas brasileiros, ocupados com política, de ordinário esquecem a produção, desdenham o número, são inimigos de estatísticas. Excetuando-se as primeiras obras de José Lins do Rego e as últimas de Jorge Amado, em que assistimos à decadência da família rural, queda motivada pela exploração gringa sobre os engenhos de bangüê e as fazendas de cacau, o que temos são criações mais ou menos arbitrárias, complicações psicológicas, às vezes um lirismo atordoante, espécie de morfina, poesia adocicada, música de palavras ${ }^{400}$.
\end{abstract}

De certa maneira, Graciliano julgava que "números” e “estatísticas”, ao lado de dados de caráter sociológico, consubstanciavam a própria "realidade”, ou seja, considerava que essas informações não apresentavam o estatuto de mediações simbólicas, mas sim o de traduções diretas do próprio mundo. Nesse sentido, o romance, enquanto gênero que visava à redescoberta e ao estudo do país, não poderia deixar de lado a "objetividade” expressa por tais conhecimentos para fiar-se tão somente em abordagens de cunho introspectivo e individual. Tome-se o seguinte exemplo fornecido pelo escritor ao tratar do fazer literário na referida crônica: “Quando um negociante toca fogo na casa, devemos procurar o motivo deste lamentável acontecimento, não contá-lo como se ele fosse um arranjo indispensável ao desenvolvimento da história que narramos”. Dessa maneira, o autor alagoano subentende que a estória deveria subordinar-se ao que chama de "real”, ou seja, àquilo que entende como preexistente a qualquer formulação. Ao invés de comportar-se como um deus que tira “criaturas vivas da cabeça”, caberia ao romancista encontrar o fundamento para estas no próprio “mundo objetivo". Ele deveria compor tipos que se comportassem “como toda a gente”.

Para tanto, no tratamento das matérias nacionais, os escritores deveriam obedecer a certa perspectiva "científica”. Cabia-lhes deixar de lado paixões e apriorismos que pudessem interferir na observação das “verdades” supostamente inscritas na natureza:

... a obrigação do romancista não é condenar nem perdoar a malvadez: é analisá-la, explicá-la. Sem ódios, sem idéias preconcebidas, que não somos moralistas.

Estamos diante de um fato. Vamos estudá-lo friamente.

\footnotetext{
${ }^{400}$ RAMOS, Graciliano. Linhas Tortas. Rio de Janeiro: Record, 2005, p.363.
} 
Parece que este advérbio não será bem recebido. A frieza convém aos homens de ciência. O artista deve ser quente, exaltado. E mentiroso.

Não sei por quê. Acho que o artista deve procurar dizer a verdade. Não a grande verdade, naturalmente. Pequenas verdades, essas que são nossas conhecidas ${ }^{401}$.

Graciliano toma as obras que deixavam de lado o estudo "frio" do país e de sua coletividade, para privilegiarem dramas subjetivos, como manifestações do que chama de "espiritismo literário”. A definição de tal categoria ganha corpo na crônica "Norte e Sul”, publicada também em abril de 1937. Nela, o autor de Angústia argumenta que a separação geográfica entre os escritores nortistas e sulistas não seria correta. Segundo ele, a divisão mais producente seria entre pessoas que "gostam de escrever sobre coisas que existem na realidade” (os realistas críticos e documentais) e outras que "preferem tratar de fatos existentes na imaginação” (os escritores tachados de intimistas). A oposição entre verdade e imaginação, num tom de manifesto, funciona como procedimento narrativo para defender e elevar os romances nordestinos ${ }^{402}$, que estariam sendo alvos de referências pouco lisonjeiras, e depreciar os títulos dos autores considerados introspectivos:

\begin{abstract}
Os inimigos da vida torcem o nariz e fecham os olhos diante da narrativa crua, da expressão áspera. Querem que se fabrique nos romances um mundo diferente deste, uma confusa humanidade só de almas, cheias de sofrimentos atrapalhados que o leitor comum não entende. Põe essas almas longe da terra, soltas no espaço. Um espiritismo literário excelente como tapeação. Não admitem as dores ordinárias, que sentimos por as encontrarmos em toda parte, em nós e fora de nós. A miséria é incômoda. Não toquemos em monturos ${ }^{403}$.
\end{abstract}

Em resposta a este artigo, no qual Graciliano mais uma vez atribui um maior efeito de verdade às produções nordestinas, Octávio de Faria, um dos maiores expoentes do chamado romance intimista de orientação católica, publica, em maio de 1937, em O Jornal, o texto "O defunto se levanta”. O autor da série Tragédia Burguesa aponta a parcialidade e o reducionismo da separação interessada proposta pelo escritor alagoano:

\footnotetext{
${ }^{401}$ Idem, p.369-370.

402 Graciliano também procurava elevar os romances nordestinos de seus companheiros de geração ao afirmar que eles teriam a preferência dos leitores. Segundo o escritor, o público estaria interessado em obras que oferecessem personagens "críveis" e "reais" dentro da proposta do realismo documental que se supunha mais verdadeiro por priorizar a representação de certas mazelas nacionais.

${ }^{403}$ RAMOS, Graciliano, Linhas Tortas, p.192.
} 
Ao que se depreende do artigo ou nota do Sr. Graciliano Ramos, existe aqui, entre nós, todo um partido literário da mentira organizada, de pudibundos metafísicos, que quer asfixiar as vozes ‘verdadeiras' de José Lins do Rego, Rachel de Queirós, Jorge Amado e não sei que outros (entre os quais certamente deve estar o Sr. Graciliano Ramos), roubar-lhes traiçoeiramente os leitores, substituir aos seus romances outros inteiramente fantasiosos (...) Tamanha simplificação das coisas, tamanha recusa à compreensão da natureza do verdadeiro material do romance, a admitir a possibilidade da liberdade na criação literária, tamanha obstinação em limitar o romance à narração dos casinhos de vida cotidiana, do interior do Brasil, já catalogados pelos nosso sociólogos, tamanha ojeriza à idéia de que exista em certas criaturas o monstro reacionário conhecido pelo nome de alma, com problemas próprios e sutilezas irredutíveis ao econômico puro, tamanho apertado da visão, espantam realmente no autor de contos tão bons, de um romance de qualidade tão segura, num autor que por tanto outros lados merece o nosso respeito e a nossa consideração ${ }^{404}$.

Como se vê, o articulista trata especificamente do binarismo de Graciliano, quando este se propunha a defender, sem restrições, seus companheiros de geração, que naquele momento eram alvos de críticas. O próprio Octávio de Faria, anos antes, na revista Literatura já mostrara sua indisposição contra a "avalanche de testemunhos vindos do Norte e Nordeste, todos eles se pretendendo romances, mas na maioria dos casos simples depoimentos sobre a mediocridade literária nacional”405. Nesse sentido, tais posicionamentos devem ser enquadrados num contexto de polarização no campo literário, situação na qual o romance regionalista começava a perder força, mas, paralelamente, mostrava-se pronto a defender, com unhas e dentes, o estatuto de literatura “autenticamente nacional” que conseguira conquistar durante a década de 1930.

Tendo esse propósito em seu horizonte, Jorge Amado escreve a biografia $A B C$ de Castro Alves, obra pautada menos pelo relato dos fatos, que recomporiam a vida do "poeta dos escravos”, do que pela realização de propaganda político-literária em seu momento presente. Os objetivos do projeto são, entre outros, os de, simultaneamente, exaltar Castro Alves e promover o romance social, do qual o escritor baiano era um dos principais expoentes e divulgadores. De acordo com tal perspectiva, o biógrafo mostrava-se umbilicalmente ligado ao biografado; ambos fariam parte da mesma linhagem das artes brasileiras, pois realizariam, cada um em seu tempo, uma literatura interessada, "revolucionária”, voltada para o povo. Nesse sentido, tanto um como outro se contraporiam aos literatos considerados conservadores,

\footnotetext{
${ }^{404}$ FARIA, Octávio. O defunto se levanta. O Jornal, Rio de Janeiro, maio 1937.

${ }^{405}$ FARIA, Otávio de. Excesso de Norte. Literatura, Rio de Janeiro, ano 4, n.10, jul. 1935.
} 
que ou cultivariam a chamada "arte pela arte” ou privilegiariam, tão somente, análises psicológicas em suas obras:

\begin{abstract}
Isso basta para que se possa medir com acerto a enorme, a quase infinita distância que separa Castro Alves dos versajadores medíocres da "arte pela arte" e da "realidade interior" dos nossos tempos. O argumento, muito usado pela nossa crítica bem pensante, de que a ação social do artista não contribui senão para deformá-lo, exaurindo-lhe as fontes do "lirismo puro", esse lirismo abstrato e transcendental que é a muleta dos maus poetas, e o outro - muito do gosto de alguns - de que a poesia é apenas “imaginação - encontram na obra de Castro Alves a mais esmagadora contradita ${ }^{406}$.
\end{abstract}

O autor de Navio Negreiro era apontado como o maior exemplo de que a ação social de um escritor não prejudicaria sua obra literária. Muito pelo contrário. Ainda segundo a leitura de Amado, o lirismo do poeta viria justamente do contato íntimo com a sociedade e os homens da época em que vivera. "Se ao invés de aproximar-se do povo, como fez, Castro se tivesse fechado na sua torre de marfim, a sua herança teria sido, talvez, a de lindos versos, não a de uma grande poesia”407.

Na defesa da função social da literatura, Jorge Amado era mais radical. Como apontava Graciliano, o escritor baiano defendia a idéia de que o romance moderno deveria suprimir o personagem, matar o protagonista ${ }^{408}$. Na opinião do autor de Cacau, a figura do herói era considerada um ranço do romance burguês. Nesse sentido, guiado pela idéia de que os problemas sociais decorriam da luta de classes, argumenta que o foco principal dos artistas deveria ser transferido da esfera individual para a coletiva, ou seja, ao invés de dramas individuais estes deveriam privilegiar atores coletivos em seus textos. O que interessaria era o grupo - “uma cidade inteira, um colégio, uma fábrica, um engenho de açúcar”,409.

Bueno afirma que Amado procurou levar a termo tais considerações em seus romances iniciais. Para tanto, foi gradualmente realizando adaptações em seu programa estético. Em Suor (1934), pretendeu apresentar um conjunto de destinos particulares como forma de compor, tal qual um mosaico, a noção de ator coletivo. No romance seguinte, Jubiabá (1935), o escritor empreendeu a tentativa de redefinir, em termo populares, o velho herói de matriz burguesa. Já, em Mar morto (1936), seu objetivo foi o de unir luta política e malandragem,

\footnotetext{
${ }^{406}$ AMADO, Jorge. ABC de Castro Alves. $3^{\mathrm{a}}$ ed. São Paulo: Livraria Martins Editora, 1950, p.138.

${ }^{407}$ Idem, ibidem.

${ }^{408}$ AMADO, Jorge. P.S. Boletim de Ariel, Rio de Janeiro, ago. 1933, p.292.

${ }^{409}$ RAMOS, Graciliano. op.cit. p.132.
} 
algo que aconteceria de forma mais direta em Capitães da areia (1937) $)^{410}$. Ao mesmo tempo, Jorge Amado, assim como Graciliano, realizava a defesa de um tratamento “objetivo” das matérias que se punha a representar:

\begin{abstract}
O romancista, entre todos os intelectuais, é o que está em maior contato com a humanidade. Porque num romancista se exigem qualidades de observação, já que deve retratar em seus livros os homens e os ambientes em que vive ou que conhece. - É necessário repetir que o romancista não inventa. O romancista cria, mas através da humanidade, assentando no real a sua criação, tirando-a da vida diária, os homens e o ambiente. Seria facílimo inventar homens e ambientes e colocá-los num romance. Onde residiria o encanto, o interesse desse livro falso? O que o público procura num romance é vida ${ }^{411}$.
\end{abstract}

Apesar de críticas como aquela de Octávio de Faria, o discurso favorável a uma abordagem de cunho pretensamente objetivo, voltada para a coletividade, nos moldes propostos por Jorge Amado (e também por Graciliano), ocupou posição de destaque ao longo da década de 1930. No referido número da revista Lanterna Verde, que pretendeu fazer um balanço tanto do Modernismo quanto do que se chamava de Pós-Modernismo, ou seja, do romance de 1930, Tristão de Athayde, escrevendo em 1936, dizia que o elemento sócio-político invadira o campo literário: “As notas que soam mais vivas e claras, nos dias de hoje, não são as literárias e sim as políticas e sociais” ${ }^{412}$. Tal alteração seria indício de que tanto a prosa quanto à poesia deixavam a superficialidade "literária” das abordagens modernistas para tratar, de maneira profunda, “sociológica” dos problemas pelos quais o mundo atravessava ${ }^{413}$.

Esta perspectiva fica mais clara no texto "Sociologia e Literatura”, publicado por Gilberto Freyre no aludido número de Lanterna Verde. Invertendo a lógica usual, o estudioso "eleva” as obras dos romancistas nordestinos de 1930 à condição de documentos. Elas não poderiam ser enquadradas apenas na categoria "belas-letras":

\footnotetext{
O que principalmente passou a caracterizar o romance novo foi o seu tom de reportagem social e quase sociológica; a sua qualidade de documento; as evidências que reuniu de vida esmagada, machucada, deformada por influências de natureza principalmente econômica; os seus transbordamentos políticos. Tal o caso dos romances de Jorge Amado, principalmente os anteriores a Jubiabá: Cacau e Suor. O caso, até certo ponto, dos romances de José Lins do Rego, de Graciliano Ramos, de José Américo de

${ }^{410}$ BUENO, Luís. op.cit. 243-283.

${ }^{411}$ AMADO, Jorge. Literatura, romance e política como resultados sociais. Pan, Buenos Aires, 11 mar. 1936. In: TATIT, Miécio. Jorge Amado: vida e obra. Belo Horizonte: Editora Itatiaia, 1961, p.89.

${ }^{412}$ ATHAYDE, Tristão. op.cit. p.95.

${ }^{413}$ Idem, ibidem.
} 
Almeida, de Rachel de Queirós - formidável documentação da vida regional, do maior interesse sociológico e até político, e suprimindo a falta de inquéritos, sondagens, pesquisas sistematizadas. Quase nada nesses romances é obra de ficção: apenas os disfarces; apenas a deformação para os efeitos artísticos, sentimentais ou, em certos casos, políticos ${ }^{414}$.

Tratando de seu momento presente, o autor de Casa-grande e Senzala apontava para a ruptura definitiva das fronteiras que separavam as ciências sociais da literatura. Segundo ele, tornavase cada vez mais comum encontrar filósofos e economistas que escreviam de maneira fácil, abdicando de um estilo pedregoso, ao mesmo tempo avultavam escritores que deixavam de tratar somente de casos sentimentais para se dedicarem a assuntos de caráter coletivo. Nesse sentido, pressupunha que os estudos científicos, cada vez mais, aproximavam-se das obras literárias no que dizia respeito à forma, ou seja, ao tratamento artístico do texto, ao passo que estas passaram a se valer dos assuntos e a utilizar as técnicas de coleta de dados daqueles. Para Freyre, o único risco da interpenetração entre essas duas áreas encontrava-se na possibilidade dos romances deixarem de ser considerados belas-letras para se tornarem má sociologia, algo que só aconteceria em função da incompetência tanto artística quanto analítica de seus autores.

De uma maneira geral, para o Estado Novo, a arte também deveria apresentar uma finalidade social. Cassiano Ricardo afirmava que o individualismo, presente no ofício dos escritores, seria apenas uma condição, mas nunca um fim. Ele ainda acrescentava que o isolamento e o esforço criativo dos homens de letras só seriam efetivamente recompensados quando as obras destes refletissem e encontrassem ressonância no público. Nesse sentido, a perspectiva individual dos autores seria encarada não como uma fuga, mas como um "mergulho profundo no próprio recôndito da vida coletiva”:

Tudo o que ele realiza não é dele, é da consciência que o cerca. Tudo o que ele cria, ou arranca de si mesmo, tem o dom de representar um momento que é de todos, ou um espaço de cultura em que todos cabem ou se compreendem, sejam quais forem os disparates de origem, de credo, e de tempo. Só a arte nos dá, pois, a sensação de um milagre de coexistência entre indivíduo e sociedade ${ }^{415}$.

Metonimicamente, o escritor era tomado pela própria coletividade e as criações individuais deste deveriam ser encaradas, sem exceção, como produtos sociais. De acordo com um ponto

\footnotetext{
${ }^{414}$ FREYRE, Gilberto. Sociologia e literatura. Lanterna Verde, Rio de Janeiro, n.4, nov. 1936, p.15.

${ }^{415}$ RICARDO, Cassiano. Getúlio Vargas e a nova inteligência do Brasil. Estudos e Conferências, Rio de Janeiro, p.34-35.
} 
de vista elitista, tornava-se imperativo ao artista, na qualidade de intérprete dos destinos da pátria, conferir um objetivo a sua obra, caso desejasse que ela repercutisse sobre a vida nacional. Segundo Ricardo, não haveria “inteligências neutras”, pois a função da literatura não seria apenas estética, mas eminentemente política. Portanto, era preciso que o escritor tomasse um partido, uma posição. E, no horizonte do poeta, esta seria a do Estado Novo, que, enfim, teria imprimido um "sentido social” à política brasileira, em perspectiva "bem diferente do velho Estado Liberal”, pautado por personalismos e pelo divórcio entre intelectuais e governo.

\subsubsection{Política e letras}

Com o intuito de rebaixar o alegado individualismo das práticas políticas da liberaldemocracia, vigentes durante a Primeira República, o Estado Novo valia-se de argumentação semelhante à utilizada pelos escritores nordestinos para criticar os romances intimistas. Assim como estes eram tachados de “abstratos” e "artificiais”, pois, conforme dizia Graciliano, teriam deixado de lado "as coisas que existiam realmente" para se focarem em dramas subjetivos e introspectivos, o período que se estendia de 1889 a 1930 era descrito pelos ideólogos estadonovistas como aquele em que prevalecera o personalismo, o desprezo pela coletividade e o desinteresse pelas matérias brasileiras na condução da vida nacional. Portanto, apesar dos diferentes fins, os termos, assuntos e temas utilizados para conferir estatuto de realidade às obras literárias eram utilizados de maneira semelhante pelo governo para justificar suas medidas administrativas.

Paralelamente, se o discurso e certos procedimentos oriundos da sociologia invadiam a literatura, como forma de enobrecê-la e colocá-la em contato com a “materialidade” dos problemas nacionais, o mesmo acontecia com a política. Em texto publicado em Cultura Política, Gilberto Freyre refere-se a tal questão ao apontar o caráter inovador do governo de Getúlio Vargas:

(...) Com o atual Presidente a base do governo - de sua técnica - deslocou-se da pura interpretação política dos problemas, acompanhada de soluções e tentativas de solução, simplesmente financeiras e jurídicas, para aventurar-se o Brasil à procura de novas bases de técnica de governo e de administração: 
sociais e, principalmente, sociológicas e econômicas. Estamos hoje num período de experimentação social ${ }^{416}$.

O articulista faz uma oposição entre os gestores do passado, “doutores” versados em direito e política, e a figura de Vargas, "homem de inteligência realista” que recuperou o "sentido amplamente social” de governo. Logo, enquanto os primeiros seriam adeptos de um “intelectualismo superficial” e bacharelesco, o segundo deixaria de lado a retórica "vazia” para se inclinar a soluções sociológicas e econômicas, a partir do "contato com a terra crua e com a gente nativa, mestiça ou adventícia das várias regiões”. Em outro sentido, o Estado Novo se mostrava superior, frente à Primeira República e ao Império, pois substituíra a administração de gabinete, abstrata e desconectada do país, para se aventurar pela nação, recolhendo as virtudes, doenças, problemas, necessidades, possibilidades e aspirações do povo ${ }^{417}$.

Partindo de um ponto de vista semelhante, cujo principal propósito era ressaltar um suposto contato direto entre o novo regime e a "essência brasileira”, Almir de Andrade já indicava em Força, Cultura e Liberdade, que o privilégio para a coletividade, tomada como uma ordem social superior, em detrimento do indivíduo, aparecia como um fator atributivo de realidade as ações do Estado Novo. O autor partia do princípio de que o sujeito tomado isoladamente era artificial, preso a egoísmos, personalismos e abstrações. Por outro lado, quando ele era visto em termos sociais, automaticamente ganhava materialidade e concretude, pois enquadrava-se no movimento “natural” da civilização. O futuro editor de Cultura Política retira da biologia e da física a justificativa para tal afirmação de cunho sociológico:

\footnotetext{
Quando deitamos a vista sobre a evolução dos seres vivos e sobre a evolução de todo o universo físico, por toda a parte encontramos o todo modelando a parte, o indivíduo trabalhando para a espécie, as partículas de matéria obedecendo às grandes formas de estruturação e de organização dos corpos mais complexos. A inquietação das sociedades humanas não poderá cessar, enquanto elas não ajustarem definitivamente as suas leis políticas a essas leis naturais ${ }^{418}$.
}

Portanto, para Andrade, a supressão de particularismos, bem como a prevalência de "sentimentos sociais” fazia parte da evolução geral da humanidade. Ainda segundo seu

\footnotetext{
${ }^{416}$ FREYRE, Gilberto. A propósito do presidente. Cultura Política, Rio de Janeiro, ano1, n.5, jul.1941, p.123. ${ }^{417}$ Idem, p.125.

${ }^{418}$ ANDRADE, Almir. Força, Cultura e Liberdade. Rio de Janeiro: Livraria José Olympio Editora, 1940, p.151.
} 
argumento, apenas a integração dos sujeitos num todo mais vasto e numeroso teria permitido a conquista da natureza e a construção de um "ambiente de paz e disciplina para o trabalho”.

De maneira semelhante, Azevedo Amaral, outro importante ideólogo do Estado Novo, procurava apresentar o indivíduo como um ser limitado, ao passo que a coletividade figurava como atemporal e infinita; ela se prolongaria ao longo dos séculos, desde os "primórdios" da nacionalidade até o momento de enunciação do articulista ${ }^{419}$. Ainda por esse ângulo, tomava o individualismo como sinônimo de primitivismo, de retrocesso a tempos de selvageria, tendo em vista seu interesse em afirmar o predomínio da noção de bem coletivo, num contexto de rebaixamento da liberal-democracia.

O conceito de "realismo político", recorrentemente utilizado pela retórica estadonovista, assentava-se sobre tais valores. Mediante ao estabelecimento de um contato quase mediúnico com o "espírito nacional”, o governo se auto-imputava a condição de salvador e recuperador das tradições nacionais, o que lhe permitiria, segundo este raciocínio, entrar em contato direto com as necessidades e as aspirações do povo. Portanto, observa-se que o privilégio discursivo concedido à coletividade funcionava como contraponto ao "idealismo" administrativo atribuído ao regime liberal:

\footnotetext{
A substituição do velho ideal liberal-democrático por um critério realista de governo resultou da compreensão de que o idealismo político só traz decepções e falências desastrosas. As idéias que dirigem os povos não nascem de meditações filosóficas, nem de explosões sentimentais: nascem da vida, nascem ao calor do sangue humano ardendo nas veias dos povos viris, que, antes de preocupar-se com fórmulas e ideais românticos, sabem reconhecer o que precisam, o que lhes falta, o que lhes é imprescindível para viver, trabalhar e produzir ${ }^{420}$.
}

Por essa lógica, enquanto o Estado Novo esforçava-se por se adaptar às "mutações sucessivas do fluxo da história”, os governos da Primeira República teriam se agarrado a conceitos “eternos” e “imutáveis”, e, por conseguinte, “falsos” e “artificiais”, pois não estariam adaptados à vida nacional. Nesse sentido, como sublinha Amaral, a ditadura varguista apresentava-se como mais verdadeira, pois deixara de lado o apriorismo ideológico das idéias

\footnotetext{
${ }^{419}$ AMARAL, Azevedo. Realismo político e democracia. Cultura Política, Rio de Janeiro, ano 1, n.1, mar. 1941.

${ }^{420}$ ANDRADE, Almir. op.cit. p.15-16.
} 
universais e abstratas do liberalismo para privilegiar "as exigências da realidade social, coloridas pelos traços do psiquismo particular do período a que correspondem»²1.

Segundo a ótica do regime, o desprezo pela vida nacional e o individualismo eram noções conexas. Nesse sentido, a democracia liberal figurava como uma forma de governo contrária à coletividade, que, astuciosamente, teria imposto a vontade de um pequeno grupo como correspondente aos anseios de toda a sociedade. Para Amaral, o sufrágio universal e a representatividade dos partidos políticos, instituições que fundamentavam esse sistema de governo, estavam na base do conceito "ficcional” de "governar-se a si próprio” propalado pelo liberalismo. Com isso, o povo se imaginava participando do poder quando, na verdade, o comando do país permanecia nas mãos de uma casta dirigente.

Amaral sublinha ainda que o liberalismo, na medida em que reivindicava a condição de promotor da igualdade entre todos os cidadãos, procurava se apresentar como a forma ideal e perfeita de organização política a ser implantada por todos os países que atingissem determinado nível de “cultura e civilização”. E, dessa maneira:

As nações influenciadas pelas correntes intelectuais coloridas por tendências liberais, foram, uma após a outra, copiando as instituições que se lhe apresentavam como modelos padronizados de governo popular. Na grande maioria dos casos, essa adaptação artificial de um regime incompatível com a realidade nacional agravou os vícios essenciais da democracia liberal, com males decorrentes do conflito entre as condições peculiares de cada povo que fazia essa experiência e certos aspectos das instituições arbitrariamente introduzidas ${ }^{422}$.

Em sentido contrário, a democracia proposta pelo articulista, fundada numa perspectiva ao mesmo tempo nacionalista e anti-liberal (e, por isso, realista, segundo suas postulações) deveria apresentar um sentido econômico e coletivo, cabendo ao Estado regular os interesses dos diferentes grupos privados, bem como coordenar a distribuição da riqueza a toda a sociedade $^{423}$.

Nesse sentido, a prevalência do social sobre o individual funcionava como estratégia de legitimação do governo golpista, pois justificava a supressão de antigos direitos fundamentais,

\footnotetext{
421 AMARAL, Amaral. op.cit. p.169.

422 Idem, p.167.

${ }^{423}$ Idem, p.171.
} 
norteadores do liberalismo, especificamente a liberdade e a igualdade. No lugar deles, emergia uma noção de justiça social ${ }^{424}$, tutelada e gerida pelo Estado. De acordo com tal perspectiva, caberia ao regime exprimir tudo o que fosse fundamentalmente social no homem, colocando-se acima dos interesses individuais, na defesa das aspirações populares. Por outro lado, essa diretriz previa que a realização pessoal confundia-se com a promoção do bem-estar coletivo empreendida pelo governo, o que pressupunha, por sua vez, um processo de estatização do ideal de auto-realização do homem, bem como a politização da esfera privada $^{425}$.

Ao mesmo tempo, proclamava-se que o verdadeiro problema do país não seria a falta de liberdade, mas sim a pobreza (necessidade). Logo, caberia ao regime intervir na ordem econômica e social e reverter esse quadro. O progresso só seria atingido por meio da valorização, do estímulo e da criação de condições favoráveis ao incremento do trabalho. Em contrapartida, só era considerado cidadão (ou seja, digno de receber o amparo estatal) aquele que se mostrasse socialmente útil à coletividade, pois se tomava o trabalhador como responsável não só por sua própria riqueza, como também pelo progresso da nação.

Dessa maneira, a reivindicação de “realismo político” por parte do governo englobava também certa noção de cotidianidade, a qual definia o trabalhador anônimo como principal destinatário das políticas públicas. Um dos fins “naturais” do Estado seria o de se aproximar das necessidades de todos os cidadãos, ao invés de colocar-se a serviço de grupos, classes ou refugiar-se em "ideais abstratos e soluções alheias às grandes exigências da vida social”426.

O homem comum é o material vivo que faz a riqueza das nações. É a realidade concreta de todos os dias; é a soma de todos os homens que concorre para o progresso coletivo (...) - [ele] é a própria razão de ser do Estado, que só se criou para beneficiá-lo, para ampará-lo, para aperfeiçoá-lo, para engrandecê$10^{427}$.

\footnotetext{
${ }^{424}$ GOMES, Ângela de Castro. O redescobrimento do Brasil. In: OLIVEIRA, Lúcia Lippi et al. Estado Novo: ideologia e poder. Rio de Janeiro: Zahar Editores S.A., 1982, p.129.

${ }^{425}$ Diz ainda Almir de Andrade: “É a sociedade que torna o homem bom. Ele não 'nasce' bom, como queria Rousseau. É o hábito da disciplina, das restrições individuais impostas pelo bem comum, da compreensão dos direitos e atribuições dos outros indivíduos, da interdependência natural entre os seres - que faz do homem egoísta e ambicioso um homem justo, nobre e altruísta” (ANDRADE, Almir. op.cit. p.152).

${ }^{426}$ ANDRADE, Almir. op.cit. p.205.

${ }^{427}$ Idem, ibidem.
} 
Portanto, a crítica ao individualismo passava pela exaltação do trabalho e pelo tratamento da coletividade como uma ordem social hierarquizada, sob o controle do Estado. Ao mesmo tempo, previa-se que o cidadão não seria mais detentor de diretos civis e políticos, mas sim de direitos sociais $^{428}$, desde que trabalhasse em prol do bem-comum. Constrói-se, assim, um movimento de mão dupla: se por um lado, o trabalhador, em teoria, participa da sociedade e se relaciona com o governo através dos sindicatos, no assimétrico sistema corporativo criado, por outro, o regime, supostamente, humanizar-se-ia ao criar um ambiente propício às atividades produtivas e ao desenvolvimento das potencialidades de cada pessoa, considerada a partir da idéia de bem-estar comum. Como efeito, tal argumentação procurava autenticar o Estado Novo na medida em que o apresentava como agente responsável pela organização do povo brasileiro em nação e pelo desenvolvimento social e econômico do país.

Concluindo, apesar dos objetivos totalmente diferentes de ideólogos estadonovistas e escritores nordestinos (os primeiros buscavam construir as bases para a justificação ideológica do Estado autoritário e os segundos, manter a posição destaque alcançada no campo literário), são similares os tratamentos conferidos por ambos aos conceitos de "indivíduo" e “coletividade”, como forma de legitimarem suas propostas. Enquanto esta última noção, numa abordagem predominantemente sociológica, era sinônima de "realismo" e apego às "raízes” da nacionalidade, aquela, por oposição, significava “artificialismo” e “absenteísmo”, seja nas realizações políticas ou literárias.

De maneira geral, ambos os atores (regime e escritores) apontavam que o remédio tanto contra o individualismo pernicioso como contra a cópia de figurinos políticos importados, encontrava-se na valorização das matérias brasileiras, mais especificamente das manifestações populares. Por esta perspectiva, o nacionalismo e o interesse pela coletividade, ao se contraporem à "universalização abstrata e artificial” promovida pela liberal-democracia e pelos romances intimistas, forneceriam a medida do "realismo” das realizações tanto administrativas como artísticas.

\footnotetext{
428 Tal noção levava em conta uma ampla gama de aspectos que influiriam na capacidade produtiva dos trabalhadores e que teriam recebido atenção especial do regime: saúde (destaque para os seguros e a medicina no cuidado “da mente e do corpo dos cidadãos”), educação, habitação (atenção para Liga Nacional Contra o Mocambo e para os planos de construção de casas populares, alavancados por Institutos e Caixas de Pensões), alimentação (criação do Serviço de Alimentação da Previdência Social), entre outros.
} 


\section{Cultura Política e seu discurso}

Além de ter em vista os princípios que orientaram a escrita de Graciliano (as noções a partir das quais se pode extrair um código organizador de seu pensamento artístico), faz-se necessário, paralelamente, considerando-se a idéia de que o meio participa da constituição da mensagem $^{429}$, analisar os diferentes enquadramentos discursivos conferidos pela revista Cultura Política aos “Quadros e Costumes do Nordeste”, ou seja, cabe verificar o sentido e as diretrizes de leitura atribuídas aos textos do autor alagoano pela retórica getulista.

Conforme sublinha Chartier, referindo-se à história do livro, os textos não existiriam fora dos suportes materiais por meio dos quais foram veiculados, pois a construção de seus significados estaria diretamente ligada às formas que permitiriam sua leitura, audição ou visão $^{430}$. Advogando contra certa atitude analítica que desconsideraria tal materialidade das obras, o estudioso ressalta que a dupla historicidade das mesmas deveria ser respeitada, ou seja, conviria não esquecer o fato de elas terem sido publicadas num momento e num meio editorial específicos. Esse procedimento, por sua vez, ajudaria a evitar interpretações anacrônicas, as quais, em regra, acabariam por desfigurar os textos analisados, impondo-lhes formas e sentidos que lhes seriam totalmente estranhos ${ }^{431}$.

Nesse sentido, também como forma de se evitar uma leitura abstrata e desistoricizada dos quadros nordestinos do autor, impõe-se examinar de maneira detida a ambiência estadonovista que lhes serviu de suporte inicial, reconstruindo-se assim a situação em que os mesmos foram produzidos, veiculados e recebidos. Em linhas gerais, tal atividade corrobora a

\footnotetext{
${ }^{429}$ Conceito tratado por Marshall McLuhan, em Os meios de comunicação como extensões do homem (1964). Neste livro, o pesquisador, levando em conta as possibilidades proporcionadas, sobretudo, pelas "mídias" contemporâneas (destaque para o rádio e para a TV), afirma que se tornava cada vez mais evidente, nos estudos empreendidos, examinar não só o que se diz (o conteúdo), mas a maneira como se diz determinada mensagem, ou seja, o modo como esta era apresentada pelos diferentes veículos, bem como as implicações sociais e psíquicas envolvidas no processo comunicativo.

${ }^{430}$ CHARTIER, Roger. “A mediação editorial”. In: Os desafios da escrita. São Paulo: Editora UNESP, 2002, p.62

${ }^{431}$ Segundo Chartier, essa perspectiva analítica que separaria o estudo "das condições técnicas e materiais de produção ou difusão de objetos impressos" dos textos por eles transmitidos decorreria, entre outros aspectos, da invenção do copyright, da oposição filosófica e poética entre a pureza da idéia e sua corrupção pela matéria e da estética que privilegia apenas o exame do conteúdo das obras em detrimento da forma. "Não há dúvida nenhuma de que são as possibilidades de reprodução oferecidas pela invenção de Gutenberg, assim como a dispersão do texto impresso em múltiplos estados que, nos raciocínios neoplatônicos, conduziram as justificativas da propriedade literária ou as categorias do julgamento de gosto à abstração dos discursos” (Idem, p.62-63).
} 
recuperação das coordenadas do debate cultural do qual essas narrativas gracilianas participavam, ampliando e especificando, assim, o trabalho realizado no capítulo anterior.

\subsection{O Departamento de Imprensa e Propaganda}

Contudo, antes de tratar especificamente da publicação getulista, na qual foram estampados os “Quadros e Costumes do Nordeste” de Graciliano Ramos, convém realizar uma rápida incursão pelo histórico e pelas atribuições do Departamento de Imprensa e Propaganda (DIP). Como se sabe, este órgão foi responsável, simultaneamente, pela difusão, controle e elaboração do projeto político-ideológico governamental, que tinha em Cultura Política um de seus principais expoentes. O objetivo deste capítulo é fornecer a moldura histórica e interpretativa em que se pode localizar e entender o papel desempenhado pela revista e, por conseguinte, pelos escritos do autor de Vidas Secas nela publicados.

De início, vale lembrar que o DIP foi criado por decreto presidencial em dezembro de 1939, num contexto de ampliação do aparelho estatal, tendo em vista as diretrizes centralistas e autoritárias do regime. Sua função primordial era concentrar e coordenar a veiculação da ideologia estadonovista para os diferentes segmentos da sociedade, visando à construção do consenso em torno do novo governo. Nesse sentido, dirigia-se tanto a estratos mais populares como a grupos mais abastados. Aos primeiros, procurava construir a imagem de uma sociedade homogênea, negando a problemática de classe e destacando o trabalho como fator basilar da dignidade humana. Aos segundos, pretendia enfatizar o caráter inovador do governo, bem como a adequação deste tanto à “alma do país” como a um cenário internacional de falência do liberalismo. Segundo sua perspectiva, o Estado Novo colocava-se como uma resposta autenticamente nacional frente à situação catastrófica pela qual o mundo passava.

Apesar de ter sido criado oficialmente no final de 1939, por meio do decreto-lei $\mathrm{n}^{0} 1915$, as origens DIP remontavam a um período anterior. Ele representou o ponto culminante de uma trajetória ascendente de controle dos meios de comunicação pelo Estado ao longo dos anos de 1930. Logo depois da chegada vitoriosa de Getúlio ao Catete, em 1931, foi criado o Departamento Oficial de Publicidade (DOP), com a finalidade de divulgar e esclarecer os atos do governo provisório. Em 1934, substitui-se o DOP pelo Departamento de Propaganda e Difusão Cultural (DPDC), tendo em vista a preocupação estatal em sistematizar, organizar e 
ampliar suas iniciativas no setor. Segundo destaca José Inácio de Melo e Souza, além de fornecer dados e informações à imprensa, competia ao novo órgão:

o estudo do cinema, do rádio e demais processos técnicos como instrumento de difusão; estimular a produção, a circulação e a exibição dos filmes educativos para difusão; orientar a cultura física e realizar a censura por meio de uma comissão com representantes do Ministério da Justiça, da Educação, do Juizado de Menores, da Associação Cinematográfica dos Produtores Brasileiros e pelo chefe da seção competente no DPDC ${ }^{432}$.

Depois do golpe de novembro de 1937, tendo em vista a ampliação da atividade censória a todos os meios de comunicação pelas determinações da nova constituição, o DPDC transformou-se no Departamento Nacional de Propaganda (DNP), que finalmente deu lugar ao Departamento de Imprensa e Propaganda. Ao longo dessa trajetória institucional, a presença do jornalista e escritor Lourival Fontes a frente dos diferentes órgãos, voltados à publicidade governamental, foi marcante. Ele assumiu tais atribuições em 1934 e manteve-se no comando das sucessivas agências estatais até 1942, quando seria demitido da direção do $\mathrm{DIP}^{433}$. Admirador do fascismo e casado com a poetisa Adalgisa Nery, ele colocou-se como um dos principais agentes no estreitamento de laços entre governo e intelectualidade durante os anos de 1930 e 1940, contribuindo ativamente para a construção do consenso em torno do novo governo. Tome-se, ainda em 1936, uma declaração de Lourival à imprensa sobre as atribuições do DPDC e seu caráter nacionalista:

\begin{abstract}
Vulgarizamos não só as realizações do governo como também procuramos esclarecer a opinião pública sobre certos problemas do momento (...) E, assim, pelo rádio, pela imprensa e pelo cinema estamos realizando uma obra duradoura, patriótica e sincera - cuja finalidade superior consiste justamente no ideal que todos devemos cultuar de tornar o Brasil conhecido no Mundo inteiro ${ }^{434}$.
\end{abstract}

Com o passar dos anos, o poder, o prestígio, a abrangência e a amplitude de atuação da propaganda governamental só aumentaram. Enquanto seus antecessores estavam

432 SOUZA, José Inácio de Melo. O estado contra os meios de comunicação (1889-1945). São Paulo: Annablume/Fapesp, 2003, p.84.

${ }^{433}$ Uma curiosidade. Em 1934, Getúlio Vargas destaca em seu diário que chegou a convidar Monteiro Lobato para a direção do Departamento de Propaganda e Difusão Cultural, mas este recusara o pedido: "Chamei o escritor Monteiro Lobato para entregar-lhe a direção do Serviço de Propaganda, mas encontrei-o muito absorvido pelas suas sondagens em busca do petróleo" (VARGAS, Getúlio. Getúlio Vargas: diário. 2.v. São Paulo: Siciliano; Rio de Janeiro: FGV, 1995 p.341). Conforme destaca a historiadora Tania Regina de Luca fora essa recusa, conjugada às críticas à política adotada pelo Conselho Nacional de Petróleo, que levaram o autor de Urupês a ser encarcerado pelo regime no início dos anos 1940. Ver: LUCA, Tania Regina. Coerção e persuasão no Estado Novo. São Paulo, BrHistória, ano 1, n.5, [?], p.26.

${ }^{434}$ In: LUCA, Tania Regina. op.cit. p.26. 
subordinados ao Ministério da Justiça, o DIP, quando da sua criação, vinculava-se diretamente ao gabinete da presidência da República. Tal proximidade ao centro do poder, no contexto de um Estado autoritário, já dá mostra de seu caráter estratégico. Além disso, institucionalmente, ele apresentava uma estrutura extremamente hierarquizada e organizada, espelhando a organicidade pretendida pelo regime. Para tanto, contava com setores de divulgação, radiodifusão, teatro, cinema, turismo e imprensa. Nesse sentido, suas atribuições eram vastas. Além de coordenar, orientar e centralizar a propaganda interna e externa e servir de agente complementar à informação, cabia-lhe fazer censura prévia à imprensa, teatro, cinema, diversões públicas, esportes, literatura social e política, entre outras manifestações. Suas funções não paravam por aí: responsabilizava-se ainda pela promoção, organização e patrocínio de manifestações cívicas, festas patrióticas, exposições, concertos, conferências, e pela direção da Hora do Brasil e pela produção do Cine Jornal Brasileiro, respectivamente programas de radiodifusão e cinema oficiais do governo.

Por desempenhar tão amplas e diversificadas funções, além de centralizar todos os órgãos de propaganda e publicidade pertencentes ao Estado ${ }^{435}$, o DIP acabou se transformando numa espécie de superministério. Ironicamente, sua sede ficava no Palácio Tiradentes, ex-sede da Câmara dos Deputados, no Rio de Janeiro. No entanto, seu raio de ação não se restringia aos limites da capital federal; sua presença expandiu-se pelo território brasileiro com a criação de departamentos estaduais de mesmo teor, os DEIPs. Tais ramificações, por sua vez, subordinavam-se diretamente à agência central, que definia as políticas e as linhas de ação a serem adotadas. Vista em conjunto, essa estrutura altamente hierarquizada permitia ao governo, exercer o controle nacional da informação, assegurando-lhe, em certa medida, o domínio da vida cultural do país ${ }^{436}$.

No que diz respeito à censura prévia exercida pelo órgão, ela se enquadrava dentro dos marcos definidos pela Constituição de 1937, especificamente seu artigo 122, que oficializava o controle dos meios de comunicação pelo governo como forma de garantir a paz, a ordem e a

\footnotetext{
435 Segundo o art. 19 do decreto de criação do DIP, cabia-lhe realizar todos os serviços de propaganda e publicidade dos ministérios e de quaisquer outros departamentos e institutos vinculados à administração pública federal, bem como de entidades autárquicas. Nesse sentido, procurava exercer um controle amplo sobre todas as ações e informações produzidas pela burocracia estatal.

${ }^{436}$ No entanto, como aponta o historiador José Inácio de Melo e Souza, os DEIPs, com exceção do de São Paulo, tiveram uma trajetória dificultosa. Devido à demora na sua implantação, Vargas teria sido forçado a decretar, em novembro de 1942, o prazo limite de 120 dias para a efetiva regionalização do DIP, reservando-se $0,5 \%$ do orçamento estadual para o funcionamento dos departamentos subsidiários.

SOUZA, José Inácio de Melo. op.cit. p.110.
} 
segurança nacional. Ao mesmo tempo, fixava-se que o Estado poderia proibir a circulação, difusão ou representação (no caso das peças de teatro) daquilo que considerasse impróprio. No entanto, tais marcos jurídicos que permitiam o controle da imprensa iam além. Num contexto antiliberal, a nova Carta Constitucional passava a considerá-la como um serviço de utilidade pública, o que redefinia seu caráter e suas atribuições; as notícias e informações passavam a ser tomadas como elementos para o desenvolvimento e modelagem da “consciência nacional”, segundo a perspectiva do regime. Diante desse cenário, o DIP passara a exercer o monopólio sobre os veículos informativos, "procurando garantir a uniformidade das mensagens e eliminar a contra propaganda, para que os efeitos da comunicação se ampliassem״ ${ }^{\text {437 }}$. A censura era feita, inicialmente, de forma presencial, por meio de figuras que atuavam diretamente nas redações, e, depois, por telefone. Havia a ainda a divulgação de boletins que, de forma preliminar, preveniam as publicações sobre assuntos proibidos, bem como os informava sobre o tratamento que deveria ser dado a determinados temas.

Nessa iniciativa de propaganda e uniformização das informações veiculadas pela imprensa, tinha grande peso o trabalho realizado pela Agência Nacional. Ela funcionava como uma espécie de jornal diário no interior do DIP, produzindo o noticiário oficial, que era distribuído gratuitamente aos veículos de comunicação de todo o país ${ }^{438}$. Na verdade, tratava-se de matérias subvencionadas, voltadas à propaganda do regime. Estas eram difundidas nacionalmente tendo em vista a abrangência de atuação do órgão, a facilitação do trabalho jornalístico proporcionada ${ }^{439}$ e as imposições de conteúdo prescritas pelo governo. Estima-se que $60 \%$ dos textos publicados teriam sido fornecidas pela agência.

Ainda havia mais. O controle exercido sobre a imprensa escrita ocorria ainda por outras vias. Os periódicos impressos eram obrigados a se registrarem no Conselho Nacional de Imprensa (CNI), bem como os trabalhadores do meio: jornalistas, fotógrafos, ilustradores e revisores. No que diz respeito aos veículos, especificamente, há estimativas de que em 17 meses de

\footnotetext{
${ }^{437}$ GUIMARÃES, Silvana Goulart. Sob a verdade oficial: ideologia, propaganda e censura no Estado Novo. São Paulo: Marco Zero; Programa Nacional do Centenário da República e Bicentenário da Inconfidência Mineira: MCT/CNPq, 1990, p.21.

${ }^{438}$ Como mostra de suas proporções significativas, em 1941, a Agência já contava com 220 funcionários, trabalhando em sua sede carioca. Nesse mesmo ano, o volume de material produzido pelo órgão fora o seguinte: fotografias (20 mil para os jornais cariocas e do interior, 14 mil para revistas e outras 14 mil para "diversos destinos"), notícias (13 mil para jornais do Rio), informes, comunicados, telegramas expedidos etc. In: SOUZA, José Inácio de Melo. op.cit, p.139.

${ }^{439}$ Por mais que se tratasse, quase sempre, de notícias elogiosas ao Estado Novo e a seus representantes, os periódicos as recebiam de graça.
} 
funcionamento do órgão, 645 deles não conseguiram obter a autorização necessária e deixaram de $\operatorname{circular}^{440}$. Havia também as pressões econômicas exercidas sobre jornais, revistas e outras publicações quando da importação de papel. Às publicações que colaboravam com o governo era conferida isenção de taxa alfandegária sobre o produto. Enquanto isso, as demais deveriam pagar tarifas aduaneiras elevadas, no prazo de 24 horas, o que dificultava a empreitada editorial.

Além das tarefas coercitivas de censura, coube ao DIP sistematizar o conjunto de idéias e noções que embasavam e sustentavam o arcabouço político e ideológico do Estado. Tal tarefa dava-se, sobretudo, por meio da utilização da palavra escrita seja em livros, seja em periódicos, seja em outros materiais editados pelo órgão, nos quais a participação da intelectualidade foi intensa. Nesse processo, apesar das recorrentes iniciativas propagandísticas, visando conquistar o apoio dos trabalhadores urbanos, as elites constituíamse nos principais destinatários do discurso estadonovista. Daí o privilégio para tais publicações impressas na elaboração e difusão da doutrina consolidada pelo regime. Segundo Maria Helena Capelato, o foco no topo da sociedade tinha sua razão de ser no fato de que a necessidade de apoio popular era secundária para um regime instaurado a partir de um golpe, o qual contou, para tanto, com o apoio dos próprios grupos dominantes e das Forças Armadas $^{441}$.

O movimento editorial foi intenso. Quanto aos livros, foram publicadas, entre outras, cartilhas, monografias, trabalhos vencedores de concursos e inúmeros estudos patrocinados pelo DIP que, em geral, abordavam diferentes aspectos da história e da cultura brasileiras por um viés nacionalista. Tais materiais ainda procuravam justificar o golpe de 1937 ou louvar as realizações do regime e a figura de seu líder. Com relação a este último aspecto, os títulos de algumas obras já servem para indicar o esforço de inculcação e construção de legitimidade empreendido pelo órgão: Getúlio Vargas: o amigo das crianças $^{442}$; $O$ sorriso do presidente Vargas $^{443}$; Getúlio Vargas: estadista, orador e homem de coração ${ }^{444}$; Getúlio Vargas e a

\footnotetext{
${ }^{440}$ Idem, p.137.

${ }^{441}$ CAPELATO, Maria Helena. Multidões em cena. Campinas: Papirus, 1998. p.57. Como destaca a historiadora, esse era o cenário dominante nos primeiros anos de Estado Novo. No entanto, tal situação vai mudando com o passar dos anos. Diante de crises internas (sobretudo a partir de 1942, em virtude da profusão de manifestações favoráveis a entrada no Brasil na guerra, em apoio aos Aliados), o regime se viu obrigado, a estabelecer, progressivamente, um contato mais direto com as massas. A partir daí, ganha mais ênfase a política trabalhista.

${ }^{442}$ VARGAS, Getúlio. Getúlio Vargas: o amigo das crianças. Rio de Janeiro: DIP, 1940.

${ }^{443}$ ROBERTO, P. O sorriso do presidente Vargas. Rio de Janeiro: Olímpica, s.d.

${ }^{444}$ DINIZ, Zolachio. Getúlio Vargas: estadista, orador e homem de coração. Rio de Janeiro: Século 20, 1942.
} 
inteligência nacional ${ }^{445}$; Getúlio Vargas e a arte no Brasil ${ }^{446}$; O Brasil em marcha ${ }^{447}$; O Brasil na posse de si mesmo ${ }^{448}$. Quanto às revistas, a atuação dipiana também foi ampla. A lista de periódicos criados incluía Cultura Política, Estudos e Conferências, Brasil Novo, Brasil reportagens, Dos jornais, Planalto e Política ${ }^{449}$, sem esquecer também de Ciência Política, sob a responsabilidade do Instituto Nacional de Ciência Política, que também se dedicou à construção e à difusão das diretrizes e postulados estadonovistas.

Ainda no que diz respeito à construção do ideário político-ideológico estadonovista por meio da imprensa escrita, ocuparam importante papel os jornais diários $A$ Noite, de São Paulo e $A$ Manhã, do Rio de Janeiro ${ }^{450}$. Eles se comportavam como autênticos porta-vozes oficiais do governo e, cada qual, era comandado por um destacado poeta modernista; o primeiro foi dirigido por Menotti del Picchia e o segundo por Cassiano Ricardo. Ambos os periódicos, a partir de 1940, passaram a fazer parte das Empresas Incorporadas da União, no do processo de estatização conduzido pelo regime. O mesmo ocorrera com a Rádio Nacional e a Rádio Mauá $^{451}$. Em tais moldes, a centralização da informação é colocada como uma forma de consultar diretamente o povo, num contexto em que o Legislativo, bem como os partidos políticos deixaram de existir em função de suas supostas deficiências e anacronismos.

O privilégio conferido à imprensa escrita ao longo deste trabalho justifica-se seja pela delimitação de seu objeto, seja por seus objetivos, seja por seus fins. Mas isso não quer dizer que os outros meios de comunicação (rádio, cinema, teatro, música etc.) não tiveram destaque no interior da máquina propagandística estadonovista. Muito pelo contrário. No entanto, em consonância com a hipótese da historiadora Mônica Pimenta Velloso, considera-se, aqui, que os discursos veiculados pelas diferentes mídias tinham sua matriz nas publicações impressas, tidas como produtoras e difusoras por excelência do ideário do regime ${ }^{452}$. Por conferirem maior prestígio pessoal a seus colaboradores, quase sempre provenientes de uma tradição bacharelesca, eram nelas que se encontravam os grandes intelectuais vinculados ao governo.

\footnotetext{
${ }^{445}$ CAMARGO, J. Getúlio Vargas e a inteligência nacional. Rio de Janeiro: Olímpica, s.d.

${ }^{446}$ TEIXEIRA, Oswaldo. Getúlio Vargas e a arte no Brasil. Rio de Janeiro: DIP, 1940.

${ }^{447}$ AQUILES, Paulo. O Brasil em marcha. Rio de Janeiro: José Olympio, 1943.

${ }^{448}$ PADILHA, J. O Brasil na posse de si mesmo. Rio de Janeiro: DIP, s.d.

449 Tanto Política quanto Planalto foram editadas pelo Departamento de Imprensa e Propaganda de São Paulo.

${ }^{450}$ GARCIA, Nelson Jahar. Estado Novo: ideologia e propaganda política. São Paulo: Loyola, 1982. p.102.

${ }^{451}$ Segundo o artigo 19, do decreto lei 2073, de 8 de março de 1940, eram incorporadas ao Patrimônio da União “todo o acervo das Sociedades A Noite, Rio Editora e Rádio Nacional.” (Diário Oficial, 9 março de 1940).

452 OLIVEIRA, Lúcia Lippi; VELLOSO, Mônica Pimenta; GOMES, Ângela Maria de Castro. Estado Novo: ideologia e poder. Rio de Janeiro: Zahar Ed.,1982, p.73.
} 
Tais figuras assumiram o encargo de definir as bases sobre as quais se assentava o projeto político e ideológico do Estado, algo reforçado pela conformação autoritária, elitista e centralizadora que orientava as diretivas estadonovistas.

De qualquer maneira, vale mencionar, de passagem, o papel desempenhado pelo rádio na consolidação do ideário getulista ${ }^{453}$. Este veículo, que foi se firmando como um dos principais meios de comunicação de massa na década de 1940, teve significativa importância no processo de popularização do regime. Isso porque era consumido não só pelos moradores dos grandes centros urbanos, como por habitantes de pequenas cidades do interior e das zonas rurais. Nesse sentido, exerceu relevante influência na integração e na uniformização das propostas políticas, culturais, lingüísticas e educativas veiculadas pelo regime, encurtando distâncias e minimizando diferenças regionais, de acordo com o seu projeto nacionalizador ${ }^{454}$. Tal homogeneização atendia também aos propósitos orgânicos e centralistas colocados em prática pelo Estado Novo.

Produzida pelo DIP e retransmitida obrigatoriamente por todas as emissoras do país, A Hora do Brasil procurava materializar tais objetivos. Além de divulgar medidas, atos governamentais e o noticiário em geral, o programa apresentava uma série de crônicas destinadas a tratar da evolução econômica, política e cultural ou de aspectos do passado brasileiro, mais precisamente de datas e heróis representativos para a nacionalidade. Juntamente com as notícias, eram anunciados os vencedores dos concursos musicais promovidos pela Rádio Nacional, dos quais participavam famosos cantores da época, como Carmem Miranda e Francisco Alves. Tal estratégia, de mesclar a veiculação de informações e mensagens oficiais com a divulgação dos resultados dos certames, que movimentavam a opinião pública, pode ser tomada como um meio de tornar as transmissões mais atraentes e manter a audiência popular. Nesse sentido, o DIP passava a fazer uma série de entrevistas

\footnotetext{
${ }^{453}$ Entre outras, pode-se citar também as ações do governo nos campos do cinema e da música. No primeiro, a principal iniciativa foi a realização do Cine Jornal Brasileiro, um documentário em curta-metragem, com exibição obrigatória antes da programação usual dos cinemas. Ele trazia cenas da vida política nacional, com destaque para atos e realizações do governo, sobretudo do presidente e de seus principais ministros: inauguração de obras, cerimônias oficiais, desfiles militares etc. Além disso, abordava temas como "a vida econômica nacional, as cidades brasileiras, as visitas de presidentes e personalidades estrangeiras, as diversas modalidades de esporte, as procissões, as romarias e festas populares” (GUIMARÃES, Silvana Goluart. op.cit. p.25). No que diz respeito ao universo musical, tornaram-se notórias as interferências do governo na reorientação dos temas de certos sambas. A malandragem e a vida boêmia passaram a ser preteridas por canções ufanistas da brasilidade e por aquelas que exaltavam o trabalho. (Ver: CUNHA, Fabiana Lopes da. Da marginalidade ao estrelato: o samba na construção da nacionalidade (1917-1945). São Paulo: Annablume, 2004).

${ }^{454}$ GUIMARÃES, Silvana Goulart. op.cit. p.19.
} 
radiofônicas com o povo, inquirindo-o sobre as medidas e realizações do regime. Seu objetivo com essa iniciativa era o de substituir os longos e monótonos discursos pelo "depoimento vivo” da sociedade. Construía-se, assim, o efeito de que o Estado Novo deixava de emitir sozinho sua fala, passando a privilegiar o "locutor-povo"

A construção dessa aproximação, via A Hora do Brasil, muitas vezes assumia um caráter deliberadamente pedagógico, como quando a partir de 1942, o Ministro do Trabalho, Alexandre Marcondes Machado Filho, passou a proferir palestras semanais com o intuito de explicar aos ouvintes os avanços realizados pelo Estado Novo no campo da legislação social e trabalhista. Em regra, nesse empreendimento, que procurava unir governo e classe trabalhadora, as conquistas sociais eram apresentadas, quase sempre, como fruto da iniciativa pessoal do presidente.

De maneira geral, o DIP trabalhou ativamente na construção e na celebração do mito Vargas, apresentado como um "homem providencial” que "encarnava” o destino e as aspirações da brasilidade. Além da larga exposição do presidente nos mais variados suportes e meios de comunicação (marchinhas carnavalescas, cartilhas, livros, notícias impressas, programas radiofônicos, teatro de revista, documentários cinematográficos etc.), tal propaganda se complementava com as diferentes comemorações, promovidas pelo Estado. Elas procuravam criar um efeito de proximidade e comunhão entre governante e governados. "As grandes concentrações populares em estádios e praças, com desfiles de estudantes, pontuadas por discursos, homenagens, saudações criavam um clima apoteótico de euforia e aprovação do regime”, ${ }^{456}$.

O próprio aniversário do presidente, no dia 19 de abril, passou a fazer parte do rol festivo do governo, que incluía o Dia do Trabalho, Independência, implantação do Estado Novo, Natal, Ano Novo, entre outras celebrações. Além disso, o chefe da Nação tornou-se uma figura praticamente “onipresente”. Sua foto oficial era exposta em todos os espaços públicos: repartições, escolas, aeroportos, bancos, casas comerciais etc. Tanto que um estrangeiro, de passagem pelo país, reportou a seguinte anedota: “O que sobra no açougue quando não há

\footnotetext{
${ }^{455}$ VELLOSO, Mônica Pimenta. Os intelectuais e a politica cultural no Estado Novo. In: FERREIRA, Jorge; NEVES, Lucília de Almeida (orgs). O Brasil Republicano. 1 ed. livro 2. Rio de Janeiro: Civilização Brasileira, 2003, v. 2, p. 160.

${ }^{456}$ GUIMARÃES, Silvana Goulart. op.cit. p.23.
} 
mais carne? O retrato de Vargas”457. Metonimicamente, tal conjunto de elementos servia para mostrar a força, influência e abrangência do regime em sua empreitada de apresentar sistematicamente, aos diferentes setores da sociedade, seus pressupostos centralistas, autoritários e nacionalistas.

\subsection{Outras publicações estadonovistas}

A fim de confirmar a primazia de Cultura Política na consecução do projeto políticoideológico estadonovista, cabe analisar de forma breve o caráter e as finalidades de outras publicações também criadas ou financiadas pelo Departamento de Imprensa e Propaganda e por seu braço paulista, o Departamento Estadual de Imprensa e Propaganda de São Paulo. O numero de revistas ou simples boletins informativos é extenso. Entre eles pode-se listar: Brasil Novo, Brasil de hoje, ontem e amanhã, Estudos e conferências, Ciência Política, São Paulo de hoje, ontem e amanhã, Planalto, Dos jornais, Política e Brasil Reportagens. Como visto acima, havia ainda dois jornais diários: A Manhã e A Noite que circulavam no Rio de Janeiro e em São Paulo, respectivamente ${ }^{458}$.

Brasil Novo foi lançada em novembro de 1938, quando a coordenação da propaganda política do Estado ainda estava a cargo do Departamento Nacional de Propaganda, antecessor do DIP. Contava para isso com o apoio do Departamento de Propaganda e Publicidade (DEIP) da capital paulista. Ela circulou com periodicidade inconstante e formato irregular até janeiro de $1941^{459}$. Era impressa em rotogravura e podia chegar a quase cem páginas, como ocorrera com a edição de janeiro de 1941 , seu sexto número ${ }^{460}$.

\footnotetext{
${ }^{457}$ Depoimento de Louis Jouvet, ator e diretor da companhia teatral L’Athénée-Louis Jouvet, quando de sua visita ao país em 1941. In: ROLLAND, Denis. O estatuto da cultura no Brasil do Estado Novo: entre o controle das culturas nacionais e a instrumentalização das culturas estrangeiras. In: BASTOS, Elide Rugai; RIDENTI, Marcelo; et ROLLAND, Denis (orgs). Intelectuais: sociedade e política, São Paulo: Cortez Editora, 2003 p.88.

${ }^{458}$ Como o objetivo do presente levantamento é definir o lugar ocupado por Cultura Política entre as revistas e periódicos publicados pelo DIP e pelo DEIP-SP, por meio de uma análise contrastiva, acabou-se deixando de lado os dois jornais diários. No entanto, A Manhã já fora parcialmente recuperada no capítulo anterior, sobretudo, no que diz respeito a seu suplemento semanal “Autores e livros”, por meio do qual é possível recuperar a concepção de literatura definida pelo regime.

459 Não foi localizada uma coleção completa do periódico. Tal informação tem como base os fascículos seqüenciais de Brasil Novo, localizados nos seguintes acervos: Biblioteca Mario de Andrade (obras raras), Instituto de Estudos Brasileiros (IEB), Centro de Documentação Cultural Alexandre Eulálio (CEDAE-Unicamp; fundo Paulo Duarte) e Biblioteca Nacional.

${ }^{460}$ Conforme destaca Marina Takami, na dissertação de mestrado Fotografia em marcha: revista S.Paulo - 1936 (2008), Brasil Novo teria tido como modelo a revista S.Paulo, publicada ao longo de 1936 com o objetivo de registrar o “desenvolvimento” do Estado, durante a gestão do governador Armando Salles de Oliveira. Tal veículo contava com a colaboração de Cassiano Ricardo e Menotti del Picchia, entre outros. Segundo a pesquisadora, Brasil Novo teria adotado o aparato gráfico e os quadros profissionais da publicação paulista,
} 
Apesar de a revista não apresentar expediente, sabe-se que Cassiano Ricardo participou ativamente da elaboração de seu projeto e esteve ligado a ela, sobretudo nos números iniciais. Em suas memórias, o poeta destaca que a publicação teria sido uma "contribuição de São Paulo para focar as realizações do Estado Novo, já no plano nacional”461. Tal fato pode ser observado logo no primeiro número no qual predominam reportagens sobre o estado paulista, bem como há a presença destacada do próprio interventor federal em São Paulo, Adhemar de Barros.

A maioria de suas páginas era ocupada por peças publicitárias que utilizavam simultaneamente foto e texto (quase como se fossem legendas) para louvar as realizações do governo. Mas ocasionalmente havia também contribuições literárias. Ao longo dos fascículos, sobretudo ao final deles, são observados poemas de Cassiano Ricardo, Menotti Del Picchia e isoladamente, no segundo volume, de junho de 1939, há um extenso conto de Graciliano Ramos. Trata-se do escrito "Um ladrão”, que depois, com algumas modificações, seria recolhido no livro Insônia $(1947)^{462}$. No entanto, diferentemente de Cultura Política, que de maneira sistemática procurava privilegiar e discutir aspectos variados da literatura nacional, segundo os postulados estadonovistas, em Brasil Novo tal abordagem é episódica e desprovida de enquadramento teórico.

Por outro lado, os editoriais eram mais incisivos na glorificação do regime. Tome-se, por exemplo, aquele que introduz o segundo número, o mesmo no qual foi publicado o texto de Graciliano:

\footnotetext{
Caracterizam o Estado Novo a audácia e o vulto de seus empreendimentos destinados a remodelar fundamentalmente a própria estrutura da economia nacional. Obras de grande estilo, racionalmente planificadas, que somente uma administração dotada de clarividência e realmente empenhada em melhorar as condições de vida do homem brasileiro poderia empreender, são atacadas e levadas avante com entusiasmo $(. . .)^{463}$.
}

\footnotetext{
incluindo o poeta de Martim Cererê, o fotógrafo Theodor Preising, além da oficina gráfica de Romiti e Lanzara que a editava anteriormente.

${ }^{461}$ RICARDO, Cassiano. Viagem no tempo e no espaço. Rio de Janeiro: José Olympio, 1970, p.78.

${ }^{462}$ Tal fato será analisado mais detidamente quando se tratar da colaboração do escritor alagoano em Cultura Política.

${ }^{463}$ EDITORIAL. Brasil Novo, Rio de Janeiro, ano 1, fascículo III, $1^{\circ}$ jun. 1939.
} 
Em linhas gerais, este exemplar procurava privilegiar ações realizadas pelo regime na Baixada Fluminense, no Vale do Paraíba e na região Nordeste. No que diz respeito a esta última, o foco são as obras conduzidas contra a seca. Os números e informações arrolados procuram conferir materialidade ao discurso propagandístico e assim "provar” a aparente eficiência governamental no trato dos problemas de tais lugares.

Não existem dados sobre a tiragem e a distribuição de Brasil Novo, mas a partir do número cinco, de agosto de 1940, a publicação passa a adotar, parcialmente, um formato bilíngüe, algo que se concretiza com o número seguinte, de janeiro de 1941, todo em português e inglês. Tal mudança indica que a revista deixara de se restringir ao público interno e passava a funcionar como cartão de visitas internacional do regime varguista.

Além disso, o referido volume, de janeiro de 1941 era especial. Ele disponibilizava informações recolhidas dos pavilhões da XII Feira Internacional de Amostra da Cidade do Rio de Janeiro, promovida pelo DIP. O objetivo de tal exposição, que trazia números e documentos fotográficos dispostos em painéis, era divulgar "os benefícios outorgados ao Brasil pela fecunda ação administrativa, pelo patriotismo e pela profunda visão do presidente Getúlio Vargas”. Nesse sentido, o exemplar de Brasil Novo procurava espelhar e reordenar o conteúdo do evento. Nas seis páginas iniciais e finais predominam textos nos quais são louvadas as ações do governo nas seguintes áreas: finanças e comércio, evolução econômica, agricultura e riqueza do sub-solo, organização do trabalho, exército e marinha, educação e saúde, obras públicas, política imigratória, projeção internacional do Brasil, a legislação. Ao centro, os artigos cedem lugar a uma sucessão de fotografias, com pequenas legendas informativas (também bilíngües), que tinha o intuito de documentar e evidenciar os argumentos apresentados anteriormente. Logo no início dessa parte, há uma foto de Getúlio, em traje esporte, segurando um charuto na mão direita e uma criança indígena no braço esquerdo. Abaixo dela, há os dizeres do presidente: “O Brasil, sob o novo regime, deixou de ter áreas mortas e territórios de reserva. Quer sentir-se na plenitude de sua força e mobiliza, para isso, todas as energias, sem distinguir regiões e diferençar os seus filhos"464. Em

\footnotetext{
${ }^{464}$ Brasil Novo, Rio de Janeiro, ano III, fascículo VI, jan. 1941.
} 
perspectiva diferente daquela presente em Cultura Política, nota-se aqui, portanto, que as prerrogativas publicitárias se tornam explícitas, deixando de lado qualquer véu informativo ${ }^{465}$.

Escrito por redatores do próprio DIP, começou a circular, em janeiro de 1940, o boletim Brasil de hoje, de ontem e de amanhã. De periodicidade mensal, foi publicado até outubro de 1943, totalizando 46 exemplares. Seu formato era pequeno $(14$ x 21,3 cm) e sua extensão ficava entre 30 e 60 páginas por edição. O veículo não trazia qualquer informação sobre os nomes dos editores, bem como dos autores, pois não havia expediente e nem os artigos eram assinados. Além disso, não há dados sobre tiragem e circulação, mas supõe-se que a publicação voltava-se para um público amplo e que sua distribuição era gratuita. Ao final de cada exemplar havia a indicação: “Todos os tópicos acima podem ser livremente transcritos pela imprensa, com ou sem indicação da fonte original”. Nesse sentido, o periódico servia de canal para o espraiamento da literatura oficial para os diferentes meios de comunicação.

Apresentava um caráter deliberadamente doutrinário, procurando esclarecer as diretrizes do novo governo. No entanto, reunia artigos de pequena extensão, pautados por trechos de discursos e atos do presidente, sem a sistematicidade e a sofisticação que tal iniciativa atingiria em Cultura Política. Talvez porque o intuito de Brasil de hoje, de ontem e de amanhã fosse vulgarizar os postulados getulistas para um público mais diversificado, não privilegiando um destinatário elitizado, tal como ocorria com a revista dirigida por Almir de Andrade, como se verá.

O boletim trazia notícia de eventos, medidas e realizações governamentais nos mais variados setores da vida nacional, em praticamente todos os Estados do país. Reportam-se tantos acontecimentos e ações recentes, como passados, ocorridos ao longo da ditadura varguista. No ano de 1943, com a entrada do país da guerra, o foco do veículo volta-se, sobretudo, para a repercussão do conflito mundial sobre o país, procurando esclarecer medidas e condutas desejáveis aos brasileiros.

Como exemplo de sua proposta deliberadamente doutrinária, o texto "Poder”, que abria o número 2, de fevereiro de 1940 fazia as seguintes afirmações sobre a centralização política empreendida pelo novo governo:

\footnotetext{
${ }^{465}$ Ao longo do volume, há ainda imagens do chefe da nação acompanhado de inúmeras crianças e jovens, fotos dos próprios painéis presentes na XII Feira Internacional de Amostra da Cidade do Rio de Janeiro, entre outras.
} 
A concentração do poder nas mãos do Presidente Getúlio Vargas não é, pois, apenas um fenômeno natural que resulta da política moderna. É uma providência benéfica, que afastando o país de lutas sangrentas a que se via exposto e da dissolução a que estava fadado, vem permitindo a reconstrução nacional, sob moldes capazes de fazer do Brasil uma nação próspera, forte, grande e feliz ${ }^{466}$.

Esse processo de construção da legitimidade da nova ordem continuava na exaltação do trabalhismo, no rebaixamento do liberalismo, na glorificação da figura mítica de Vargas, no repúdio aos regionalismos, na recuperação dos "valores morais da nação", no amparo à intelectualidade, na construção da "unidade nacional”, no suposto contato direto entre governante e governados, sem a necessidade de partidos políticos, entre outros aspectos. Sobre este último aspecto, o artigo “O governo e o povo” pontuava:

\begin{abstract}
Ainda há poucos dias, registravam os jornais que o presidente da República despachara pessoalmente o processo em que um humilde operário pedia a revisão do cálculo da sua aposentadoria, por haver sido prejudicado. E face da prova dos autos o sr. Getúlio Vargas julgou procedente a reclamação, determinando que fosse revista a aposentadoria do reclamante, para ser fixado o seu quantum na base do salário dos três últimos anos de efetivo emprego (...) Aí está um testemunho expressivo da boa vontade e do interesse com que o presidente da República atende às reclamações que lhe são dirigidas ${ }^{467}$.
\end{abstract}

Percebe-se que mesmo quando uma notícia era recuperada pelo boletim, seu objetivo era servir de argumento para autenticação dos postulados do Estado autoritário, incluindo aí a exaltação da figura do presidente. Ao mesmo tempo, observa-se a construção de um leitor implícito oriundo da classe trabalhadora, distante daquele usualmente configurado por Cultura Política, órgão dirigido, sobretudo, a setores da intelectualidade.

Seguindo uma seqüência cronológica, o próximo periódico lançado pelo DIP foi Estudos $e$ Conferências. Ele tinha também um formato pequeno (12 x 23,5cm), com mais ou menos 100 páginas, e circulou mensalmente, com algumas exceções, de abril de 1940 a fevereiro de 1944, data do último exemplar localizado na Biblioteca Nacional ${ }^{468}$. Os volumes também não oferecem quaisquer informações sobre seus editores, sede de sua redação, tiragem etc. A vinculação da revista ao referido órgão de propaganda aparece explicitamente no pé da capa,

\footnotetext{
${ }^{466}$ PODER. Brasil de hoje, de ontem e de amanhã, Rio de Janeiro, ano 1, n.2, fev.1940, p.2.

${ }^{467}$ O GOVERNO e o povo. Brasil de hoje, de ontem e de amanhã, Rio de Janeiro, ano 1, n.2, fev.1940, p.21.

${ }^{468}$ Em determinados momentos, ela apresentava periodicidade oscilante. Por exemplo, três exemplares, os de número 9, 10 e 11 são datados de julho de 1941. O volume 18 é de outubro de 1942, ao passo que o 19 apareceria apenas em abril de 1943.
} 
na qual se escrevia em letras capitulares: D.I.P. Além disso, na quarta capa de todos os números, há a repetida citação de um discurso de Getúlio - “O trabalho é o maior fator de elevação da dignidade humana”.

Quanto ao conteúdo, a publicação reunia, em geral, transcrições de palestras e cursos realizados por simpatizantes e funcionários do governo (civis e militares) no Palácio Tiradentes, sede do DIP na capital federal. Por exemplo, o número11, de julho de 1941, reuniu conferências de uma série intitulada "Curso de economia pública”, organizada pelo órgão de propaganda. Já o volume 14, de novembro de 1941, trazia discursos de uma série patrocinada pela Associação Brasileira de Educação Física, tendo a frente Lourenço Filho, diretor do Instituto Nacional de Estudos Pedagógicos. Em determinados momentos, como nos meses posteriores ao aniversário de Getúlio, o periódico procurava oferecer a reprodução de textos proferidos em diferentes lugares do Brasil em homenagem ao presidente. Nesse contexto, seu interesse era documentar as manifestações em favor do governo e de seu líder em todos os Estados do país, construindo uma perspectiva de unidade em torno do Estado Novo.

Com exceção das presenças episódicas de Gustavo Capanema, Lourival Fontes, Cassiano Ricardo, Menotti Del Picchia e Cândido Motta Filho, os colaboradores não possuíam grande expressão no cenário intelectual. Os temas das conferências eram variados (economia, saúde, educação, forças armadas, entre outros), e o tratamento destes procurava, em regra, enaltecer a figura de Vargas e as realizações do governo. Quanto à organização dos assuntos, Estudos e Conferências não apresentava seções, nem uma rígida organização hierárquica dos textos.

Em meio à retórica propagandística, observa-se a tentativa dos articulistas de teorizar e, assim, legitimar as diretrizes estadonovistas para um público mais elitizado, afeito a argumentos de cunho filosófico e científico. Tome-se, por exemplo, a palestra de Menotti Del Picchia “Getúlio Vargas, o nacionalizador”, publicada no número 10 de Estudos e Conferências, em 10 de julho de 1941. Nele o poeta estabelece vínculos entre o Estado Novo e o movimento de 1922, bem como procura contrapor o realismo do regime de 1937 às práticas políticas liberais da "República Velha”: 
cópia, de tanto teorismo, de tanta metafísica social, esforçava-se para surgir da nudez bravia do seu primitivismo, ansioso pela alegria virginal de ser uma nação inda nova, sem vícios políticos medulares, capaz de apresentar ao mundo não a democracia demagógica e falaciosa das urnas viciadas; não a democracia convencional dos chefetes, dos caudilhos eleitorais, mas a democracia espontânea e real de um povo que transformara seus processos de convivência numa cristã e absoluta fraternidade. Esse era o caminho histórico do Brasil, caminho falseado pelo intelectualismo litorâneo, caminho pelo qual deveriam guiar o idealismo de alguns estudiosos e o gênio político de um grande Chefe ${ }^{469}$.

Por essa perspectiva, Estudos e Conferências aproxima-se do viés doutrinário adotado por Cultura Política, inclusive pelo tom acadêmico empregado, porém numa escala muito menor e sem a mesma sistematicidade, como se verá nas páginas seguintes.

Na qualidade de órgão oficial do Instituto Nacional de Ciência Política (INPC), a revista Ciência Política circulou mensalmente entre novembro de 1940 e maio de 1945. No entanto, antes de falar do periódico, convém tratar rapidamente desta entidade. Criado por Pedro Vergara, o INPC tinha como função “congregar as elites intelectuais em torno do pensamento do Estado Novo" 470 , o que incluía "familiarizar o povo brasileiro com os problemas nacionais; (...) esclarecer a opinião da nação; colaborar com os poderes instituídos para a grandeza da

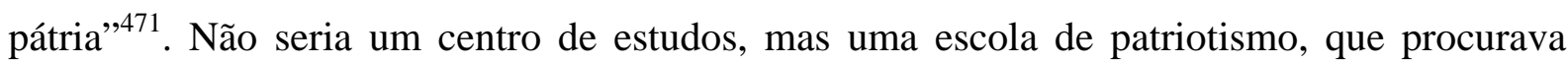
despertar o interesse da sociedade em torno das realizações oficiais e criar uma ponte entre ela e o governo. Seu caráter accional previa a promoção da educação cívica com o objetivo de despertar o amor 'consciente e cultural' ao Brasil, deixando de lado visões “sentimentais” e “arroubos literários" 472 .

Considerando esse modelo de patriotismo "pragmático”, Ciência Política objetivava divulgar o pensamento e as realizações dos dirigentes do instituto. Nesse sentido, seus receptores preferenciais eram os próprios associados deste, o que, por sua vez, não impedia a revista de atingir leitores interessados em estudos políticos e o público em geral. No entanto, novamente, não existem quaisquer dados sobre a circulação, tiragem e distribuição do periódico. De qualquer maneira, a ausência de indicações sobre seu preço de venda (tanto na

\footnotetext{
469 PICCHIA, Menotti Del. Getúlio Vargas, o nacionalizador. Rio de Janeiro, Estudos e Conferências, 10 jul. 1941, p.83-84.

${ }^{470}$ IDÉIA e ação. Ciência Política, Rio de Janeiro, n.1, mar. 1941, p.4.

${ }^{471}$ VELLOSO, Mônica Pimenta. op.cit. p.76.

${ }^{472}$ Idem, ibidem.
} 
capa quanto no expediente), bem como a inexistência de publicidade, seriam indícios de que ele era distribuído gratuitamente.

A revista não dividia as matérias em seções, mas abarcava os mais variados temas: direito, economia, educação, forças armadas, relações internacionais, cultura e, principalmente, política, assim como sugere seu título de periódico especializado. Em geral, o tratamento de tais assuntos vinculava-se às atividades realizadas pelo próprio INPC, as quais Ciência Política propunha-se a registrar, enquanto órgão oficial. Nesse sentido, reunia a transcrição das palestras semanais promovidas pela entidade, divulgava suas campanhas cívicas, relatava os eventos nos quais seus dirigentes tomavam parte, tornava públicas as menções honrosas recebidas por seus membros, entre outras diligências. Trazia ainda artigos exclusivos, além de resenhas dos últimos livros lançados. Atingia algo em torno de 65 páginas por edição.

O referido caráter prático e propositivo de Ciência Política pode ser observado em sua própria concepção de cultura. Ao tratar desse aspecto, a publicação defende a realização de uma espécie de revolução como forma de despertar as “energias sociais do povo” e consolidar os ideais do novo regime. Para isso aponta as seguintes diretrizes:

\footnotetext{
$1^{\text {a }}$ - A cultura brasileira em ação requer, para realizar algo de importante, diretrizes justas e acertadas na esfera política, econômica e social. Estas para serem bem definidas implicam sérios estudos objetivos, observação sociológica e investigação da psiquê nacional;

$2^{\mathrm{a}}$ - Para se afirmar, nesta época, a cultura brasileira exige um Movimento Cultural Brasileiro, que é elemento imprescindível para despertar a consciência da nação. A propaganda desse movimento deve ser feita nas escolas, colégios e universidades; na imprensa, rádio e conferência pública; nas sociedades, quartéis e instituições sociais;

$3^{\mathrm{a}}$ - Constituir-se-á o Movimento Cultural Brasileiro de movimentos idênticos nos diferentes Estados do país; esse processo tornará conhecido nos variados aspectos sociológicos o país, porque implica estudos sérios e objetivos, procedidos em toda a nação ${ }^{473}$;
}

Se de um lado tal perspectiva accional previa a socialização da cultura, por outro, voltava-se contra o "intelectualismo estéril”, tomado como uma herança negativa de nosso passado escravista. Pela orientação do periódico, o desenvolvimento da inteligência deveria pautar-se, necessariamente, por finalidades sociais e cívicas. Nesse movimento, Getúlio Vargas era

\footnotetext{
${ }^{473}$ GRANDE, Humberto. Diretrizes nacionais. Ciência Política, Rio de Janeiro, novembro de 1940, p.11-12.
} 
apontado como o grande modelo de homem letrado a ser seguido, pois era, a um só tempo, presidente da República e membro da Academia Brasileira de Letras.

Ao tratar da figura do chefe da nação, Ciência Política adota um discurso enfático e doutrinário, seguindo as diretrizes previstas pelo INPC. Tal entidade se colocava como uma instituição, “cujo maior objetivo era o de estudar a vida e a obra de Vargas” ${ }^{474}$. A própria disposição da revista expõe esse propósito: em cada contracapa eram reproduzidos trechos dos discursos do presidente, assim como cada pé de página apresentava fragmentos de seus pensamentos $^{475}$. Nesse sentido, ao longo dos números, proliferam artigos de caráter analítico que o tomavam como objeto central. "Getúlio Vargas e a predestinação siderúrgica do Brasil”476, “Getúlio Vargas, a tradição, o presente e o futuro”477, “A unidade nacional e Getúlio Vargas”,478, “Getúlio Vargas e os portugueses”479, "Getúlio Vargas e a política internacional”480 “"Getúlio Vargas e o porto de São Francisco”481 etc.

Em sua análise da configuração do campo intelectual no Estado Novo, Mônica Pimenta Velloso contrapõe as revistas Cultura Política e Ciência Política. Ela parte da hipótese de que haveria uma divisão hierárquica do trabalho intelectual na execução do projeto políticoideológico do regime, exemplificada pelos diferentes papéis desempenhados por esses dois veículos: enquanto o primeiro estaria mais voltado para a produção sistemática de um discurso sofisticado de legitimação do governo, o segundo preocupava-se prioritariamente em decodificá-lo e difundi-lo.

A historiadora argumenta que Cultura Política, tal como se verá, era composta por colaboradores renomados, ao passo que Ciência Política reunia nomes de pouca expressão (tais como Pedro Vergara, Humberto Grande, Viriato Vargas, Benjamim Vieira, Sabóia Lima, entre outros $)^{482}$. Nesse sentido, a primeira tinha como público-alvo a própria elite intelectual na medida em que se valia de ampla argumentação teórica (permeada por concepções

\footnotetext{
${ }^{474}$ VELLOSO, Mônica Pimenta. op.cit. p.96.

475 Idem, ibidem.

${ }^{476}$ VIVACQUA, Attilio. Ciência Política, Rio de Janeiro, ano 1, n.1, nov. 1940, p13-22;

${ }^{477}$ BARRETO, Mario. Ciência Política, Rio de Janeiro, ano 1, n.1, nov. 1940, p39-42.

${ }^{478}$ OLIVEIRA, Carlos Gomes de. Ciência Política, Rio de Janeiro, ano 1, n.1, nov. 1940, p48-49.

${ }^{479}$ BARBOSA, Viana. Ciência Política, Rio de Janeiro, ano 1, n.2, dez. 1940.

${ }^{480}$ MELO, Lineu de Albuquerque. Ciência Política, Rio de Janeiro, ano 1, n.1, dez. 1940.

${ }^{481}$ CARVALHO, Deodoro. Ciência Política, Rio de Janeiro, ano 1, n.4, fev. 1941.

${ }^{482}$ Os grandes intelectuais ocasionalmente colaborariam com Ciência Política. Almir de Andrade escreve artigos esporádicos para a publicação e, a partir de 1943, preside a seção "Pesquisas sociológicas. Também de maneira efêmera aparecerem Oliveira Viana (na seção Niterói) e Menotti del Picchia.
} 
filosóficas acerca da natureza do Estado e da nação) na elaboração das diretrizes estadonovistas. Já a segunda, ao privilegiar uma linguagem mais simples e um tom mobilizador, procurava vulgarizar tais fundamentos para um público mais amplo, bem como propor um programa de ação. Assim, a autora opõe a sofisticação intelectual de uma (tomada como manifestação de um discurso "político-teórico”) ao pragmatismo da outra (categorizada como “política-militante”).

A fim de embasar a sua hipótese, Velloso toma como base a análise de Gramsci, em Os intelectuais e a organização da cultura. Segundo as categorias definidas pelo autor italiano, haveria os intelectuais criadores, no caso, os grandes nomes de Cultura Política, e os intelectuais medianos, administradores ou divulgadores de Ciência Política.

Todo o artigo do Velloso continua a apontar distinções entre os periódicos, o que soa, em alguns momentos como algo esquemático e estanque, apesar do didatismo da análise contrastiva. Veja-se a passagem:

Se no seu discurso Cultura Política parece suportar as oposições, desde que não interfiram no jogo político, Ciência Política mostra-se intolerante para com elas, quando enfatiza a preeminência em afastar e combater os opositores, vistos como 'traidores'”, ${ }^{\text {(833. }}$

No entanto, acredita-se, aqui, que o aspecto mais importante não está no fato de uma das revistas tolerar inimigos e a outra não; a diferença principal entre elas dizia a respeito ao tratamento conferido à cultura como elemento de legitimação política. Cultura Política dedicava-se a uma abordagem sistemática do tema, encarando-o como uma forma privilegiada de acessar o "espírito nacional” e, assim, fundamentar a identificação entre Estado e Nação. Nesse sentido, como será analisado mais à frente, a seção "Brasil, social, cultural e artístico" teria papel fundamental em definir tais bases e em congregar intelectuais não alinhados ao governo autoritário, como Graciliano Ramos. Por outro lado, Ciência Política não conferia ao assunto um destaque especial, nem mesmo dispunha de um espaço privilegiado para abordálo. A publicação se restringia a uma abordagem encomiástica, revestida de uma retórica acadêmica, na análise das realizações do regime e da postura do presidente. Daí o privilégio para um tom deliberadamente propagandístico, coisa que também estava presente no veículo

\footnotetext{
${ }^{483}$ VELLOSO, Mônica Pimenta. op.cit. p.99-100.
} 
dirigido por Almir de Andrade, mas que era contrabalanceado pelo interesse dedicado ao estudo da sempre invocada "realidade” brasileira.

Além disso, Ciência Política começou a circular antes de Cultura Política e sua atuação não estava atrelada a da revista dirigida por Almir de Andrade. Outro ponto é a própria relação pouco amigável entre DIP e INPC, algo existente desde a fundação deste último:

... a direção do DIP reagiu com desconfiança à fundação desse Instituto, considerando invadida sua área de atuação. Lourival Fontes procurou, inclusive, fundar uma Academia de Cultura Política, um desdobramento do DIP, objetivando divulgar o ideário do regime. Pedro Vergara não deixou de reagir a essa proposta e ironizava o caráter de imobilismo e inutilidade que lhe inspirava uma academia ${ }^{484}$.

Segundo Silvana Goulart, por diversas vezes o órgão de propaganda censurou a divulgação de conferências realizadas pelo instituto, bem como proibiu a propaganda da "ditadura republicana”, concepção política defendida pela entidade como a mais ajudada ao país, pois mesclava o autoritarismo tradicional às conquistas provenientes do sistema de governo implantado em 1889.

Um mês depois do lançamento de Cultura Política, em abril de 1941, o Departamento Estadual de Imprensa e Propaganda de São Paulo lançou o boletim São Paulo de hoje, ontem e amanhã, congênere regional, com sutis diferenças, de o Brasil de hoje, de ontem e de amanhã. Seu formato também era relativamente pequeno (13,3 x 19,2 cm). Tinha entre 35 e 40 páginas e dividia-se nas seguintes seções: Economia, Demografia, Finanças, Urbanismo, Transporte, Defesa, Nacionalismo, Educação, Cultura, Resenha, Noticiário. Estas não eram fixas; a cada número novos segmentos tomavam lugar. Rotineiramente, o periódico tratava ainda de música, artes plásticas, literatura, apresentando ao fim um levantamento dos últimos livros publicados. Sua periodicidade, a princípio era quinzenal, mas depois se tornou irregular. Quanto a sua circulação, ela estendeu-se até janeiro de 1948, mesmo com o fim do Estado Novo, totalizando 28 exemplares ${ }^{485}$.

Escrito por redatores do próprio DEIP, numa linguagem próxima daquela comumente utilizada pelas agências de notícia, São Paulo de hoje, ontem e amanhã também não

\footnotetext{
${ }^{484}$ GUIMARÃES, Silvana Goulart. op.cit. p.153.

485 O IEB possui os primeiros 27 números dessa publicação em seu acervo. A Biblioteca Nacional apresenta apenas alguns exemplares esparsos, entre eles o volume 28, de janeiro de 1948.
} 
apresentava textos assinados. Em geral, estes não passavam de uma única página. Ao contrário de Brasil de hoje, de ontem e de amanhã, o teor das matérias era mais informativo, versando preferencialmente sobre os atos e ações governamentais nos mais variados setores, sobretudo o produtivo. Por outro lado, nessa iniciativa, o privilégio para a propaganda das realizações estadonovistas fica evidente, sobretudo para as medidas tomadas em prol do desenvolvimento e progresso das várias regiões do Estado de São Paulo e de sua capital, realizadas pelo interventor Adhemar de Barros. O editorial do volume inaugural explicita tais atribuições:

Este boletim do DEIP pretende ser um espelho fiel da vida paulista, em suas variadas manifestações. Seu caráter é sobretudo informativo. Nele, portanto, a objetividade no trato das questões ventiladas impõe-se como norma de exposição. (...) Destinando-se a ampla distribuição - dentro e fora das fronteiras do Estado - este boletim propõe-se a realizar um trabalho de divulgação das coisas paulistas dentro de um critério realista e anti-retórico. Mesmo os problemas que envolvem matéria de ordem técnica obedecerão a esse critério, e serão expostos em linguagem simples e acessível. (...) São inúmeras as realizações paulistas que merecem um conhecimento mais íntimo não só dos próprios paulistas como dos brasileiros de outros Estados. Fiel a sua divisa que é a de "trabalhar noite e dia” pelo progresso do Brasil, São Paulo tem contribuído, de modo expressivo, para a consolidação da nova ordem de coisas ${ }^{486}$.

A ênfase publicitária às ações da interventoria paulista pode ser comprovada pelos títulos das matérias deste mesmo exemplar inaugural: “O reerguimento econômico do litoral norte”; “Em benefício do Vale do Ribeira”; “O Banco do Estado e a economia paulista”; “O crescimento da metrópole paulista”; “A economia paulista em face da guerra”; “A eletrificação da Sorocabana” etc. Essa abordagem estendia-se ao universo literário. O texto "Uma vitória das letras paulistas”, presente neste mesmo número, trata da menção honrosa do livro A fogueira, de Cecílio J. Carneiro no concurso “Novelas latino-americanas”, promovido pela Divisão de Cooperação Intelectual da União Pan-americana.

Por outro lado, o próprio nome do periódico pretendia mostrar que as ações estadonovistas em São Paulo além estarem conectadas à história estadual, anunciavam um devir glorioso para os paulistas. Nesse sentido, presente, passado e futuro perdiam suas divisas e eram unificados e tutelados segundo a perspectiva centralista e autoritária do regime.

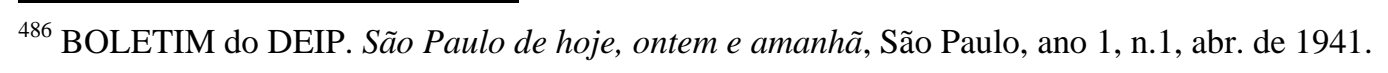


O DEIP paulista também teve participação na criação da revista Planalto, em maio de 1941. Com foco eminentemente cultural, o veículo era dirigido pelo escritor Orígenes Lessa e tinha em seu conselho editorial figuras eméritas do órgão de propaganda paulista, com destaque para três delas que foram seus diretores: Cassiano Ricardo, Menotti Del Picchia e Cândido Motta Filho. Ele possuía o formato de um jornal convencional, com as dimensões de 35 x 47 cm, e algo em torno de 24 páginas por edição ${ }^{487}$. Como São Paulo de hoje, ontem e amanhã sua circulação era quinzenal, mas sua vida foi mais curta; estendeu-se por apenas um ano, chegando a 22 exemplares. Por outro lado, era vendida em bancas (a 1\$000 o exemplar), possuindo uma distribuição, aparentemente, mais ampla.

Apenas o nome "Planalto" apresentava cores variadas a cada edição. Já o restante da publicação era todo em preto e branco, valendo-se recorrentemente de fotos, gravuras, imagens de pinturas e ilustrações em geral, inclusive de artistas famosos, como algumas feitas por Di Cavalcanti. Estruturalmente, ela não apresentava seções rígidas, bem como qualquer hierarquização mais aparente dos textos. Em oposição aos outros veículos tratados até aqui, a revista contava, a cada edição, com nomes de peso no cenário intelectual: além dos escritores citados acima, eram presenças constantes Almeida Salles, Amadeu Amaral Júnior, Mário Silva Brito, Sérgio Milliet entre outros.

Na capa, o título do periódico vinha acompanhado da seguinte frase (numa caixa, no canto superior direito): “O verdadeiro sentido da brasilidade está na marcha para o Oeste”. Ela serve de indicação, juntamente com o próprio nome da publicação, para mostrar o vínculo de Planalto com o Movimento Cultural Bandeira (MCB), grupo que tinha a sua frente Cassiano Ricardo, Menotti Del Picchia e Cândido Mota Filho. Observando-se os desdobramentos da chamada vertente "conservadora” do Modernismo brasileiro, a retórica nacionalista dos Verde-Amarelos ${ }^{488}$ acabara convergindo para a idéia de bandeirantismo e para o papel desbravador de São Paulo na construção da brasilidade. Por essa perspectiva, tomava-se a figura do bandeirante como origem sintética da nação e do desenvolvimento industrial alcançado pelo Estado até aquele momento. Tratava-se, portanto, de uma concepção territorial

\footnotetext{
487 Seus últimos números, já no ano de 1942, apresentam 16 páginas.

488 Tratava-se de um grupo paulista composto por Plínio Salgado, Cassiano Ricardo, Menotti del Picchia, Cândido Mota Filho e Alfredo Élis. Colocava em primeiro plano o culto às tradições brasileiras, defendendo a criação de uma política de defesa do “espírito nacional”, frente às influências estrangeiras, sobretudo a herança cultural européia. Ao longo da década de 1930, os verde-amarelos separaram-se e deram origem a dois movimentos distintos. Enquanto, Plínio Salgado fundou a Ação Integralista Brasileira, Cassiano Ricardo e os demais integrantes criaram o Movimento Cultural Bandeira (MCB), cujo foco era o bandeirantismo.
} 
da nacionalidade, na qual a Paulicéia assumia historicamente o papel central ${ }^{489}$. Nesse processo, considerava-se que a literatura teria a função social de colaborar para a integração do país; ela partiria do planalto de Piratininga e se espraiaria.

O editorial do primeiro número procurava destacar tal perspectiva de projeção da cultura paulista pelo espaço nacional, reforçando o caráter brasileiro e integrador desta última:

\begin{abstract}
Foram os homens do Planalto que realizaram a obra das bandeiras. Do Planalto eles desceram e se espraiaram, fundando cidades, varando sertões, descobrindo riquezas, levando para bem longe o poder de audácia e de bravura, as estreitas linhas de demarcação traçadas pelo caduco tratado de Tordesilhas.
\end{abstract}

Planalto não tem um sentido regional. Planalto é para nós o símbolo da integração dos homens de São Paulo no Brasil, construindo o Brasil.

E quando um grupo de escritores de São Paulo pensou em fundar um jornal que levasse a toda a nossa terra um reflexo da sua contribuição cultural, Planalto foi o primeiro título que ocorreu, como a fórmula de maior conteúdo e sugestão. Seria uma projeção noutro terreno da obra dos nossos maiores bandeirantes [relação com os nomes destes] (...) Foram os homens do Planalto (de Piratininga) que realizaram a obra das bandeiras.

Nesse sentido, o veículo colocava-se como espaço privilegiado para a divulgação de diferentes aspectos da produção cultural de São Paulo, bem como para a expressão de seus realizadores. São particularizadas as mais variadas manifestações artísticas: pintura, teatro, escultura, cinema e, sobretudo, literatura. São publicados ainda poemas e contos de diferentes autores com destaque para as figuras de Mário de Andrade e Alcântara Machado. Sérgio Milliet mantém uma seção fixa de crítica literária, enfocando principalmente obras e autores paulistas $^{490}$. Além disso, são recorrentes as matérias que procuram sublinhar a importância do modernismo no processo de renovação das letras nacionais. Esse é o tom dos artigos "Sobre a incompreensão da poesia modernista" e "História da Paulicéia Desvairada", de Fernando Goés, presentes respectivamente nos números um e três de Planalto ${ }^{491}$. O sexto volume, de agosto de 1941, traz uma entrevista com o autor de Macunaíma, apresentando-o como o

\footnotetext{
489 Para mais informações, ver VELLOSO, Mônica Pimenta. A brasilidade verde-amarela: nacionalismo e regionalismo paulista. Rio de Janeiro, Estudos Históricos, 1993.

${ }^{490}$ Por exemplo, no número três, de junho de 1941, no texto "O drama do café", ele analisava o livro Fazenda de Luís Martins, bem como a ausência de tratamento da crise no setor cafeeiro pelos romancistas paulistas. Já no número cinco, saído no mês seguinte, ao analisar o volume Região e tradição, de Gilberto Freyre, ele procurava ressaltar a importância de Mário de Andrade e dos modernistas na abertura de novos caminhos aos escritores nordestinos de 1930, algo que era questionado pelo sociólogo pernambucano.

${ }^{491}$ Respectivamente de maio de 1941 e junho de 1941.
} 
primeiro poeta a usar a "língua nacional”. O próprio Mário, a partir do oitavo volume, tornase colaborador assíduo da revista, versando, principalmente, sobre música.

Planalto trazia ainda biografias de paulistas ilustres (o primeiro número dedica uma extensa reportagem ao ex-presidente Campos Salles; no segundo, o destaque é Tarsila do Amaral), fotos da capital e matérias sobre o crescimento de municípios do interior do Estado. Nesse processo de construção da imagem de uma São Paulo grandiosa, chamam a atenção ainda artigos sobre o linguajar paulistano ou que tratavam a Paulicéia como destino freqüente de populações provenientes de todo o mundo e da assimilação do elemento estrangeiro por ela; a cidade seria o ponto de partida e de chegada da brasilidade. Por outro lado, numa perspectiva internacionalista, a revista abre espaço para produções de autores estrangeiros, sobretudo sul e norte-americanos (há, inclusive, uma seção intitulada “Poetas da América”), contrariando a orientação predominantemente nacionalista de Cultura Política, que privilegiava somente obras e artistas brasileiros.

O primeiro exemplar não traz publicidade como forma de captação recursos, mas tal situação muda a partir do segundo número, que passa a contar com diferentes anúncios. Esta situação se manteria ao longo da existência da revista. Em seu expediente, não há qualquer menção ao apoio do DEIP de São Paulo, que, como se sabe, financiava a publicação ${ }^{492}$. E curioso: ao longo das edições não se observa qualquer artigo com menções elogiosas e explícitas ao Estado Novo. Como sublinhado acima, o foco do veículo é eminentemente cultural, procurando destacar a participação paulista na construção da brasilidade. Nessa empreitada, se as referências explícitas ao governo são deixadas de lado, elas encontravam-se embutidas no próprio projeto de matiz bandeirante levado em frente pelo veículo, que previa o expansionismo das fronteiras internas da nação, nos moldes da proposta oficial de "Marcha para o Oeste״ ${ }^{\text {493. }}$.

\footnotetext{
${ }^{492}$ Ver GUIMARÃES, Silvana Goulart. op.cit, p.20.

${ }^{493}$ Em outubro de 1944, começa a circular, na capital paulista, outra revista também chamada Planalto. Há a informação de que ela seria edita pelo Intercâmbio Cultural Latino, Interlat LTDA, em São Paulo. Sua diretora geral era Rose-Marie Tanco de Argaez. Heraldo Barbuy ocupava direção literária. Seu preço era de Cr\$ 8 e sua distribuição, para todo o Brasil, era realizada por Fernando Chinaglia, que também respondia por tal função em Cultura Política. Seu formato e sua diagramação lembram muito a referida revista getulista. Era um pouco maior (19,5 x 24,8 cm), mas possuía menos páginas, entre 100 e 150. A princípio, tal publicação teria circulação mensal, mas, de acordo com os números a que se teve acesso, vai perdendo a regularidade com o tempo. Estende-se até fevereiro de 1946. Ao longo de sua existência, contou com colaborações episódicas de figuras destacadas como Rachel de Queiroz, Augusto Frederico Schimdt, Sérgio Milliet e Graciliano Ramos. Este estampa o trecho de Infância, intitulado "Mudança", logo no volume inaugural. A capa do veículo, composta por cores sóbrias que variavam a cada edição, trazia, no topo, o título e, abaixo, a lista de assuntos abordados -
} 
Com formato e atribuições completamente diferentes, é lançada em junho de 1941, pelo DIP da capital federal, o periódico Dos jornais. De periodicidade mensal, ele tinha as dimensões de 13,8 x 19,3 cm e entre 80 e 100 páginas. Sua função era selecionar e reunir artigos em louvor, seja ao presidente seja ao governo, publicados nos meses anteriores, em publicações diárias de todo o Brasil. A revista não traz especificação sobre quem realizava o trabalho editorial de escolha dos textos. Estes eram dispostos sem uma ordem aparente, criando a idéia de miscelânea e acúmulo. Possivelmente, ela circulou até outubro de 1943, data do último volume encontrado na Biblioteca Nacional.

Na confecção dessa espécie de clipping oficial, os nomes dos autores contavam pouco; importava mais a temática e o tratamento elogioso consagrado às ações e medidas do Estado Novo e de seus dirigentes. O número inaugural trazia, em sua maioria, artigos (tanto assinados quanto trechos de editoriais) referentes ao aniversário de Getúlio, em abril daquele ano. A lista era extensa e procurava criar o efeito de uniformidade e totalidade, como se todos os Estados do Brasil estivessem unidos em torno do presidente. Há textos de jornais do Acre, Manaus, Alagoas, Bahia, Espírito Santo, Goiás, Maranhão, Minas, Pará, São Paulo, Rio de Janeiro etc ${ }^{494}$. Além disso, por se tratarem de textos saídos em periódicos particulares, criava-

Filosofia, Literatura, Ciência, Artes Plásticas, Economia, Teatro, Música, Cinema, Vida social, Atualidade. Havia ainda uma seção feminina, com artigos sobre moda, beleza, decoração e comportamento. O órgão contava com inúmeros anúncios publicitários. No pé da página em que se encontra o sumário, há a indicação: "Planalto não se responsabiliza pelos conceitos emitidos nos artigos assinados”. Outra característica do veículo é o uso recorrente da fotografia, reservando-se às imagens, inclusive, uma seção intitulada "Atualidade fotográfica”. Não há qualquer especificação sobre o vínculo da revista e de seus editores com o DIP. O conteúdo das colaborações também não faz referência às realizações estadonovistas.

${ }^{494}$ Segue-se a lista de textos reunidos no primeiro exemplar da publicação: "Aniversaria, hoje, o Presidente GV” (De O Acre, Rio Branco); “Getúlio Vargas” (Gazeta de Alagoas, Maceió); "Perfil do Presidente Getúlio Vargas” (TELLECHEA, J. Gazeta de Alagoas, Maceió); “GV, o homem do Brasil” (O Jornal, Manaus); “Getúlio Vargas, o homem necessário ao Brasil” (O Imparcial, Bahia); "Preito Nacional” (O Estado, Fortaleza); “Dezenove de abril” (PESSOA, Alfredo, Correio da Noite, Distrito Federal); “O Presidente Getúlio Vargas” (A Notícia, Distrito Federal); "Lincoln e Getulio” (A Gazeta, Vitória); “O Estado de Goiás presta expressivas homenagens a s. excia. o Presidente Getúlio Vargas, ao ensejo de seu natalício” (Correio Oficial, Goiânia); "No pórtico” (MORAES, Nascimento, Diário Oficial, São Luiz); “O Brasil comemora, hoje, o aniversário do Presidente Getúlio Vargas” (Folha de Minas, Belo Horizonte); “O aniversário do Presidente Getúlio Vargas” (Diário Mercantil, Juiz de Fora); “Dr. Getúlio Vargas” (Folha do Norte, Belém); “A revolução que o conduziu ao poder, para repetir um conceito feliz, seria, sem ele, um cataclisma. - Nele, com ele e por ele, foi uma ressurreição do Brasil” (Estado do Pará, Belém); “Expressiva manifestação de brasilidade” (A União, João Pessoa); “O significado nacional de um natalício” (Diário da Tarde, Curitiba); “O aniversário do chefe do governo” (Diário de Pernambuco, Recife); “O Presidente Getúlio Vargas e o povo brasileiro” (Diário Oficial, Teresina); “As razões da festa de 19 de abril” (PEREIRA, Altamirano Nunes, Folha do Comércio, Campos, RJ); “Getúlio Vargas” (MIRANDA, Cardoso, Petrópolis, RJ); “O aniversário do Presidente” (A República, de Natal); "Traços biográficos do Presidente da República” (Correio do Povo, Porto Alegre); "O ínclito Presidente da República, sr. dr. Getúlio Vargas, faz anos hoje” (A Gazeta, Florianópolis); “'O Dia da Juventude Brasileira”” (Correio Paulistano, São Paulo). "Presidente Getúlio Vargas” (Folha da Manhã, Aracaju); “Atos e não palavras” (Diário Carioca, Distrito Federal); “Governar em contato com o povo e no meio dos fatos” (Jornal do 
se a impressão de independência e descomprometimento dos comentários emitidos, o que colaborava para desoficialização do discurso laudatório ao regime. No entanto, como se sabe, a censura atuava fortemente naquele momento não só cerceando, como impondo as informações julgadas relevantes ao país.

Já no apagar das luzes do Estado Novo, em agosto de 1944, a revista Política - Arquivo de Estudos Políticos começa a circular na capital paulista. Editada por Cândido Motta Filho, exdiretor do DEIP de São Paulo, a publicação apresentava um formato livresco muito parecido com o de Cultura Política (suas dimensões físicas eram de 15,5 x 22,5 cm). No entanto, sua extensão era bem menor; rotineiramente, não ultrapassava cem páginas. Outra diferença dizia respeito à presença de publicidade. Política trazia inúmeros anúncios, que de alguma maneira explicam e justificavam seu suposto "desinteresse” (imparcialidade crítica) no tratamento de diferentes aspectos da vida nacional. Entre eles, propagandas de hotéis, restaurantes, bancos, lojas de roupa, escritórios de contabilidade e produtos diversificados, como cremes dentais, cervejas e refrigerantes. Cada exemplar custava Cr\$12, quatro vezes mais do que o referido periódico editado por Almir de Andrade.

Tratava-se de uma revista "sisuda”. Além de apresentar artigos longos, dedicados ao estudo de assuntos específicos, não utilizava muitos recursos visuais (cores, fotos, gravuras, ilustrações, gráficos, variações tipográficas) para atrair os leitores. Seu destinatário preferencial era um público de elite, especializado em assuntos políticos, o que pode ser observado, sobretudo, pelo instrumental analítico mobilizado; há uma profusão de citações a diferentes autores europeus e americanos.

Política dividia-se em oito seções: "Cultura” (estudo de obras e autores variados), "Direito" (comentários à legislação brasileira e à história da disciplina de maneira geral), Política (tratamento de temas internacionais, relacionados ao grande conflito mundial), “Assuntos nacionais” (abordagem de temas e personagens do passado), "História” (retomada de figuras eminentes), “Educação”, “Letras” (trazia uma listagem com comentários das obras e revistas

Comércio, Campo Grande); "Mais uma grande iniciativa do Governo Nacional” (MAGALHÃES, Agamemnon, Folha da Manhã, Recife); "O transporte ferroviário e a economia nacional” (PINTO, Ricardo, O Dia, Curitiba); "Realização" (Correio da Manhã, Distrito Federal); "Getúlio Vargas, protetor das Letras e das Artes" (CARDOSO, Natércio, Diário da Bahia, Salvador); "Ordem moral” (Folha da Manhã, Recife); "Força miraculosa" (Diário da Bahia, Salvador); "A fisionomia da pedra” (ODISSO, Agostinho Baimês, O Estado, Fortaleza); "Estradas” (A Tribuna, Vitória); "Serviço Social” (O Nordeste, Aracaju); "Novo e sadio entusiasmo" (Jornal do Estado, Porto Alegre); “O progresso de uma civilização” (Diário do Povo, Campinas). 
saídas no mês anterior), "Resenha” (reunia recortes de notícias saídos em diferentes veículos da imprensa). No entanto, não se tratava de seções fixas. Nos diferentes números, elas poderiam desaparecer e dar lugar a outras como “Ciência”, "Problemas de hoje” (atualidades) etc.

A revista circulou até meados de 1945 , totalizando dez números ${ }^{495}$. Preferencialmente, ela abria espaço a análises da conjuntura política do país e do mundo, no iminente pós-guerra. Nesse sentido, deixava de lado a ladainha de exaltação ao regime, algo justificável pelo próprio contexto de seu aparecimento, no qual o Estado Novo vivia seu declínio. No editorial, de seu segundo número, em setembro de 1944, ao comentar o volume anterior, o editor dizia: "Num momento amargado pela impiedade da guerra, num instante histórico propício a improvisações e imediatismos, ela [Política] surgia com um tom de desinteresse tão acentuado que chegou a provocar desconfiança”496. Em meio a tal cenário conflituoso, a publicação procurava colocar-se como um porto de sensatez e razão. Ao mesmo tempo, tal estratégia revelava a proposta do veículo em mobilizar e unir à classe intelectual em torno do "bem comum”: “Seguimos o caminho com a consciência de que estamos vivendo, depois de tantas mutilações, conflitos e divergências, - uma hora que aspira uma conjugação de esforços restauradores, um reencontro de inteligências corajosas, de culturas construtivas e de espíritos solícitos" ${ }^{497}$.

A publicação apresentava um rol de nomes pouco expressivo no cenário intelectual, as exceções de Jose Geraldo Vieira e Afonso Schimidt. Este último era conhecido por sua orientação comunista. Logo em sua primeira colaboração em Política, ele faz a seguinte afirmação sobre o país que controlava a URSS: "Estado onde a liberdade religiosa é completa, onde o pão do espírito é dado de graça como o ar e o sol, a Rússia, pelos seus bispos, pelos seus filósofos, pelas suas forças morais, que são enormes, poderá representar um papel de importância na obra que se aproxima” ${ }^{\text {,98 }}$. Tal como se observa aqui, a revista permitia-se abordar temas até então proibidos pela censura. Outra prova disso é o texto “A religião do Marxismo”, de Manuel Carlos de Figueiredo Ferraz, uma espécie de resenha do livro de mesmo nome, de Nicolas Berdiaeff. Nesta obra, o autor defendia que Marx teria permanecido

\footnotetext{
${ }^{495}$ O IEB tem os dez volumes iniciais da revista.

${ }^{496}$ CONVITE à vida nova. Política, São Paulo, set. 1944, p.5.

${ }^{497}$ Idem, p.5-6.

498 SCHMIDIT, Afonso. Ordem cristã. Política - Arquivo de Estudos Políticos, São Paulo, ano 1, n.2, set. 1944, p. 24.
} 
judeu e passara a pregar o messianismo do proletariado. Logo, pode-se perceber que Política já sinalizava para uma aproximação entre governo e PCB no cenário de derrocada do regime, algo que se concretizaria com o movimento queremista.

Por fim, um pouco antes da criação de Política, em março de 1944, o DIP lançava o periódico Brasil Reportagens. De periodicidade mensal nos primeiros números, reunia farto material fotográfico sobre os mais variados temas, com o objetivo de documentar as diferentes facetas da vida nacional. Por esse aspecto, aproximava-se da proposta de Brasil de Novo. Considerando-se os exemplares reunidos na Biblioteca Nacional, circulou apenas até dezembro de 1944, chegando à apenas ao oitavo volume.

Brasil Reportagens era descrito por Cultura Política como um veículo de "aspecto agradável e feição moderna”, enquadrando-se numa nova diretriz do DIP, cujo objetivo era substituir os antigos Dos jornais, Estudos e Conferências e Brasil de hoje, de ontem e de amanha ${ }^{499}$. Do ponto de vista conteudístico, depois da “consolidação da unidade nacional e das instituições inauguradas em 1937”, a participação do Brasil no conflito mundial tornava-se o novo foco da propaganda do governo e cabia à publicação recém-criada atender a tal diretriz.

\subsection{A revista Cultura Política}

A recuperação do conjunto de publicações criadas ou subvencionadas pelo Departamento de Imprensa e Propagada ou por sua filial paulista permite delimitar melhor o lugar diferenciado ocupado por Cultura Política. Seja por suas qualidades editoriais, seja pela representatividade e extensão dos conteúdos veiculados, esta revista colocava-se como o principal canal de produção e veiculação do projeto político e ideológico do Estado Novo. Assim como o regime instaurado em 1937, que se caracterizava pela centralização do poder político, a publicação exercia a centralização do poder simbólico na medida em que procurava se colocar como um “espelho” do Brasil ao tratar das mais variadas áreas e assuntos, além de reunir um corpo diversificado de colaboradores.

Mesclando propósitos culturais e propagandísticos, ela foi o periódico oficial de maior fôlego e envergadura ao longo da ditadura varguista: circulou mensalmente (com exceção dos

\footnotetext{
${ }^{499}$ ATIVIDADES do Departamento de Imprensa e Propaganda. Cultura Política, Rio de Janeiro, ano 1, n.47, dez. 1944, p.153.
} 
números 50 e 51, trimestrais) de março de 1941 a outubro de 1945, em edições de caráter austero e livresco, quase sempre com mais de trezentas páginas, medindo 16 x 22,5 cm. Além disso, era um veículo bem divulgado, sendo vendido em bancas de jornais do Brasil inteiro, conforme destacou seu próprio diretor Almir de Andrade, em entrevista concedida nos anos $1980^{500}$. Segundo ele, sua distribuição era realizada pela Fernando Chinaglia S/A, empresa que desempenhava a mesma função com as Seleções do Reader's Digest, o que por si só já sinaliza a capilaridade alcançada pela revista ${ }^{501}$.

A princípio, Cultura Política se dirigia a uma parcela restrita do público, capaz de decodificar seus textos marcados por ampla argumentação teórica e, conseqüentemente, por citações e referências a diferentes autores e correntes de pensamento ocidentais. “A revista produz um discurso altamente elaborado, permeado por concepções filosóficas acerca da natureza do Estado e da nação, do lugar do indivíduo na ordem política, do exercício da autoridade etc. ${ }^{502}$. Nesse sentido, pressupunha leitores familiarizados com tal conjunto de conhecimentos acadêmicos, que, em geral, faziam parte do universo de homens letrados do período: professores, jornalistas, profissionais liberais, burocratas, ligados aos mais variados institutos e departamentos, e intelectuais de uma maneira geral. Em regra, sua orientação elitista, voltada aos grupos dominantes, procurava demonstrar, por meio de uma retórica nacionalista, permeada por argumentos de cunho filosófico e científico, o caráter inovador do regime, justificando a suposta superioridade dele frente ao "falido" liberalismo. Nesse processo, a publicação também privilegiava uma visada cultural (daí a importância conferida à literatura e as outras artes) e a retomada, em tom erudito, da história do país como formas de atestar a aparente simbiose entre o regime e a “essência” da nação.

\footnotetext{
${ }^{500}$ ANDRADE, Almir. Almir de Andrade (depoimento, 1981). Rio de Janeiro: FGV/Cpdoc-História Oral, 1985, 48p. dat. Entrevista concedida à Lúcia Lippi de Oliveira. O diretor de Cultura Política destaca ainda que a revista era vendida por um preço simbólico de $\mathrm{Cr} \$ 3,00$, quando na verdade os custos de produção ultrapassavam os $\mathrm{Cr} \$ 10,00$.

${ }^{501}$ Segundo dados obtidos no próprio site de Seleções <http://www.selecoes.com.br/aempresa 65anos.asp, Acessado em 17 de janeiro de 2009 >, a primeira edição da revista, em português, esgotou-se rapidamente, com 100 mil exemplares vendidos em várias cidades brasileiras. Além disso, em menos de seis meses, sua circulação teria chegado a 150 mil volumes. Numa rápida comparação entre Cultura Política e este popular periódico de origem americana, pode-se detectar semelhanças tanto quanto ao formato (apesar de ele ser um pouco menor; 13 x 18,8 cm) como quanto à diagramação (em duas colunas, em que ainda se notam o uso do mesmo tipo, capitulares e cabeçalho). Contudo, havia também diferenças marcantes. Enquanto a revista getulista apresentava capas similares, variando apenas o uso da cor dos tipos empregados, as de Seleções eram diferenciadas, com fotos, tonalidades e disposição variada do nome da publicação no topo da página a cada edição. Neste último veículo, ainda, percebe-se a presença marcante da publicidade ao longo de toda sua extensão (com destaque para as páginas iniciais), algo que não acontecia com a publicação getulista.

502 VELLOSO, Mônica Pimenta. Uma configuração no campo intelectual. In: OLIVEIRA, Lúcia Lippi; VELlOSO, Mônica Pimenta; GOMES, Ângela Maria de Castro. Estado Novo: ideologia e poder. Rio de Janeiro: Zahar Ed., 1982. p.80.
} 
Capas do segundo e do quarto números de Cultura Política, respectivamente de abril e junho de 1941
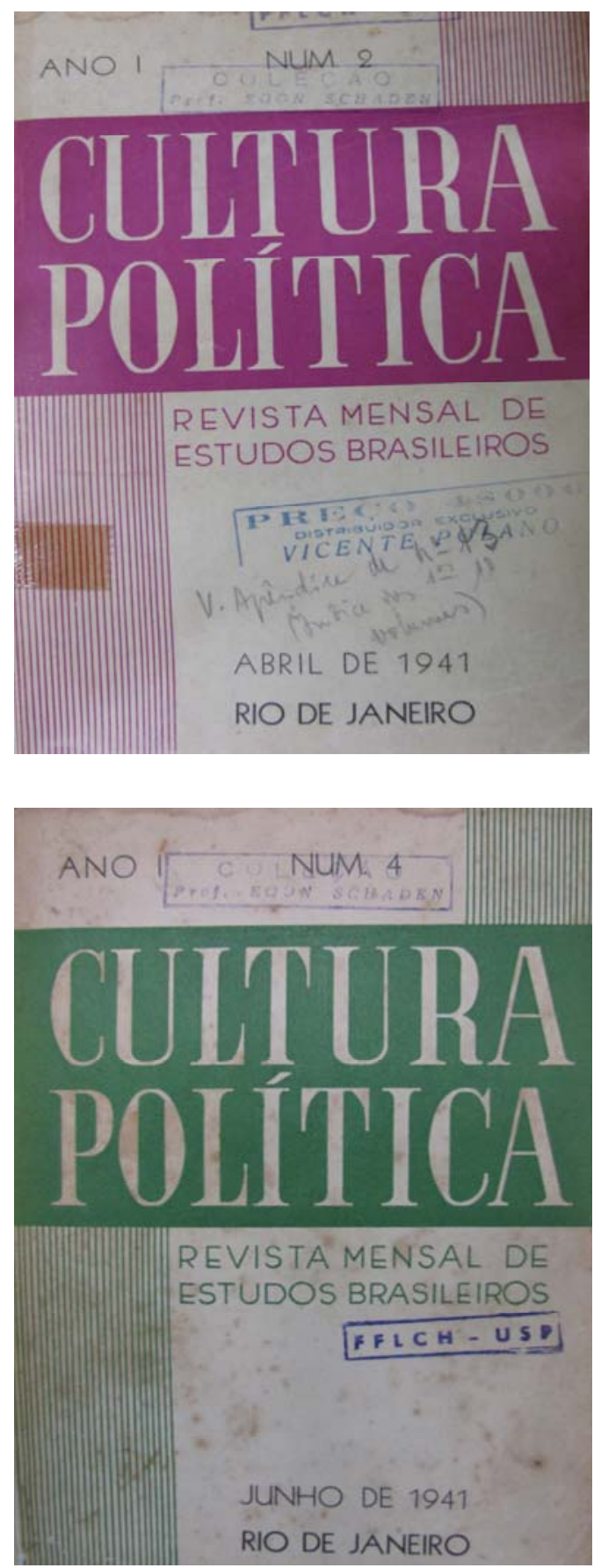
Fac-símile das palavras que o próprio Getúlio Vargas endereçou à edição extraordinária de Cultura Política, de novembro de 1941, na qual se comemorava o quarto aniversário do Estado Novo (In: CULTURA POLÍTICA, ano 1, n.9, nov. 1941, p.V)

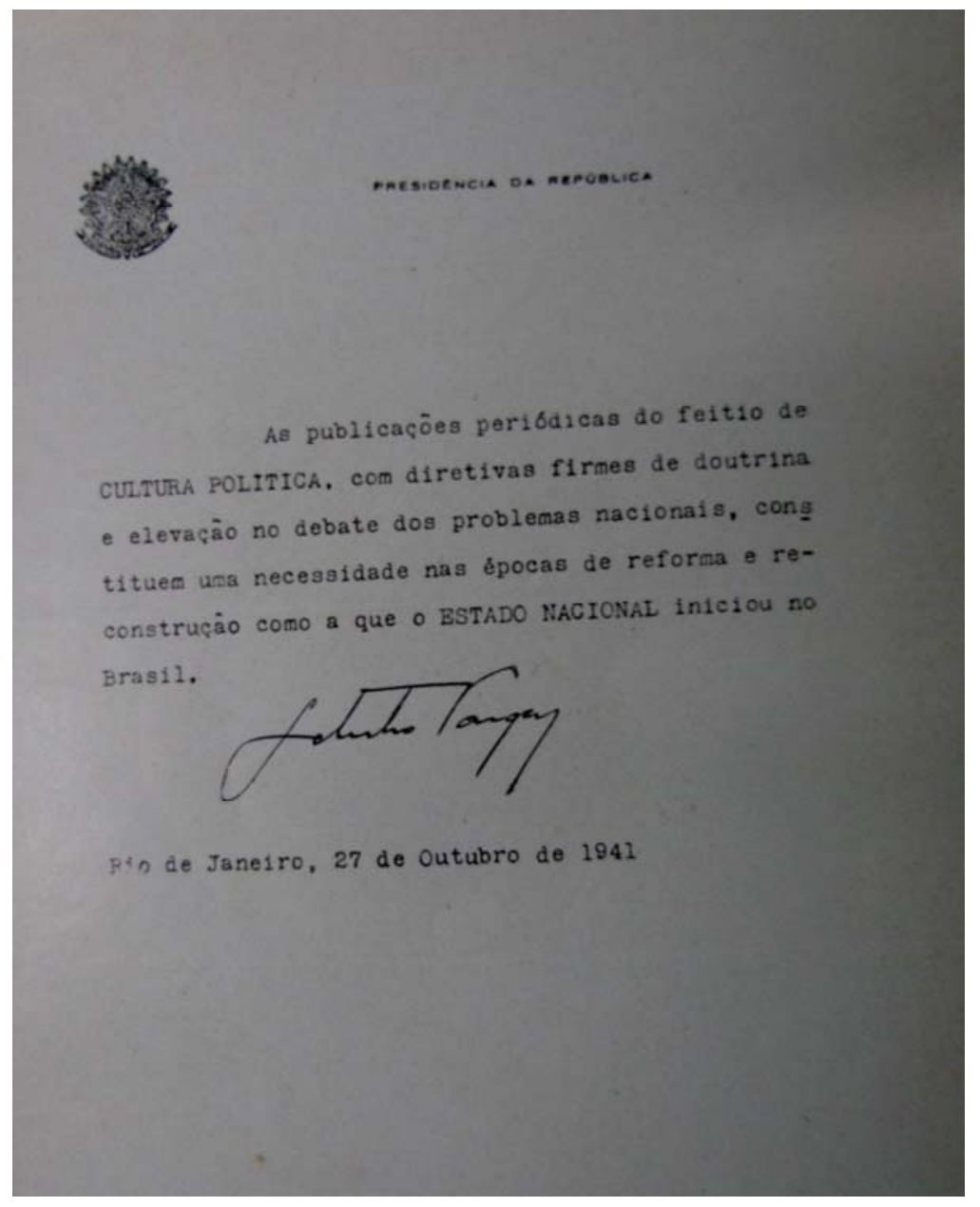


A tiragem normal da revista era de três mil exemplares. Almir destaca que praticamente toda essa quantidade era enviada às bancas e apenas uma parcela reduzida era distribuída gratuitamente pelo DIP. Segundo ele, não se pensava em tirar um número maior de volumes, pois a publicação tinha um caráter bem diferente do apresentado por Seleções, por exemplo: “ela era pesada, maçuda”. No entanto, o diretor do periódico relembra com orgulho o sucesso de vendagem do número inicial e as razões desse fenômeno:

... a revista já saiu desde o primeiro número com seções sobre tudo: arte, literatura, música, quadros e costumes, e com escritores como Graciliano, Marques Rebelo; críticos que eram da oposição, como Pedro Dantas, o Prudente de Morais Neto (...) E com isso a revista teve um lançamento muito bom e pegou impulso ${ }^{503}$.

Tal êxito editorial, mas, sobretudo, a remuneração vultosa atraía intelectuais dispostos a publicar artigos. Almir destaca que só precisou batalhar por colaboração nos primeiros números. "Daí por diante, nunca mais tive que pedir. Eles [os colaboradores] vinham a mim. O pessoal todo vinha, inclusive porque a revista na época pagava um preço que ninguém pagava. Pagávamos um preço relativamente alto. Até em alguns casos o dobro que os jornais e revistas (...) De forma que havia uma grande afluência de ofertas de trabalho"504. Outro ponto destacado por Almir, que também servia de chamariz à intelectualidade, era o fato de a revista tratar não só de política e doutrina, mas também de cultura. Essa amplitude e relativa flexibilização do conteúdo veiculado, possibilitava participações que dispensavam apologias ou encômios ao regime, mas que, de qualquer maneira, enquadravam-se nas diretrizes impostas pelo regime, como se verá ainda no decorrer deste capítulo.

Esses atrativos permitiam que a revista se colocasse como uma espécie de atestado de união e cordialidade da intelectualidade em torno das diretrizes e propostas governamentais. No editorial do primeiro número, o mesmo Almir de Andrade deixava isso claro:

Nós todos esquecemos as desavenças de ontem, as diferenças de opinião e de doutrina, os conflitos possíveis de critérios de solução dos problemas. As formas superiores de convivência social são feitas de ajustamentos recíprocos, em que há, necessariamente, renúncias, concessões, em benefício da

\footnotetext{
503 ALMIR, Andrade. op.cit. p.2.

${ }^{504}$ Idem, p.3.
} 
comunhão material e espiritual. E nós já nos vamos integrando, pouco a pouco, numa dessas formas de viver $^{505}$.

Em seus quadros, Cultura Política reuniu intelectuais renomados, de variadas tendências levando a termo a proposta getulista de construção de uma aparente unidade nacional em torno do novo governo. Além dos ideólogos do regime (Almir de Andrade, Francisco Campos, Azevedo Amaral, Lourival Fontes e Cassiano Ricardo), contou com a colaboração diversificada de destacadas figuras do cenário cultural brasileiro que ou se responsabilizavam por alguma seção (como foram os casos de Graciliano Ramos, Marques Rebelo, Prudente de Morais Neto, Rosário Fusco) ou publicavam textos esporadicamente (algo observado com Gilberto Freyre, Nelson Werneck Sodré, Dalcídio Jurandir, Jorge de Lima, entre outros).

Tendo em vista a construção dessa idéia de unidade, importava à publicação congregar nomes de diferentes tendências e posições político-ideológicas, inclusive os de supostos opositores ao governo. Nesse sentido, ganharam destaque as participações de Nelson Werneck Sodré, Dalcídio Jurandir e, sobretudo, Graciliano Ramos, figuras que seriam historicamente associadas ao Partido Comunista Brasileiro. Aos olhos da coesão intelectual proposta pelo regime, o caso de Graciliano apresentava ainda o aspecto “favorável” de o escritor ter sido preso sem acusação prévia pelo mesmo regime com o qual passava a colaborar, fato que, por si só, chamava a atenção para os propósitos agregadores governamentais e, em certo sentido, validava-os $^{506}$. A simples presença do autor de Vidas Secas no periódico, portanto, dava margem a tal pensamento, fazendo supor que se ele propunha-se a emprestar sua pena a um Estado que lhe causara tamanha violência era porque as propostas estadonovistas eram aparentemente legítimas. Essa era a imagem que o Estado Novo desejava vender: intelectuais deixando de lado suas mágoas e divergência para participar do projeto getulista. Naturalmente, o slogan propagandístico omitia os altos valores pagos aos colaboradores, o que no caso de Graciliano era um ponto a ser considerado.

Ainda com relação ao trabalho de Graciliano Ramos em Cultura Política e ao simbolismo de sua presença no órgão oficial, sabe-se que além de autor dos "Quadros e costumes do Nordeste”, o escritor era responsável pela revisão dos textos de outros articulistas, “um

\footnotetext{
${ }^{505}$ ANDRADE, Almir de. A evolução política e social do Brasil. Cultura Política, Rio de Janeiro, ano 1, n.1, mar. 1941, p.7.

${ }^{506} \mathrm{O}$ autor de Angústia ficara preso entre março de 1936 e janeiro de 1937.
} 
capinar, escoimar, melhorar da escrita avulsa” ${ }^{507}$. No entanto, além de cumprir tal tarefa de copidesque, o autor de Vidas Secas também realizava a filtragem dos artigos que, em volume cada vez maior, chegavam à publicação. Segundo Almir de Andrade, o artista alagoano, assim como uma espécie de subeditor, selecionava "o que era bom e o que não era”508. Logo em seguida, apenas as colaborações julgadas “aproveitáveis” pelo romancista eram examinadas pelo diretor do periódico.

Apesar desse relato de Almir de Andrade, Cultura Política não apresentava um expediente no qual constassem os nomes e as funções exercidas por seus diferentes colaboradores a cada edição $^{509}$. Contudo, a proximidade de Graciliano com o dia-a-dia da publicação getulista pode ser atestada mediante duas cartas trocadas pelo escritor alagoano com Nelson Werneck Sodré, que, à época (primeira metade da década de 1940), também colaborava com o periódico oficial e encontrava-se distante do Rio de Janeiro ${ }^{510}$. Em tais missivas, o autor de Caetés relata que estava intermediando as solicitações de pagamento feitas pelo amigo militar ao periódico. Vejam-se os trechos de duas correspondências, encontradas na seção de manuscritos da Biblioteca Nacional:

Adeus, meu caro Nelson. Falei na revista [Cultura Política] sobre a remessa de seus cobres. E, receando que haja esquecimento, insisto diariamente na recomendação (RAMOS, Graciliano. Carta de Graciliano Ramos a Nelson Werneck Sodré, em 2 de outubro de1942. Manuscrito autógrafo. Rio de Janeiro: Biblioteca Nacional, Seção de manuscritos, 32, 2,10, nº 78, 2 out. 1942).

A carta em que se referia ao pagamento da colaboração foi entregue depois do telegrama, equivalente a um recibo. Tranqüilizei-me. Várias vezes havia falado nisso - e sempre me diziam que o dinheiro tinha

\footnotetext{
${ }^{507}$ RAMOS, Ricardo. op.cit. p.218.

${ }^{508}$ ANDRADE, Almir. op.cit. p.3. Ainda segundo Almir, a contratação de Graciliano teria ocorrido depois de quatro ou cinco meses de funcionamento da revista, tendo em vista a grande afluência de ofertas de trabalho que a ela passavam a chegar, sobretudo, em virtude dos altos valores pagos por cada colaboração (Idem, ibidem).

${ }^{509}$ Em geral, na quarta página, apresentavam-se apenas informações sobre quem era o diretor da revista (Almir de Andrade, em capitulares) e sobre seu lugar de funcionamento (Rua da Misericórdia, Palácio Tiradentes, $4^{\circ}$ andar, Rio de Janeiro, Brasil) e telefones de contato.

${ }^{510}$ Sobre as andanças de Sodré, militar e autoditada, após a decretação do Estado Novo, ainda tenente, tornou-se ajudante-de-ordens do general José Pessoa, designado comandante da 9 a Região Militar, em Mato Grosso, em março de 1938. Após um ano e meio no Centro-Oeste, retornou à tropa da área de Itu-Jundiaí. Em seguida, passou um ano em São Paulo, participando da organização da Escola Preparatória de Cadetes. Logo depois, como capitão, estabeleceu-se em Salvador, para, então, voltar em 1943 ao Rio de Janeiro como aluno da Escola de Estado-Maior. (COSTA, Octávio, Vida e obra de Nelson Werneck Sodré. In: CUNHA, Paulo; CABRAL, Fátima (org). Nelson Werneck Sodré entre o saber e a pena. São Paulo: Editora da UNESP, 2006, p.18).
} 
seguido. Agora houve um atraso de cinco ou seis meses na tesouraria, o que afastou e desgostou diversos colaboradores.

Aqui só existe um original seu (“Sentimento de Nacionalidade na Literatura Brasileira”) [referência a texto de mesmo nome, que seria publicado em Cultura Política, ano 3, n.27, maio de 1943, p-118-130], que há dias foi para a composição. Os últimos artigos saíram nos números 18 e 19 parece.

Continuarei a atenazar d. Heloísa para que ela não se esqueça de mencionar o seu nome nas folhas, coisa que faz regularmente com todos, porque escreve conversando.

Falei ao Almir [de Andrade] sobre a remessa da revista, e soube que ela tem sido enviada pontualmente. Como é possível que tenha havido extravio, o rapaz da expedição lhe remete agora os números que lhe faltam, de agosto para cá (RAMOS, Graciliano. Carta de Graciliano Ramos a Nelson Werneck Sodré, em 29 de março de 1943. Manuscrito autógrafo. Rio de Janeiro: Biblioteca Nacional, Seção de manuscritos, 32, 2,10, $\mathrm{n}^{\circ}$ 77, 29 mar. 1943).

No primeiro trecho transcrito acima, a parte final de uma carta de 2 de outubro de 1942, Graciliano ressalta que insistia “diariamente” com a direção do periódico para que fossem enviados os “cobres” de Sodré, referentes a colaborações escritas por este último, publicadas pela revista, mas ainda não remuneradas. Provavelmente, faz menção aos textos "Fronteira Móvel” e "Primeiros documentos literários no Brasil”, publicados pelo autor de História da literatura brasileira, respectivamente nos números 18 e 19 de Cultura Política, de agosto e setembro de 1942.

Por sua vez, na segunda missiva, de 29 de março de 1943, fica mais explícito o contato relativamente estreito do escritor alagoano com a rotina administrativa do periódico. Como se prestasse satisfações a Sodré, Graciliano diz que continuava a cobrar da direção da revista a remuneração correspondente às colaborações ainda não pagas ao amigo, bem como a remessa a este último de exemplares de Cultura Política extraviados. Mais especificamente, ao longo do texto, dá mostras de conhecer o funcionamento interno do veículo: refere-se a um atraso de cinco ou seis meses na tesouraria, que desagradara diversos colaboradores; à sua atitude de “atenazar” uma espécie de secretária distraída (d. Heloísa), responsável pelas folhas de pagamento; e a uma conversa que tivera com o próprio diretor do veículo, Almir de Andrade, sobre o envio de números da publicação. 
Outro índice da proximidade de Graciliano com a publicação oficial encontra-se no fato de o escritor ter utilizado papel timbrado do Departamento de Imprensa e Propaganda para rascunhar alguns trechos de Infância, livro publicado pela José Olympio em 1945, mas escrito, sobretudo, durante a passagem de Graciliano por Cultura Política entre 1941 e $1944^{511}$. No Instituto de Estudos Brasileiros, foram localizadas três folhas manuscritas, nãoseqüenciadas e não-datadas com passagens referentes aos seguintes capítulos da obra memorialística: "Meu avô", “Adelaide” e "Um enterro" (ver imagens a seguir) ${ }^{512}$. Tal informação, que por si mesma não diz muita coisa, sugere apenas que o artista tinha acesso ao material impresso do órgão propagandístico, provavelmente, em virtude de seu trabalho como revisor, “filtro" e autor da revista getulista, e o utilizava para fins pessoais.

Voltando à iniciativa da revista de congregar a intelectualidade, inclusive aparentes opositores do regime, e construir uma imagem de suposta unidade em torno do Estado Novo, além de Graciliano, outro nome também chamava a atenção: o de Prudente de Morais Neto, que assinava seus textos em Cultura Política com o pseudônimo de Pedro Dantas. Homem de direita, ele destacou-se por sua oposição a Vargas desde a Revolução Constitucionalista de São Paulo, em 1932, chegando a ser preso e enviado a Lisboa após o conflito. Retornando ao Brasil em 1934, participou da criação do Partido Constitucionalista, ocupando a secretaria geral da agremiação, liderada por Armando de Sales Oliveira, então interventor em São Paulo. Com a frustrada campanha eleitoral de 1937 e a posterior extinção da vida partidária, ocorrida em decorrência da implantação do Estado Novo, passou a contribuir na campanha de resistência ao novo regime. Tal fato não impediu sua presença na revista à frente da seção “Literatura de Idéias” ao longo de seus dez números iniciais.

No que diz respeito à diversidade de colaboradores convidados, importava à construção das noções de unidade e consenso não só a postura política do intelectual, mas também a região do país do qual ele era procedente. Almir de Andrade também sinalizava no número inicial:

\footnotetext{
${ }^{511}$ Conforme sugere manuscrito do próprio Graciliano, contendo as prováveis datas de composição dos 39 capítulos de Infância, três capítulos foram escritos em 1938, quatro em 1939, dois em 1940, quatro em 1941, nove em 1942, sete em 1943 e dez em 1944 (ver DA SILVA, Márcia Cabral. Infância, de Graciliano Ramos: uma história da formação do leitor no Brasil. 2004, 196 f. Tese (Doutorado em Teoria e História Literária) Instituto de Estudos da Linguagem, Universidade Estadual de Campinas, Campinas, 2004, p.53). Nesse sentido, praticamente dois terços da obra foi produzido quando Graciliano era colaborador de Cultura Política.

${ }^{512}$ No Arquivo Graciliano Ramos, tais manuscritos encontram-se nas pastas 51 e 52 - "Matérias publicadas em periódico", misturados a uma série de recortes de jornal. Segundo informações recolhidas na tese referida na nota anterior, os três capítulos supracitados (não os rascunhos destes) teriam sido escritos, respectivamente, em 27 out. 1942, 16 abr. 1944 e 22 abr. 1944.
} 
Espécie de rascunho do capítulo "Meu avô", manuscrito em papel timbrado do Departamento de Imprensa e Propaganda e, depois, publicado, na versão final do livro de memórias Infância. Documento pertencente ao Arquivo Graciliano Ramos, depositado no Instituto de Estudos Brasileiros, pastas 51 e 52 - "Matérias publicadas em periódico".

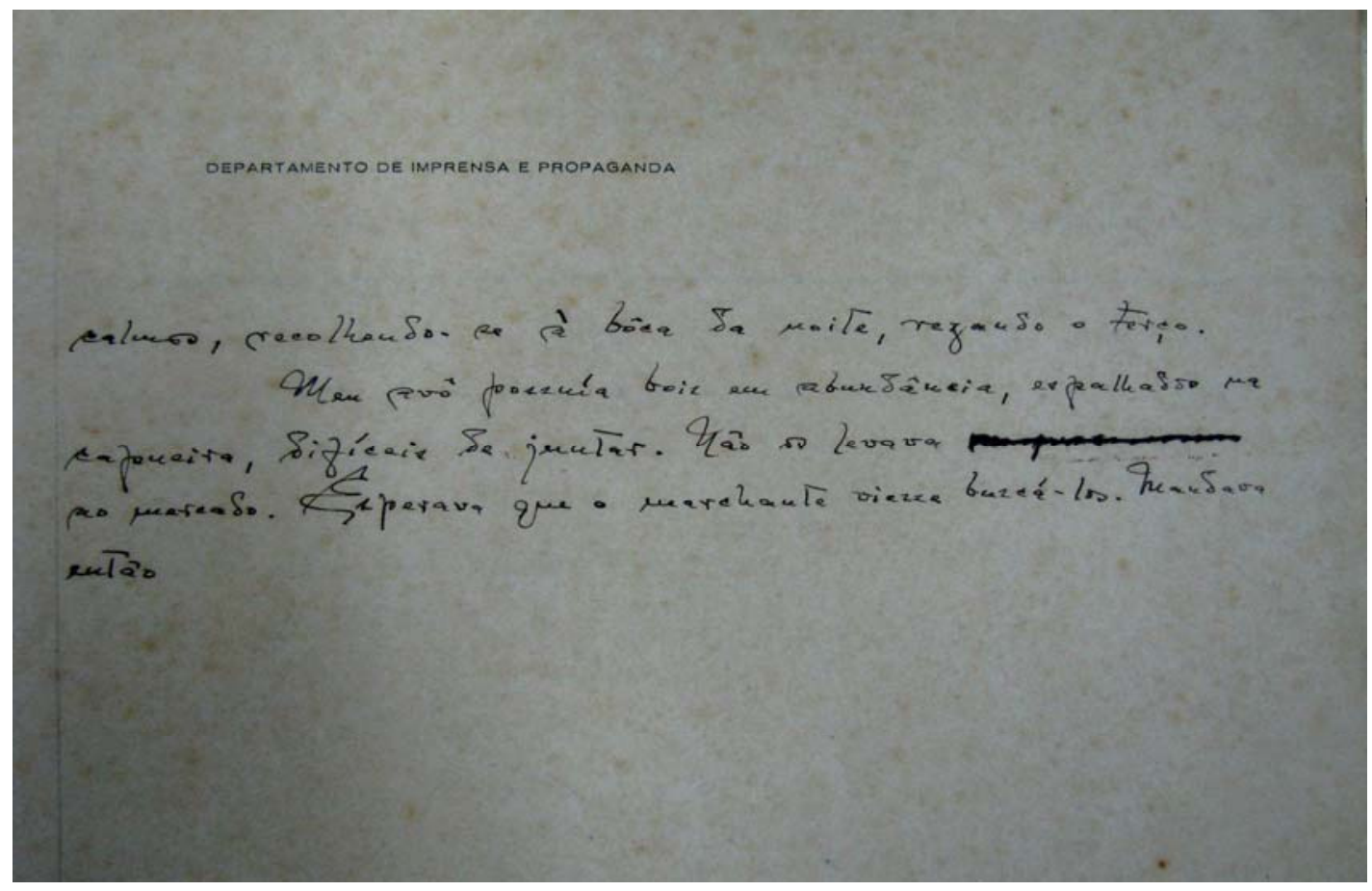

Segue o trecho transcrito:

1. calmos, recolhendo-se à boca da noite, rezando o terço.

2. Meu avô possuía bois em abundância, espalhados na

3. capoeira, difíceis de juntar. Não os levava

4. ao mercado. Esperava que o marchante viesse buscá-los. Mandava

5. então" ${ }^{, 513}$.

${ }^{513}$ RAMOS, Graciliano. Infância. 3.ed. Rio de Janeiro: Livraria Editora José Olympio, 1953, p.129. 
Pequeno trecho de rascunho do capítulo “Adelaide”, manuscrito em papel timbrado do Departamento de Imprensa e Propaganda e, depois, publicado, com modificações, na versão final do livro de memórias Infância. Documento pertencente ao Arquivo Graciliano Ramos, depositado no Instituto de Estudos Brasileiros, pastas 51 e 52 - "Matérias publicadas em periódico".

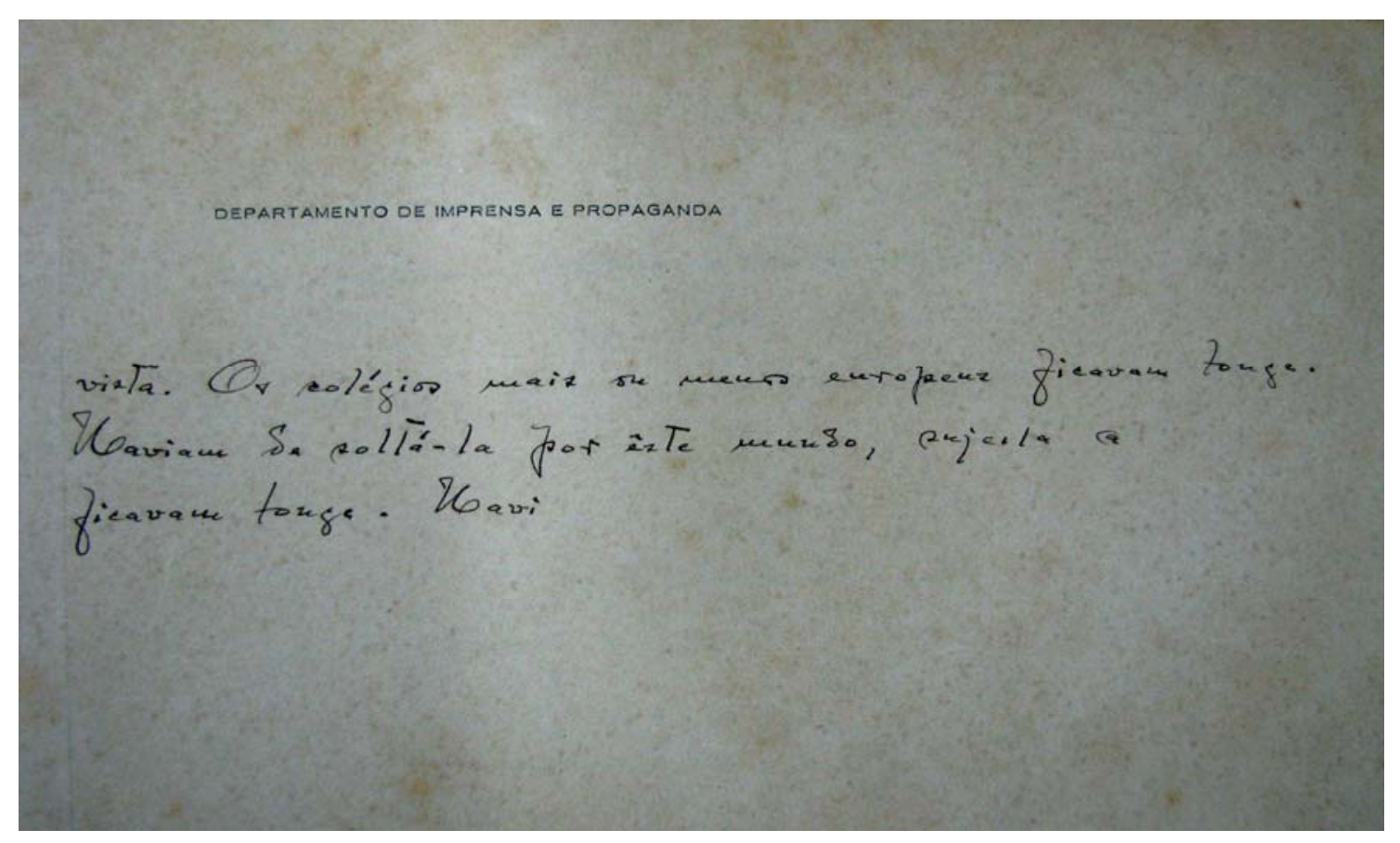

Segue o trecho transcrito:

1. vista. Os colégios mais ou menos europeus ficavam longe.

2. Haviam soltá-la por este mundo, sujeita a

3. ficavam longe. Havi ${ }^{514}$

${ }^{514}$ As duas primeiras linhas, apenas com a substituição do termo "Haviam de” (na segunda linha) por "Iriam”, foi publicada em RAMOS, Graciliano. Infância. 3.ed. Rio de Janeiro: Livraria Editora José Olympio, 1953, p.168. 
Um sentimentos mais forte de unidade nos aproxima uns dos outros - nós todos filhos do Norte, do Centro e do Sul. Os nossos mais sinceros e mais graves pensamentos se erguem nesta hora, para o Brasil - para o Brasil unido, cada vez mais consciente de sua unidade, e que se defronta com uma das mais tremendas convulsões da civilização ocidental ${ }^{515}$.

Nesse sentido, o nome de Graciliano ganhava ainda mais destaque, pois além de ex-preso político e de apresentar ligações com a esquerda, era originário do Nordeste, região que ocupava um papel de destaque nas concepções governamentais; ela era tratada como matriz da brasilidade, frente ao Sul desnacionalizado. Além disso, o escritor alagoano nascera no século XIX (1892) e antes do início da Primeira Guerra já contava com 22 anos, o que ajudava a corroborar a amplitude temporal dos colaboradores da revista, anunciada por seu editor.

No editorial "O segundo ano de Cultura Política”, saído no número 14, de abril de 1942, Almir de Andrade assinalava que o plano "vasto” e os objetivos “complexos” da publicação foram cumpridos à risca ao longo do primeiro ano de trabalho. Isso seria testemunhado pela amplitude das próprias seções do periódico que tinham por finalidade tratar dos principais aspectos da realidade nacional, “desde a parte essencialmente técnica, industrial, econômica, até a parte literária e artística” ${ }^{\$ 16}$. Outra meta alcançada pelo veículo seria a de congregar intelectuais, como visto acima, das mais variadas regiões, doutrinas e tendências ("não num círculo de colaboradores mais ou menos próximos do centro”) em torno dos problemas nacionais.

Nesse número de Cultura Política, aparecem destacados os nomes, as especialidades e a procedência de todos aqueles que contribuíram com a revista desde o primeiro número até aquele momento. Ao todo são mais de 150 personalidades, listadas sem uma ordem aparente. Além disso, a disposição destas não apresentava distinções, seja pelo lugar ocupado na lista, seja pela utilização de algum recurso tipográfico diferenciador, visando ressaltar os colaboradores de maior peso no meio intelectual ou os que desfrutavam de prestígio dentro do próprio regime. Em meio a um mar de engenheiros, advogados, jornalista e burocratas de diferentes secretarias, departamentos etc. figuram aleatoriamente os nomes já assinalados de Gilberto Freyre, Prudente de Morais Neto, Lúcio Cardoso, Jorge de Lima, Rosário Fusco,

\footnotetext{
${ }^{515}$ Idem, ibidem.

516 ANDRADE, Almir. O segundo ano de Cultura Política. Cultura Política, Rio de Janeiro, ano2, n.14, abr.1942, p.2.
} 
Cassiano Ricardo, Nelson Werneck Sodré, Marques Rebelo, entre outros. O próprio Almir de Andrade, por exemplo, ocupava a posição 33, entre as figuras de Luiz Antonio da Costa Carvalho (Professor da Faculdade Nacional de Direito e Universidade do Brasil) e Mercedes Dantas (Diretora de escola na prefeitura do Distrito Federal e pertencente à Academia de Letras da Bahia e ao Instituto Histórico e Geográfico de Alagoas). Já Graciliano Ramos (descrito como romancista e escritor de Alagoas) aparece com o número 113, entre os nomes de Ulysses Ramalhete Maia (Inspetor-chefe do ensino secundário, profissional e técnico no Estado do Espírito Santo) e Antonio Simões dos Reis (Bibliógrafo e historiador, ligado ao Instituto Nacional do Livro e ao Instituto Histórico e Geográfico de Sergipe).

Tal disposição, somada ao propósito declarado de juntar tipos das mais diferentes procedências e origens, procura nivelar e uniformizar os colaboradores, dando ensejo à afirmação de Almir de Andrade:

“... tal variedade de especialistas, tão diversa e expressiva contribuição de representantes dos diferentes Estados do Brasil - que poderíamos ter quase a certeza de não errar, afirmando que foi a primeira vez, em nosso país, que se reuniram, nas páginas de um periódico cultural, tão grande e variado número de valores, unificados por um só pensamento comum: descrever e compreender o Brasil, numa demonstração de sincera e esclarecida solidariedade com a ação política do Governo”517.

Reafirmava-se, portanto, a construção de uma aparente unidade, algo que seria atestado quantitativamente pela própria revista. Todos os autores, vistos em conjunto, são destacados como participantes da mesma obra comum de recuperação e fundação da brasilidade.

Ainda com relação aos colaboradores, a tentativa de uniformização dos nomes podia ser observada na própria seção com a qual Graciliano colaborava. Ao lado do Autor de Angústia e de Marques Rebelo, grandes escritores do período ${ }^{518}$, ocupava o mesmo espaço e posição o jornalista e ex-inspetor de ensino no Estado do Pará, Raimundo Pinheiro. Cabia a ele traçar os "Quadros e Costumes do Norte”, tal como aos outros dois os "Quadros e Costumes do Nordeste” e os “Quadros e Costumes do Centro e do Sul”, respectivamente ${ }^{519}$. Nessa

\footnotetext{
${ }^{517}$ Idem, ibidem.

${ }^{518}$ Até o convite para colaborar com Cultura Política, em 1941, Marques Rebelo, já havia publicado as seguintes obras: Oscarina, contos, (1931); Três caminhos, contos (1933); Marafa, romance, (1935) e a A estrela sobe, romance, (1939).

${ }^{519}$ Diferentemente de Graciliano Ramos e de Marques Rebelo, presentes em Cultura Política desde o primeiro número, Raimundo Pinheiro passa a estampar seus textos apenas a partir do quinto volume, de julho de 1941.
} 
empreitada, parecia contar mais o fato deste desconhecido articulista encontrar-se ligado à região que se propunha retratar (Pinheiro era paraense), do que seu histórico no mundo das letras. De acordo com a idéia de “realismo” defendida por Cultura Política, tal argumento de origem tornaria seus escritos mais verdadeiros, equiparando-os aos dos outros dois romancistas. Estes, por sua vez, segundo as coordenadas oficiais, assumiam preferencialmente o papel de “cronistas”, na medida em que eram apresentados tanto como grandes artistas, mas, sobretudo, como documentadores do cotidiano, tendo em vista a familiaridade com os espaços que se propunham a representar.

No que diz respeito a esse último aspecto, não é à toa que no primeiro número, Almir de Andrade destaca que as colaborações reunidas em Cultura Política seriam depoimentos ("Uns após os outros esses depoimentos virão, do norte e do sul, do litoral e do centro, de velhos e moços, de gerações da República e do Império, de antes e de após a guerra”520). A revista revela predileção por uma interpretação biográfica e documentalista, indicando que as vivências de determinado o autor, em determinado lugar, poderiam explicar seus escritos e conferir-lhes estatuto de real. Por exemplo, por esta perspectiva estadonovista, o fato de Graciliano ser procedente do Nordeste do país tornava seus relatos sobre tal região autênticos. E mais: seus escritos passavam a ser tratados como a própria materialização viva da realidade das paragens sertanejas e litorâneas descritas. Como se observou anteriormente, esse era um forte ponto de convergência entre a poética graciliânica, explicitada em seus textos críticos (não a partir da interpretação dos romances), e os postulados governamentais: o autor de Angústia defendia que o artista deveria privilegiar a fabulação de suas experiências pessoais, defendendo, em seus artigos de jornal, a prevalência de um protocolo documental-biográfico.

\subsubsection{A estrutura da revista}

Cultura Política trazia o subtítulo de Revista Mensal de Estudos Brasileiros o que já evidenciava seu propósito fundador de definir e esclarecer o rumo das transformações sociais e políticas pelas quais o país passava, sobretudo após a Revolução de 1930, acontecimento tratado como marco fundador do regime implantado em 1937. Colocava-se, portanto, como um órgão informativo de amplo espectro, sem deixar de combinar tal tarefa com a preocupação explícita de formar consciências em apoio aos ideais do Estado Novo, os quais

\footnotetext{
${ }^{520}$ ANDRADE, Almir de. A evolução política e social do Brasil. Cultura Política, Rio de Janeiro, ano 1, n.1, mar. 1941, p.8.
} 
tomava como as próprias aspirações da brasilidade ${ }^{521}$. Além de tratar detidamente das realizações governamentais, o periódico centralizava as informações bibliográficas sobre o governo e seu líder, noticiando e resenhando, de maneira sistemática e exaustiva, todas as publicações (livros, artigos de revistas e jornais) que se detinham sobre tais matérias ${ }^{522}$.

Na consecução desse projeto, chamava a atenção o cuidado editorial do periódico, responsável em grande medida por sua eficácia discursiva. Cada uma das seções de Cultura Política era antecedida por notas introdutórias que explicitavam seus objetivos e intenções, bem como definiam sua abrangência e justificavam seus princípios. Na maioria das vezes, as colaborações eram acompanhadas de paratextos explicativos que traziam informações biobibliográficas sobre os articulistas. Além de contextualizar e enaltecer os autores, tais sumários também ofereciam chaves interpretativas para os artigos, enquadrando-os nos postulados estadonovistas. Vistos em conjunto, esses recursos editoriais cumpriam o papel de unificar não só as produções dos diferentes escritores, mas as possíveis leituras destas de acordo a temática orientadora central da publicação. Nesse sentido, ao colocar-se como espelho do Estado Novo, governo que se propunha total e orgânico, a revista procurava se apresentar editorialmente como um corpo unitário, hierarquizado e amplo.

Ao longo de seus números iniciais, Cultura Política apresentava a seguinte estrutura, com seis seções, que iriam se manter até o número 18, de agosto de 1942:

1. Problemas políticos e sociais

2. O pensamento político do Chefe do governo

3. A estrutura jurídico-política do Brasil

4. Textos e documentos históricos

5. A atividade governamental

6. Brasil social, intelectual e artístico

\footnotetext{
${ }^{521}$ GOMES, Ângela de Castro. História e historiadores. Rio de Janeiro: Editora da FGV, 1999, p.128.

${ }^{522}$ Como mostra da importância dessa iniciativa, foi publicada em abril de 1943 a separata "O pensamento político do presidente", que agrupava de maneira retrospectiva todo o material bibliográfico sobre o regime e seu chefe, saído ao longo dos primeiros 25 números de Cultura Política. Tratava-se de uma edição comemorativa ao $60^{\circ}$ aniversário de Vargas. Como destaca Velloso, “a preocupação explícita em atualizar, centralizar e controlar as informações na imprensa dão conta do alto grau de organização e eficácia do projeto ideológico” levado cabo pela publicação (VELLOSO, Mônica Pimenta. op.cit. p.75).
} 
“Problemas políticos e sociais”, a seção de abertura, reunia artigos sobre os mais variados temas, procurando situar e debater questões que diziam respeito ao processo histórico do país. Seu objetivo final era ressaltar as soluções e o encaminhamento dado aos problemas brasileiros pelo Estado Novo, enfatizando a suposta guinada política testemunhada pelo Brasil, após novembro de 1937. Em geral, os textos de caráter erudito procuravam destacar a complexidade da situação nacional. Nesse movimento, acabavam construindo um discurso sofisticado de legitimação do regime, no qual o despertar da consciência da brasilidade pressupunha a união entre Estado e nação, sem abdicar, muitas vezes, do recorrente tom apologético.

Havia escritos que tratavam tanto de assuntos gerais, de abrangência nacional (como, por exemplo, "O Estado Novo e seu sentido bandeirante”, de Cassiano Ricardo, presente no número inicial de Cultura Política, que abordava a perspectiva de "Marcha para o Oeste" defendida pelo regime), como aqueles que versavam sobre matérias específicas, em geral de caráter regional. Contudo, tanto os primeiros quanto os segundos podiam tratar de temas variados, entre eles, doutrina, história, economia, administração pública, educação, saúde, organização e ação militares, vida operária, política internacional e legislação.

O texto introdutório à seção ressaltava o fato de que os colaboradores do primeiro número procediam de diferentes Estados brasileiros, construindo o efeito de uma aparente totalidade nacional a unificar os fragmentos interpretativos sobre o país apresentados:

Há colaboradores do Amazonas (Francisco Galvão), do Ceará (Djacir Menezes e Monte Arraes), de Pernambuco (José Maria Belo), da Bahia (Arthur H. Neiva), do Espírito Santo (U. Ramalhete Maia), de Minas Gerais (Menelick de Carvalho), do Estado do Rio (Jaime de Barros), da capital federal (Mário Travassos e Silvio Peixoto), de São Paulo (Cassiano Ricardo), de Goiás (Paulo A. de Figueiredo), do Rio Grande do Sul (Fernando Callage).

De outros Estados virão ainda em números futuros. De Norte a Sul, do litoral ao sertão, é o concurso de todos os estudiosos brasileiros para o esclarecimentos dos problemas e realidades do Brasil o que vamos promover, estimular e desenvolver. O Brasil Novo recobra a consciência de si mesmo - da sua unidade histórica, econômica, social e intelectual ${ }^{523}$.

\footnotetext{
${ }^{523}$ PROBLEMAS políticos e sociais. Cultura Política, Rio de Janeiro, ano 1, n.1, mar. 1941, p.10.
} 
Ao mesmo tempo, sinalizava-se que os privilégios regionais teriam caído por terra, bem como as distinções entre Estados grandes e pequenos: "Um só pensamento nos une: o Brasil grande e unido, com uma só alma e como um só todo solidário”524. Defendia-se, portanto, a um só tempo a unidade e a totalidade tanto física (geográfica), quanto conceitual (temática) em torno das diretrizes e orientações implementadas pela ditadura getulista.

Já a seção “O pensamento político do Chefe do Governo” dedicava-se à interpretação das palavras e ações de Getúlio, o qual é apresentado como o mais "ativo doutrinador do novo Estado brasileiro”. Os textos procuram fazer uma associação direta entre o modo de pensar de Vargas e os rumos seguidos pela nacionalidade seja no passado, seja no presente, seja no futuro, pois se considerava o presidente integrado a "nossas tradições”, ao "espírito popular” e às legítimas “aspirações brasileiras”. Em geral, os articulistas detêm-se sobre trechos de $A$ nova política do Brasil, seleção de discursos e mensagens de Vargas, publicada em mais de dez volumes pela Livraria e Editora José Olympio, a partir de 1938. Os autores, com destaque para as presenças de Azevedo Amaral, Rosário Fusco e o próprio Almir de Andrade, procuravam explicar determinadas noções como cultura, realismo e democracia contidas nos textos getulistas. Fora isso, esse segmento de Cultura Política também publicava, em menor número, entrevistas concedidas pelo estadista, bem como seus pronunciamentos mais recentes que ainda não haviam ganho o formato de livro.

A terceira seção, “A estrutura jurídico-política do Brasil”, agrupava artigos e reportagens sobre as transformações operadas pelo Estado Novo na esfera do direito e da administração pública, com destaque para o caráter “inovador” da constituição de 1937. Segundo o discurso oficial, ela estaria conectada tanto às "realidades" e às "tradições brasileiras”, como ao “espírito avançado das grandes correntes da evolução política do mundo moderno”. Por essa perspectiva, seria a um só tempo moderna e tradicional. Via de regra seus colaboradores eram magistrados de renome: membros do Ministério Público, desembargadores, ministros do Supremo Tribunal Federal, jurisconsultos, entre outros.

“Textos e documentos históricos”, como o próprio título dava a entender, propunha-se a resgatar momentos considerados "fundamentais" do passado brasileiro, pautando-se obviamente pelas orientações governamentais. De maneira específica, procurava fornecer

${ }^{524}$ Idem, ibidem. 
subsídios à construção da história do país anterior a 1930, ao mesmo tempo em que esclarecia ao leitor comum a importância da noção de “documento” para a consecução de tal empreitada. Paralelamente, seus propósitos enquadravam-se no esforço de recuperação historiográfica levado a cabo pelo governo, do qual também faziam parte os Anais da Biblioteca Nacional, as publicações do Arquivo Nacional, a Revista do Serviço do Patrimônio Histórico e Artístico Nacional, o Anuário do Museu Imperial, entre outras iniciativas editoriais que tinham como objetivo disponibilizar manuscritos e outras fontes primárias.

Ao longo da existência da seção, que se estendeu desde o primeiro número, em março de 1941, até o quadragésimo, em maio de 1944, foram publicados 54 documentos. Desse conjunto apenas uma minoria era de textos saídos em livros e jornais; o maior volume era composto de correspondências, cartas régias, cartas de brasão, autos de processo, testamentos, pareceres, memorandos e manifestos ${ }^{525}$. Os momentos da história do país mais abordados obedecem a seguinte ordem: Império (44,4\%), Colônia (27,7\%) e Primeira República (18,5\%). Segundo a pesquisadora Ângela de Castro Gomes, apesar da importância conferida às lutas pela independência, anteriores a 1822, a ênfase maior recai no período imperial, com destaque para o Segundo Reinado, quando a construção do Estado/Nação impôs-se aos brasileiros $^{526}$. Trata-se do momento de afirmação da nacionalidade. As referências à República são quase sempre desabonadoras, pois serviam para reforçar, por oposição, a política centralista e autoritária levada a cabo pelo regime.

Em linhas gerais, os documentos eram antecedidos por notas introdutórias, que os situavam historicamente, bem como a seus autores, além de fornecerem a chave para sua leitura, segundo os postulados estadonovistas expressos pela publicação. Como forma de ilustrar o funcionamento desse expediente, vale citar um rápido exemplo. No terceiro número de Cultura Política, de maio de 1941, há a apresentação de um "Memorandum sobre a situação agrícola nacional no último período do II Império", elaborado por dois fazendeiros da província do Rio de Janeiro, o Com. Domingos Teodoro de Azevedo e o Tenente Coronel Augusto de Miranda Jordão. Os latifundiários requisitavam auxilio governamental num contexto de instabilidade econômica e política, sobretudo, em decorrência do fim eminente da escravidão. Exposto esse quadro, o editor da revista destacava como a situação do país teria

\footnotetext{
${ }^{525}$ GOMES, Ângela de Castro. op.cit. p.182.

${ }^{526}$ Idem, ibidem.
} 
mudado com o novo governo. Para tanto, passava a enumerar as conquistas e avanços levados a cabo por Getúlio:

\begin{abstract}
A criação de institutos, as leis do Reajustamento Econômico, as leis de Proteção aos trabalhadores rurais, as Leis de Assistência Social, a técnica de especialização e tanto outros benefícios alcançados pela numerosa classe, representam uma paisagem nova na história agrícola do nosso País. - Já não é a velha história, enferrujada dos "engenhos" no atraso das veredas para carros "plangentes" e retardatários, ou para as "aranhas" aristocráticas dos "Senhores". - As estradas largas, os caminhos de ferro, ligando quase todas as cidades do Brasil imenso, e ainda as linhas aéreas, nem recordam mais aquele legítimo quadro colonial, quase lendário no pensamento da nova geração ${ }^{527}$.
\end{abstract}

A leitura teleológica, que enfatiza a superação das mazelas do passado, impõe-se nesse caso. No entanto, era mais comum que os documentos procurassem servir de atestado da suposta conexão entre Estado Novo e as tradições brasileiras. Nesse sentido, o governo valia-se do passado como forma de confirmar e legitimar suas ações no presente. Veja-se, como exemplo, o trecho extraído do texto introdutório ao "Manifesto da Independência do Brasil (1822)”, documento presente no segundo volume de Cultura Política, de abril de 1941:

\begin{abstract}
Embora não seja um documento inédito, é muito pouco conhecido do grande público, razão pela qual o transcrevemos hoje em nossas páginas, que levarão ao sabor dos estudiosos da história e das coisas do Brasil mais o conhecimento de um dos grandes trabalhos do estadista ilustre [José Bonifácio de Andrade e Silva]. - Por ele se sente a tendência do nosso espírito nacionalista, que hoje cresce cada vez mais, com a nova política do Brasil ${ }^{528}$.
\end{abstract}

Tal ênfase nacionalista não se restringia ao Império; estendia-se também aos períodos colonial e republicano, pautando-se pelo objetivo pedagógico de despertar nos brasileiros a “consciência de si”, ideal que norteava a própria razão de ser da revista.

Em seguida, vinha o segmento “A atividade governamental”. Tal seção destinava-se ao registro mensal das medidas governamentais nos mais diferentes campos de atividade: cultura, educação, saúde, moradia, agricultura, combate às secas, relações internacionais, estrutura de governo entre outras. Consistia-se de uma crônica panorâmica, sem assinatura, que agrupava tais realizações do regime, e de textos mais específicos, escritos por variados integrantes da burocracia civil e militar.

\footnotetext{
${ }^{527}$ ESTE MEMORANDUM. Cultura Política, Rio de Janeiro, ano 1, n.3, maio 1941, p.209.

${ }^{528}$ EM 5 DE AGOSTO... Cultura Política, Rio de Janeiro, ano 1, n.2, abr.1941, p.198.
} 
Em linhas gerais, servia como atestado do caráter tentacular e tutelar da administração estadonovista, que se espraiava pela organização social. No entanto, não se contentava apenas em fazer o relato das realizações atuais do regime. Do primeiro ao oitavo número, sob o título de “Transformações no campo do direito”, propõe-se a realizar um levantamento do histórico das transformações no campo jurídico-legislativo, promovidas pelo governo desde 1930. O responsável por esse conjunto de escritos era Luiz Antônio da Costa Carvalho, professor da Faculdade Nacional de Direito da Universidade do Brasil, autor de uma monografia sobre o mesmo tema, premiada pelo DIP. Empreende-se aqui, portanto, não só a divulgação como a construção de um relato histórico dos feitos do próprio regime.

Já a seção “Brasil social, intelectual e artístico” destacava-se pela abrangência e amplitude no tratamento de diferentes manifestações culturais e sociais do país. Seu papel era esclarecer, difundir e exemplificar os rumos e a influência da política governamental sobre as letras, as artes, as ciências e os usos e costumes, abarcando tanto o universo erudito quanto o popular. Ela comportava-se, portanto, como uma espécie de "guarda-chuva” temático que englobava três subseções - "Evolução Social”, “Evolução Intelectual” e “Evolução Artística” -, que por sua vez apresentavam suas próprias e múltiplas subseções, formando uma espécie de teia que pretendia a englobar a totalidade da cultura nacional. Veja, abaixo, o esquema deste segmento de Cultura Política e suas respectivas subdivisões:

Editorial: “Influência política sobre a evolução social, intelectual e artística do Brasil”.

\section{A) Evolução Social}

Editorial: A ordem política e a evolução social

Quadros e Costumes do Nordeste

Quadros e Costumes do Centro e do Sul

Quadros e Costumes do Norte

O povo brasileiro através do folclore

Intérpretes da vida social brasileira

Páginas do passado brasileiro

B) Evolução Intelectual

Editorial: A ordem política e a evolução intelectual 
Literatura de Ficção

Literatura de Idéias

Literatura Histórica

História Literária do Brasil

Estudos e pesquisas científicas

Educação

Movimento bibliográfico

Bibliografia estrangeira sobre o Brasil

C) Evolução Artística

Editorial: A ordem política e a evolução artística

Música

Artes Plásticas

Teatro

Cinema

Rádio

No editorial de lançamento da seção, reforça-se aquela proposta, presente ao longo de todo o periódico, de utilizar a diversidade dos assuntos e dos autores como atestado de unidade e como forma de legitimar as ações regimentais. Paralelamente, há o enaltecimento da qualidade dos colaboradores que teriam a missão de testemunhar o "renascimento" intelectual e estético do país nas páginas de Cultura Política:

Colaboram nelas, desde o primeiro número, elementos escolhidos dentre os mais significativos da elite intelectual do Brasil. Elementos de diversas correntes literárias, artísticas e científicas se encontram aqui representados (...) Aqui colaboram nomes de todas as gerações que hoje vivem no Brasil; gerações jovens de após a guerra; gerações do princípio do século; gerações que nasceram com a República; gerações de antes da República, que assistiram a Abolição. Cada uma delas tem representantes assinando as crônicas mensais desta seção ${ }^{529}$.

Ao mesmo tempo, enfatizava-se que a revista não teria partido e que seu objetivo seria o de “espelhar tudo o que fosse genuinamente brasileiro”. Esse privilégio para uma temática de caráter nacionalista, bem como o predomínio de uma visada cultural funcionavam como

${ }^{529}$ BRASIL social, intelectual e artístico. Cultura Política, Rio de Janeiro, ano 1, n.1, p.226. 
elementos agregadores e atrativos para a intelectualidade, abrindo espaço para colaborações diversificadas. É ao longo dos múltiplos segmentos dessa seção, por exemplo, que se encontram impressos os nomes de Graciliano Ramos, Marques Rebelo, Prudente de Morais Neto, Lúcio Cardoso e Hélio Viana. Todos estes presentes na publicação, pelo menos, ao longo de seus dez primeiros números.

No entanto aqui, como nas outras partes da revista, ao lado dos grandes intelectuais (a ínfima minoria dos nomes presentes em "Brasil, social, intelectual e artístico”), havia um grande número de colaboradores sem a mesma expressão e relevância cultural. Estes, em geral, ocupavam diferentes cargos na burocracia estatal. É longa a lista de professores (primários, secundários e do ensino superior), inspetores de ensino, profissionais liberais, estudiosos vinculados a museus, conselhos e institutos de pesquisa, entre outros, que publicaram textos específicos, relacionados às suas áreas de atividade. Se por um lado não possuíam renome, por outro abordavam assuntos que conheciam de perto, pois, comumente, diziam respeito às suas ocupações profissionais. Tais colaborações podiam ser tanto costumeiras como bissextas. No primeiro caso, tome-se o exemplo dos artigos de Luiz Heitor, professor catedrático da Escola Nacional de Música da Universidade do Brasil, crítico da subseção de música ao longo de quase toda a existência da revista. No segundo, pode-se citar o desconhecido Raul de Azevedo, Presidente da Comissão de Eficiência do Ministério da Viação, que no número 5, de julho de 1941, publicou um texto sobre a Amazônia.

Como se pode ver acima, de acordo com a estrutura hierarquizada de "Brasil, social, intelectual e artístico”, o termo "evolução” aparece nos títulos de suas três principais subseções ("Evolução Social”, “Evolução Intelectual” e “Evolução Artística”). A recorrência da palavra pressupõe o desenrolar de uma situação inicial até o momento presente, representado no texto pelo Estado Novo, no qual determinados aspectos do passado teriam atingido uma posição mais desenvolvida. Nesse sentido, o uso recorrente de tal conceito já indicava a proposta de leitura do tempo pretérito levada a cabo pelo regime, a qual ganhava contornos mais definidos ao longo deste segmento do periódico. Nele, são inúmeros os espaços destinados à história do país, seja ela política (focada em personalidades e acontecimentos singulares) ou social. No primeiro grupo estão "Literatura histórica”, “História literária do Brasil” e "Intérpretes da vida social brasileira”. Já no segundo, encontram-se "Páginas do passado brasileiro", “O povo brasileiro através do folclore” e, inclusive, os “Quadros e costumes do Nordeste”, voltados à construção de uma história 
literária do cotidiano, por meio da elaboração de uma espécie de inventário etnográfico da vida sertaneja.

Ao olhar para a história brasileira, a revista destacava um conjunto permanente de noções definidoras da identidade nacional, que se desdobrariam ao longo do tempo. Nesse sentido, pressupõe a existência de certa essência de brasilidade que evoluía com a passagem dos anos, ganhando novas conformações, cada vez mais condizentes com seu suposto caráter "original”. Tratava-se, portanto, de um evolucionismo conservador, que previa tanto a continuidade do passado como seu aprimoramento no decorrer da duração histórica. Orientado por uma visada teleológica, o fim desse processo encontrava-se nas concepções getulistas, que ao mesmo tempo recuperavam, atualizavam e realizavam as experiências anteriores. Tal perspectiva era extramente estratégica ao governo, pois lhe permitia tanto ressaltar sua conexão com um suposto "espírito nacional”, imemorial, como sua atualidade na solução dos problemas do país.

De acordo com a organização da seção, primeiramente vinha a “evolução social”. Só em seguida apareciam, respectivamente, as "evoluções” intelectual e artística. Nesse sentido, a própria organização e disposição dos assuntos revelavam o privilégio para uma diretriz sociológica no exame tanto do universo das artes como do pensamento de uma maneira geral. Portanto, segundo a perspectiva estadonovista, na medida em que intelectuais e artistas passaram a privilegiar o "social” em suas obras, estas naturalmente "evoluíram”, atingindo patamares não observados anteriormente.

Esse pensamento dá o tom em todos os setores da cultura nacional, tratados por "Brasil, social, intelectual e artístico". Tome-se, por exemplo, a seção "Literatura de Ficção", comandada por Wilson Louzada. Em sua segunda colaboração para o periódico, o autor destacava a superioridade dos romancistas posteriores à Revolução 1930, frente aos anteriores a ela. Nesse processo, afirmava que a literatura teria deixado de valer apenas como "literatura” após a chegada de Getúlio ao poder, pois teria passado a procurar uma base social mais definida:

...os artistas novos passaram a olhar a realidade brasileira sob outros pontos de vista. Nenhum deles sentia a literatura apenas como literatura. A função social do romance definia-se, entre nós, num sentido 
de aproximação ao ambiente físico e humano, encarado como unidade. Não de um modo geral, embora a corrente mais vigorosa, na época fosse a regionalista e não a humanista ${ }^{530}$.

No entanto, se havia uma ênfase sociológica, ela subordinava-se à ação governamental. O discurso getulista fazia crer que os avanços nos diferentes ramos de atividade seriam resultados das ações do regime. Tal afirmação pode ser verificada pela própria redação dos títulos dos editoriais de cada subseção: “A ordem política e a evolução social”, “A ordem política e a evolução intelectual” e “A ordem política e a evolução artística”. Pelas prerrogativas estadonovistas, a "ordem política”, na qualidade de instância criadora e promotora do desenvolvimento em qualquer setor, sempre deveria prevalecer. Nesse sentido, o regime se colocava como uma espécie de tutor da sociedade, o garantidor do progresso, mas, para tanto, precisava da colaboração dos intelectuais. Cabia a eles produzir os bens simbólicos que alimentariam a própria mecânica do poder, pois se a política ocupava a posição central, ela precisava ser orientada por homens capacitados no sentido de promover os elos de união entre Estado e nação. Tal perspectiva elitista prevalece na definição do lugar privilegiado ocupado pelos "homens de pensamento" no regime.

Dessa maneira, a presente seção tinha grande valor estratégico, propiciando ao governo estreitar laços com os intelectuais e, assim, abrir caminho para a construção de sua legitimidade, na medida em que passava a contar com o respaldo e a colaboração de tais figuras eminentes. Estas o ajudariam direta ou indiretamente na elaboração e na validação da idéia de “espírito nacional”, noção que servia de escora conceitual para o regime justificar seu autoritarismo e centralismo, bem como o fim do sufrágio universal e sua suposta conexão direta com o povo, a qual suprimia a necessidade de intermediários partidários. Por tal perspectiva, portanto, o regime se arrogava a condição de restaurador e tutor da brasilidade, ao mesmo tempo em que Getúlio passava a ser visto, metonimicamente, como o comandante responsável por atender aos anseios populares, adormecidos ao longo da história do país.

Além disso, ao tratar da implantação e das bases da política cultural do governo, a seção ganhava um caráter de celebração; festejava-se o acordo entre Estado e intelectuais. Enquanto o primeiro promovia uma política nacionalista, de invenção da brasilidade, os segundos ocupavam o papel de intérpretes desse processo.

\footnotetext{
${ }^{530}$ LOUZADA, Wilson. Literatura de Ficção II. Cultura Política, Rio de Janeiro, n.2, abr. 1941, p.262.
} 


\subsubsection{Incorporação de novas seções}

A partir do número sete, de setembro de 1941, o periódico ganhou uma nova seção, “O trabalho e a economia nacional”, que se dedicava ao estudo dos problemas relacionados ao trabalho, à riqueza e à produção brasileiras. Seu objetivo era divulgar as iniciativas estatais nesta área, bem como recolher e apresentar dados informativos, tendo em vista a “preocupação do governo concentrada (...) no esforço gigantesco de reconstrução da economia nacional”531. Nessa iniciativa, os editores procuravam salientar o caráter controlador, centralista e orgânico do regime, produzindo o efeito de que nenhum aspecto do setor produtivo lhe escapava das mãos.

Para tanto, contava com artigos de colaboradores, bem como subseções fixas, não assinadas, mas escritas por redatores especializados no assunto, segundo informa o editorial de apresentação deste segmento de Cultura Política. Eram elas: "Economia dos Estados”, “Órgãos de defesa da economia nacional” e "Metrópoles brasileiras”. A primeira, a cada número, procurava apresentar uma radiografia da situação econômica de um Estado brasileiro, abrangendo diferentes aspectos: produção industrial, agrícola, transportes, recursos enérgicos, ocupação do território etc. Ressaltava-se que a revista deixava de lado preocupações regionalistas e que o estudo individualizado de cada divisão administrativa do país visava à unidade do todo, ou seja, as análises eram tomadas como mostras da organicidade estatal. A segunda destacava as instituições técnicas criadas pelo regime para regular e proteger a economia nacional. Ao mesmo tempo em que divulgava as realizações dos institutos criados, pedagogicamente explicava a estrutura, as funções e as finalidades deles. Já a terceira privilegiava as grandes cidades brasileiras, tomando o crescimento industrial e comercial destas como “índices seguros” de desenvolvimento econômico do país.

Em maio de 1942, quando chegava ao $15^{\circ}$ número, a revista ganhou mais uma seção, intitulada "Política militar e defesa nacional". Ela se destinava a assuntos relacionados à guerra e contava, basicamente, com a colaboração de elementos ligados às Forças Armadas brasileiras (mar, ar e terra). Segundo o general E. Leitão de Carvalho, em texto desta mesma edição, seu papel era desenvolver nas "elites responsáveis a consciência da segurança da

${ }^{531}$ O TRABALHO e a economia nacional. Cultura Política, Rio de Janeiro, ano 1, n.7, set. 1941, p.164. 


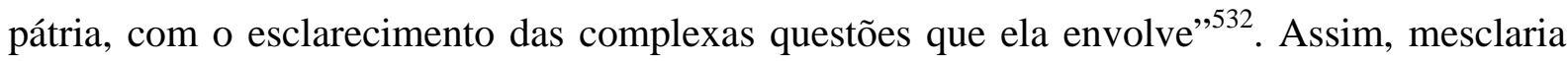
aspectos mobilizadores, doutrinários e informativos num contexto de demanda por esse tipo de informação. Tratava-se do momento imediatamente anterior à entrada oficial do país na Segunda Guerra ao lado dos Aliados, fato que aconteceria dois meses depois, em agosto de 1942. No entanto, já se vivia um clima de guerra, quando em fevereiro do mesmo ano, após o rompimento das relações diplomáticas com o Eixo no mês anterior, embarcações brasileiras passaram a ser torpedeadas por submarinos alemães.

Em editorial do número 16, de junho de 1942, Almir de Andrade sublinha que a colaboração de elementos militares nas páginas de Cultura Política era um fato corriqueiro. Nesse sentido, a seção recém-criada cumpriria apenas o papel de incentivar e coordenar os trabalhos relacionados ao tema da guerra. Paralelamente, o autor afirma que a oficialização desse novo espaço era uma forma de colocar em relevo a "cultura militar", tomada como "um dos aspectos mais importantes e imprescindíveis da cultura nacional”,533.

\footnotetext{
Muito deve a cultura brasileira à cultura militar, não só através da ação eficiente do Exército e da Marinha na orientação dos nossos destinos, como também pelo incessante concurso dos escritores militares na literatura, na história, na geografia, na economia, na filosofia, na filologia e em outros setores da cultura nacional. A união, pois, da cultura militar à multiplicidade dos demais setores em que se desdobra CULTURA POLÍTICA é nada mais que o símbolo e a concretização atual de um acontecimento de alta relevância ${ }^{534}$.
}

Ao construir vínculos entre cultura nacional e a atuação das Forças Armadas, Almir também ressalta que o incremento da participação de militares nas páginas da revista, lado a lado com os civis, era um forma de reforçar o ideal de união nacional proposto pelo periódico. Nesse movimento, procurava-se resgatar historicamente o papel desempenhado pelos homens fardados na construção da nacionalidade, como forma de conferir sentido e respaldar as ações destes no presente.

\subsubsection{A segunda fase de Cultura Política}

\footnotetext{
${ }^{532}$ CARVALHO, E. Leitão de Carvalho. Trincheira da segurança nacional. Cultura Política, Rio de Janeiro, ano 2, n.15, maio 1942, p.201.

533 ANDRADE, Almir. As classes armadas em “Cultura Política”. Cultura Política, Rio de Janeiro, ano 2, n.16, jun. 1941, p.9.

${ }^{534}$ Idem, ibidem.
} 
Paralelamente ao rompimento das relações com os países do Eixo e ao alinhamento aos Estados Unidos, na eminência da entrada do Brasil no conflito mundial, o DIP passava por uma crise interna, a qual repercutiria na própria estruturação do periódico. Em julho de 1942, por determinação do general Dutra, então Ministro da Guerra, Lourival Fontes fora demitido do comando do órgão. O fato ocorrera em virtude do apoio dado por Fontes à realização de uma passeata antinazista, organizada pela União Nacional de Estudantes (UNE). Sua atitude era consoante à de Vasco Leitão da Cunha, Ministro interino da Justiça, que autorizara à manifestação, e a de Osvaldo Aranha, Ministro das Relações Exteriores, mas ia de encontro às determinações de Filinto Müller, o chefe de polícia, que contava com o apoio de Dutra. A confusão em torno de um móvel aparentemente banal trazia à tona as disputas internas no aparelho do Estado entre os germanistas e os que apoiavam os Aliados.

No lugar de Lourival Fontes, assumira a chefia do DIP, em agosto de 1942, o major Coelho Reis, membro integrante do gabinete de Dutra. Simultaneamente, neste mesmo mês, o Brasil declarara oficialmente estado de guerra contra a Alemanha e a Itália. Diante de tais acontecimentos, a revista, já em setembro, em seu $19^{\circ}$ número, apresentava sensíveis alterações que repercutiram sobre seu perfil; seus objetivos primordiais passavam a ser os de conscientizar e mobilizar a sociedade brasileira para o conflito ${ }^{535}$, nos moldes já assinalados pela seção "Política militar e defesa nacional”, descrita acima. Na verdade, há uma amplificação dessa diretriz, na qual Cultura Política, sem deixar de ser um espelho do Brasil, passava a promover uma “cultura militar”, voltada à “segurança da pátria” e à “defesa nacional”,536.

A partir daí tem início o que se poderia chamar de segunda fase da revista, tendo em vista a repercussão de tais mudanças na estrutura do periódico. Nessa nova conjuntura, Cultura Política perde sua organização e hierarquização inicial. Apesar de continuar a tratar de uma gama ampla de temas (de legislação trabalhista às letras nacionais, de filologia à administração pública, por exemplo), não os agrupava mais em macro-categorias como fazia até então. As seções passam a proliferar-se e a variar de um número para o outro. No referido número 19, quando as alterações ganharam corpo, são observadas 26 segmentos diferentes. Destes cinco são seções ou subseções presentes na fase anterior do periódico ("Política militar e defesa nacional”, “Educação”, “Música”, “Artes plásticas” e “Rádio”), sete são partes que

\footnotetext{
${ }^{535}$ GOMES, Ângela de Castro. op.cit, p.130.

${ }^{5}$ Idem, ibidem.
} 
tiveram seus nomes alterados, mas mantiveram suas características iniciais (“Quadros e costumes regionais”, “Quadros do passado”, “Bibliografia”, “Folclore”, “Cinema e Teatro”, "Biografia” e "Textos e documentos”) ${ }^{537}$ e 14 são espaços novos, criados nesse momento (“Problemas regionais”, “Administração”, “Trabalho”, “Produção”, “Finanças”, “Educação”, “Transportes e Comunicações”, “Política Nacional”, “Política Internacional”, “Povoamento”, "Literatura”, “Literatura Panamericana”, "Filologia”, “Inquéritos e reportagens”, e “O Brasil no exterior”).

A estas novas seções ou adaptações de seções antigas o número 20, de outubro de 1942, acrescentava mais nove: “O Brasil na guerra”, “Assistência social”, “Direito constitucional”, “Doutrina Política”, “Geografia”, “História”, “Museus” e “Cidades do Brasil”. O volume 22, três: "Navegação", "Lingüística” e "Família”. Enfim, tais dados revelam a intensidade das mudanças, bem como o prolongamento delas ao longo do restante da existência do periódico, que chegara ao fim em outubro de 1945. Outra mostra das alterações sucessivas é a seção com a qual Graciliano colaborava. Ela tivera seu título modificado uma segunda vez, em maio de 1943, passando a chamar-se apenas “Quadros regionais”.

Com o novo formato, se por um lado a revista perdia sua organização fixa e hierarquizada, por outro, deixava mais evidentes os assuntos tratados, elevando-os a categoria de nomes de seções. No entanto, em duas oportunidades, nos números 39 e 47 (respectivamente de abril e dezembro de 1944), o periódico abdicou de subdivisões temáticas em seu sumário, dispondo as colaborações sem orientar-se por uma ordem aparente. Portanto, ao longo desse processo de alterações, as perdas pareciam maiores que os ganhos, quando o assunto era estrutura, sistematização e espelhamento do centralismo estatal. Outra prova disso é o desaparecimento das notas introdutórias, definidoras dos objetivos de cada seção, bem como das biografias que apresentavam e situavam os colaboradores. Estes passam a ser designados, quando muito, apenas por seu cargo ou função, sobretudo se esta era desempenhada nos quadros da burocracia estatal.

Paralelamente, nesse momento, nas páginas de Cultura Política, há o incremento da participação de articulistas provenientes dos quadros civis e militares do governo, sem

${ }^{537}$ Correspondem, respectivamente às seguintes seções anteriores: "Quadros e costumes do Nordeste”, "Quadros e costumes do Centro-sul" e "Quadros e costumes do Norte"; "Páginas do passado brasileiro"; "Movimento bibliográfico"; "O povo brasileiro através do folclore”; "Cinema” e "Teatro"; "Intérpretes da vida social brasileira"; e "Textos e documentos históricos". 
relevância no meio intelectual. Em geral, tratam de assuntos relacionados às suas áreas de atividade. No número 33, de outubro de 1943, a revista oferece uma lista dos 261 colaboradores que tivera ao longo de seus 30 primeiros volumes. Nela figuram majoritariamente membros das Forças Armadas, portadores de diferentes patentes e funções, bem como figuras integrantes dos mais variados órgãos e departamentos estatais, com destaque para estabelecimentos educacionais como escolas, faculdades e institutos de pesquisa $^{538}$.

Os grandes nomes se ausentam. Entre eles, Prudente de Morais Neto e Gilberto Freyre ${ }^{539}$. Graciliano Ramos, por exemplo, que esteve presente, rotineiramente, durante as 20 primeiras edições, publica apenas mais cinco textos entre dezembro de 1942 e outubro de 1945 . O mesmo pode-se dizer de seu ex-companheiro de seção Marques Rebelo que durante o mesmo espaço de tempo estampou apenas mais três escritos na publicação. Ainda no que diz respeito ao escritor alagoano, um atestado de seu distanciamento da revista é a publicação, em abril de 1943, da crônica “Quadros do Nordeste”, de autoria do romancista Permínio Asfora, na seção “Quadros e costumes regionais”. Apesar de se tratar de uma colaboração bissexta, ela indicava que o retrato das paragens nordestinas, nas páginas de Cultura Política, deixava de ser uma exclusividade do autor de Vidas Secas.

Até mesmo os intelectuais orgânicos afastaram-se das páginas do periódico. Não são publicadas mais contribuições de Francisco Campos, Azevedo Amaral e Cassiano Ricardo. As exceções eram o próprio Almir de Andrade, que na qualidade de editor da revista continuava a escrever os editoriais introdutórios, nos quais destacava as diretrizes da política governamental ou ressaltava a atuação da própria revista, enquanto divulgadora dos postulados regimentais, e Rosário Fusco. Este publicou apenas mais três textos; dois sobre o universo literário nacional e outro referente ao lançamento do livro As diretrizes da nova política do Brasil, de Vargas, no qual saúda a nova obra, destacando a perspicácia e o “realismo” político do chefe da nação. Outra figura constante na segunda fase de Cultura Política é Paulo Augusto Figueiredo. Apesar de não possuir a mesma representatividade dos

\footnotetext{
538 Ao mesmo tempo, a partir do número 19, aumentam o número de “reportagens especiais”, sem a especificação de autoria. O volume 35, por exemplo, conta com seis textos nestas condições.

${ }^{539}$ As exceções eram Josué Montelo, José Maria Belo, Peregrino Júnior, Luís da Câmara Cascudo e Nelson Werneck Sodré, com colaborações ocasionais, e Brito Broca, Basílio de Magalhães, Hélio Viana e Wilson Louzada que escreviam com mais freqüência. Observa-se ainda um único texto do poeta Jorge de Lima, saído no número 19, de setembro de 1942.
} 
formuladores da doutrina estadonovista arrolados acima, teve certo destaque no tratamento das relações Estado/Sociedade, sobretudo no que diz respeito à critica ao liberalismo ${ }^{540}$.

Como assinalado anteriormente, outra característica marcante desta segunda fase de Cultura Política é o destaque para a temática militar. Das novas seções criadas, muitas versavam exclusivamente sobre ela: "Política Internacional”, “O Brasil na guerra”, “Defesa Nacional” e “Política militar”. Outras acabavam se relacionando ao conflito, na medida em que passaram a privilegiar, muitas vezes, assuntos vinculados a ele: Inquéritos e reportagens (“As comemorações da semana de Caxias" e "Um mês de guerra mundial”,541), Cinema (“A guerra e o cinema brasileiro"542), Biografia (“O general Joaquim Inácio”543) Quadros do passado brasileiro (Fortificações coloniais portuguesas no Brasil ${ }^{544}$ ) etc.

Em 22 de agosto de 1943, foi publicada uma edição extraordinária de Cultura Política, em comemoração ao primeiro aniversário da entrada do Brasil na guerra. O volume, introduzido por um texto que louvava a participação brasileira no conflito, escrito pelo embaixador americano no país, Jefferson Caffery $^{545}$, contou com novas seções dedicadas aos diferentes aspectos da luta armada e suas repercussões nas diretrizes econômicas e políticas (internas e externas) do governo. Como era comum ao longo de toda a trajetória do periódico, tal iniciativa cumpria funções simultaneamente propagandísticas, informativas e mobilizatórias. Com relação a este último aspecto, havia todo um segmento, intitulado "Mobilização para a guerra”, que convocava desde pescadores a estudantes a engajarem-se no evento.

Ao mesmo tempo, havia a preocupação governamental em recuperar a história militar do país, bem como o tratamento que ela recebera dos escritores nacionais. Com esse propósito, o referido número trazia uma espécie de dossiê, com o seguinte título: “Outras guerras do

\footnotetext{
${ }^{540}$ Cultura Política apresenta-o como uma espécie de eminência parda do poder central em Goiás. Descreve-o como presidente do Departamento Administrativo estadual, ex-professor na Faculdade de Direito, ex-promotor público de Bonfim (cidade goianiense), ex-advogado do Estado. O jornalista esteve presente na revista desde seu primeiro número, com o artigo doutrinário "O Estado Novo e o Homem Novo", no qual ressalta o papel da ditadura varguista na humanização e na expressão da "verdadeira” alma do país. Elide Rugai Bastos defende que a bibliografia consolidada sobre a ditadura varguista não confere o devido lugar a esse autor, "cujo debate, aquele referido à crítica do liberalismo, é incorporado por vários escritores do período e mesmo nos discursos do chefe de governo e dos ministros”, BASTOS, Elide Rugai. Paulo Augusto Figueiredo e o pensamento autoritário no Brasil. In: RIDENTI, Marcelo et al [org.]. Intelectuais e Estado, Belo Horizonte: Editora UFMG, 2006, p.121.

${ }^{541}$ Cultura Política, Rio de Janeiro, n.19, set. 1942, p.259 e p.261, respectivamente.

542 LEMOS, Pinheiro. Cultura Política, Rio de Janeiro, n.20, out. 1942, p.153.

${ }^{543}$ PEIXOTO, Sílvio. Cultura Política, Rio de Janeiro, n.22, dez. 1942, p.153.

${ }^{544}$ Cultura Política, Rio de Janeiro, n.22, dez. 1942, p.177.

${ }^{545}$ CAFFERY, Jeferson. O papel do Brasil na guerra. Cultura Política, Rio de Janeiro, n.21, ago. 1943, p.9.
} 
Brasil: História, Literatura e Documentos”. Ele reunia textos como “A literatura de guerra no Brasil”, de Brito Broca e a "História das guerras brasileiras”, de Hélio Viana. O primeiro ressaltava que o tema bélico nunca tivera maior destaque no Brasil, a exceção das obras $A$ retirada da Laguna, de Visconde de Taunay e Os sertões, de Euclides da Cunha, seja pelo suposto alheamento dos escritores à "realidade nacional" antes de 1930, seja pela postura “não-agressiva” do Estado na resolução dos conflitos. Já o segundo, ao listar o envolvimento brasileiro em 23 conflitos internacionais, no período de 1504 a 1942, concluía que embora a nação nunca tivesse fugido à luta, seus fins eram sempre pacíficos. Ela nunca teria empreendido batalhas nas quais seus objetivos fossem conquistar ou violentar outros povos, mas sim defender sua soberania e unidade. Vistas em conjunto, tais perspectivas pretendiam indicar que o "verdadeiro" sentido histórico da brasilidade apontava para uma nação cordial, não afeita ao uso da força (daí a aludida falta de interesse literário pelo assunto), mas que sabia se valer dela quando se via ameaçada.

\subsection{Análise do discurso da revista}

Feitas tais considerações sobre a estrutura, o papel e as funções de Cultura Política na construção e difusão do arcabouço conceitual estadonovista, cabe, agora, analisar de maneira mais específica o discurso produzido pela revista. Inicialmente, levar-se-á em conta os editoriais escritos por Almir de Andrade, seu diretor, bem como o livro Força, Cultura e Liberdade, publicado pelo mesmo autor, em $1940^{546}$. Nesta obra já se encontram delineados os temas e propostas que serão desenvolvidos e particularizados pelo periódico, os quais permitem iluminar e enquadrar conceitualmente a colaboração de Graciliano, objeto central da presente análise.

Almir de Andrade foi escolhido pelo próprio presidente da República para dirigir Cultura Política, tendo em vista sua comprovada adesão às diretrizes do governo. Quando ainda era

\footnotetext{
${ }^{546}$ Formado em direito, nos anos de 1930 combinou a atividade de advogado com a de jornalista, colaborando com inúmeras revistas literárias: Literatura, Boletim de Ariel, Lanterna Verde, Revista do Brasil etc. Realizou estudos nas áreas de filosofia e psicologia e até o início dos anos de 1940 já havia publicado as seguintes obras: A verdade sobre Freud (Schmidt, 1933), Da interpretação na psicologia (Livraria José Olympio, 1936) e Aspectos da Cultura Brasileira (Schmidt, 1939). Quando do lançamento desta última, o crítico Brito Broca assim se referiu a ele num artigo: "O sr. Almir de Andrade é um exemplo raro de atividade intelectual entre nós. Com 27 anos de idade apenas, já publicou três livros, tendo outros tantos para o prelo. A quantidade realmente não é de espantar, mas a qualidade, a soma de cultura que tais obras implicam dão um relevo extraordinário à produção do jovem escritor” (BROCA, Brito. Um livro de Almir de Andrade. A Gazeta, São Paulo, 15 dez. 1939).
} 
crítico da Revista do Brasil, ele chamara a atenção de Vargas ao examinar os primeiros volumes de A nova política do Brasil. A confirmação de que o jovem ensaísta era uma figura perfeitamente afeita ao Estado Novo veio três anos depois, quando aceitara a proposta do DIP para escrever um livro sobre a evolução histórica do país. "Força, Cultura e Liberdade, o resultado desse empreendimento, consolidara a confiança do regime no intelectual e assentara as bases do convite realizado em inícios de 1941 para a direção do que deveria ser a mais importante publicação do Estado Novo - ‘um espelho do Brasil em tempo de renovação’”547.

\subsubsection{A cultura, o “espírito nacional” e a legitimação do regime}

No editorial do primeiro número de Cultura Política, intitulado “A evolução política e social do Brasil”, Almir de Andrade inicia sua argumentação partindo do pressuposto legitimador de que as instituições (sociais e políticas) seriam governadas por leis que se desdobrariam naturalmente ao longo do tempo, sendo impossível ao homem precipitar acontecimentos ou forçar mudanças. Nada ocorreria de forma imposta ou por acaso. Nenhuma alteração seria efetuada antes de atingir a sua devida maturidade. Ao mesmo tempo em que faz referência a essa transcendência, inacessível ao arbítrio humano, destaca que já seria possível visualizar, na imanência de seu momento histórico, o surgimento de um novo rumo, como se o próprio espírito da civilização impusesse "novas tendências adaptativas e novas diretrizes para o futuro”. O articulista inverte a lógica dos acontecimentos políticos: não seriam os governos que implementariam as soluções para os problemas nacionais, mas estes que imporiam os regimes mais ajustados a sua solvência. Nesse sentido, prevê que o Estado seria sempre a corporificação de algo maior do que ele.

Nesse torneio argumentativo, Almir parte de um apriori evolucionista de que a humanidade naturalmente caminharia para a paz, o progresso e a felicidade; todas as ações, mesmo as mais violentas, convergiriam para esse fim. E, de acordo com tal raciocínio, esse devir favorável, que brotava como algo inevitável e espontâneo, encontrara sua exata correspondência e tradução no regime político brasileiro, instaurado em 1937. Segundo o autor, este enfeixava o referido ideal de "humanização" do Estado, colocando-se como uma resposta democrática, solidária e realista aos problemas deixados (e ampliados) pelos governos anteriores. Seu alvo

${ }^{547}$ GOMES, Ângela de Castro. op.cit. p.127. 
preferencial é a Primeira República, período marcado na história política nacional pelo predomínio da teoria e prática liberais.

Para Almir, o liberalismo se assentava sob uma perigosa “ilusão de generalidades”, pautandose pela "hipocrisia de formas sonoras e vazias" ou por "princípios ou declarações que nunca foram cumpridas e que serviam de pretexto para explorações políticas de toda a espécie"548. Ele teria representado um intervalo regressivo no processo evolutivo da humanidade, sobretudo no que diz respeito à conquista da "verdadeira democracia" "549. Nesse sentido, observa-se que o articulista trilha dois caminhos complementares na construção da legitimidade da ditadura varguista: ao mesmo tempo em que coloca o governo como conectado a certa perspectiva evolutiva da política mundial, mostra-o como contraponto da "República Velha"550, a qual estaria desconectada da "realidade” do país e, por conseguinte, da essência de brasilidade.

No que diz respeito a este último ponto, se Almir de Andrade partia de um apriori de caráter positivista quando o assunto era as "diretrizes gerais da civilização”, o mesmo se repete quando se refere à concepção de “alma ou espírito nacional”. Para o intelectual, esta entidade metafísica promoveria necessariamente uma vida de paz, trabalho, conservação da personalidade do país, além do respeito pelos sentimentos, direitos e tendências de outros povos $^{551}$. Sua intenção é reivindicar a primazia do que ele chama de "verdadeiro" nacionalismo, o qual deixaria de lado o espírito de violência, conflito e conquista que comumente se atribuiria a tal noção. Invertendo o senso comum, num mundo em plena Segunda Guerra, destaca que esse conceito se fundaria em princípios de equilíbrio e justiça, ao mesmo tempo em que permitia o fortalecimento do país contra o imperialismo estrangeiro.

Para o autor a viabilidade desse nacionalismo não-belicoso e solidário tornava-se clara, sobretudo, no continente americano, tendo em vista suas condições históricas e sociais diferentes da Europa conflituosa. Segundo Almir, nossa posição seria mais confortável; não precisaríamos de violência para resolver nossos problemas, o que nos colocava um passo a

\footnotetext{
${ }^{548}$ ANDRADE, Almir. A evolução política e social do Brasil. Rio de Janeiro, Cultura Política, ano 1, n.1, mar.1941, p.6.

${ }^{549}$ Segundo Almir, o que teria causado a falência do regime liberal não teria sido a tendência democrática que ele aparentou traduzir, tal como afirmavam os nazistas e fascistas; sua derrocada ocorrera, na realidade, em virtude sua incapacidade de realizar a "verdadeira democracia". ANDRADE, Almir. Força, Cultura e Liberdade. Rio de Janeiro: Livraria José Olympio Editora, 1940, p.172.

${ }_{550}$ Designação criada e que ganha força com a Revolução de 1930.

${ }^{551}$ ANDRADE, Almir. op.cit. p.35.
} 
frente no quesito "evolução política dos povos”: "Na América, as lutas são menores, porque foram menores os erros do passado. A comunhão das nações americanas está muito mais próxima da comunhão universal do porvir do que o estão as relações internacionais do Velho Mundo. Nós conhecemos os limites das aspirações nacionalistas, que são o respeito mútuo e da solidariedade humanidade" 552 . Tendo em vista essas condições de aparente superioridade, o articulista reforça o argumento de que o Brasil deveria ter as mãos livres para criar suas próprias soluções, em conexão com seu fortalecido “espírito nacional” e sem sofrer a ingerência de outros países.

No livro Força, Cultura e Liberdade, Almir de Andrade fornece mais elementos para validar tal perspectiva legitimadora do governo estadonovista. Ele destaca que ao invés das fórmulas gerais e universalizantes da liberal-democracia, a evolução política do mundo contemporâneo exigia uma orientação nacionalista. $\mathrm{O}$ autor considera que cada sociedade teria uma fisionomia própria, assim como um conjunto de problemas específicos, que demandavam soluções específicas, cabendo a ela mesma escolher o caminho a ser seguido.

Essa perspectiva procura fundamentar-se em certa noção nomeada pelo autor como "realidade concreta da nação”, a qual englobava aspectos econômicos e, sobretudo, culturais, servindo de base à implementação de um sistema de governo "autenticamente” brasileiro. Segundo Almir, se a cultura nacional tinha sua literatura, sua arte, sua técnica, sua formação moral, social e histórica, era natural também que ela desse origem a um regime político próprio, orientado de acordo com suas diretrizes particulares. Seguindo a cadeia de raciocínios do articulista, o Estado Novo colocava-se como a materialização viva e consciente dessa visada nacionalista e, por isso, caberia a ele desenvolver e executar uma "política realista”. Esta alcançaria tal estatuto de "verdade", uma suposta correspondência direta com o real, tanto por seu "contato direto” com a vida do país, como pela “conexão” com o “espírito nacional”, o grande condutor dos destinos da brasilidade.

Na concepção de Almir, a postura realista de governo pressupunha sempre uma preparação para a ação; uma ação consciente que deveria se integrar "no fluxo incessante da vida”. Para tanto, fazia-se necessário que os governantes abandonassem sua posição, a princípio, estática e contemplativa e realizassem um esforço de incorporação do real. O autor qualifica este

${ }^{552}$ Idem, p.49-50. 
último como algo "móvel, heterogêneo, a cada instante diverso de si mesmo" "553, o que demandava uma atenção próxima e particularizada. Logo, impunha-se aos políticos e a intelectualidade de maneira geral a necessidade de trabalhar com os próprios "fatos sociais”, de pesquisá-los e analisá-los diretamente, longe do isolamento dos gabinetes. Portanto, as barreiras que separavam os "homens de pensamento" do contato imediato com a sociedade brasileira precisavam ser rompidas, tendo em vista a interpretação da cultura do povo.

Em referência a esse último ponto, Almir destaca que existiriam duas culturas; uma idealista e outra realista. A primeira se fundaria em apriorismos e generalizações, desenvolvendo-se num plano aparentemente místico e colocando-se “a serviço de grupos, de paixões doutrinárias, de fanatismos de toda a sorte" ${ }^{554}$. Já a segunda, nasceria em contato com “a carne e o sangue humano, que se encarna na alma popular, definindo-a, dilatando-a, revelando-a a si mesma,

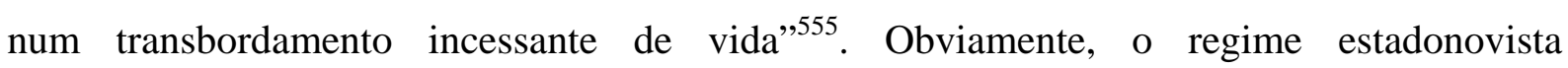
privilegiaria esta última, a qual tornaria suas políticas "fecundas e sadias”, além de conferirlhe um lastro de brasilidade, atestando sua conexão com a “alma nacional”.

Tal definição de "cultura” funda-se em bases sociológicas. Almir considera que o termo englobaria tudo que o homem, levado por um esforço coletivo de adaptação ao meio e de realização de suas necessidades, produz em sociedade. Nesse sentido, abarcaria as mais variadas manifestações da atividade humana, cristalizadas em costumes, instituições, obras de arte e de pensamento, técnica, economia e política, entre outras ${ }^{556}$. Esta perspectiva totalizadora conferida à palavra estendia-se não só à designação das práticas sociais do presente, como também as do passado. Em sua unidade, ela fundiria todos os tempos. Todas as formas de sua expressão seriam cristalizações do “espírito nacional”.

\footnotetext{
${ }^{553}$ Idem, p.60.

${ }^{554}$ Idem, p.62.

555 Idem, ibidem.

${ }^{556}$ Essa visão abrangente do termo “cultura”, que perfazia todas as atividades do homem em sociedade, já estava presente em outro livro do autor Aspectos da cultura brasileira (1939). Nele, Almir reúne ensaios sobre diferentes manifestações artísticas e científicas nacionais: a obra de Aleijadinho, lendas, carnaval, cinema, sociologia (com destaque para a figura de Gilberto Freyre), literatura, história, psicologia, filologia, lingüística. Ele partia de um viés de progresso e transformação, detectado no cenário nacional, segundo seu julgamento, a partir da revolução de 1930. "Uma febre de construir, uma ansiedade de novos caminhos (...) Valores novos, que vão surgindo. Valores antigos que aumentam a sua produtividade, arrastados pela onda, que avança em busca de rumos ainda não definidos” (ANDRADE, Almir. Aspectos da cultura brasileira. Rio de Janeiro: Schmidt, 1939, p.7). Ao mesmo tempo, já deixava explícita a necessidade de conectar a atividade intelectual com a "vida": "O mundo atual não tolera mais a cultura abstrata, fechada na estreiteza dos gabinetes, enterradas nas prateleiras das bibliotecas, isoladas dos grandes motivos humanos que por toda a parte devem inspirá-la, movimentá-la e fecundá-la”. Afirmava que tal postura seria coisa do passado. O movimento revolucionário teria apontado para o fato de que o intelectual não faria nada de útil e duradouro se não se unisse ao "homem real” (Idem, ibidem).
} 
Nota-se, portanto, que o autor fundamenta seu discurso legitimador da ditadura varguista no intercâmbio e na interdependência entre política e cultura, termos que não por acaso nomeavam a publicação que dirigiu. Se por um lado a cultura, de acordo com as diretrizes apontadas acima, conferia "realismo" às ações governamentais, colocando-as em contato "as genuínas fontes de inspiração popular”, por outro deveria apresentar um conteúdo socialmente útil e orientar-se pelo bem da coletividade, segundo as determinações estatais ${ }^{557}$. Trata-se, portanto, de uma concepção de cultura tutelada, na qual cabia aos artistas e intelectuais enquadrar-se nos moldes nacionalistas construídos pelo regime ${ }^{558}$. Dessa maneira, a organicidade estatal estendia seus tentáculos sobre tal setor orientando-o, organizando-o e promovendo-o de acordo com seus interesses ${ }^{559}$. O articulista destaca que esse processo ao invés de macular a espontaneidade das produções culturais, elevava-as ao nível "superior” das preocupações governamentais.

Como decorrência da suposta união entre política e cultura, tornava-se impossível separar o homem do cidadão. Por meio desse raciocínio pressupunha-se que as pessoas comuns, inevitavelmente, tomavam parte nos caminhos da coletividade da qual faziam parte. Conforme explica Almir "tudo o que criamos - nas artes, nas ciências, na indústria, na escola, na família - tem um fim social e uma causa social. Se tem um fim social, há de refletir-se na ordem política” ${ }^{560}$. Mas para isso acontecer, cabia ao regime reconhecer tal arranjo de coisas e, assim, coordenar e dirigir as energias populares e intelectuais na busca do interesse de todos. Por outro lado, o papel do indivíduo, fosse ele operário ou homem letrado, era labutar e vincular-se ao sindicato regulador de sua profissão, pois apenas assim alcançaria a cidadania, num contexto de "representação" corporativa. De acordo com essa lógica, o trabalhador, a partir de então, era responsável não só por sua própria riqueza, como também pelo progresso da nação. Tal estratégia, vendida pelo governo como uma forma de superar as mazelas e

\footnotetext{
${ }^{557}$ ANDRADE, Almir. Política e Cultura. Cultura Política, Rio de Janeiro, ano 1, n.1, p.6-8.

${ }^{558}$ A própria ordem dos vocábulos no título Cultura Política, indica essa perspectiva na medida em que a cultura, qualificada como "política", deveria se prestar a um fim governamental.

${ }^{559}$ Nesse processo de organização e tutela da cultura (empreendimento tomado por Almir como uma forma de defendê-la e de afirmar sua pujança e autoconsciência), a revista deve ser compreendida como uma estratégia de controle, visando à submissão dos espaços de produção artística e intelectual à ação do Estado. Conforme posto anteriormente, este não se limitava a garantir a subordinação ideológica necessária a seu projeto de dominação, mas procurava desempenhar um papel ativo na construção da "hegemonia cultural do regime", de modo a garantir o consentimento da sociedade civil e a forjar sua perspectiva de interpretação e construção da brasilidade.

${ }^{560}$ ANDRADE, Almir. op.cit. p.6.
} 
promover o desenvolvimento do país, funcionava, sobretudo, como elemento de inculcação e autenticação de seu domínio.

Portanto, a ideologia trabalhista, assim como o próprio projeto político do regime, de uma maneira geral, buscava sua legitimidade numa noção ampla de cultura, de viés nacionalista. Nesse sentido, o interesse e o espaço dedicados aos estudos brasileiros em Cultura Política, como se observou anteriormente, na estruturação e no conteúdo da seção "Brasil, social, intelectual e artístico”, podem ser tomados como parte dessa estratégia de autenticação do Estado Novo. No editorial do segundo número, Almir de Andrade enfatizava:

\footnotetext{
A política não é mais, para nós, aquele campo estéril onde se debatiam facções, se armavam conluios e se planejavam assaltos às posições de mando. Começamos a restituir à política o seu sentido verdadeiro e profundo - compreendendo-a e definindo-a como uma expressão superior de organização da própria cultura popular, em toda a sua pujança, espontaneidade e realismo.
}

Essa concepção nova da política é um dos aspectos mais impressionantes da revolução que se operou em nossa vida social. Ela há de criar, com o nosso entusiasmo, trabalho e sacrifício pelo bem comum, um Brasil melhor e mais humano para os dias de amanhã ${ }^{561}$.

Ainda segundo tal concepção, a recuperação e o privilégio conferido à cultura popular permitiriam reorientar o próprio sentido da palavra "política”, abrindo caminho para que uma interpretação “verdadeira” predominasse. Almir procura aqui conferir uma roupagem técnica ao discurso governamental como forma de justificar a supressão autoritária de toda e qualquer disputa entre os atores sociais. Nesse sentido, os conflitos de interesses, comuns ao próprio jogo parlamentar e trabalhista, eram tratados como nocivos à condução dos negócios públicos, pois preteririam os anseios gerais da coletividade. Como visto anteriormente, o autor contrapõe aqui as noções operatórias “individualismo” e "bem comum”. A primeira teria produzido a "politicalha” dos “mandatários” anteriores a 1930, ao passo que segunda norteava a administração “racional” e “realista” do regime instituído em novembro de 1937. Portanto, conforme tal diretriz, conhecer as tendências, tradições e "orientações espontâneas” do povo e traduzi-las politicamente era a forma mais adequada de construir um governo autenticamente nacional.

\subsubsection{A recusa ao liberalismo e a nova concepção de democracia}

\footnotetext{
${ }^{561}$ Idem, p.7-8.
} 
O privilégio conferido pelo novo regime à matéria "brasileira” tinha como contraponto o referido idealismo político das oligarquias republicanas. Na opinião de Almir estas só teriam produzido “uma inquietação cada vez maior nas sociedades, maior número de injustiças sociais, de explorações, de monopólios, de maquinismos organizados com o fim de desvitalizar as energias sociais e negociar com os interesses supremos dos povos"562. Portanto, ao abdicarem de uma "política realista” e, por conseguinte, "brasileira”, eram duplamente perniciosas, pois iriam de encontro tanto à evolução geral da civilização como ao “espírito nacional”.

Particularizando seu argumento, Almir afirma que a doutrina liberal teria criado e imposto a “ficção” de que a soberania popular só poderia ser expressa, em termos políticos, pelo sufrágio universal ${ }^{563}$. Para ele, esse era o meio mais pernicioso para alcançá-la. O articulista parte do pressuposto elitista de que as "verdadeiras" tendências e necessidades sociais nunca seriam manifestadas claramente nas atitudes gerais das massas. Estas seriam sempre sugestionáveis, sujeitas a ação de políticos exploradores que, “aproveitando-se do artificialismo da máquina eleitoral”, ludibriá-las-iam, alimentando-as de promessas, com a finalidade de manterem-se no poder e cuidarem de seus interesses particulares. Nesse processo, o povo seria abandonado a seu próprio destino, “sem amparo profissional, sem dinheiro, sem cultura e sem possibilidades reais de adquirir cultura, escravizado ao egoísmo dos ambiciosos, explorado e iludido pelas manobras da politicagem oficializada”564.

Ao invés da atuação dessa classe de intermediários políticos, instituída pelo voto, Almir defendia que as funções de governo deveriam ser exercidas por indivíduos especializados no tratamento dos problemas nacionais. Portanto, no lugar da capacidade de sugestionar as massas, por meio de “cabalas eleitorais”, deveria prevalecer o mérito intelectual, ou seja, os quadros administrativos deveriam ser compostos apenas por homens reconhecidos por sua inteligência política, estudo e familiaridade com as questões brasileiras. Defende-se, assim, uma espécie de cientificismo administrativo, pressupondo-se que a atuação de técnicos e

\footnotetext{
${ }^{562}$ ANDRADE, Almir. Força, Cultura e Liberdade. Rio de Janeiro: Livraria José Olympio Editora, 1940, p.19.

${ }^{563}$ Nessa mesma linha, como se verá, afirma que outras instituições liberais também seriam perniciosas e incompatíveis com a formação da sociedade brasileira: o federalismo, a separação de poderes, o parlamento, os partidos políticos, o individualismo, a idéia de "Estado fraco" etc.

${ }^{564}$ Idem, p.175.
} 
estudiosos, no lugar dos antigos políticos, retiraria de cena qualquer tipo conflito e interesse individualista, privilegiando a noção abstrata e tutelada de bem público ${ }^{565}$.

Partindo ainda do pressuposto de que o liberalismo não conseguira realizar as aspirações democráticas, Almir chega a decretar sua ruína. Em sua opinião, as explicações para tal situação “falimentar” poderiam ser encontradas no próprio conteúdo "fundamentalmente antidemocrático" das orientações liberais. Estas, ao privilegiarem os interesses particulares e deixarem de lado os objetivos maiores da nação, teriam semeado apenas desavenças, desastres, egoísmos e misérias entre os diferentes atores sociais.

Diante de tais afirmações, pode-se perceber que uma das maiores preocupações do autor é separar os conceitos “liberalismo” e “democracia”. Para o diretor de Cultura Política, a "falência” do primeiro não implicava na derrocada ou no desaparecimento do segundo. Muito pelo contrário, este último ganharia uma feição mais "realista” ao se desvincular das “mistificações” liberais. E não só isso. Almir vai além na defesa da continuidade dos ideais democráticos; ele considera que eles persistiriam no mundo moderno tanto como "fim último de toda a evolução da cultura humana” ${ }^{, 66}$ e, mais especificamente, como o sistema de governo “mais adequado à índole do nosso povo e aos imperativos do seu progresso moral e material” ${ }^{567}$. Por fim, sua cadeia de argumentos desaguava na legitimação do Estado Novo, regime apresentado como visceralmente democrático e anti-liberal, ao adotar um caminho “próprio” na solução dos problemas nacionais. Nesse sentido, o sistema político implementado por Vargas seria a própria concretização de suas hipóteses.

Em tal contexto de aparente manutenção e reforço dos ideais democráticos, estes passariam por um processo de transformação e adaptação. Almir procura estabelecer diferenças entre o que fora a "democracia liberal” e a emergente “democracia real”, aquela supostamente levada a termo pelo Estado Novo. Enquanto a primeira se fundaria em liberdades e garantias individuais, a segunda se orientaria por princípios de justiça, equilíbrio, equidade e disciplina tendo em vista o bem da sociedade:

\footnotetext{
${ }^{565}$ Ao estudar a estabilização do governo no cenário político e a maneira pela qual ele teria correspondido às causas sociais, afirmando-se perante a população, Almir chega a proclamar: "Estamos em presença de fatos sociais objetivos, e não de situações arbitrárias, criadas por um simples jogo de acaso ou manobras políticas" (Idem, p.71). Nesse sentido, no processo de construção de sua "verdade ontológica", o suposto rigor científico do Estado incidiria, retoricamente, sobre a análise que ele fazia de si mesmo.

${ }^{566}$ Idem, p.173.

567 Idem, p.180.
} 
Em essência, a democracia é isso. É uma consagração da pessoa humana na ordem social, uma afirmação dos seus direitos e das suas necessidades, uma criação de oportunidades iguais para todos os homens se expandirem dentro dos limites impostos pelo equilíbrio social, uma dosagem sadia da liberdade de cada um sem prejuízo de ninguém e sem o sacrifício do bem comum ${ }^{568}$.

Nesse sentido, tal noção de democracia previa a subordinação das ações particulares aos interesses da coletividade, o que, a um só tempo, rebaixava a autonomia individual e promovia a noção abstrata de "espírito social”, controlada pelo Estado. Paralelamente, o conceito de liberdade perdia o status de garantia fundamental e passava a figurar apenas como um "fruto do trabalho". Assim, a capacidade de ser livre, longe de ser uma prerrogativa, só poderia ser adquirida por aqueles que tivessem aprendido a disciplinar-se e orientar-se pelo bem da maioria:

\begin{abstract}
A liberdade é um preço de lutas, um coroamento de esforços incessantes, um prêmio de respeito e dedicação à causa da paz, do equilíbrio e da solidariedade humana - e nunca uma forma de comodismo, um pretexto de personalismos ou um meio de exploração da maioria em proveito de grupos, classes ou indivíduos privilegiados ${ }^{569}$.
\end{abstract}

Almir considera que esse deslocamento do individual para o coletivo conferiria maior “realismo” aos ideais democráticos, bem como maior “humanização” à máquina do Estado, pois retiraria a política da esfera artificial dos privilégios, dos monopólios e dos egoísmos para colocá-la em contato “direto” com "realidade natural” do homem em sociedade. Nesse ponto, o autor vincula democracia e cultura. Novamente, esta última ganha destaque enquanto elemento legitimador do governo autoritário, permitindo que ele se apresentasse como supremo realizador de um outro tipo de democracia; uma democracia em diálogo constante com as necessidades e as aspirações populares. Tal posição, por sua vez, permitia ao Estado Novo reivindicar a condição dupla de salvador da brasilidade e de interlocutor privilegiado do povo, cujo principal efeito era respaldar e reforçar o suposto "realismo” das políticas governamentais.

Por tal perspectiva, por exemplo, a supressão dos partidos políticos e até mesmo do poder legislativo figurava não como uma concentração excessiva de poder nas mãos do executivo, mas como um reforço democrático, ou seja, representava um avanço no sentido da soberania

\footnotetext{
${ }^{568}$ Idem, p.189.

${ }^{569}$ Idem, p.200-201.
} 
da nação, pois aproximava governantes e governados. Por outro lado, segundo a argumentação de Almir, tratava-se também de uma iniciativa que procurava reconectar o país a seu passado, o qual, nesse caso, apontaria para o centralismo administrativo desde o período colonial. Nesse sentido, o dito realismo democrático (político) fundava-se na construção de correspondências entre as ações estadonovistas e o discurso histórico elaborado pelo próprio regime. Enfim, o governo selecionava e criava as tradições com as quais ele mesmo iria se identificar.

Ao reivindicar a manutenção da democracia, embora revestida de outros pressupostos que não aqueles ditados pelo liberalismo, o Estado Novo procurava se diferenciar das experiências totalitárias (comunistas e fascistas). "Estes dois tipos clássicos de Estado seriam ambos desumanos, apartados das reais necessidades vitais do homem em sua universalidade e, no caso do Brasil, também de sua especificidade histórico-cultural”570. O regime liberal pecaria por sua omissão; ele se portaria apenas como um espectador passivo dos conflitos e das carências sociais. Além disso, era racionalista e universalista, tratando o homem como uma abstração conceitual, “transformando o seu mito de 'cidadão soberano' na realidade terrível de um indivíduo que morre de fome"571. Já os governos totalitários, que procuravam se afirmar por meio da negação da democracia, tendo em vista que esta teria ruído com o suposto fracasso do liberalismo, teriam realizado a "estatização” do homem. "O Estado tornava-se um fim em si mesmo e não um meio de auto-realização dos homens e de promoção do bem-estar nacional”572. Ele perdia, assim, suas finalidades humanas e nacionais.

Dessa maneira, o Estado Novo tenta afirmar-se como uma terceira via, projetando um modelo de governo presidencialista, teoricamente pautado tanto pela ordem e pela hierarquia, como pela valorização das potencialidades do cidadão/trabalhador. Os ideólogos do regime consideravam tais pressupostos como a expressão de um novo e moderno ideal de democracia, o qual impediria que esta não desaparecesse diante da ameaça totalitária.

\subsubsection{A relação entre passado e presente}

\footnotetext{
${ }^{570}$ Idem, p.124.

${ }^{571}$ Idem, ibidem.

${ }^{572}$ Idem, p.125.
} 
Com o intuito de legitimar certos eventos de seu presente histórico, especificamente às orientações e realizações estadonovistas que se propunha a difundir, Almir reivindica uma outra concepção de "História”. Para ele, o papel dessa disciplina seria abordar não somente situações e sucessos póstumos, mas também testemunhos atuais. Ao mesmo tempo, partia do princípio de que a inclusão deste novo e palpitante objeto de análise não representaria nenhum decréscimo à seriedade ou à objetividade dos estudos realizados. Partindo de sua já referida perspectiva evolucionista, o autor considerava o presente e o passado como uma única matéria indiferenciada e interdependente: um não poderia ser compreendido sem o outro na interpretação dos destinos do país. "O presente sem o passado não tem sentido. O passado sem o presente não tem vida” ${ }^{573}$. Assim, o editor de Cultura Política abria caminho à análise dita "científica" das obras varguistas, explicando-as como supostas manifestações das tradições nacionais.

A preocupação com a fundamentação de seu relato leva o autor a citar inúmeros estudiosos estrangeiros, defensores desse ponto de vista dito “avançado”, ou seja, intelectuais que procuravam, segundo suas palavras, "libertar” os estudos históricos da "escravização ao passado estático”. Entre eles, sua principal referência é Oswald Spengler. Mais especificamente, seu foco recai sobre a obra deste A decadência do Ocidente, na qual são comparadas culturas de diferentes povos ocidentais e orientais, de acordo com uma tese central que procurava comprovar o estágio de declínio vivenciado pelos primeiros. Almir valida a concepção circular, culturalista e globalizante da História defendida pelo pesquisador alemão, que incluía em suas análises dados econômicos, políticos, científicos e artísticos. Segundo ele, tal perspectiva colocaria a disciplina num outro patamar: ela passava a ser considerada uma "explicação viva da natureza humana, na totalidade de suas manifestações espirituais e materiais, sociais e individuais”574. Ressaltava-se, paralelamente, o aspecto sempre atual e quase onisciente dessa ciência, o que muito convinha aos propósitos do diretor de Cultura Política de tratar das realizações estadonovistas como manifestações de um “espírito nacional” imemorial.

Tendo em vista a suposta indissolubilidade entre acontecimentos antigos e recentes, Almir também dá a entender que a apregoada abordagem "realista” deveria inevitavelmente unir história e sociologia. No estudo dos desdobramentos da brasilidade ao longo do tempo, ele

\footnotetext{
${ }^{573}$ Idem, p.73.

${ }^{574}$ Idem, p.78.
} 
previa a necessidade de pautar o trabalho analítico do historiador pela crítica objetiva do sociólogo. Na sua opinião, fazia-se necessário estabelecer conexões de sentido entre fatos sociais de ontem e de hoje, com o intuito atualizar e de recuperar a direção única da brasilidade, apontada pelas tradições populares. Estas são tratadas como manifestações imanentes do intangível "espírito nacional” e, portanto, eram encaradas como meio fundamental para acessar este último.

Dessa maneira, depois de estabelecidas as bases a partir das quais seria realizada uma leitura teleológica do passado, era preciso eleger as tradições, eventos e momentos que embasariam e justificariam as ações governamentais do presente. Inicialmente, Almir recua até o Brasil Colônia, partindo do princípio de que aí já se encontravam as raízes da nacionalidade. Sua atenção recai, de maneira específica, sobre a política colonial portuguesa. Em sintonia com as teses de Gilberto Freyre, ele destaca o caráter “plástico” e “tolerante” do colonizador luso. Este, diferentemente de espanhóis, ingleses, holandeses, entre outros, teria se mostrado mais aberto e flexível às influências e demandas específicas do continente americano. Segundo seu raciocínio, tal postura menos rígida estaria na base da originalidade de nossa cultura, pois permitira a "fusão harmônica das três raças” (brancos, negros e índios), "sem qual toda a

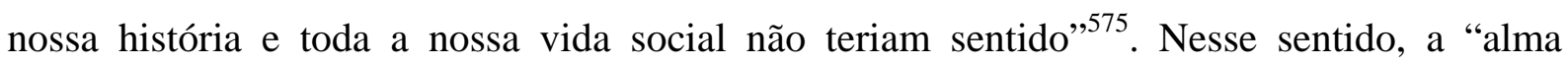
brasileira” já nascia em “consonância” com o novo meio, amoldando-se às situações novas de forma "natural”, sem imposições. Evoca-se, portanto, uma espécie de idílio original, o Éden da brasilidade, ou seja, joga-se para a esfera do mito tanto o passado como a fundação do país dentro de uma perspectiva temporal sem divisões cronológicas claras.

Continuando sua incursão pelo período colonial, Almir destaca que a referida especificidade cultural brasileira teria produzido, por sua vez, uma mentalidade política “original”. Para ele, o processo de formação histórica do país era marcado por uma particularidade: o deslocamento da autoridade política e social do Estado para os senhores de engenho. Daí resultariam duas conseqüências importantes: os brasileiros acostumaram-se a pensar de maneira local e não nacional; e adquiriram uma mentalidade refratária à imposição de leis ou princípios em que não sentisse a "proximidade" e o "prestígio social” de seu chefe. Obviamente, tais orientações eram convenientes às diretrizes estadonovistas, pois alicerçavam a necessidade de combater o localismo e particularismo políticos, ao mesmo tempo em que

${ }^{575}$ Idem, p.95. 
legitimavam a aproximação entre governante e governados, sem a necessidade de intermediários. Na opinião do autor, tendo em vista a suposta onipresença humanizadora do líder, fato “respaldado” pela história brasileira, os partidos políticos seriam desnecessários, além do que se colocavam a serviço de ambições pessoais ou grupais.

Segundo Almir, um exemplo de política ajustada a tais orientações históricas foi a instituição do poder moderador durante o reinado de Dom Pedro II. Para o estudioso, esta iniciativa teria permitido a um só tempo fortalecer o poder central e corrigir excessos localistas, de acordo com uma perspectiva "realista”: “O governo imperial não improvisava reformas, não fazia propaganda de idéias políticas estrangeiras. Procurava amoldar-se às necessidades sociais, ouvia todos os partidos, resolvia serenamente todos os conflitos internos, empregava a força com moderação, quando a mesma se fazia necessária para restabelecer a ordem do país”576.

O parentesco entre este contexto passado e o presente estadonovista subjaz na interpretação do autor, como se seu discurso se fundasse sobre a noção de simultaneidade, pressupondo um tempo vazio e homogêneo a ser preenchido pelas supostas manifestações do "espírito nacional” ${ }^{\text {577 }}$. Nesse sentido, admite-se que as práticas administrativas do imperador, datadas do século XIX, e as de Getúlio Vargas, em pleno século XX, estivessem interligadas, algo impossível de ser estabelecido racional e horizontalmente. Na verdade, a relação entre estes dois momentos díspares torna-se viável quando pensada de maneira vertical, pressupondo que o elo entre eles era "alma brasileira”, tomada a um só tempo como guardiã e chave interpretativa dos destinos históricos do país.

Percebe-se, portanto, que o ponto de vista adotado por Almir mesclava uma visão hegeliana de desenvolvimento progressivo da história e uma orientação dita historicista. Ele considerava o tempo histórico como uma linha infinita a ser preenchida por acontecimentos semelhantes, supostas manifestações da essência da brasilidade, sem deixar de lado a perspectiva de que a humanidade de uma maneira geral caminhava em direção a um fim último. Nesse sentido, ao examinar o passado, reivindica uma identidade desejada ou uma fusão hipotética entre este e o

\footnotetext{
${ }^{576}$ Idem, p.107.

577 No livro Comunidades imaginadas, Benedict Anderson, retoma o conceito de "tempo vazio e homogêneo" proposto por Walter Benjamin em Sobre o conceito de história (teses 13 e 14) para explicar a noção de simultaneidade presente nos discursos nacionalistas. Esta seria transversal, cruzando o tempo e sendo marcada "não pela prefiguração e pela realização, mas sim pela coincidência temporal, e medida pelo relógio e pelo calendário" (ANDERSON, Benedict. Comunidades Imaginadas. São Paulo: Companhia das Letras, 2008, p.54). Tal movimento permitia eleger tradições, fazer do novo, antigo, num processo de naturalização do passado como uma verdade ontológica.
} 
eu-cognoscente, a qual pressupõe, por sua vez, o encontro sempre renovado do mesmo pelo mesmo, como o se referido "espírito” encontra-se a si próprio.

No entanto, os momentos que fugiam a essa diretriz essencialista (e de matiz cristã e psicológica) eram também dignos de nota, como contra-exemplos. Como visto acima, sua artilharia volta-se contra o liberalismo da primeira República: “O regime republicano representou a primeira ruptura apreciável com as tradições políticas brasileiras. Os homens que fizeram a revolução de 1889 já não tinham uma verdadeira compreensão das realidades nacionais” ${ }^{\text {578 }}$. Segundo o autor, os principais problemas decorrentes desse sistema de governo foram a “descentralização federalista radical” e o "idealismo" que o desconectava das necessidades nacionais, o que teria resultado num "sistema de vida fictício”. Enfim, tal regime contrariava as tradições nacionais selecionadas pelo estudioso, ao mesmo tempo em que servia de contraponto para que estas fossem eleitas. Nesse sentido, a suposta essência nacional afirmava-se e tornava-se inteligível em contraposição a uma não-essência. E na luta entre Estado Novo e liberalismo, era preciso celebrar a vitória do primeiro, o que evidenciava que construção das verdades sobre o passado encontrava sua origem na perspectiva vencedora do presente.

\subsection{Editoriais e paratextos explicativos}

Depois de apresentados os conceitos gerais, norteadores do discurso veiculado pela publicação, compete agora analisá-los de maneira mais específica, a partir do estudo dos textos introdutórios à seção "Brasil, social, intelectual e artístico". Tal particularização se justifica, pois estes escritos procuraram traduzir e sistematizar as propostas do projeto político e cultural capitaneado por Almir de Andrade. Com o título de "Influência política sobre a evolução social, intelectual e artística”, eles apresentavam as demais subsecções deste segmento da revista - “Evolução social”, "Evolução intelectual” e "Evolução artística”, procurando criar o efeito de uma abordagem totalizadora da cultura nacional, em conformidade com as propostas mais gerais do periódico, analisadas no tópico anterior.

\footnotetext{
${ }^{578}$ Idem, p.111.
} 
Outra motivação para o exame desse conjunto de escritos ${ }^{579}$ é o fato de eles servirem de moldura explicativa às crônicas de Graciliano. Na verdade, como mostra de que as colaborações do escritor cumpriam um papel rigidamente delimitado pelos diretores do periódico, elas eram antecedidas não só pelos textos "Influência política sobre a evolução social, intelectual e artística”, referidos acima, mas também pelos editoriais da subseção “Evolução Social”, intitulados “Influência política sobre a evolução social”. E mais. No caso específico do primeiro número de Cultura Política, havia ainda outros dois intermediários textuais a atribuir-lhes sentido: o paratexto “A vida social no Brasil”, no qual se definia o papel a ser cumprido pelos “Quadros e Costumes”, tanto do "Nordeste” como do "Centro e do Sul”, e a biobibliografia do autor, que precedia imediatamente sua narrativa inaugural, chamada "Carnaval”580. Tratava-se, portanto, de quatro textos preliminares, sem contar os intróitos de Almir de Andrade, logo nas primeiras páginas da revista depois do sumário, a contextualizarem, especificarem e conectarem as produções do romancista ao projeto do regime.

A título de ilustração, os textos que antecediam, enquadravam e conferiam interpretação oficial às crônicas graciliânicas, depois de aberto o primeiro número de Cultura Política, apresentavam a seguinte seqüência (ver também as imagens a seguir):

$1^{\circ} \mathrm{O}$ editorial geral “A evolução política e social do Brasil”, assinado por Almir de Andrade, logo nas primeiras páginas da publicação.

$2^{\circ}$ “Influência política sobre a evolução social, intelectual e artística” (editorial da seção “Brasil, social, intelectual e artístico”)

$3^{\circ}$ “A ordem política e a evolução social” (editorial de "Evolução social”, subseção de "Brasil, social, intelectual e artístico”)

$4^{0}$ “A vida social no Brasil” (apresentação dos "Quadros e Costumes”, subseção de "Evolução social” e, por sua vez, subseção da subseção da subseção "Brasil, social, intelectual e artístico”)

\footnotetext{
${ }^{579}$ Eles estarão presentes em Cultura Política até a desintegração da seção "Brasil, social, intelectual e artístico", algo que acontece apenas no décimo nono volume, em setembro de 1942.

${ }^{580}$ RAMOS, Graciliano. Quadros e costumes do Nordeste I (“Carnaval”). Cultura Política, Rio de Janeiro, ano 1, n.1, mar. 1941, p.236.
} 
$5^{\circ}$ A biobibliografia do escritor; paratexto que louvava o artista e apresentava sua colaboração.

\section{$6^{\circ}$ Depois de toda essa parafernália paratextual, enfim, chegava à primeira colaboração do escritor: “Quadros e costumes do Nordeste I”.}

Nessas diferentes etapas de enquadramento e modulação das crônicas do escritor (algo que acontecia não só com seus textos, mas também com os artigos dos demais colaboradores da revista), observa-se um processo de afunilamento: das concepções gerais de Almir de Andrade, sinalizadoras dos pontos de vista cardeais do veículo, ao destaque para a trajetória de Graciliano, pode-se pensar na particularização do papel a ser desempenhado pelo autor e por seus escritos; respectivamente, colaborar para união da intelectualidade em torno do novo governo e recuperar as genuínas fontes da brasilidade, preservadas nos quadros e costumes do povo do interior do país.

Com o objetivo de fundamentar tais afirmações (e recuperar o caminho percorrido para se chegar até elas), é preciso antes tratar da própria estrutura, conteúdo e orientações de tais editoriais oficiais, a começar pela introdução à seção "Brasil, social, intelectual e artístico" até chegar-se aos paratextos que antecediam imediatamente as crônicas de Graciliano, os quais por estarem conectados mais diretamente ao sentido das mesmas serão examinados não agora, mas no capítulo seguinte, quando tomará corpo a análise textual e cotextual dos “Quadros e costumes do Nordeste”, propriamente ditos. Por ora serão estudados os editoriais "Influência política sobre a evolução social, intelectual e artística” e “A ordem política e a evolução social”, bem como a apresentação da subseção “Quadros e costumes”, respectivamente as etapas 2, 3 e 4 da seqüência apresentada acima. Vamos a eles.

A princípio, pensou-se que o próprio Almir de Andrade, na qualidade de editor-chefe da revista, era o autor de tais escritos, uma vez que os mesmos não eram assinados. No entanto, em depoimento já citado anteriormente, o autor de Força, Cultura e Liberdade esclareceu que o responsável pela composição destes textos não era ele, mas sim o escritor Rosário Fusco ${ }^{581}$,

\footnotetext{
${ }^{581}$ ANDRADE, Almir. Almir de Andrade (depoimento, 1981). Rio de Janeiro: FGV/Cpdoc-História Oral, 1985,
} p.4. 
Seqüência de textos que antecediam os "Quadros e costumes do Nordeste”, de Graciliano Ramos, interpostos pelos editores da revista no primeiro número de Cultura Política (tomado como exemplo)

1. Primeira página do editorial geral da revista "A evolução política e social do Brasil”, assinado por Almir de Andrade (Cultura Política, ano1, n.1, mar. 1941, p.5).

\section{A evolução politica e social do Brasil}

$S$ instituiçóes sociais e políticas são processos que se desenrolam A no tempo, sem saltos e sem paradas.

Não podemos forçar transformaçōes prematuras, nem precipitar acontecimentos que ainda não' chegaram à completa maturidade. Por outros termos, o arbitrio humano não pode modificar o que, por qualquer causa, ainda não é socialmente modificável.

Mas também não podemos impedir que as instituições se modifiquem e renovem, quando a sua própria história indica um novo rumo, quando a própria vida impōe novas tendências adaptativas e novas diretrizes para o futuro.

Hoje, parece que vivemos um momento dêsses. O mundo convulso, numa das crises mais tremendas da história, espera por algo de novo, que dê mais humanidade ao Estado, melhor assistência social às populações, maior amparo e dignidade à personalidade humana.

A democracia subsistirá, por certo, aos grandes embates e às grandes provações por que a estão fazendo passar. Porque, na verdade, a democracia encerra todo o sentido social da própria evolução da civilização humana.

Mas a democracia é uma instituiçăo viva e, por isso mesmo, uma instituição que evolue e que acompanha as mutaçōes da vida. A democracia é um ideal de solidariedade humana, de respeito ao trabalho e aos frutos do trabalho, de lealdade e sinceridade na cooperação de todos os homens para o bem comum - sem distinçóes de privilégios, nem de raças, nem de classes, nem de fortunas. 
2. Editorial da seção "Brasil, social, intelectual e artístico”, não-assinado, que, segundo Almir de Andrade, seria de autoria de Rosário Fusco (Cultura Política, ano1, n.1, mar. 1941, p.227).

\section{Influência politica sôbre a evolução social, intelectual e artistica do Brasil}

I

UM dos seus mais notáveis artigos sôbre a aboliçáo da escravatura, atemorizado com a falta de "homogeneidade nacional" de entáo, Joaquim Nabuco declarava preferir que o Brasil tivesse sido descoberto tresentos ou quatrocentos anos mais tarde.

o que êle chamava "homogeneidade nacional" é o que hoje chamariamos "conciência", "espírito nacional", equilibrio entre as fôrcas dirigentes e as dirigidas - concientes, umas e outras, das suas res. ponsabilidades, umas e outras integradas no espírito de uma mesma ordem politica.

$\mathrm{Na}$ verdade, sem êsse ajustamento entre governantes e governados, sem essa adaptaç̃o das instituiçóes políticas e sociais ao meio e ao homem que vive nêsse meio - não há ordem que se exerça, nem progresso que se realize.

Os regimes adequados a um meio social determinado, integra. dos na cultura tivamente cura de um povo devem expressar-se - e se expressam efedas do sub-concieno um éco de

3. Editorial de “Evolução Social”, subseção da seção “Brasil, social, intelectual e artístico” (Cultura Política, ano1, n.1, mar. 1941, p.230).

\section{a) Evolução social}

\section{A ordem politica e a evolução social}

I

$D^{E}$ TAL MODO a politica influencia as sociedades, que um regime póde modificar, realmente, toda a estrutura social de um povo, transfor. mando, completamente, a sua fisiono. mia coletiva.

$A$ vida social progride ou retrocede em funçäo dos elementos que a politiced the fornece.

Tais elementos podem ser divididos, preliminarmente, de der divididos, mecanismo da, de dois modos: no (pela ossisttnca administração pública cada assistencia adequada do poder a
A ordem, como condiçäo do pro. gresso, que os nossos maiores sintetiza ram como a divisa da nossa vida social, hoje se exerce em todos os setores da atividade como um verdadeiro princ. pio da nova politica do Brasil.

A administração se desenvolve em bases capazes de assegurar a todos ua direito igual, permitindo à coletivida. de um padrão de existéncia compativel com as suas necessidades.

$E$ as instituiçōes para-estatais, por ela 
4. “A vida social no Brasil”. Apresentação dos “Quadros e Costumes”, subseção de "Evolução social” e, por sua vez, subseção da subseção da subseção "Brasil, social, intelectual e artístico”. Logo em seguida, traçados os objetivos gerais do segmento nas 11 linhas iniciais, o paratexto detém-se na introdução dos "Quadros e costumes do Centro e do Sul”, de Marques Rebelo (Cultura Política, ano1, n.1, mar. 1941, p.232).

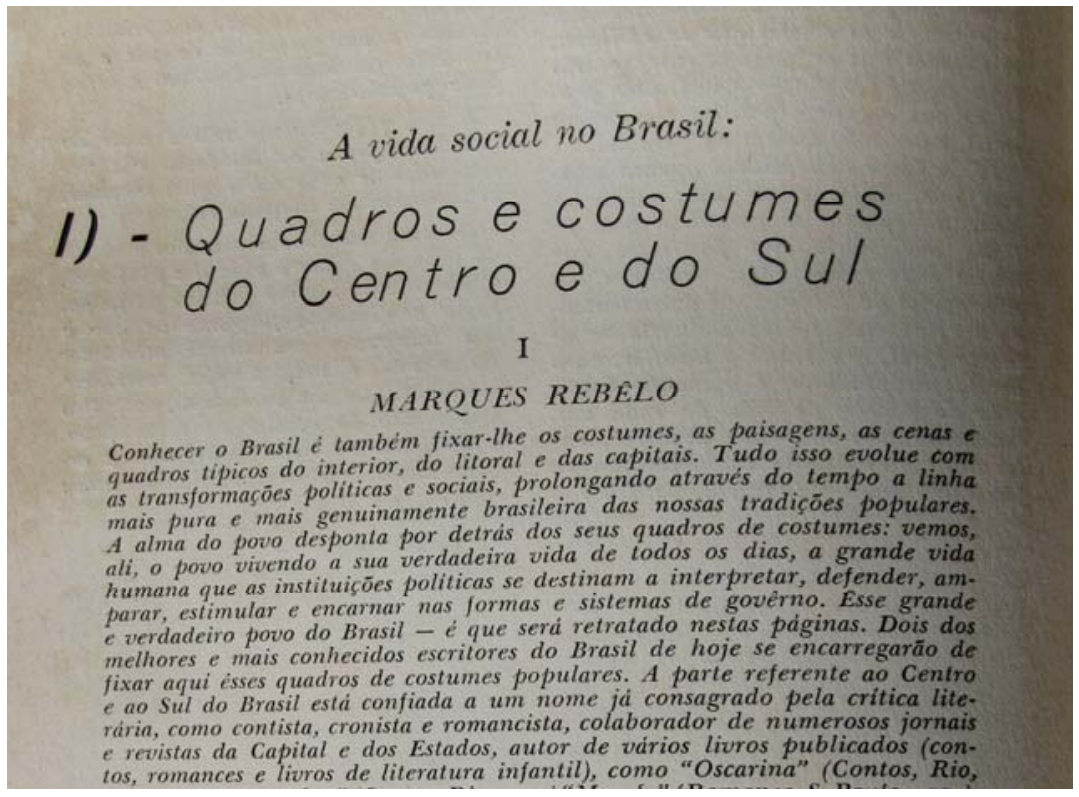

5. Paratexto que antecedia imediatamente os “Quadros e costumes do Nordeste”, de Graciliano Ramos (Cultura Política, ano1, n.1, mar. 1941, p.236).

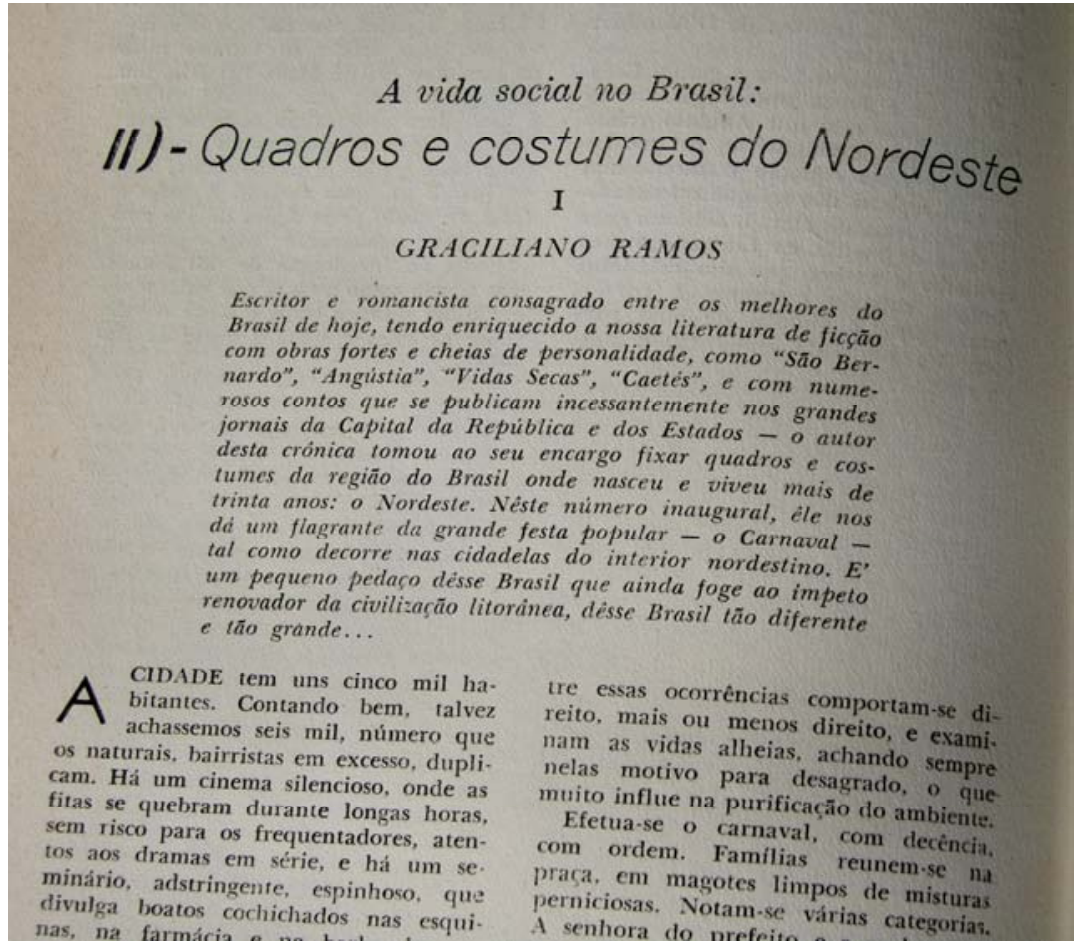


o mesmo que comandava a subseção de Cultura Política “História literária do Brasil”. Esta atribuição equivocada de autoria ao diretor da revista justifica-se, pois a afinidade entre as idéias deste e as do poeta mineiro parece total, sobretudo no que diz respeito ao papel desempenhado pelo novo governo.

No livro Política e Letras, Rosário Fusco procurava empreender uma espécie de revisão da história literária do Brasil segundo os postulados estadonovistas. Nesse processo, ele adota um ponto de vista bem demarcado, na verdade, um lugar-comum nos discursos da intelectualidade próxima ao governo varguista: até o movimento revolucionário que levou Getúlio ao poder, as obras e idéias produzidas no país estariam desconectadas da realidade nacional. Ao defender tal hipótese, obviamente, o autor não deixa de louvar o novo regime, estabelecendo uma clara associação entre política e cultura, algo já presente desde o título da obra:

... não há a menor dúvida, que em dez anos de governo eficiente, caminhamos mais do que em quarenta passados à beira das mesas de café, preocupados com discursos parlamentares ou com as intrigas estéreis que, enfraquecendo o país, politicamente, impediam, pelas suas lutas contínuas e absorventes, o progresso das letras e as manifestações criadoras da arte, que são manifestações da inteligência, da imaginação, mas também da liberdade de pensar ${ }^{582}$.

Em sua opinião, a Primeira República teria sido marcada por retrocessos não só políticos como culturais. O liberalismo, “alienante” e “utópico”, bem como as tensões e conflitos decorrentes da perspectiva individualista dos governantes, teriam corroborado o predomínio de uma "literatura superficial”, afeita apenas à beleza das formas e das palavras, que ao invés de enfrentar a realidade do país, preferia sublimá-la. Em sentido oposto, a última década com Getúlio à frente da nação representava, segundo sua perspectiva psicologizante (muito semelhante à manifesta por Almir de Andrade), o momento de pacificação e de afirmação da “consciência nacional”. Com o novo presidente, criava-se, enfim, um ambiente propício à produção cultural “autenticamente” brasileira:

Liberdade e inteligência só são possíveis quando a paz do meio ambiente permite aos homens o recolhimento fecundo, gerador de obras duradouras. Que, sendo um consolo para quem as cria, torna, de outra parte, para quem as contempla, a vida melhor e mais bela ${ }^{583}$.

\footnotetext{
${ }^{582}$ FUSCO, Rosário. Política e letras, Rio de Janeiro: Jose Olympio, 1940, p.177-178.

${ }^{583}$ Idem, ibidem.
} 
Ainda no que diz respeito às relações entre governo e cultura, na epígrafe presente no frontispício de Política e Letras, Fusco cita uma passagem do livro Principes de sociologie, de Herbert Spencer: “... les arts de n’importe quel genre ne font de progrès qu'autant que les sociétés font des progrès en volume et en structure”. O poeta modernista não só incorporava a perspectiva sociológica presente em tal excerto, bem como a reelaborava em termos políticos. Fusco também partia do pressuposto de que o progresso artístico estava subordinado ao progresso social, mas afirmava que o condutor de tal processo evolutivo seria o Estado, considerando a premência e a primazia das diretrizes governamentais sobre todos os aspectos da vida nacional. Não por acaso os editoriais de abertura da seção "Brasil, social, intelectual e artístico", chamavam-se "Influência da política sobre a evolução, social e intelectual e artística”.

Assim, apesar de considerar a interdependência entre cultura e política, cabia a esta última organizar e controlar as demais áreas, o que reforçava a perspectiva centralista e autoritária da ditadura varguista. Quanto à primeira, seu papel resumia-se, sobretudo, a fazer a justificação ideológica deste mesmo regime, conferindo-lhe legitimidade e realismo na medida em que era tomada como um dos principais meios para acessar às “aspirações populares”584. Nesse sentido, ela era pensada como um repositório da “consciência nacional”, uma forma de a nação tomar "posse de si mesma”.

Nessa rápida incursão pelas orientações políticas e literárias de Rosário Fusco, já fica saliente o parentesco entre elas e as diretrizes traçadas por Almir de Andrade, desde a publicação de Aspectos da cultura brasileira, em 1939 e de Força, Cultura e Liberdade, saído também em 1940, tal como Política e letras. Pelo exposto acima, a afinidade se mostrava na crítica ao liberalismo; na identificação entre Estado e nação; na exaltação mítica do gênio político de Vargas; na afirmação do caráter democrático, popular e “científico” do novo governo, que teria deixado as disputas individualistas para privilegiar o bem da coletividade; na concepção teleológica e revisionista de história; sem contar a confirmação da suposta reconexão do país a sua própria essência, o que conferia realismo tanto as ações governamentais como aos empreendimentos na área cultural. Enfim, trata-se de um conjunto amplo de noções, muito

\footnotetext{
${ }^{584}$ Destaca o poeta: "Decididamente, estamos diante de um autêntico governo do povo para o povo. E se um governo desce ao encontro das aspirações populares deve ter algum rótulo que as teorias constitucionais justifiquem, esse governo brasileiro, mais do que qualquer outro, deverá chamar-se democrático” (Idem, p.71).
} 
próximas daquelas sustentadas pelo diretor de Cultura Política, que gabaritavam o poeta mineiro a responder pelos textos da seção “Brasil, social, intelectual e artístico”.

\subsection{1“Influência política sobre a evolução social, intelectual e artística do Brasil”}

Feitas essas explicações preliminares quanto à autoria dos editoriais, cabe agora analisar os textos propriamente ditos. Ao longo destes escritos a ênfase argumentativa recai, principalmente, sobre em como a "política realista” do Estado Novo ancorava-se na retomada do "espírito nacional”, algo que só se tornava possível mediante ao privilégio concedido à cultura brasileira. Esta era tomada como o principal instrumento para se recuperar a "essência de brasilidade”, preterida durante os sucessivos anos de vigência do liberalismo. Nesse sentido, como era tratada como reservatório de costumes e tradições populares, poderia recolocar o país nos trilhos apontados por seu "destino histórico” na medida em que permitia ao regime realizar uma política dita "realista”, aparentemente oposta ao romantismo e internacionalismo da Primeira República.

De maneira sumária, pode-se dizer que a retórica governamental, contida nesse entrecho da revista, parece se pautar e organizar-se pelo aparente silogismo:

Todo governo que recupera o “espírito nacional”, por meio do privilégio concedido à cultura, é realista.

O Estado Novo adotou tal perspectiva

Logo Estado Novo é realista

Nesse processo discursivo “quase lógico”585 (uma vez que os editoriais procuravam apresentar um raciocínio preferível, como um raciocínio necessário) ${ }^{586}$, o conceito de “espírito nacional”, bem como seus congêneres "alma nacional”, “consciência nacional” e "subconsciente

\footnotetext{
${ }^{585}$ Perelman em seu Tratado de argumentação destaca que haveria três tipos de argumentos: os quase lógicos; os que se fundam na estrutura do real; e os que fundam a estrutura do real. PERELMAN, Chaim. Tratado da argumentação: a nova retórica. São Paulo: Martins Fontes, 1996.

${ }^{586}$ Retomando Aristóteles, Fiorin explica que haveria dois tipos de raciocínios: os necessários e os preferíveis. Enquanto nos primeiros a conclusão decorre necessariamente das premissas enunciadas, excluindo-se do processo convicções morais, políticas ou religiosas, nos segundos ela é apenas provável possível ou verossímil, pois não advém das proposições colocadas (FIORIN, José Luiz. Quase lógico. Língua Portuguesa, São Paulo, ano 1, n.10, 2006, p.44). Opõe-se aqui, respectivamente a Lógica (âmbito daquilo que seria indiscutível, de acordo com uma perspectiva monológica) e a Retórica (domínio próprio da argumentação, do debate e da construção do consenso).
} 
nacional”, são apresentados como noções preexistentes e inquestionáveis. O articulista, portanto, toma como uma verdade indiscutível algo que precisaria ser provado, o que acaba aprisionando o interlocutor em sua teia argumentativa. Mais especificamente, deseja fazê-lo concordar com a existência de tal entidade transcendental pelo simples fato de que ela existe, sem a necessidade de deduções, num processo análogo ao daqueles que pretendem afirmar a realidade divina, dizendo, a um só tempo, que a Bíblia confirma tal afirmação e que o texto bíblico seria a palavra de Deus.

Empiricamente, como já supracitado, a forma de acessar a essa entidade transcendental era voltar-se para a cultura popular, a partir da recuperação e da valorização do homem e das tradições do país. Segundo o articulista, teria cabido ao Estado Novo realizar tal movimento de retomada. E ao fazer isso, ele passava a se colocar como a própria encarnação da essência brasileira. Logo, as obras do regime seriam manifestações e comprovações diretas desta. Nota-se, portanto, que para a definição da noção de "espírito nacional”, o articulista acabara lançando mão de um raciocínio circular, ou seja, valera-se de uma forma de pensar na qual o argumento a ser demonstrado coloca-se como a própria conclusão. Portanto, ao mesmo tempo em que tal concepção era apresentada como fundadora do Estado, seu conteúdo, apesar de reivindicar uma suposta existência prévia, encontrava-se até então oculto, cabendo a este mesmo Estado dar-lhe vida:

Os regimes adequados a um meio social determinado, integrados na cultura de um povo devem expressar-se - e se expressam efetivamente, - como um eco de aspirações latentes, vigorosas, profundas do subconsciente coletivo ${ }^{587}$.

Quanto à estrutura do discurso, nos editorais predomina a utilização de asserções genéricas como as da citação acima. Estas favorecem a proclamação de regras gerais e definições fora de qualquer especificidade histórica ou individual, como se traduzissem uma verdade inquestionável. Tal procedimento acaba por incitar o conformismo, pois, praticamente, elimina a contra-argumentação e revela que o emissor detém o poder total sobre o papel a ser representado pelo destinatário. Nesse sentido tais atos de linguagem, assemelham à ordem, ao mandamento; haveria um único caminho correto a ser seguido e caberia aos leitores percorrêlo, respeitando as diretrizes do Estado.

\footnotetext{
${ }^{587}$ INFLUÊNCIA POLÍTICA sobre a evolução social, intelectual e artística do Brasil. Cultura Política, Rio de Janeiro, ano 1, n.1, mar. 1941, 227.
} 
Mais especificamente, em tal estrutura monológica, as asserções generalizantes fazem referência a uma espécie de sujeito universal e transcendental, criando o efeito de que era o próprio “espírito nacional” quem emitia os juízos. Portanto, por meio deste recurso, este passava a ser incorporado na própria superfície do discurso, ganhando materialidade ao longo dos editoriais. Nesse processo ainda, o “eu” configurado pela revista, que por extensão poderia ser tomado pelo próprio Estado, transferiria a responsabilidade sobre a emissão de sua fala a esta instância superior como forma de garantir a validade de suas afirmativas. Tal estratégia, ao considerar o Estado como atrelado a algo maior e intangível, permitia-lhe apresentar suas decisões de maneira convincente, levando os enunciatários a acreditarem que o discurso dominante seria uma “obrigação”, uma “necessidade”.

Num paralelo com as categorias instituídas pela semiótica greimasiana, o dito "espírito nacional” colocava-se como destinador manipulador a persuadir o Estado Novo que, enquanto destinatário, investido semanticamente da função de sujeito, deveria realizar a missão de salvar e engrandecer a nacionalidade (o objeto a ser conquistado). Nesse sentido, a legitimidade governamental adviria do ato de realizar os desígnios dessa ordem sobrenatural, a qual não poderia ser explicada, mas sentida. Caberia ao regime, portanto, realizar tal processo sensorial na medida em que se colocava como representante autêntico da nacionalidade.

Por conseguinte, tomava-se o conceito de "espírito nacional” como causa e conseqüência do regime, pois, ele, simultaneamente, definiria e seria definido pelas ações governamentais. Assim como no discurso religioso, o próprio Estado Novo colocava-se tanto como intermediário quanto como confirmação viva dessa essência de brasilidade, vindo daí o caráter providencial e progressista por ele invocado. Logo, bastava-lhe apresentar as obras e leis que elaborara como forma de atestar sua aparente conexão com a "alma do país”. Ao mesmo tempo, esta última só existia como uma construção do próprio Estado, que se ancorava em tal pressuposto como forma de legitimar-se. Portanto, não se tratava da retomada de tradições inertes, mas de um trabalho ativo de recuperação, seleção e elaboração das mesmas de acordo com a perspectiva do poder central.

Prosseguindo com a aproximação entre o discurso dos editoriais e a retórica do catolicismo, a ditadura varguista não era investida apenas do papel de sacerdote, aquele que, na qualidade de 
representante de Deus na terra, dizia estabelecer um contato direto com a "alma nacional”. Tal processo argumentativo ia além. Muitas vezes, o regime é apresentado como o próprio messias, a materialização viva dessa entidade transcendente. Segundo tal perspectiva, ele teria chegado ao poder para salvar a nacionalidade, num ato ao mesmo tempo de coragem e de humildade. Segui-lo era estar em consonância com o caminho do bem e ter a certeza do acesso futuro (ou mesmo imediato) aos benefícios veiculados pelo periódico. Afastar-se dele significava incorrer em pecado, sendo que o mal era personificado pelo passado liberal, que teria afastado os brasileiros de suas próprias origens.

Portanto, cabia a revista, tal como o texto bíblico, destacar a influência benéfica do Estado sobre a vida nacional. Os dados, estatísticas e depoimentos apresentados procuram confirmar esse elo espiritual entre Estado e nação ${ }^{588}$. São ressaltados a seguinte cadeia de argumentos (de um conjunto amplo de proposições): a ordem geraria paz; a paz, confiança; a confiança reforçava a vocação e, por fim, toda a sociedade, a inteligência e a sensibilidade nacionais progrediriam.

Apesar desse encadeamento de proposições, os textos continuam a fazer referência a constantes “fugas da lógica”. Diante da insistência na idéia de que haveria algo maior tramando o curso dos acontecimentos humanos, afirma-se que o homem, fundamentalmente, seria definido por aspectos sobrenaturais, aquilo que há de eterno nas criaturas. Esse dado incognoscível poderia ser apenas sentido, mas não racionalizado. O articulista sugere, portanto, a existência de uma "essência de humanidade” (congênere ao "espírito nacional”) e caberia a política retomá-la como condição para não "transformar o homem em fórmula”. Para tanto era preciso buscar o “equilíbrio do bom senso coletivo" e "refugiar-se da suficiência enganadora das idéias” ${ }^{\text {589 }}$. Nota-se, portanto, a recorrência a argumentos que estariam além de processos dedutivos, e a procura da persuasão por meio da comoção ${ }^{590}$.

\footnotetext{
588 Segundo ainda às categorias estabelecidas pela semiótica greimasiana, o mesmo “espírito nacional” voltava no momento da sanção como destinador julgador, a verificar se o Estado teria cumprido sua missão. Nesse sentido, cabia às páginas de Cultura Política documentar o sucesso da empreitada de salvação nacional empreendido pelo regime.

589 INFLUÊNCIA POLÍTICA sobre a evolução social, intelectual e artística do Brasil. Cultura Política, Rio de Janeiro, ano 2, n.15, maio1942, p.264.

${ }^{590}$ Com respeito a tal vinculação à retórica religiosa, o próprio autor caracteriza a nova política como cristã por seu respeito à “dignidade pessoal” e "por fazer e distribuir justiça, em nome das leis que sanciona”. Além disso, nos textos de Basílio Magalhães, presentes na subseção "O povo brasileiro através do folclore”, de "Brasil social, intelectual e artístico”, a marca do catolicismo fica clara na insistente tematização da figura dos santos.
} 
Nesse movimento de construção de um arcabouço de "valores espirituais”, o articulista, mais uma vez, procurava retomar, reforçar e particularizar a interdependência entre cultura e política. De maneira mais específica, a própria definição de “política realista” pressupunha necessariamente o privilégio para a especificidade dos problemas nacionais. Estes, por sua vez, só poderiam encontrar espaço e ressonância numa cultura tradicional que privilegiasse a matéria brasileira, mostrando-se atrelada à vida do país:

\begin{abstract}
A nossa realidade atual não se abasteceu de fontes estranhas para viver: dentro de nós mesmos encontramos o que procurávamos por fora, numa inquietação dramática de conseqüências perigosas (...) A nova política do Brasil não aspira outra coisa senão a união da cultura com a vida. Realista, seus postulados se firmam em bases de uma segurança que, existindo no presente, vai firmar seu ponto de apoio nos alicerces do passado ${ }^{591}$.
\end{abstract}

Como atesta em caráter exemplar o trecho acima, a argumentatividade dos editoriais opera pelo acúmulo de evidências (consubstancializadas em assertivas genéricas), que procuram criar o efeito de que não estamos diante de premissas plausíveis, mas sim de axiomas. Tal perspectiva estaria assentada na ancestralidade, na recuperação do passado que forneceria as diretrizes "incontestes" da nacionalidade, superando os riscos do imediatismo do presente. Toma-se esse olhar para a tradição como algo natural, como se ela estivesse dormente no passado esperando o momento de ser recuperada e continuada por aqueles que a soubessem revivê-la e reanimá-la, quando na verdade, sabe-se muito bem que há todo um processo de construção desse "jeito de ser brasileiro”, desse "espírito que vem informando a nação desde o seu nascimento”.

Segundo os editoriais, o presente seria efêmero e o futuro, uma projeção necessária do passado. A filiação aos tempos idos seria uma forma de reviver as "origens", resistir ao desaparecimento e, simultaneamente, acelerar a evolução do país na medida em que estabeleceria um elo contínuo entre o que éramos, o que somos e o que seremos. Em parte, essa ênfase na ancestralidade também pode ser tomada como uma forma de naturalizar tanto da “revolução" de 1930, como o governo autoritário de 1937, considerados como eventos sucessivos e intimamente inter-relacionados, marcos centrais na periodicidade construída pelo regime:

\footnotetext{
${ }^{591}$ INFLUÊNCIA POLÍTICA sobre a evolução social, intelectual e artística do Brasil. Cultura Política, Rio de Janeiro, ano 1, n.2, abr. 1941, p.239.
} 
Foi contra ele [o liberalismo da Primeira República] que se insurgiram os homens de 30, assim como em seu nome, as crises sucessivas que daquela data atravessamos nos assolaram. Foi contra ele, com sua corte espetacular de conseqüências malsãs que se insurgiu, por sua vez, em 37 o Presidente da República, evitando, com uma intuição prodigiosa de nossas necessidades, o esfacelamento da unidade nacional, ameaçada tantas vezes pelo apetite 'patriótico' de tantos brasileiros iludidos pela deformação da paisagem que a sede de mando dá e a preocupação da conquista da autoridade concede ${ }^{592}$.

Novamente não há dados explicativos, mas apenas afirmações de que até a "revolução" realizada pela Aliança Liberal vivíamos uma crise de autoridade, afundados no excesso de liberalismo. Dessa maneira, o articulista acaba erigindo o marco periodizador de 1930, como se houvesse Brasis diferentes antes e depois desse momento. Tratava-se do ano de "fundação" do Estado Novo, já que a inauguração deste, em 1937, era vista como um "prolongamento dos ideais revolucionários de Outubro”. No entanto, entre 1930 e 1937, haveria um hiato: 1934, data da promulgação da nova Constituição, que representou uma espécie de renascimento dos ideais liberais e, por isso, precisou ser corrigida: “logo após a sua outorga, e menos de menos de um ano após a sua vigência, veio nos demonstrar, mais uma vez, que o trabalho de reforma não poderia ser dado como findo e que muita coisa restava por fazer”593.

$\mathrm{Na}$ construção de tais balizas temporais, subjaz a idéia de que o processo evolutivo implementado pelo governo seria produto de uma “modificação revolucionária”, que longe de romper com o passado, consagrava-o como até então nunca havia acontecido na história brasileira. No entanto, uma revolução que retomava e privilegiava a vida pregressa da nacionalidade não poderia ser tachada estritamente como uma revolução ${ }^{594}$. Na verdade, esta aparente contradição pode ser tomada como astúcia argumentativa, pois ao mesmo tempo em que marcava o rompimento do Estado Novo com o sistema político anterior, construía as bases de sua legitimidade ao enfatizar a retomada da essência da nacionalidade.

Feitas tais considerações, os editoriais passam a discriminar os elementos que preencheriam esta categoria “tradição nacional”, a qual orientaria as ações políticas do regime autoritário. Entre eles, é possível enumerar os seguintes:

\footnotetext{
${ }^{592}$ INFLUÊNCIA POLÍTICA sobre a evolução social, intelectual e artística do Brasil. Cultura Política, Rio de Janeiro, ano 1, n.3, maio. 1941, p.242.

593 INFLUÊNCIA POLÍTICA sobre a evolução social, intelectual e artística do Brasil. Cultura Política, Rio de Janeiro, ano 1, n.6, ago.1941, p.252.

${ }^{594}$ Como destaca Florestan Fernandes, mesmo na linguagem cotidiana, o termo “revolução" designa alterações drásticas e violentas na estrutura social. Nesse sentido, “uma mudança revolucionária” pressupõe a subversão da ordem imperante em certa coletividade (FERNANDES, Florestan. O que é revolução, São Paulo: Abril Cultural; Brasiliense, 1984, p.8, Coleção Primeiros Passos, n.14).
} 
- Predomínio de princípios humanos e cristãos, como o respeito pela dignidade pessoal, probidade e cordura;

- Construção de um ambiente de paz e trabalho, no qual prevalecia a harmonia e a cordialidade;

- Política de unidade nacional, com destaque para o centralismo administrativo do executivo e para o combate ao individualismo regionalista;

- Defesa de um estado apolítico, pautado por princípios científicos;

- Supremacia da coletividade, mais especificamente para a noção de "bem comum”;

- Perspectiva de expansão das fronteiras internas, materializada no bandeirantismo da "Marcha para o Oeste";

- Interesse por particularidades regionais vistas a partir do centro.

Em contrapartida, ao longo dos textos, o articulista enumerava uma série de "falsas" tradições, uma espécie de lista negra daquilo que era repudiado pelo novo governo e, por oposição, servia para definir sua identidade diferenciada:

- O abuso do federalismo que consagraria a "descontinuidade nacional” e conseqüentes conflitos e tensões;

- A consideração da pátria como um "grêmio político", na qual os governantes encontravam-se distantes da realidade do país, incapazes, portanto, de realizar uma administração racional e científica;

- O individualismo e personalismo de homens e instituições;

- O repúdio ao passado em benefício do presente, desprezando nossas origens e tradições;

- O exotismo no emprego de soluções importadas, as quais eram forçosamente impostas aos problemas nacionais, em detrimento aos os estudos brasileiros;

Estas balizas, tanto as tradições afirmadas como as mal-afamadas pseudo-tradições, são pinçadas a partir de uma leitura interessada, que procura conferir sentido e inteligibilidade ao passado, segundo a perspectiva autoritária e centralista do presente. E nesse processo de seleção e construção, tais listas de definições acabavam sendo naturalizadas na medida em que eram apresentadas como um conjunto ou de aspirações ou de negações próprias do 
pensamento popular que, enfim, encontravam respaldo no poder central. Logo, não seriam imposições de um governo ditatorial, mas desejos inconscientes presentes na vida da própria população.

Como decorrência desse raciocínio, os textos apontavam como uma evidência, a suposta coincidência de interesses entre povo e governo:

... tamanho ajuste, como esse que em nossos dias verificamos, entre o 'querer' de cada grupo social e o 'poder' do Estado, que desce a seu encontro, apaziguando interesses desencontrados, conciliando desentendimentos eventuais, aproveitando os elementos de boa vontade, eliminando as dissensões meramente pessoais em benefício da coletividade ${ }^{595}$.

Destacava-se, portanto, o papel central do Estado que, como "autêntico" representante da nacionalidade, encontraria respaldo para descer até os cidadãos e promover “a confraternização na ordem, sem a qual não há trabalho que se realize, nem progresso que se afirme" ${ }^{596}$. Essa suposta conexão com as tradições do país, que, na verdade, estavam sendo selecionadas e hierarquizadas, estava na matriz do privilégio concedido a certa noção de coletividade, abstrata e total, que vinha se sobrepor aos indivíduos. Argumentava-se que na medida em que eram satisfeitos os anseios daquela, cada um destes seria contemplado, pois, como pano de fundo, estavam sendo recuperadas as "raízes de nossa formação como sociedade e povo" ${ }^{, 597}$.

Tal proposição tornava-se possível, pois os interlocutores, interpelados pelos editoriais, eram tratados como reflexos do transcendente “espírito nacional”. Parte-se do princípio que eles teriam sido criados a sua imagem e semelhança. Ao mesmo tempo, subentendia-se que os sujeitos se reconheciam e apenas eram reconhecidos como seres únicos quando aceitavam seus semelhantes e eram por eles aceitos, levando-se em conta a subordinação de todos à onisciência da consciência nacional encarnada pelo Estado Novo.

Esse privilégio declarado para o bem coletivo, o qual era medido, controlado e arbitrado unicamente pelo estado autoritário, além de reforçar o poder central, definia as bases da visão de progresso vendida. A influência da política sobre o social teria proporcionado um

\footnotetext{
${ }^{595}$ Idem, p.237-238.

${ }^{596}$ Idem, p.238.

${ }^{597}$ Idem, ibidem.
} 
aceleramento de todas as nossas energias nacionais, que se redescobrem, de nossas possibilidades intelectuais, que se reavivam, de nossas concepções artísticas, que se afirmam independentemente de quaisquer influências (...) Socialmente, intelectualmente, artisticamente, estamos valendo mais. Essa prova de valor temo-la, diariamente, nas leis que acatamos, nos progressos que fazemos, nos benefícios que usufruímos, nas obras que criamos ${ }^{598}$.

No trecho acima, está marcado outro procedimento retórico comum ao longo dos editorais: o uso recorrente da primeira pessoa do plural (“nossas energias”; "nossas possibilidades”; “estamos valendo mais”; “acatamos”; "nos progressos que fazemos”; "nos benefícios que usufruímos”), como forma de estabelecer a unidade entre interlocutores e atores políticos e reavivar a memória de um suposto acordo construído entre eles. Esse recurso, além de estimular a adesão dos destinatários aos projetos do governo, trazia para a própria superfície do texto a noção abstrata de "bem comum” na qual todos estavam implicados. O "nós” nos textos dizia respeito ao articulista (um “eu” que era tomado metonimicamente pelo próprio Estado) mais um referente (“ele”) que remetia ao povo brasileiro. Nesse sentido, o enunciador não falava aos sujeitos isoladamente, mas a cada um deles enquanto pertencentes a um todo maior. Reaviva-se a memória de um pacto pregresso. “Tal método discursivo permite assimilar a conquista da legitimidade da palavra no plano enunciativo à legitimidade no plano político. Permite também engajar o destinatário nos projetos do regime fazendo com que ele seja implicado diretamente em tudo o que concerne à nação" ${ }^{\text {„99 }}$. Além disso, o mesmo artifício mascarava o caráter elitista do governo, mediante a criação de uma falsa idéia de igualdade e harmonia que pressupunha a horizontalização das relações.

Outro dispositivo retórico que trazia para a superfície do texto o efeito de homogeneidade era o uso abundante de quantificadores, notadamente as diversas formas associadas ao pronome indefinido “todos” e a advérbios como “sempre” e “jamais”, utilizados em sentido globalizante. Eles colaboravam para neutralizar possíveis diferenças, além de reforçar o caráter absoluto das verdades proclamadas, num processo que ia do particular ao geral, sem deixar de apelar para o universal, enredando os interlocutores. O trecho abaixo pode ser tomado como exemplo:

\footnotetext{
${ }^{598}$ Idem, ibidem.

${ }^{599}$ FORGET, Danielle, Conquistas e resistências do poder. São Paulo: Edusp, 1994, p.72.
} 
Em Política, toda e qualquer generalização é sempre perigosa, de vez que ela sendo uma ciência dos fatos sociais, tem como base de sua existência precisamente a mobilidade de tais fatos, que se expressam ou que existem em função das relações sociais que, por sua vez, se estabelecem entre os variados grupos de que se constitui a sociedade $\mathrm{e}^{600}$.

O texto acaba fazendo aquilo que se propõe a refutar. Ao apoiar-se em valores que se dizem absolutos e, consequentemente, irrefutáveis, o discurso coloca-se como uma petição de princípios a partir da qual o exercício autoritário do poder será justificado. Constrói-se uma perspectiva unitária que não deixa espaço para dissidências, fazendo crer que as verdades proclamadas universais jamais devem ser contraditas e que o grupo referido como "todos", por definição, não poderá ser separado ${ }^{601}$. O outro só aparece no texto quando em comunhão de interesses com o governo.

Muitas vezes, é utilizada uma forma semelhante ao dialogismo, na qual o articulista ressignifica e neutraliza um discurso que a princípio seria de seus adversários. Por exemplo, tome-se a frase "Reduzindo a aspiração social à vontade do Estado, sob a forma de disposição legal, a impressão que se tem é sempre de que a vontade partiu do alto...”602. Tal estratégia argumentativa funcionava como um meio de se precaver contra eventuais objeções dos destinatários, ao mesmo tempo em que colabora para justificar e legitimar o arcabouço conceitual do regime, ou seja, sua aparente identificação com os ideais da nação. Trata-se, portanto, da eliminação da diversidade de vozes na afirmação do nacional. Nesse sentido, não são apresentadas situações de conflito ou definidos inimigos; vende-se a imagem de um país sem divisões políticas.

Prosseguindo com sua cadeia de argumentos ao longo dos textos, o articulista passa a descrever um círculo de influências recíprocas que tinham como ponto de partida as ações políticas do governo. Estas promoveriam a evolução da vida social, intelectual e a artística, ao mesmo tempo em que se valeriam deste aparente progresso multidisciplinar como subsídio para fundamentar sua visada nacionalista. Há uma interdependência entre tais áreas, mas, hierarquicamente, a política ocupava a posição principal:

\footnotetext{
${ }^{600}$ INFLUÊNCIA POLÍTICA sobre a evolução social, intelectual e artística do Brasil. Cultura Política, Rio de Janeiro, ano 1, n.6, ago.1941, p.251.

${ }^{601}$ FORGET, Danielle. op.cit. p.90.

${ }^{602}$ INFLUÊNCIA POLÍTICA sobre a evolução social, intelectual e artística do Brasil. Cultura Política, Rio de Janeiro, ano 2, n.15, jun.1942, p.264.
} 
A nossa realidade atual não se abasteceu de fontes estranhas para viver: dentro de nós mesmos encontrávamos o que procurávamos por fora, numa inquietação dramática de conseqüências perigosas. Evitando esse perigo em 1937, foi aceitando a nossa vocação social, intelectual e artística que encontramos a nossa própria rota, sem trair a nossa alma e sem comprometer as nossas tradições ${ }^{603}$.

A "valorização do homem brasileiro" é apontada como pilar do progresso econômico da nação. Com a ênfase no trabalho e na disciplina, a produção teria crescido e com ela a distribuição da riqueza e o poder aquisitivo da população. A forma de comprovar isso era não só verificando dados e estatísticas (índices de referencialidade que falariam por si mesmos), mas conversando com os próprios trabalhadores e comparando a vida deles no presente e no passado construídos pelo texto. As evidências da evolução aludidas pelo regime, portanto, poderiam ser constatas pelo contato direto com os trabalhadores, testemunhas pulverizadas por toda a trama social desse suposto sucesso, o que amplificava o próprio efeito de real proposto. Tal afirmação ancora-se nos benefícios e garantias proporcionados pelas leis trabalhistas, que de certa maneira legitimavam o respaldo popular e a aproximação "natural” entre Estado e massas, algo que não ocorreria no sistema político anterior. No entanto, vale lembrar que tal aparato jurídico estendia-se apenas a trabalhadores sindicalizados (limitando a noção de cidadania), ao mesmo tempo em que controlava e desmobilizava a classe trabalhadora.

Esse suposto avanço também atingiria as atividades intelectuais e artísticas, pois o governo se dizia preocupado tanto com o "pão" como com as "rosas” do poeta. Logo, os textos procuravam atestar que o Estado Novo teria determinado o interesse pela cultura e não o contrário, ou seja, que ele teria se aproveitado do incremento dos estudos sobre o país como fator de construção de sua legitimidade. Tal afirmação subordina-se à idéia central veiculada pelos editoriais de que a política, causa primeira da ressurreição da brasilidade, exercia tutela completa sobre a sociedade. Além disso, pela ótica estatal, a ênfase e o estímulo à matéria nacional não significavam limitação aos “homens de pensamento e sensibilidade”, muito pelo contrário. Os editoriais partiam do princípio de que as realizações humanas fatalmente traziam a marca do tempo e do espaço em que foram criadas. E como tais sinais eram encarados pelo regime como reflexos de sua atuação, prestavam-se, em última instância, como testemunhos dos avanços políticos.

${ }^{603}$ Idem, p.239. 
Como visto, apesar da postura autoritária ${ }^{604}$, o governo se dizia mais democrático que seus predecessores, pois teria solucionado certos problemas referentes à gestão do Estado e aberto o caminho para que o país avançasse nas mais variadas áreas. No editorial do quarto volume da revista, o articulista chega a destacar que a "política” fora extinta pelos “os responsáveis por nosso destino" e que o governo teve a coragem de romper com as “animosidades” e com a rotina de “processos políticos viciados”. Há, portanto, todo um trabalho discursivo de reorientação do significado das práticas administrativas. Era preciso mostrar que elas não se apresentavam mais como um fenômeno pernicioso, sinônimo de lutas, individualismo e distanciamento das vontades da população. O regime impunha-se alardeando realizar o reverso dessa moeda; ele se dizia promotor da harmonia, do bem coletivo e executor das vontades populares por meio de ações e não teorias. Em tal estrutura enunciativa, adota uma fala em que ressalta seu racionalismo administrativo, como se fosse um governo científico e apolítico.

Tal cientificismo ganhava materialidade na própria estrutura argumentativa dos editoriais, mais particularmente nas recorrentes citações a autores estrangeiros, bem como na conceituação das noções utilizadas. No texto presente no décimo primeiro volume da revista, o articulista lança mão de uma idéia tirada de um pronunciamento de Paul Valery: "toda política implica alguma idéia do homem”605. Ela é uma espécie de premissa geral e genérica, emitida por uma fonte abalizada, que depois será particularizada para o caso brasileiro, ganhando uma leitura adequada às diretrizes propagandísticas da publicação. Ao mesmo tempo em que conferia autoridade ao pensamento veiculado pela revista, o enquadramento discursivo da fala do poeta francês criava o efeito de territorialização dos conceitos “importados” expressos por ele. Esse procedimento funcionava, em certa medida, como uma crítica ao liberalismo da Primeira República, apresentado pela publicação como servil às teorias vindas de fora e incapaz de traduzi-las para a "realidade” nacional.

Em seguida, o autor de Varieté é utilizado para fundamentar a definição de realismo político definida pelo novo governo. Como forma de evitar a falsificação da realidade, o articulista

\footnotetext{
${ }^{604}$ A lista de procedimentos retóricos que atestam o aspecto autoritário do discurso expresso pelos editoriais, aqui, analisados é extensa. Entre elas pode-se incluir a utilização de perguntas retóricas, as quais simulam um diálogo, mas não conduzem a uma resposta. Trata-se apenas de uma espécie de afirmação simulada em interrogação; uma fórmula fática para tornar mais vivo o monólogo. Por meio delas, os leitores se sentiam interpelados, o que aparentemente reduzia a assimetria do discurso governamental.

${ }^{605}$ INFLUÊNCIA POLÍTICA sobre a evolução social, intelectual e artística do Brasil. Cultura Política, Rio de Janeiro, ano 2, n.11, jan.1942, p.241.
} 
destaca que era preciso não só ver, mas sentir o ser humano, considerando, simultaneamente, a eternidade de sua natureza e a imprevisibilidade dos fenômenos sociais. Tal seria a visada estadonovista na apresentação do "homem brasileiro como um ser total, indiviso, composto de ‘tempo’ e ‘espaço’, isto é, como o representante de uma civilização em determinado período de uma cultura”606. Enfim, os editoriais procuravam afirmar a especificidade do homem nacional ao mesmo tempo em que o vinculava a certos valores do que se supunha ser a essência humana.

Nessa mesma linha de atribuição de certa perspectiva “cientificista” aos textos doutrinários, ocorre a conceituação das noções de “evolução” e "influência” que aparecem nos títulos deste conjunto de editoriais. A primeira tinha como base as orientações do filósofo inglês Herbert Spencer. Ele considerava que a realidade seria marcada pelo desenvolvimento perpétuo de uma força de caráter incognoscível, manifestada na evolução do que é de início homogêneo, indeterminado e simples, para a heterogeneidade, determinação e complexidade. Ao mesmo tempo, partia da definição da sociedade como um organismo (daí sua vinculação ao biologismo sociológico); assim como os organismos eram formados por unidades (as células) o mesmo ocorria com os agrupamentos humanos, compostos por indivíduos. Por analogia, considerava os processos de crescimento, expressos por meio de diferenciações estruturais e funcionais, como resultado da correlação entre as partes do todo.

O articulista incorpora tais pressupostos spencerianos ao destacar que haveria uma "ordem no mundo que escapa ao nosso entendimento” (referência ao incognoscível), mas que também, por outro lado, existiria um "nexo edificante” entre a estrutura dos homens e da sociedade. Levando em conta estes conceitos ressalta a interdependência entre individual e social no Estado Novo, procurando fundamentar tanto a idéia da supremacia da coletividade (sob a tutela do regime), assim como a onipresença da “consciência social” nas atitudes particulares de cada brasileiro.

Simultaneamente, percebe-se na argumentação do articulista a permanência de certa orientação determinista do historicismo do século XIX, na medida em que concebe a mudança social ou desenvolvimento histórico como processos sujeitos a leis gerais e absolutas. Tomese o trecho:

${ }^{606}$ Idem, p.242. 
A primeira grande regra sociológica, portanto, deve ser aquela que enuncie: as propriedades das unidades determinam as propriedades do todo. E é o estudo das relações estabelecidas entre as unidades humanas e o agregado humano que constitui, por sua vez, o conteúdo da ciência social. Tal estudo poderá concluir, com precisão espantosa, sobre cada fenômeno que lhe for submetido ${ }^{607}$.

Assim, subentende-se que da análise empírica do estado atual de uma dada sociedade, é possível prever seu progresso. Ou seja, é possível apontar o sentido (ou direção) que a evolução tomará. No caso estadonovista, afirmava-se que tanto os avanços do presente como os do futuro seriam decorrentes da retomada do passado. Este aparece sempre como elo coesivo e legitimador. O momento atual, portanto, seria de reconexão com uma pressuposta essência de brasilidade, daí as marcas de seu aparente sucesso e vitalidade.

No que diz respeito ao termo "influência”, no editorial do número 18, o articulista procura tratá-lo como algo imprevisto (pois poderia ocorrer a qualquer momento, com qualquer um, de diferentes maneiras) e inevitável, tal como um “contágio”. Por um lado, a afirmação é apresentada como uma evidência, uma regra generalizável. Por outro, procurando se desvencilhar da aparente banalidade do argumento, o autor se vale de citações parciais, de diferentes fontes abalizadas, como forma de autorizá-la e fundamentá-la. Feito isso, em seguida, a premissa é particularizada e transferida para o campo das ações estatais, lugar em que seria potencializada. Esse enquadramento político do lugar-comum também era uma estratégia argumentativa recorrente ao longo dos editoriais, como forma de estender a suposta evidência da idéia inicial à esfera das atribuições do governo. Na verdade, o regime é apresentado como ocupante da posição central nesse processo que se ramificaria pelas áreas social, intelectual e artística: “uma influência comum que nos dá consciência do momento do mundo, através das diretrizes políticas que seguimos” ${ }^{\text {608 }}$.

Com relação a essa apresentação dos múltiplos avanços propagandeados pelo governo como algo evidente, o editorial do número nove da revista dizia: "E como tais progressos constituem, por si mesmos, 'permissões’ políticas ineludíveis, são às diretrizes políticas do Estado Nacional que devemos atribuí-los. Negá-lo seria negar a evidência da própria

\footnotetext{
${ }^{607}$ INFLUÊNCIA POLÍTICA sobre a evolução social, intelectual e artística do Brasil. Cultura Política, Rio de Janeiro, ano 2, n.14, abr.1942, p.190.

${ }^{608}$ INFLUÊNCIA POLÍTICA sobre a evolução social, intelectual e artística do Brasil. Cultura Política, Rio de Janeiro, ano 2, n.18, ago.1942, p.307.
} 
realidade. Cego, nesse caso, não é quem não vê"é quem não quer ver"609. Nessa referência a uma suposta cegueira (não física, mais política e intelectual), o articulista não classifica os destinatários como “cegos”, ou seja não imputa-lhes diretamente a suposta falta. Por outro lado, ele lhes atribuí a tarefa de avaliar a posição assumida, pressupondo um exame de consciência. Logo, o “eu” do enunciador impõe-se como juiz, mas coloca-se à distância, deixando de se referir aos leitores na segunda pessoa, tendo em vista que a abertura ao diálogo é vedada.

No início deste segmento de capítulo, ao tratar da noção de espírito nacional, foi mencionado que os editoriais ora analisados tomavam como prova algo que precisaria antes ser demonstrado. A parte esse aparente paralogismo, há que se considerar que eles não se fechavam em si mesmos. Na qualidade de intróitos à seção "Brasil social, intelectual e artístico”, tais textos eram compostos por uma série de afirmações que os colocavam como anunciadores de algo a ser exposto e confirmado nas páginas sucessivas, ou seja, eles funcionavam como uma porta de entrada coesiva para todos os escritos a ele subordinados de acordo com a hierarquia interna do periódico. Nesse sentido, a demonstração dos pressupostos que lançavam ocorria extrinsecamente, pelo acúmulo e justaposição do conteúdo das subseções que vinham a seguir, reunindo números, estatísticas e, sobretudo, o “depoimento insuspeito dos brasileiros de várias latitudes ${ }^{\text {}}{ }^{\text {. }}$

Há, dessa maneira, segundo tal delimitação oficial, uma marcação clara da função que os “Quadros e costumes do Nordeste” de Graciliano, assim como outros textos congêneres, irão cumprir: confirmar a primazia do aspecto político e sua ascendência sobre os demais setores da vida nacional. Seriam eles que corporificariam o "espírito nacional”, consubstanciado no “providencial” e “realista” Estado Novo e, metonimicamente, na figura de seu líder Getúlio Vargas.

\subsubsection{Apresentação das subseções “Quadros e Costumes”}

Ao longo da leitura dos editoriais "Influência sobre a evolução social, intelectual e artística do Brasil”, com algumas poucas variantes, predomina certa repetição dos argumentos e da

${ }^{609}$ INFLUÊNCIA POLÍTICA sobre a evolução social, intelectual e artística do Brasil. Cultura Política, Rio de Janeiro, ano 1, n.9, nov. 1941, p.363.

${ }^{610}$ INFLUÊNCIA POLÍTICA sobre a evolução social, intelectual e artística do Brasil. Cultura Política, Rio de Janeiro, ano 1, n.2, abr. 1941, p.239. 
maneira de estruturá-los. Como os textos restringiam o intercâmbio com os receptores, eles eram sucedidos por outros que obrigatoriamente mantinham semelhanças quanto à coerência e às definições empregadas. Logo, nestes editoriais, criava-se o efeito de um discurso oficial unitário e exclusivo, que tirava todos os outros de cena, salvo os que (dentro da mesma linha de raciocínio) possuíssem pretensões e estruturas afins. Tal similaridade, portanto, fazia parte do esforço do articulista de se repetir sem ser repetitivo, de acordo com o duplo objetivo de cercear possíveis linhas de fuga (inerentes a cada nova enunciação) e inculcar, pela insistência, as diretrizes estadonovistas.

Este também parece ser o papel cumprido pelos editoriais subseqüentes "A ordem política e a evolução social”, introdutórios à subseção “Evolução Social”, que, enfim, reunia os “Quadros e costumes do Nordeste”. Eles enfatizavam o caráter realista, apolítico e científico do Estado Novo; a supremacia do bem comum, numa sociedade tutelada pelo regime; o caráter democrático do governo que, deixando de lado as utopias liberais de liberdade e igualdade irrestritas, passou a privilegiar o ideal de justiça social; o acordo consensual entre indivíduos e poder central; a leitura interessada do passado, como forma de justificar certos postulados estadonovistas como o centralismo e o autoritarismo; utilização de uma retórica propagandística, revestida de certas premissas pertencentes ao âmbito da ciência e da filosofia (com destaque para o positivismo e o evolucionismo de Spencer); a recuperação do "espírito nacional”, encarnado pela ditadura varguista em seu movimento de construção de tradições etc. Enfim, um conjunto de especificações e procedimentos já observados no item anterior.

Nesse sentido, parece mais produtivo analisar diretamente as linhas com que o primeiro número de Cultura Política particularizava as subseções “Quadros e Costumes” (tanto do Centro-Sul, como do Nordeste). O texto dos editores (possivelmente também de Rosário Fusco) poderia ser tomado como uma verdadeira carta de princípios, na qual são especificados o papel que tais textos iram cumprir dentro do projeto estadonovista, ao longo dos números do periódico que se seguirão:

Conhecer o Brasil é também fixar-lhe os costumes, as paisagens, as cenas e quadros típicos do interior, do litoral e das capitais. Tudo isso evolui com as transformações políticas e sociais, prolongando através do tempo a linha mais pura e mais genuinamente brasileira das nossas tradições populares. A alma do povo desponta por detrás dos seus quadros de costumes: vemos, ali, o povo vivendo a sua verdadeira vida de todos os dias, a grande vida humana que as instituições políticas se destinam a interpretar, 
defender, amparar, estimular e encarnar nas formas e sistemas de governo. Esse grande e verdadeiro povo do Brasil - é que será retratado nestas páginas ${ }^{611}$.

A princípio, nota-se que os “os quadros de costumes” eram tomados como uma forma de corporificar e dar sentido a instância superior e transcendental do "espírito nacional” (a "alma do povo” a despontar nas tradições recuperadas). Nesse sentido, ocupariam uma posição fundamental, tendo em vista o peso conferido a essa "essência de brasilidade” pelo discurso autoritário, como forma de justificar e legitimar suas ações. Os autores dos quadros, portanto, colaborariam com a perspectiva de realismo político do regime, pois supostamente documentariam e recolheriam material que daria subsídio às ações governamentais, aparentemente ancoradas na “realidade” do país.

Observa-se ainda que o editorialista confere um caráter salvacionista aos escritores, pois teriam a missão de recuperar e fixar imagens, costumes e personagens de um Brasil "perdido na imensidade de si mesmo”, colaborando, assim, com a construção da unidade nacional, já que juntariam as partes ao todo. Nesse processo, o estatuo literário dos textos ficaria em segundo plano; estes passam a ser tratados como autênticos documentos, dotados de um valor de verdade absoluto. Seriam provas (experiências diretas) e não mediações sígnica do cotidiano das populações sertanejas. Nesse sentido, reforçariam o suposto pacto entre ditadura e coletividade, pois suas crônicas alimentavam a idéia de que por mais que Estado fosse maior que os indivíduos, falava em nome de “todos” eles. Logo, tanto pelo enquadramento como pela maneira como são apresentados, os textos de Graciliano e Marques Rebelo colaborariam para a construção da legitimidade e do consenso em torno do Estado Novo.

Mais do que enfocar a influência da “evolução política” sobre a “evolução social”, o presente trecho procura destacar o descompasso entre essas duas: enquanto um caminharia a passos largos, a outra ainda engatinhava, mas o ritmo desta última precisava ser respeitado. Nesse momento, ficam expostas as rachaduras da máscara progressista do regime:

Mas o Brasil é grande, imensamente grande: a rotina continua a espreguiçar-se com lentidão secular, porque os governos não operam milagres e a vida social brasileira tem que seguir a sua marcha natural. Se a nossa evolução política segue o ritmo veloz de decênios, a nossa evolução social terá que seguir, inevitavelmente, um ritmo paciente de séculos (idem).

${ }^{611}$ A VIDA social no Brasil. Cultura Política, Rio de Janeiro, ano 1, n.1, mar.1941, p.230. 
Ao mesmo tempo em que menciona certas fraturas e descompassos na proposta governamental, tal postura sinaliza que caberia aos “Quadros e Costumes”, principalmente, estudar, recolher e dar a conhecer a vida brasileira (o que o autor chama de "evolução social”), e, de forma secundária, louvar as conquistas e realizações políticas do regime (evolução política). Portanto, a retórica propagandística deliberada cederia lugar ao estudo e à documentação do país. No entanto, esta última perspectiva, como visto acima, estava longe de ser isenta: trabalhava para a afirmação da dita "política realista”, vendida pela ditadura varguista.

Corroborando este argumento, Raul Antelo sinaliza as diferenças entre as propostas de 1930 e as diretrizes de 1937: enquanto as primeiras vinculam-se a idéias de "força, velocidade, ruptura” e a uma noção dinâmica de governo, as segundas privilegiam um regime “evolucionário e parcimonioso”. Dessa maneira, O Estado Novo, no processo de domesticação do conceito antinatural de revolução, teria promovido “o culto às tradições populares, ancestrais, ‘imutáveis’, e dignas de respeito como a própria natureza”612. Pesando estritamente na revista, tal perspectiva abria caminho para colaborações que não precisavam se restringir a uma retórica deliberadamente encomiástica, ao mesmo tempo em que, por outras vias, colaboravam para legitimar o governo e o interesse deste pela matéria nacional:

\footnotetext{
... a forma que na relação entre escritor e realidade é a de fixar (congelar com valor documental) aquilo que não pode ser apreendido: os instantâneos. Ao não poder narrar - o tempo foi abolido - descreve-se a vida social do Brasil. A literatura confunde-se com uma kodak "verdadeira" e cotidiana do povo (idem).
}

A “abolição do tempo" a que se refere o pesquisador diz respeito à estratégia discursiva do Estado Novo de estabelecer uma equivalência entre passado, presente e futuro, num processo que procura desideologizar a história e mostrá-la como manifestação de uma suposta essência de brasilidade. Em tal contexto, a narrativa, enquanto sucessão de acontecimentos organizados em torno de um enredo, ficaria restrita, sobretudo, à esfera governamental. Ele se arrogava a condição de construtor do sentido da nacionalidade. E nesse processo, os autores dos quadros colocavam-se como co-participantes; seu papel era fornecer os instantâneos que figurariam no álbum do país elaborado pelo regime. Metonimicamente, a revista Cultura

\footnotetext{
${ }^{612}$ ANTELO, Raul. Literatura em revista. São Paulo: Ática, 1984, p.60.
} 
Política era a corporificação desse livro imagético, que pretendia não só apresentar, mas tal como um espelho, ser o reflexo da "alma do país”. Nesse sentido, não custa retomar mais uma vez o que diz Almir de Andrade no editorial de estréia do periódico:

\begin{abstract}
O instante que vivemos é apenas etapa de um caminho mais longo - talvez mais cheio de surpresas do que o que ficou para trás. Anima-nos, todavia, a consciência de já termos vencido as nossas hesitações de ontem e de já havermos traçado um rumo definido para as nossas caminhadas do porvir.
\end{abstract}

As páginas desta Revista procurarão definir e esclarecer esse rumo. Elas serão, nesse sentido, um espelho do Brasil. O que somos, o que pensamos, o que realizamos em todos os setores da nossa atividade criadora - na política, na economia, na técnica, nas artes, nas letras, nas ciências - focará estampado nestas páginas, através do depoimento de todas as gerações que hoje vivem, em todas as cidades e rincões do Brasil. Um após outros esses depoimentos virão, do norte e do sul, do litoral e do centro, de velhos e moços, de gerações da República e do Império, de antes e após-guerra. Eles falarão pelo Brasil. Porque eles são o Brasil ${ }^{613}$.

Segundo esse raciocínio do autor, se os depoimentos contidos na revista são o país, o periódico, enquanto local de reunião de todos estes testemunhos, também o seria. E ao juntálos comporia a imagem de uma nação única, tanto geográfica quanto temporalmente, abarcando todos os lugares e todos os tempos.

Nesse sentido, a revista pode ser tomada tanto como metáfora como metonímia. No primeiro caso, ao apresentar-se como um corpo unitário e orgânico, ela procurava se colocar tanto no lugar do Estado, como, por extensão, no da própria essência do país (“Eles falarão pelo Brasil. Porque eles são o Brasil”). Tal fato pode ser observado, sobretudo, pela abrangência dos temas tratados, pela excessiva hierarquização de suas seções e pela organização retórica do discurso autoritário (como fora visto antes). No segundo caso, pode-se tomar o periódico como um texto, uma tentativa de construção do sentido da nacionalidade que acabava designando, por contigüidade, este mesmo regime autoritário, na medida em que reproduzia o ponto de vista deste. A publicação era, portanto, uma realização do Estado que acabava por nomeá-lo e defini-lo. Ao mesmo tempo, pode-se pensar na presença de uma sinédoque, pois há um intento da publicação (a parte) falar em nome do Estado e do país (o todo).

\footnotetext{
${ }^{613}$ ANDRADE, Almir de. A evolução política e social do Brasil. Cultura Política, Rio de Janeiro, ano 1, n.1, mar. 1941, p.8.
} 
Continuando esse paralelo do governo/revista com a noção de texto, a publicação, ao assumir o papel do Estado, colocava-se tanto como autora de uma narrativa sobre o país, como o próprio conteúdo desta mesma narrativa que, como dito acima, desempenhava a função de orientar, propagandear e legitimar a atuação do regime ao passo que construía um sentido para a nacionalidade. Na verdade, pode-se falar, nesse momento, que o governo buscou concentrar em suas mãos o poder de narrar e, assim, de reorientar o discurso sobre o Brasil, cerceando o desenvolvimento de outros projetos paralelos, contrários a seus ideais centralistas e autoritários. A revista, portanto, seria a materialização desse projeto, identificando o regime a um narrador que a todo custo reforça sua confiabilidade, sem deixar margem a dúvidas sobre suas diretrizes e orientações.

No entanto, como sublinha Lúcia Lippi Oliveira, o Estado Novo não teria produzido um pensamento oficial uniforme, orientado numa única direção. Durante o regime de 1937, era observada a convivência de diferentes interpretações doutrinárias para o país, que procuravam conferir sentidos específicos à brasilidade: “Os intelectuais que estavam direta ou indiretamente ligados ao regime procuraram traduzir os pronunciamentos do presidente em palavras de ordem, em linhas de conduta. E nessa tarefa, transformaram-se em doutrinadores”,614. Apesar das diferentes vozes e enfoques, cada qual procurando se afirmar como definidor do próprio governo (e, consequentemente, do Brasil), todos partilhavam de uma matriz autoritária comum que estabelecia, sobretudo, o fortalecimento do poder estatal, a crítica ao modelo liberal da Primeira República e o papel fundamental das elites no processo de mudança social.

E, nesse cenário, Cultura Política aparecia como formuladora de um projeto que procurava relacionar a ação política do regime às raízes culturais brasileiras ${ }^{615}$. Tal projeto, como foi visto até aqui, alcançou destaque e notoriedade, pois ao vincular as ações de Vargas a certa noção de “essência de brasilidade” teria aberto espaço para a colaboração de intelectuais de diferentes origens e orientações com o governo, ao mesmo tempo em que conferia um destacado papel a estes, ao qualificá-los como intérpretes da vida nacional.

\footnotetext{
${ }^{614}$ OLIVEIRA, Lúcia Lippi. O pensamento de Almir de Andrade. In: OLIVEIRA, Lúcia Lippi; VELLOSO, Mônica Pimenta; GOMES, Ângela Maria de Castro. Estado Novo: ideologia e poder. Rio de Janeiro: Zahar Ed.,1982, p.31.

${ }^{615}$ Lúcia Lippi considera os intelectuais Almir de Andrade, Azevedo Amaral e Francisco Campos como pólos ideológicos que disputavam um espaço ao sol durante a ditadura varguista.
} 
Na qualidade de autora de uma narrativa da nacionalidade, a revista controlava, emoldurava e subordinava as outras autorias que agrupava. E é em editoriais como este, de apresentação da subseção "Quadros e Costumes”, no qual a voz do regime se manifesta de forma efetiva, apontando as diretrizes que deveriam ser levadas em conta na construção e interpretação da história do país. Na condição de enunciadora deste discurso, a publicação governamental apresenta-se preferencialmente como um narrador ao mesmo tempo protagonista e onisciente, sobretudo nos momentos destinados a propagandear as ações do Estado e mostrar o vínculo estreito dele com o "espírito nacional”, entidade superior de que se diz representante, a qual fora particularizada no item anterior ${ }^{616}$.

Além de recuperar "quem fala” (ou seja, a revista tomada como o próprio Estado e como uma manifestação direta dele), é preciso também retomar o ponto de vista adotado por este narrador. Quase sempre ele se coloca como uma extensão do sempre referido "espírito nacional”. E é a partir desta entidade transcendental, construída e naturalizada pelo discurso, que se dá a visão empregada pelo periódico. Adota-se, portanto, uma focalização demiúrgica, caracterizada pelo acesso direto e irrestrito a pensamentos e manifestações ocultas no que diz respeito ao país. Assim, ao falar em nome daquilo que é desconhecido e imprevisto, reforçando a idéia de que o mundo (país) seria compreensível, tal processo corrobora para o que Anderson chama de a "mágia do nacionalismo": sua capacidade de transformar o acaso em destino, a fatalidade em continuidade, a contingência em significado ${ }^{617}$.

Tendo em vista tal perspectiva, os textos de “Quadros de Costumes” procuravam incorporar em sua estrutura a "personalidade" do povo, por meio da observação testemunhal da coletividade "vivendo a sua verdadeira vida de todos os dias”. Trata-se da fixação daquilo que era comum e permanecia ao longo das décadas e dos séculos, apresentando um ritmo próprio de desenvolvimento, diferentemente daquele reivindicado pela política. Caberia a esta última

\footnotetext{
${ }^{616}$ FRIEDMAN, Norman. O ponto de vista na ficção: o desenvolvimento de um conceito crítico. Revista USP, São Paulo, n.53, mar./maio 2002. De acordo com as categorias estabelecidas por este crítico, trata-se da presença de um "Autor onisciente intruso", falando, especificamente, por meio de um "nós". "Onisciência' significa literalmente, aqui, um ponto de vista totalmente ilimitado (...) A estória pode ser vista de um ou de todos os ângulos, à vontade: de um vantajoso e como que divino ponto além do tempo e do espaço, do centro, da periferia ou frontalmente. Não há nada que impeça o autor de escolher qualquer deles ou alternar de um a outro o muito ou pouco que lhe aprouver" (Idem, p.173). De um ponto de vista oposto, enquanto tal perspectiva enfatizava o sumário narrativo, aquela adotada pelos escritores da seção "Quadros e Costumes" privilegia cena, o "o evento ele mesmo", a descrição (apresentação de detalhes específicos de espaço e tempo; portanto, não se trata tão somente da construção de diálogos). Apesar das orientações distintas, a voz generalizante do Estado irá orientar o sentido das particularizações realizadas pelos autores.
}

${ }^{617}$ ANDERSON, Benedict. op.cit. p.38-39. 
amparar e corporificar tais formas de vida, manifestas nas formas de pensar, sentir e agir das populações interioranas $^{618}$.

No diz respeito que à questão dos narratários, vale destacar que os leitores do periódico não são explicitamente identificados, mas apenas inferidos. No entanto, por meio daquilo que o texto aceita sem discussão e daquilo que ele explica é possível verificar, sobretudo, o diálogo da revista com um público mais erudito, afeitos a fontes, argumentos e raciocínios de cunho mais sociológico e filosófico. Tal parece ser o caso dos textos de Graciliano e Rebelo. Cada um, com as suas devidas especificidades, procurava apresentar aos receptores letrados dos grandes centros, afeitos à linguagem literária, o mundo longínquo interiorano de acordo com certa perspectiva fundada na ilusão referencial.

No entanto, como já observado, por mais que os textos do periódico partam de citações de autores abalizados e de noções teórico-especulativas, estas são traduzidas e incorporadas de acordo com as perspectivas e prerrogativas do regime, ou seja, são emolduradas por uma retórica propagandística. Nesse processo, nota-se também o uso predominante de enunciados generalizantes, auto-evidentes (o que acaba por silenciar possíveis contra-argumentos), paralelamente à apresentação de dados comprobatórios (depoimentos, estatísticas e diagnósticos), da qual as crônicas de “Quadros e Costumes” faziam parte e ocupavam um papel de destaque na construção do efeito de verdade dos discursos oficiais.

Quanto à categoria temporal, nota-se que a narrativa da nacionalidade proposta por Cultura Política transcorre num presente dilatado que engloba tanto o passado quanto o futuro. É nesse tempo único que ocorreria o processo evolutivo do país, tematizado pelas páginas da publicação. E como todos os momentos da nacionalidade estavam conectados, pela perspectiva do Estado Novo a evolução do país, sob sua tutela, era algo natural e inevitável. Tal discurso sobre a história brasileira ancora-se numa premissa principal: ao realizar o trabalho que teria permitido o país a "reconectar-se consigo mesmo", recuperando tradições populares, ancestrais e praticamente imutáveis, o governo teria aberto caminho para o progresso da nação. Nota-se, portanto, o papel central do passado no processo de construção do sentido para o país e da legitimidade estadonovista. Especificamente, no que diz respeito aos textos de Graciliano e Rebelo, tal moldura discursiva que lhes é imposta, também os

${ }^{618}$ GOMES, Ângela de Castro. op.cit. p.174. 
direciona nesse sentido de costurar elos de continuidade entre o presente do texto e as tradições imemoriais representadas. Ao mesmo tempo, tais autores não deixam de aterem-se às transformações encontradas no interior de tal processo com o objetivo de refletir, focalizar e resguardar do esquecimento a vida do homem brasileiro do interior.

Pela retórica oficial, nesse momento, enquanto as capitais litorâneas eram tachadas de desnacionalizadas (voltadas para modismos e "artificialismos” vindos do interior), o interior, por outro lado, era alçado à condição de guardião da brasilidade. Nesse sentido, a retomada de quadros e costumes sertanejos, pela perspectiva supostamente testemunhal adotada por Graciliano e Rebelo, além de ampliar o efeito de real dos textos, reforçava a vocação nacional que o governo procurava conferir a suas iniciativas políticas e ideológicas. Ao mesmo tempo, tal perspectiva aproximava os dois escritores das qualidades que faziam o Estado Novo tomar Euclides da Cunha como um intelectual modelo, assim como fora visto anteriormente. Ele ocupava um lugar diferenciado, pois teria deixado de lado o gabinete (“a vida fingida” e livresca das cidades litorâneas) e partira para o confronto direto com a "realidade” do interior país. Segundo a versão oficial, esta iniciativa, de dirigir-se ao campo de batalha, por si só, conferiria a seus escritos um sentido ao mesmo tempo social e nacional. 
PARTE III - Análise dos “Quadros e costumes do Nordeste”: as estratégias do autor consubstanciadas no texto 


\section{Capítulo 5 - Panorama geral da estrutura, das funções e do enquadramento dos quadros nordestinos}

.uma palavra, conforme o ambiente onde é empregada, pode traduzir conceitos diversos (Graciliano Ramos) $^{619}$.

\subsection{Introdução}

Conceituada a revista e expostas as tópicas norteadoras do discurso oficial, bem como a maneira como elas circularam nas formulações críticas de diferentes atores ao longo dos anos de 1930 e 1940, cabe, agora, analisar o modo particular de elocução de tais lugares-comuns, adotado por Graciliano na composição de seus “Quadros e Costumes do Nordeste”. Nesse processo, objetiva-se examinar a relação que o artista acabou estabelecendo com os postulados regimentais mediante seus escritos.

A empreitada prevê um movimento duplo e articulado: investigar a especificidade do trabalho artístico realizado pelo escritor, ou seja, a dimensão de "artefato verbal” de suas narrativas publicadas em Cultura Política, recuperando e esquadrinhando, assim, os aspectos formais destas, para então relacioná-las com o universo de referência do qual elas participavam enquanto “eventos culturais”. Nesse sentido, busca-se verificar a conexão do microtexto das crônicas com o macrotexto da realidade discursiva ao qual elas aludem, procurando, ao final, recompor a relação do artista com o Estado, com destaque para as estratégias utilizadas pelo primeiro para mover-se em meio ao terreno minadíssimo, de articulações políticas comprometedoras, no qual se encontrava, onde a necessidade de colaboração se contrapunha ao receio e à recusa em aderir explicitamente à ideologia do Estado Novo, expressa pela revista em questão.

Como estratégia argumentativa para tratar desse universo de vinte e três ao todo será apresentado, inicialmente, uma panorama geral dos escritos, para, em seguida, analisarem-se algumas narrativas representativas como forma de particularizar os argumentos norteadores da investigação proposta. Posteriormente, as colaborações de Graciliano serão comparadas

\footnotetext{
${ }^{619}$ RAMOS, Graciliano. As rãs estão pedindo um rei. In: BOSI, Alfredo et. al. Graciliano Ramos. São Paulo:
} Ática, 1987, p.113. 
com as de seu companheiro de seção Marques Rebelo, responsável pelos “Quadros e costumes do Centro e do Sul”. Como referido anteriormente, tal seção, juntamente com as crônicas de Graciliano sobre a vida nordestina, compunham o mosaico do país pretendido pela abordagem espacial e testemunhal da brasilidade, proposta pela revista Cultura Política. Ao colocá-las lado a lado, procura-se, por posição e oposição, definir melhor as particularidades do discurso do artista alagoano presente no periódico.

\subsection{Aspectos panorâmicos dos “Quadros e costumes do Nordeste”}

Em linhas gerais, nos “Quadros e costumes do Nordeste” predomina a abordagem do modo de pensar e de agir das elites sertanejas em sua interação com a sociedade local, com privilégio para temas relacionados à política, letras (educação), economia e sociedade (especificamente os costumes e particularidades da região enfocada). Geralmente, o cronista trata a atuação da classe dirigente como sendo marcada pela estreiteza de espírito, pela cópia servil de modelos importados e, principalmente, pelo desejo de controlar toda a sociedade, impondo-lhe normas e cerceando desvios, como meio de reafirmar seu mando. Ao mesmo tempo, o alegado artificialismo e domínio dos estratos mais elevados é contraposto à espontaneidade dos costumes tacanhos do povo, com o narrador focalizando o tratamento dispensado pelos primeiros ao segundo.

Sobretudo nos textos que têm como cenário uma pequena cidade sertaneja, de maneira semelhante ao que fizera em Caetés, a ênfase do cronista recai sobre o registro do cotidiano rasteiro da municipalidade, povoado de tipos miúdos que se moviam no ambiente insípido da província. Tal ambientação predomina nos “Quadros e Costumes do Nordeste”, com 13 ocorrências. Em seguida, vêm as crônicas que privilegiam o espaço rural; sete ao todo. Nestas tomam corpo, principalmente, uma galeria de chefes rurais; mandões da mesma estirpe de Paulo Honório, de S. Bernardo, que vivem ou o apogeu de sua força ou um momento de declínio, tendo em vista a lenta chegada de novos tempos e a conseqüente alteração da dinâmica entre a classe dirigente de tais rincões. Outro lugar privilegiado pelos escritos, apenas em três oportunidades, é a capital do Estado, situada no litoral, mas que, apesar do maior porte, reproduz, em escala ampliada, o provincianismo detectado nas localidades no interior. Nestas colaborações, há o privilégio para o tratamento dos políticos estaduais; mais especificamente o governador e seu séqüito. 
Todos estes espaços supracitados são construídos e figurativizados exaustivamente pelo autor, seja de maneira direta mediante a descrição, seja indireta, por meio da apresentação de personagens e ações. Menos da metade das narrativas oferece uma localização espacial absoluta, com referências diretas, inscritas no mundo partilhado entre enunciador e enuciatário. Valendo-se de debreagens enuncivas de enunciado e enunciação, o narrador instaura um "lá”, sem projetar o “aqui” de onde fala, o que acaba por distanciá-lo dos quadros apresentados. A maioria das colaborações traz apenas topônimos situacionais imprecisos: “cidade”, “cidadezinha de cinco mil habitantes”, “cidadezinha do interior”, “fazenda”, “pequena capital”, entre outros. Portanto, cabe ao narrador investir na concretização de tais ambientes, a fim de atrelá-los às histórias, juntamente com as personagens e as situações enfocadas. Por outras vias, o enquadramento espacial acaba sendo efetuado pelo título da própria seção, ao restringir os relatos aos limites nordestinos.

Comumente, a descrição dos espaços e dos costumes locais, é apresentada ou segundo o ponto de vista distanciado de um narrador em terceira pessoa onisciente (grande conhecedor dos mandatários interioranos, o que permite aos leitores admitir que ele teria vivido entre eles), ou por um narrador, misto de protagonista e testemunha, membro da classe dirigente, ou por meio da incorporação, da parte do cronista observador, do olhar de integrantes da elite local. Apenas em três momentos, de maneira pontual, o autor assume a perspectiva de actantes pertencentes aos estratos mais baixos da população, privilegiando uma focalização que se aproximava, ainda que timidamente, do povo. Tanto neste último caso, como no anterior, o cronista vale-se da utilização do expediente do discurso indireto livre, que será analisado de maneira mais detida no momento em que forem examinadas algumas crônicas específicas.

De acordo com as coordenadas e categorizações apresentadas até aqui, as tabelas, abaixo, pretendem dividir e categorizar as 23 crônicas de Graciliano publicadas em Cultura Política e analisadas no presente trabalho: 


\begin{tabular}{|c|c|c|c|}
\hline \multicolumn{4}{|l|}{ Conteúdo } \\
\hline Política & Letras e educação & $\begin{array}{l}\text { Sociedade } \\
\text { (Costumes) }\end{array}$ & Economia \\
\hline Carnaval & O moço da farmácia & Casamentos & $\begin{array}{l}\text { A decadência de um senhor } \\
\text { de engenho } \\
\text { Recordações de uma }\end{array}$ \\
\hline D. Maria Amália & Um homem de letras & Ciríaco & $\begin{array}{l}\text { indústria morta } \\
\text { Transação de cigano (o }\end{array}$ \\
\hline Teatro I & Um antepassado & Libório & povo em geral) \\
\hline Bagunça & Um homem notável & Dr. Pelado & \\
\hline D. Maria & Desafio & Habitação & \\
\hline Funcionário Independente & Um gramático & Carnaval & \\
\hline senhor de engenho & Ciríaco & Teatro II & \\
\hline Uma visita inconveniente & Teatro I (sobre a escola) & Desafio & \\
\hline & $\begin{array}{l}\text { Uma visita } \\
\text { inconveniente }\end{array}$ & $\begin{array}{l}\text { Transação de cigano } \\
\text { Um gramático } \\
\text { "Está aberta a sessão } \\
\text { do júri" }\end{array}$ & \\
\hline
\end{tabular}

\begin{tabular}{|c|c|c|c|}
\hline \multicolumn{4}{|l|}{ Demarcação espacial } \\
\hline \multicolumn{4}{|l|}{ Cidadezinha sertaneja } \\
\hline Carnaval & Ciríaco & $\begin{array}{l}\text { Uma visita } \\
\text { inconveniente }\end{array}$ & $\begin{array}{l}\text { D. Maria Amália (cidade } \\
\text { do interior e capital) } \\
\text { Dr. Pelado (cidade do }\end{array}$ \\
\hline O moço da farmácia & Um antepassado & Teatro I & $\begin{array}{l}\text { interior e sertão) } \\
\text { Recordacões de uma }\end{array}$ \\
\hline Teatro II & D. Maria & Bagunça & $\begin{array}{l}\text { indústria morta } \\
\text { (sertão, cidades do interior, }\end{array}$ \\
\hline Funcionário Indenpendente & $\begin{array}{l}\text { Habitação } \\
\text { A decadência de um } \\
\text { senhor de engenho }\end{array}$ & & capital, exterior) \\
\hline $\begin{array}{l}\text { D. Maria (final do texto) } \\
\text { Libório }\end{array}$ & $\begin{array}{l}\text { Transação de cigano } \\
\text { Um homem notável }\end{array}$ & & \\
\hline \multicolumn{4}{|l|}{ Desafio } \\
\hline \multicolumn{4}{|l|}{$\begin{array}{l}\text { Um homem de letras } \\
\text { "Está aberta a sessão do }\end{array}$} \\
\hline \multicolumn{4}{|l|}{ 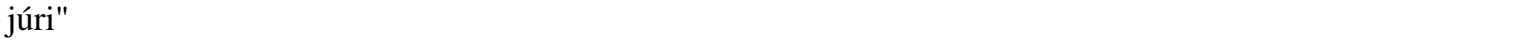 } \\
\hline \multicolumn{4}{|l|}{ Um gramático } \\
\hline Um homem notável & & & \\
\hline
\end{tabular}

\begin{tabular}{|l|c|}
\hline Nomeação do espaço \\
\hline Crônicas & Referências \\
\hline Carnaval & - \\
D. Maria Amália & - \\
O moço da farmácia & - \\
Casamentos & "interior do Nordeste" \\
Ciríaco & "fazenda antiga", "no interior de PE" \\
Habitação & "cafundós de PE" \\
Teatro I & -
\end{tabular}




\begin{tabular}{|l|c|} 
Teatro II & - \\
Bagunça & Maceió. Referência por vias indiretas: "Se PE for abaixo, tomam \\
D. Maria & isto" \\
Libório & "Nordeste" \\
Desafio & "interior da Paraíba" \\
Funcionário independente & - \\
Um antepassado (modo dramático) & - \\
Um homem de letras & Nordeste. Referência indireta mediante à citação da empresa \\
Um gramático & ferroviária Great Western \\
Dr. Pelado & "Em Patos, no estado da Paraíba" \\
Transação de cigano & "Viçosa, interior de Alagoas" \\
A decadência de um senhor de & - \\
engenho & - \\
Recordações de uma indústria morta & - \\
Uma visita inconveniente & - \\
"Está aberta a sessão do júri" & - \\
Um homem notável & -
\end{tabular}

\begin{tabular}{|c|c|c|c|}
\hline \multicolumn{4}{|l|}{ Focalização } \\
\hline $\begin{array}{l}\text { Olhar de fora } \\
\text { (cronista } \\
\text { distanciado) }\end{array}$ & $\begin{array}{l}\text { Olhar de fora e de dentro } \\
\text { (elite) }\end{array}$ & $\begin{array}{l}\text { Olhar de fora e de } \\
\text { dentro (povo) }\end{array}$ & $\begin{array}{l}\text { Olha de dentro (cronista } \\
\text { como membro da elite) }\end{array}$ \\
\hline Casamentos & $\begin{array}{l}\text { Carnaval (prefeira e } \\
\text { negoviantes) } \\
\text { D. Maria Amália }\end{array}$ & $\begin{array}{l}\text { Desafio (Inácio da } \\
\text { Catingueira) } \\
\text { Um homem de letras }\end{array}$ & Ciríaco (olha o povo) \\
\hline Habitação & (governador) & (Domingos Barbosa) & Um antepassado (olha a elite) \\
\hline Teatro II & $\begin{array}{l}\text { O moço da farmácia (alter- } \\
\text { ego) }\end{array}$ & $\begin{array}{l}\text { Transação de cigano (o } \\
\text { povo em geral) }\end{array}$ & $\begin{array}{l}\text { Teatro II (ver a ambiguidade } \\
\text { de } 1^{\text {a }} \text { pessoa do plural) }\end{array}$ \\
\hline Libório & Teatro I (governador) & & \\
\hline Um gramático & Bagunça (governador) & & \\
\hline Dr. Pelado & D. Maria (população local) & & \\
\hline $\begin{array}{l}\text { "Está aberta a sessão } \\
\text { do júri" }\end{array}$ & $\begin{array}{l}\text { Funcionário independente } \\
\text { (população local) } \\
\text { A decadência de um senhor }\end{array}$ & & \\
\hline $\begin{array}{l}\text { Um homem notável } \\
\text { Recordações de uma } \\
\text { indústria morta } \\
\text { Uma visita } \\
\text { inconveniente }\end{array}$ & de engenho (coronel) & & \\
\hline
\end{tabular}

Comumente, o cronista mostra simpatia pelo povo, o que não o impede de denunciar as limitações deste, decorrentes, sobretudo, da reinante precariedade social. Se procura tratá-lo sem idealizações, não deixa de reconhecer certa coragem e autenticidade nas manifestações populares. Em sentido oposto, dirige suas críticas às elites sertanejas, situando seus posicionamentos, preferencialmente, antes de 1930, o que muito convinha às prerrogativas do governo autoritário da era Vargas, como se verá logo abaixo. Conforme fora observado no 
capítulo anterior, apesar de instituído em 1937, o Estado Novo tomava como seu marco fundador a revolução de $1930^{620}$.

De qualquer maneira, aos olhos dos leitores, configura-se nos textos um narrador, que, apesar de encontrar-se fora daquele ambiente mofino das paragens sertanejas (alguém que lá vivera, mas agora se encontrava situado na faixa litorânea do sul do país), continuava a investir contra a obscuridade e a monotonia do mesmo, que vivia um processo superficial de mudanças, mantendo a mesma estrutura autoritária e desigual.

Nesse sentido, o cronista produz um saber tanto sobre a elite interiorana quanto sobre o povo, segundo as orientações editoriais da publicação, no que diz respeito à legitimação do status quo e ao embasamento das políticas públicas. Em tal movimento, critica os arcaísmos de ambos, mostrando acidez para com a primeira e simpatia pelo segundo, em meio a um lento processo de modernização e modificação dos costumes. Ao mesmo tempo, toma o passadismo sertanejo de diferentes maneiras: se para a classe dirigente ele era uma forma de manter-se no poder, por meio da manutenção da estrutura de dominação, para o povo era um modo de preservar as tradições (daí a autenticidade atribuída a este último).

Em resumo, percebe-se que o cronista atribui as seguintes características ao povo:

- Idéias reduzidas. Tal limitação no modo de pensar infundia-lhe certezas e convicções rasteiras. Considera que, em virtude dos reduzidos conhecimentos, a ciência sertaneja era livre de vacilações;

- Ausência de especialização em seus afazeres; precariedade das diferentes profissões.

- Vida em estado de miséria;

- Apego às tradições e certa lentidão na assimilação de novas formas de agir e pensar em meio a um processo de transformações sociais e econômicas;

- Certa impermeabilidade a mudanças vindas de fora, que estivessem desconectadas com o modo de vida sertanejo;

\footnotetext{
${ }^{620}$ Ao mesmo tempo, por um viés biográfico e de acordo com o caráter testemunhal requisitado pela seção "Quadros e costumes”, pode-se imaginar também que Graciliano gabaritava-se a tratar do Nordeste que conhecera, antes de sua vinda forçada para o Rio de Janeiro como preso político, em meados da década de 1930. Segundo tal perspectiva, não caberia a ele enfocar o sertão de seu momento de enunciação nos anos de 1940 , pois se encontrava, há algum tempo, distante dele.
} 
- Louvor a tipos tratados como doutores num contexto de analfabetismo. Os sertanejos consideravam a palavra escrita como algo misterioso, bem como exaltavam a arte de bem falar cultivada pelas elites locais, o que reforçava sua submissão.

À elite, percebe-se que ele confere os seguintes aspectos:

- Controle da vida política, econômica e social local, com destaque para o uso da violência;

- Decadentismo; tentativa de se apegar ao passado, como forma de manutenção de seu status e poder, em meio a um movimento de mudança represado;

- Condução de uma modernização de superfície, tacanha; nada de transformações abruptas ou de rupturas, como forma de perpetuar sua política individualista, de matiz liberal, consubstanciada no coronelismo sertanejo;

- Postura contrária à educação (as escolas serviam tão somente para dar emprego às filhas dos coronéis) e ao progresso efetivo da população;

- Verbosidade vazia (educação na retórica e na poesia). A escrita como forma de manutenção do poder (daí as restrições a seu espraiamento mediante ao incremento do aparelho educacional);

- Precariedade e auto-suficiência na forma de agir e de pensar, análogas àquelas manifestas pelo povo, mas com algumas gradações. De certa maneira, pode-se concluir que tais características, somadas à certa noção de mediania e de fracasso (ruínas) $^{621}$, seriam inerentes ao próprio espaço sertanejo;

Como visto anteriormente, tais posicionamentos já estavam presentes nas produções cronísticas de Graciliano veiculadas em jornais e revistas alagoanos, no período anterior à sua vinda forçada para o Rio de Janeiro, bem como em suas obras ficcionais publicadas até então ${ }^{622}$. Nesse sentido, pretende-se mostrar que o artista não teria feito um reajustamento ideológico em sua visão de mundo, seja para afirmar os postulados do regime, seja para criticá-los de maneira astuciosa, nas páginas do veículo oficial com o qual colaborava. $\mathrm{Na}$ verdade, em Cultura Política, ele continua a enfatizar o tradicionalismo das manifestações populares de acordo com as diretrizes da própria revista (mais especificamente da macroseção “Brasil, social, intelectual e artístico”), mantendo, no entanto, sua habitual perspectiva

\footnotetext{
${ }^{621}$ Não haveria a possibilidade de evasão seja no passado, seja no futuro.

${ }^{622}$ Para consultá-las, ver o capítulo 1.
} 
problematizadora, sem endereçar elogios aos sertanejos. Ao mesmo tempo, segue dirigindo suas críticas à elite regional, sobretudo à política individualista conduzida por esta. Mostra que ela estaria mais interessada em dispor de modernidades importadas do que se debruçar sobre a "realidade nacional". Contudo, neste último caso, como estratégia textual para colaborar sem aderir, o escritor situa seus posicionamentos questionadores à classe dirigente num período anterior a 1930, deixando em aberto se tal estado de coisas teria continuado ou sido superado após a implantação do Estado Novo.

Esta abertura interpretativa ocorre, principalmente, em virtude do trabalho do autor de figurativização das tópicas regimentais, abordando-as de modo encoberto, num registro mais próximo da ficcionalização da linguagem literária do que da busca por veridicção da crônica. Nesse sentido, seus textos demandavam uma exegese específica, pois não traziam a simples descrição de quadros ou situações ou, muito menos, lidavam de maneira aberta com os lugares-comuns pretendidos pela retórica governamental. Diante de tal necessidade, obviamente, a ditadura varguista enquadrou e preencheu as lacunas deixadas pelas narrativas da perspectiva que lhe interessava, ou seja, tomou os escritos de Graciliano como instantes congelados de um passado que já não existia mais (pois sua atuação política pressupunha que o passado descrito pelo escritor não existia mais), ou mesmo como balizas para sua atuação futura naqueles rincões ainda distantes do “ímpeto renovador da civilização litorânea”623.

\subsection{Efeitos das estratégias textuais de Graciliano}

Conforme afirma Eneida, Graciliano, apesar de enojado e contrafeito, continuara a colaborar com Cultura Política, em função das necessidades materiais que enfrentava ${ }^{624}$. Dênis de Moraes, biógrafo do artista, também valida essa tese, destacando a estabilidade financeira desfrutada pelo escritor ao longo de sua passagem pelo periódico getulista:

\footnotetext{
${ }^{623}$ ESCRITOR e romancista... Rio de Janeiro, Cultura Política, ano 1, n.1, mar. 1941, pp.236. Trata-se aqui de trecho do texto que apresenta o início da colaboração de Graciliano. Ele será analisado mais detidamente nas páginas seguintes.

${ }^{624}$ Ver trecho transcrito no primeiro capítulo, no qual a escritora relata, entre outras passagens: “Assistia sua revolta e seu nojo (sic) em colaborar na Cultura Política [referindo-se a Graciliano], aquela célebre realização do Estado Novo. / - Mas Graça, precisas viver, que diabo! Só sabes escrever que outra coisa poderias fazer? / - Mas é sujeira. / Os encargos da família crescendo, as meninas precisando estudar, Heloísa procura emprego, o velho Graça numa vida dura, roendo as unhas (ENEIDA. Graciliano Ramos/ "Viventes das Alagoas". Diário de Notícias, Rio de Janeiro, 15 abr. 1962).
} 
Por mais que se busque outra explicação, a verdade é que a longa permanência em Cultura Política se converteria em emprego estável para Graciliano. Acima de tudo, ali obtinha remuneração constante que lhe permitia saldar o orçamento ${ }^{625}$.

Ambas as afirmações constroem-se em torno da idéia da "necessidade” e não da "vontade” do escritor em colaborar com a publicação. Embora não compactuasse com o novo regime, imperativos financeiros levaram-no a aceitar o convite e a manter-se nas funções de autor e revisor de Cultura Política durante longo período ${ }^{626}$. Ao mesmo tempo, em consonância com a afirmação de Antonio Candido, recuperada por Moraes, reafirma-se a integridade do artista que teria apenas servido ao Estado Novo e não se vendido ${ }^{627}$. No entanto, mais do que assumir ou refutar tais justificativas, que tomam a noção de autor como núcleo de atenção crítica, cabe examinar melhor as estratégias textuais empregadas por Graciliano, bem como o efeito produzido pelos “Quadros e costumes do Nordeste” na revista getulista, expandindo e especificando as observações preliminares feitas no tópico anterior.

De maneira geral, em seus textos de Cultura Política, ao tratar de quadros, costumes e personagens sertanejos, Graciliano adota certo tom de problematização, mas não se volta abertamente contra o status quo, ou seja, não endereça críticas diretas ao regime (algo limitado pelo próprio caráter autoritário e truculento do governo instituído). Na verdade, muito pelo contrário, ele costuma se indispor contra determinadas idéias, práticas e situações localizadas no passado, identificadas, mais especificamente, com a Primeira República, período ao qual o Estado Novo se contrapunha como estratégia para afirmar-se e justificar sua legitimidade. No entanto, diferentemente de outros colaboradores do periódico, o artista alagoano, após situar suas narrativas num período anterior a 1930, não indicava de maneira aberta que os problemas aludidos teriam sido superados com a proclamação da ditadura de 1937, deixando tal lacuna descerrada; cabia ao leitor julgar se isso teria ocorrido ou não.

Essa abertura na estrutura, que possibilitava a suspensão de opinião ou mais de uma interpretação, tornava-se possível, tendo em vista a opção do autor por narrativas ambivalentes, que a um só tempo afastavam-se do gênero crônica e aproximavam-se do protocolo ficcional do conto. Mas tal movimento, obviamente, era enquadrado pela própria revista. Se o escritor procurava indeterminar o sentido de suas produções, como estratégia

\footnotetext{
${ }^{625}$ MORAES, Dênis de. O velho Graça. Rio de Janeiro: José Olympio, 1992, p.189.

${ }^{626}$ Para mais informações, ver o segundo capítulo da presente tese.

${ }^{627}$ Idem, ibidem.
} 
para evitar o compromisso declarado com o Estado, o direcionamento dado a elas por Cultura Política tratava de tomá-las enquanto peças que fundamentavam postulados oficiais.

A localização temporal das crônicas, proposta por Graciliano, pode ser mais bem especificada pelo quadro abaixo. Mesmos nos escritos que não a apresentam de modo absoluto ou mesmo relativo é possível recuperar, mediante certos índices dispersos pelas narrativas, que estas se situavam num período anterior a 1930. Apenas dois textos (“Casamentos” e "Transação de Cigano”; ver marcação em azul), justamente os únicos nos quais prevalece o gênero dissertativo, tratam de práticas e costumes sertanejos mediante a utilização de debreagens enunciativas de tempo (instauração de um presente), fazendo pressupor, de maneira direta, que os assuntos abordados perdurariam no momento de enunciação do autor em Cultura Política. No restante, predominam debreagens temporais enuncivas de enunciado (utilização do tempo passado, sem referência ao momento de enunciação), ou ainda, ocasionalmente, o presente histórico (embreagem na qual o “agora” deve ser tomado como “então”):

\begin{tabular}{|c|c|}
\hline Tempo situado & \\
\hline Crônicas & Referências \\
\hline Carnaval & Antes de 1930 (localização indireta) - uso do presente histórico \\
\hline D. Maria Amália & Antes de 1930 (localização indireta) \\
\hline O moço da farmácia & $\begin{array}{c}\text { Passado em perspectiva biográfica sem localização específica - uso do } \\
\text { presente histórico }\end{array}$ \\
\hline Casamentos & Presente \\
\hline Ciríaco & Passagem biográfica (ano de 1911) \\
\hline Habitação & Passagem biográfica (ano de 1911) \\
\hline Teatro I & Primeira década do século XX \\
\hline Teatro II & Entre o final do século XIX e primeiras década do XX \\
\hline Bagunça & Por volta de 1930 \\
\hline D. Maria & "Pouco antes de 1930" \\
\hline Libório & Passado não identificado \\
\hline Desafio & Final do século XIX ("há mais de meio século") \\
\hline Funcionário independente & "ano remoto de princípio do século" \\
\hline Um antepassado & Passagem biográfica (ano de 1911) \\
\hline Um homem de letras & Passado não identificado (antes de 1930; referência ao começo do século) \\
\hline Um gramático & "Por volta de 1930" \\
\hline Dr. Pelado & "começo do século" \\
\hline Transação de cigano & Presente \\
\hline $\begin{array}{l}\text { A decadência de um senhor de } \\
\text { engenho }\end{array}$ & "começo do século" \\
\hline Uma visita inconveniente & Antes de 1930 (indireto) \\
\hline "Está aberta a sessão do júri" & Passado não identificado \\
\hline
\end{tabular}


Nestas narrativas particularizadoras, Graciliano tematiza um conjunto de elementos politicamente "nocivos", comumente atribuídos ao regime liberal pela ditadura varguista: o coronelismo; o clientelismo; a falta de unidade política do país; o individualismo no tratamento de matérias de interesse coletivo; o internacionalismo; o desprezo pelo país, sobretudo, pelo hinterland brasileiro, que convergia para o desprezo pela "realidade nacional" como um todo. Tais questões privilegiadas pelo artista podem ser consideradas como um misto de lugares-comuns e de desejos da intelectualidade, que vinham, sobretudo, desde as primeiras décadas do século $\mathrm{XX}$, ou seja, não pertenciam exclusivamente ao ideário estadonovista.

No entanto, essas tópicas foram incorporadas e amalgamadas ao regime de 1937, que procurava construir sua legitimidade ao se colocar, a um só tempo, como intérprete da vida brasileira e esteio das demandas intelectuais, em contraposição à política liberal anterior à Revolução de Outubro. Logo, o trabalho do autor alagoano com tal arcabouço conceitual, mediante o recuo de suas narrativas ao passado, permitia-lhe afirmar, por meio da negação, os postulados incorporados pelo Estado, pois recusava um estado de coisas situado antes de 1930, que, segundo a retórica estatal, já teria sido superado, apesar de Graciliano, em nenhum momento, textualizar de maneira explícita a ocorrência disso.

Por mais que o escritor alagoano dirigisse suas críticas a problemas estruturais, que não se restringiam ao período da Primeira República, tal como o discurso estadonovista fazia crer, elas abriam a possibilidade para a veiculação de um elogio implícito ao governo. Assim, essa estratégia permitia que suas crônicas se tornassem próprias para a publicação em Cultura Política. Como se verá, a revista, sobretudo por meio dos paratextos introdutórios às narrativas do escritor, tomava-as enquanto reprodutoras de fatos ultrapassados, como se o cronista descrevesse algo que já não tivesse mais lugar, mas que, por sua vez, devia ser enquadrado como contra-exemplo, para exaltar o Estado que se dizia "novo". Pode-se dizer, assim, que os editores da publicação completavam as lacunas e índices presentes no texto do autor alagoano, dirigindo a leitura dos mesmos a favor dos interesses do regime. O passado tematizado pelo romancista não valia apenas enquanto passado, pois servia de contraponto 
para a glorificação das ações presentes. Dessa maneira, a revista nuançava e conduzia o tom com que deviam ser interpretados os "Quadros e costumes do Nordeste”.

Paralelamente, ao se valer da estratégia de trabalhar com as mesmas tópicas presentes no arcabouço regimental, mas não exclusivas a ele, tomadas enquanto problemas ainda não solucionados (ou seja, segundo um modo particular de elocução), Graciliano procurava evitar a adesão ao regime, ou mesmo seu comprometimento direto com este, ao mesmo tempo em que se gabaritava a receber o rendoso pagamento pelos textos publicados. Ainda que defendesse determinadas propostas incorporadas pelo Estado Novo o fazia com uma dignidade admirável, desempenhando muito bem o ofício de escritor que sabia lidar com as demandas de determinado ideário, sem tomar uma postura aberta a favor dele, e manter, assim, a coerência artística, manifesta nas obras anteriores. Para tanto, vale-se da ficção, permeada por procedimentos criadores da ilusão referencial, fundando seu discurso no jogo entre esses dois efeitos (“fingimento” e "realidade”). Tal estratégia permitia-lhe trabalhar com os lugares-comuns norteadores do regime de maneira encoberta, em relatos que se pressupunham verdadeiros e que se abriam a variadas interpretações, em virtude dos diferentes recursos ficcionais empregados.

Para além do sentido literal de tais textos, que se diziam "reais”, em função, sobretudo, do enquadramento documental dado a eles pela revista e de certos procedimentos utilizados pelo artista, subjaz nas narrativas um desacordo entre a enunciação enunciada (conjunto de traços identificáveis no texto, que remetem à instância de enunciação) e o enunciado enunciado (seqüência que não apresenta tais marcas), como se o escritor procurasse dizer algo além daquilo que fora efetivamente dito num primeiro momento. De acordo com o jogo que se institui entre as categorias modais do "ser” (dizer) e do “parecer” (dito), os textos de Graciliano estabeleceriam, num segundo nível, o contrato enunciativo do segredo (/ser/ e /não-parecer// ${ }^{628}$, como se suas narrativas não devessem ser lidas apenas como elas mesmas (ou seja, de acordo com um sentido próprio, presente no primeiro nível ${ }^{629}$ ), mas como

\footnotetext{
${ }^{628}$ De acordo com as relações previstas pelo quadro semiótico formado pelas categorias modais do "ser" e do "parecer”, respectivamente, /ser/, /não-ser /, /parecer/ e /não-parecer/ são estabelecidos contratos enunciativos diferenciados. No caso de acordo entre enunciado e enunciação ou têm-se a verdade (/ser/ e /parecer/) ou a falsidade (/não-ser/ e /não-parecer/). Quando, por outro lado, ocorre desacordo, tomam corpo ou a mentira (/nãoser/ e /parecer/) ou o segredo (/ser/ e /não-parecer/), como expresso acima (FIORIN, José Luiz. As astúcias da enunciação. São Paulo: Editora Ática, 2008, p.39-40).

${ }^{629}$ No primeiro nível, haveria uma espécie de acordo entre enunciado e enunciação, tendo em vista o estatuto de verdade simulado pelos textos. Nesse sentido, aquilo que o autor diz deveria ser interpretado como tal.
} 
figurativizações de uma significação ausente pretendida pelo autor ${ }^{630}$. Por meio de tal mecanismo discursivo, ele buscava dissimular os temas veiculados por suas historinhas ditas “verdadeiras”, abrindo espaço para interpretações variadas. Não se deve esquecer que estas leituras, por sua vez, estavam previstas pela própria estrutura dos escritos, que procuravam tratar das tópicas estadonovistas de modo encoberto.

Em outras palavras, pode-se dizer que tais textos do artista são predominantemente figurativos, ou seja, neles predominariam a aplicação de termos concretos que visam à construção de um efeito de realidade mediante a perspectiva de representação do mundo, mais especificamente do universo nordestino presumido pelo leitor ${ }^{631}$. Por outro lado, suas narrativas ditas figurativas não valiam apenas por si mesmas, enquanto quadros ou relatos supostamente realistas da vida provinciana; elas apresentariam um nível temático subjacente. $\mathrm{O}$ artista diria b para significar a. Caberia ao leitor competente perceber os significados mais abstratos encobertos pelos termos concretos e recuperar o percurso figurativo, ou seja, retomar as figuras que se articulam e que permitem extrair os temas (tópicas) do percurso temático, enfatizados pelo autor. Em resumo, os relatos em sentido próprio serviriam para tornar inteligível uma outra significação, que não seria expressa diretamente ${ }^{632}$.

Nesse sentido, pode-se afirmar que os textos de Graciliano, publicados em Cultura Política, permitiriam uma interpretação alegórica, pois as ações, personagens, descrições e situações que ficcionaliza podem ser tomados, na grande maioria dos casos, como particularizações de certas tópicas presentes no ideário estadonovista, mas não restritas a ele. No entanto, a recuperação de tal significação, preexistente aos “Quadros e Costumes” propostos pelo artista, deve levar em conta os procedimentos formais utilizados por este para produzi-la. Não se trata simplesmente da busca de uma essência contida nos posicionamentos do escritor, mas sim do exame da estratégia textual empregada pelo mesmo para discutir e apresentar certos lugares-

\footnotetext{
${ }^{630}$ Como explica Fiorin, “a discordância entre enunciado e enunciação não é um desacordo entre um conteúdo manifesto e uma intenção comunicativa inefável, pois as únicas intenções do sujeito que se podem apreender são as inscritas no enunciado" (FIORIN, José Luiz. op.cit. p.39). No que diz respeito à questão, Benveniste destaca: "A que, então, se refere o eu? A algo de muito singular, que é exclusivamente lingüístico: eu se refere ao ato de discurso individual no qual é pronunciado, e lhe designa o locutor. É um termo que não pode ser identificado a não ser dentro do que, noutro passo, chamamos uma instância de discurso, e que só tem referência atual. A realidade a qual ele remete é a realidade do discurso" (BENVENISTE, Émile. Da subjetividade na linguagem. In: Problemas de Lingüística Geral I, Campinas: Pontes Editores, 2005, p.288).

631 Já os escritos de caráter deliberadamente temático, como se verá, são minoria entre as colaborações estampadas pelo autor de Vidas Secas em Cultura Política. Por meio deles, o artista busca explicar, ordenar, conceituar e classificar determinados aspectos do referido mundo provinciano, sob o qual concentra suas atenções.

${ }^{632}$ LAUSBERG, Heinrich. Elementos de retórica literária. Lisboa: Fundação Calouste Gulbenkian, 1972, p.311.
} 
comuns. Como se verá, na consecução de suas narrativas, Graciliano, por exemplo, vale-se da ênfase em elementos ficcionais (construção de personagens, ambientes e ações particulares) e da indeterminação das coordenadas temporais, espaciais e actanciais do conto (sobretudo as duas últimas) como estratégia para tratar dos temas de interesse do regime sem a necessidade de discorrer abertamente sobre estes, evitando, assim, adesões, como as manifestas pela grande maioria dos outros colaboradores, entre eles Marques Rebelo. Ao mesmo tempo, o autor lança mão de procedimentos que instauram o efeito de real (realismo), ou seja, além da verossimilhança artística, manifesta a pretensão de verdade, algo que seria reforçado por sua postura de especialista, didática, mas, sobretudo, pelo enquadramento fornecido aos textos pela revista.

No que diz respeito a este último ponto, ao inventar histórias que se pressupunham verdadeiras, apesar da modulação crítica e irônica e da composição do estilo como negatividade, procurando vencer a facticidade ${ }^{633}$, Graciliano produzia um tipo de saber sobre a região nordestina. O artista descreve paisagens, compara, avalia, hierarquiza, separa tipos e práticas sertanejas. Por meio desse trabalho, em última instância, fornecia subsídios à individualização do espaço e dos habitantes interioranos que passavam a se apresentar como objetos de saber privilegiados, num contexto em que o Nordeste brasileiro figurava como uma “espécie de reservatório da nacionalidade”, frente ao sul desnacionalizado pelo excessivo influxo imigratório ${ }^{634}$.

Ao governo convinha tratar as narrativas de Graciliano como documentos, tendo em vista sua proposta integradora e autoritária de composição de um amplo painel do país, com ênfase na valorização de certas particularidades locais. Nessa condição, os textos corroboravam bem o ideal estadonovista de centralização e unidade nacional na medida em que realizavam a apropriação simbólica daquele mundo longínquo sertanejo e o dava a conhecer aos leitores urbanos, como se o discurso do artista coincidisse com a própria realidade ${ }^{635}$. Como a maioria

${ }^{633}$ Noções aplicadas por João Adolfo Hansen, no ensaio "Drummond e o livro inútil”, para descrever procedimento recorrente na produção cronística de Drummond, na qual a dramatização dos conflitos subordinava a estrutura comunicativa do gênero (In: Letterature d'America, Roma, ano XXV, n.107, 2005, p.84).

${ }^{634}$ BRANCO, R.P. Castelo. Imigração e nacionalismo. Cultura Política, Rio de Janeiro, ano 1, n.15, maio 1942, p.29.

${ }^{635}$ Como se viu, o conhecimento geográfico também ocupava um papel de destaque no processo de construção da nacionalidade, levado a cabo pelo Estado Novo. Nesse sentido, pela perspectiva oficial, a seção "Quadros e Costumes” poderia ser enquadrada dentro do mesmo movimento de produção de conhecimento e informações sobre o território nacional, do qual fizeram parte o Conselho Nacional de Geografia, o Conselho Nacional de Cartografia, o Conselho Nacional de Estatística e o Instituto Brasileiro de Geografia e Estatística, instituições 
dos textos não se limitava ao registro documental, aproximando-se de protocolos ficcionais, tornava-se preciso também reforçar-lhes tal estatuto de realidade, muitas vezes esgarçado, além direcionar-lhes a leitura. Em suma, era como se Graciliano pintasse um quadro com traçado "realista” (não real) e a revista reforçasse a ilusão referencial deste, produzindo a moldura e a legenda explicativa, que o enquadrariam e dirigiriam sua interpretação.

Graciliano, portanto, funda seu discurso numa aparente ambigüidade entre os efeitos de verdade e ficção. Na verdade, a ilusão referencial acaba sendo desconstruída pelo processo de ficcionalização de práticas, personagens e situações sertanejas, empreendido pelo artista. Por mais que se mostrem verossímeis e se pretendam verdadeiras, a maioria das narrativas do escritor, para serem mais eficazes na abordagem do real, foge do imediatismo deste, não requisitando, de maneira explícita, o mundo fora delas. Na grande maioria dos casos, os escritos não demandam, obrigatoriamente, um discurso extradiegético, historicamente comprovado, que lhes autentique ou confira sentido, além de não remeterem de maneira precisa a seres e coisas. Por outro lado, se indeterminam o referente (ou seja, aquilo que se interpõe entre a realidade e o falante, fingindo ser real ${ }^{636}$ ), mantendo, entretanto os contornos deste identificáveis ao leitor, o autor alagoano não deixa de aludir a um conjunto de noções interessantes ao regime (mas não exclusivas a ele, pois encontravam acolhida em grande parte da intelectualidade da época). Procura fazer isso de maneira crítica, segundo seus postulados de "autor de obras fortes e cheias de personalidade" ${ }^{237}$, mas deixa em aberto se a alteração dos quadros recuados no passado liberal teriam realmente ocorrido, como fazia crer o Estado Novo, ou não, como afirmariam os opositores.

Em grande medida, tal abertura interpretativa tornava-se possível em função da revista getulista, que admitia colaborações sem um viés doutrinário aparente, diferentemente de outros veículos oficiais de caráter predominantemente apologético, nos quais a participação de Graciliano tornar-se-ia improvável. Como se sabe Cultura Política, mais precisamente a macro-seção na qual se encontravam os "Quadros e costumes do Nordeste”, "Brasil, social,

criadas pelo regime no final ao longo dos anos de 1930, com o propósito de embasar a implantação de suas políticas. O governo procurava vencer os vazios territoriais, encontrados no interior sertanejo, orientando-se pela diretriz bandeirante da Marcha para Oeste. Esta última, apesar de mais direcionada ao Centro-Oeste e à Amazônia, colocava em primeiro plano a idéia de redescobrimento do Brasil. Destacava-se, sobretudo, a necessidade de se desentranhar da terra tanto as riquezas físicas quanto simbólicas da nação.

${ }^{636}$ BLIKSTEIN, Izidoro. Kaspar Hauser ou A fabricação da realidade. São Paulo: Cultrix, 1995, p.17. In: CRUZ JR, Dílson F. Estratégias e máscaras de um fingidor. São Paulo: Nankin Editorial; Humanitas FFLCH/USP, 2002, p.208.

${ }^{637}$ ESCRITOR e romancista... Rio de Janeiro, Cultura Política, ano 1, n.1, mar. 1941, p.236. 
intelectual e artístico", dedicava-se a um tratamento sistemático da cultura dita brasileira, tomando o tema (e suas distintas manifestações) como forma privilegiada de ratificar a identificação entre Estado e Nação. Nesse sentido, servia de cimento ideológico para congregar a intelectualidade em torno da reivindicada perspectiva nacionalista do governo. Ao mesmo tempo, por voltar-se a um público mais elitizado, pressupunha certa abertura à discussão como forma de se legitimar (e legitimar o governo) perante seus leitores mais críticos $^{638}$. Portanto, previa a incorporação de vozes dissonantes como parte da diretriz agregadora e supra-partidária do regime, procurando limitar, docilizar e edulcorar a crítica.

\subsection{Os paratextos}

Conforme exposto acima, uma das principais estratégias utilizadas pela revista para disciplinar e se apropriar dos escritos de Graciliano fora o emprego de paratextos introdutórios. Compostos pelos editores de Cultura Política, eles eram colocados, imediatamente, antes do início de algumas colaborações do escritor, funcionando como espécies de proêmios.

Em regra, tais itens seriam a ponta do iceberg de um processo maior de enquadramento das narrativas do artista (e dos demais colaboradores), realizado pela estrutura hierarquizada do periódico. Como se viu no capítulo anterior, a ordenação de Cultura Política, ou seja, a disposição metódica de suas partes, previa uma série de intermediários textuais que antecediam as crônicas do autor propriamente ditas e lhes atribuíam um direcionamento de sentido adequado ao ideário do regime. Tais escritos mediadores iam desde o editorial de abertura, (em geral, de autoria de Almir de Andrade), passando pelo nome da macro-seção "Brasil, social, intelectual e artístico" e por um texto introdutório a ela ("Influência política sobre a evolução social, intelectual e artística”), pela subseção “Evolução social”, apresentada pelo artigo “A ordem política e a evolução social”, até chegar aos “Quadros e Costumes do Nordeste”639 e, enfim, ao paratexto que antecedia imediatamente (na mesma página) a colaboração de Graciliano.

\footnotetext{
${ }^{638}$ Como sintetiza Facioli, Cultura Política, voltada para um público elitizado, tolerava ambigüidades e questionamentos, o que permitia a Graciliano, a um só tempo "manter as ilusões de sua independência pessoal e receber vantajosa remuneração por seus textos, de vez que aquela revista era que melhor pagava (e em dia...) os seus colaboradores” (FACIOLI, Valentim. Um homem bruto da terra. In: BOSI et al. Graciliano Ramos. São Paulo: Ática, 1987, p.68).

${ }^{639}$ No primeiro número, a seção chamava-se "A vida social no Brasil: Quadros e Costumes do Nordeste”. Nos 17 volumes seguintes, era referida apenas como "Quadros e costumes do Nordeste”.
} 
No que diz respeito ao conceito de paratexto, Genette, referindo-se ao suporte livresco, afirma que os escritos, em geral, nunca seriam apresentados em estado "nu”. Comumente, eles ganhariam o reforço e o acompanhamento de outras produções verbais ou não, que comporiam o seu entorno ou o seu prolongamento. Tais elementos, que permitiriam a uma obra apresentar-se como tal a seus leitores, são designados por ele como itens paratextuais ou aparelho liminar ${ }^{640}$.

Tomando como corpus um conjunto de obras publicadas, sobretudo, na França, Genette elege e depois procura definir a essência de alguns paratextos: formato, capa, composição, nome do autor, título, prière de insere (espécie de encarte destinado à crítica), dedicatória, epígrafe, prefácio, intertítulo, notas, correspondências, diários, debates, entrevistas, comentários, entre outros. Nesse processo analítico, norteados por uma perspectiva sincrônica (estruturalista), o estudioso sugere a utilização de parâmetros espaciais, temporais, substâncias (ontológicos), pragmáticos e funcionais, como meio de descrever e abordar tais gêneros paratextuais. Segundo o autor, apesar de diferenciados, eles apresentariam em comum uma identidade de interesses e uma convergência de efeitos.

Como sugere o título de sua obra dedicado ao tema (Seuils), os paratextos seriam uma espécie de soleira (limiar) ou vestíbulo que ofereceriam aos destinatários a possibilidade de entrar ou voltar atrás, indicando-lhes, assim, um caminho a ser trilhado. Ao mesmo tempo, poderiam ser tomados como uma espécie de "franja do texto", zona indecisa entre o interior e o exterior da obra, que, mais do que um espaço de transição, comportar-se-ia como um lugar de transação: “lieu privilégié d'une pragmatique et d'une stratégie, d'une action sur le public au service $^{\text {} 641}$. Em perspectiva semelhante, Turrer considera que o paratexto, na qualidade de espaço intermediário, tramaria a receptibilidade do texto, pois teria a função de exibi-lo, apresentá-lo e encená-lo ao leitor ${ }^{642}$.

Mais especificamente, Genette considera a noção de paratexto como a soma do peritexto (elementos pertencentes ao volume propriamente dito: título, prefácio, intertítulo, quarta-

\footnotetext{
${ }^{640}$ Tal como sugere Caminha, apoiada em Genette, o paratexto efetuaria a passagem do imaterial do texto ao material da obra, ressaltando a relação de dependência entre ambos (CAMINHA, Heda Maciel. Por uma leitura do aparelho liminar. Letras de Hoje, Porto Alegre, 19(2), jun. 1986, p.55).

${ }^{641}$ GENETTE, Gérard. Seuils. Paris: Éditions du Seuil, 1987, p.8.

${ }^{642}$ TURRER, Daisy. O livro e ausência do livro em Tutaméia, de Guimarães Rosa. Belo Horizonte: Autêntica, 2002, p.30
} 
página, notas etc.) e do epitexto (mensagens situadas fora do livro como entrevistas, correspondências, diário, entre outras). Dessa maneira, o estudioso francês expande os limites do conceito, definindo-o para além dos itens intencionais ou de responsabilidade do autor presentes em uma obra.

No caso específico das narrativas de Graciliano em Cultura Política, elas são antecedidas por elementos de caráter peritextual, mas que não seriam de autoria do escritor. Como sublinhado anteriormente, trata-se de uma espécie de prefácio/nota de caráter introdutório, composto pelos editores, com a força ilocutória específica no contexto enunciativo da revista getulista. Em linhas gerais, tais paratextos cumpririam quatro funções básicas, no que diz respeito ao encaminhamento do sentido: louvar o artista (o que além de chamar a atenção para a colaboração do mesmo, justificava a presença deste nas páginas de uma revista que se afirmava tão importante: era o principal veículo doutrinário do Estado); apresentar e reforçar o caráter documental dos textos (excluindo a aproximação das narrativas de um registro ficcional); direcionar-lhes a leitura (castração da polissemia e ajuste fino da participação do romancista aos interesses do regime, inserindo-a, portanto, no projeto governamental) e unificar as produções (tendo em vista a perspectiva de construir um todo orgânico).

Ao longo dos doze primeiros exemplares da revista, a presença dos paratextos que antecediam os escritos do artista fora mais freqüente. Eles aparecem em cinco momentos: precedem as colaborações de Graciliano encontradas nos números 1, 2, 9, 10 e 11 de Cultura Política. A partir do $13^{\circ}$ volume da publicação, como se o fôlego controlador e unificador dos editores diminuísse de intensidade ou, pressupondo-se que as coordenadas gerais do periódico já haviam sido expressas e assimiladas pelos destinatários, os referidos paratextos deixam de ser utilizados.

Esta última hipótese parece ser a mais viável para justificar a supressão das notas introdutórias, pois Cultura Política tinha em seu horizonte um leitor cativo, interessado em formar uma coleção da revista. Tal fato é presumido pelo próprio caráter livresco do veículo, bem como pela estrutura de algumas seções como os "Quadros e costumes do Nordeste”, cujos textos não apresentavam títulos individualizados, sendo identificados apenas por números em escala crescente a cada edição. Além disso, ao final do primeiro ano de vida, o periódico lançou um encarte com o "Índice dos autores e assuntos” publicados até então, o que visava facilitar a consulta dos exemplares pelos presumíveis colecionadores. Nesse 
sentido, estes acompanhariam a seqüência de conteúdos veiculados, ou seja, algo editado no primeiro número poderia repercutir nos volumes subseqüentes ${ }^{643}$.

Eliminados os paratextos, os escritos editados na revista passam a ser antecedidos apenas pelo nome de seus autores (como no caso do escritor alagoano). Porém, este, muitas vezes, podia ser acompanhado da função desempenhada pelos articulistas nos diferentes órgãos da burocracia estatal (quando ele era funcionário da máquina pública) ${ }^{644}$.

Com o propósito de realizar uma análise geral das funções desempenhadas pelos referidos paratextos, que introduzem, sobretudo, escritos de temática política, segue-se abaixo, primeiramente, a transcrição dos mesmos:

Escritor e romancista consagrado entre os melhores do Brasil de hoje, tendo enriquecido a nossa literatura de ficção com obras fortes e cheias de personalidade como São Bernardo, Angústia, Vidas Secas, Caetés, e com numerosos contos que se publicam incessantemente nos grandes jornais da Capital da República e dos Estados - o autor desta crônica tomou a seu encargo fixar quadros e costumes da região do Brasil onde nasceu e viveu mais de trinta anos: o Nordeste. Neste número inaugural, ele nos dá um flagrante da grande festa popular - o carnaval - tal como decorre nas cidades do interior nordestino. É um pequeno pedaço desse Brasil que ainda foge do ímpeto renovador da civilização litorânea, desse Brasil tão diferente e tão grande... (Quadros e costumes do Nordeste I, Cultura Política, Rio de Janeiro, ano 1, n.1, mar. 1941).

O sistema eleitoral da Primeira República criou, no interior do Brasil, curiosos tipos de caudilhos. Em torno deles girava a vida estadual e municipal. Todo um grupo de interesses pessoais se organizava em redor dessas figuras, que comandavam os negócios sociais. Cada uma delas podia repetir a frase simbólica de Luiz XIV: 'L’Etat c'est moi'. E era mesmo. Depois de novembro de 1937, as coisas mudaram de rumo. Essas figuras caíram, se apagaram, se dissolveram na onda revolucionária que introduziu novos costumes e novos métodos de conduzir a vida regional. Em sua crônica de hoje, o autor procura fixar um desses tipos, encarnado na pessoa de uma mulher. Era comum as mulheres manobrarem tiranicamente com os negócios do Estado. Elas faziam nomeações, derrubavam prefeitos, elaboravam leis, faziam da administração pública uma continuação de seu 'boudoir'. O caudilhismo feminino provocava manifestações curiosas, na vida pública do Nordeste Brasileiro. E é a pena segura

\footnotetext{
${ }^{643}$ O número 14, de abril de 1942, e o número 33, de outubro de 1943 trazem ainda a lista de colaboradores até os volumes 13 e 30 , respectivamente.

${ }_{644}$ Apesar de ocupar o cargo menor de inspetor federal de ensino, Graciliano, como grande escritor que era, nunca teve seu nome seguido de tal designação nas páginas de Cultura Política.
} 
de um dos maiores romancistas do Brasil de hoje que nos vai pintar, em poucas palavras, esse quadro tão familiar aos que conheceram o Nordeste há alguns anos atrás (Quadros e costumes do Nordeste II, Cultura Política, Rio de Janeiro, ano 1, n.2, abr. 1941).

Nessa página de puro regionalismo o autor pincela um quadro típico do Nordeste do Brasil - o que era a repercussão de um movimento revolucionário. Todas aquelas cenas são passadas rapidamente em revista. Políticos, a cochichar boatos alarmantes, fazendo a revolução. Deputados desolados, porém crendo, até às últimas, no governo antigo. O azáfama palaciano, onde, aqui e acolá, acode um segredo ou uma arenga abafada. O indefectível feriado quando, finalmente, a revolução triunfa. Oradores nas praças, dando expansão aos seus entusiasmos insopitados. Enfim, é um quadro sugestivo de como repercutia naquelas regiões uma revolução embrionária” (Quadros e costumes do Nordeste IX, Cultura Política, Rio de Janeiro, ano 1, n.9, 10 nov. 1941).

Continuando seus artigos regionais, dá-nos o autor mais um, tratando da vida sertaneja, na pessoa de uma matrona, típica daquelas paragens brasileiras. É a vida de uma mulher forte, rija desembaraçada. Tratando de tudo que diz respeito a sua fazendola, ela, dona Maria, é a encarnação da mulher sertaneja que tudo trata, resolve e soluciona. Não possuindo dengos femininos, herdando uma educação masculina, casando por casar, pois quase não dá importância ao marido, ao “Quincas”, dona Maria é uma reminiscência do matriarcado, ainda existente no Nordeste. De tudo trata a mulher: da casa, da roça, das feiras, é enfim, a pessoa de todos os instantes. Enquanto trabalha, o marido encharca-se de cachaça nas vendas. A página é real e fixa a vida da mulher, sem preconceitos, no sertão nordestino. Até contato com o famigerado Lampião teve dona Maria, achando isso a coisa mais natural do mundo (Quadros e costumes do Nordeste X, Cultura Política, Rio de Janeiro, ano 1, n.10, dez. 1941, p.288).

O tema do presente artigo é a retratação de um tipo lendário ou mesmo verídico do malandro nordestino. O autor conta uma história, naturalmente passada realmente, de um certo Libório, que a tradição oral conserva nos seus pontos mais sugestivos.

O Libório faz uma certa falcatrua que envolve um vigário, falcatrua essa de espertalhão, mas o pároco não se deixou enganar, ficando numa situação melindrosa. Por fim o Libório passa o "conto" noutro matuto, continuando a fazer das suas (Quadros e costumes do Nordeste XI, Cultura Política, Rio de Janeiro, ano 2, n.11, jan. 1942, p.248). 
O primeiro paratexto apresenta um estilo guinado próprio do encômio, enquadrando-se, portanto, no gênero demonstrativo ou epidítico. Em tom hiperbólico, ele procura naturalizar a importância do autor mediante a utilização de dispositivos retóricos de convencimento puro e simples, na base do adjetivo e do censo comum: “escritor consagrado”, “entre os melhores do Brasil”, que "enriquecera” a literatura brasileira com "obras fortes”, “cheias de personalidade"; autor de "numerosos" contos, que se publicam “incessantemente” em “grandes jornais” da "capital da República”. Ao elevar a figura do escritor, a revista tomava-o como um valor adquirido por seu corpo de colaboradores, ganhando com isso maior projeção. Nesse sentido, a dignificação de Graciliano não valia apenas por si mesma, mas também como meio de valorizar o próprio discurso estatal, que passava a contar com a participação de homens da altura dele para ganhar vida ${ }^{645}$.

Concomitantemente a esse processo de enobrecimento da figura do artista, o paratexto visa, ao fim, aliciar o leitor, levando-o a tomar uma atitude favorável em relação ao conteúdo exposto, ao autor deste e, por conseguinte, ao próprio Estado que tornara a colaboração de tal sujeito notável possível. Portanto, quando o destinatário começa a ler o texto, já está convicto de que tem diante de si o escrito de um grande artista, o qual vai lhe apresentar uma verdade inquestionável, pois além de tudo ela encontra-se publicada na revista de um Estado forte, suposto recuperador da essência de brasilidade.

Na segunda metade do primeiro paratexto (de "Neste número inaugural” a "tão diferente e tão grande...”), depois da preponderância de uma visada encomiástica, passa a predominar o tom didático. O estilo elevado dá lugar a um modo de elocução médio para se referir não mais ao autor, mas ao conteúdo de sua colaboração. Reforça-se aí o suposto caráter documental desta última. Sua “crônica”, além de “fixar” e “flagrar” quadros e costumes da região na qual nascera e vivera, equivalia ao próprio “pedaço de Brasil” que ela se propunha representar. Dessa maneira, pretende-se apagar tanto quanto possível a condição de texto, de versão, de mediação, de retrato relativo da composição do artista, como se ele produzisse a própria materizalização dos quadros e costumes nordestinos por meio de sua pena.

\footnotetext{
${ }^{645}$ Como lamenta Borges, referindo-se a textos prefaciais, “o prólogo na triste maioria dos casos confina com a oratória de sobremesa ou com os panegíricos fúnebres e abunda em hipérboles irresponsáveis, que a leitura incrédula aceita como convenções do gênero" (BORGES, Jorge Luís. Prólogos com um prólogo dos prólogos. trad. Ivan Junqueira. Rio de Janeiro: Rocco, 1985, p.8). Apenas quando os astros se mostravam propícios, ele se apresentaria como uma forma lateral de crítica (Idem, p.9).
} 
E como resultado de tal absolutização da realidade, produz-se um efeito de neutralidade como se a função dos quadros fosse tratar somente do "Brasil tão diferente e tão grande” e não do Estado Novo, quando na verdade a abordagem do primeiro funcionava como meio de dignificar o segundo, ou seja, tinha um caráter político conforme a diretriz propagandeada pelo periódico. Apenas relembrando, o discurso oficial procurava afirmar que o regime de 1937 empreendia um movimento de recuperação da "essência da brasilidade", pois dizia estar intimamente conectado a ela. Nesse sentido, não ocultaria o real, mas ao contrário desejava conduzir a retomada deste.

Se a orientação encomiástica perde espaço, a ênfase documental predomina nos demais paratextos. Aquele que se refere a uma personagem folclórica de nome Libório trata a história lendária desta como tendo se passado "realmente", apesar de o próprio Graciliano ter destacado em sua narrativa que tal "figura de sonho”,646, provavelmente nunca existira. Outro, ao se referir ao relato sobre a vida da matrona dona Maria, afirma que "a página é real e fixa a vida da mulher, sem preconceitos, no sertão nordestino”, como se o artista não fugisse da captação da realidade pura e simples. Dessa maneira, a revista tomava tais tipos não como arquétipos que personificavam aspectos da vida sertaneja descrita ${ }^{647}$, mas como sujeitos históricos, apagando o efeito de ficção ao pressupor a existência material deles.

Outra função dos paratextos é direcionar a leitura das colaborações do autor, tendo em vista a melhor apropriação destas pela revista. Tal processo se torna mais evidente na segunda das notas introdutórias transcritas acima, na qual ganha contornos mais nítidos o didatismo político do regime: a narrativa do artista é apresentada como um retrato do liberalismo da Primeira República, que, supostamente, teria sido superado pelo regime de 1937, como se o artista contrapusesse dois brasis diferentes - o de ontem e o de hoje, ou seja, antes e depois da chegada de Getúlio ao poder. Logo, segundo o comentário oficial, o passado recuperado pelo cronista não valia por si mesmo; funcionava como meio de legitimar e exaltar, por oposição, o novo governo.

Ao eleger tal interpretação, os editores acabaram preterindo outras leituras passíveis de serem extraídas da colaboração do artista. Trata-se, portanto, de uma clara tentativa de cercear o

\footnotetext{
${ }^{646}$ RAMOS, Graciliano. Quadros e costumes do Nordeste XI, Cultura Política, Rio de Janeiro, ano 2, n.11, jan. 1942, p.248.

${ }^{647}$ Considerando-se os exemplos descritos, Libório encarnava a malandragem rasteira do sertanejo e d. Maria, o coronelismo feminino.
} 
caráter polissêmico do relato produzido pelo autor. No caso específico deste paratexto, ele introduz um escrito no qual Graciliano discute o caráter pernicioso do coronelismo por vias indiretas, mediante a construção do retrato de um tipo que personificava a instituição do "voto de cabresto”. Em nenhum momento, o cronista se refere ao problema de maneira explicita, mas sempre a partir da descrição da trajetória da personagem enfocada. Além disso, mais especificamente, ele não afirma que a prática do mandonismo teria terminado após a vigência do Estado Novo, apesar de deixar tal possibilidade em aberto.

Já no terceiro paratexto, o direcionamento do sentido apresenta um aspecto diferenciado. Mais do que impor uma leitura ajustável ao Estado, vinculando a colaboração do autor a uma das tópicas norteadoras do discurso oficial, ele parece despistar uma interpretação, subjacente no relato do artista, que talvez pudesse ser desabonadora ao governo. Ao mesmo tempo, não revelaria a mesma perspicácia populista encontrada na segunda nota introdutória.

$\mathrm{Na}$ crônica introduzida por esta terceira sinopse transcrita acima, Graciliano alude à repercussão da Revolução de 1930 na capital de Alagoas, sem, no entanto, fazer menção direta ao evento, o qual pode apenas ser depreendido por alguns índices dispersos pela narrativa. Ao mesmo tempo, por meios oblíquos, o artista dá a entender que os antigos oligarcas, supostamente depostos pelo movimento revoltoso, ainda permaneciam no poder no período posterior à vitória de Getúlio. Diante dessa possibilidade interpretativa, o autor do paratexto opta por apagar a referência específica à ação dos insurretos da Aliança Liberal, ressaltando que o escritor abordava não um caso singular, mas "a repercussão de uma revolução embrionária” no Nordeste. Pela ótica da revista, o texto continuava a ser "real”, referenciado na região nordestina, mas era tratado não como um quadro particular, mas como um panorama geral. Nesse sentido, o paratexto privilegia um caráter didático-descritivo, resumindo as cenas tratadas pelo cronista, como se reforçasse a suposta neutralidade destas.

De certa maneira, essa interpretação torna o texto do autor apropriado para ser veiculado na revista oficial, mais especificamente num volume comemorativo do quarto aniversário do governo $^{648}$. Por outro lado, mostra-se menos eficaz do que a leitura proposta pelo segundo paratexto.

\footnotetext{
${ }^{648}$ Trata-se da edição extraordinária (ano 1, número 9) de 10 de novembro de 1941.
} 
Em geral, não soava como uma crítica ao Estado Novo o relato da permanência do mandonismo depois da Revolução de 1930, evento tomado como marco fundador do regime de 1937. A experiência constitucional de 1934 confirmava que um "ranço individualista",649, resquício do liberalismo da primeira República, continuava presente na vida política brasileira mesmo após a vitória da Aliança Liberal. Segundo a perspectiva finalista da retórica oficial, tal herança só teria sido superada com o golpe de 10 de novembro. Nesse sentido, Graciliano, ao destacar a atuação de políticos “educados na poesia e na retórica”650 num período pósrevolucionário, não veiculava necessariamente uma crítica à ditadura varguista. Muito pelo contrário, pois indicava o prolongamento de um conjunto de práticas políticas reprováveis, que justificaram a implantação de um Estado de exceção ${ }^{651}$.

Essa possibilidade interpretativa permite pensar, por hipótese, que o paratextista poderia ter tomado a crônica do escritor alagoano como um retrato do individualismo político da Primeira República, que supostamente viria a ser extirpado pelo regime de 1937, da mesma maneira que fizera no segundo paratexto. De acordo com uma visada propagandística, ele poderia utilizar o passado descrito pelo escritor como uma forma de engrandecer, por oposição, o status quo estadonovista. No entanto, tal direcionamento específico fora deixado de lado, apesar de a estrutura da colaboração de Graciliano permitir tal apropriação.

Em resumo, os paratextos pretendiam integrar os escritos de Graciliano ao uso geral, autorizado e estabelecido pela retórica oficial, por mais que eles não coubessem inteiramente no figurino proposto. Para tanto, Cultura Política reduzia os escritos do autor a uma significação referencial, tendo em vista a necessidade de omitir ou extrair deles um sentido oculto que precisava ser orientado: as lacunas decorrentes do processo interpretativo deviam ser preenchidas segundo as diretrizes previstas pelo Estado. Tal iniciativa, ao mesmo tempo em que procurava controlar a interpretação do leitor, revelava que a publicação configurava um destinatário que talvez não pudesse vincular, de maneira imediata, a colaboração do artista ao projeto estatal, sobretudo, levando-se em conta o caráter ficcional desta.

\footnotetext{
${ }^{649}$ A ORDEM política e a evolução social II. Cultura Política, Rio de Janeiro, ano 1, n.2. abr. 1941.

${ }^{650}$ RAMOS, Graciliano. Quadros e costumes do Nordeste IX. Cultura Política, Rio de Janeiro, ano 1, n.9. nov. 1941, p.370.

${ }^{651}$ Como afirma Almir de Andrade: "Para que não perecessem as aspirações renovadoras que haviam inspirado a Revolução de 1930, era preciso uma nova reviravolta política. Cada uma das forças que se empenhava em luta, esperava dar, ela própria o golpe decisivo. Este veio, porém, de onde menos se esperava: do próprio governo inspirado pelas forças armadas, a 10 de novembro de 1937” (ANDRADE, Almir de. Força, Cultura e Liberdade. p.123-124).
} 
No que diz respeito aos paratextos que antecediam as colaborações dos demais colaboradores de Cultura Política, eles cumpriam a função semelhante de apresentar e dignificar os articulistas, como forma de enaltecer a própria revista e, por conseguinte, o regime. Tome-se, por exemplo, a maneira como foram apresentados, respectivamente, Basílio de Magalhães, responsável pela seção “O povo brasileiro através do folclore” e Pedro Dantas (pseudônimo de Prudente de Morais Neto), a frente do segmento "Literatura de idéias":

Espelho vivo do Brasil, das suas realidades, dos seus problemas, das suas tendências sociais e políticas, da sua vida popular - como procurará ser esta Revista - não poderia faltar nela uma seção de folclore, reflexo profundo da alma e da cultura nacionais, nas suas genuínas fontes populares. - O nome escolhido para dirigi-la é o de um dos maiores conhecedores da história e do folclore brasileiros, que faz parte do quadro social de quase todos os Institutos Históricos e Geográficos do Brasil e de vários grêmios científicos europeus e americanos, professor catedrático de história no Instituto de Educação do Distrito Federal, autor de mais de 60 obras publicadas (originais e traduções), dentre as quais “Expansão Geográfica do Brasil Colonial” (1915, publ. em S. Paulo, 2ª ed., 1932), “O Folclore no Brasil” (1928, publ. em 1937 pela Revista do Instituto Histórico e Geográfico Brasileiro), “O Café na história, no folclore e nas belas-artes” (1936, publ. do Ministério do Trabalho), “História da Civilização” (Rio, 1939-1941) (ESPELHO vivo do Brasil. Cultura Política, Rio de Janeiro, ano 1, n.1. mar. 1941, p.257).

\footnotetext{
Vai redigir esta crônica mensal um nome já consagrado, de há muito, como o de um dos maiores críticos literários do Brasil de hoje. Sob pseudônimo jornalístico de Pedro Dantas há, como se sabe a figura de um intelectual que já exerceu cargos públicos de responsabilidade, tendo sido diretor de uma das mais importantes faculdades da extinta Universidade do Distrito Federal, e que, como crítico de livros e de idéias, é um dos de maior prestígio nosso país (VAI REDIGIR esta crônica. Cultura Política, Rio de Janeiro, ano 1, n.1. mar. 1941, p.257).
}

Apesar das semelhanças entre os encômios dirigidos aos diferentes autores e a Graciliano, havia diferenças entre o teor dos paratextos. Como introduziam, em geral, escritos mais referenciais (dissertações, estudos, literatura de viagem, crônica propriamente dita, entre outros gêneros), tais molduras preliminares não precisavam ressaltar a todo o momento a suposta “realidade” destes, assim como acontecia com as participações de Graciliano.

Além disso, como a maioria das colaborações dos articulistas mostrava-se mais ajustada ao ideário estadonovista, grande parte delas beirando o tom apologético, haveria uma adequação maior entre texto e paratexto, sem algumas das dissonâncias observadas nas produções do 
artista alagoano. Era como se os editores não precisassem fazer grande esforço para adequar os trabalhos às diretrizes do regime. A título de exemplo, seguem um trecho do segundo dos “Quadros e costumes do Centro e do Sul”, de autoria de Marques Rebelo, e sua respectiva nota introdutória produzida pelos editores:

[Em referência à cidade mineira de Januária] Quando foi proclamado o Estado Novo, o senhor juiz de direito, um homem rígido, que lutara bravamente para manter uma autoridade que lhe era quase sempre desrespeitada, mandou chamar ao Foro os chefes políticos locais, que eram uns trinta. Em poucas palavras expôs-lhes a nova situação do Brasil. O regime não mais comportaria lutas partidárias.

- Que é que o senhor é? perguntou a um chefete.

- Sou médico.

- Pois então agora o senhor vai tratar dos seus doentes. E o senhor? - perguntou a outro.

- Fazendeiro.

- Pois deixará a cidade para ir cuidar da sua fazenda.

E o farmacêutico foi cuidar da farmácia, o negociante do negócio, o boiadeiro do gado, cada um foi tratar da sua vida, e os que nada faziam senão política tiveram que arranjar uma obra. E os jagunços foram desarmados e dispersados. Muitos caíram no eito, pacíficos que eram, feitos valentões apenas numa época de costas largas e de dinheiro fácil nos cofres da prefeitura (REBELO, Marques. Quadros e costumes do Centro e do Sul I. Cultura Política, Rio de Janeiro, ano 1, n.2. abr. 1941, p.243).

... Em Januária também chegou, depois de 1937, o influxo renovador do Estado Novo: modificam-se os costumes locais, pelo desaparecimento das velhas figuras da politicagem, pelo retorno dos que exploravam aos campos, às fazendas, ao comércio, à clínica. Um novo ambiente de tranqüilidade sem temores desce sobre Januária (PROCURANDO fixar quadros e costumes. Cultura Política, Rio de Janeiro, ano 1, n.2. abr. 1941, p.242).

O gesto de louvor ao regime de 1937 e de conseqüente legitimação do mesmo, presente no discurso elaborado pelo cronista, fora condensado e mantido pelo paratexto, retirando-se daquele, apenas, os componentes ficcionais utilizados pelo artista (construção de cena e personagens, sobretudo). Portanto, tanto em uma quanto na outra passagem, sem meias 
palavras, fica evidente a contraposição entre o Brasil estadonovista e o Brasil da Primeira República, como estratégia de exaltação do Estado Novo. Dessa maneira, aquilo que na colaboração alegórica de Graciliano era apenas uma virtualidade interpretativa e precisava ser explicitada e orientada pelos editores, aqui, tornava-se imediatamente perceptível aos leitores. Em linhas gerais, o paratexto não afirmava nada que o próprio autor não dissera categórica e enfaticamente em seu próprio escrito, dispensando justificativas.

A análise desses trechos será aprofundada mais adiante, no momento em que tomar corpo o estudo específico da colaboração de Marques Rebelo em Cultura Política.

\subsection{Além da crônica}

Segundo tradição constituída, convencionou-se tratar as colaborações de Graciliano publicadas em Cultura Política como crônicas. A própria revista assim o faz, logo na primeira participação do artista: “o autor desta crônica tomou a seu encargo fixar quadros e costumes da região do Brasil onde nasceu e viveu mais de trinta anos: o Nordeste” ${ }^{652}$. Postumamente, como se sabe, os “Quadros e costumes” foram reunidos em Viventes das Alagoas, um volume designado como sendo de “crônicas”, assim como seu congênere Linhas Tortas. Estudos que apenas citam ou se dedicam a uma análise mais detida dos textos vão pelo mesmo caminho ${ }^{653}$. Ledo Ivo, no ensaio “O mundo concentracionário de Graciliano Ramos” apesar de não enquadrar tais escritos num ethos cronístico, vale-se de categoria similar, definindo-os como “jornalismo literário"654.

Na ocasião em que se dá a prática periodística de Graciliano estampada em Cultura Política, trata-se de um momento, pós-Modernismo, no qual a crônica recebe a configuração que

\footnotetext{
${ }^{652}$ ESCRITOR e romancista... Rio de Janeiro, Cultura Política, ano 1, n.1, mar. 1941, p.236 (grifos do autor).

${ }^{653}$ Com relação aos trabalhos que fazem uma análise mais aprofundada dos escritos de Graciliano na revista getulista, confirmando o estatuto cronístico destes, pode-se destacar: a biografia intelectual do artista "Um homem bruto da terra", elaborada por Valentim Facioli; a tese de doutorado Graciliano Ramos e a revista Cultura Política, de Nádia Regina Bumirg; o artigo "Pensando o Brasil”, de Ana Amélia M. C. de Melo; e a obra O velho Graça, de Dênis de Moraes. A exceção é Raul Antelo, no livro Literatura em Revista. No trecho dedicado ao exame dos textos de Graciliano publicados em Cultura Política, o autor refere-se a eles como escritos que oscilavam "às vezes entre o conto, a crônica de costumes e, mais raramente, a crítica bibliográfica" (ANTELO, Raul. Literatura em revista, p.27). Para referências mais detalhadas sobre as obras listadas, ver bibliografia.

${ }^{654}$ Assim destaca o poeta alagoano: “Como boa parte dos expoentes da intelectualidade da época, colaborava na Cultura Política, a revista editada pelo DIP. Nela estampou suas melhores páginas de jornalismo literário aquelas que, retratando homens, fatos e coisas do sertão, foram reunidas no Viventes das Alagoas” (IVO, Ledo. O mundo concentracionário de Graciliano Ramos. In: Teoria e celebração. São Paulo: Duas Cidades / Secretaria da Cultura, Ciência e Tecnologia do Estado de São Paulo, 1976, p.96-97).
} 
perdura até o momento, quando vai se desatrelando da obrigação de recuperar os sucessos da semana (fait divers que tiveram um tratamento mais objetivo e referencial em outras seções) ${ }^{655}$ e ganhando um espaço mais autônomo, como reflexo da mudança do próprio conceito de jornal ${ }^{656}$. Nesse processo, contudo, não deixa de lado suas pretensões veridictórias, mantendo-se como meio para outra coisa fora de si, sem se preocupar apenas com a verossimilança artística, tratando criticamente das matérias cotidianas, mas mantendo a normatividade da estrutura comunicativa.

Ao ficcionalizar diferentes aspectos da vida prosaica, os cronistas do século XX, em geral, também procuram construir uma relação de intimidade e de proximidade com o leitor, com privilégio para o narrador participante e para o narrador testemunha, abdicando da posição distanciada da terceira pessoa. Assim, adotam um viés subjetivo, marcado pela noção de gesto artístico, contrário à importância objetiva exigida pelo discurso jornalístico, presente em reportagens, matérias, artigos e notas ${ }^{657}$. Nesse processo, os autores apresentam-se como sujeitos participantes da comunidade imaginada pelo jornal, assim como seus leitores, fazendo referência a dados singulares e concretos partilhados com estes, sem a necessidade de realizar

\footnotetext{
${ }^{655}$ Ainda no século XIX, os conteúdos que seguiam os protocolos ficcionais do romance, do conto, da poesia, etc. dividiam espaço com a crônica nas páginas dos periódicos. Esta, para se diferenciar, mantinha-se mais presa ao relato de fatos considerados importantes no processo de conceituação do mundo externo, realizado pelo jornal, atrelando-se ao referencial e ao circunstancial instituídos discursivamente pelo jornalismo diário. O texto assumia funções como informar ou comentar, pautando-se, muitas vezes, pela lógica argumentativa e pela crítica política. Por outro lado, a crônica não se assemelhava às produções discursivamente mais referenciais de outras seções dos jornais como artigos de fundo, notas e telegramas. Ela privilegiava, portanto, um tratamento livre e plural das tópicas extraídas dos sucessos da semana, que eram incorporados como eventos ficcionalizados na economia interna do texto. Dessa maneira, atributos como hibridismo e indeterminação passam a ser incluídos à tradição do gênero, como atestam as tentativas de defini-lo e enobrecê-lo, empreendidas por diferentes cronistas. ${ }^{656}$ A modernização da imprensa brasileira, sobretudo, ao longo do século XX foi marcada pela adoção do modelo norte-americano de jornalismo, o qual privilegia a informação, a reportagem e a notícia, separando o comentário pessoal da transmissão supostamente objetiva e impessoal dos fatos. Certos valores como objetividade e imparcialidade tornam-se os alicerces fundamentais das produções jornalísticas (COSTA, Cristiane. Pena de Aluguel. São Paulo: Companhia das Letras, 2005, p.15). E, cada vez mais, as pretensões literárias nas redações tornaram-se românticas e obsoletas, fazendo com que a veiculação das obras literárias voltasse a ter um caráter predominantemente livresco. Em meio a esse processo, em que também se nota a incorporação de certos princípios modernistas pelas redações (Idem, ibidem), a crônica passa a privilegiar, sobretudo, assuntos atrelados a diversos aspectos do cotidiano dos centros urbanos. Essa seria a estratégia para obter, de acordo com o discurso cultural vigente, o efeito de real. Dessa maneira, um diálogo entre namorados, a visita de um inseto noturno, a posição de um quadro na parede, a carta de uma ginasial, uma conversa entre patrão e empregada, entre outros assuntos (extraídos, por exemplo, de algumas crônicas de Carlos Drummond de Andrade, escolhidas aleatoriamente, em diferentes livros publicados do autor), seriam objetos possíveis de um texto cronístico no século XX, na medida em que estariam previstos pela poética do gênero no período. A orientação veridictória da crônica continuava a pautar-se por inclú́-la na dinâmica da vida, como se esta não fosse um discurso, mas sim uma extensão do mundo vivido e partilhado com os leitores. Porém, fazia isso guiando-se por uma perspectiva divergente daquela adotada por Alencar ou Bilac, por exemplo, que procuravam, sobretudo, tecer comentários de maneira singular e pessoal, a partir de tópicas associadas aos fatos da semana destacados pela imprensa.

${ }^{657}$ Nestes, percebe-se a construção de um ponto de vista distanciado, exigido pelas normas específicas de composição de tais escritos que privilegiam certo recorte dos assuntos tidos como mais importantes e urgentes.
} 
grandes retomadas informativas ou de construir toda uma ambientação para situar as matérias e assuntos sobre as quais se debruçam. Simulam, portanto, que estariam em comunhão fática com seu auditório, como se os laços de união entre uns e outro fossem criados pela mera troca de palavras, tal como o conceito de "conversa fiada”, comumente atribuído a crônica nas mais variadas definições sobre o gênero, faz crer ${ }^{658}$.

Mediante tal movimento, que também prevê a incorporação de certa roupagem lúdica e lírica, a crônica acaba construindo para si um lugar discursivo diferenciado no jornal em que sai estampada. Além disso, pressupõe um outro tipo de leitor, afeito a esta perspectiva textual destoante do noticiário usual. No entanto, o entretenimento e o lirismo pressupostos devem ser vistos como artifícios para a apresentação de noções e conceitos úteis ao receptor, com um tratamento próximo daquilo que se entende por Literatura, sem deixar de lado, contudo, suas pretensões de verdade, o que confere a tais composições certa perenidade e enobrecimento em meio ao contexto efêmero, apressado e referencial do jornal diário.

Por mais que se diferencie literariamente, a vida real da crônica está na publicação para a qual ela foi pensada, pois cabe a seu autor se adequar às diretrizes desta, aos leitores, ao espaço restrito ocupado, enfim sujeitar-se a todo horizonte comunicativo e circunstancial do processo de construção do texto. Ao mesmo tempo, as atribuições semióticas de novidade, urgência e facticidade, caracterizadoras do discurso jornalístico, fazem com que o gênero privilegie o tempo presente, aproximando-se, por esse aspecto, dos textos que lhe são vizinhos. Na verdade, o cronista seleciona e extrai temas associados a eventos ou incidentes ocorridos recentemente, tratando o passado como coisa atual. Tal processo faz com que a memória presentifique o que interessa ao jornal como contínua contemporaneidade.

Desse conjunto de elementos sumarizados acima, que foram se sedimentando ao longo do processo de consolidação do gênero no século XX, pode-se dizer que os "Quadros e Costumes do Nordeste" aproximar-se-iam apenas tangencialmente. Em comum com o conceito moderno de crônica, tais escritos guardam apenas a utilização de certos recursos estilísticos, além da seleção temática operada pelo artista. Quanto ao primeiro aspecto, prevalece o uso de uma

\footnotetext{
${ }^{658}$ Segundo Benveniste, recuperando Malinowski, a comunhão fática se mostra como um tipo de discurso em que os laços de união entre os sujeitos são criados pela mera troca de palavras, preenchendo uma função social de união entre locutor e ouvinte (BENVENISTE, Emile. O aparelho formal da enunciação. Problemas de lingüística geral II. Campinas: Pontes, p.88-90).
} 
linguagem que prima pela facilitação comunicativa, marcada pela brevidade, por certa cotidianidade, sem abdicar da presença da ironia. Quanto ao segundo, destaque para o tratamento de personagens e cenas da vida prosaica, como meio para se produzir reflexões existenciais, sociais e políticas: a história de um pastor de cabras, um desafio de cantadores, a vida de um romancista de província, entre outras matérias.

Outro ponto de aproximação, diz respeito à categoria modal da veridicção. Assim como a crônica de maneira geral, os textos de Graciliano de Cultura Política pretendem-se verdadeiros, de acordo com o contrato fiduciário estabelecido entre enunciador e enunciatário. Mediante tal convenção, as narrativas produzem determinado efeito de ilusão referencial, decorrente tanto de recursos estilísticos empregados pelo autor, como da própria ambiência conferida a elas pela revista. Em regra, a maioria de seus textos finge não ser ficção por mais que se mostre mais próxima de certos protocolos ficcionais, como será visto.

Além disso, o próprio hibridismo do conjunto daria margem a esse tipo de enquadramento, de acordo com as definições convencionais que historicamente se estabeleceram sobre a crônica $^{659}$. O próprio título da seção, abrangente e pluralizado, daria ensejo ao tratamento do diverso. Como se verá, seus textos transitam por diferentes gêneros (conto, ensaio, memórias, retrato), bem como recuperam assuntos e temas diversificados, que vão, por exemplo, desde a história de um cantador sertanejo, que nas horas vagas professava a medicina como forma de obter vencimentos, até o relato da revolução de 1930, sob a perspectiva de uma capital nordestina afetada pelo movimento.

No entanto, mais do que semelhanças, avultam diferenças. Como imputar a classificação de “crônica” ao referido conjunto de narrativas de Graciliano se a grande maioria dele tem como objeto personagens, práticas e eventos recuados no tempo, num distante passado sertanejo, evocado pelo narrador? E mesmo nas crônicas que lançam mão do tempo presente, ele pode ser tomado, na maioria das vezes, mais como uma estratégia de aproximação e vivificação do material passado (ou seja, seria uma modalidade do presente histórico ou aorístico) ou para mostrar o aspecto durativo e tradicional das descrições apresentadas. Portanto, nada da

\footnotetext{
${ }^{659}$ Inúmeros autores que se debruçaram sobre o território cronístico destacaram que ninguém teria delimitado com precisão suas fronteiras flutuantes: trata-se de um gênero marcadamente ambíguo que conduz ao conto (quando se conta uma história), ao ensaio (quando predomina o caráter conceitual), ao poema em prosa (quando o significante prevalece sobre o significado). Dessa maneira, teria uma forma prismática, com muitos ângulos e insinuações temáticas, mimetizando a pluralidade dos assuntos abordados pelo jornal.
} 
tematização de fait divers, nada de diálogo efetivo com os leitores e de construção de intimidade, nada de soltura sintática, nada de representação do espaço urbano em que circula a revista, nem sinal das andanças de um flâneur. Enfim, muitas das características que são atribuídas ao gênero crônica, ao longo do processo de modernização da imprensa brasileira, são deixadas de lado. Inclusive, o próprio narrador, de maneira recorrente, assume uma posição distanciada da matéria descrita: na grande maioria dos textos há o predomínio da terceira pessoa.

De acordo com a função predominantemente comunicativa do gênero, com destaque para a interlocução pretendida pelo cronista, ele pressupõe o uso de dêiticos ou marcos referenciais (embreantes) que remetam a própria cena enunciativa (o lugar e o momento da fala), da qual artista e público fariam parte, respectivamente, enquanto enunciador e enunciatário. No caso dos “Quadros e costumes do Nordeste”, Graciliano vale-se desse expediente de maneira ocasional, sobretudo no que diz respeito à categoria "tempo", ou como forma de atualizar relatos localizados no passado (“hoje”, “agora”, “ultimamente”, “nestes últimos tempos”), ou como meio de situá-los em relação a seu momento de enunciação presente (“há tempo”, "no começo do século”, “há muitos anos”, “ali por volta de 1930”). Em menor número, há aqueles que fazem referência ao espaço, como recurso para marcar o distanciamento do narrador, bem como de seus leitores pressupostos, do lugar que recupera em seus escritos.

Nesse sentido, o artista refere-se apenas de maneira eventual a um universo comum compartilhado com seus interlocutores. Em geral, Graciliano é vago, preterindo a abordagem de situações historicamente comprovadas e passíveis de serem conhecidas por seus leitores urbanos e sulistas. Em decorrência desse distanciamento, vê-se obrigado a produzir toda uma ambientação com o objetivo de situar espacial, actancial e temporalmente as matérias sobre as quais trabalha (sobretudo no que diz respeito às categorias espaço e pessoa). Tal iniciativa permite que os destinatários adentrem nesse novo mundo construído, que a um só tempo aproxima-se da ficção (pela autonomia, pois os textos produzidos dispensam um discurso supostamente real para serem compreendidos, já que apresentam lógica e estrutura próprias), mas guarda laços com o universo cultural do leitor, na medida em que trata da região nordestina, como título da seção faz crer, simulando o estatuto de verdade. Ao mesmo tempo, nos textos de Cultura Política que se aproximam do gênero dissertativo, o autor quase sempre se refere a uma realidade distante de seus receptores habituais, necessitando antes localizá-la e enquadrá-la para depois analisá-la e interpretá-la. 
Por outro lado, apesar do distanciamento decorrente do predomínio da terceira pessoa, o enunciador acaba se fazendo presente pela posição de onisciência, com destaque para seu domínio sobre cenas e personagens apresentados. Ao mesmo tempo, intromete-se recorrentemente no assunto (como se houvesse uma instância inscrita no enunciado, mas que não diz “eu”), sobretudo por meio de tiradas irônicas, da emissão de opiniões e, em alguns escritos, pela utilização do discurso indireto livre, outro indício de que não escreveria "ao correr da pena”, como usualmente se define a condição de cronista.

A comparação entre as crônicas "Inácio da Catingueira e Romano”, publicada no Diário de Notícias, em 1937, e “Desafio”, presente na edição de fevereiro de 1942 de Cultura Política, pode ser usada para exemplificar sumariamente as diferenças entre uma crônica propriamente “crônica” e uma narrativa que apresenta uma estrutura ficcional mais bem acabada, aproximando-se da noção de conto. Ambas foram escritas por Graciliano e tratam do mesmo assunto: o duelo entre os cantadores Inácio da Catingueira, negro, pobre e sem instrução, e Romano, branco, de família destacada e alfabetizado. Este último, achando-se superior, empregava procedimento desleal: “introduzia uma palavra difícil no martelo com o intuito de atrapalhar o adversário”660. Inácio se defendia ironicamente dizendo que não possuía ciência, mas dominava os recursos da cantoria. Contudo, Romano dá o golpe final que esmaga o inimigo. Faz um verso “sem pé nem cabeça”, elencando uma série de figuras mitológicas e pede a réplica de Inácio. A platéia entusiasmada aplaude mesmo desconhecendo o significado daqueles nomes que, todavia, lhe pareciam importantes. O negro, obviamente, fica sem resposta uma vez que era analfabeto e nunca ouvira falar de tais entidades ${ }^{661}$.

A fim de confrontar os dois textos, tome-se o primeiro parágrafo de cada um deles:

Li, há dias, numa revista a cantoria ou “martelo” que, há perto de setenta anos, Inácio da Catingueira teve com Romano, em Patos, na Paraíba. Inácio da Catingueira, um negro, era apenas Inácio; Romano, pessoa de família, possuía um nome mais comprido - era Francisco Romano Teixeira, irmão de Veríssimo Romano, cangaceiro e poeta, pai de Josué Romano, também cantador, enfim, um Romano

\footnotetext{
${ }^{660}$ RAMOS, Graciliano. Viventes das Alagoas. São Paulo: Martins, 2 ed, 1962, p.121.

661 Câmara Cascudo reproduz os versos finais desse desafio: Romano: Latona, Cibele, Réa,/ Íris, Vulcano, Netuno,/ Minerva, Diana, Juno,/ Anfitrite, Androquéa,/ Vênus, Climene, Amaltéa,/ Plutão, Mercúrio, Tezeu,/ Júpiter, Zoilo, Perseu,/ Apolo, Ceres, Pandora,/ Inácio, desata, agora,/ O nó que Romano deu. Inácio: Seu Romano, deste jeito/ Eu não posso acompanhá-lo;/ Se desse um nó em martelo/ Viria eu desatá-lo;/ Mas como foi em ciência/ Cante só que eu me calo. (In: CASCUDO, Luís da Câmara. Vaqueiros e Cantadores. Belo Horizonte: Ed. Itatiaia / São Paulo: EDUSP, 1984, p.197).
} 
bem classificado, cheio de suficiência, até com discípulos (Diário de Notícias, Rio de Janeiro, 19 dez. 1937 (Copyright de I.B.R). In: Viventes das Alagoas, Rio de Janeiro: Record, 2007, p.131).

\begin{abstract}
No interior da Paraíba, viveram há mais de meio século dois cantores famosos, ouvidos com admiração e respeito em cidades e vilas: Inácio da Catingueira, preto, e Romano, branco, de boa família, cheio de fumaças. O negro isento de leituras, repentista por graça de Deus, exprimia-se com simplicidade, na língua comum do lugar. O branco exibia conhecimentos: andara uns meses na escola e, em razão da palmatória e dos cascudos, saíra arrumando algarismos, decifrando por alto o mistério dos jornais e das cartas. Possuía um vocabulário de que não alcançava direito a significação e lhe prejudicava o estro, mas isto o elevava na consideração do público. Nos torneios consideráveis reunia palavras esquisitas, de pronúncia difícil, e atrapalhava o adversário. Processo desleal (Cultura Política, Rio de Janeiro, ano 2, n.12, fev. 1942, p.217. In: Viventes das Alagoas, Rio de Janeiro: Record, 2007, p.79).
\end{abstract}

No trecho publicado em jornal, percebe-se a marca introdutória da primeira pessoa (debreagem actancial enunciativa) e, conseqüentemente, a construção de um canal mais direto e afetivo com o leitor, remetendo a um mundo comum compartilhado por ambos. Ao mesmo tempo, o enunciador vale-se de traços mais informativos, marcados pela brevidade, uma vez que passa em revista, rapidamente, os dois personagens que nomeiam o texto e servem de mote para o comentário que fará mais adiante sobre seu momento de enunciação. Há ainda a explicitação da referência a um fait divers específico (“Li, há dias, numa revista a cantoria...”) e o estabelecimento de um diálogo mais efetivo com o meio jornalístico, reforçando o enquadramento do texto em tal universo. Na narrativa de Cultura Política, por outro lado, há o apagamento da citação ou comentário a um discurso extradiegético, que supostamente atestaria o duelo entre os cantadores. Ao mesmo tempo, o narrador em terceira pessoa (produzido mediante uma debreagem actancial enunciva, geradora de impessoalidade), distante temporal e espacialmente das matérias narradas, situa, logo nas primeiras linhas, o lugar e o momento em que se dará a ação que norteará seu relato. Em certo sentido, apresenta aos leitores um novo mundo, diferente daquele que lhes era habitual, por mais que este estivesse referenciado no real (“No interior da Paraíba, viveram há mais de meio século dois cantadores famosos”).

Paralelamente, em meio a certa orientação descritiva, investe na caracterização dos tipos que centralizaram o enredo, na atmosfera do confronto entre eles e no próprio desdobramento da 
trama, conferindo não unidade de tempo (algo comum à crônica), mas sim unidade de ação ao relato:

Foram-se esquentando e vieram as ameaças. Romano combatia brutalmente. Inácio desviava-se dos golpes, ligeiro, e pregava-lhe de quando em quando um espinho em lugar muito sensível. Fingia humildade, tratava-o numa cortesia zombeteira, por meu branco, oferecia-lhe conselhos. Para que soberba, aquela grandeza? Lorota não dava camisa à ninguém. O mundo estava cheio de quedas, desastres, e tanto se arriscava o pau como o machado.

Correu uma hora. As primas se esganiçavam, os bordões zumbiam - e o martelo continuava, sem vantagem para nenhum dos contendores ${ }^{662}$.

Já na crônica do Diário de Notícias, o autor alagoano adota um estilo mais direto e informativo, no qual a retomada da peleja entre os dois cantadores serve de mote para que ele comente o universo literário de seu momento de enunciação, em perspectiva semelhante à adotada em outros textos seus deste período, nos quais procura exaltar os escritores nordestinos de sua geração, num contexto de disputas no campo literário. Para tanto, o cronista cita um livro publicado no ano anterior com medonhos erros de sintaxe, em que o cidadão que o redigiu afirmava em linguagem errada que sabia escrever. Tal paradoxo é associado ao caso de Inácio e Romano que acabou de ser relatado: "Que pedantismo e que miséria! Ali bocados de mitologia, aqui um português arrevesado, pretensioso e manco"663. Da mesma maneira que os ouvintes do desafio, os leitores do livro também foram coniventes com os solecismos do escritor - "engoliram o que o homem disse, exatamente como aconteceu em Patos, há setenta anos” ${ }^{664}$. Não satisfeito, o artista continua:

\footnotetext{
Não devemos, contudo, perder as esperanças. Inácio da Catingueira, esse honesto conterrâneo do sr. José Américo e do sr. José Lins do Rego, esse tipo direito, sensato, extravagância viva num país de insensatos, deixou descendentes. Graças a Deus isto é verdade. Será preciso mencioná-los? Talvez não seja, talvez os parentes deles se ofendam, porque enfim, Inácio era preto e, se não me engano, solteiro.
}

Certamente muitos preferem descender dos Romanos, que sempre fora os donos intelectuais do Brasil $^{665}$.

662 RAMOS, Graciliano. Quadros e Costumes do Nordeste XII ["Desafio"]. Cultura Política, Rio de Janeiro, ano 2, n.12, fev. 1942, p.217-218. In: Viventes das Alagoas, Rio de Janeiro: Record, 2007, p.81.

663 RAMOS, Graciliano. "Inácio da Catingueira e Romano”. Diário de Notícias, Rio de Janeiro, 19 dez. 1937 (Copyright de I.B.R). In: Viventes das Alagoas, Rio de Janeiro: Record, 2007, p.133.

664 Idem, ibidem.

${ }^{665}$ Idem, ibidem. 
De maneira mais direta e específica, algo também presente no texto de Cultura Política, porém de modo encoberto, Inácio e Romano alegorizariam vertentes distintas da literatura brasileira, de acordo com a visão binária do autor: o primeiro, preto e analfabeto, é colocado ao lado dos "sapateiros da literatura”, categoria na qual o escritor e os demais escritores nordestinos se colocavam (o cantador seria conterrâneo de José Américo de Almeida e de José Lins do Rêgo e se destacava pela sensatez e honestidade); o segundo, branco, educado e de família tradicional, representaria os "literatos gordos”, de frases vazias e campanudas, “os donos intelectuais do Brasil”, que tanto Graciliano critica na segunda parte de Linhas Tortas.

\subsection{Reenquadramento dos textos quanto ao gênero}

De certa maneira, as particularidades observadas acima no modo de elocução do texto sobre a peleja entre os cantadores Inácio da Catingueira e Romano, saído em Cultura Política, o qual fugiria do figurino cronístico tradicional, podem ser estendidas ao conjunto dos "Quadros e costumes do Nordeste”, publicados por Graciliano na revista getulista. Mais especificamente, no que diz respeito à composição destes últimos, se por um lado o autor deixa de imitar a estrutura da crônica stricto sensu, por outro, vale-se de procedimentos que aproximariam suas narrativas de outros protocolos, com destaque para o conto, memórias, dissertação e quadros descritivos (retratos de pessoas e ambientes). Na maioria dos casos, seus escritos apenas apresentariam uma aparência de crônica, além de ocuparem um espaço, supostamente dedicado a tal espécie literária. Astutamente, o artista não deixa de jogar com alguns elementos desta categoria (gênero textual), pretendido pelo caráter referencial da seção e da revista como um todo.

No entanto, na maioria de suas colaborações, percebe-se a utilização de recursos tipicamente ficcionais, com ênfase na estrutura narrativa, que permitiriam tratá-las, predominantemente, como pequenos contos e retratos ficcionais. Assim, seus escritos colocariam, de maneira implícita, a questão da verdade não enquanto adequação exclusiva e imediata a um referente externo, mas sim à própria história: a veridicção cederia espaço à verossimilhança.

Em regra, mesmo se referindo predominantemente ao passado, o escritor lança mão de poucas cenas e personagens lastreadas historicamente, sobretudo daquelas que poderiam ser conhecidas de seus leitores sulistas, aos quais a revista preferencialmente se dirigia. No caso 
das cenas, há textos que tratam da Revolução de 1930 e da construção de um teatro em Maceió por meios indiretos e, até certo ponto, generalizantes. No que diz respeito às personagens, o rol também é limitado: há figuras presentes em relatos biográficos (seu bisavô materno e um funcionário da fazenda de seus familiares, no interior pernambucano, de nome Ciríaco) ${ }^{666}$; uma dupla de cantadores que disputaram um peleja famosa no sertão $^{667}$; um romancista alagoano de repercussão local ${ }^{668}$; e o nacionalmente conhecido coronel Delmiro Gouveia $^{669}$. Com relação a este último, por mais que se refira a um ator com passagens marcantes no discurso histórico erigido sobre o país ${ }^{670}$, Graciliano, ao tratar de sua trajetória no texto "Recordações de uma indústria morta" 671 , finge instituir um outro pacto fiduciário com o leitor, como se fugisse do registro do "real":

\begin{abstract}
Era uma vez um sertanejo que se chamava Gouveia e se mantinha comprando peles de bode na catinga, vendendo em povoações do interior, em dias de feira. Negócio difícil. Os armazenistas fixam preço mínimo para mercadoria aproveitável: o que fica abaixo é refugo. Em conseqüência os matutos se defendem derramando chumbo miúdo nas orelhas murchas das peles, tapando os buracos depois com cera $^{672}$.
\end{abstract}

\footnotetext{
${ }^{666}$ Este último aparece referido em Infância (Rio de Janeiro: Livraria Editora José Olympio, 1953, p.126) e no volume de Cartas endereçadas por Graciliano a seus familiares (Rio de Janeiro: Record, 1981, p.16).

${ }^{667}$ Trata-se dos cantadores Inácio da Catingueira e Romano. A disputa entre eles acontecera no começo do século XX, no interior da Paraíba e fora recolhida em livro (ver CASCUDO, Luís da Câmara. Vaqueiros e Cantadores. Belo Horizonte: Ed. Itatiaia / São Paulo: EDUSP, 1984, p.197).

${ }^{668}$ Referência a Domingos Soares Barbosa. O volume $A B C$ das Alagoas dedica-lhe o seguinte verbete: "BARBOSA, Domingos (Maroim SE 4/8/1862 - Maceió AL 3/2/ 1922) Teatrólogo, ator. Obras: A Heróica Alagoana, Maceió, Litografia Trigueiros, 1904 (romance); Orgulho Humilhado, 1904 (drama); O Brado da Consciência, Maceió, Livraria Fonseca, 1905 (romance); Duas Esposas e Um Só Marido, Maceió, Livraria Fonseca, 1907; A Filha do Mestre Bráz, Maceió, Oficina Fonseca, Maceió, 1905 (drama); Guilherme o Recrutado, Maceió, Livraria Fonseca, 1907 (drama); Um Homem Perigoso, 1906 (romance); Centelhas, Liv. Trigueiros, Maceió, 1906 ( contos - citado por R. de Avelar); A Virgem Bela e Duílio, 1907 (conto); A Rosa de Valparaiso ou o Pecador Arrependido, Maceió, Oficinas da Livraria Fonseca, 1909 (drama). O Cavalheiro da Rosa Branca. Graciliano Ramos em seu livro Viventes das Alagoas, o cita. Romeu de Avelar, em especial os contos do livro Centelhas, os considerava um trabalho de composição escolar" (In: BARROS, Francisco Reinaldo Amorim de. ABC das Alagoas: dicionário, histórico e geográfico das Alagoas. Brasília: Senado Federal, Conselho Editorial, 2005, v.1, p.121-122).

${ }^{669} \mathrm{Na}$ maioria das vezes, o narrador se refere às personagens não por meio de um nome próprio identificável, mas sim pela função desempenhada por estas na sociedade local. O governador do Estado é chamado apenas de "governador", o mesmo valendo para "a mulher do prefeito", o "promotor", o "juiz", o "padre”, o "moço da farmácia", o "senhor de engenho", entre outros que compõem a galeria de tipos abordados pelo escritor. De certa maneira, tal procedimento de indeterminação colabora para a produção do efeito de ficção pretendido pelo texto.

${ }^{670}$ Delmiro Gouveia é considerado um dos pioneiros da industrialização nacional e da construção da usina hidrelétrica de Paulo Afonso. Vários livros procuram traçar o seu perfil e descrever suas façanhas: ARARIPE, J. C. Alencar. A glória de um pioneiro: a vida de Delmiro Gouveia. [Rio de Janeiro]: Edições O Cruzeiro, [1965]; SEGALL, Maurício. O coronel dos coronéis: a história e a lenda do "coronel" Delmiro Gouveia. Rio de Janeiro: Civilização Brasileira, 1979; LIMA, Félix. Delmiro Gouveia: o Mauá do sertão alagoano. Maceió: Departamento Estadual de Cultura, 1963; entre outros.

${ }^{671}$ RAMOS, Graciliano. Recordações de uma indústria morta. Cultura Política, Rio de Janeiro, n.20, out. 1942, p.166-167.

${ }^{672}$ RAMOS, Graciliano. Recordações de uma indústria morta. Cultura Política, Rio de Janeiro, ano 2, n.20, out. 1942, p.123
} 
Assim como se observa nas fábulas de Esopo e La Fontaine, o protocolo "Era uma vez" estabelece uma relação entre enunciador e enunciatário marcada pela irrealidade. No entanto, o tratamento cronológico da vida do personagem, num registro próximo do discurso histórico e biográfico produzido sobre ele, revela o contrário. O estranhamento proporcionado por tal desacordo entre enunciado enunciado e enunciação enunciada procura chamar a atenção do leitor para o caráter fantástico da trajetória de Gouveia (digna de uma história de faz de conta), bem como para o absurdo da falta de apoio estatal dispensada pelo governo da Primeira República às iniciativas do empreendedor sertanejo. Ele fora morto numa emboscada, supostamente a mando de agentes internacionais, e a fábrica que construíra no sertão, a qual ameaçava interesses do capital estrangeiro no país, desmantelada.

Neste texto, apesar de referenciar sua narrativa em relatos históricos conhecidos, presentes, inclusive, na própria revista ${ }^{673}$, o escritor procura construir um perfil do coronel Delmiro Gouveia, aproximando sua narrativa do chamado conto de personagem ${ }^{674}$. Ao longo de sua colaboração em Cultura Política, este procedimento mostra-se comum, tornando-se mais evidente nas narrativas que depois receberiam como títulos os próprios nomes dos protagonistas: “D. Maria Amália”, “O moço da farmácia”, “Ciríaco”, “D. Maria”, “Um antepassado”, “Dr. Pelado”, “Funcionário Independente”, “Um homem notável”, “A decadência de um senhor de engenho”, entre outros. Em tal tipo de construção, o retrato de uma figura central (prosopografia) apresenta-se como o objetivo preferencial do narrador. Paralelamente, o enredo tradicional, com começo, meio e fim, perde importância e as ações servem, principalmente, de mote para o tratamento de certas particularidades do tipo enfocado. Este é tomado, via de regra, como a figurativização de determinados conceitos discutidos pelo escritor, tendo em vista a recuperação de certos lugares-comuns sertanejos segundo pressupostos governamentais.

Contudo, diferentemente do relato sobre o famoso coronel nordestino, em tais narrativas predomina o efeito de ficção uma vez que, pensando-se prioritariamente na categoria “personagem”, são perfilados tipos desconhecidos, sem referência específica no mundo

\footnotetext{
673 "Foi um pernambucano pioneiro que ensinou o caminho da verdadeira solução da energia elétrica e força matriz para Pernambuco, Delmiro Gouveia, indo montar sua indústria de linhas na Pedra, ao pé da Cachoeira de Paulo Afonso”. In: A ECONOMIA dos Estados - II) Pernambuco. Cultura Política, Rio de Janeiro, ano 1, n.8, out. 1941, p.142.

${ }^{674}$ Classificação sugerida por Carl H. Grabo em The art of short story (Charleston, SC: Bibliolife, 2009; livro publicado originalmente em 1913, pela editora Scribner's).
} 
“concreto”, quase sempre nomeados imprecisa e arquetipicamente apenas pela função que exercem na sociedade, acompanhada de um qualificativo. Mais especificamente, este é o caso dos textos “O moço da farmácia”, “Funcionário independente”, “Um homem notável”, “Um antepassado” e “A decadência de um senhor de engenho”. Apesar de individualizar as figuras, o narrador parece tratá-las enquanto protótipos, modelos imagéticos, reproduzíveis em todo o interior do país, que corroborariam tanto a idéia que constrói sobre o lugar, como o ajuste desta às tópicas estadonovistas.

Em outras palavras, o narrador imagina uma situação ou um personagem e o descreve, orientando-se por coordenadas sócio-culturais específicas, mas sem apegar-se a um referente historicamente avalizado. Mediante tal procedimento, demonstra imitar a imitação, produzindo um conhecimento, não especificamente do lugar ou das pessoas, mas da ficção do lugar e das pessoas, ou seja, das práticas e discursos que lhes infundiam especificidade.

Como se descrevesse em palavras um quadro imagético por ele mesmo inventado, em parentesco com o princípio norteador da ekphrasis antiga, o artista produziria imagens fictícias de espaços, tipos e situações, as quais, por sua vez, não deixariam de ser compostas de topoi conhecidos de seus leitores, o que, por sua vez, conferiria verossimilhança a seus textos $^{675}$. Por outro lado, estes não se pretendiam apenas verossímeis, mas verdadeiros, como o próprio nome da seção faz questão de salientar, pois, contrariamente ao que prescrevia o referido artifício retórico, presumiam a existência empírica dos objetos e seres representados ${ }^{676}$. Em todo o caso, mesmo diante de tal pressuposto, pode-se dizer que os relatos do escritor não representariam a realidade nordestina stricto sensu; na verdade, eles particularizariam e elaborariam artisticamente aspectos, temas e enunciados cristalizados nos discursos sobre a região, produzindo, assim, o efeito de ilusão especular.

Consequentemente, seus textos de Cultura Política, estariam muito mais próximos, no que diz respeito ao gênero (não quanto ao diálogo com as prerrogativas governamentais ou quanto ao enquadramento regionalista da seção), dos contos Insônia do que, por exemplo, das crônicas de Linhas Tortas. Publicado em 1947, Insônia reúne narrativas de cunho ficcional, nas quais as ações são reduzidas; histórias sem muito movimento, quase sempre focadas na sondagem

\footnotetext{
${ }^{675}$ Faz-se referência aqui a tal princípio mimético geral, não à especificidade da técnica da ekphrasis propriamente dita, cuja descrição exaustiva pode ser encontrada no artigo "Categoria epidíticas da ekphrasis" de João Adolfo Hansen (Revista USP, São Paulo, n.71, set./nov. 2006, p.85-105).

${ }^{676}$ HANSEN, João Adolfo. op.cit. p.88.
} 
do universo íntimo de uma única personagem. Mesmo quando tomam lugar outros tipos, a função deles é, prioritariamente, corroborar a investigação interna do protagonista, como se o narrador procurasse revelar o mecanismo interior de cada criatura, povoada de uma multidão de imagens ${ }^{677}$. Assim, Graciliano parece trilhar caminho semelhante ao de Tchekhov, privilegiando contos sem grandes acontecimentos, mas marcados por certa densidade existencial (e no seu caso, social, tendo em vista a tomada dos personagens como estratégia de particularização de tópicas condizentes com o universo sertanejo), nos quais registra os eventos numa sucessão de quadros, como se produzisse um mosaico seqüenciado. Em tal movimento, secundariza a construção tradicional, que previa uma ação, com desenvolvimento, clímax e desenlace.

A aproximação entre os textos de Cultura Política e Insônia leva em conta, deste último, não o volume como um todo, mas, mais especificamente, os escritos focados no exame de uma figura específica, ou seja, aqueles que se aproximam da referida categoria de conto de personagem (retrato). Tais narrativas apresentam ainda um narrador em terceira pessoa onisciente, nos moldes daquele que prevalece nos “Quadros e Costumes do Nordeste”. Elas ocupam a maior parte da obra em questão. São elas “Um ladrão”, “Luciana”, “Minsk”, “A prisão de J. Carmo Gomes”, “Dois dedos”, “A testemunha”, “Ciúmes” e “Um pobre diabo" ${ }^{\prime 678}$.

Apesar da aludida semelhança entre os textos da publicação getulista e do referido livro de contos, avultam também diferenças, condizentes, sobretudo, com as condições específicas de produção e veiculação de uns e outros. Os escritos de Insônia, saídos integralmente em revistas literárias ou suplementos especializados de jornais (ver apêndice, com a lista de textos de Graciliano publicada na imprensa), além de não se ajustarem a uma seção específica, não cumpriam uma finalidade imediata, estendendo-se ainda por um número maior de páginas. Nesse sentido, apresentavam maior liberdade na escolha de temas e figuras (sem referências ou mesmo alusões ao universo sertanejo, por exemplo), bem como um processo mais efetivo de exame das disposições e motivações internas das personagens, com privilégio

\footnotetext{
677 BOSI et. al. Graciliano Ramos, p.137.

${ }^{678}$ Insônia apresenta ainda outras cinco narrativas, inclusive aquela que lhe dá o título: "Insônia”, “O Relógio do Hospital”, "Paulo”, “Silveira Pereira” e "Uma visita”. As quatro primeiras são conduzidas por um narradorprotagonista, que via de regra, lança mão da técnica do monólogo interior, como forma de expressar e investigar suas motivações internas, bem como a urdidura do tempo que as rege. Já a última, escrita sob uma perspectiva cubista, apresenta uma mesma cena por pontos de vista diferentes, compondo quadros diversificados das personagens participantes da ação dirigida por um narrador onisciente.
} 
para a utilização dos recursos da análise mental e do discurso indireto livre, entre outros, abrindo-se a certa dose de experimentalismo. Nos "Quadros e costumes do Nordeste”, os dois últimos expedientes também estavam presentes, sobretudo a introdução de uma multiplicidade de vozes mescladas à fala do narrador, porém em escala reduzida, tendo em vista o espaço mais limitado e as restrições editoriais do periódico getulista. Além disso, a sondagem interna dos tipos sertanejos perdia espaço para a investigação das práticas e procedimentos das quais eles participavam enquanto agentes particularizadores. Ao mesmo tempo, em Cultura Política, o narrador onisciente se mostrava mais intrusivo (sobretudo didático), comentando e explicando situações relacionadas à atuação das figuras ou ao universo sertanejo presumido de que elas faziam parte.

Nos “Quadros e Costumes do Nordeste” também avultam textos passíveis de serem enquadrados, prioritariamente (ou seja, não de maneira absoluta), como contos anedóticos ou de enredo. Tal categoria narrativa, estabelecida, sobretudo, a partir da tradição instaurada pelo escritor francês Guy de Maupassant, caracteriza-se pela construção de uma estória breve, concentrada e com desfecho surpreendente. Ao priorizar uma única célula dramática, apresenta unidade de ação, ou seja, seu enredo resume-se a um só conflito que se sobrepõe aos demais componentes da estória. Assim, diferentemente da elaboração de perfis, vista acima, nesta modalidade textual o interesse por um acontecimento específico não é suplantado por outros focos de atenção, representados pelas próprias personagens ou pelo ambiente, por exemplo.

Tal gênero predomina em algumas colaborações, tais como "Bagunça”, "Desafio”, "Uma visita inconveniente” e “Teatro I”. No caso específico desta última, tem-se a história da construção de uma casa de espetáculos numa modesta capital nordestina, conduzida pelas mãos do governador do Estado, um tipo individualista, interessado apenas em sua autopromoção. Depois de apresentar, nos parágrafos iniciais, a localidade, a figura do político e as intenções deste, o narrador, caracterizado pela onisciência de sua focalização total, dedica-se à exposição da ação norteadora da narrativa:

Tudo ponderado, S. Exa. resolveu edificar um teatro. Era o que necessitava a capital. Davam-se ali representações de amadores, apareciam, com modéstia, companhias cambembes, cinemas vagabundos, mágicos e hipnotizadores. Espetáculos verdadeiros não se conheciam. 
O projeto foi bem recebido, cresceu. Mas para executá-lo faltava numerário. Pouco se podia esperar do orçamento minguado, tão minguado que os tipos mais volumosos ganhavam, aparentemente, uma insignificância. Impossível aumentar a receita, pois os amigos não pagavam impostos e os inimigos, espremidos, estavam secos. Assim os agentes políticos arrancavam dos proprietários numerosos presentes para o governador no aniversário dele. Na de presentes e discursos: valores ${ }^{679}$.

Apesar de possuir unidade de espaço, o texto, assim como seus congêneres supracitados, foge das coordenadas esperadas do conto clássico no que diz respeito à reivindicada unidade de tempo. Ao invés de privilegiar o presente e acompanhar os acontecimentos como se ocorressem no momento em que os apresenta ou operar um breve recuo ao passado, o narrador traça uma espécie de panorama da construção do edifício. Mediante debreagens enunciavas de tempo, o enunciador constrói uma instância narrativa que recupera sucessos pregressos, produzindo o efeito de afastamento e objetividade. No entanto, ao final, referindose ao dinheiro conseguido no exterior para o pagamento da obra, acaba atualizando o relato:

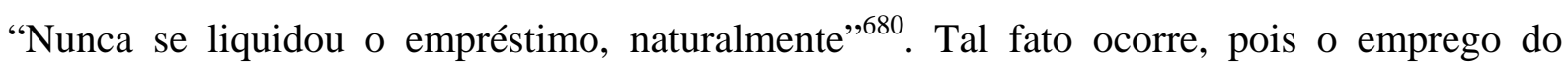
pretérito de hábito ou gnômico (“liquidou”, acompanhado do advérbio “nunca”) faz com que o ponto de referência erigido no passado avançasse até o momento de enunciação presente na expressão de uma verdade geral.

Além disso, apesar de a exposição do acontecimento sobrepor-se aos demais elementos, o tratamento da figura do governador, feita parágrafos antes, rivaliza em importância com as ações descritas; parte do protagonista a iniciativa de construir o teatro. E mais; como subjaz em todo o texto, a trajetória dele pode ser tomado como uma particularização da idéia de administrador canalha, aludindo, portanto, ao desinteresse geral da classe política pelo bem coletivo.

Em caráter episódico, os “Quadros e Costumes” apresentavam também passagens de cunho memorialístico, ensaiando um processo que seria concretizado, alguns anos depois, com o volume Infância ${ }^{681}$. Trata-se dos escritos pontuais “Ciríaco” e "Um antepassado”, que, se se levar em conta tal semelhança com o supracitado volume de memórias infantis, também se

${ }^{679}$ RAMOS, Graciliano. Quadros e Costumes do Nordeste VII, Cultura Política, Rio de Janeiro, ano 1, n.7, set. 1941, p. 264. Presente ainda em Viventes das Alagoas, com o título referido acima “Teatro I” (Rio de Janeiro: Record, 2007, p.55).

${ }^{680}$ Idem, ibidem. (In: Viventes das Alagoas, p.57).

${ }^{681}$ Infância fora lançado pela José Olympio em 1945, mas já vinha sendo publicado na imprensa desde o final dos anos de 1930. Para mais informações, ver, entre os anexos, a lista de trechos das obras ficcionais de Graciliano saídas primeiramente em periódico. 
afastariam de um possível enquadramento cronístico tradicional. As duas narrativas, estampadas em Cultura Política, procuram traçar perfis dos personagens a que se referem, ao mesmo tempo em que estão centradas numa única ação de caráter anedótico, conduzida por um narrador que participa da história enquanto personagem. Este se faz presente no texto mediante a instauração, no enunciado, de debreagens enuciativas de pessoa, na recuperação de lembranças de sua juventude (espaço e tempo enuncivos). Em outras palavras, o eu-narrante (na temporalidade da narração) localiza os acontecimentos no passado ao mesmo tempo em participa destes na qualidade de eu-narrado.

Pela lógica cronística da seção, este "eu” inscrito no enunciado pressupõe a figura do autor implícito que assina os textos dos “Quadros e Costumes”; o mesmo que, desde 1938, vinha recriando quadros de sua meninice em colaborações para outros veículos da imprensa carioca, que depois seriam incorporados ao volume Infância (ver listagem dos escritos de Graciliano publicados na imprensa, em anexo). Nesse sentido, em experiências sucessivas, ele acabava construindo um simulacro de si no interior de tais relatos ${ }^{682}$, pressupondo, pelo pacto autobiográfico, a identificação entre enunciador, narrador e ator.

Além disso, a vinculação dos dois textos de Cultura Política à trajetória de vida do autor dáse também por vias externas e documentais. Por meio de suas cartas, sabe-se que as duas narrativas inscrevem-se na biografia do artista no momento em que ele, por volta dos 18 anos de idade, foi se recuperar de uma moléstia na fazenda de sua avó materna, Teresa Ferro, perto de Buíque, no sertão Pernambucano. Em ambos os escritos, o narrador faz referência ao fato de ter se recolhido a uma propriedade rural familiar para restabelecer-se de uma "doença teimosa”.

Se por um lado avultam semelhanças temáticas e estilísticas entre as memórias infantis e os dois textos dos “Quadros e Costumes do Nordeste” referidos, sobretudo, no que diz respeito à ficcionalização de passagens da vida do autor, localizadas no sertão, por outro, devem-se ressaltar as diferenças. Em Infância, os personagens que nomeiam diversos capítulos da obra (“Padre João Inácio”, “O moleque José”, “José da Luz”, “D. Maria”, “Meu avô”, “Chico

\footnotetext{
${ }^{682}$ Nunca, portanto, trata-se do autor de carne e osso, pois como destaca Bakhtin: "Mesmo se ele (autor) escrevesse uma autobiografia ou a mais verídica das confissões, como seu criador, ele igualmente permanecerá fora do mundo representado. Se eu narrar (escrever) um fato que acaba de acontecer comigo, já me encontro, como narrador (ou escritor), fora do tempo-espaço onde o evento se realizou. É tão impossível a identificação absoluta do meu "eu" como o "eu" de que falo, como suspender a si mesmo pelos cabelos" (BAKHTIN, Mikhail. Questões de literatura e estética: a teoria do romance. São Paulo, Hucitec,1998, p. 360).
} 
Brabo”, “José Leonardo”, “Minha irmã natural”, entre outros) são utilizados, sobretudo, enquanto elementos caracterizadores do narrador-protagonista em seu processo de formação, segundo as preceptivas do registro biográfico adotado. Geralmente, tais figuras funcionam como especificadores de impressões, pensamentos, sensações, percepções e da visão de mundo da criança imaginada e investigada por Graciliano, que parece compor suas memórias infantis para justificar o perfil de escritor construído até o momento de redação das mesmas. Trata-se de uma espécie de hermenêutica de si, por meio da qual o artista procura dar inteligibilidade e articulação aos quadros do passado, segundo uma perspectiva do presente. Em segundo plano, mas não menos importante, os tipos funcionam como índices caracterizadores da ambiência sertaneja, bem como de práticas e costumes locais, privilegiados no relato.

Já nos “Quadros e costumes do Nordeste" que apresentam a figura de um narrador protagonista ocorre o inverso. As personagens apresentam maior autonomia, sobrepujando a figura do narrador em primeira pessoa, não mais um menino no processo de descoberta do mundo a sua volta, mas um jovem urbano, na iminência de entrar na fase adulta, que apenas realizava uma visita ocasional às paragens interioranas e deparava-se com um universo que não seria mais o seu. Os escritos tematizam tal interação entre este jovem ilustrado e o ambiente rústico, bárbaro, porém cheio de vida do “hinterland brasileiro”, em contraposição ao artificialismo atribuído à vida na cidade. Como se verá a frente, as figuras enfocadas podem ser tomadas como encarnação de tópicas condizentes com o espaço sertanejo, corroborando para especificá-lo e para produzir um saber sobre ele: Ciríaco representaria o aspecto tacanho e desconfiado da população rural; seu bisavô materno particularizaria a pureza e o vigor, atribuídos ao sertão, enquanto repositório da nacionalidade, ao qual o enunciador se dirigia para recobrar as forças.

A título de comparação, tomem-se trechos do capítulo "Meu avô", de Infância e do texto "Um antepassado”, publicado em Cultura Política, escolhidos em função da semelhança temática e situacional: ambos tratam do encontro do narrador com um ancestral familiar. Contudo, a apresentação deste dá-se de maneira diferente em cada escrito:

\footnotetext{
Meus tios pequenos se distanciavam, corriam na catinga, abandonavam-me ao capricho de meu avô, que me jungiu à prosa do Barão de Macaúbas e ao catecismo, trazidos na carona de Sarapo. Mas o velho dava às letras nomes desconhecidos, lia de forma esquisita — e eu lamentava a ausência de d. Maria, a
} 
excelente mestra que me deixava errar, murmurava conselhos com doçura, como se pedisse desculpa. Meu avô era exigente. Detinha-se numa desgraçada sílaba, forçava-me a repeti-la, e isto me perturbava. As longas barbas brancas varriam-me a cara assustada; os olhos azuis, repletos de ameaças, feriam-me; a voz engrossava, rolava, entrava-me nos ouvidos como um trovão fanhoso e encatarroado. Os meus conhecimentos debandavam; as linhas misturavam-se, fugiam; no papel e dentro de mim grandes manchas alargavam-se. Nessa deplorável situação, eu embrulhava estupidamente a leitura, balbuciava respostas insensatas. O grito ribombava, enchia-me de pavor, transformava-se pouco a pouco numa gargalhada imensa que atraía gente e me encabulava. A alegria ruidosa parecia-me intempestiva: as minhas tolices não tinham graça (Infância, Rio de Janeiro: José Olympio Editora, 1953, p.125).

O velinho apeou, entregou o cavalo a um moleque, subiu os degraus do copiar, avizinhou-se do banco onde me distraía olhando, na preguiça e no calor as secas do curral, a serra distante, as árvores torradas, os xique-xiques e os mandacarus que manchavam de salpicos verdes a campina amarela.

- É você o meu bisneto?

Ergui-me, atentei no corpo musculoso e aprumado, na boca enérgica, no rosto liso e vermelho, rosto de criança.

- Talvez seja. Cheguei ontem e não conheço ninguém por estes arredores. Tenho um bisavô do outro lado do rio. Talvez seja o senhor. Não sei.

- Sou eu mesmo. Vim fazer-lhe uma visita (Cultura Política, Rio de Janeiro, ano 2, n.14, abr. 1942, p.197).

No primeiro excerto, avulta o tratamento da personagem como forma de especificar e caracterizar o narrador-protagonista, segundo a perspectiva do eu-narrante. Para tanto, ele retoma a situação em que o avô lhe impingia, de maneira áspera e agressiva, a leitura da cartilha do Barão de Macaúbas, o que lhe causara mais uma experiência traumatizante. Esta vinha se somar às demais, que permeiam o livro, na composição e na legitimação de sua personalidade artística conhecida no momento da escritura de Infância, marcada por algumas características, tais como pessimismo, rabugice, sofrimento, desamparo, violência, laconismo, a dificuldade do trabalho intelectual. Portanto, o capítulo do livro do qual foi retirado o trecho, assim como os outros da obra, simula recuperar aspectos, momentos e situações decisivas do processo de formação do escritor que redigia e ordenava suas memórias, segundo o protocolo autobiográfico. 
No segundo trecho, apesar de participar da narrativa enquanto personagem (o texto é todo elaborado no modo dramático), o enunciador estaria mais próximo de uma testemunha do que de um protagonista efetivo, servindo de contraponto para a caracterização de seu bisavô que dá nome à narrativa. Este ocupa a posição central, funcionando, alegoricamente, como forma de particularizar determinados aspectos do interior, tais como a rusticidade e o estatuto de manancial de tradições do lugar. Portanto, o texto se coloca mais como uma forma de compreender aquele vivente inculto e impoluto e, por meio dele, o próprio sertão que ele encarnava.

Lejune propõe uma diferença entre a autobiografia e as memórias. Enquanto a primeira narraria a história de uma personalidade, de um ponto de vista mais íntimo e pessoal, nas segundas o "eu" figuraria mais como testemunha de um processo que ultrapassaria sua vida individual $^{683}$. De acordo com tais coordenadas, enquanto Infância seria um relato autobiográfico, conduzido por um narrador-protagonista, as duas narrativas publicadas em Cultura Política, decorrente de seu caráter testemunhal nas apresentações dos referidos tipos, podem ser descritas como memórias.

Além disso, apesar do caráter fragmentário e compósito de Infância, os capítulos da obra articulam-se entre si, apresentando soluções de continuidade, coisa que não acontece com as colaborações de Cultura Política. Enquanto “Ciríaco” é publicado na edição de número 5, em julho de1941, “Um antepassado” aparece somente nove meses depois, na 14 edição da revista. Apesar do caráter genérico dos topônimos, cronônimos e antropônimos empregados, pode-se apenas inferir que os textos decorrem de experiências coetâneas de um mesmo narrador-protagonista, em visita a uma propriedade sertaneja, pois apresentam o mesmo mote e uma localização espacial semelhante, mas sem especificações temporais precisas ${ }^{684}$.

Há, contudo, textos que preterem o esquema narrativo, priorizando ou tratamento mais abrangente das tópicas sertanejas e regimentais, sem necessariamente concretizá-las numa história única e exemplar (dissertação), ou a construção de quadros com privilégio para a simultaneidade descritiva. No primeiro caso, têm-se pequenos ensaios sociológicos e históricos com predomínio da função didática, nos quais o artista discorre sobre determinadas

\footnotetext{
${ }^{683}$ LEJEUNE, Philippe. L'autobiographie en France. Paris, Armand Colin, 1971, p.15.

${ }^{684}$ Destaque para as semelhanças na descrição do quarto ocupado pelo narrador tanto em um quanto no outro texto. Tratava-se de aposentos que contavam com reboco, “ordinário e rachado", em meio a uma residência toda feita em "taipa negra e revestida de pucumã".
} 
práticas interioranas, tais como os escritos “Transação de cigano" e “Casamentos”. Ambos procuram explicar o mundo sertanejo a que se referem, classificando-o, ordenando-o e estabelecendo relações e dependências entre os elementos apresentados. Não aqui a preocupação em delimitar uma realidade no tempo, mas sim o de apresentá-la sob seus aspectos gerais, desvinculada de uma linha temporal específica. Nesse sentido, são colaborações caracterizadas por certa noção de atemporalidade, cuja marca principal é a utilização do tempo presente. Tome-se, por exemplo, os dois parágrafos iniciais de "Casamento":

Para a realização do casamento há solenidades curiosas no interior do Nordeste. O matuto, conservador, resigna-se às maçadas impostas pela tradição, vê nelas o meio de tornar-se uma criatura perceptível aos seus próprios olhos e à sociedade. Apenas, como é prudente, desconfiado, econômico, tenta obtê-las com despesa módica, se possível à crédito, forma que em geral adota em suas transações.

Certamente os aperreios são necessários: banhos, ajuste com o padre, idas e vindas, conversas longas, cálculos que estragam o miolo, roupa de cassineta, um guarda-chuva, botinas, colarinho, gravata, sem falar nas trapalhadas na casa do sogro, o enxoval e a festa. Isso, porém, consome tempo e esgota as reservas: só se efetua com rigor entre indivíduos que possuem um pedaço de terra, algumas vacas, chiqueiro de bodes. Na miuçalha do campo as exigências são menores. Dispensa-se o contrato civil, por ausência de propriedade. E se os noivos se relacionarem intimamente, será possível também suprimir a grinalda e o véu. Surgem novas concessões, a coisa finda longe das fórmulas autorizadas. Realmente não finda: o casal tem o intuito de regularizar a situação num futuro incerto, quando os negócios andarem bem ${ }^{685}$.

Tal ênfase predicativa e interpretativa, que procura categorizar a instituição social do casamento no interior nordestino mediante determinada logicidade argumentativa, já estava presente nas colaborações publicadas por Graciliano na revista Observador Econômico $e$ Financeiro, alguns anos antes de iniciar seu trabalho em Cultura Política. Nelas discorreu de maneira mais alongada sobre certos aspectos da vida sertaneja, com preferência para assuntos mais conhecidos do público carioca, como o cangaço e a seca ${ }^{686}$.

\footnotetext{
${ }^{685}$ RAMOS, Graciliano. Quadros e Costumes IV. Cultura Política, Rio de Janeiro, ano 1, n.4, jun. 1941, p.221. In: Viventes das Alagoas. Rio de Janeiro: Record, 2007, p.37-38.

${ }^{686}$ Refere-se, aqui, mais especificamente aos textos "A propósito da seca" e "O fenômeno do cangaço", saídos na revista carioca Observador Econômico e Financeiro, respectivamente em fevereiro de 1937 e outubro de 1938. Tal periódico de orientação direitista, criado nos moldes da publicação norte-americana Fortune por Valentim Fernandes Bouças, secretário do Conselho Técnico de Economia e Finanças do Ministério da Fazenda, era dirigido pelo economista Olímpio Guilherme, presidente do Conselho Nacional de Imprensa e um dos diretores do Departamento de Imprensa e Propaganda (DIP) (In: MENDONÇA, Marina Gusmão de. Imprensa e política no Brasil: Carlos Lacerda e a tentativa de destruição da Última Hora. Histórica - revista eletrônica do
} 
No que diz respeito aos quadros predominantemente descritivos, prevalece a caracterização de figuras, práticas ou cenas, sem transformações de estado aparentes, como se os enunciados arrolassem ocorrências simultâneas, num certo tempo estático, que é reproduzido pelo artista. Apenas relembrando, na elaboração dos perfis aludidos acima, segundo o registro do conto de personagem, subjaz uma ação norteadora, sob a qual a imagem do tipo enfocado predomina. Neste caso, não há uma seqüência de acontecimentos eclipsados por um protagonista, mas tão somente a utilização de procedimentos ecfráticos na apresentação de pessoas, espaços ou situações, segundo determinada idéia de imobilidade. O exemplo mais gritante pode ser observado na crônica "Habitação”:

Aqui vai com os pormenores inúteis do realismo, a descrição duma casa sertaneja, vista há algum tempo nos cafundós de Pernambuco.

Baixa, de taipa, cheia de esconderijos, lúgubre. O teto chato, acaçapado, quase sem declive, é negro; é negro o chão sem ladrilho, de terra batida, esburacado e sujo; negras as paredes sem reboco, com o barro que as reveste a rachar-se, deixando ver aqui e ali o frágil madeiramento que serve de carcaça.

Três portas de frente e suas janelas. As portas têm altura suficiente para que possa entrar uma pessoa de média estatura sem curvar-se. As janelas, aberturas pequenas, quase quadradas, estão situadas lá em cima, perto da telha. Para atingi-la, trepa-se a gente a um caixão. Tem dobradiças de couro e trancam-se com pedaços de pau roliços, envernizados pelo uso, que se introduzem em buracos abertos nos batentes, presos a cordéis amarrados em pregos. As portas fecham-se interiormente com taramelas ${ }^{687}$.

Centrado em procedimentos como a enumeração e a acumulação de caracteres, além da conectividade figurativa entre estes, o texto prossegue na apresentação detalhada de todas as dependências da tacanha residência rural, índice da precariedade reinante naqueles recantos. Tal visada topográfica-arquitetônica introduz um narrador presencial (anunciado logo nas primeiras linhas pelo enunciador), que simula descrever o espaço à medida que não só o vê, mas o percorre. Para tanto, concorre ainda a utilização do presente histórico como forma de

Arquivo do Estado, São Paulo, n.31, jun. 2008. Disponível em: <http://www.historica.arquivoestado.sp.gov.br/ materias/anteriores/edicao31/materia04/ > . Acesso em 06 out. 2009). Ligada ao Estado Novo e, em certo sentido, semelhante à Cultura Política, dedicava-se ao estudo dos problemas nacionais, reunindo artigos extensos, escritos tanto por intelectuais renomados, como Gilberto Freire e o próprio Graciliano, como por técnicos nas respectivas áreas abordadas.

${ }^{687}$ RAMOS, Graciliano. Quadros e Costumes VI. Cultura Política, Rio de Janeiro, ano 1, n.6, ago. 1941, p.259. In: Viventes das Alagoas. Rio de Janeiro: Record, 2007, p.47-48. 
atualizar e acentuar tal visualidade do relato ecfrático, de acordo com as prerrogativas do símile horaciano, orientadoras do artista.

A somatória dos recursos empregados acaba por imprimir ao discurso a marca de um simulacro do mundo (efeito de real), como se houvesse correspondência imediata entre um e outro (não por acaso o autor refere-se aos "pormenores inúteis do realismo", ironizando o efeito que produz). Ao mesmo tempo, os expedientes retóricos empregados permitem a sequencialização dos enunciados, ou seja, a continuidade do processo mimético evocado pelo próprio texto. Apenas ao final, nos dois últimos parágrafos, o enunciador torna a aparecer de maneira direta no relato, como no início, para completar a moldura na qual se inseria o quadro descrito; ele indica quem vivera ali ("uma família decente, religiosa e pastoril, domesticada no regime patriarcal”688 ) e qual o provável destino da habitação pictorializada: tornara-se ruína.

\subsection{O estatuto de "real" dos textos}

Além dos dois últimos gêneros textuais abordados (pequenos ensaios de caráter dissertativo e quadros ecfráticos), predominam nos “Quadros e Costumes do Nordeste”, como visto acima, escritos de caráter narrativo, que mais se aproximariam das modalidades do conto [especialmente do conto de personagem (retrato) e do conto anedótico], e, em menor escala, da ficcionalização das memórias, em trabalho semelhante ao realizado em Infância. Na verdade, no mais das vezes a dissertação e a descrição são procedimentos integrados de modo orgânico às narrativas, demarcadores de suas fronteiras, que lhes infundem certo caráter didático e referencial e acabam por reforçar o efeito de real das mesmas.

Nesse sentido, para além do aludido status ficcional atribuído aos textos, eles são construídos segundo certo registro realista, com ênfase na tematização, mas, sobretudo, na figurativização (catalogadora), que procura produzir o efeito de ilusão referencial. Do ponto de vista actancial, a construção deste simulacro da realidade efetua-se por meio de um movimento articulado: de um lado tem-se o distanciamento do narrador mediante o emprego de debreagens enuncivas de pessoa e de tempo, o que acaba produzindo a sensação de objetividade; de outro, apesar de não dizer "eu” os posicionamentos do enunciador se fazem presentes pelas marcas da enunciação enunciada que deixa ao longo dos textos (destaque para

\footnotetext{
${ }^{688}$ Idem p.260. In: Idem, p.51.
} 
a escolha lexical, como a utilização de adjetivos e advérbios apreciativos, certos verbos e substantivos carregados de subjetividade, alguns dêiticos, entre outros), gerando a impressão de que quem fala teria familiaridade com o universo representado. Tome-se o trecho:

Residia no interior e tinha duas qualidades que lhe adoçaram a vida, e eximiram de inquietações: era branco e analfabeto.

Se não fosse branco, nivelar-se-ia à canalha da roça, mais ou menos cabocla, mais ou menos preta, sentir-se-ia pequeno, disposto à obediência. Se não fosse analfabeto, consumir-se-ia em exercício inúteis à lavoura do algodão e da mamona, leria romances e telegramas da Europa, alargaria pelo mundo, à toa, pensamentos improdutivos ${ }^{689}$.

Os adjetivos “branco”, “preta”, “cabocla”, “pequeno”, a expressão qualificativa “disposto à obediência” e o substantivo “canalha” de um lado; “analfabeto”, “inúteis”, “improdutivos” e o advérbio “à toa”, do outro. Tais percursos figurativos diferentes marcam de maneira irônica a presença do enunciador no enunciado, no que diz respeito, respectivamente, ao tratamento de questões de cunho racial e educacional, de acordo com uma focalização sertaneja: ele parece apresentar o personagem, segundo as coordenadas dos próprios habitantes do interior, especificamente a elite local, como se a voz daqueles rincões ecoasse em sua fala aparentemente distanciada. É por esta perspectiva que se refere à suposta inferioridade dos negros e ao analfabetismo como meio de aproximar-se da realidade imediata. Ao mimetizar e incorporar, por um viés satírico, a maneira tacanha de pensar e as categorias de valor do lugar, o narrador em terceira pessoa acaba produzindo o efeito de aproximação da história enfocada.

Tal contigüidade aparente é reforçada ainda pela utilização de outros recursos com destaque para a ironia e o discurso indireto livre. Por meio deles tanto satiriza discursos quanto introduz vozes de atores presentes àquele universo, indiciando seu domínio sobre os objetos que apresenta aos leitores.

Constrói-se, portanto, para o enunciatário a imagem de um enunciador testemunha, que apesar de seu afastamento temporal do material narrado, ainda o mantém vivo em sua lembrança, ressaltando-se sua confiabilidade e conhecimento das matérias sobre as quais se debruça. Tal posicionamento se reforça mediante a utilização dos expedientes dissertativos e descritivos

\footnotetext{
${ }^{689}$ RAMOS, Graciliano. Um homem notável, Cultura Política, Rio de Janeiro, ano 3, n.27, maio 1943, p.159. In: Viventes das Alagoas. Rio de Janeiro: Record, 2007, p.119.
} 
tratados acima. Mais especificamente, além da referida ênfase enumerativa e catalogadora, os “Quadros e Costumes do Nordeste” são permeados por comentários de cunho didático, que procuram situar os personagens, espaços e situações particularizadas, num enquadramento mais geral, de "verdades” quase atemporais sobre o mundo sertanejo. Nesse processo, destaca-se a utilização pontual do chamado presente omnitemporal ou gnômico. Este apresenta um momento de referência é ilimitado, pressupondo, em regra, um "sempre” implícito. Tome-se o trecho extraído do escrito “Um gramático”. Em meio à elaboração do perfil da figura que nomeia o texto, o narrador, mediante a estratégia argumentativa da exemplificação, procura aproximá-la de outros tipos interioranos que também poderiam ser tomados como símbolos da ciência canhestra, mas corajosa dos sertanejos nordestinos:

\footnotetext{
Quando alguém, naquela região dura de espinho, deseja construir uma casa, pega lápis e papel, traça firmes as paredes, as portas, as janelas, o copiar, as salas e as camarinhas. Escolhe o material e dirige os carpinteiros e os pedreiros, que executam, sem regras complicadas, uma espécie de habitação. Não se consulta arquiteto. Realmente não existe arquiteto no lugar. Se existisse, porém, seria desprezado, pois quem vai morar na casa é o proprietário - e não há razão para submetê-lo ao gosto de pessoas estranhas. As paredes ficam baixas, as portas e janelas pequenas, os quartos escuros. Foi assim que sempre se fez e não se modifica a tradição ${ }^{690}$..
}

Ao apresentar o exemplo de maneira assertiva, revestindo-o de uma suposta verdade (que se não era imutável, prolongava-se até seu momento de enunciação), o narrador reforça o efeito de ilusão referencial, construindo justificativas que embasavam sua história e conceituavam melhor o universo sócio-histórico no qual ela se situava. Paralelamente, deixa clara também sua função ideológica ao discorrer sobre o narrado.

No que diz respeito aos textos de cunho memorialístico, a ilusão referencial é produzida, sobretudo, pela pressuposição de identidade, de acordo com a lógica da seção, entre o autor que assina as crônicas e o narrador, bem como entre este e o ator que participa da história, ambos referidos pelo mesmo pronome “eu” (ou seja, uma debreagem enunciativa do enunciado). A utilização de topônimos, antropônimos e cronônimos, bem como certa ênfase descritiva na caracterização dos mesmos, também colaboram para a produção do efeito de

\footnotetext{
${ }^{690}$ RAMOS, Graciliano. Quadros e Costumes XVI. Cultura Política, Rio de Janeiro, ano 1, n.2, abr. 1941, p.321. In: Viventes das Alagoas. Rio de Janeiro: Record, 2007, p.96.
} 
realidade, pois situam lugares, pessoas e tempos, inscritos, de algum modo, nos relatos sobre a biografia do artista $^{691}$.

Portanto, pelo que foi visto até aqui, o referido realismo de “Graciliano” define-se como tal porque coincide com a utilização de artifícios de certa estética tida como realista, mas que não é necessariamente real. Ele imitaria discursos que produzem o efeito de verossimilhança, valendo-se, para isso, dos dispositivos retóricos listados acima. Com freqüência e de maneira equivocada, a crítica costuma cometer o erro epistemológico de tomar o efeito pela coisa em si, como se houvesse uma correspondência direta e imediata entre texto e mundo, sem mediação sígnica.

\subsubsection{A revista e o enquadramento cronístico}

Mas deve-se considerar também o efeito de real atribuído aos textos pela própria seção e pela revista de maneira geral. A imprecisão e, muitas vezes, o apagamento das coordenadas espaciais e actanciais, fato recorrente em muitos dos escritos (respectivamente, indeterminação da suposta correspondência geográfica das paisagens com o mundo e do lastro histórico dos personagens) seria contrabalanceado pelo caráter veredictório pressuposto pelo título da seção “Quadros e Costumes do Nordeste”. Esta procuraria enquadrar e conferir caráter documental aos cenários, situações, figuras e práticas descritas. Como referido anteriormente, são os próprios editores de Cultura Política, no paratexto de apresentação da primeira colaboração de Graciliano, que se referem ao trabalho do artista como “crônica”:

\footnotetext{
Escritor e romancista consagrado entre os melhores do Brasil de hoje, tendo enriquecido a nossa literatura de ficção com obras fortes e cheias de personalidade como São Bernardo, Angústia, Vidas Secas, Caetés, e com numerosos contos que se publicam incessantemente nos grandes jornais da Capital da República e dos Estados - o autor desta crônica tomou a seu encargo fixar quadros e costumes da região do Brasil onde nasceu e viveu mais de trinta anos: o Nordeste. Neste número inaugural, ele nos dá um flagrante da grande festa popular - o carnaval - tal como decorre nas cidades do interior
}

\footnotetext{
${ }^{691}$ Em sentido oposto, a utilização do sistema enunciativo de pessoa, produz um efeito de subjetividade e aproximação entre enunciador e enunciatário, que, se não apaga a ilusão referencial, pode criar dúvidas, pois faz com que a história seja narrada por aquele que a viveu, ou seja, seu principal interessado (BARROS, Mariana Luz Pessoa de. A arquitetura das memórias - um estudo do tempo no discurso biográfico. 2006. 233f. Dissertação (Mestrado em Lingüística) - Faculdade de Filosofia Letras e Ciências Humanas, Universidade de São Paulo, São Paulo, 2006).
} 
nordestino. É um pequeno pedaço desse Brasil que ainda foge do ímpeto renovador da civilização litorânea, desse Brasil tão diferente e tão grande... ${ }^{692}$

Essa introdução explicativa, já citada anteriormente, serve de baliza para a leitura do trabalho a ser realizado pelo cronista, segundo as coordenadas governamentais. Por mais que a maior parte das colaborações do autor alagoano se aproximasse da estrutura ficcional do conto, como visto acima, ela explicita que o texto não teria um fim em si mesmo, mas deveria ser tomado como meio para outra coisa fora dele; seria uma forma de recuperar para os leitores urbanos "um pequeno pedaço desse Brasil que ainda fugia do ímpeto renovador da civilização litorânea”. Ao mesmo tempo, fica subentendido que o emissor das narrativas seria o autor mesmo (e não um suposto enunciador ficcional) e que tudo o que ele diz, supõe-se como tendo acontecido de fato. Daí viria o tom de veracidade jornalística e testemunhal imprimido ao relato: o autor seria o narrador que descreve as experiências que vê de forma direta, acentuando o chamado efeito de real.

Nesse sentido, como já visto, percebe-se a tentativa deliberada da revista de aproximar os textos de Graciliano da noção de documento, idéia basilar embutida no conceito de “crônica”. Outro dado que corrobora essa vinculação é que as narrativas faziam parte de uma seção maior da revista chamada "Evolução Social”, que procurava construir um grande painel do país, por meio da descrição de certas particularidades regionais. Por essa diretriz editorial, as crônicas deveriam ser tomadas mais como dados empíricos do que como escritos literários.

Em regra, a revista utilizava o termo "crônica” para se referir a uma ampla gama de colaborações, tratando-as segundo tal ponto de vista documental. Praticamente todos os escritos da macrosseção "Brasil, social intelectual e artístico"693 recebiam dos editores tal designação ${ }^{694}$ : os “Quadros e Costumes do Centro e do Sul”, de Marques Rebelo; os estudos sobre folclore, de Basílio Magalhães; a crítica literária realizada por Prudente de Morais Neto e Wilson Louzada; o exame da produção historiográfica brasileira, sob a responsabilidade de Hélio Viana; a recuperação da história literária nacional a cargo de Rosário Fusco; a crítica de cinema, de Lúcio Cardoso; o relato das pesquisas científicas no país, de Vieira Pinto; a crítica

\footnotetext{
${ }^{692}$ ESCRITOR e romancista... Rio de Janeiro, Cultura Política, ano 1, n.1, mar. 1941, p.236 (grifos do autor).

${ }^{693}$ Vale lembrar, conforme exposto no quarto capítulo, "Brasil, social, intelectual e artístico” abrangia a seção "Evolução social”, que, por sua vez, abarcava os "Quadros e Costumes do Nordeste”.

${ }^{694}$ No primeiro número de Cultura Política, todas as colaborações reunidas na seção "Brasil, social, intelectual e artístico” são tratadas como "crônica”, por seus respectivos paratextos introdutórios.
} 
teatral, de R. Magalhães Júnior etc. Nesse sentido, a palavra poderia se referir tanto a colaborações propriamente cronística, como no caso das participações do autor de A estrela sobre, como a textos dissertativos variados que poderiam ter como objeto, tanto as diferentes manifestações artísticas, como dados culturais, sociais e científicos.

Voltando ao paratexto de apresentação da colaboração de Graciliano, este sinaliza ainda que as matérias tematizadas por Graciliano estariam localizadas no passado: caberia a ele fixar os quadros e costumes da região em que "nasceu e viveu por mais de trinta anos"695. Subentende-se que o autor de Vidas Secas, estabelecido na capital federal, não retornaria à sua região natal e que seus relatos se apoiariam na figuração de suas lembranças ou em fontes históricas, que, por sua vez, não são explicitadas. Como se verá, o companheiro de seção de Graciliano na revista, Marques Rebelo, responsável pelos “Quadros e Costumes do CentroSul”, adota perspectiva diversa: ele assume e retrata a condição de viajante que se desloca até os espaços tematizados em seus textos. Nesse sentido, fica marcada sua posição de narrador como contemporânea aos fatos apresentados.

\subsubsection{O registro histórico}

De maneira mais específica, cabe examinar o efeito de real produzido pelo distanciamento do narrador e pelo recuo temporal por ele empreendido no tratamento das matérias sobre as quais se debruça. Em certo sentido, pode-se pensar que Graciliano, mediante tal procedimento, conexo a outros, como a produção dos efeitos de assertividade e de objetividade, aproximaria, em certo sentido, seu relato do discurso historiográfico ou ainda, mais vagamente, da experiência dos cronistas antigos. Entretanto, cabe analisar como isso ocorre, levando-se em conta a especificidade desse procedimento, bem como a recorrência com que ele era utilizado por outros escritores, sobretudo Manuel Bandeira, no momento de enunciação do escritor alagoano.

Se se considerar a hipótese de Davi Arrigucci, os textos de Graciliano para Cultura Política teriam seguido o rumo assumido pela crônica depois de 1930. Para o crítico, o gênero, após a Revolução de outubro, adequou-se à necessidade de pesquisa da "realidade” brasileira que aflorava nos meios intelectuais. Nesse sentido, passou a ser tomado como meio de mapear e

\footnotetext{
${ }^{695}$ Na verdade, mais de quarenta anos. Graciliano nasceu em 1892 e veio de maneira definitiva para o Rio de Janeiro com sua prisão em 1936.
} 
descobrir um Brasil heterogêneo e complexo, "largamente desconhecido de seus próprios habitantes, caracterizado pelo desenvolvimento histórico desigual”696. De acordo com Arrigucci, os textos passariam a dar destaque, por exemplo, à discrepância do processo de modernização que mesclava bolsões de riqueza com vastas áreas de miséria. Dessa maneira, a presença de certa “consciência abrangente do país” na crônica modernista justificaria o recuo ao passado para recuperar “retalhos da memória da nação”697.

O crítico parece ter razão quando se consideram, por exemplo, algumas crônicas de Drummond de Confissões de Minas (1944) e Passeios na Ilha (1954) e, principalmente, o livro Crônicas da Província do Brasil (1937), de Manuel Bandeira. Em inúmeros textos desta obra, o poeta relembra uma parcela passado do país (sobretudo o período colonial) que ou estava se perdendo ou era recuperada de maneira incorreta pelos atores sociais de seu momento de enunciação. Como explicita na "Advertência”, as crônicas reunidas no volume foram publicadas primeiramente nos jornais A Província, do Recife, Diário Nacional, de São Paulo e O Estado de Minas, de Belo Horizonte. Nomeia tais localidades como províncias, mas não vê tal designação como desabonadora. Pelo contrário, destaca que mesmo o Rio de Janeiro tinha uma alma de província, bem como todo o Brasil seria ainda provinciano. Em seguida, pede ironicamente a Deus para que conserve o país de tal maneira.

O uso do termo "província”, na medida em que inclui também a capital federal, parece se opor a "grandes centros estrangeiros", contrapondo aquilo que seria eminentemente local ao internacional. Ao mesmo tempo, tem um quê de passadista, pois recupera a divisão administrativa do país durante o Segundo Reinado. Tais inferências, somadas ao desejo de que o país se mantivesse provinciano, sinalizam a perspectiva nacionalista assumida pelo autor: a essência da brasilidade estaria no passado, na tradição. Nesse sentido, segundo o registro histórico adotado, elege espaços e costumes ditos provincianos como objetos de saber privilegiados, tomando-os como repositórios de elementos para a afirmação da identidade nacional em oposição às influências externas ${ }^{698}$.

\footnotetext{
${ }^{696}$ ARRIGUCCI JÚNIOR, Davi. Fragmentos sobre a crônica. In: Enigma e Comentário. São Paulo: Companhia das Letras, 2001, p. 63.

${ }^{697}$ Idem, ibidem.

${ }^{698}$ Suas considerações participam do debate em torno da criação do Serviço do Patrimônio Histórico e Artístico, fornecendo elementos orientadores para o desenvolvimento de políticas voltadas para a preservação da memória nacional. Não é à toa que o livro é dedicado a Rodrigo Melo Franco de Andrade, intelectual que conduziu a criação e a definição das bases de tal instituição.
} 
No texto de abertura, “De Vila Rica de Albuquerque a Ouro Preto dos Estudantes”, o cronista sinaliza que sua narrativa teria sido elaborada com base tanto em dados e impressões coletadas em loco ${ }^{699}$, como em relatos antigos, na grande maioria depoimentos de estrangeiros que passaram pela região das Minas Gerais, ao longo dos séculos XVIII e XIX, com destaque para Mawe, Saint-Hilaire e Burton. A partir deles reconstrói o perfil histórico da cidade. Como título sugere, propõe-se a abordar a localidade desde a fundação desta até a década de 1930, momento do qual escreve. Nesse processo, mostra-se aberto a interlocução, fugindo do distanciamento histórico habitual: em meio ao relato circunstanciado de fatos e costumes antigos o leitor é indagado constantemente pelo narrador, que lança questionamentos e comentários sobre a matéria narrada. Trata-se de um enunciador opinativo que vai norteando a maneira pela qual os destinatários devem retomar o passado. Por mais que respeite a ordem cronológica, seu relato é fragmentário, tal como um mosaico, que tem como peças outros textos e observações.

A narrativa interessada que o cronista empreende parte de um dado específico, observado em seu momento de enunciação: ele colocava-se contra o estilo chamado de neo-colonial, descrevendo-o como uma tentativa "afetada” (cheia de arrebiques) de recuperar a robustez, força e severidade da arquitetura do período que se estende da Colônia até o final do Segundo Reinado $^{700}$. As construções realizadas nesse espaço de tempo são apontadas pelo cronista como sendo autenticamente nacionais, pois nos sobradões pesados e nas frontarias barrocas algo de brasileiro teria começado a se firmar ${ }^{701}$, tendo em vista que os arquitetos procuraram se adaptar ao ambiente e as necessidades do país. Mais do que uma crítica ao novo estilo, seu texto coloca-se didaticamente como uma guia para a recuperação do passado de acordo com uma perspectiva valorização de matérias eleitas como definidoras da nacionalidade.

Ao tratar de Aleijadinho, em outra crônica, coloca-o como um dos maiores gênios brasileiros, pois ele teria produzido um estilo único, renovando e adaptando o "barroco" ao ambiente rude da região das Minas. Com o objetivo de recuperar a trajetória de vida do escultor, Bandeira baseia-se fundamentalmente no trabalho Traços Biográficos Relativos ao Finado Antônio Francisco Lisboa, de Rodrigo Bretãs, bisavô de Rodrigo Mello Franco de Andrade, a quem o

\footnotetext{
${ }^{699}$ O narrador se coloca como participante da história que relata: "Depois de conhecer Ouro Preto, tive curiosidade de ler as impressões dos viajantes estrangeiros que escreveram a respeito dela” (BANDEIRA, Manuel. Crônicas da província do Brasil. 1. ed. Rio de Janeiro: Civilização Brasileira, 1937, p.23).

700 "O fim do segundo império assinalou a decadência do espírito nacional na construção". O mau gosto teria assumido maiores proporções com a República, período apontado como sem nobreza em todos os sentidos.

${ }^{701}$ Idem, p.11-12.
} 
livro Crônicas da Província do Brasil é dedicado. A obra do biografista mineiro segue as coordenadas românticas, mais precisamente de Victor Hugo, apresentando Aleijadinho, que perdera os dedos das mãos e dos pés, além de ter a cara desfigurada em função da lepra, como uma espécie de Quasímodo. O narrador, em tal empreitada, propõe-se a corrigir equívocos, adotando uma postura informativa e didática, ao mesmo tempo em que confere a seu texto um caráter encomiástico. Veja-se o trecho:

\footnotetext{
Entenda-se que o diminutivo Aleijadinho é significativo da pura compaixão e meiguice brasileiras. O homem a que ele se aplicou nada tinha de fraco em pequeno. Era em sua disformidade, formidável. Nem no físico, nem no moral, nem na arte, nenhum vestígio de tibieza sentimental. Toda sua obra de arquiteto e de escultor é de uma saúde, de uma robustez, de uma dignidade a que não atingiu nunca nenhum outro artista plástico entre nós ${ }^{702}$.
}

Bandeira, portanto, defende que Aleijadinho deveria ocupar uma posição de destaque na história cultural do país. Além da efeméride dos duzentos anos de nascimento do artista, o mote que utiliza para recuperar a história de tal personagem encontrava-se na falta de estudos sobre ele. No entanto, como indica nota de rodapé do próprio autor, esse problema acontecia no período anterior a 1930 quando o texto fora escrito. Quando da edição do livro, em 1937, já havia numerosos estudos sobre o escultor mineiro.

Em seu processo de recuperação do passado, portanto, Bandeira explicita tanto suas fontes historiográficas como suas impressões sobre as matérias e os escritos com os quais trabalha, marcando-se ativamente na narrativa por meio debreagens actanciais enunciativas (diz “eu”). Ao recobrar os tempos idos, o cronista tomava como ponto de partida dados específicos de seu momento de enunciação (a crítica ao estilo neo-colonial ou o descaso para com o gênio Aleijadinho, por exemplo), modulando sua crônica sobre o passado em função de uma visada nacionalista, que repercute na escolha e na localização de suas matérias ${ }^{703}$.

\footnotetext{
${ }^{702}$ Idem, p.65-66.

${ }^{703}$ Outros textos, coligidos em Crônicas da província do Brasil, mostram a mesma preocupação nacionalista: o narrador apresenta a festa de Nossa Senhora da Glória como essencialmente brasileira; retoma o livro Journal of a Voyage to Brazil, da inglesa Maria Grahan, que faz a crônica do Recife de 1821, anunciando a inevitabilidade do processo de independência de Portugal; defende o trabalho de Mário de Andrade na busca da fala nacional e na valorização desta no texto literário, entre outros objetos privilegiados. Além disso, Bandeira trata preferencialmente de situações e personagens localizadas em centros urbanos de grande importância para a história do país: Ouro Preto, Bahia, Recife, Olinda e Rio de Janeiro.
} 
Escrevendo para a revista oficial, Graciliano lança mão de dispositivo inverso: valendo-se do distanciamento e da pressuposição de objetividade da terceira pessoa, ele raramente se marca no texto, mas, por outro lado, além de indeterminar as coordenadas espaciais e actanciais, não faz referência a documentos históricos que poderiam autenticar e embasar seus relatos, como se esperaria de um historiador moderno ou de um cronista antigo. $\mathrm{O}$ autor de Caetés inventa histórias verossímeis, aparentemente autônomas, desviculadas, na maioria dos casos, de outros discursos abalizados, mas que guardam laços com o universo cultural do leitor. Por meios externos (a biografia do artista e o enquadramento dado aos escritos pela revista) e por certas marcas textuais dispersas pelo texto (didatismo, figuração do modo de pensar local etc.) supõe-se que se esta diante de um especialista, que se não cita ou explicita fontes bibliográficas, travara contato com as matérias abordadas (ainda que ele não se inscrevesse diretamente na narrativa).

\subsubsection{A crônica antiga}

De acordo com a etmologia grega da palavra (khronos - tempo), a crônica antiga/medieval (ou seja, anterior ao advento da imprensa folhetinesca no século XIX) correspondia ao relato dos acontecimentos em ordem cronológica, que, em geral, era encomendado por um indivíduo destacado ou por um clã poderoso. Via de regra, ela era vista como uma forma de elogio aos melhores. Por essa perspectiva, poderia ser tomada como imitação de feitos exemplares de homens ilustres, conforme as orientações do gênero epidítico, cujos lugares-comuns foram sistematizados por Quintiliano $^{704}$.

Portanto, tal tipo de discurso visava menos à exatidão dos fatos do que à glorificação do grande homem sobre o qual se falava. Para tanto, seguia-se a ordo naturalis (ordem cronológica), com destaque para uma representação progressiva do tempo na apresentação dos fatos. Nesse caso, nunca se tratava estritamente da validação imediata da realidade empírica, mas de uma determinação convencional a partir do gênero adotado, com base nas autoridades do passado invocadas ${ }^{705}$. Pela concepção antiga, os textos admitiam críticas ou

\footnotetext{
704 BARBOZA, Jeronymo Soares. Instituições Oratórias de M. Fábio Quintiliano, Escolhidas dos seus XII Livros, Traduzidas em linguagem e ilustrada com notas críticas, Históricas e Retóricas, para uso dos que aprendem. Livro I. Coimbra: Imprensa Real da Universidade. MDCCLXXXVIII (1788), p.82-98.

${ }^{705}$ Fernão Lopes, por exemplo, na confecção de sua Crônica de D. João I, valeu-se de outras obras históricas, como forma de autorizar seu relato: Crônica do Condestável, a Crônica de Don Juan I, do castelhano Pero
} 
interpretações que poderiam ser mais ou menos adequadas de acordo com o decoro. Posteriormente, relatos desse tipo são apropriados de variadas maneiras por leituras iluministas ou românticas e seus aspectos retóricos vão perdendo importância; passa-se a se valorizar, sobretudo, a correspondência da narrativa com o real.

Graciliano, escrevendo no século XX, volta também seus olhos para o passado, mas sua perspectiva, naturalmente, é outra, apesar de beber da mesma tradição. A princípio, sua prosa procura apresentar-se como verdadeira, de acordo com o pacto fiduciário estabelecido como o enunciatário, previsto pela seção "Quadros e costumes do Nordeste“ e pelas diretrizes veridictórias do gênero crônica: na maioria dos textos coloca-se como um narrador onisciente, que, mesmo distante dos objetos narrados, acaba assenhoreando-se deles. Adota, portanto, uma postura de especialista, que domina o universo que representa, abordando-o de forma fragmentária, mas explicativa e didática: procura torná-lo compreensível para seus leitores. Principalmente nos escritos que têm como cenário uma cidadezinha sertaneja, o narrador assume, muitas vezes, o ponto de vista dos habitantes da localidade, o que reforça a ironia da construção. Dessa maneira, além dos cenários e atores, ele recupera, inclusive, o modo tradicional de pensar dos interioranos.

Outro ponto é que cada texto pode ser tomado como uma peça autônoma. Não há um princípio temporal ordenador dos relatos, como a seqüência cronológica fornecia às crônicas medievais. A descrição de práticas, personagens e eventos localizados no passado sucedem-se e acumulam-se. E pela recorrência de certas figuras e tropos a imagem do lugar vai sendo composta de forma descontínua, multifacetada e cumulativa.

As prerrogativas do artista também seria outras. Seja tratando dos figurões locais ou da arraia miúda (sobretudo dos primeiros), Graciliano privilegia a vida prosaica, a vida besta provinciana (na concepção poética de Drummond). Não há a perspectiva encomiástica ou saudosa dirigida aos personagens ou ao próprio lugar representado. Seu objetivo, num primeiro momento, seria dar a conhecer aquele espaço arruinado e os habitantes deste, norteando-se pela necessidade maior de estudo da “realidade do país”, respaldada pela revista. Mas não ficava por aí. Nesse movimento, o artista procurava também figurativizar certas

Lopes Ayala e a história em latim do eclesiástico Dr. Christophorus relativa à época de D. João I. Além disso, retoma outros livros, como a Bíblia, a Demanda do Graal, Dos Ofícios de Cícero, De temporibus de Eusébio Cesaréia e a história de Beda, entre outras (Ver AMADO, Teresa. Apresentação crítica. In: LOPES, Fernão. Crônica de D. João I. Lisboa: Editorial Comunicação, 1992, p.17-72). 
tópicas de interesse do regime, discutindo-as de maneira velada. Em seu relatos, Graciliano adota uma perspectiva nacionalista crítica, sem, no entanto, direcioná-la ao status quo; opta pela recusa tanto à nostalgia pelo passado quanto à euforia pelas mudanças futuras. Parece defender a hipótese de que só se conhecendo as ruínas nacionais, recuadas no tempo, poderse-ia construir algo novo: as feridas só seriam curadas se se convivesse com elas. 


\section{Capítulo 6 - Estudo específico dos quadros enquanto artefatos verbais e eventos culturais}

\subsection{No começo, um olhar sobre o carnaval}

Como assunto de sua primeira participação em Cultura Política, Graciliano Ramos privilegiou o carnaval na província, tema recorrente em sua produção cronística até então, pois fora trabalhado em duas outras oportunidades ${ }^{706}$. Mais do que descrever as peculiaridades da festa carnavalesca no interior nordestino, o artista utiliza o evento como mote para produzir um retrato da elite sertaneja em seu contato com o povo, de maneira semelhante ao que fizera com o texto "Natal no interior", publicado meses antes na revista $O$ Cruzeiro ${ }^{707}$. De maneira irônica, o artista procurará enfocar a dominação realizada pela classe dirigente municipal, tematizando a tensão entre norma e desvio, a partir de certa focalização que oscila entre um olhar de fora (distanciado) e um olhar de dentro (provinciano).

Quanto ao gênero, o texto pode ser visto como um cromo do município, um retrato autônomo, com certa vivacidade em que se nota a presença de um olhar crítico e moralizante do narrador. Este parece partilhar da tópica ut pictura poesis (que associa poesia e pintura, pressupondo que a função da primeira seria copiar, imitar, pintar). Nesse sentido, procura construir um quadro literário da sociedade sertaneja com suas várias camadas, com destaque para a inevitabilidade da mudança operada pela maioria, mas, sobretudo, para o moralismo da elite e para vigilância exercida por ela (mais do que a folia, registra o predomínio da ordem segundo o olhar dos poderosos). Em tal movimento, o autor coloca-se a serviço de um registro pitoresco, regional, em que se nota a prevalência de uma perspectiva progressista, simpática à metrópole. Não se trata, portanto, de uma crítica ao governo, muito pelo contrário, pois o narrador se aproxima de certa perspectiva metropolitana, que censura o atraso provincial. Por outro lado, adota um estilo ambivalente e alusivo, marcado pela polifonia, que abre o escrito a diferentes interpretações, fugindo de um registro sociológico ou etnográfico estrito.

\footnotetext{
706 Trata-se dos seguintes textos: A crônica “IV” (sem título), da seção “Traços a Esmo”, contida no livro póstumo Linhas Tortas (1962), mas que fora publicada inicialmente no jornal O Índio de Palmeira dos Índios (Alagoas), em fevereiro de 1921, quando o autor ainda vivia no interior nordestino; e "Carnaval 1910", presente no livro póstumo Viventes das Alagoas, mas que antes saiu estampada na revista carioca O Cruzeiro, em 14 fevereiro de 1942;

${ }^{707}$ RAMOS, Graciliano. "Natal no interior”, O Cruzeiro, Rio de Janeiro, 21 dez. 1940. Texto publicado em Viventes das Alagoas apenas com o título "Natal”.
} 
Para análise de certos procedimentos narrativos (debreagens e embreagens actanciais, temporais e espaciais, entre outros), de que o cronista lança mão para configurar seu texto, tome-se o primeiro parágrafo:

\begin{abstract}
A cidade tem uns cinco mil habitantes. Contando bem, talvez achássemos seis mil, número que os naturais bairrista em excesso, duplicam. Há um cinema silencioso, onde as fitas se quebram durante longas horas, sem risco para os freqüentadores, atentos aos dramas em série, e há um semanário, adstringente, espinhoso, que divulga boatos cochichados nas esquinas, na farmácia e na barbearia, em redor dos tabuleiros de gamão. Tudo se realiza às claras, no cinema na rua, e as casas estão fiscalizadas rigorosamente. Qualquer derrapagem medíocre, sorriso considerado impróprio, suspiro ou afoiteza de opinião, determina comentários, zangas, críticas acerbas, equívocos ${ }^{708}$.
\end{abstract}

Um dos primeiros aspectos a serem observados no trecho acima é a ocorrência de uma embreagem temporal enunciativa, presente no emprego do tempo presente ("tem", “achássemos”, “duplicam”, “quebram”, “há”, “se realiza”, “estão”, “determina”) como forma de recuperar sucessos passados, ocorridos num momento anterior àquele no qual se dá a enunciação da crônica. Trata-se, portanto, do uso do chamado presente histórico (aorístico), o qual, esteticamente, cumpriria a função de vivificar acontecimentos pregressos, mostrando a aparente ressonância destes no momento de elaboração da narrativa ${ }^{709}$. Nesse sentido, a aplicação de tal recurso, ocasional ao longo dos “Quadros e costumes do Nordeste”, permitiria a construção de um efeito de sentido de simultaneidade entre narração e narrado, como se o cronista distante, tanto espacial como temporalmente do mundo descrito no texto, esbatesse seu afastamento e promovesse a "ressurreição" dos fatos transcorridos. De certa maneira, isso ocorreria graças à deslocação metafórica do ponto de vista do locutor: ele dá a impressão de se envolver com maior proximidade da história, como se fosse testemunha da ação representada e desejasse transmitir aos leitores a sensação dramática de seu suposto testemunho ocular.

\footnotetext{
${ }^{708}$ RAMOS, Graciliano. A vida social no Brasil: Quadros e Costumes do Nordeste I. Cultura Política, Rio de Janeiro, ano 1, n.1, mar. 1941, p.236.

${ }^{709}$ Maingueneau, ao tratar do presente aorístico, afirma que ele não constituiria um fato de embreagem enunciativa, pois não indicaria o prolongamento temporal dos processos descritos, bem como a contemporaneidade deles em relação ao momento de enunciação. Por outro, lado o teórico francês retoma um estudo de A. Culioli ("Valeurs aspectuelles et opérations énociatives: l'aoristique”. In: DAVID, J.; MARTIN, R. (eds). La notion d'aspect. Paris: Klincksieck 1980), para destacar que este emprego do presente não estaria nem ligado à cena enunciativa (como no caso do presente dêitico), nem desligado dela (como no passado simples), mas situada em relação a uma marca "fictícia" construída a partir do momento de enunciação: uma marca que seria ao mesmo tempo desligada desse momento de enunciação e identificada com ele (MAINGUENEAU, Dominique. Elementos de lingüística para o texto literário, p.64-65).
} 
A princípio, no referido excerto, não há nenhum marco temporal explícito ${ }^{710}$, que permita referendar a afirmação de que os verbos empregados no presente remeteriam não há fatos concomitantes à narração do cronista (supostamente realizada em março de 1941, data de publicação da crônica), mas anteriores a ela. No entanto, quando se busca respaldo no contexto histórico, que permeia a narrativa, a presença da expressão “cinema silencioso" alude de maneira inquestionável a um período anterior aos anos de 1940, mais especificamente o final da década de 1920 ou início de 1930, quando passa a predominar o cinema falado ou musicado, com o som sincronizado à imagem, em praticamente todo o mundo $^{711}$. Tal aferição, ainda que imprecisa, torna reconhecível a presença do referido artifício retórico de aproximação entre enunciado e enunciação, mostrando que o autor se referia a um período anterior ao Estado Novo.

Considerando-se ainda a estruturação discursiva do referido excerto, nota-se que o espaço é apresentado por meio de uma debreagem enunciva, ou seja, o cronista situa os acontecimentos num “lá”, distante do “aqui”, pressuposto por sua fala (enunciação). Logo na primeira frase, ele se refere, de maneira imprecisa, a um cidadezinha provinciana, de cinco mil habitantes, que procurava se mostrar maior e mais desenvolvida do que seria realmente. A falta de exatidão geográfica enfeixada pelo cronista, se por um lado prejudica a individuação do lugar retratado, por outro, permite tomá-lo como um município arquetípico, passível de ser encontrado em diferentes localidades do interior do país.

Tal expediente acaba resultando numa espécie de reforço ficcional à crônica, que seria conexo à utilização do presente histórico. Maingueneau afirma que este último colaboraria para instauração de um “fora-do-tempo", um mundo simultaneamente atual e desconhecido, ao definir processos sem duração, a um só tempo próximos e distantes da instância enuciativa. Portanto, o emprego desta forma favoreceria a construção de um universo particular; o espaço textual no qual tomam corpo as ações narradas. No entanto, como o cenário estava enquadrado numa seção com o título “Quadros e Costumes do Nordeste”, a própria moldura fornecida pelo periódico acabava por restringi-lo aos limites nordestinos.

\footnotetext{
${ }^{710}$ Seja ele uma localização temporal absoluta (como ocorre na crônica XIII, dos "Quadros e Costumes do Nordeste", situada "naquele ano remoto do princípio do século XX”), seja uma localização relativa ao enunciado ou relativa à enunciação (por exemplo, nos textos em que aparece o dêitico "hoje").

${ }^{711}$ Como destaca Paulo Emílio, no Brasil, "a coexistência do cinema mudo e falado de 1929 a 1933 justifica por certo o fato extraordinário de terem sido feitas no ano de 1930 cerca de vinte fitas. Realmente o cinema falado desempenhou um papel estimulante na nossa produção, mas isso antes de 1934, quando então houve um colapso tão radical quanto o de 1911 ou de 1921” (GOMES, Paulo Emílio Sales. Cinema: trajetória no subdesenvolvimento, p.51-52).
} 
Levando-se em conta a história de vida do homem Graciliano, tal cidadezinha poderia ser tomada como a representação literária de Palmeira dos Índios, município no agreste alagoano, onde o escritor passara boa parte de sua juventude e da fase adulta. Ele não faz essa relação, que restringiria seu relato a uma experiência específica. No entanto, a crônica menciona a possível chegada da estrada de ferro à localidade, depois de um longo tempo de espera. Engenheiros estariam lá para dar prosseguimento aos estudos necessários à realização das obras.

Os relatos que tratam da expansão da malha ferroviária pelo interior alagoano dão conta de que os trilhos teriam chegado a Quebrangulo em 1912 e em Palmeira dos Índios, distante menos de $25 \mathrm{Km}$ desse município, apenas em 1934, ou seja, os palmeirenses teriam esperado mais de 22 anos para ter acesso local aos vagões da Great Western ${ }^{712}$, assim como seus vizinhos. Se se levar em conta tal informação extradiegética ${ }^{713}$, tem-se mais um elemento para situar a narrativa num momento anterior ao governo estadonovista, ou seja, o cronista faria referência a acontecimentos anteriores a 1937, o que lhe conferiria maior abertura para tratar criticamente os conteúdos, como se verá.

Ainda no que diz respeito à Palmeira dos Índios, Graciliano já trabalhara literariamente com o município nas séries de textos “Traços a Esmo” e "Garranchos”, publicadas no jornal O Índio, em 1921, e também em seu romance de estréia Caetés, saído em 1933, pela Schmidt Editora. Em crônica na qual recupera sua própria trajetória literária, o cronista relembra as origens deste último livro:

\footnotetext{
712 BARROS, Francisco Reinaldo Amorim de, ABC das Alagoas Dicionário Biobliográfico, Histórico e Geográfico de Alagoas. Brasília: Senado Federal, Conselho Editorial, 2005, tomo 1, p.36. Outras fontes confirmam a informação: "Na administração Arlindo Luz [de agosto de 1932 a maio de 1936] (...) a rede ferroviária da Great Western foi elevada a 1.736 Km,122, com a incorporação dos trechos de Tigre a Alagoa de Baixo $(13 \mathrm{Km}, 386)$ e de Anum a Palmeira dos Î́ndios $(14 \mathrm{Km}, 488)$ " (PINTO, Estevão. História de uma estrada de ferro do Nordeste. Col. Documentos Brasileiros. Rio de Janeiro: José Olympio Editora, 1949, p.186).

${ }^{713}$ Em sua correspondência íntima, Graciliano faz comentários sobre a construção da ferrovia em duas oportunidades. Na primeira, em carta de 19 de junho de 1911, endereçada a sua mãe, destaca com ironia: "Quando chegar aí [Palmeira dos Índios] - está compreendendo? - hei de ter o corpo pesando 70 quilos e a alma leve de pecados, tão leve como os vagons que levam material para a construção da estrada de ferro de Palmeira" (Nesse momento, Graciliano passava uma temporada na fazenda da avó materna, em Maniçoba, interior pernambucano) (RAMOS, Graciliano. Cartas. Rio de Janeiro: Record, 1982, p.16). Na segunda, em carta de 17 de setembro de 1932, ele fala com sua mulher, depois de voltar a residir no município palmeirense: "Dizem que a estrada de ferro chegará ainda este ano. Não acredito, pois isto por aqui tem caveira de burro” (Idem, p.126.).
} 
Há alguns anos porém, achei-me numa situação difícil - ausência de numerário, compromissos de peso, umas noites longas cheias de projetos lúgubres. Esforcei-me por distrair-me redigindo contos ordinários e em dois deles se esboçaram uns criminosos que extinguiram as minhas apoquentações. O terceiro conto estirou-se demais e desandou em romance, pouco mais ou menos romance, com uma quantidade admirável de tipos miúdos, desses que fervilham em todas as cidades do interior. Várias pessoas se julgaram representadas nele e supuseram que eu havia feito crônica, o que muito me aborreceu ${ }^{714}$.

Este "terceiro conto" corresponderia ao romance Caetés, obra na qual Graciliano tematiza uma série de "tipos miúdos” que perambulavam por uma cidadezinha interiorana chamada Palmeira dos Índios. Apesar de localizar a trama no mundo, o escritor trabalha com tais coordenadas geográficas de um ponto de vista literário: incorpora e transforma os discursos sobre tal cenário particular do interior alagoano, visando à construção do espaço ficcional no qual transitam as personagens. Apesar das semelhanças entre um e outro texto, o autor institui uma nova realidade, fundada nas tópicas que tornavam seu discurso sobre o provincianismo do interior do país verossímil. Nesse sentido, povoa a narrativa com figuras planas, ou seja, tipos arquetípicos, comumente presentes nos relatos elaborados sobre vilas e municípios do hinterland brasileiro. No entanto, tal restrição não parece correta. Na verdade, o artista parece ter como referência direta a Leiria, enfeixada por Eça de Queirós, em $O$ crime do padre Amaro, sobretudo, no que diz respeito às notações irônicas sobre a estreiteza de horizontes do lugar, bem como à eleição e ao tratamento sarcástico dos tipos locais. Em certo sentido, tratase também da reprodução do lugar-comum da "vida besta”, tematizada por Drummond no poema “Cidadezinha Qualquer”, recolhido em Alguma Poesia (1930 ${ }^{715}$. Diante destas constatações, justifica-se o aborrecimento de Graciliano ao recusar o rótulo de “crônica”, imputado a seu texto por certos munícipes palmeirenses que se julgavam representados na narrativa.

Como esperado, no referido romance de Graciliano não faltam as figuras do padre, do médico, do prefeito, do promotor, do advogado, do jornalista, da velha beata, do comerciante, do farmacêutico, da jovem carola, da dona da pensão, enfim, de um conjunto de caricaturas, que representariam comportamentos comuns, condizentes com o papel social que estas

\footnotetext{
${ }^{714}$ Alguns tipos sem importância, p.195.

715 ANDRADE, Carlos Drummond. Obra completa. Rio de Janeiro: Companhia J. Aguilar, 1967, p.67. Cidadezinha qualquer - Casas entre bananeiras / mulheres entre laranjeiras / pomar amor cantar. // Um homem vai devagar. / Um cachorro vai devagar. / Um burro vai devagar. / Devagar... as janelas olham. // Eta vida besta, meu Deus.
} 
exerceriam, principalmente, na classe dirigente sertaneja ${ }^{716}$. Elas operariam, portanto, por meio de traços distintivos, fortemente escolhidos e demarcados; por meio, em suma, de tudo aquilo que os distingue vistos de fora ${ }^{717}$.

Nos “Quadros e costumes do Nordeste” também estão presentes arquétipos semelhantes, sobretudo porque a maior parte dos textos, assim como observado Caetés, tem como cenário uma cidadezinha sertaneja. Sua primeira colaboração na revista não foge à regra. Nela estão presentes, entre outros, a mulher do prefeito, a mulher do médico, gente do promotor e do juiz, negociantes, a filha do telegrafista, o ajudante da farmácia, a professora vinda de fora, o instrutor de tiro, agentes externos em visita ao município (mulheres dos engenheiros, responsáveis pela construção da estrada de ferro), enfim, uma galeria de tipos que parecem encarnar a tipologia de caracteres descrita por Teofrasto. Neste quesito, mais especificamente, a atenção do narrador se concentra na figura da primeira-dama que parece personificar o modelo da dissimulação proposto pelo escritor grego ${ }^{718}$ : para que as engenheiras não formassem mau juízo da localidade, ela procura a todo o custo maquiar, num disfarce grosseiro, a imagem provinciana da cidadezinha. Para tanto, procurava realizar a vigilância do município, cerceando comportamentos tidos como linhas de fuga, entre eles o hábito de se expandir livremente durante a festa carnavalesca, tido como índice de deterioração social.

Ainda tratando das personagens, falta elucidar uma questão. Comparando as versões do texto publicadas em Cultura Política e a partir da segunda edição de Viventes das Alagoas, percebe-se a ausência na primeira de todo o trecho em que há a descrição da figura e da atuação do rígido padre local. O único manuscrito, presente no Arquivo Graciliano Ramos no IEB, traz dois parágrafos referentes ao pároco (o segundo e o terceiro), que não constam na revista getulista, mas que foram incorporados ao referido livro. Tome-se o trecho:

Faz trinta anos que S. Revma. profere no púlpito, com ligeiras variantes, o mesmo sermão, ataque feroz
ao mundo, à carne e ao diabo, férteis em tentações não-especificadas. Prudente, S. Revma. impugna o
exterior do mal. Acusou as primeiras mulheres que vestiram calças e montaram a cavalo de frente,
escanchadas, como os homens, mas este indício de perdição vulgarizou-se rapidamente, os silhões e
costume de cavalgar de banda caíram em desprestígio - e o vigário passou a denunciar outras manhãs

\footnotetext{
${ }^{716}$ Em consonância com o que fora referido acima, em O crime do padre Amaro, também não faltariam tais figuras: sacerdotes, farmacêutico, prefeito, médico, advogado, redator de um jornal etc.

${ }^{717}$ CANDIDO, Antonio. A personagem do romance. In: CANDIDO, Antonio et al. A personagem de ficção. São Paulo: Perspectiva, 1976, p.61.

${ }^{718}$ TEOFRASTO. Os caracteres. São Paulo: E.P.U.; FFLCH/USP, 1978, p.34.
} 
dos inimigos da alma. Agrediu as saias curtas das moças e os braços descobertos, Ante a resistência foi inexorável: esbaforiu-se e enrouqueceu depois da missa, usou argumentos rijos e, no batismo, afastou da pia as madrinhas não inteiramente agasalhadas. Recusou desculpas, triunfou. Idoso e de óculos, enxerga sem dificuldade os colos expostos. E julga que alguns centímetros de pele nua ocasionam prejuízo sério à cristã.

Na campanha mais enérgica do reverendo, contra o carnaval, um aliado considerável rendeu-se, o hebdomadário noticioso e austero, que entrou na folia para não desgostar os assinantes. O vigário compreendeu que perdia terreno e contemporizou: admitiu a festa pagã, limitando-se a condenar exageros que nunca existiram $^{719}$.

Ainda que de maneira alusiva, recuperando trechos do próprio texto de Graciliano, Raul Antelo levantou uma hipótese para esse hiato:

\begin{abstract}
Em sua primeira colaboração dipiana, tudo às claras, pois 'as casas estão fiscalizadas rigorosamente', a derrapagem medíocre não passa desapercebida ao Poder. Embora o julgue idoso e míope, o Estado vigia e aparece em cada interstício. Ele sabe ver colos expostos, inclusive por que conta com aliados eventuais, ‘o hebdomadário noticioso e austero', que entrou na folia para não desgostar os anunciantes $^{720}$.
\end{abstract}

Logo, pode-se pensar em censura ou em autocensura da parte do autor alagoano. No entanto, estas duas hipóteses parecem não se confirmar, pois a mesma versão editada em Cultura Política, ou seja, sem o referido trecho sobre o padre, fora republicada anos depois no periódico comunista Revista do Povo - Cultura e Orientação Popular ${ }^{721}$. Supõe-se que nesta nova ocasião, com o fim do Estado Novo, o artista, escrevendo para uma publicação com inclinações anticlericais, teria liberdade para incluir os dois parágrafos, mas não o fizera ${ }^{722}$.

Em resumo, apesar da referência pouco abonadora à Igreja Católica, instituição que apoiara o Estado $\mathrm{Novo}^{723}$, o trecho faltante na revista não teria sido excluído por motivos censórios. Na

\footnotetext{
${ }^{719}$ RAMOS, Graciliano. Viventes das Alagoas. Rio de Janeiro: Record, 2007, p.19-20.

${ }^{720}$ ANTELO, Raul. Literatura em revista. São Paulo: Ática, 1984, pp. 30-31

${ }^{721}$ RAMOS, Graciliano. Quadros e Costumes do Nordeste - O Carnaval, Revista do povo: Cultura e Orientação Popular, Rio de Janeiro, ano 2, n.4, abr. 1946, p.3-4.

${ }^{722}$ Há ainda a possibilidade de existência de outro manuscrito, no qual os dois parágrafos transcritos não estivessem presentes. No entanto, tendo em vista a documentação disponível, torna-se impossível confirmá-la, daí a preferência por se considerar os textos éditos.

${ }^{723}$ Com a instauração do regime de 1937, mantiveram-se a colaboração e as cordiais relações e entre Igreja e o Estado. No terceiro aniversário do regime, a 10 de novembro de 1940, pregara o arcebispo de Cuiabá e membro da ABL Dom Aquino Correa, perante o presidente da República e de todas as autoridades do governo: “(...) a tribuna sacra não discute formas de governo nem regimes políticos, senão à luz da fé e dos ditames da moral
} 
verdade, ele parece ter sido incorporado pelos editores de Viventes das Alagoas como uma espécie de complemento, por meio do qual se oferecia ao leitor mais um tipo alegórico importante, tendo em vista o propósito original do escrito de conceituar a cidadezinha. Nesse sentido, o padre seria uma espécie de caricatura do clero diante dos avanços sociais, que completaria o retrato da localidade provinciana.

Voltando ao parágrafo inicial do texto transcrito no início, depois dessa breve digressão, falta ainda caracterizar o narrador. Apesar da debreagem enunciativa de pessoa, presente no uso do “nós” (“achássemos”), não há uma voz narrativa que diga “eu”, deliberada e exclusivamente inscrita no enunciado. Nota-se somente a presença de um “eu narrante” extradiegético, ou seja, de um actante discursivo que apenas narra e que, apesar de assumir diferentes pontos de vista, não participa como personagem das ações representadas. No entanto, ao longo da crônica, isso não quer dizer que não sejam identificáveis certas marcas da enunciação enunciada, ou seja, um conjunto sinais que remeteriam à instância da enunciação (mais especificamente, ao autor implícito Graciliano Ramos, não ao homem, mas à figura produzida pela leitura do texto ${ }^{724}$ ). No segmento acima, destacam-se, sobretudo, alguns adjetivos e advérbios apreciativos, tais como "bairristas em excesso”, “às claras”, "rigorosamente”, “adstringente”, “espinhoso”, “impróprio”, “medíocre”, “acerba”. Neles estariam presentes os julgamentos e modalizações do narrador, quanto ao provincianismo, ao atraso e ao moralismo do município tematizado.

Do ponto de vista actancial, no trecho acima, o cronista realiza uma embreagem ao utilizar a primeira pessoa do plural (“achássemos”) em lugar da terceira do singular (achasse-se). Nesse sentido, o eu pluralizado, já amplificado anteriormente no anonimato do "nós”, neutralizaria a indeterminação do “ele”. Por meio de tal procedimento, o narrador constrói um efeito de subjetivação e de aproximação de seus leitores litorâneos, aos quais, preferencialmente, dirige-se o texto; ambos estariam incluídos nesse "nós". Ao mesmo tempo, observa-se o

católica. Respeitadas estas normas supremas, todas as formas de governo são boas, mas os governos são os homens que os fazem. É isto, senhores, que viemos aqui hoje agradecer à Providência Divina: um governo tão forte quão tolerante, esta situação de ordem e de progresso, de que goza o Brasil, em se completando o decênio da presidência Getúlio Vargas” (PATARRA, Neide. Dinâmica populacional e urbanização no Brasil: o período pós 1930. In: O Brasil Republicano. Rio de Janeiro: Bertrand Brasil, vol. 3, 1995, p. 325).

${ }_{724}$ Por tal perspectiva, o autor poderia ser tomado como uma "invenção da obra", ou seja, como uma "categoria conceitual inerente à ficcionalidade do texto", cuja imagem seria produzida a partir da "astúcia cognitiva do leitor", que deveria "reconhecer na escrita a presença indicial do artista que o compôs" (TEIXEIRA, Ivan. Semiosfera \& invenção do autor. In: MARTINS, Plínio et TENÓRIO, Waldecy. João Alexandre Barbosa: o leitor insone. São Paulo: Edusp, 2007, p.317-349). 
distanciamento do autor implícito dos habitantes da localidade; ele não se colocava entre os “naturais” do município, o que retiraria da referida primeira pessoa do plural seu caráter exclusivo.

Como indica tal procedimento, o narrador se colocava numa posição afastada do material narrado. Na verdade, como se verá, o cronista realiza um movimento constante de aproximação e distanciamento do mundo representado em seu texto. Em geral, mantêm-se apartado da população do município, não se identifica com ela. No entanto, avizinha-se dos munícipes, sobretudo da classe dirigente local, por meio da utilização do discurso direto livre, fazendo resplandecer sua visada irônica.

No que diz respeito ao posicionamento do narrador, ele oscila entre uma focalização externa e outra interna. Inicialmente, nos dois parágrafos iniciais, predomina um olhar distanciado, analítico, de quem se encontra de fora da situação retratada e busca apresentá-la ao leitor. A partir daí, com o aparecimento de personagens, ganha espaço certa visada provinciana, que procura enxergar as cenas conforme a perspectiva moralista da elite do município tematizado. Tal focalização interna, por sua vez, mostra-se variável, tendo em vista as mudanças do actante observador ao longo da narrativa (não daquele que narra, mas daquele que vê), sobretudo, por meio do uso do discurso indireto livre, que permite ao cronista diversificar o ponto de vista adotado. No decorrer da crônica, este se limita, preferencialmente, à prefeita da cidade (primeira-dama, que ironicamente é referida dessa maneira, como a indiciar a fraqueza do marido da mesma, que oficialmente conduzia a vida municipal), como pode ser visto no trecho abaixo:

A prefeita, alarmada, suspende a conversa, olha os rapazes do comércio, que gingam e dançam misturando-se aos cordões, alguns caixeiros-viajantes, tipos viciados, com certeza, mulheres duvidosas. Que diriam as engenheiras se as luzes se extinguissem? Felizmente a usina elétrica se esforça: vê-se, através das grades, o maquinista zeloso mexendo naqueles ferrinhos.

- Parece que o motor aguenta.

A cidade não têm razão para se envergonhar. O largo vai se enchendo. Na vizinhança crescem rumores de um frevo honesto.

Antigamente não era assim. Marmanjos, de saco a tiracolo, armados de enormes bisnagas, molhavam as pessoas, jogavam-lhe punhados de ocre e vermelhão. 
Agora estamos civilizados, bastante civilizados. Concertaram-se todos os automóveis. Meia dúzia deles, arrastando serpentinas, buzinando pelas ruas, transporta risos, a alegria indispensável. Não é só meia dúzia. Passam três ou quatro desconhecidos: vieram carros de outros municípios, sinal de que temos um carnaval excelente, o melhor das redondezas ${ }^{725}$.

Em outro momento, o cronista incorpora o ponto de vista dos comerciantes do município:

\begin{abstract}
Os negociantes resmungam. Papel cortado, rasgado, pisado, roupas desnecessárias. O ano vindouro, muitos daqueles trajes coloridos estarão imprestáveis. Ora sim senhores. O ajudante da farmácia despejou cinco lança-perfumes na filha do telegrafista. Onde foi ele buscar dinheiro para dar banho de éter numa sirigaita? Hem? Na gaveta do patrão, é claro. O instrutor de tiro bebe cerveja e namora uma professora do grupo escolar. Bem, bem, esse pode consumir lança-perfumes e cerveja. Não manipula em botica nem compra fiado. Está certo ${ }^{726}$.
\end{abstract}

Mais ao fim, a voz do promotor aparece mesclada a sua:

A cidade, tradicionalista, acomoda-se aos hábitos modernos. Acomoda-se, pois não. É o que diz muitas vezes o promotor, homem de leitura e poesia. Acomoda-se devagar. Nada de choque, perturbações ${ }^{727}$.

Como se sabe, o discurso indireto livre permite que se ouçam, de maneira simultânea e mesclada, tanto o narrador como a personagem. Tal fato ocorre, pois esta modalidade de citação do discurso de outrem seria marcada por uma dissonância enunciativa de fronteiras imprecisas, na qual o narrador colocaria em cena dois enunciadores distintos, identificando-se apenas com um deles. "Não são dois verdadeiros locutores, que se encarregariam das enunciações, das palavras, mas 'dois pontos de vista', duas vozes, aos quais não se pode atribuir nenhum fragmento do discurso citado"728.

Como não apresenta marcas lingüísticas específicas, fazendo-se interpretável apenas num contexto apropriado (pois não seria um fenômeno concernente à frase, mas ao discurso) ${ }^{729}$, o discurso indireto livre atenua o desnível entre discurso citante e discurso citado, sem retirar a autonomia deste último e sem, por outro lado, romper a trama narrativa. Em linhas gerais,

\footnotetext{
${ }^{725}$ RAMOS, Graciliano. A vida social no Brasil: Quadros e Costumes do Nordeste I. Cultura Política, Rio de Janeiro, ano 1, n.1, mar. 1941, p.237.

${ }^{726}$ Idem, ibidem.

${ }^{727}$ Idem, ibidem.

${ }^{728}$ MAINGUENEAU, Dominique. op.cit. p.117-118.

${ }^{729}$ FIORIN, José Luiz. op.cit. p.82.
} 
diferencia-se do discurso indireto e do discurso direto, respectivamente, por não apresentar subordinação a um verbo dicendi e o par de embreantes eu-tu na configuração de dois interlocutores em dois sistemas enunciativos autônomos.

No trecho acima, referente ao olhar da "prefeita", a dupla enunciação pode ser percebida na incorporação pelo narrador, em seu próprio discurso, da visão conservadora e castradora da personagem, a julgar os foliões que gingavam no largo da cidade ("tipos viciados, com certeza, mulheres duvidosas”) ou a ressaltar os supostos avanços da municipalidade (“Agora estamos civilizados, bastante civilizados”). Além disso, aparecem no texto interrogações (Que diriam as engenheiras se as luzes se apagassem?), advérbios modalizadores ("Felizmente a usina elétrica se esforça”), além de outros índices avaliativos (“o melhor das redondezas”), passíveis de serem atribuídos à primeira-dama, levando-se em conta as fronteiras imprecisas que marcam a separação das vozes presentes no escrito. Além disso, considerando-se que o artista lança mão do presente aorístico, as debreagens enunciativas de tempo e pessoa (respectivamente, “Agora” e “estamos”, “temos”), contidas no referido excerto, remeteriam não à enunciação, ou seja, à relação entre destinador e destinatário, mas ao enunciado, pois seriam aplicáveis, sobretudo, à cena da qual participavam a prefeita, as engenheiras e a elite da localidade.

Recursos semelhantes estariam presentes nos trechos nos quais o artista incorpora pontos de vista dos negociantes e do promotor. Conforme sublinha Bakhtin, o discurso indireto livre, variante de transmissão da fala de outrem que apresentaria um "estilo pictórico", permitiria ao narrador reproduzir os matizes lingüísticos individuais do pensamento, das opiniões, dos sentimentos das personagens ${ }^{730}$. Nesse sentido, privilegiaria as “cores” das enunciações (subjetividade), que, muitas vezes, sobrepor-se-iam ao significado das mesmas. Considerando-se tais diretrizes, Graciliano parece lançar mão do referido expediente com o intuito de vivificar o retrato da elite municipal proposto. Ao fazer ressoar as vozes (acentos e entoações) dos próprios integrantes da classe dirigente no fio de sua narração, sem interrompê-la, transporta-se para eles, evocando e reconstituindo a ação relatada ao invés de apenas constatá-la. Nesse movimento, portanto, dirige-se preferencialmente à imaginação do leitor.

\footnotetext{
${ }^{730}$ BAKHTIN, Mikhail. Marxismo e filosofia da linguagem. São Paulo: Editora Hucitec, 1981, p.151.
} 
Ao mesmo tempo, mediante tal dispositivo, o autor acaba engendrando um olhar metalingüístico que observa a observação realizada pela classe dirigente, como se houvesse camadas revestindo a apreensão da festa popular. A elite, ao invés de brincar o carnaval, preferia vigiar a comemoração. Ou seja, enquanto o povo comemorava, os poderosos, apartados do “desfile dos cordões”, controlavam. A prefeita, espécie de personificação do poder político a ser combatido, visava construir, por meio de seus juízos, uma imagem mais elevada de si e, por conseguinte, da cidade. Fazia isso não por meio do carnaval, mas a partir das opiniões que emitia sobre o carnaval para a engenheira, personagem vinda de fora (espécie de elite itinerante que deveria levar uma boa imagem do município). Por seu turno, o narrador, que também se encontrava distante, mas contrabalanceava seu afastamento pela incorporação de pontos de vista alheios, deixava de lado o tratamento dos festejos para exercer uma espécie de vigilância por meio da arte: produzia um retrato da elite sertaneja com o fito de condenar o artificialismo e o provincianismo desta e, em contrapartida, colocar-se em favor de certa espontaneidade popular.

Paralelamente, a utilização do discurso indireto livre reforça a atitude de especialista do autor. Ele mostra conhecer tão profundamente o estilo de vida local que é capaz de assumir, valendo-se das fronteiras imprecisas do discurso indireto livre, o ponto de vista de diferentes figuras da elite provinciana, sobretudo da prefeita, seu alvo preferencial. Tal expediente permite-lhe ainda hiperdimensionar os efeitos da ironia utilizada ao longo de todo o texto, pois, ao imiscuir seus julgamentos (condenação) às vozes das personagens faz com que o leitor as interprete por um viés negativo. Pode-se pensar que o artista alagoano utilizaria o discurso indireto livre de maneira semelhante a La Bruyère, ou seja, como um recurso para exprimir seu conflito interno com os caracteres representados, como se, apesar da proximidade, marcasse a sua distância em relação a eles. “A pseudo-objetividade de La Bruyère serve para refratar ironicamente todas as suas representações”,731.

Mais especificamente, a ironia aparece como mais um item a promover a polifonia na colaboração do autor. “... uma enunciação irônica põe em cena uma personagem que enuncia algo de deslocado e do qual o locutor (narrador) se distancia por seu tom e sua mímica. Ele se coloca como uma espécie de imitador dessa personagem que se exprime de maneira incongruente”. Assim, quando o autor expressa “Agora estamos civilizados”, ele fez com que

${ }^{731}$ Idem, p.187. 
se percebesse na sua fala o ponto de vista a um só tempo provinciano e dissimulado da prefeita, do qual se distanciava como pode ser percebido pelos índices dispersos ao longo de todo o texto que dão conta da precariedade e limitação do município: este possuía um cinema incapaz de passar um filme inteiro (lugar onde “onde as fitas se quebravam durante longas horas de exibição”), um jornal fofoqueiro, iluminação pública que cochilava, entre outros aspectos.

Nesse sentido, conforme a interpretação retórica tradicional, ao se valer da antífrase, o artista produz um desacordo entre enunciado e enunciação, estabelecendo um contrato com o leitor no qual o fato de “estar civilizado” deveria ser tomado pelo seu contrário, o que situa a primeira-dama no âmbito da mentira (não-ser, mas procurar aparentar o oposto).

Ao se valer de tais procedimentos para produzir uma crítica interna à elite sertaneja, o autor pretende abstrair, a contrapelo, uma poética comportamental, uma espécie de gramática do pensamento das pessoas pertencentes à classe dirigente do município tematizado pela narrativa. Como a singularização da visão dos poderosos se dá a partir de um ponto de vista fundamentalmente feminino (com destaque para a primeira-dama), pressupõe que cabia à mulher, numa perspectiva tradicionalista, formular a consciência moral da coletividade, já que seus maridos se encontrariam no exercício e no gozo do mando.

Como forma de particularizar as diretrizes castradoras da elite conservadora, ao final do texto, ganha destaque a linha de fuga promovida pela filha do telegrafista.

\footnotetext{
A prefeita se aborrece também. Aquela agarração da menina do telegrafista com o ajudante da farmácia é um escândalo. A sonsa, que vive na igreja, confessando-se, comungando, perde os estribos e dá amostra péssima da localidade. Bom que o vigário amanhã se inteire do fato: haverá no domingo um sermão terrível. (...) Esse caso da filha do telegrafista, por exemplo, destoa. Uma sujeitinha nascida na roça, criada na fé, sem emprego, tola como peru novo, pode tomar o freio nos dentes, desembestar? Com franqueza não pode ${ }^{732}$.
}

Tal como um cavalo que tomava o freio nos dentes, negando o comando do cavaleiro (figura sintética), ela deixava de obedecer às diretrizes gerais da sociedade provinciana ao se atracar publicamente com o ajudante da farmácia. Sua atitude seria mostra da autonomia e da

\footnotetext{
${ }^{732}$ RAMOS, Graciliano. op.cit, p.237.
} 
liberdade que deveriam ser extirpadas, segundo o discurso castrador da prefeita. Em sentido oposto, outro personagem destoante seria o escrivão da coletoria, que apesar de ser um funcionário insignificante, caía na farra de domingo à terça-feira gorda e ninguém o vencia: "Por isso tem prerrogativas: é geralmente aceito”, ou seja, sua atitude, apesar de espontânea, estava prevista pelo código da festa, de acordo com a vigilância exercida pela elite. Dessa maneira, enquanto seu comportamento seria tratado como simples extravasamento de alegria, o da jovem, não passava de uma manifestação instintiva, algo permissivo e promíscuo, que fugia da moralidade do local; como uma besta ela descontrolada, ela se desvencilhara do cabresto da norma.

Em princípio, poder-se-ia pressupor uma tensão entre o regramento da elite e a espontaneidade popular, mas isso não ocorre. Tudo parece se encontrar no seu devido lugar; não há uma manifestação explosiva do povo, mas apenas o apontamento de linhas de fuga ocasionais por parte da prefeita; ela seleciona as tópicas que lhe são convenientes para causar boa impressão na engenheira visitante. Paralelamente, por um viés irônico, a tensão maior repousa na censura dirigida pelo narrador ao ponto de vista da primeira-dama e da classe dirigente como um todo. Ao mesmo tempo, ele parece lastimar o fato de o povo não ser ele mesmo e subordinar-se a tal estado de coisas.

\subsubsection{A política individualista em cheque}

Em sua primeira colaboração em Cultura Política, mais do que se referir a uma situação específica, o autor vale-se da indeterminação das coordenadas espaciais, temporais e actanciais para produzir um quadro supostamente autônomo. Ao mesmo tempo, abusa de elementos que instauram a polifonia (discurso indireto livre e ironia) e requisitam a perspicácia do leitor para se concretizarem como significação, pois acabam gerando uma interpretação ambivalente. Nada é expresso de maneira direta, em sentido que se pretende unívoco, como se esperaria de um quadro descritivo tradicional ou de uma dissertação sobre a festa carnavalesca, por exemplo. Isto vale para o próprio posicionamento do narrador que ao incorporar em sua própria enunciação fragmentos da fala de outrem, colocava-se no meio do caminho entre a completa dissociação das personagens (condenação) e a aproximação (partilha) do universo delas. 
Graciliano, portanto, não abandona seu compromisso com a ficção, como se sobrepusesse mais camadas de sentido entre as suas produções e o universo de referência pretendido pela revista. Tal procedimento permitia-lhe trabalhar de maneira mais alusiva com as tópicas de interesse do governo, sem a necessidade de explicitar seus posicionamentos, ou mesmo, em último caso, de fazer elogios ao regime. Ao mesmo tempo, mesmo por vias indiretas, trazia elementos passíveis de serem ajustados à ideologia do Estado Novo e à legitimação desta.

No texto acima, o retrato da elite sertaneja, situado num momento anterior aos anos de 1930, pode ser interpretado como uma maneira de tratar de política, mais especificamente do individualismo político e do alheamento da "realidade" nacional, o que se adequava a perspectiva governamental de combate ao liberalismo da Primeira República. Por mais que Graciliano se referisse a um problema estrutural, que ultrapassava o período pré-1930, o enquadramento de sua narrativa numa revista propagandística, interessada em legitimar um estado de coisas, conferia-lhe uma leitura específica, condizente com os postulados oficiais.

O autor ressalta a iniciativa da classe dirigente municipal em mostrar uma imagem falseada da localidade, presente tanto no conteúdo quanto na fala da primeira-dama. Com o intuito de construir uma imagem "artificial” do lugar, tal figura escolhia rigorosamente as palavras, lançava mão de circunlóquios e amabilidades, procurando explicar as condutas e comportamentos inadequados, dos munícipes que brincavam o carnaval. Tudo para que as engenheiras não formassem "um mau conceito da terra”. Por exclusão, se faltava naturalidade ao discurso da prefeita, cabia ao narrador retirar esse véu do quadro apresentado e mostrar a cidadezinha em toda sua precariedade, ridículo e provincianismo, segundo olhares de seus dirigentes.

Na descrição da postura adotada pela mulher do prefeito aparece um lugar-comum muito recorrente nos textos de Graciliano, que interessava o reivindicado tecnicismo estadonovista, como contra-exemplo ao liberalismo de gabinete: a apresentação do discurso político como meio de mascarar a realidade, de construir uma imagem falsa do mundo, a qual seria interessante tão somente aos detentores do poder municipal. No caso interiorano, o artista se volta ainda contra a propalada urgência em se levar ao sertão as conquistas técnicas da modernidade, quando ainda se mantinham as bases desiguais, autoritárias e violentas da sociedade sertaneja. Nesse sentido, luz elétrica, cinema, automóvel, estrada de ferro entre 
outros avanços, não passavam de perfumaria, pois a verdadeira mudança deveria ocorrer não na superestrutura, mas na infra-estrutura da organização social.

O autor reivindicava, implicitamente, não uma mudança dos mais pobres, mas da elite dirigente, que se recusava a aceitar as transformações e as liberdades populares. Há aqui uma relação direta com o texto "Natal no interior"733, no qual o artista, ao se referir aos relacionamentos amorosos, contrapõe a "alarmada pudicícia” e os "rubores” ainda observados nas camadas mais altas da sociedade sertaneja, com a ausência de obstáculos para as instâncias do coração, notada entre os menos abastados. Em “Carnaval”, a separação entre as classes durante a festa também fica evidente. De um lado o povo em festa, dançando, gingando. No meio dele, não faltavam “tipos viciados”, “mulheres duvidosa”, pertencentes aos estratos mais baixos da sociedade. De outro, "magotes limpos de misturas perniciosas", onde se encontravam as famílias tradicionais do município, com destaque para o grupo formado pela mulher do prefeito, as visitantes e a gente do promotor e do juiz.

Ainda com relação ao discurso progressista e modernizador imposto ao sertão, pouco significava para os políticos se os avanços tecnológicos, como a implantação da eletricidade, melhoravam a vida da sociedade; o importante era não fazer feio frente às avaliações externas e aumentar o próprio prestígio. Nesse sentido, pode-se considerar que a modernidade não cumpria um papel de transformação na vida do lugar, mas servia apenas como meio de incrementar o poder daqueles que estavam à frente da administração municipal. Em função dessa prerrogativa, as benesses da civilização chegavam ao sertão de maneira precária: iluminação pública que cochilava, cinema onde as fitas se quebravam, o atraso na implantação da estrada de ferro, entre outros casos. Como cumpriam objetivos eleitorais, as melhorias valiam mais como obras propagandísticas, pouco importando a qualidade do produto oferecido aos munícipes, que submetidos ao regime de força dos coronéis não podiam reclamar, temendo represálias.

No sétimo texto da série “Quadros e Costumes do Nordeste”, reunido em Viventes das Alagoas com o título “Teatro I”, o enfoque de tal perspectiva individualista na condução dos negócios públicos, adotada, sobretudo, por políticos ligados à Primeira República, salta para o

\footnotetext{
${ }^{733}$ Conforme o manuscrito da primeira colaboração de Graciliano em Cultura Política, ela aparece com o título "O carnaval no interior", o que reforça a proximidade entre as duas narrativas (LIMA, Yêdda Dias; REIS, Zenir Campos. Catálogo de manuscritos do Arquivo Graciliano Ramos. São Paulo: Edusp, 1992, p.159). Ambas se propõem a tratar das respectivas festas sertanejas, mas privilegiam o exame da elite do lugar.
} 
primeiro plano. Nesta colaboração, Graciliano trata mais especificamente da atuação de um chefe estadual, no contexto da chamada "Política dos Governadores", uma espécie de pacto de apoio mútuo, firmado entre a presidência da República e as oligarquias estaduais, a partir do governo de Campos Salles (1898-1902), que se estendeu até por volta de $1930^{734}$.

Escorado nas diretrizes descentralizadoras da Constituição de $1891^{735}$, esse acordo entre as esferas federal e estadual propiciava relativa autonomia a ambas, embora mantivesse a interdependência política entre uma à outra: enquanto as oligarquias dependiam do presidente para se manterem no poder, nomearem deputados e senadores (entre outros cargos) e mandarem e desmandarem em seus domínios, o chefe da nação necessitava do apoio governadores (e das forças locais em geral) para implementar suas políticas. Ao mesmo tempo, tal iniciativa permitia reduzir ao máximo as disputas políticas nos Estados, pois eram prestigiados pela União apenas os grupos mais fortes, que acabavam se perpetuando no poder.

Na aludido texto, Graciliano refere-se à atitude de um presidente de Estado nordestino (modo como se chamavam os governadores à época), que depois de reeleito, mediante sucessivos pleitos fraudulentos, desejava construir uma obra que o perpetuaria, ou seja, reforçaria ainda mais seu prestígio e poder aos olhos da população. De maneira sarcástica, o escritor trabalha com certa imagem da prevalência do individualismo na política estadual, num período correspondente ao início do século XX:

\footnotetext{
Sempre escolhido, S. Exa. determinou exibir gratidão: realizar uma obra que o perpetuasse. Refletiu, fez estudos e procurou conselhos. As rodovias foram repelidas, porque no Estado existiam poucos veículos, além dos carros de boi. Excluíram-se também as pontes e quaisquer construções de alicerces profundos e duvidosos. As escolas eram consideradas prejudiciais. Havia algumas é certo, para dar emprego às filhas dos prefeitos, mas estas não forneciam aos alunos conhecimentos.
}

Tudo ponderado, S. Exa. resolveu edificar um teatro. Era o que necessitava a capital. Davam-se ali representações de amadores, apareciam com modéstia companhias cambembes, cinemas vagabundos, mágicos e hipnotizadores. Espetáculos verdadeiros não se conheciam ${ }^{736}$.

\footnotetext{
${ }^{734}$ FAUSTO, Boris. História do Brasil. São Paulo: Edusp, 2003, p.258-259.

${ }^{735}$ Segundo o artigo 63 desta, cada Estado tinha liberdade para elaborar sua própria Constituição desde que respeitados os princípios constitucionais da União. O modelo adotado foi o da carta dos EUA. De acordo com tal perspectiva, Alagoas, por exemplo, promulgou sua Constituição Estadual em 11 de junho de 1891.

${ }^{736}$ RAMOS, Graciliano. A vida social no Brasil: Quadros e Costumes do Nordeste VII. Cultura Política, Rio de Janeiro, ano 1, n.7, set. 1941, p.264.
} 
Ironicamente, o cronista sugere que, para o citado governador, a palavra "gratidão" apresentava um sentido invertido: ao invés de sinônimo de reconhecimento, de retribuição, tendo em vista a obtenção de algum apoio ou benefício anterior, ela se aproximava do que usualmente se entende por vaidade: um desejo imoderado de atrair admiração ou homenagens. Nesse sentido, diante da vanglória e das pretensões pessoais do político, pouco importava o interesse público, ou seja, a construção de obras que, consensualmente, poderiam melhorar a vida da coletividade.

Por esta perspectiva, obras de infra-estrutura, tais como rodovias, não lhe dariam a notoriedade desejada, pois em face do atraso e das limitações do Estado, ele ainda contava com poucos automóveis e muitos carros de boi. Por outro lado, pontes e outras edificações, de alicerces "profundos e duvidosos”, poderiam abalar sua credibilidade e manchar sua imagem, caso viessem a cair num futuro próximo. Outra possibilidade, as escolas eram consideradas prejudiciais. A função primeira de tais estabelecimentos não seria o ensino, mas sim servir de instrumento clientelista; não passavam de cabides de emprego para filhas de prefeitos do interior. Nesse sentido, não cumpririam, nem de longe, o papel almejado pelo cacique estadual.

Diante de tal impasse, ironicamente erigido pelo autor, a solução encontrada, ao final, é a construção de um teatro. A escolha do chefe estadual não é aleatória. Para hiperdimensionar sua autopromoção, ela dá preferência a uma obra que repercutiria mais intensamente entre a elite local, afeita a tal universo “requintado” e supostamente preocupada com a elevação da vida artística estadual. Paralelamente, o empreendimento servia para mascarar a precária situação local, apagando a necessidade de se construir obras de interesse da maioria.

Como atendia a fins políticos (propagandísticos) de última hora, estudos mais abalizados, que dessem conta da viabilidade técnica e financeira da obra, foram deixados de lado. E, obviamente, todo o processo desde a captação de recursos até a construção do teatro fora marcado por sucessivos problemas: empréstimos feitos no exterior pra viabilizar o empreendimento foram parcialmente desviados pelo emissário enviado ao exterior; a edificação começou a ser feita num local, mas depois teve que ser desmanchada e recomeçada em outro, devido a impropriedades com o terreno escolhido inicialmente. Além disso, inaugurada a casa de espetáculos, a companhia italiana que subira a seu palco para cantar as óperas Rigoletto, Aída e Barbeiro de Sevilha morrera quase toda de febre amarela, doença 
tropical típica de localidades pobres, sem infra-estrutura sanitária e de saúde. A aparência pretendida pela classe dirigente contrapunha-se a essência precária do quadro estadual.

Diante de tais considerações, a história da construção do teatro pode ser tomada como meio para se discutir alegórica e ironicamente a política levada a termo pelas elites republicanas, a qual o tecnicismo centralizador do regime de 1937 procurava se contrapor. Argumentos não faltam para justificar tal transposição de sentido: a execução da obra fora resultado de motivações personalistas e autopromocionais, que deixavam de lado o interesse pelo bem comum; ela tornara-se possível mediante a contração de empréstimos no exterior, desviados e nunca pagos, o que refletia a descentralização administrativa, a corrupção dos funcionários e a permissividade do sistema político que não coibia a má conduta de seus integrantes; mostra da falta de planejamento, incompetência, despreparo e ineficiência técnica da burocracia estadual a frente do projeto; atestado do internacionalismo e do desprezo da classe dirigente pela “realidade nacional”, pois privilegiava, em seu palco, a encenação de obras estrangeiras, esquecendo-se das manifestações artísticas nacionais; e representação de toda precariedade em que se encontrava a vida nacional e do descompasso entre os poderosos, que mantinham o vívido interesse pela operística européia, e o restante da população, desprovida de condições básicas de sobrevivência.

Por mais que descrevesse um quadro situado antes de 1930 e não mencionasse, em nenhum momento, que tal situação teria se alterado a partir da vitória da Revolução de Outubro, Graciliano municiava o discurso oficial de contra-exemplos legitimadores. Tomem-se alguns pontos levantados pelo autor que corroboravam a retórica governamental:

- A prevalência do bem coletivo em detrimento de interesses e motivações particulares. “A mudança radical de pontos de vista, dando lugar à substituição do império do individualismo pela afirmação vitoriosa do conceito do predomínio do bem comum, tornou automaticamente impossível a subsistência das facções e grupos partidários. A estes sobrepõe-se hoje a coesão nacional, que se traduz na unidade política do povo"737.

\footnotetext{
${ }^{737}$ AMARAL, Azevedo. Realismo político e democracia. Cultura Política, Rio de Janeiro, ano 1, n.1, mar. 1941, p.170.
} 
- A contração de empréstimos pelos Estados era algo feito em larga escala e sem o devido controle pelo federalismo da Primeira República. São Paulo sobressaía-se nesse quesito: “Convertendo em dólares o total das dívidas, o vice-cônsul norteamericano em São Paulo calculou, em 1935, que o Estado e seus órgão semiautônomos eviam ao estrangeiro cerca de 225 milhões de dólares”,738. Tal modalidade de captação autônoma de recursos pelas unidades federativas passara a ser controlada pela centralização política conduzida pela ditadura varguista. A Constituição de 1937 vedava tal forma de endividamento externo por parte das interventorias estaduais sem a prévia autorização do Conselho Federal (espécie de órgão que funcionava como poder legislativo, mas era controlado pelo presidente).

- Por outro lado, nesse momento, o Estado Novo projetava e executava grandes obras, com destaque para o prédio do Ministério da Educação e Saúde, que contou com o suporte do afamado Le Corbusier. Muito bem planejado, o edifício fora tomado como gesto inaugural de uma linguagem arquitetônica inovadora, que, para se legitimar, procurava construir seus laços com o período colonial, tomado como momento de fundação de um estilo dito brasileiro ${ }^{739}$.

- O privilégio para a produção artística nacional. “A arte brasileira, que hoje se afirma mais do que ontem, está, neste momento, vivendo um de seus períodos mais fulgurantes justamente porque, aspirando o universal, parte do nacional para afirmarse juntamente com as características essenciais da nossa alma, da alma do Brasil”740.

No cotejo entre o texto de Graciliano e a história de construção do Teatro Deodoro, em Maceió, observa-se alguns parentescos factuais: a obra foi iniciada e logo depois demolida para ser realizada em outro lugar ${ }^{741}$; a inauguração, em 15 de novembro de 1910, deu-se no

\footnotetext{
${ }^{738}$ LOVE, Joseph et. al. O poder dos Estados. Análise regional. In: FAUSTO, Boris (dir.).História Geral da Civilização Brasileira. São Paulo: Difel, vol. 1, tomo 3, 1975, p.62.

${ }^{739}$ Essa relação entre moderno e antigo, na qual o novo procurava se afirmar historicamente, como se estivesse desde sempre presente nas raízes da nacionalidade, nortearia a seleção dos monumentos a serem tombados pelo Serviço de Patrimônio Histórico e Artístico Nacional, também um produto do regime de 1937. Ver LONDRES, Cecília. A invenção do patrimônio e a memória nacional. In: BOMENY, Helena (org.). Constelação Capanema. Rio de Janeiro: Ed. Fundação Getúlio Vargas: Bragança Paulista: Ed. Universidade São Francisco, 2001, p.85101.

${ }^{740}$ A ORDEM política e a evolução artística. Cultura Política, Rio de Janeiro, ano 1, n.3, maio 1941, p.290.

${ }^{741}$ O edifício começou a ser levantado em 16/09/1898, no governo de Manoel José Duarte. Inicialmente, a casa de espetáculos se chamaria "Teatro 16 de setembro", mas a construção foi interrompida e posteriormente demolida e sua área foi ocupada pela estátua eqüestre do proclamador da República. Quando do início da
} 
governo de Euclides Malta, governador que mais tempo ficou no cargo na primeira década do século $\mathrm{XX}^{742}$ (apesar de a pedra fundamental ter sido lançada na gestão anterior). Por outro lado, na abertura da casa de espetáculos, não esteve presente uma companhia italiana que posteriormente foi dizimada pela febre amarela. Além disso, na première, encenaram-se as peças Um Beijo, de autoria do alagoano J. Britto, e O Dote, de Arthur de Azevedo, ou seja, nada de óperas estrangeiras.

Há, portanto, uma matriz discursiva que serve apenas de detonador para a fabulação empreendida pelo artista, que joga com os dados na confecção de um texto que se aproxima do protocolo ficcional do conto. O discurso histórico autenticador nunca é mencionado, além disso, o artista não “dá nome aos bois”, indeterminando as coordenadas actanciais, espaciais e temporais $^{743}$ de referência ao mundo. Trata-se, portanto, de um relato que se pressupõe autônomo. Como visto, nele o escritor critica ironicamente certos procedimentos políticos localizados na Primeira República, o que torna a sua fala ajustável ao discurso estadonovista, o qual retirava sua legitimidade do rebaixamento do liberalismo anterior a 1930.

\subsubsection{O combate ao provincianismo}

edificação do Teatro 16 de setembro, o Secretário de Estado, José Duarte, proferiu as seguintes palavras: "Festeje-se, pois, com pleno regozijo, o assentamento do primeiro monólito e da primeira pá de argamassa que vão servir de núcleo da suntuosa construção que ora se iniciar e que nos vai elevar muito no conceito das comunhões cultas; porque este cerimonial é eminentemente edificante: ele significa a fundação de um templo majestoso consagrado à nossa arte, às nossas letras e à nossa sublimação moral: ele exprime o arrojo de um nobre cometimento e afirma bem claro as louváveis inclinações do nosso meio; ele é, em suma, o apostolado bendito de nosso progresso" (In: DUARTE, Abelardo. Autores alagoanos e peças teatrais, Maceió: Fundação Teatro Deodoro, 1980, p.33).

${ }^{742}$ Em 12 de junho de 1900, Euclides Vieira de Malta é eleito presidente de Estado para o triênio 1900-1903. Findo o mandato, assume seu irmão, Joaquim Paulo Vieira Malta, que governa Alagoas pelos três anos seguintes. Euclides, por sua vez, sucede ao irmão em 1906. Esta última permuta fraternal não foi feita tranquilamente; a oposição procurou resistir, levantando a candidatura do general Gabino Besouro. "Findo esse período governamental, Euclides Malta, de posse de toda engrenagem administrativa e contando com o apoio do governo federal, que fazia, desde Campos Salles, a política dos governadores, reelege-se para o triênio de 19091912” (COSTA, Craveiro. História das Alagoas. São Paulo: Melhoramentos, 1983, p.165). A oposição cresce, mas Euclides resiste à onda de impopularidade que o cercava e o apontava como oligarca.

${ }^{743}$ Com relação ao tempo, o autor oferece algumas referências que permitem situar a narrativa no início do século XX. No início do texto, ao caracterizar a pequena capital, ele destaca: "Na pequena capital, de gostos simples e desejos modestos, havia poucas escadas e ignoravam-se completamente os elevadores. Três andares representavam quase montanha entre casas acaçapadas. Ninguém pensava em andar nos ares, naturalmente. Santos Dumont ensaiava os seus primeiros vôos baixos, em Paris, com muitas quedas, e não se dava crédito aos telegramas que os anunciavam” (RAMOS, Graciliano. Quadros e Costumes do Nordeste VII, Cultura Política, ano 1, n.7, set. 1941, p.263). Como se sabe, em 23 de outubro de 1906, Dumont voou cerca de 60 metros, a uma altura de dois a três metros do chão com seu 14 Bis, no Campo de Bagatelle, em Paris (SODRÉ, Antonio. Santos=Dumont, um herói brasileiro. São Paulo: Arindiuva Editora, 2006, p.120). 
Voltando ao escrito sobre o carnaval, além do combate ao individualismo político, Graciliano se aproxima da perspectiva governista ao condenar de maneira irônica e oblíqua o provincianismo e o moralismo sertanejos. O paratexto que antecedia à colaboração do escritor e direcionava-lhe a leitura trata de especificar um pouco melhor a questão ${ }^{744}$ :

...o autor desta crônica [Graciliano] tomou a seu encargo fixar quadros e costumes da região do Brasil onde nasceu e viveu mais de trinta anos: o Nordeste. Neste número inaugural, ele nos dá um flagrante da grande festa popular - o carnaval - tal como decorre nas cidades do interior nordestino. É um pequeno pedaço desse Brasil que ainda foge do ímpeto renovador da civilização litorânea, desse Brasil tão diferente e tão grande..., ${ }^{745}$.

De acordo com as diretrizes documentais dos “Quadros e costumes do Nordeste”, os editores tomam o escrito de Graciliano como um "flagrante”, como se um "pedaço” do interior do país, e não uma simples representação do mesmo, fosse transposto para as páginas de Cultura Política. Paralelamente a esse reforço do estatuto de verdade da colaboração, destacam que o artista se referiria a uma porção “desse Brasil tão diferente e tão grande” que ainda "fugia do ímpeto renovador da civilização litorânea”, ou seja, separavam o quadro descrito pelo autor do raio de ação do regime. Ao mesmo tempo, presumem uma contraposição entre uma suposta modernidade litorânea e uma não-modernidade sertaneja, sendo que esta última precisava ser combatida, enquanto linha de fuga, e integrada ao corpo da "civilização litorânea”.

No que diz respeito ao tópico "provincianismo”, a revista dá destaque ao pensamento de Gilberto Freyre. Em artigo presente na publicação, o autor de Casa-grande e Senzala faz uma diferenciação entre um "provincianismo básico" de matriz cultural e o que ele chama de estadualismo balcanizante, originado pela “política perigosa de autonomias estaduais”, conduzida pela Primeira República. Enquanto o primeiro seria “uma condição de vitalidade, de autenticidade, de vigor, de permanência e de espontaneidade, para a nossa arte, para a nossa literatura, para nossa cultura em formação”, o segundo não passava de uma caricatura mal-ajambrada do federalismo norte-americano, que perturbava e comprometia as energias regionais. Segundo o autor, este último ancorava-se numa política de balcanização, cujo único propósito seria satisfazer os interesses particulares de grupos, "intitulados pomposamente de

\footnotetext{
${ }^{744}$ Tendo em vista a consecução de tal propósito, repete-se novamente a transcrição do trecho, que já fora analisado, segundo outros parâmetros, no capítulo anterior.

${ }^{745}$ ESCRITOR e romancista... Rio de Janeiro, Cultura Política, ano 1, n.1, mar. 1941, pp.236-237.
} 
partidos ou disfarçados em campeões de um progresso baseados sobre favores da União a Estados dominantes" ${ }^{746}$.

Freyre louva a iniciativa centralizadora e modernizadora do governo, voltada a um só tempo ao combate do "mal-estadualismo" e à defesa da unidade nacional, mas destaca que esta última não deveria ser confundida com uniformidade e sobrepor-se às especificidades regionais:

A ordem que convém ao Brasil é, tanto quanto a unidade, um plano ou sistema de organização nacional - na verdade quase continental - a que a cooperação interregional [sic] de cultura só fará dar vida, evitando-se que entre nós "ordem” se torne sinônimo de estagnação ou mesmo de regularidade, de simetria, de sacrifício de quanto for espontaneidade de província a um critério único de urbanismo, de paisagismo, de pedagogismo rígido ${ }^{747}$.

O ensaísta volta-se contra certos "unitaristas" e "metropolitanistas", identificados com as aspirações de uma arte e de uma cultura simétrica e urbana, “quase européia”, que rebaixavam as particularidades regionais como “caipirismo" e até "separatismo". Para Freyre, ao contrário, era preciso enriquecer “o todo cultural brasileiro” com as energias de província. E esse caminho fora indicado pelo próprio presidente Getúlio Vargas, segundo o qual a unificação Brasil se consolidaria não pelo esmagamento, mas sim pelo ajustamento orgânico das províncias ou das regiões "como membros de um só corpo a serviço do ideal e do engrandecimento comum, ${ }^{748}$.

Ao privilegiar o ponto de vista castrador da elite sertaneja, Graciliano parece criticar tanto o “mau-provincianismo” (o estadualismo balcanizante), atrelado à política individualista desta última, como repudiar certo olhar metropolitano, dominante na apreensão de mundo realizada pelos integrantes da mesma classe dirigente municipal: eles deixavam de valorizar as especificidades da cultura local para exaltar a modernidade de arremedo chegada ao sertão. Nesse sentido, durante o festejo popular, a prefeita procurava elevar-se diante das visitantes, ressaltando, por exemplo, não o rancho de maracatus que passava, em meio a outras particularidades do carnaval interiorano, mas a iluminação elétrica, o número de automóveis,

\footnotetext{
${ }^{746}$ FREYRE, Gilberto. A condição de provinciano no Brasil. Cultura Política, Rio de Janeiro, ano 2, n.15, maio 1942, p.13-15.

${ }^{747}$ Idem, p.14.

${ }^{748}$ Idem, p.15.
} 
a chegada da estrada de ferro, entre outros itens da "civilização litorânea” que aportavam precariamente ao hinterland brasileiro.

Em tal processo, a primeira-dama louva também o fim do “bárbaro” entrudo, que dava lugar a uma forma mais "nobre” e ordeira de comemoração, adequada a certos padrões metropolitanos:

A cidade não têm razão para se envergonhar. O largo vai se enchendo. Na vizinhança crescem rumores de um frevo honesto.

Antigamente não era assim. Marmanjos, de saco a tiracolo, armados de enormes bisnagas, molhavam as pessoas, jogavam-lhe punhados de ocre e vermelhão.

Agora estamos civilizados ${ }^{749}$.

Durante o período colonial, o entrudo reinara sozinho no Brasil. A partir da metade do século XIX, a situação começava a mudar: a festa carnavalesca, com raízes francesas, foi disseminase por toda a parte. No início do século XX, o antigo folguedo de origem portuguesa praticamente desaparecera nas grandes cidades brasileiras, suplantado pelo carnaval burguês, caracterizado por bailes privados, desfiles em carros alegóricos (corso) e guerras de confete e serpentina (versão “civilizada” das antigas pelejas entre os foliões, marcadas pelo uso de água, farinha e tinta como munições). Contudo, o entrudo teria persistido, durante algum tempo, em cidades mais tradicionais ou de menor vulto ${ }^{750}$.

Na cidadezinha construída pelo artista, observava-se a mescla de festejos da elite, aparentemente mais modernos (o corso, nos poucos carros que circulavam com seus passageiros travando guerras de serpentina e confete; desfile de cordões) e do povo, mais antigos (com os foliões em ranchos e maracatus, gingando e dançando frevo no largo da cidade e nas circunvizinhanças deste; repetição de pilhérias, em alusão a torneios verbais e as zombarias). As guerras entrudísticas haviam ficado para trás, mas a espontaneidade popular continuava a dar o tom da festa, que, apesar das mudanças, ainda mantinha sua faceta

\footnotetext{
${ }^{749}$ RAMOS, Graciliano. A vida social no Brasil: Quadros e Costumes do Nordeste I. Cultura Política, Rio de Janeiro, ano 1, n.1, mar. 1941, p.237.

750 "Porém, mesmo nelas, houve a formação de grupos mascarados denominados ora blocos, ora cordões, em geral por iniciativa de famílias ricas; dançavam e cantavam pelas ruas, tentando copiar, na medida de seus recursos, os cortejos da capital do país, sempre com a assistência e os aplausos do poviléu” (QUEIROZ, Maria Isaura Pereira de. Carnaval Brasileiro: o vivido e o mito. São Paulo: Editora Brasiliense, 1992, p.55).
} 
tradicional e pitoresca. Por outro lado, a classe dirigente local, interessada na adoção de um estilo de vida moderno e burguês, mantinha sua postura controladora, vigiando as manifestações instintivas e livres de constrangimento da população em festa ao invés de destacá-las, enquanto expressões de vitalidade, como reivindicava Gilberto Freyre.

Ao adotar a focalização da elite, o autor investe na produção da imagem de um carnaval regrado, "executado com decência e ordem”, no qual os foliões marchavam como soldados em paradas cívicas e os grupos se encontravam divididos, sem a típica subversão de papéis atribuída ao evento. Tal opção textual hiperdimensiona o efeito do controle exercido pelos poderosos locais e, conseqüentemente, potencializa sua crítica a esta conduta castradora. Ele volta-se, preferencialmente, contra o uso da disciplina para a produção de uma imagem artificial da localidade, interessante somente para a classe dirigente imitadora de valores exógenos, que desejava vender uma imagem moderna de si, mas, em sentido oposto, apenas reforçava seu aspecto tacanho.

Apesar do enquadramento da revista, que limitava as colaborações de Graciliano ao retrato da vida nordestina, certas leituras procuraram aproximar a vigilância exercida pela elite interiorana, ficcionalizada pelo escritor, do comportamento disciplinador adotado pelo Estado Novo na padronização do carnaval carioca.

Como se sabe, a ditadura varguista terminara por institucionalizar e elevar o “carnaval popular” ao posto de grande festa brasileira. Sabe-se que, nesse momento, na capital, o governo patrocinava blocos carnavalescos e escolas que adotassem enredos nacionalistas, utilizando-os como forma de propaganda. Além de sambas ufanistas da brasilidade, o governo getulista privilegiava aqueles que exaltassem o trabalho. Com a criação do DIP, em 1939, a censura intensificou a repressão aos sambas que tratassem da malandragem e da vida boêmia, algo comum nesse gênero musical. Nota-se, dessa maneira, a tentativa de adequação da festa ao ideário do estado nação que se construía naquele momento ${ }^{751}$.

\footnotetext{
751 “O governo estadonovista, contando com o apoio do Departamento de Informação e Propaganda (DIP), e com os projetos de alguns intelectuais contratados, conseguirá concretizar, até certo ponto de forma bem sucedida, a construção de uma ideologia coadunada com a sua propaganda política e cultural e de certa forma utilizar o rádio e os sambas para 'educar' e disciplinar os consumidores desse tipo de música. Isso se dará através da censura, dos sambas celebrando o trabalho disciplinado, do nacionalismo ufanista das canções de exaltação, dos grandes concertos promovidos pelo Estado e por Villa-Lobos nos estádios de futebol e, em última instância, através dos concursos carnavalescos” (CUNHA, Fabiana Lopes da. Da marginalidade ao estrelato: o samba na construção da nacionalidade (1917-1945). São Paulo: Annablume, 2004, p.200). Ver ainda SEBE, José Carlos. Carnaval,
} 
Desprezando a moldura estadonovista imposta ao texto em questão pela revista, bem como o tratamento da tópica “carnaval de província” ao longo da produção do autor, Bumirgh pressupõe que Graciliano, por meio desta “crônica”, faria referência ao controle imposto pela ditadura varguista à grande festa popular, como se o escritor denunciasse certo estado de coisas getulista:

O DIP tentará padronizar o carnaval e na cidade de cinco mil habitantes, o carnaval será realizado “com decência, com ordem” e será hierarquizado, já que “famílias reunem-se na praça, em magotes limpos de misturas perniciosas"752.

No entanto, muito pelo contrário, a aplicação de imagens antitéticas, para se referir à festa dionisíaca da loucura como uma manifestação ordeira, correta e hierarquizada, configurava-se como um lugar-comum na produção do autor. Além da colaboração editada na revista oficial, Graciliano tratara do carnaval em duas outras oportunidades. Em “Carnaval 1910”, texto saído em O Cruzeiro, em 1942, ele destaca que algumas figuras que brincavam o entrudo “marchavam na disciplina”, outras “desregravam-se com moderação, quase a pedir desculpas encabuladas à cidadezinha pacata”, um cidadão levara uma surra - "berros, súplicas, sangue, apitos, sumiam-se na festa”, moças sentadas em cadeiras nas calçadas "comportavam-se direito como se esperasse uma procissão"753. Num escrito mais antigo, publicado em $O$ Índio, quando o autor ainda vivia na província, ele faz referência a truculentos cordões que “marchavam pela rua a vociferar quadrinhas sem pé nem cabeça”, sob a música fúnebre de fados de além-mar ${ }^{754}$.

Portanto, segundo a ótica elitista e acanhada da província, o tratamento do carnaval como uma festa de disciplina e controle, longe da imagem de desregramento comumente difundida, não se restringia à colaboração estampada em Cultura Política. Além disso, o enquadramento conferido ao texto pela revista getulista tratava de abafar tal suposta leitura questionadora do status quo estadonovista, na medida em que definia o escrito como um documento restrito ao

carnavais. São Paulo, Ática, 1986 e PARANHOS, Adalberto. Os desafinados do samba na cadência do Estado Novo. Rio de Janeiro, Nossa História, ano 1, n.4, fev. 2004.

${ }^{752}$ BUMIRGH, Nádia Regina Marques Coelho. op.cit, p.82.

${ }^{753}$ RAMOS, Graciliano. Carnaval 1910. O Cruzeiro, Rio de Janeiro, 14 fev. 1942. In: Viventes das Alagoas. Rio de Janeiro: Record, 2007, p.9-12.

${ }^{754}$ RAMOS, Graciliano. Traços a esmo IV. O Índio, Palmeira dos Índios, Rio de Janeiro, fev. 1921. In: Linhas Tortas. Rio de Janeiro: Record, 2005, p.85. 
passado do interior nordestino, região tida naquele momento como berço da nacionalidade. Ao mesmo tempo, de acordo com a perspectiva governamental de se firmar na "realidade" brasileira, o artista fornecia elementos para incorporação simbólica do interior do país, produzindo um saber sobre aquele espaço que ainda fugia do "ímpeto renovador da civilização litorânea”. E se Graciliano fazia isso por um viés crítico, sem glórias, a publicação, voltada para a elite, admitia tais dissonâncias, ainda mais se se considerar o caráter alusivo das narrativas, que, apesar de particularizadoras, não se restringiam à representação de um fato específico.

\subsection{Maria Amália, a personificação do coronelismo}

Em sua segunda colaboração em Cultura Política, Graciliano traça o perfil de D. Maria Amália, personagem feminina que se portava como um verdadeiro coronel de saias no comando da vida municipal, sempre cobrando do governador do Estado favores a seus aliados e sanções a seus inimigos. Em linhas gerais, o artista apresenta-a como uma espécie de personificação do parasitismo, do nepotismo, do clientelismo e da malandragem que teriam marcado a vida política brasileira. Nesse sentido, mais do que descrever um tipo, o escritor produz, alegoricamente, um símbolo da instituição “coronelismo”, que tomava a cara de uma mulher e interagia com os demais atores no universo ficcional traçado.

Tal dispositivo, associado à colocação do retrato no passado, num período anterior a 1930, permitia-lhe tratar, por meios encobertos, da tópica do rebaixamento da Primeira República sem a necessidade de tomar partido aberto em favor do governo. Por hipótese, se optasse pela composição de um texto dissertativo sobre o voto de cabresto ou mesmo por uma crônica com referência imediata no real sobre o mandonismo feminino, ou seja, caso abdicasse da ficção, como faziam os demais autores da revista, supõe-se que seria mais difícil para o autor tratar desse lugar-comum, central no ideário estadonovista, sem abordar, de maneira explícita, a suposta atuação “positiva” do regime na superação problema.

Portanto, com relação ao escrito em questão, não se trata propriamente de uma crônica, como a própria revista fazia crer, mas de um pequeno conto de personagem (retrato) no qual a conceituação de D. Maria Amália, focalizada por um narrador onisciente (que não participa dos fatos), impõe-se sobre a construção de uma trama com começo, meio e fim. Em rápidas pinceladas, o autor constrói o perfil moral do tipo feminino, sumarizando e descrevendo 
situações, sem deixar de, ocasionalmente, comentá-las de maneira crítica, marcando sua função ideológica no relato. Ao mesmo tempo, indetermina as coordenadas espaciais, temporais e actanciais, reforçando o efeito de ficção, por mais que aluda a um macrotexto facilmente apreensível (o coronelismo nordestino). Na grande maioria do conto, ele detém-se no período do auge da força da mulher para somente ao final apresentar, em breves palavras, a trajetória de declínio de tal figura. Este movimento descendente é relacionado com certa mudança no cenário político, que repercutira na perda de influência da senhora mandona.

Curiosamente, Graciliano abre o texto tratando de outro tipo, que será contraposto à protagonista com o propósito de mais bem conceituá-la. Trata-se do governo do Estado, agente público que, duas vezes por semana, abandonava a capital e se deslocava até o sertão. Sua motivação psicológica para deixar o aparente conforto do gabinete e enfrentar os solavancos e atoleiros da viagem pelas estradas rurais encontrava-se, principalmente, na fuga do clientelismo, da troca de favores, práticas que povoavam seu cotidiano enquanto chefe estadual e tornavam-no um “inferno". Ao mesmo tempo, dirigindo-se ao interior, ele procurava distribuir sabedoria (“ensinava agricultura e zootecnia aos matutos”) e marcar sua presença física enquanto administrador; alguém que conferia, in loco, a veracidade dos relatórios de prestação de contas apresentados pelos prefeitos (tentava "endireitar os orçamentos municipais”). Nesse movimento, ele se colocava em contato direto com as misérias da terra ("E as misérias vestiam-se mal e falavam linguagem incorreta”), o que, supostamente, conferia realismo ao seu governo, segundo o ponto de vista político do autor alagoano.

Ao longo de sua trajetória jornalística, sobretudo nos textos dedicados a temas políticos, Graciliano defendeu a idéia de que a administração do Estado deveria se assentar em saberes construídos a partir do contato direto entre o executivo e a vida local. Tome-se, por exemplo, o texto "Prefeituras Municipais I", de julho de 1930, no qual o articulista, referindo-se ao interior alagoano, comenta o aprimoramento da fiscalização dos gastos dos gestores municipais durante o mandato do governador Álvaro Paes:

Nestes últimos tempos os governadores de Alagoas apanharam o hábito de viajar, hábito incômodo para eles, para os que os acompanham, para os que são visitados e fiscalizados. O atual é viajante incansável. Mora num automóvel. Chega aos lugarejos do interior, ouve as embaraçadas conversas dos matutos e 
sugere idéias, aconselha, discute, anima, exige. Não é fácil um administrador declarar a ele, que despendeu mundos e fundos numa estrada imaginária.

As obras públicas têm hoje existência real. Todos podem examiná-las, medi-las, apalpá-las, saber quanto custaram, como foram construídas, a quem foram pagas. Há por aí vários trabalhos realizados. Não são, de certo, os trabalhos de Hércules. As pretensões dos que os executaram não chegam tão longe. Ainda estão em começo. Mas bastam para demonstrar que Alagoas vai em bom caminho ${ }^{755}$.

A defesa de tal caráter presencial e verificador do poder torna a merecer destaque em texto de louvor à figura do mesmo Álvaro Paes, divulgado também no Jornal de Alagoas, em 1930. Nele, Graciliano volta a destacar a iniciativa do político de deixar o gabinete e examinar, de perto, a vida dos municípios do interior alagoano, como se prescindisse de intermediários políticos para consultar as aspirações e necessidades populares:

\begin{abstract}
Álvaro Paes transformou-se num infatigável caixeiro-viajante. E, com pertinácia admirável, andou e anda a semear idéias novas, idéias que tem desenvolvido e preconizado em artigos, em livros, em discursos, em palestras, em cartas, em telegramas, em mensagens, em confidências.

Há pouco tempo, em trânsito por esses cafundós onde Judas perdeu as botas, saltou do automóvel e entrou num casebre, que tinha por mobília dois tamboretes e uma esteira. Visitou as plantações e deu à família conselhos que levaram o dono da casa a oferecer-lhe, comovido, um tatu.

(...)
\end{abstract}

Ele ama o sertão, está convencido de que existem ali recursos imensos. E quer transmitir aos outros o entusiasmo que o anima ${ }^{756}$.

Portanto, em tal processo de deslocamento permanente do governador, que deixava a capital para visitar as prefeituras do interior, destacava-se não só o caráter fiscalizador, mas centralizador da empreitada. Isso porque não se tratava de um processo de exame qualquer: era o próprio chefe do executivo estadual que se empenhava pessoalmente no trabalho. Nesse sentido, as obras relatadas em balancetes e depois publicadas no Diário Oficial, não bastavam

\footnotetext{
${ }^{755}$ GUEDES, Lúcio [Graciliano Ramos]. Prefeituras municipais I. Jornal de Alagoas, Maceió, 31 jul. 1930, p.3 (texto inédito em livro).

${ }^{756}$ RAMOS, Graciliano. Álvaro Paes, Jornal de Alagoas, Maceió, 12 jun. 1930.
} 
como provas; as obras realizadas precisavam passar pela vistoria pessoal de Álvaro Paes que concentrava funções e expandia as fronteiras de suas atribuições habituais.

De maneira semelhante, anos depois, Getúlio também procurava cultivar a imagem de um presidente itinerante, que, em escala maior, viajava por todo o país com o propósito de reforçar a unidade nacional por meio da recuperação de espaços abandonados, localizados, sobretudo, no interior do país. Nessa empreitada, paralelamente, demonstrava interesse pelos problemas nacionais, bem como vistoriava as ações de seu governo. Entre tais andanças, destacou-se a excursão do presidente ao Norte do país, no início da década de 1940. Cultura Política deu intenso destaque à iniciativa. Seu número 9, de novembro de 1941, comemorativo do quarto aniversário do Estado Novo, procurou retomar as palavras do discurso proferido por Vargas na ocasião. Nele, o chefe da Nação procurou expor os problemas da região amazônica e a urgência de integrá-la ao todo nacional, como se recuperasse e ampliasse o pensamento manifesto anteriormente por Euclides da Cunha.

Em reportagem sobre “O Discurso do Rio Amazonas”, proferido por Vargas, o ex-governador do Acre, Hugo Carneiro, destaca:

[Fazendo referência à Amazônia] Getúlio Vargas é o seu mais recente descobridor. Na sua famosa oração pronunciada na capital do Amazonas, o presidente, com grande autoridade de sua palavra, com a precisão de sua observação penetrante e vendo com a visão larga do estadista familiarizado com problemas ainda mais remotos do país que há onze anos administra revelou aos brasileiros um Amazonas novo, e a todos conclamou a desvendarem ${ }^{757}$.

De maneira mais geral, o texto também intitulado “O Discurso do Rio Amazonas”, de Raul de Azevedo (da Academia Amazonense de Letras), procurava destacar o caráter civilizatório das ações de Getúlio. Ao embrenhar-se pelo interior do país, o presidente buscava revitalizá-lo, em moldes semelhantes aos do governador alagoano destacado por Graciliano:

O Meio-Norte e o Oeste foram despertados pela ação vivificadora daquele que, com descortínio só possuído por estadistas de escol, está levando para os rumos altos e superiores terras e gerações que andaram quase esquecidas ou abandonadas ${ }^{758}$.

\footnotetext{
${ }^{757}$ À MARGEM do “Discurso do Rio Amazonas”. Cultura Política, Rio de Janeiro, n.9, nov. 1941, p.165.

${ }^{758}$ AZEVEDO, Raul. O Discurso do Rio Amazonas. Cultura Política, Rio de Janeiro, n.9, nov. 1941, p.158.
} 
Em “A marcha para o campo”, texto de 1938, o próprio Graciliano destaca o interesse do governo federal pelo interior do país, o que incluía o deslocamento deste ao hinterland brasileiro e a intervenção em tal meio. O cronista comenta o discurso no qual Getúlio levantou explicitamente tal bandeira (fala proferida no limiar de 1938) ${ }^{759}$ :

Teremos, pois, muitas vidas sacrificadas pela estagnação em que jaz o interior e pelo progresso rápido que inundou a capital. É indubitável, porém, que, aumentados os nossos recursos, criadas novas indústrias, estabelecido um regular sistema de transportes para os produtos agrícolas, que às vezes por falta de escoamento, deixam de representar valor, as populações rurais ficarão valorizadas e não mais terão necessidade de emigrar. É nesse sentido que se devem tomar as palavras do sr. Presidente da República quando ele se refere à "marcha para o oeste"

\section{$(\ldots)$}

No discurso de $1^{\circ}$ de janeiro nem o mais leve remoque ao roceiro que emigra, nenhuma frase de admiração inútil a riquezas inexploradas. Afirma-se ali, porém, que essas riquezas serão arrancadas do seio da terra. Assim, o homem acabará prendendo-se a ela e amando-a, não com o amor palavroso e estéril aconselhado em gritos por aqueles que fazem do patriotismo um indústria, mais em silêncio e energicamente, trabalhando ${ }^{760}$.

Graciliano louva a proposta getulista de "marcha para o oeste”, destacando a necessidade de se conhecer o sertanejo, prendê-lo a seu "torrão natal” e torná-lo útil, revertendo uma situação de êxodo que perduraria desde o Brasil colonial. Segundo a proposta oficial, isso só seria possível mediante a exploração de recursos ainda adormecidos no interior brasileiro, o que levaria a um desenvolvimento mais homogêneo do país. Ao mesmo tempo, a chegada dos "benefícios da civilização" a todas as regiões daria mais subsídios para que o interiorano se fixasse na terra onde nascera, não por patriotismo, mas por encontrar nela condições de trabalho, sem a necessidade de emigrar em busca de oportunidades ou mesmo apenas para garantir sua sobrevivência ${ }^{761}$.

\footnotetext{
${ }^{759}$ Com a palavra o presidente: “A civilização brasileira, mercê dos fatores geográficos, estendeu-se no sentido da longitude, ocupando o vasto litoral, onde se localizaram os centros principais de atividade, riqueza e vida. Mais do que uma simples imagem, transpor planaltos e expandir-nos no sentido das latitudes. Retomando a trilha dos pioneiros que plantaram no coração do Continente, em vigorosa e épica arremetida, os marcos das fronteiras territoriais, precisamos de novo suprimir obstáculos, encurtar distâncias, abrir caminhos e estender as fronteiras econômicas, consolidando definitivamente os alicerces da Nação. / O verdadeiro caminho da brasilidade é a marcha para o Oeste (VARGAS, Getúlio. A nova política do Brasil, vol. V, p.124).

${ }^{760}$ RAMOS, Graciliano. Linhas Tortas, p.183-185.

${ }^{761}$ Em tal discurso, Getúlio destaca que o governado continuaria vigilante, coibindo qualquer tipo de "extremismo" que atentasse contra "a segurança para o trabalho e as realizações de interesse geral" (VARGAS, Getúlio. op.cit. p.127). Nesse sentido, os elementos perturbadores da ordem continuariam ser segregados em
} 
Voltando ao texto sobre D. Maria Amália, tal figura feminina apresentava-se como uma antípoda do referido governador, personagem que, apesar de ajustar-se ao jogo clientelista da troca de favores e da compra e venda de votos, simbolizava o conceito de um gestor aparentemente preocupado com o bem da coletividade, lutando pelo progresso sertão. Neste último ponto, a imagem do político aproximava-se dos discursos erigidos em torno da prática administrativa de Álvaro Paes e Getúlio, referidos acima.

Em sentido oposto, D. Maria Amália, longe de aventurar-se pelo interior com o propósito de promover o avanço estadual ou mesmo trabalhar para o desenvolvimento de sua cidade de origem, o que a motivava era tão somente seus interesses pessoais. A "senhora terrível” manejava a máquina pública municipal inteiramente a seu favor, loteando e controlando cargos, desde os mais comezinhos até os mais elevados. O delegado, o subdelegado, o inspetor de quarteirões, o administrador da recebedoria, o coletor federal, o promotor, os jurados, os conselheiros municipais, o prefeito, entre outras autoridades do staff local estavam em suas mãos. Estas ou corriam para contentá-la prontamente ou simulavam rebeldia, obedecendo com suposta independência.

Personalização da instituição “voto de cabresto”, D. Maria Amália dispunha ainda de dois mil votos, o que lhe garantia respeito e maior poder barganha no trato com o governador: "depois da eleição, exigia empregos para todos os eleitores, adotava por intermédio do marido, o negócio de vendas à vista, tanto por voto”. Nesse sentido, seu poder se exercia por meios indiretos, uma vez que o artista se refere a um momento em que as mulheres estavam alijadas do processo político. Era o esposo da senhora-coronel, quem aparentava ter influência, quando, na verdade, era ela quem controlava tiranicamente a vida municipal. Tal informação permite depreender que Graciliano situava as ações retratadas num período anterior a 24 de fevereiro de 1932, quando é instituído Código Eleitoral Provisório, que estabelecera o sufrágio eleitoral feminino ${ }^{762}$. A partir desta data, muitas delas se candidataram a uma vaga para a Constituinte de 1934, deixando de lado a necessidade de utilizar o cônjuge como testa de ferro, quando desejavam exercer o mando em determinada localidade.

presídios e colônias agrícolas. Pela própria explicitude das palavras do discurso presidencial, Graciliano detêmse apenas nos trechos referentes à proposta de marcha para o interior, sem fazer alusão a tais linhas de caráter repressivo.

${ }^{762}$ LEAL, Vitor Nunes. Coronelismo, enxada e voto: o município e o regime representativo no Brasil. São Paulo, Alfa-Ômega, 1975, p.230. 
Como meio de evitar as manifestações que tal "figura antipática e exigente" lhe trazia de malandragem e parasitismo, o governador resolvera fugir da capital. Mas a mulher, como se ganhasse um estatuto de onipresença, perseguia-o por todos os lugares. Não adiantava se esconder. Quando não era a própria D. Maria Amália em carne e osso, eram seus representantes ou mesmo a lembrança dela, assim como um fantasma, que "aperreavam” o chefe estadual. Aos olhos deste, a senhora mandona teria crescido tanto que assumira para as proporções de uma calamidade, como se se tornasse a própria "representação da trapalhada econômica social e política” em que se encontrava o país:

Quando a malandragem e o parasitismo, embrulhados em boa sintaxe e enfeitados de retórica, mostravam a cauda numa coluna de jornal ou nas declamações excessivas dum discurso, s. excia. franzia a testa e queixava-se de d. Maria Amália.

Um conselho aprovava as contas do prefeito que esquecia as obras públicas e gastava mundos e fundos com pessoal.

- Administração de d. Maria Amália.

Um coronel mandava o júri absolver ou condenar criminosos.

- Justiça de d. Maria Amália.

Um delegado tomava a faca de um cabra e ia vendê-la a outro.

- Polícia de d. Maria Amália.

Todos os anos, no dia 7 de Setembro, o governador recebia um telegrama que nunca mudava: “Congratulo-me com eminente amigo comemoração data independência querida pátria. Cordiais saudações”.

- Política de D. Maria Amália ${ }^{763}$.

Como estratégia para ressaltar a representatividade e a força da personagem, seu nome passa a ser utilizado como designativo da corrupção e do parasitismo, entre outras práticas reprováveis, que se alastravam pelos poderes político, judiciário e policial dos municípios do

${ }^{763}$ RAMOS, Graciliano. Cultura Política, Rio de Janeiro, ano 1, n.2, abr. 1941, p.247. 
referido Estado. De acordo com o ponto de vista do governador, qualquer ato digno de repúdio, mostra da falta de comprometimento com o bem da coletividade ou do uso da força e da malandragem para obter benefícios pessoais, passava a ser tomado como mais uma manifestação do câncer “D. Maria Amália”. O narrador, ao apresentar tal ponto de vista (a partir da sumarização das impressões do chefe estadual, finalizadas, a cada período, por uma frase em discurso direto atribuído a este), compartilha da mesma constatação, como se pode depreender das marcas de enunciação enunciada distribuídas ao longo de todo o texto, com quais rebaixa a figura da mulher. Por mais que adote uma posição distanciada, não deixa de reportar-se a ela como uma "senhora terrível”, uma "mulher temerosa”, uma "figura antipática e exigente”, que possuía um "nariz bicudo" a "farejar” decretos com o objetivo de fazer valer seus interesses.

Tal mulher poderosa teve, porém, a sua queda:

E d. Maria Amália subia.

Hoje é uma senhora grisalha, gorda, respeitável, com boas cores, bom estômago, boa memória. E vive descontente $^{764}$.

No trecho acima, a utilização do dêitico temporal "hoje”, como marco de virada, pressupõe uma contraposição entre o presente lingüístico do autor e o período anterior, tematizado ao longo de todo o texto, no qual d. Maria Amália vivera seu apogeu coronelístico. Mais especificamente, há aqui uma clara oposição entre momento de veiculação do texto (reforçado pelo presente do indicativo), ou seja, o contexto político estadonovista, e o liberalismo da Primeira República, em que o individualismo prevalecia e uma mulher precisava da fachada do marido para exercer o mando.

No Estado Novo, a senhora-coronel, apesar do aspecto saudável, viveria descontente, pois, pressupõe-se que teria sido alijada do poder, perdendo o esplendor de outros tempos. Contudo, a causa da queda de tal tipo feminino não é explicitada pelo autor. Ele apenas constata, em seu momento de enunciação, que houvera uma mudança no antigo status da mulher, sem apresentar as razões para o fenômeno. No entanto, mediante o paratexto introdutório, a revista trata de preencher essa lacuna da maneira que melhor lhe convinha,

${ }^{764}$ Idem, ibidem. 
colocando o Estado Novo como responsável pelo declínio de tipos como d. Maria Amália no bojo da instauração de novos tempos na vida política brasileira:

\begin{abstract}
O sistema eleitoral da Primeira República criou, no interior do Brasil, curiosos tipos de caudilhos. Em torno deles girava a vida estadual e municipal. Todo um grupo de interesses pessoais se organizava em redor dessas figuras, que comandavam os negócios sociais. Cada uma delas podia repetir a frase simbólica de Luiz XIV: 'L’Etat c'est moi'. E era mesmo. Depois de novembro de 1937, as coisas mudaram de rumo. Essas figuras caíram, se apagaram, se dissolveram na onda revolucionária que introduziu novos costumes e novos métodos de conduzir a vida regional. Em sua crônica de hoje, o autor procura fixar um desses tipos, encarnado na pessoa de uma mulher. Era comum as mulheres manobrarem tiranicamente com os negócios do Estado. Elas faziam nomeações, derrubavam prefeitos, elaboravam leis, faziam da administração pública uma continuação de seu 'boudoir'. O caudilhismo feminino provocava manifestações curiosas, na vida pública do Nordeste Brasileiro. E é a pena segura de um dos maiores romancistas do Brasil de hoje que nos vai pintar, em poucas palavras, esse quadro tão familiar aos que conheceram o Nordeste há alguns anos atrás ${ }^{765}$.
\end{abstract}

Como se vê, o autor do paratexto dirige todo o sentido da colaboração de Graciliano, utilizando-a didaticamente para contrapor o sistema eleitoral da Primeira República ao regime de 1937: enquanto o primeiro teria criado caudilhos que manobravam os negócios do Estado conforme seus interesses pessoais, o segundo introduzira novos rumos, voltando-se contra o individualismo liberal e banindo coronéis da estirpe de d. Maria Amália. De certa maneira, prevê um leitor incapaz ou que simplesmente precisava da orientação “correta”, oficial, para interpretar aquilo que o autor teria tomado o cuidado de disfarçar ao aproximar seu relato do protocolo ficcional do conto ${ }^{766}$. Nesse sentido, a introdução produzida pela revista acaba por desficcionalizar a história ambígua e encoberta construída pelo artista, atribuindo-lhe o estatuto de documento (“crônica”), a representar um estado de coisas pretérito que supostamente não teria mais lugar com o Estado Novo. Por oposição, o retrato do passado (“um quadro tão familiar aos que conheceram o Nordeste há alguns anos atrás”) serviria para reafirmar o "hoje” estadonovista, atribuindo a este último o caráter de reformador da vida política brasileira.

Tal proposta interpretativa estava inscrita na colaboração do autor como virtualidade. O autor do paratexto valeu-se das coordenadas expressas por Graciliano para exprimi-la, ou seja,

\footnotetext{
${ }^{765}$ O SISTEMA eleitoral. Rio de Janeiro, Cultura Política, ano 1, n.2, abr. 1941, 246.

${ }^{766}$ Ao mesmo tempo, o paratexto visava à formação de um receptor, pois o ensinava a buscar no escrito do artista o fragmento de "realidade" que lhe competia. Ao invés de censurar, dirigia o sentido, tratando os desmandos coronelísticos como um problema superado.
} 
baseou-se na recorrência de traços semânticos que permitiam contrapor um passado, identificado com o liberalismo da Primeira República e personificado em d. Maria Amália, a um presente, no qual o contexto político anterior sofrera alterações, manifestas no declínio da referida personagem.

No entanto, como as causas dessa mudança não são explicitadas, as razões para o descontentamento da mulher podem ser de outra ordem (mas sempre motivada pelo afastamento do poder do passado): desponta a possibilidade de ela ter sido preterida em favor de outros coronéis, que passaram a ganhar espaço com a nova ordem. Longe de significar o fim das práticas políticas atribuídas à “República Velha”, o golpe de 1937 teria proporcionado apenas a substituição das elites rurais por outras congêneres na administração do Estado. O próprio Graciliano refere-se a este fenômeno em carta ao pai de três de agosto de 1931, num contexto posterior à Revolução de Outubro:

(...) A desorganização em que está aí o município [Palmeira dos Índios] presentemente não me preocupa. Qualquer transformação agora seria inútil. É maluqueira a gente comprometer-se à toa. Não sei se me faço compreender. Pensa que, se me aparecesse a possibilidade de uma combinação para modificar isso por aí, eu desejaria colaborar nela? As nomeações de delegados de polícia, só servem para alimentar a vaidade de alguns coronéis que estavam encostados há vinte anos e que agora infelizmente surgiram. O que nos falta é um plano de trabalho, uma orientação segura, coisa que será obtida por gente que conheça as necessidades e as possibilidades do Estado ${ }^{767}$.

Em resumo, o escritor trata da desorganização do novo governo, que repercutia negativamente sobre a vida municipal, e do retorno ao poder de certos setores da oligarquia preteridos pelo regime anterior (“coronéis que estavam encostados há vinte anos e que agora infelizmente surgiram”). Embora o Estado Novo seja visto sob a ótica da centralização e da nacionalização do poder político, vários estudos demonstram que a estrutura deste não era homogênea. Ao mesmo tempo, ressalta-se que ele não teria representado um momento de ruptura absoluta em relação às influências regionais e coronelísticas. “(...) ainda que o regime [de 1937] tenha adotado uma série de medidas para centralizar o poder e racionalizar a administração pública, a influência oligárquica continuou a manifestar-se através de novos canais - como as

\footnotetext{
${ }^{767}$ RAMOS, Graciliano. Cartas. Rio de Janeiro: Record, p.118.
} 
interventorias e o DASP [Departamento Administrativo do Serviço Público], por exemplo fazendo com que boa dose de clientelismo continuasse orientando a administração estatal”768.

De qualquer maneira, por mais que a indeterminação das causas do declínio da personagem abra espaço para a veiculação de uma crítica aparente ao governo, a colaboração do artista acaba cumprindo os interesses do Estado, na medida em que possibilita a reafirmação do suposto caráter inovador da ditadura getulista, conforme o paratexto faz questão de afirmar. Além disso, deve-se levar em conta o fato de o autor ter privilegiado esta tópica, a crítica à política individualista, e não outra. Tal escolha lhe permitia discorrer, a um só tempo, sobre um problema estrutural, mas que fora apropriado como elemento fundador pelo discurso oficial em vias de construir sua legitimidade.

\subsubsection{Duas versões do mesmo texto}

Outro dado importante é que o texto sobre a senhora-coronel não fora produzido originariamente para Cultura Política. Com o título de "D. Maria Amália”, ele foi publicado no Jornal de Alagoas, em $1933^{769}$, quando Graciliano ainda residia no Nordeste e ocupava o cargo de diretor da Instrução Pública de Alagoas, na interventoria de Afonso Carvalho ${ }^{770}$. Ao reaproveitar tal material nos anos de 1940, o artista procurou ajustá-lo às diretrizes do periódico estadonovista, o que ocasionou alterações textuais em relação à matriz dos anos de 1930. O trabalho de cotejo realizado mostra que se trata de duas versões distintas do mesmo escrito. Com pequenas variações, elas se mantêm as mesmas ao longo de toda a extensão dos relatos, com exceção dos finais, que, devido às mudanças substanciais propostas, acabam levando a interpretações diferenciadas sobre o destino da personagem e, por conseguinte, sobre o sentido geral das colaborações. A título de comparação, tomem-se os trechos dos respectivos remates propostos pelo autor em cada situação, começando por aquele saído no referido periódico alagoano e, posteriormente, recolhido em Viventes das Alagoas:

\section{E d. Maria Amália crescia.}

\footnotetext{
${ }^{768}$ ABREU, Luciano Aronne de. Um olhar regional sobre o Estado Novo. Porto Alegre: EDIPUCRS, 2007 p.14. Campelo Souza também destaca que “(...) as antigas e novas oligarquias foram absorvidas ou encurraladas num sistema que tinha como fulcro as interventorias, acopladas a órgãos burocráticos subordinados ao DASP, sujeitos por sua vez ao Presidente da República” (CAMPELO DE SOUZA, Maria do Carmo. Estado e partidos políticos no Brasil (1930-1964), p.86). Ver ainda D’ARAÚJO, Maria Celina. O Estado Novo. Rio de Janeiro: Jorge Zahar, 2000.

${ }^{769}$ RAMOS, Graciliano. D. Maria Amália, Jornal de Alagoas, Maceió, 18 de jun. 1933.

${ }^{770}$ FACIOLI, Valentim. op.cit, p.52.
} 
Hoje é uma senhora bem conservada, respeitável, com excelentes relações.

Algumas pessoas julgaram há tempo que ela iria morrer. Tolice. Morrer tão moça, quando, como diz o poeta, o mundo é um paraíso!

Resistiu a todas as comissões de sindicância e está forte, gorda e bonita ${ }^{771}$.

E, agora, a versão de Cultura Política, já transcrita acima:

E d. Maria Amália subia.

Hoje é uma senhora grisalha, gorda, respeitável, com boas cores, bom estômago, boa memória. E vive descontente $^{772}$.

Na primeira versão, mesmo em meio a turbulências, prevalece a idéia da manutenção ou até mesmo do incremento do status político da personagem com o passar do tempo. D. Maria Amália continuava a ostentar boas relações e desfrutar de prestígio. Vencera os anúncios que davam conta de seu falecimento iminente e, de quebra, resistira a todas as comissões de sindicância, permanecendo forte, gorda e bonita. Considerando-se a mulher como personalização da instituição “coronelismo”, os boatos desencontrados sobre sua morte não confirmada, significavam, por extensão, a continuidade das práticas nocivas que ela representava. O fim do mandonismo não passara de uma notícia falsa, perspectiva reforçada pela ineficácia dos inquéritos a que a personagem inescrupulosa fora submetida. Nesse sentido, toma corpo a ironia proposta pelo autor de que não haveria motivos para a senhora morrer quando este mundo ainda era um "paraíso". Mais especificamente, um paraíso particular, válido tão somente para tal tipo feminino, que se apossara da máquina pública para fazer valer seus interesses, enquanto a maioria da população continuava a padecer.

Em tal versão, por conseguinte, o narrador adota um tom de resignação histórica, como se dissesse: esta é a realidade brasileira, até quando, infelizmente, não se sabe. Ao mesmo tempo, não deixa de se colocar como um crítico do status quo, que constata os malefícios sócio-culturais do mandonismo, sem vislumbrar modificações na vida brasileira. Já em

\footnotetext{
${ }^{771}$ RAMOS, Graciliano. Jornal de Alagoas, Maceió, 18 de jun. 1933. In: Viventes das Alagoas, Rio de Janeiro: Record, 2007, p.32.

${ }_{772}$ RAMOS, Graciliano. Cultura Política, Rio de Janeiro, ano 1, n.2, abr. 1941, p.247.
} 
Cultura Política, seu ponto de vista revela-se bem diferente. O autor ressalta uma mudança na condição da personagem, pressupondo, por sua vez, uma alteração no contexto político: depois de subir, ela desceu e passou a viver descontente. Nesse sentido, opõe de maneira clara o "ontem” ao "hoje”, como tempos, respectivamente, do apogeu e do descenso de d. Maria Amália ${ }^{773}$.

Por mais que Graciliano continuasse a tratar de um problema estrutural de maneira encoberta, ou seja, segundo uma chave ficcional, a alteração que realiza ao final do escrito não poderia ser tratada como simples minúcia para melhorar o estilo, mas sim como uma tentativa de se ajustar, por vias indiretas, ao pressuposto estatal de contrapor-se ao individualismo da Primeira República. Se o artista não toma o regime como causa do declínio da personagem, todavia, deixa subentendida tal possibilidade de leitura. Ao mesmo tempo, o paratexto produzido pela revista, ressaltando a oposição entre o passado liberal e o presente estadonovista, não teria o mesmo alcance caso em Cultura Política fosse publicada, ipsis litteris, a versão do Jornal de Alagoas. A mudança no remate proporcionou uma adequação do sentido, facilitando a apropriação e o direcionamento dado ao texto pelo periódico getulista.

Portanto, se d. Maria Amália alegorizava uma instituição a ser combatida e, ao final da versão de Cultura Política tal personagem vive seu momento de declínio, subentende-se que tudo aquilo que ela personificava caía também. No entanto, como o autor não determina as causas do fenômeno, cabe aos editores da revista explicitar que "depois de 1937 as coisas mudaram de rumo" ${ }^{774}$, ou seja, que o Estado Novo fora responsável por uma guinada na vida política brasileira. Em sentido oposto, como visto anteriormente, pode-se também considerar a história da senhora mandona como símbolo não da erradicação do coronelismo, mas sim da simples substituição de uma parcela da oligarquia por outra. Por hipótese, os mandões emergentes (e não a ditadura getulista) poderiam também ser apontados como causa da insatisfação da mulher.

\footnotetext{
${ }^{773}$ No caso da versão da revista getulista, há ainda outras alterações pontuais detectadas no cotejo com o texto saído no Jornal de Alagoas. O artista apaga debreagens temporais (mediante a substituição do presente pelo pretérito imperfeito em três ocasiões no décimo parágrafo) e actanciais (a supressão do possessivo "nossa" no décimo terceiro parágrafo), o que reforça seu afastamento do material narrado e o melhor enquadramento deste no passado (mais especificamente, no passado republicano a ser combatido). Reforça-se ainda o efeito de objetividade.

${ }^{774}$ O SISTEMA eleitoral. op.cit. p.246.
} 
Em resumo, o descontentamento de d. Maria Amália encontrava-se no fato de ela ter sido alijada do poder, mas o responsável por tal ação podia ser tanto o governo como outra facção da elite, o que correspondia, respectivamente, ou a reformulação ou a manutenção de um estado de coisas. No entanto, diante de tamanha ambivalência, a última possibilidade de leitura é afastada pela publicação e o texto acaba funcionando, de acordo com o enquadramento proposto, como um elogio ao Estado, por mais que também trouxesse uma crítica latente.

\section{3. "Uma visita inconveniente” e a unificação do sistema de ensino}

Além da crítica à política individualista, com destaque para a censura ao mandonismo e ao clientelismo, as narrativas ficcionais de Graciliano, recuadas no passado, permitiam ao autor tematizar outros lugares-comuns presentes nos debates intelectuais dos anos 1920, 1930 e 1940, que, por sua vez, teriam sido incorporados como elementos legitimadores pelo discurso oficial. Entre eles estariam o questionamento à falta de unidade política do país e o desprezo pela realidade nacional, tópicas recorrentemente utilizadas pela retórica estadonovista para rebaixar a Primeira República (considerada descentralizadora e internacionalista) e, por oposição, afirmar a superioridade do regime de 1937.

Este é o caso do texto "Uma visita inconveniente”, editado em dezembro de 1942, no número 22 de Cultura Política, e ainda inédito em livro, uma vez que fora deixado de fora das sucessivas edições de Viventes das Alagoas $^{775}$. Nesta colaboração, mais especificamente, Graciliano tematiza tanto o alheamento dos políticos dos problemas brasileiros, como a falta de uma política nacional de ensino, que sistematizasse e centralizasse a prática educativa em todos os níveis.

Quanto ao assunto (percurso figurativo), a narrativa trata da visita de um sociólogo estrangeiro a uma capital nordestina. Tal viagem tinha motivações científicas: ele procurava reunir dados para a confecção de uma obra "séria e acadêmica", que examinaria aspectos sociais, econômicos, políticos e culturais da localidade. Para cumprir seu intento, o visitante dirigi-se ao palácio do governo. Munido de uma recomendação ministerial, consegue ser atendido prontamente pelo chefe do executivo estadual, que não só autoriza-lhe o trabalho,

\footnotetext{
${ }^{775}$ Para consulta, o texto se encontra no volume em anexo, que reúne outras colaborações de Graciliano saídas na imprensa e ainda inéditas em livro.
} 
como lhe oferece "um funcionário de vulto” para acompanhá-lo em suas pesquisas de campo. Após percorrer diversos órgãos da burocracia estatal, jornais, mercados, instituições culturais e esportivas, além de casas de família e pontas de rua, o pesquisador se concentra no exame dos estabelecimentos de ensino. Numa escola secundária, requisita ao cicerone uma aula sobre os índios brasileiros. Este encaminha o pedido a um professor que se incumbe da tarefa solicitada pelo estudioso. Para surpresa de todos, o lente acaba fazendo um relato disparatado, sem o mínimo respaldo historiográfico, sobre os selvagens nacionais o que causa o espanto e a reprovação do forasteiro.

No que diz respeito ao estatuto do texto, não se trata de uma crônica propriamente dita, tendo em vista sua razoável distância dos lugares-comuns que se consagraram a respeito do gênero. Aqui, como nas outras colaborações vistas até o momento, o destinador não referencia seu texto nos signos sociais do mundo de maneira direta. Apesar de escrever para destinatários de todo o Brasil, preferencialmente da capital carioca, Graciliano não os privilegia como actantes em seu relato. Por mais que aluda a um macrodiscurso conhecido de todos, ele fala de outro universo e de outra localidade. Sabe-se apenas que se trata de uma capital de Estado modesta e que ela se localiza no Nordeste, em função do enquadramento conferido pela revista. Não há, portanto, a configuração de um cronista que interage com o mundo representado, bem como o diálogo deste com os leitores que partilhariam de um espaço comum. Além disso, tem-se aqui um narrador bem caracterizado, que se vale de recursos ficcionais tais como a construção de cenas, cenários, personagens, dramatizações e o enquadramento do relato numa estrutura narrativa típica com começo, meio e fim.

Em outras palavras, considerando-se a natureza ficcional do texto, o narrador não explicita o problema de que está falando, trazendo o leitor para um mundo não facilmente identificável a primeira vista. Ao fingir que está contando uma história transforma as questões sociais, culturais e políticas de que trata em dados de sua ficção. Como visto anteriormente, os cronistas tradicionais, em sentido oposto, costumam explicitar os assuntos a que se referem, desficcionalizando o discurso. Em Graciliano, pelo contrário, salta para o primeiro plano não um eu-enunciador, em interação aberta com o espaço e com o leitor, mas um eu-efabulador, responsável por narrar uma história com um universo de referência específico, que acaba apenas aludindo aos temas pretendidos por vias indiretas. Em Cultura Política, se não interpusesse mais camadas de sentido entre as suas colaborações e o universo de referência 
presumido pela revista dificilmente conseguiria evitar o compromisso, a adesão, comprometendo sua reivindicada isenção de artista.

Se se afasta do registro cronístico, o escrito pode ser mais bem enquadrado, por outro lado, como um conto de enredo, de caráter anedótico e exemplar, ou seja, com um começo, um meio e um final surpreendente, concentrado no percurso linear do visitante: chegada, estabelecimento no hotel, reconhecimento preliminar do lugar, contato com as autoridades estaduais, autorização do governador para a realização da pesquisa, nomeação de um funcionário do executivo estadual para acompanhá-lo em suas andanças e visita aos espaços analisados, com destaque para os estabelecimentos de ensino onde se dá a cena derradeira. No transcorrer dessa trajetória (nada extraordinária), constrói-se uma tensão entre a imagem da capital apresentada pelo funcionário e as constatações do sociólogo, que seria arrematada por um desfecho inesperado, de caráter humorístico. Além disso, reforçando o enquadramento do texto como conto, há nele a ênfase, ainda que sem grande densidade, na atuação do narrador, na caracterização dos personagens que participam da ação, bem como do espaço e do tempo em que esta se situa.

A fim de examinar tais categorias, tome-se um trecho inicial do texto:

O sociólogo estrangeiro desembarcou, dirigiu-se ao hotel, aboletou-se e no dia seguinte percorreu a cidade, exibindo a roupa de sábio, surrada e com joelheiras, o guarda-chuva de cabo torto, o chapéu de palha, sujo, roído nas abas, um grande pacote amarelo debaixo do braço.

Conhecidas várias ruas, encaminhou-se ao palácio do governo, entregou a um contínuo o cartão de visita e sentou-se. Pouco depois mandaram-no entrar, pois tinha vindo pelo telégrafo recomendação forte. Ergueu-se, afastou o reposteiro verde com símbolos bordados a ouro e achou-se na presença do poder executivo, a quem endereçou um pequeno discurso organizado na antecâmara, mentalmente.

Em seguida, sobre a mesa larga onde o expediente se acumulava, desatou os cordões do embrulho e ofereceu a S. Excia. diversas brochuras grossas, que encerravam, com largo saber, as transações humanas dos tempos pré-históricos e as do futuro.

O governador incluiu num rápido balanço os títulos sisudos, as dedicatórias amáveis, os milheiros de páginas cobertas de letra miúda, floresta raramente quebrada por espaços brancos. Juntou a isso as duas linhas que negrejavam no cartão, sob o nome do visitante, os termos da recomendação telegráfica, ministerial - e disse as palavras aplicáveis à situação. 
Conversou durante os minutos precisos e regulamentares, pensando nos encrencados artigos dum vago decreto e numa criatura feminina, também vaga e encrencada. Ditas as frases necessárias, calcou o botão da campainha e mandou chamar um funcionário de vulto, conveniente às exigências do sociólogo que ali descansava na cadeira de espaldar alto, encimado por uma águia e outros objetos oficiais. Vindo o burocrata, fez a apresentação:

- Professor Fulano, da universidade de... (Onde era a universidade, santo Deus?) A universidade de tal parte. Deseja...

Houve uma pausa, exame de papéis - e o sociólogo explicou minuciosamente o que desejava.

O governador não entendeu e transportou-se aos parágrafos difíceis do decreto e a certas palavras da mulher vaga. O funcionário balançou a cabeça:

- Perfeitamente.

Despedidas protocolares, sorrisos, agradecimentos. O contínuo percebendo que o sujeito era importante, franziu, curvando-se, os símbolos dourados do reposteiro verde ${ }^{776}$.

Logo de saída, o sociólogo, personagem principal da trama, é apresentado como um sujeito supostamente despretensioso, que, por seu modo de vestir, aproximar-se-ia da imagem convencional de um sábio. Como se sabe, tal estereótipo seria marcado pela aparente despreocupação com a aparência externa, paralelamente ao privilégio a uma suposta essência, na qual repousaria a sabedoria. Na verdade, esta última regularia aquela, ou seja, a escolha de seus trajes modestos (roupa surrada e com joelheiras, o chapéu de palha sujo e roído nas abas e o guarda-chuva de cabo torto) se orientaria pelo desejo de parecer sábio. Além disso, na enumeração dos itens de vestuário que compõe a figura do sociólogo, o pacote amarelo, cheio de livros, que ele carregava debaixo do braço é colocado no mesmo nível dos demais elementos. No entanto, este, como se verá, pode ser tomado como um índice que reaparecerá ao longo de toda narrativa: as "brochuras espessas”, que o estudioso trazia consigo, além de autenticarem sua erudição (caráter antecipatório), configuravam-se como seu objetivo final ao se dirigir até aquela capital de Estado (feitas as pesquisas de campo produziria uma livro de quinhentas páginas, corpo 8).

\footnotetext{
${ }^{776}$ RAMOS, Graciliano. Uma visita inconveniente. Cultura Política, Rio de Janeiro, ano 2, n.22, dez. 1942, p.154.
} 
Em seguida, observa-se o contraste entre as vestimentas do sábio e o ambiente pomposo, conservador e burocrático do gabinete do governador. Este era ornado por uma “mesa larga”, um “reposteiro verde com símbolos bordados a ouro” e "uma cadeira de espaldar alto, encimado por uma águia e outros objetos oficiais”777. Trata-se, portanto, da apresentação de uma suposta aparência sem essência, como se o espaço repercutisse na caracterização do político. De acordo com as categorias estabelecidas por Osman Lins, tem-se aqui um cenário com “função caracterizadora”, distante da suposta neutralidade atribuída à descrição, pois além de situar o tipo, funciona como índice psicológico e social, informando sobre seu modo de $\operatorname{ser}^{778}$.

Ao mesmo tempo, se o sociólogo é caracterizado por traços externos, em sentido oposto, na apresentação do chefe do poder executivo predominam dados de natureza psicológica. Apesar de atender prontamente ao visitante, dispensa-lhe um tratamento protocolar e apressado, pois sua cabeça estaria longe daquele encontro: pensava nos artigos de um decreto a ser promulgado e em sua amante, conforme expressa o narrador onisciente, a realçar o contraste entre as motivações internas e externas da personagem. Nesse sentido, ela ganha contornos de uma figura alienada, cuja presença estaria num lugar, mas o pensamento em outro, revelando sua inadequação para a o exercício da função que desempenhava.

Paralelamente, ao examinar as obras do estudioso, demonstra falta de hábito de leitura e desinteresse; tomava os volumes como uma "floresta raramente quebrada por espaços brancos”. E na recepção de tal sujeito, dera mais atenção à "recomendação telegráfica ministerial”, do que ao trabalho científico que este já realizara ou iria executar. Nesse sentido, mostra seu desinteresse pela pesquisa e pelo saber sociológico de maneira geral, em contraposição a uma atenção excessiva às convenções burocráticas. Tal postura fica mais clara no modo como repassa as solicitações do visitante a um funcionário que exerceria a função de cicerone do estudioso:

\footnotetext{
777 Alguns destes elementos que compõem o cenário do gabinete do chefe político estadual tornam a ser utilizados em "Dois dedos", texto que nomeia um volume de contos publicado em 1945 pela Revista Acadêmica, posteriormente recolhido em Insônia (1947). Entre os itens comuns, destaque para o reposteiro, para o contínuo a exigir um cartão de visitas, para a cadeira alta com uma águia sobre o espaldar. Além disso, no conto, o governador também era apresentado como um tipo que tinha as horas contadas; "tantos minutos para isto, tanto para aquilo. Não se ocupam em conversas fiadas” (RAMOS, Graciliano. Insônia. Rio de Janeiro: Livraria José Olympio Editora, 1953, p.103-112) e que no momento do encontro com o protagonista redigia um documento.

${ }^{778}$ LINS, Osman. Lima Barreto e o espaço romanesco. São Paulo: Ática, 1976, p.97.
} 
- Professor Fulano, da universidade de... (Onde era a universidade, santo Deus?) A universidade de tal parte. Deseja... ${ }^{779}$

Mostra não saber quem era o sociólogo, nem o que ele desejava fazer e nem mesmo de onde ele viera, referindo-se ao pesquisador de modo impessoal ("Professor Fulano”). Além disso, despendera apenas os “minutos precisos e regulamentares” com tal sujeito, o que denotava pouca atenção e descaso. Ao mesmo tempo, tal tratamento reforçava sua posição de superioridade em relação ao pesquisador, como se indicasse que a política estivesse além dos problemas a serem examinados pelo cientista.

Em resumo, no tratamento dispensado ao sociólogo e ao governador, há um completo espelhamento entre ambos, que figuram como antípodas. O primeiro aparenta ter essência, mas em sua caracterização predominam dados exteriores. Com o segundo acontece o oposto: apesar de ser um homem de aparências tem seu interior privilegiado pelo autor do relato. Além disso, tal oposição guardaria semelhanças com aquele confronto exemplar entre as figuras de Euclides da Cunha e Machado de Assis, visto anteriormente. Enquanto o estudioso ia direto às fontes, pois deixara seu país de origem para visitar diferentes espaços e instituições locais (do Instituto Histórico e Geográfico a casas de ponta de rua), com o objetivo de recolher informações e produzir conhecimento sobre a realidade que se propunha a estudar (documentar), o segundo permanecia em seu gabinete, preso a tarefas políticas, mescladas a pensamentos de ordem sentimental. Nesse sentido, ao passo que um procurava examinar a organização social, cultural e econômica daquele lugar, o outro se alheava do mesmo, fazendo pouco caso do trabalho científico e da instituição universitária.

Por outro lado, o fato de o estudioso ser estrangeiro sugeriria a incapacidade de o país produzir conhecimento sobre si mesmo, além de aludir a certo desprezo pelo saber sociológico, sobretudo, quanto à aplicação deste à gestão do Estado, bandeira defendida pelo cientificismo político estadonovista. Ao mesmo tempo, ressalta-se a incapacidade do poder executivo, encarnado na figura do governador, tomar parte nos problemas da localidade, principalmente naqueles relacionados à educação. A política, ao invés de se revestir da pesquisa da realidade local, pautar-se-ia por interesse individuais, tal como observado anteriormente naquele texto sobre um outro governador, que, com o propósito de perpetuar sua imagem perante a opinião pública estadual escolhera construir um teatro, deixando de

${ }^{779}$ RAMOS, Graciliano. op.cit, p.154. 
lado estradas, pontes e estabelecimentos de ensino. Aliás, estes últimos eram tidos em baixa conta: “As escolas eram consideradas prejudiciais. Havia algumas é certo para dar emprego às filhas dos prefeitos, mas estas não forneciam aos alunos conhecimentos”780.

Ainda no que diz respeito à caracterização das personagens do texto, merecem atenção as figuras do funcionário (contínuo), incumbido de ciceronear o pesquisador, e do professor secundarista. Assim como o sociólogo e o governador, trata-se de tipos planos, designados tão somente pelas funções que exerciam na máquina pública, o que reforça o caráter típico de ambos. Nada de nomes próprios na configuração de subjetividades menos superficiais, tal como, por exemplo, o retrato de d. Maria Amália visto anteriormente.

Na condição de filtro seletor, o "funcionário de vulto” fora designado pelo governador para atender às demandas do sociólogo, devendo apresentar-lhe "as curiosidades indispensáveis à fabricação duma obra séria e acadêmica”. Entre elas estariam aspectos da vida econômica, social e cultural da localidade, desnudados em toda a sua precariedade a partir do momento em que ganham a atenção (olhar) do cientista:

Percorreram secretarias, diretorias, o serviço de algodão. Viram e comentaram a estrada de rodagem, o hóspede exigindo pormenores, os construtores alargando-se em considerações alheias às perguntas. Estudaram, no aprendizado agrícola, o banheiro carrapaticida, as pocilgas, o estábulo e o galinheiro, coleções de animais desenvolvidos cientificamente e improdutivos. Foram ao tribunal e aos jornais, leram sentenças e artigos de fundo. As sentenças eram o que no lugar havia de melhor em sintaxe; os artigos, mal escritos, revelavam energia e lirismo. Visitaram o mercado, o Instituto Histórico, os clubes de football, os cafés, os cinemas, casas de família e casas onde não existiam famílias, em pontas de rua $^{781}$.

Pela própria maneira como se refere a tais elementos como simples “curiosidades”, dados pitorescos, “coisas para inglês ver”, quando na verdade se tratava de itens basilares na constituição do Estado para o qual trabalhava, o empregado, por mais tenha sido designado por seu superior como um "funcionário de vulto”, demonstra toda a sua inadequação e incompetência para o desempenho do cargo. Assim como o governador, revelava desconhecer

\footnotetext{
${ }^{780}$ RAMOS, Graciliano. Quadros e Costumes do Nordeste VII, Cultura Política, Rio de Janeiro, ano 1, n.7, set. 1941, p. 264. Presente ainda em Viventes das Alagoas, com o título referido acima "Teatro I” (Rio de Janeiro: Record, 2007, p.55).

${ }^{781}$ RAMOS, Graciliano. Uma visita inconveniente. Cultura Política, Rio de Janeiro, ano 2, n.22, dez. 1942, p.154-155.
} 
os problemas locais, bem como mostrava certo desprezo pela figura do estudioso e pelo trabalho de pesquisa realizado por este. Estava longe de admitir a possibilidade de utilização do saber sociológico no embasamento das iniciativas governamentais, como advogava a ladainha estadonovista, permanecendo no âmbito da política tradicional.

Sua pequenez intelectual e moral ganha contornos mais nítidos a partir do momento em que seleciona certo "lente sabido" para ministrar uma aula sobre os índios ao visitante ilustre. Segue-se o trecho:

Nesse ponto, como era preciso estirar o volume, exploraram-se as escolas. Tudo correu bem nas elementares. As professoras disseram o que sabiam e os meninos indicaram no mapa o sítio onde frei Henrique de Coimbra rezou a missa de estréia. Mas num estabelecimento secundário houve desastre.

- Esse tipo, cochichou o funcionário a um lente sabido, quer uns esclarecimentos sobre os índios. Vou levá-lo a sua classe. Pensei em você para explicar direito esse negócio. Conte umas lorotas que o homem é de universidade.

- Muito bem, respondeu a douta personagem agradecida, feliz por sair da sombra e manifestar-se diante de quem pudesse compreendê-la.

Meia hora depois, numa preleção muito verbosa, dizia aos alunos (dirigia-se na verdade ao estrangeiro, que o escutava assombrado ali perto, o guarda-chuva entre os joelhos) coisas admiráveis a respeito de inscrições achadas no sertão. Garantiu que elas tinham sido feitas pelos egípcios e pelos fenícios, desembarcados no Brasil tantos séculos antes de Jesus (estabeleceu a data), agentes de colônias prósperas, ligadas por um comércio regular às metrópoles. Tentou decifrar alguns caracteres, percebeu neles os nomes de Osíris e dos engenheiros que, há quatro mil anos, executaram obras notáveis na cachoeira de Paulo Afonso. Sim senhor. Os devotos de Osíris e de Isis misturados aos selvagens nacionais, que ainda não eram tupis.

- Não senhor.

O estrangeiro embasbacava, arregalava os olhos. E o funcionário suava, agitava-se desesperadamente na cadeira, parecia mordido de pulgas. Trincava os beiços e fazia gestos inúteis. Segurava-se à idéia de que o sujeito importante, conhecedor de fatos relativos à pré-história e ao fim do mundo, não entendesse a linguagem do professor cambembe, provinciana e corrupta.

- Ora muito bem. Dessas relações entre o elemento indígena, os egípcios e os fenícios, nasceram os tupis. 
Os estudantes maus bocejaram. Os estudantes bons sorriram. Os medíocres pegaram os cadernos e tomaram notas $^{782}$.

Embora aparentasse estar vinculado à secretaria da cultura ou da educação, o referido “funcionário de vulto” ignorava as deficiências locais, fugindo das obrigações mínimas de um sujeito em sua condição. Mais especificamente, não sabia ou aparentava não saber que tipo de professor trabalhava nas escolas sob sua administração, muito menos os conteúdos ministrados por tais docentes. Tanto que escolhera, mediante uma espécie de conchavo, uma figura totalmente inábil para falar ao estrangeiro, o que tornou ainda mais gritante seu despreparo. Em certo sentido, por mais que o desejasse, ele não tinha competência nem ao menos para acobertar os problemas da localidade e, assim, vender uma imagem falsa do lugar, pois o desconhecia ou nunca fora chamado a conhecê-lo.

No entanto, ao longo da preleção do docente, tem o mínimo de consciência de que a teoria sobre os índios, expressa por este, seria insustentável. Desespera-se: passa a suar frio, a agitarse na cadeira, a trincar os beiços, a fazer gestos inúteis, guardando, como último recurso, a esperança de que o sociólogo não compreendesse o discurso verboso, balofo e capenga do professor. No entanto, as impropriedades eram tão óbvias que o acadêmico estrangeiro, apesar de não ser falante de português, percebeu-o sem titubear, para o desespero do funcionário:

- Felizmente lá fora ninguém entende um português assim estragado, consolou-se o funcionário. Estamos em segurança.

O sociólogo estrangeiro desiludiu-o, fulminou-o com uma pergunta brutal:

- Os senhores não têm programa? Um homem pode aqui ensinar isso na escola? ${ }^{783}$

Se o estudioso, recém-chegado de fora do país, percebera de imediato o gritante descaso para com o ensino no Estado, o burocrata, supostamente em contato rotineiro com essa realidade, nada sabia ou recusava-se a saber, alimentando uma situação de aparente normalidade que, na verdade, mostrava-se indecente. Sua responsabilidade perante o caso dava lugar à omissão ou a um simples desprezo pelas mazelas locais, em consonância com a visada política manifesta anteriormente pelo governador. Nesse sentido, ao invés de reconhecer e propor a erradicação

\footnotetext{
${ }^{782}$ Idem, p.155.

${ }^{783}$ Idem, p.155.
} 
das chagas detectadas a partir da visita do sociólogo, sua primeira preocupação fora a de manter em segurança a imagem do poder local, deixando subentendido que apenas a ignorância e a dissimulação poderiam manter tal estado de coisas encoberto e inalterado.

Continuando a descida pela escada da incompetência burocrática, no degrau mais baixo encontrava-se o "lente sabido". Não por acaso, é sobre ele que o processo de degradação caricatural empreendido pelo artista incide com maior intensidade, ressaltando o grotesco e o ridículo. Novamente, a figura do sociólogo serve de parâmetro comparativo para rebaixar mais este integrante do funcionalismo público. Enquanto tal estudioso estrangeiro, para falar sobre o Brasil, deixara seu país de origem e viera para cá recolher dados in loco, travando uma relação empírica com seu objeto, o professor secundarista, por mais que vivesse aqui, elaborou um discurso completamente estapafúrdio sobre as origens do homem brasileiro, como se não tivesse contato direto com a terra e com os discursos consensualmente admitidos sobre ela.

A tese exposta pelo docente recupera o mito da vinda dos fenícios para o Nordeste brasileiro, muito antes dos portugueses, presente em trabalhos protocientíficos do final do século XIX e início do século XX. Segundo Gabriela Martin, tais estudos “cientificamente desacreditados” teriam sido alimentados pela famosa e apócrifa inscrição fenícia na Paraíba, supostamente encontrada em 1872, e pelo vivo interesse do alagoano Ladislau Netto, então diretor do Museu Nacional do Rio de Janeiro e protegido de Dom Pedro II, pela cultura fenícia. Como se sabe, tal hipótese logo se mostrou insustentável. A referida itaquatiara paraibana teria sido encontrada em "Pouzo Alto", um lugar inexistente, por um também inexistente Joaquim Alves da $\operatorname{Costa}^{784}$. O próprio Ladislau Neto teria reconhecido que havia sido vítima de uma fraude e "honestamente o declarou numa patética carta enviada a Renan [seu mestre durante o período que passara estudando arqueologia em Paris] e no seu artigo "Inscrição Phenícia”, publicado no Jornal do Comércio, do Rio de Janeiro, de 8 de junho de 1875,"785. Nesse ínterim, recebera ataques ferozes de, entre outros, Sylvio Romero que o chamava de "beduíno anthropológico"786.

\footnotetext{
${ }^{784}$ MARTIN, Gabriela, Pré-história do Nordeste do Brasil. 4. ed. Recife: Ed. Universitária da UFPE, 2005, p.26.

${ }_{785}$ Idem, p.27.

${ }^{786}$ Idem, p.29.
} 
Apesar de aludir ironicamente a essa mesma tradição (a fase mitológica da Pré-história brasileira), o texto de Graciliano fazia referência mais específica ao livro Antiga História do Brasil, de 1100 A. Crh. a 1500 Dep. Chr., publicado em Teresina (PI), em 1928, por Ludwig Schennhagen, austríaco excêntrico que percorrera os sertões nordestinos nas décadas de 1910 e 1920 a procura de inscrições e formações geológicas que atestassem a presença de civilizações perdidas em solo brasileiro ${ }^{787}$. Segundo Gabriela Martin, "Ludovico Chovenágua”, como era chamado pelos sertanejos pela dificuldade de se pronunciar seu nome europeu, teria sido mais fértil e pitoresco de todos os defensores do mito fenício ${ }^{788}$.

No referido volume, o aventureiro, auto-intitulado professor de filologia e história, afirmava de maneira categórica, sem mencionar fontes bibliográficas, que os primeiros navios fenícios teriam chegado ao país em 1100 d.C. e, já em 1008 a.C. o rei Hiran de Tiro firmara uma aliança com o rei David da Judéia, para explorarem comumente a Amazônia brasileira ${ }^{789}$. Em seguida, no tempo do usurpador Chechonk, que se apoderou do trono dos faraós em 935 a.C., fora a vez da chegada dos egípcios ao Brasil, sobretudo de engenheiros, vindos por intermédio da frota fenícia. Eles foram responsáveis por obras grandiosas na cachoeira de Paulo Afonso, semelhantes às realizadas por eles mesmos no rio Nilo ${ }^{790}$. Por fim, para colonizar o país, os fenícios trouxeram ainda os tupis. Tal povo teria vindo da América Central, mais precisamente de um pedaço de terra firme chamado "Caraiba”, onde se refugiaram depois do desaparecimento de Atlântida ${ }^{791}$.

Com o intuito de impressionar o sociólogo, o docente retoma tais teorias desprovidas do mínimo respaldo científico ${ }^{792}$, que apenas repugnam o visitante, fazendo-o questionar a falta de um programa de ensino secundário, responsável tanto pela regulação dos conteúdos ministrados como pelo aprimoramento e controle dos professores. Nesse sentido, o lente acabou desferindo um tiro contra o próprio pé sem sabê-lo, pois na tentativa de mostrar

\footnotetext{
${ }^{787}$ Como se pode constatar numa rápida consulta aos livros de Graciliano doados ao Instituto de Estudos Brasileiros (IEB), o autor possuía um volume desta obra de Schwennhagen em sua biblioteca pessoal.

${ }^{788}$ MARTIN, Gabriela. op.cit. p.31.

789 SCHWENNHAGEN, Ludwig. Antiga História do Brasil, de 1100 A. Crh. a 1500 Dep. Chr. Theresina: Imprensa Official, 1928, p.7.

${ }^{790}$ Idem, p.57.

${ }^{791}$ Idem, p.16. O país Caraiba tivera o mesmo fim de Atlântida, afundando no mar. Os tupis teriam se salvado em pequenos botes e se estabelecido onde hoje se encontra a Venezuela antes de virem para o Brasil com o auxílio dos fenícios (Idem, ibidem).

${ }^{792}$ Em artigo sobre a vida do aventureiro austríaco, Camara Cascudo destaca a maneira apaixonada como este defendia suas teorias estapafúrdias e o receio dos Institutos Históricos do país em patrocinar-lhes as conferências, tendo em vista falta de rigor de seu trabalho (CASCUDO, Luís da Camara. Ludovico Schennhagen. Boletim de Ariel, Rio de Janeiro, ano 5, n.2, nov. 1935, p.36-37).
} 
erudição, projetando uma imagem elevada de si, apenas tornou mais aparente sua condição de intelectual de província, sem critérios para julgar a correção daquilo que lia e assimilava. Ao mesmo tempo, em escala reduzida, ele reproduzia a mesma perspectiva interesseira do governador, pois, mais do que educar as crianças, seu objetivo maior seria o de "sair da sombra”, exibir-se diante do pesquisador internacional, tanto que, em sua palestra, dirigiu-se, exclusivamente a este, esquecendo-se do restante da classe.

Em linhas gerais, por mais que o narrador simule certa neutralidade na abordagem das personagens, algo reforçado pela adoção de uma focalização onisciente, refere-se a elas de maneira irônica. Mediante a escolha lexical, a adjetivação, entre outros índices avaliativos o artista marca recorrentemente sua posição no material narrado, revelando, por sua vez, certo desacordo entre enunciado e enunciação (diz “x”, para dizer “não-X”). O cicerone inepto é nomeado como um "funcionário de vulto". O professor secundarista, defensor de teorias despropositadas, é chamado de "lente sabido". A exposição das motivações ocultas do governador, em contraste com as razões aparentes expressas por este para dispensar o sociólogo, também dão mostra do sarcasmo dispensado pelo enunciador a tal integrante da burocracia estadual.

Dessa maneira, partindo do governador até chegar ao professor secundarista, o narrador acaba por fazer uma denúncia feroz do papel desempenhado pelo funcionalismo público, evidenciando, em todos os níveis, a começar pela chefia do executivo, a incapacidade para o exercício das funções a que se propunham. De alguma maneira, está presente uma sátira semelhante àquela presente em $O$ triste fim de Policarpo Quaresma, de Lima Barreto, no que diz respeito ao papel exercido pela burocracia estatal. Mais especificamente, fica implícita a idéia do império da ignorância na condução da política nacional. Os responsáveis pela administração do Estado por mais que lidassem cotidianamente com a realidade imediata do lugar, nada sabiam sobre ela (ou não queriam saber). Algo conveniente para o governo estadual como um todo, pois mediante o desconhecimento ou a dissimulação das dificuldades locais, ele podia manter-se no poder, sem inconvenientes. Em tal contexto, apenas um visitante externo poderia perturbar tal estado de coisas, tendo em vista o desinteresse dos dirigentes ou a inexistência de estudiosos dedicados aos problemas nacionais.

O título do texto "Uma visita inconveniente" reproduz o ponto de vista dos burocratas da localidade em relação ao protagonista. Aos olhos dos homens do governo, tal figura se 
mostrava "inconveniente”, justamente, porque, na condição de estudioso, propõe-se a fazer um inventário das realizações governamentais, bem como daquilo que o Brasil pensava e difundia sobre si mesmo (manifesto, sobretudo, no ensino público), apontando deficiências, estultices e descasos com a coisa pública, sobretudo no campo educacional. Focada nessa matéria, a colaboração do artista destaca, sobretudo, a precariedade dos professores e a ausência de delimitação, por parte do poder estatal, de um programa de ensino centralizado, que definisse os conteúdos a serem ministrados e evitasse a veiculação de absurdos, com atenção específica para o ensino secundário. Ao mesmo tempo, em escala menor, mostra também a condição deficitária e rasteira do ensino primário, caracterizado por uma série de aluninhos apontando no mapa o local em que teria sido realizada a primeira missa em solo brasileiro. Porém, no que diz respeito a estes últimos, pode-se considerar que dominavam com alguma precisão certo repertório, por mais modesto que ele fosse, referindo-se a um evento historicamente reconhecido: a celebração realizada por frade Henrique de Coimbra, no litoral sul do atual estado da Bahia, em 26 de abril de 1500. O lente secundarista, por outro lado, ensinava os maiores disparates possíveis e imagináveis, tomando como base teorias sem nenhuma legitimidade.

De qualquer maneira, nem o cientista estrangeiro se safa do tratamento irônico dispensado pelo narrador. A sátira respinga sobre o sociólogo tanto pelo modo como o enunciador o caracteriza (um tipo que fazia questão de ostentar sabedoria por meio de suas vestimentas, com destaque para o guarda-chuva de cabo torto, presente em todas as situações) como pela maneira que comenta as brochuras apresentas por este ao governador. Segue-se o trecho:

“[sociólogo] (...) desatou os cordões do embrulho e ofereceu a S. Excia. diversas brochuras grossas, que encerravam, com largo saber, as transações humanas dos tempos pré-históricos e as do futuro”793.

A ironia fica evidente na hipérbole empregada: os escritos dariam conta de toda a história da humanidade, como se o artista desejasse intensificar a imagem do cientista no enunciado, mas para, pelo contrário, rebaixá-la na enunciação. Em resumo, trata-se de um narrador descrente e desencantado, tal como aqueles típicos da escola realista, que duvidavam de tudo e todos em suas obras.

\footnotetext{
${ }^{793}$ RAMOS, Graciliano. op.cit. p.154.
} 
No que diz respeito a este último aspecto, a influência oitocentista transcende a opção por um narrador desiludido. O próprio modo de elocução de Graciliano como um todo se revela mais próximo de um Eça de Queirós do que, por exemplo, do estilo adotado por ele mesmo em seu romance Vidas Secas. Prova disso pode ser encontrada logo de saída no primeiro parágrafo:

O sociólogo estrangeiro desembarcou, dirigiu-se ao hotel, aboletou-se e no dia seguinte percorreu a cidade, exibindo a roupa de sábio, surrada e com joelheiras, o guarda-chuva de cabo torto, o chapéu de palha, sujo, roído nas abas, um grande pacote amarelo debaixo do braço ${ }^{794}$.

Tem-se, aqui, uma unidade textual formada por um único e extenso período, no qual predominam a abundância de detalhes (abuso da adjetivação) e um modo de composição cumulativo de matriz queirosiano $^{795}$, distante da frase precisa e geométrica que consagraram o estilo “Graciliano Ramos” em livros como São Bernardo ou Infância, por exemplo. Além disso, se se levar em conta a imagem de um escritor afeito ao "essencial"796, comumente vinculada ao artista alagoano, pode-se considerar que o trecho acima seria marcado pelo desequilíbrio, pela informalidade e pela frouxidão sintática. Se por um lado esses aspectos depõem contra o autor, por outro, abrem novas possibilidades ao escrito em questão, pois lançam fagulhas semânticas que irão repercutir no decorrer de todo o percurso narrativo, tendo em vista o caráter indicial e cintilante dos itens listados. Como visto acima, eles se colocavam além da simples apresentação do protagonista, refletindo-se, por oposição, na caracterização de outros personagens e no caminhar do próprio conto.

\subsubsection{Novamente o passado liberal em cena}

Quanto à organização temporal, o texto seria marcado pela linearidade, com pequenos recuos, cujas funções básicas seriam gerar surpresa e contribuir para a ficcionalidade da trama. Já do ponto de vista do tempo crônico, levando-se em conta a categoria enunciativa, prevalecem debreagens enuncivas (não-agora) que situam o relato no passado (momento de referência pretérito). Apesar de o narrador não expressar uma localização absoluta ou mesmo relativa, a

\footnotetext{
${ }^{794}$ Idem, p.154.

795 FRANCHETTI, Paulo. Apresentação. In: QUEIRÓS, Eça de. O primo Basílio: episódio doméstico. São Paulo: Ateliê Editorial, 2001, p.20.

796 Carpeaux destacava que a mestria singular do romancista Graciliano Ramos residia em seu estilo. "É meticuloso. Quer eliminar tudo o que não é essencial: as descrições pitorescas, o lugar-comum das frases feitas, a eloqüência tendenciosa. Seria capaz de eliminar ainda páginas inteiras, eliminar os seus romances inteiros, eliminar o próprio mundo” (CARPEAUX, Otto Maria. Visão de Graciliano Ramos. In: BRAYNER, Sônia (org.). Graciliano Ramos. 2 ed. Rio de Janeiro: Civilização Brasileira, 1978, p.25).
} 
utilização do termo “governador” e não “interventor” para referir-se ao chefe do poder executivo estadual, sobretudo no encontro protocolar entre este e o sociólogo, indicaria que o texto remeteria a um período anterior a 1930.

Como se sabe, com a vitória da Aliança Liberal, todos os antigos governadores, excetuandose o chefe do executivo estadual de Minas Gerais, foram demitidos e, no lugar destes, nomeados interventores subordinados diretamente ao Presidente da República ${ }^{797}$. Logo depois, em agosto de 1931, começava a valer o decreto ${ }^{0}$ 20.348, chamado de "Código dos Interventores”, que visava regulamentar o controle a ser exercido pelo presidente da República sobre tais coordenadores políticos/agentes federais nos Estados, completando a Lei Orgânica do governo provisório ${ }^{798}$. Esse quadro muda apenas no curto espaço de tempo em que vigorou a Constituição de 1934 (1935-1937), que tornava a assegurar o regime federativo nos moldes liberais. Logo após a promulgação da carta, eram realizadas eleições indiretas para governador nos Estados ${ }^{799}$.

Porém, com a instauração do Estado Novo, as medidas centralizadoras retornaram com toda a força. Nas "Disposições transitórias e finais” da Carta de 1937, o presidente recebia poderes para confirmar ou não o mandato dos governadores eleitos, nomeando interventores nos casos de não-confirmação. Na prática, os chefes dos executivos estaduais teriam sido convertidos em interventores ${ }^{800}$, antes de serem substituídos posteriormente ${ }^{801}$. O nono artigo da “Constituição Polaca” era bem claro quanto ao poder presidencial no que dizia respeito a essa questão:

O Governo federal intervirá nos Estados, mediante a nomeação pelo Presidente da República de um interventor, que assumirá no Estado as funções que, pela sua Constituição, competirem ao Poder

\footnotetext{
${ }^{797}$ FAUSTO, Boris. op.cit, p.333.

${ }^{798}$ Segundo Fausto, tal decreto também limitava a área de ação dos Estados, "que ficaram proibidos de contrair empréstimos externos sem a autorização do governo federal; gastar mais de $10 \%$ da despesa ordinária com os serviços da polícia militar; dotar as polícias estaduais de artilharia e aviação ou armá-las em proporção superior ao exército" (Idem, ibidem).

${ }^{799}$ PANDOLFI, Dulce Chaves. Os anos 1930: as incertezas do regime. In: Ferreira, J.; DELGADO, L. A. N. Brasil Republicano. O tempo do nacional-estatismo: do início da década de 1930 ao apogeu do Estado Novo. Rio de Janeiro: Civilização Brasileira, 2007, p.29.

${ }^{800}$ Segundo Almir de Andrade, em referência à legislação, os poderes conferidos aos interventores seriam muito mais limitados do que os dos antigos governadores. "O interventor é como um instrumento de ligação entre a administração estadual e o Presidente da República é um auxiliar imediato deste último dentro dos Estados, tendo a sua atividade limitada pelas atribuições especiais que lhe confere a Lei Orgânica” (ANDRADE, Almir. O Brasil e a centralização do governo. Cultura Política, Rio de Janeiro, ano 1, n.4, jun. 1941, p.5).

${ }^{801}$ FAUSTO, Boris. op.cit. p.366.
} 
Executivo, ou as que, de acordo com as conveniências e necessidades de cada caso, lhe forem atribuídas pelo Presidente da República ${ }^{802}$.

Ao longo da ditadura varguista, o controle de tal sistema de interventorias fora aperfeiçoado pelo Decreto-Lei n ${ }^{0}$ 1.202, de 8 de abril de 1939 (“Lei dos Estados e Municípios”), responsável pela criação de Departamentos Administrativos em cada uma das unidades federativas. Estes funcionavam como órgãos fiscalizadores e de colaboração legislativa, seja a nível estadual ou municipal. Eram compostos por membros de livre escolha e nomeação do governo federal, o que aparentemente conferia ao "Presidente da República o controle perfeito e geral de todo o movimento da administração pública do país”803.

Levando-se em conta tais afirmações, os questionamentos lançados por Graciliano à burocracia estatal e, mais especificamente, à falta de um programa nacional de ensino, tomariam como momento de referência a Primeira República. Logo o autor não estaria satirizando o status quo getulista, ou seja, o mundo contemporâneo à revista, mas sim o período pregresso, correspondente ao regime liberal. Como repisado até aqui, o rebaixamento de tal intervalo pré-1930 era a principal estratégia utilizada pela retórica oficial para produzir sua legitimidade. Nesse sentido, se se levar em conta esta tópica estadonovista, orientadora do discurso de Cultura Política, Graciliano estaria corroborando a ação e a oração estatal, que visava produzir unidade, justificando sua intervenção nas mais variadas áreas, entre elas a educação. Ao retomar o passado, encoberto pelo protocolo ficcional do conto, tornaria sua colaboração ajustável aos postulados do Estado, por mais que, em nenhum momento, tenha se valido dos encômios presentes na ladainha dos outros colaboradores do periódico.

Meses antes da publicação de "Uma visita inconveniente”, Gustavo Capanema empreendera a reforma do ensino secundário por meio do decreto-lei n.4.244, de 9 de abril de 1942, reproduzido integralmente em Cultura Política ${ }^{804}$. De caráter centralizador, regulador e elitista, a iniciativa previa entre outras coisas: divisão do ensino secundário em dois ciclos: ginásio e colégio, sendo que este último dividir-se-ia em dois cursos paralelos: o clássico e o científico; prescrição das matérias a serem ministradas em cada um dos níveis; indicação de

\footnotetext{
${ }^{802}$ PORTO, Walter Costa (coord). As constituições brasileiras. v.4. A Constituição de 1937. Brasília, Ministério da Ciência e Tecnologia, Centro de Estudos Estratégicos, 1999, p.22.

${ }^{803}$ MAIA, Ulisses Ramalhete. Três importantes decretos. Cultura Política, Rio de Janeiro, ano 2, n.17, jul. 1942, p.141.

${ }^{804}$ CAPANEMA, Gustavo. Lei orgânica do ensino secundário. Cultura Política, Rio de Janeiro, ano2, n.16, jun. 1942, 278-299.
} 
que os programas das disciplinas seriam organizados por uma comissão geral ou por comissões especiais, designadas pelo Ministério da Educação; definição de critérios de admissão e avaliação dos alunos, das tarefas e exercícios a serem realizados e dos certificados emitidos; especificação da formação dos professores que deveriam receber "formação em cursos apropriados, em regra de ensino superior” ${ }^{805}$, entre outras determinações. Com relação aos estabelecimentos de ensino, delimita três categorias: os federais, os equiparados (mantidos por Estados e pelo Distrito Federal) e os reconhecidos (mantidos por municípios ou pela iniciativa privada). Para funcionarem, os dois últimos precisavam da autorização do Ministério da Educação e Saúde, que ainda realizava a inspeção dos mesmos e regulava a inscrição dos docentes, o que reforçava o controle exercido pela União.

Em oposição à situação do ensino secundário ficcionalizada por Graciliano, na qual grassavam a falta de programa e de formação do corpo docente, cujo resultado seria a mutilação da História do Brasil ${ }^{806}$, o governo estabelecia marcos regulatórios válidos para todo o território nacional, com o objetivo regrar e unificar a educação brasileira. Em perspectiva elitista, Capanema elevava o papel a ser desempenhado por tal nível educacional; ele destinar-se-ia à preparação das “individualidades condutoras, isto é, dos homens que deverão assumir as responsabilidades maiores dentro da sociedade»"807. Teria, assim, um caráter nacionalista, pois forneceria aos adolescentes “a compreensão da continuidade histórica da pátria, a compreensão dos problemas e das necessidades, da missão e dos ideais da nação, e bem assim dos perigos que a acompanham, cerquem ou ameacem”808. Diante dessas considerações, portanto, o quadro descrito pelo artista alagoano poderia ser tomado como contraponto para justificar o conjunto de medidas adotadas pelo Ministério de Educação e Saúde.

A lei elaborada por Capanema era considerada como uma ampliação necessária ou mesmo um aperfeiçoamento da reformulação do ensino secundário realizada onze anos antes por Francisco Campos, então ministro da educação. Colocada em vigor em 1931, já num contexto pós-revolucionário, a "Reforma Campos” teria sido a primeira a estabelecer a metodização de tal nível educacional, definindo entre outros pontos a seriação obrigatória, critérios para a

\footnotetext{
${ }^{805}$ Idem, p.295.

${ }^{806}$ No programa de ensino estipulado pela Reforma Capanema, estipulava-se a introdução da História do Brasil e da Geografia do Brasil como disciplinas autônomas, tendo em vista a formação da consciência patriótica nos alunos.

${ }^{807}$ Idem, p.279.

${ }^{808}$ Idem, ibidem.
} 
formação de professores e a obrigatoriedade de concurso público para o magistério secundário e superior oficial ${ }^{809}$. Seria um dos primeiros passos rumo à unificação do sistema nacional de ensino $^{810}$, que ganharia contornos mais nítidos depois de 1937, “em consonância com a direção e a fisionomia”, ${ }^{811}$ que o Estado Novo teria dado à questão.

Recuando a questão educacional ainda mais ao passado, a revista procurava estabelecer uma contraposição entre antes e depois da chegada de Getúlio ao poder. Fazia referência, sobretudo, à implantação do Ministério de Educação e Saúde, ocorrida logo após a vitória da Aliança Liberal, em 18 de novembro de 1930. Num contexto em que o ensino era tomado como "problema nacional” ${ }^{212}$, tal instituição teria sido criada como forma de unificar, centralizar e sistematizar o ensino brasileiro, até então descentralizado e desprovido de regulação federal:

Até 1930 faltava ao país um órgão que contivesse no seu âmbito específico de ação os elementos essenciais de ordem técnica para os estudos indispensáveis à realização de cunho prático no domínio da educação. (...) A criação do Ministério da Educação e Saúde, se bem que ainda destituído das linhas estruturais que a remodelação de 1937 lhe veio a imprimir, pode ser considerada sem favor, o remate da longa série de experiências iniciadas em 1890, com a obra de Benjamin Constant ${ }^{813}$.

Aludindo ainda à antiga autonomia estadual em matéria de educação elementar, o articulista de Cultura Política afirmava: "Faltava-nos os elementos imprescindíveis à realização de uma verdadeira política educacional, isto é, a possibilidade de encararmos o problema da formação do homem no seu sentido global, tomando-o nos primórdios do seu enunciado e acompanhando-o até as suas últimas resoluções"814. Segundo ele, com a "Reforma Gustavo Capanema”, continuando a anterior "Reforma Campos”, o governo estabelecera um novo paradigma, no qual o “dever de educar se apresentou ao Brasil com amplitude jamais atingida”815.

\footnotetext{
${ }^{809}$ FILHO, Venâncio F. Educação IX. Cultura Política, Rio de Janeiro, ano 1, n.9, nov. 1941, p.404.

${ }^{810}$ Segundo Cunha, tratava-se do "momento mais alto da sistematização da educação brasileira, até então. Uma sistematização bastante minuciosa que abrangia até mesmo os mínimos detalhes de natureza didático pedagógica” (CUNHA, Célio da. Educação e autoritarismo no Estado Novo. São Paulo: Cortez Editora/Autores Associados, 1981, p.169).

${ }^{811}$ LIMA, José Augusto de. A reforma Gustavo Capanema. Cultura Política, Rio de Janeiro, ano 2, n.16, jun. 1942, p.277.

${ }^{812}$ HORTA, José Silvério Baía. O hino, o sermão e a ordem do dia: a educação no Brasil (1930-1945). Rio de Janeiro: Ed. UFRJ, 1994, p.2.

${ }^{813}$ Idem, p.274-275.

${ }^{814}$ Idem, p.276-277.

${ }^{815}$ Idem, p.277.
} 
No entanto, a crítica ao tratamento assistemático dado à questão educacional durante a Primeira República antecedia ao Estado Novo. No Manifesto dos pioneiros da educação nova ${ }^{816}$, de1932, assinado por Fernando Azevedo, Anísio Teixeira e Lourenço Filho, entre outros intelectuais difusores do movimento da Escola Nova no Brasil, tal questionamento tomava corpo logo de saída:

\begin{abstract}
No entanto, se depois de 43 anos de regime republicano, se der um balanço ao estado atual da educação pública, no Brasil, se verificará que, dissociadas sempre as reformas econômicas e educacionais, que era indispensável entrelaçar e encadear, dirigindo-as no mesmo sentido, todos os nossos esforços, sem unidade de plano e sem espírito de continuidade, não lograram ainda criar um sistema de organização escolar, à altura das necessidades modernas e das necessidades do país. Tudo fragmentário e desarticulado $^{817}$.
\end{abstract}

Resultados das disputas entre católicos e pioneiros no âmbito da Associação Brasileira de Educação $(\mathrm{ABE})^{818}$, os questionamentos e propostas contidos em tal Manifesto respondiam às demandas feitas pelo governo federal aos participantes da IV Conferência Nacional de Educação. Estes deveriam definir as bases da política de ensino a ser adotada no período pósrevolução ${ }^{819}$. Prestigiando o evento, o próprio Getúlio solicitava aos conferencistas que colaborassem com a União na busca de uma "fórmula feliz" para a "unidade da educação nacional” ${ }^{\text {820 }}$. Levando em conta esse pedido, os escolanovistas redigem o referido documento, no qual defendem o privilégio para uma escola pública, obrigatória, gratuita e leiga, além da co-educação.

\footnotetext{
${ }^{816}$ Tal documento merece destaque em função de seu impacto que tivera na redefinição do campo dos debates educacionais. "O que, antes, na década de 1920, era convergência em torno da 'causa cívico-educacional' passa a explicitar-se como confronto de posições: escola única x escola dual; ensino público x ensino particular, ensino leigo $\mathrm{x}$ ensino religioso. Com essa redefinição ganha visibilidade a crítica à dualidade estrutural do sistema educacional brasileiro" (CARVALHO, Marta Maria Chagas de. O Manifesto e a Liga Internacional pela Educação Nova. In: XAVIER, Maria do Carmo (org.). Manifesto dos pioneiros da educação: um legado educacional em debate. Rio de Janeiro: Editora FGV, 2004, p.147).

${ }^{817}$ AZEVEDO, Fernando. Reconstrução educacional no Brasil. Manifesto dos pioneiros da educação nova. In: A educação entre dois mundos. São Paulo: Edições Melhoramentos, [1958], p.59.

${ }^{818}$ Tal confronto entre católicos e pioneiros dá-se num contexto posterior à Revolução de 1930, quando, em virtude da criação do Ministério de Educação e Saúde, são inaugurados novos espaços de poder de importância estratégica. "Com isso, o consenso em torno da 'causa educacional' transmuda-se em disputa pela implementação de programas político-pedagógicos concorrentes” (CARVALHO, Marta Maria Chagas de. O território do consenso e a demarcação do perigo: política e memória no debate educacional dos anos 30. In: FREITAS, Marcos Cezar (org.) et al. Memória intelectual da educação brasileira. Bragança Paulista: EDUSF, 1999, p.17).

${ }^{819}$ XAVIER, Libânia Nacif. O manifesto dos pioneiros da educação nova como divisor de águas na história da educação brasileira. In: XAVIER, Maria do Carmo (org.). Manifesto dos pioneiros da educação: um legado educacional em debate. Rio de Janeiro: Editora FGV, 2004, p.26.

${ }^{820}$ Idem, ibidem.
} 
Ao proclamar a necessidade de a educação ser reconhecida como função pública, os signatários do Manifesto consideravam o Estado como elemento central na realização de tal projeto. Anos depois, o próprio Fernando Azevedo, autor do referido documento, considerava que uma das novidades das propostas que começaram a tomar corpo nos anos 1920 era a unificação do sistema educacional em nível nacional, mediante "uma política traçada pelas elites governantes”, ${ }^{\sharp 21}$. Mais do que um direito do cidadão, o ensino aparecia como um dever, tendo em vista a afirmação da nacionalidade segundo orientações cívico-educacionais ${ }^{822}$.

Mais especificamente, no âmbito da ABE, havia grupos como os de Fernando Labouriau que, já em 1927, defendiam a criação de um Ministério da Educação, como um "aparelho ramificado convenientemente por todo o país”, cuja função principal seria assegurar “a unidade da pátria, por meio de um plano NACIONAL de educação”,823. Segundo ele, o lastimável atraso em que vegetava a população do interior, até então, seria fruto do alheamento da União do controle da instrução popular. E continua: “Deixar aos Municípios ou aos Estados a 'incumbência’ de prover a educação’ era permitir 'orientações tão diversas por esse Brasil afora que a nossa unidade como povo nunca mais se poderia conseguir»»824.

Nesse sentido, o debate em torno da proposição de um programa nacional de ensino, incorporado e enquadrado pelo regime de $1937^{825}$, também era anterior ao centralismo autoritário deste. Tratava-se de um problema mais amplo, que, dentre as mazelas nacionais, sobrelevava-se aos demais. Como afirmava o Manifesto, o incremento do ensino estaria na base dos planos de reconstrução nacional. "Pois, se a evolução orgânica do sistema cultural de um país depende de suas condições econômicas, é impossível desenvolver as forças econômicas ou de produção, sem o preparo intensivo das forças culturais e o desenvolvimento

\footnotetext{
${ }^{821}$ AZEVEDO, Fernando. Cultura brasileira. In: CARVALHO, Marta Maria Chagas de. Molde nacional e fôrma cívica. Bragança Paulista: Edusf, 1998, p.23. ${ }^{822}$ Idem, p. 41.

823 LABOURIAU, Fernando. Sobre o Ministério da Educação Nacional. In: DIRETORIA GERAL DA INSTRUÇÃO PÚBLICA e da Sociologia de Educação de São Paulo, vol.II, n.3, mar. 1928 apud CARVALHO, Marta Maria Chagas de. op.cit. p.219.

${ }^{824}$ Idem, p.219.

825 Diferentemente das propostas traçadas no Manifesto, no Estado Novo, segundo perspectiva defendida por Capanema a partir de 1937, prega-se que a educação deveria atuar "não no sentido de preparar o homem para uma ação qualquer na sociedade", mas sim "no sentido de prepará-lo para uma ação necessária e definida, de modo que ele entre a constituir uma unidade moral, política e econômica, que integre e engrandeça a nação" (HORTA, José Silvério Baia. op.cit, p.167). Em outras palavras, a escola deveria funcionar como "aparelho ideológico a serviço do Estado” (Idem, p.171).
} 
das aptidões à invenção e à iniciativa que são os fatores fundamentais do acréscimo de riqueza de uma sociedade”.

Em nível local, na qualidade de Diretor de Instrução Pública de Alagoas, o próprio Graciliano promovera políticas que ampliaram a atuação do governo no campo educacional. Tendo em vista o aperfeiçoamento do ensino, como instrumento de melhora da situação popular, tomara as seguintes medidas: “... proibição de ingresso no magistério público primário de pessoas não-diplomadas; a exoneração de todas as professoras primárias interinas; a criação - na verdade recriação - das Juntas Escolares, destinadas a propagar e fiscalizar o ensino nas escolas estaduais, municipais e particulares; a organização do serviço de estatística escolar; a supressão, nos grupos escolares do interior, do curso de formação de professores rurais”, Trata-se de iniciativas que visavam, sobretudo, aperfeiçoar a formação de professores, acabar com cargos temporários e criar ferramentas de fiscalização e produção de dados sobre o universo educacional do Estado das Alagoas. Outra disposição, análoga às anteriores foi a instituição de concurso público para suprir o vácuo deixado pelos lentes demitidos; a partir de então, o professorado só poderia ingressar nos quadros estaduais mediante tal tipo avaliação. Paralelamente, autorizou a Escola Normal a criar um curso de preparação para os docentes interessados em prestar a prova ${ }^{827}$.

Graciliano, no artigo “Alguns números relativos à instrução primária em Alagoas”, publicado na revista maceioense Escola, em 1935, prestava contas das melhoras proporcionadas por sua pasta ao ensino do Estado como um todo. Antes traçava um panorama geral da precariedade em que se encontrava a educação local:

\footnotetext{
O quadro que nos apresentava, há poucos anos, a instrução em Alagoas era este: dezena e meia de grupos escolares, ordinariamente localizados em edifícios impróprios, e várias escolas isoladas na capital e no interior, livres de fiscalização, providas de material bastante primitivo e quase desertas. As professoras novas ingressavam comumente nos grupos; as velhas ficavam nas escolas isoladas, desaprendendo o que sabiam, longe do mundo, ensinando coisas absurdas. Salas acanhadas, palmatória,
}

\footnotetext{
${ }^{826}$ SANT’ANA, Moacir Medeiros de. Graciliano Ramos: vida e obra. Maceió: Secretaria de Comunicação Social, 1992, p.53.

${ }^{827}$ No entanto, as medidas não surtiram o efeito o desejado, pois o interventor federal à época, pressionado por injunções políticas, reduzira o rigor do concurso, bem como determinara que as vagas remanescentes, após a nomeação dos aprovados, seriam preenchidas por professoras rurais e por alunas diplomadas pela Escola Normal. (Idem p.54).
} 
mobília de caixões, santos nas paredes, em vez de mapas. Em 1932 eram assim as escolas rurais, as distritais e também grande parte das urbanas ${ }^{828}$.

As estatísticas escolares, que começaram a ser realizadas por sua gestão, a partir de 1933, mostravam a mudança desse quadro. Teria havido o incremento do número de alunos, de professores contratados e de estabelecimentos de ensino, depois da implementação das medidas regulatórias listadas acima:

Em 1932 havia nas escolas públicas 15.826 alunos, 22.821 em 1933, 25.840 em 1934. A freqüência média de 11.285 em 1932 subiu a 15.264 em 1933, a 16.900 em 1934 (...)

Em 1932 existiam 434 professores em 337 estabelecimentos de ensino, compreendidos 17 grupos escolares. Temos hoje 473 professores trabalhando em 358 estabelecimentos: 335 escolas isoladas e 23 grupos escolares $^{829}$.

Voltando a "Uma visita inconveniente”, percebe-se, portanto, que a sátira de Graciliano, enfeixada nesta narrativa sobre a precariedade do ensino e sobre a necessidade de se definir um programa orientador do magistério, participa de um macro-discurso mais amplo em torno dos mesmos temas, que marcou os debates sobre a educação nacional desde os anos 19201930. Logo o artista aludiria a um problema estrutural, reconhecido de maneira imediata por seus leitores da época (daí admitir-se o efeito cômico do texto, pressuposto pela anedota empregada), sem, necessariamente, restringir seus questionamentos à Primeira República, como prescrevia a retórica oficial. Em outras palavras, os personagens caricaturizados pelo escritor alagoano - o governador distante dos problemas da população, o funcionário incompetente e o professor obtuso - não deveriam existir em nenhum tipo de Estado fosse ele "Novo” ou não. Além disso, em nenhum momento, ele afirma que o regime de 1937 teria solucionado as críticas levantas por sua colaboração, deixando tal lacuna em aberto.

Por outro lado, a publicação da referida narrativa numa revista de propaganda dos postulados estadonovistas, que, basicamente, tinha como função anunciar a prevalência do "novo" governo sobre o “antigo” regime, levava a uma interpretação da mesma favorável à ditadura varguista. Segundo o enquadramento discursivo conferido ao texto por Cultura Política, o passado recuperado pelo artista serviria como contraponto para afirmar a para a superioridade

${ }^{828}$ RAMOS, Graciliano. Alguns números relativos à instrução primária em Alagoas. Escola, Maceió, vol. I, fasc. 1, set. 1935, p.13. Artigo ainda inédito em livro (vide anexos).

${ }^{829}$ Idem, p.14. 
do Estado Novo, por mais que o autor, em nenhum momento, diferentemente dos demais colaboradores, tenha explicitado tal leitura. De maneira mais específica, a sátira sobre professor secundarista poderia ser tomada como meio de respaldar a Reforma Capanema, bem como outras medidas governamentais que visavam unificar o sistema educacional brasileiro, apesar do viés autoritário e doutrinário conferido a estas.

Diferentemente do que ocorria com os demais colaboradores, tal leitura imposta pela própria materialidade da publicação, incluindo-se aí todo o aparato paratextual e discursivo utilizado, assumia um papel mais efetivo no enquadramento das produções de Graciliano. Como já sublinhado, para discutir a ineficiência e o descaso da burocracia brasileira, com destaque para a precariedade do ensino, o artista produz uma narrativa com um grau de ficcionalização acima da média dos textos de seus colegas de revista, em sua maioria dissertações de caráter encomiástico sobre variados aspectos do governo. Assim, ao escolher participar do debate sobre a educação nacional por meio de um conto anedótico, recuado num passado identificado com a Primeira República, o autor alagoano sujeitava sua colaboração ao duplo sentido, o qual seria desfeito ou amenizado, caso tivesse optado por um texto expositivo e referencial sobre o tema. Deixando de lado esta última hipótese, sua escolha por um escrito de matiz alegórico, revela-se conveniente a sua situação: colaborar com uma revista de direita, sem se comprometer com os ideais ali expressos. Aparentemente, a preferência pela ficção seria uma forma de tentar desvencilhar-se do mundo de compromisso imediato com a política estatal.

Em situação diversa da encontrada em Cultura Política, Graciliano tratara dos problemas educacionais de Palmeira dos Índios de maneira aberta ${ }^{830}$. Em texto deliberadamente cronístico, publicado na série "Garranchos”, em fevereiro de 1921, no jornal O Índio, o

\footnotetext{
${ }^{830}$ Ao longo da produção jornalística, missivística e ficcional de Graciliano, o questionamento à qualidade do ensino, mais especificamente à inaptidão do professorado brasileiro, sobretudo o sertanejo, aparece como um lugar-comum recorrente. Também em $O$ Índio, na seção “Traços a Esmo”, o cronista J. Calisto indigna-se contra o livro o infantil e contra os professores que o adotam: "Ou me engano muito, ou os autores ou colecionadores de semelhantes judiarias (referências aos compêndios escolares) são malucos. Malucos ou perversos, que escrevem com a idéia preconcebida de embrutecer a infância. Parece até que nunca foram pequenos, tão grande ignorância revelam da psicologia da criança” (RAMOS, Graciliano. Linhas Tortas, p.93). Numa carta à irmã Leonor, revolta-se: "Vão para o diabo todos as professoras analfabetas que há por aí" (RAMOS, Graciliano. Cartas, p.41). Em Infância, no relato da relação da criança com o universo letrado, ganham espaço capítulos inteiros dedicados à precariedade do magistério no interior nordestino, bem como à aproximação entre escola e prisão. Destaque para os trechos “Escola”, “D. Maria”, "Barão de Macaúbas”, entre outros. Quando era prefeito de Palmeira dos Î́ndios, no segundo relatório enviado ao governador Álvaro Paes, assim se referia às escolas recém-instaladas em três aldeias: "Presumo que esses estabelecimentos são de eficiência contestável. As aspirantes a professoras, revelaram, com admirável unanimidade, uma lastimosa ignorância (...) Não creio que os alunos aprendam ali grande coisa. Obterão, contudo, a habilidade precisa para ler jornais e almanaques, discutir política e decorar sonetos, passatempos acessíveis a quase todos os roceiros” (RAMOS, Graciliano. Viventes das Alagoas, p.213).
} 
escritor, encoberto pelo pseudônimo " $\mathrm{X}$ ”, comenta as deficiências educacionais do Estado, destacando a falta de interesse na construção de escolas, bem como o baixo nível dos professores:

Criam-se aqui todos os dias, quase, centros de diversões, e no entanto uma escola não se abre!

É simplesmente horroroso que numa cidade como a nossa (já não digo o município, contento-me com a sua capital) não tenhamos quem nos ensine a ler, arrancando-nos a cegueira da alma. Bem longe ainda vai de nós o progresso... O governo, descurando a maior necessidade do povo, entrega a sua instrução a criaturas tão ineptas que mal poderiam freqüentar o primeiro ano de um estabelecimento de ensino! Que podem elas ensinar, santo Deus, se nada sabem? Só por milagre. Milagres? Ah! Mas a poeira dos séculos apagou-lhes o vestígio! E a ignorância aumenta, e os crimes multiplicam-se! Temos (miséria!) escolas de vício, aprendizagem de crime, escadas para a prostituição. É a casa de jogo, é o álcool, é a aluvião de mendigas, crianças à puberdade, que infestam a cidade, oferecendo-se quase ${ }^{831}$.

Diante do descaso da administração pública, a miséria e o crime proliferavam. E apenas um milagre poderia melhorar a instrução, bem como as condições de vida dos moradores do lugar. De certa maneira, um texto parece remeter ao outro e ambos a certas práticas políticas voltadas à área da educação. Porém fazem isso segundo perspectivas diferentes: enquanto neste o articulista adota um discurso mais direto e participativo, assumindo, muitas vezes, a condição de protetor da população sertaneja representada pelo jornal, naquele vale-se da construção de personagens, cenário, cenas entre outros recursos literários, orientando-se pelo viés da sátira e dirigindo-se a outros leitores, especialmente os da capital federal. Se no trecho acima, refere-se a um caso específico, na crônica de Cultura Política, tendo em vista os recursos formais utilizados, também se refere a uma situação particular, mas transcende os limites desta, a qual pode ser tomada, metonimicamente, como válida para todo o país, além das metrópoles do Centro-Sul.

Continuando a comparação, ao passo que no jornalzinho interiorano Graciliano ocultava a autoria do texto, mas direcionava de maneira bem clara suas críticas ao governo de então, em “Uma visita inconveniente”, pelo contrário, nada de pseudônimo (assinava a narrativa com nome pelo qual se tornara literariamente conhecido), encobrindo, todavia, tanto o tratamento

${ }^{831}$ X [Graciliano Ramos]. Garranchos IV. O Índio, ano 1, n.4, 20 fev. 1921. Texto ainda inédito em livro, encontrado integramente entre os anexos do presente trabalho. 
do tema (por meio de uma fábula muito bem caracterizada), como a destinação dos questionamentos efetuados.

Portanto, em Cultura Política, ao imitar a estrutura do conto e não os discursos associados à vida cotidiana (ou seja, os signos usualmente tomados como "realidade”) da crônica, o artista produz um distanciamento, que força o leitor a adentrar no mundo ficcional construído e a desvendar os sentidos codificados pela trama. Apesar de gozar de relativa autonomia, tal universo figurado guardava semelhanças com o universo sócio-cultural do receptor, permitindo-lhe estabelecer correspondências entre um e outro. Logo, tendo em vista as possibilidades de leitura abertas pela narrativa, situada no passado, caberia a este destinatário interpretar, em perspectiva histórica, se o quadro apresentado pelo escritor permanecia inalterado ou fora modificado com o passar do tempo. Obviamente, o enquadramento do texto e o direcionamento do sentido deste, realizados pela aparelhagem paratextual e discursiva da revista, privilegiaram a segunda hipótese, procurando tomá-lo como contraponto para exaltar o novo, inscrito no próprio nome do regime de 1937. 


\title{
Capítulo 7 - Contraponto e a republicação dos quadros gracilianos
}

\author{
- Acredita em algum regime? \\ - Nenhum presta. \\ - Anarquista. \\ - Niilista. \\ - Então não vota nas eleições? \\ - Voto sempre no doutor Getúlio Vargas. \\ (Marques Rebelo) $^{832}$
}

\subsection{Marques Rebelo e o contraponto dos “Quadros e costumes do Centro e do Sul”}

Se os "Quadros e costumes do Nordeste”, de Graciliano, guardavam distância dos editoriais de autoria de Almir de Andrade e de outros escritos de caráter dissertativo vistos no capítulo anterior, também se afastavam das crônicas de seu companheiro de seção Marques Rebelo, responsável pelos “Quadros e costumes do Centro e do Sul”. Seja pelo gênero e estilo adotados, pela postura do narrador, pela estruturação do texto, mas, sobretudo, pelo grau de comprometimento deste com os postulados estatais avultam disparidades entre as composições de um e outro escritor ${ }^{833}$.

Ao todo Marques Rebelo escreveu 23 crônicas para Cultura Política. Assim como Graciliano, seus textos mensais estiveram presentes, ininterruptamente, nos dezoito primeiros números da revista. A partir décimo nono volume, de setembro de 1942, quando o periódico entra em sua

\footnotetext{
${ }^{832}$ MARQUES Rebelo; um escritor olha o mundo. Voga, Rio de Janeiro, ano 1, n.1, mar. 1951 (entrevista). apud ANTELO, Raul. op.cit. p.65.

${ }^{833}$ Além dos "Quadros e costumes do Centro e do Sul” e dos “Quadros e costumes do Nordeste”, a partir do quinto número de Cultura Política, de julho de 1941, passam a ser publicados também os "Quadros e costumes do Norte”, sob a responsabilidade do jornalista Raimundo Pinheiro, com o objetivo de ampliar a cobertura da vida regional feita pelo periódico getulista. A colaboração deste cronista estende-se pelos doze volumes seguintes, até julho de 1942, mesclando certo tom dissertativo e descritivo no recorte e apresentação de tradições nortistas. Destaque para festas, lugares, personagens, objetos e práticas, retratados segundo sua aparente especificidade frente ao restante do país. Em geral, o autor demonstra o objetivo de tornar o Norte visível aos olhos do Sul, não poupando imagens associativas entre ambos os universos. Ao mesmo tempo, orientando-se explicitamente por postulados estadonovistas, ressalta a modificação da paisagem política local, após a Revolução de 1930, que representou um duro golpe para o coronelismo; crítica a desambição e o sedentarismo dos caboclos; enfoca a alegria da vida cotidiana, nas paragens mais distantes e afastadas da Amazônia brasileira. / Em virtude não só da maior relevância literária e cultural de Rebelo, mas também do fato de ele estar presente na publicação oficial, assim como Graciliano, desde o primeiro número, o presente trabalho optou por preterir o exame dos textos de Pinheiro e restringir a análise comparativa dos "Quadros e costumes do Nordeste" aos retratos regionais da vida sulista.
} 
segunda fase e passa por uma reformulação estrutural ${ }^{834}$, o autor torna a colaborar apenas em cinco oportunidades. De maneira esparsa, publica mais dois textos em 1942 e outros três em $1943^{835}$. Além das participações como autor, Rebelo era citado, recorrentemente, pela seção “Movimento bibliográfico”, na qual eram arrolados livros lançados pelo meio editorial brasileiro no último mês. Trabalhando para os Irmãos Pongetti, o autor de Oscarina traduziu, revisou traduções e prefaciou inúmeros romances ${ }^{836}$, que não deixaram de ser listadas pelo veículo getulista.

Como a própria revista fazia questão de destacar, Rebelo, ao assumir os “Quadros e costumes do Centro e do Sul”, já seria um autor consagrado pela crítica. Seja como contista, cronista e romancista, ele teria publicado, até aquele momento, as seguintes obras: Oscarina (contos, Rio de Janeiro: Schmidt, 1931; relançado em 1937 pela Livraria José Olympio Editora), Três Caminhos (contos, Rio de Janeiro: Ariel Editora Ltda, 1933), Marafa (romance, S. Paulo: Livraria Martins, 1935; laureado com o Grande Prêmio de Romance Machado de Assis, da Cia. Editora Nacional), Vida de Manuel Antônio de Almeida (biografia, Rio de Janeiro: Ministério de Educação e Saúde, 1938), A estrela sobe (romance, Rio de Janeiro: Livraria José Olympio Editora, 1939), A Casa das Três Rolinhas (literatura infantil, Porto Alegre, 1939; ganhador de prêmio oferecido pelo Ministério da Educação), Rua Alegre, 12 (teatro, Curitiba: Guaíra 1940) ${ }^{837}$. No que ainda diz respeito à produção de obras para o público infantil, publicara pela Nestlé, em parceria com Santa Rosa, ABC de João e Maria (1938); Pequena tabuada de João e Maria (1939) e Amigos e inimigos de João e Maria (1940) ${ }^{838}$.

\footnotetext{
${ }^{834}$ Nesse momento, os “Quadros e costumes do Centro e do Sul”, assim como os "Quadros e costumes do Nordeste” passam a ser englobados numa única seção, chamada primeiramente de "Quadros e costumes regionais” e, logo depois, de “Quadros regionais” somente. Além disso, as colaborações de Rebelo, como as de Graciliano, que até o número 19 eram apenas numeradas em romano, passam a receber títulos individualizados.

835 Trata-se dos seguintes textos: “Cataguazes (Minas Gerais)”, Cultura Política, Rio de Janeiro, ano 2, n.19, set. 1942, p.181-183; “Trechos da suíte barbarense”, Cultura Política, Rio de Janeiro, ano 2, n.22, dez. 1942, p.141143; Novos trechos da suíte barbarense” Cultura Política, Rio de Janeiro, ano 3, n.24, fev. 1943, p.141-143; “Fim de suíte”, Cultura Política, Rio de Janeiro, ano 3, n.30, ago. 1943, p.168-171; “Caderno de viagens”, Cultura Política, Rio de Janeiro, ano 3, n.33, out. 1942, p.204-206.

${ }^{836}$ Entre eles, Crime e castigo de Dostoievski, Werther, de Goethe, O lírio vermelho, de Anatole France, A volta de Vivante, de Sydney Horley, Salambô, de Gustave Flaubert, Rudine, de Ivan Turgueneff e O mundo em transe, de Leopold Schwarzschild, referidos pelos números 2, 15, 18, 20, 21, 25 e 35 de Cultura Política, respectivamente.

${ }^{837}$ CONHECER O BRASIL. Cultura Política, Rio de Janeiro, ano 1, n.1, mar. 1941, p.232.

${ }^{838}$ Voltados ao público infantil, produzira também os títulos Pequena história de amor (Rio de Janeiro: Ed. Criança) e Aventuras de Barrigudinho, ambos em parceria com Arnaldo Tabaiá, além da Cartilha o Cruzeiro (Rio de Janeiro: Cruzeiro; em colaboração com Herberto Sales), obras possivelmente produzidas antes de sua entrada em Cultura Política, mas cujas datas de publicação não foram localizadas.
} 
Diferentemente das colaborações de Graciliano, os textos de Rebelo em Cultura Política podem ser chamados, efetivamente, de crônica. Em regra, o artista constrói um narradorviajante, que, tal como um flâneur em escala ampliada, percorre diferentes espaços urbanos, sobretudo, do interior do país, recolhendo dados pitorescos em meio ao processo de modernização do país ${ }^{839}$. Ancorado no presente, ele narra ou descreve cenas e personagens de um ponto de vista particular, transcrevendo informações, observações, impressões líricas e comentários em interação afetiva com seus destinatários. Ao mesmo tempo, o cronista não deixa de referenciar, de maneira direta, seu relato no mundo historicamente conhecido pelo leitor, em sentido oposto à indeterminação das categorias espaciais e actanciais dos "Quadros e costumes do Nordeste”.

Ao longo da trajetória dos "Quadros e costumes do Centro e do Sul”, a explicitação dos nomes dos lugares visitados por Rebelo fora ganhando destaque editorial por parte dos editores da revista. A partir do terceiro número de Cultura Política, os textos do autor, logo depois do título da seção, passavam a ser antecedidos pelos topônimos dos espaços por ele retratados. Tal procedimento de ancoragem no real, impensável no caso das colaborações de Graciliano, figurava como um dos elementos constitutivos centrais a corroborar o efeito de real pretendido pelos relatos do artista. Dos destinos tematizados pelo cronista carioca, predominam, com larga vantagem, aqueles encontrados no Estado de Minas Gerais: Itajubá, Januária, Cataguazes, Montes Claros, Belo Horizonte, Conceição do Serro, Conrado Niemeyer, Barbacena, entre outros. Há ainda três dedicados ao Rio de Janeiro, berço ficcional do romancista de A estrela sobe, e um a algumas cidades encontradas no Chapadão Goiano ${ }^{840}$.

A título de exame mais detalhado dos componentes formais presentes nas crônicas de Rebelo de Cultura Política, tome-se, por exemplo, o trecho inicial de sua segunda colaboração na revista. Esse escrito é composto por doze blocos textuais independentes entre si (conforme sinaliza a própria diagramação do texto, que o divide em módulos). Apesar da ausência de continuidade narrativa entre tais vinhetas, elas estão unidas pela mesma temática e propósito:

\footnotetext{
839 Por meio de seu alter-ego, em $O$ trapicheiro, afirma que se trata da produção de uma "literatura deambulatória para leitores apressados” (O Trapicheiro. São Paulo: Livraria Martins Editora, 1959, p.267).

${ }^{840} \mathrm{O}$ contato do artista com o interior de Minas era antigo. Levando-se em conta sua biografia, tendo em vista a pretensão especular e documental do relato, Marques Rebelo (pseudônimo de Edi Dias da Cruz, 1907-1973) era carioca de nascimento, mas passara parte de sua infância em Barbacena, no interior de Minas, local para onde sua família se mudara quando ele tinha apenas quatro anos (BOSI, Alfredo. História concisa da literatura brasileira. São Paulo: Cultrix, 2006, p.409).
} 
a composição de um retrato dinâmico da cidade de Januária, situada no interior mineiro. Vejase o excerto:

Januária fica encolhida sobre o barranco, triste e árida, como uma moça sem amor. Diante dela o São Francisco tem um quilômetro, pontuado de coroas amarelas, onde de noite se recolhem aves aquáticas. Mas quando vem a cheia, o rio se estende, põe seis a léguas de margem a margem, proibindo plantações regulares, ameaçando o gado, roendo os barrancos como uma doença de mau caráter, devastando populações ribeirinhas, e, ao descer das águas, vêem os mosquitos, o anófeles, principalmente, e tudo treme e os cemitérios enchem ${ }^{841}$.

Na composição de um retrato multifacetado do município mineiro de Januária, o artista começa por situá-lo no mundo, mais especificamente às margens do conhecido rio São Francisco. Tomando a cidade como actante (“ele”), por meio do processo de personificação, o narrador parece vê-la à distância, traçando-lhe o panorama. A instauração dessa não-pessoa produz o efeito de objetividade (como numa dissertação geográfica), que, por sua vez, é contrabalanceado pelas marcas da enunciação enunciada deixadas pelo narrador em terceira pessoa no texto, com destaque para a adjetivação e para os símiles empregados. Paralelamente, como forma de tratar da sujeição da localidade aos ciclos “eternos” da natureza (as cheias e vazantes do rio), prevalece a utilização do presente omnitemporal (debreagem enunciativa de tempo), prefigurando um momento de referência dilatado.

Até aí, apesar da utilização do tempo presente e da explicitação das coordenadas geográficas do retrato realizado, quem dava as cartas era um narrador em terceira pessoa, em moldes semelhantes daquele construído por Graciliano. No entanto, tal situação muda de figura no decorrer do texto. Depois de fornecer uma vista geral do município, por meio do qual recupera a história natural e política do mesmo, o narrador passa a tematizar suas experiências enquanto turista-viajante que, obrigado a permanecer em Januária em função da escassez de navios chegados ao porto local no período de seca do rio, passa a interagir com os habitantes do lugar e a participar de diferentes situações “pitorescas”. Tome-se outro excerto da crônica:

\footnotetext{
Sento-me na grama. Palmeiras estáticas. Vôos pesados de mergulhões paralelos à água. Tons roxos, distantes, na serra do Chapéu. Urubus se misturam nas praias com as lavadeiras e com os burrinhos d’água, pequenos, gentis, orelhas muito grandes, que servem a cidade do líquido. Passa Rui Canedo,
}

\footnotetext{
${ }^{841}$ REBELO, Marques. Quadros e costumes do Centro e do Sul II. Cultura Política, Rio de Janeiro, ano 1, n.2, abr. 1941, p.242.
} 
magro como uma ave pernalta, dirigindo-se para casa, sobraçando a pasta de sua advocacia. O sol desce cada vez mais. Há cores verdes no poente. Ecos repetem os gritos dos aguadeiros na outra margem. Sinto-me tranqüilo como se me despedisse da vida com grande saldo de felicidade. Pressinto um outro mundo de estranha paz esperando por mim. Mosquitos zumbem. E a cada momento estou para ver surgir da placidez do rio, onde as canoas presas flutuam, a virgem das águas para me levar ${ }^{842}$.

Ao contrário dos textos de Graciliano, marcados por debreagens enuncivas de pessoa, espaço e tempo (que instauram no enunciado, respectivamente um “ele”, um “lá” e um “então”), nas crônicas de Rebelo são comuns debreagens enunciativas destas mesmas categorias, com o privilégio para implantação nos discursos de um “eu”, de um “aqui” e de um “agora”. Como se vê acima, o narrador-protagonista coloca-se no centro do relato ("Sento-me na grama”, "Sinto-me tranqüilo”, "Pressinto um outro mundo”, “estou para ver surgir”), apresentando-se como ponto de referência a partir do qual se organizam as coordenadas espaço-temporais enunciativas. Tem-se um “aqui”, dêitico que pressupõe a cidade de Januária, às margens do Rio São Francisco, em visita pelo cronista, e o tempo presente, por meio do qual faz coincidir o evento descrito e o ato de enunciação que o descreve.

No trecho supracitado, o aparente monólogo recobre a interlocução entre um enunciador e um enunciatário interiorizados pelo mesmo ator, no caso o cronista, como numa espécie de diálogo reflexivo e confessional, marcado por certa dose de lirismo. Ao mesmo tempo, tal como num poema pastoril, prevalece a noção de idílio, como se o poeta se encontrasse numa espécie de locus amoenus interiorano e, enfim, pudesse despedir-se da vida "com grande saldo de felicidade”, nos braços de Iara, ao entardecer. Ao tomar o mundo representado como um lugar ideal (em que até a mãe-d’água perdia sua voracidade), opõe-se diretamente ao tom problematizador adotado por Graciliano. Nos “Quadros e costumes do Nordeste”, os espaços situados no passado apresentam um caráter inóspito, como se o artista privilegiasse o travo de uma "realidade" um tanto quanto desagradável. Nesse sentido, enquanto Rebelo elogiava de maneira aberta o status quo, Graciliano recuava em perspectiva crítica aos tempos idos, despindo-se de saudosismos.

Em Rebelo, por outro lado, o idílio seria acompanhado pela nostalgia. Ao final da crônica, no último bloco descritivo, o cronista atualiza sua saudade das moças (“pastoras”) de Januária,

${ }^{842}$ Idem, p.244. 
dirigindo-se tanto a elas, na qualidade de interlocutoras contemporâneas a seu relato, como as suas próprias lembranças:

Lilá, Eurídice, Berenice, Diva, Zizinha, Lindaura, para vós, moças de Januária, a minha saudade!

Saudade do churrasco na casa de Zizinha, numa véspera de São João, sem foguetes no céu, mas com um chorinho de baianos de Carinhanha e vozes de gente alegre cantando modinhas tristes:

“Amemos que a vida passa,

A vida é sombra e fumaça,

Amemos que a vida passa”

E a cachacinha rolando - cachacinha com limão, cachacinha com gengibre, cachacinha com erva-doce, cachacinha com pau-de-cheiro, cachacinha com groselha, e as moças todas cantando, fazendo roda, sambando, "amemos que a vida passa"!

Saudade do vôlei feminino, Escola Normal versus Clube dos Quarenta, e as meninas pulando atrás da bola, e o povo gritando, e as moças suando, caindo, se arranhando, e a Escola Normal numa virada empolgante que endoideceu o dr. Vale, que é presidente do Clube! ${ }^{843}$

O saudosismo se manifestava nas pequenas coisas, que, apesar do prosaísmo, teriam deixado marcas fundas no visitante: o churrasco na casa de Zizinha, as modinhas tristes cantadas na oportunidade, a cachacinha rolando, o jogo de vôlei feminino. Tal privilégio para a retomada de fatos cotidianos por um viés subjetivo, artifício retórico comum à crônica, sobretudo, após o modernismo, repete-se ao longo de todos os “Quadros e costumes do Centro e do Sul”. Em A mudança, segundo volume da trilogia $O$ espelho partido, obra autobiográfica em que buscava traçar um painel fragmentário da vida brasileira, especialmente carioca, da primeira metade do século XX, Marques Rebelo levanta alguns elementos concernentes a sua poética. Entre eles, destaca seu interesse por acontecimentos "miúdos":

E reporto-me ao interesse pelos pormenores, pelas nugas da existência, pela obrigação de atos comezinhos, pela ordenação das coisas insignificantes (...) Atraem-me vertiginosamente minudências, os mofinos recantos das almas, os tiques e gestos microscópicos, perturbam-me doentemente os sutis achados lingüísticos, ninharias, ninharias, quando as obras de vulto e peso abstêm-se dos detalhes ${ }^{844}$.

\footnotetext{
${ }^{843}$ Idem, p.245.

${ }^{844}$ REBELO, Marques. O espelho partido; a mudança. São Paulo: Livraria Martins Editora, v.2, 1959, p.486.
} 
Indiretamente, esta postura, lugar-comum no discurso dos cronistas desde o século XIX, procura ressaltar o olhar do escritor, capaz de encontrar e atribuir valor a aparentes banalidades. Esse pseudo-rebaixamento da matéria de seus textos persiste na divisão arbitrária estabelecida por Rebelo entre obras de vulto, que se absteriam dos detalhes, e sua produção, focada em situações e eventos "triviais". No entanto, se se levar em conta as orientações prévias que norteavam os “Quadros e costumes do Centro e do Sul”, o interesse por aquilo que seria aparentemente corriqueiro era algo valorizado, pois o objetivo da seção era documentar e apresentar ao poder central "o povo vivendo sua vida”. Logo, a figurativização de pormenores realistas das diferentes localidades visitadas servia ao propósito de legitimar o regime, pois lhe permitia estender seus tentáculos a diferentes aspectos e setores da sociedade, dentro do processo de construção de uma suposta unidade e homogeneidade nacionais ${ }^{845}$.

Nessa mesma linha, o artista constrói um tom de familiaridade com o mundo visitado, personalizando o geral mediante a eleição e o tratamento aproximado de certas figuras, sobretudo, tipos miúdos. Tal tratamento afetivo dispensado àqueles com quem acabara de estabelecer contato, considerando-se sua condição de "narrador de passagem”, contrasta com o estranhamento e o distanciamento irônico construído por Graciliano na ficcionalização do passado sertanejo.

Além disso, tendo em vista o pacto fiduciário veridictório previsto pelo registro cronístico, os textos de Rebelo, que também se aproximavam da perspectiva documental dos relatos de viagem, pressupunham a existência material dos personagens nomeados. Estes eram tomados enquanto munícipes que compunham a paisagem humana dos espaços retratados, reforçando o efeito de real pretendido pelo cronista. Alguns são apresentados com nome e sobrenome. Já o autor dos “Quadros e costumes do Nordeste”, por outro lado, costumava indeterminar o lastro referencial dos atores, adensando o efeito ficcional de suas colaborações.

\footnotetext{
${ }^{845}$ A própria revista Cultura Política, ao noticiar o lançamento do livro Suíte n.1, enfatizava esse interesse do artista pelo "rés-do-chão” (para utilizar expressão consagrada pela crítica), na recuperação da vida interiorana característica: "Nas cidades mineiras por onde andou em peregrinação, nos dois anos em que habitou o vizinho Estado, o autor de Oscarina procurou ambientes e tipos do mesmo gênero de seus contos. Assim tanto mais humilde, mais obscura a cidade, maior seu interesse, ou antes sua ternura por ela (...). Preferiu lugares dos quais pouca gente tem falado, e ali, numa modesta dona de pensão, num farmacêutico pachorrento à porta de sua botica, num chefe de estação irônico, surpreendeu o que de mais típico lhe pareceu existir na vida provinciana mineira” (MOVIMENTO literário. Cultura Política, Rio de Janeiro, ano 4, n.39, abr. 1944, p.238).
} 
Como referido anteriormente, os trechos da segunda participação de Rebelo em Cultura Política, transcritos acima, apresentavam-se como blocos textuais independentes entre si, mas que se ligam em torno da mesma temática (a cidade de Januária) e do mesmo assunto genérico (o retrato de usos, tipos, cenários e práticas sulistas). A opção por tal composição fragmentária, na qual diversas cenas e descrições sucedem-se unidas pelo fato de se referirem a um mesmo espaço e orientarem-se por um mesmo propósito, predomina nos "Quadros e costumes do Centro e do Sul”. Em regra, o autor toma as cidades visitadas como todos heterogêneos, com superfícies múltiplas e fracionadas, e para apreendê-los justapõe uma série de fragmentos como se costurasse uma colcha de retalhos. Nesse processo, ao fugir de uma suposta totalidade, o artista dá entender que existiriam vários universos no cosmos maior chamado cidade, por mais que ela se localizasse, por exemplo, no remoto Chapadão Goiano $^{846}$.

Na verdade, o rabiscador dos "Quadros e costumes do Centro e do Sul” privilegiaria dramas miúdos, quadros dentro de um quadro maior. Trata-se de um narrador vinhetista, atendo a minudências, que abdica dos movimentos gerais para traduzir a imagem conceitual dos espaços visitados mediante a noção de mosaico. Em resumo, opera a atomização do cenário e das figuras ao encadear e dirigir cenas e descrições sinedóquicas, orientando-se, portanto, por uma perspectiva metonímica. Graciliano, por outro lado, ao privilegiar retratos inteiriços (sem quebras discursivas) de situações, lugares e pessoas, confere a seus escritos unidade dramática. Nesse processo, mostra-se, sobretudo, alegórico, tecendo histórias que não se esgotariam em si mesmas, pois teriam um sentido imediato e outro sobreposto.

Na urdidura dos quadros multifacetados de Rebelo, ganha destaque a noção de "suíte"847 na composição de uma espécie de painel, cujas peças vão se somando, embora não ofereçam uma visão globalizante ${ }^{848}$. Tanto do ponto de vista musical quanto no âmbito da dança, “suíte” diria respeito à união de partes diversas na composição de uma obra mais complexa.

\footnotetext{
${ }^{846}$ REBELO, Marques. Quadros e costumes do Centro e do Sul IV. Cultura Política, Rio de Janeiro, ano 1, n.4, jun. 1941, p.218-220.

${ }^{847}$ A partir do $19^{\circ}$ volume da revista, quando os textos dos "Quadros e costumes" passaram a ser identificados não mais por números romanos, mas por títulos por extenso, o termo "suíte" ganha destaque na nomeação das crônicas: "Trechos de suíte barbacenense" (n.22), "Novos trechos da suíte barbacenense" (n.24) e "Fim de suíte" (n.30). Como se verá, quando o autor reunir seus textos de Cultura Política em livro, em 1944, nomeará a obra como Suíte n.1.

${ }^{848}$ GOMES, Renato Cordeiro. Todas as cidades, a cidade. Rio de Janeiro: Rocco, 1994, p.118.
} 
Mas em Rebelo, perde-se a dimensão de um todo intrincado, predominando a idéia de acúmulo aberto, cuja lei seria a adição ${ }^{849}$.

O conceito de suíte, como afirma de Gilda Melo e Souza ao analisar Macunaíma, seria um dos processos mais antigos de composição. “Comum à música erudita e popular, não é patrimônio de povo nenhum. Constitui uma união de várias peças de estrutura e caráter distintos, todas de tipo coreográfico, para formar obras mais complexas e maiores. Este processo rapsódico foi muito difundido no Romantismo e entre nós tornou-se um hábito nacional (...) São formas primárias de suíte todas as nossas principais danças dramáticas: os fandangos do Sul paulista, os cateretês do Centro brasileiro, e no Nordeste os caboclinhos, 'os cortejos semi-religiosos, semicarnavalescos dos maracatus’, as cheganças, os reisados”850 ${ }^{\text {. No }}$ caso de Rebelo, tal noção coaduna-se com uma espécie de retomada (ainda que parcial) do projeto modernista de representação de uma nacionalidade heteróclita, análoga à suíte do Bumba-meu-boi, tomada por Mário de Andrade como metáfora do país ${ }^{851}$.

Se do ponto de vista macro-estrutural a influência modernista de Rebelo se manifestava na produção de retratos estilhaçados, fragmentados em vários quadros sem continuidade narrativa entre si, o mesmo se pode dizer quando se examina, em particular, cada bloco textual produzido pelo autor. Em geral, estes também são marcados pelas noções de mosaico, justaposição e simultaneísmo. Tome-se um trecho de sua $16^{\mathrm{a}}$ colaboração em Cultura Política, na qual o cronista passa em revista sua passagem por uma série de municípios do interior de Minas Gerais:

Soledade Ponto de almoço e baldeação. Pedras no feijão, bife de pedra, pudim de pedra. Garçom lúgubre como um corvo. (O cérebro do reverendo, que vai fazer uma estação de águas, sofre a influência do bife e do pudim). O Rio Verde é amarelo. O carregador número um não tem braços! Meninas rondam a estação de braço dado, duas a duas: "Mas você gosta dele...” "Para casar, não”. Duas horas de atraso. Horas depressivas, desamparadas. Solidão! Solidão! ${ }^{852}$

\footnotetext{
${ }^{849}$ Idem, ibidem.

${ }^{850}$ MELO E SOUZA, Gilda de. Tupi e o alaúde. São Paulo: Duas Cidades; Ed. 34, 2003, p.13-14.

${ }^{851}$ Idem, p.17.

${ }^{852}$ REBELO, Marques. Quadros e costumes do Centro e do Sul XVI. Cultura Política, Rio de Janeiro, ano 2, n.16, jun. 1942, p.323.
} 
Na passagem, predominam a descontinuidade cênica e a simultaneidade no tratamento de matérias variadas, colocadas lado a lado, em flashes rápidos: o almoço petrificado, o aspecto fúnebre do garçom, o pensamento do reverendo, os comentários irônicos sobre o rio e sobre o carregador da estação, o diálogo das meninas casadoiras e o estado solitário do cronista, reforçado pelo próprio nome do município, Soledade, transcrito no intertítulo. De certa maneira, Rebelo recupera o caráter prismático da prosa oswaldiana, compondo o quadro por meio da sucessão de imagens fragmentárias, de cuja seqüência ou colisão emergiria uma nova imagem maior, tal como estabelecia a técnica de montagem cinematográfica de Eisenstein, que influenciara o modernismo de Oswald ${ }^{853}$.

No entanto, apesar de também recuperar a frase curta, de estilo telegráfico, presente, por exemplo, em Memórias sentimentais de João Miramar, o autor dos “Quadros e costumes do Centro e do Sul” deixa de lado o radicalismo da estrutura fraseológica sincopada. Em lugar da ruptura discursiva vanguardista, privilegiaria a confecção de um texto agradável, ameno, adequado a um convite à leitura, sem demandar do leitor o esforço de articulação e complementação das construções paratáticas e violadoras das regras de pontuação. Ao mesmo tempo, praticamente abdica da agudeza e do humor da “metáfora lancinante” de Oswald, optando, em regra, por um tom sério e documental, que pressupunha, de certa maneira, não a opacidade, mas a transparência das palavras ${ }^{854}$.

Em outros momentos, as tomadas ligeiras e sucessivas, vistas acima, são contrabalançadas por um olhar perscrutador, mas ainda impressionista, que se demora na recuperação da heterogeneidade dos componentes de um mesmo quadro:

Dentro do mercado, sujíssimo, mal se pode andar - o chão de terra batida desaparece sob sacos, jacás,
barricas, caixotes, cestas, bruacas. Açúcar, feijão, carne de sol, rapadura - e as moscas fervem! -
sandálias, chapéus de couro, esteiras, caroços de mamona, farinha de mandioca, lingüiça, cachaça... O
vozeiro ensurdece. Burros rincham. Um papagaio berra. Tropeça-se nos balaios, esbarra-se, o chão foge,

853 CAMPOS, Haroldo de. Miramar na Mira. In: ANDRADE, Oswald de. Obras completas II: Memórias sentimentais de João Miramar e Serafim Ponte Grande. Rio de Janeiro: Civilização brasileira, 1978, p. xli.

${ }^{854}$ Bem verdade, que em alguns momentos, como aponta Antelo (op.cit, p.74-75), Rebelo ensaia certo humor oswaldiano, como na conversinha ocorrida na cidade de Lontras: “- Morreu Zé Fagundes. - Quem matou” (REBELO, Marques. Quadros e costumes do Centro e do Sul XVI. Cultura Política, Rio de Janeiro, ano 2, n.16, jun. 1942, p.323). 
pisa-se em pés descalços, o calor atordoa. E o cheiro! Cheiro de suor, de couros frescos, de couros mal curtidos, de galinheiro sujo, de dentes podres, de hálitos pestilentos, de hálito de cachaça... ${ }^{855}$

Tem-se aqui a perspectiva modernista de reunião caótica - acumulação, antítese e paradoxo de um todo variado, mediante a utilização de um processo enumerativo típico da rapsódia. Ao mesmo tempo, tal procedimento destaca a visada realista do cronista viajante, cujo foco se concentrava na nomeação, na caracterização e na visualidade do cenário.

Em sentido amplo, tal perspectiva documentalista, que procurava recuperar uma suposta essência de brasilidade localizada no interior do país (conforme também prediziam os postulados modernistas), estava inscrita nas imagens selecionadas pela revista para ornar a primeira participação de Rebelo nos “Quadros e costumes do Centro e do Sul”. Esta era ilustrada por duas imagens pictóricas, que retratavam cenas "típicas" do sertão brasileiro. Tratava-se de paisagens feitas por artistas estrangeiros em viagens científicas pelos rincões nacionais, durante o século XIX. A primeira, sem autoria expressa, intitulava-se "Festa da Rainha, em Minas”, tendo sido publicada originalmente no livro Reise in Brasilien, de Von Spix e Von Martius, de 1823. A tela representava uma procissão feita a Nossa Senhora por uma rica fazendeira, vestida de gala (à direita do quadro), que conduzia o séquito, formado pelos habitantes da freguesia, até a Igreja para assistir à missa e depois de volta a sua casa, onde uma recepção era preparada apenas para convidados seletos ${ }^{856}$. A segunda pintura, assinada pelo famoso alemão Johann Moritz Rugendas, chamava-se "Famille de Planteurs”857 ("Família de fazendeiros”, na tradução de Sergio Milliet ${ }^{858}$ ) e fora estampada no volume Voyage pittoresque dans le Brésil, publicado pelo artista em 1835, na França. A obra representava o ambiente doméstico dos agricultores do hinterland nacional, indicando como estes viveriam sobriamente (até mesmo os mais abastados) ${ }^{859}$.

Realmente, a utilização de tais paisagens novecentistas por Cultura Política não parece gratuita, conectando-se diretamente com os pressupostos dos "Quadros e costumes do Centro

\footnotetext{
${ }^{855}$ REBELO, Marques. Quadros e costumes do Centro e do Sul VIII. Cultura Política, Rio de Janeiro, ano 1, n.8, out. 1941, p.252.

${ }^{856}$ SPIX, Johann Baptist von. Viagem pelo Brasil: 1817-1820. Belo Horizonte: Ed. Itatiaia; São Paulo: Ed. da Universidade de São Paulo, 1981, p.93.

${ }^{857}$ RUGENDAS, Johann Moritz. Voyage pittoresque dans le Brésil. Paris: Engelmann \& Cie., 1835.

${ }^{858}$ RUGENDAS, João Maurício. Viagem pitoresca através do Brasil. trad. Sérgio Milliet, Belo Horizonte: Ed. Itatiaia; São Paulo: Ed. da Universidade de São Paulo, 1979, p.167.

859 "Julgando-o apenas pelo interior de sua residência, pelas suas vestimentas, pela sua alimentação, o europeu teria dificuldade em acreditar que a maioria desses colonos é abastada e que muitos deles são mesmo ricos. A casa do colono abastado tem apenas um andar; as paredes são de taipa e algumas vezes caiadas” (Idem, p.212).
} 
Imagens pictóricas que acompanhavam a primeira colaboração de Marques Rebelo, em Cultura Política. A primeira, sem autoria expressa, intitulava-se "Festa da Rainha, em Minas”, e foi publicada originalmente no livro Reise in Brasilien, de Von Spix e Von Martius, em 1823. Já a segunda, "Famille de Planteurs”, de Johann Moritz Rugendas, foi estampada, em 1835, no volume de autoria do mesmo artista Voyage pittoresque dans le Brésil.
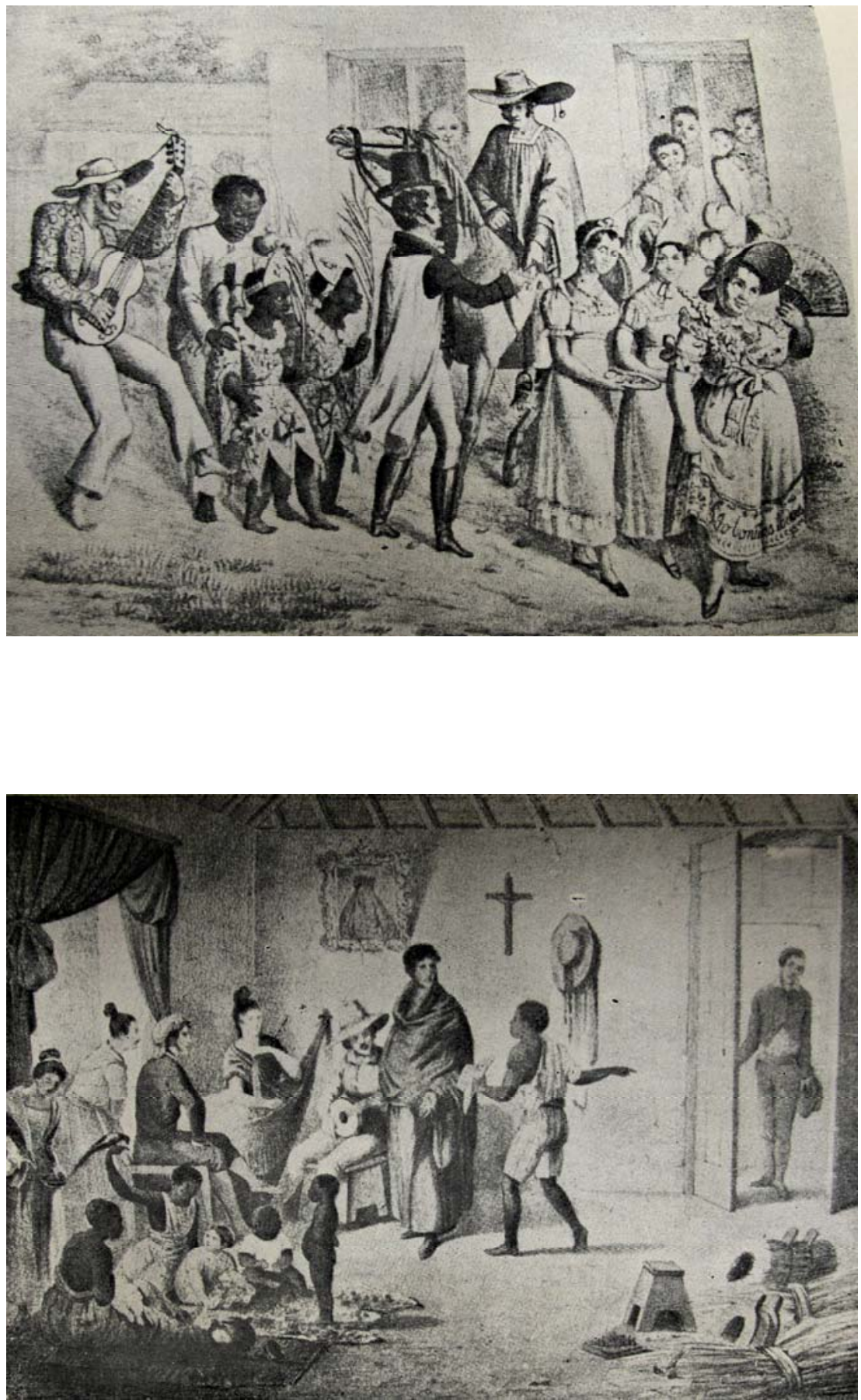
e do Sul”. Em Voyage pittoresque dans le Brésil, mais especificamente no texto do capítulo que acompanhava sua pintura reapropriada pela revista getulista, Rugendas assim se referia ao sertão brasileiro:

\begin{abstract}
Um europeu que só tenha visitado no Brasil as cidades marítimas, que conheça apenas os ricos proletários, os empregados ou o povo das cidades, não deveria arrogar-se o direito de se pronunciaracerca do país e de seus habitantes. É o que acontece, entretanto, o mais das vezes, e não raro emitem-se opiniões ou juízos igualmente inexatos e parciais. A única coisa que permite constituir uma opinião sadia e meritória é a longa permanência no interior do país, a freqüentação habitual e familiar da parte da população que se dedica à agricultura, isto é, os colonos ${ }^{860}$.
\end{abstract}

Conforme exposto no paratexto introdutório à seção de Rebelo, o objetivo desta também seria recuperar o "Brasil perdido na imensidade de si mesmo, seguindo o ritmo lento de sua história social”, com o privilégio para a fixação de “quadros típicos”, pitorescos. Se, no século XX, esta última palavra (presente no título da obra do referido paisagista alemão) perdera o conteúdo estético que tivera no passado ${ }^{861}$, por outro lado tornava-se uma espécie de lugarcomum nos relatos de viagem, passando a significar tudo que seria “'original', 'autêntico', visualmente atrativo, e freqüentemente carregado de associações sentimentais, de cunho nacionalista ou regionalista”862. Tal caráter emotivo, interessado na reposição do local e do tradicional, parece orientar o trabalho de Rebelo, que, posteriormente, ao reunir parte dos textos de Cultura Política, em livro, pretendia chamá-lo de Viagem sentimental a Minas Gerais.

Ao mesmo tempo, a atitude do cronista viajante de dirigir-se ao interior do país assemelhavase a dos exploradores do passado. No entanto, se, antes, a captura da paisagem local obedecia às coordenadas científicas da pintura paisagística novecentista (que pretendia abarcar a totalidade do panorama retratado, guiando-se pelas exigências do homem total da época

\footnotetext{
${ }^{860}$ Idem, p.209.

${ }^{861}$ Como a "beleza” e o "sublime”, o "pitoresco" constituía-se num dos conceitos mais importantes da estética do século XVIII. Destaque para as postulações teóricas de Willian Gilpin que procurava estabelecer diferenças entre o "belo" e o "belo pitoresco". Enquanto primeiro seria norteado por atributos clássicos como regularidade, uniformidade, polidez das superfícies e precisão dos contornos, o segundo englobaria "a variedade, o inusitado, o inesperado, a dissimetria, a ruptura das formas pelo jogo de luz e sombra”, privilegiando a união, num conjunto, de uma diversidade de "objetos rudes" (FONSECA, Cláudia Damasceno. Irregularidades ou pitorescas? Olhares sobre as paisagens urbanas mineiras. In: FURTADO, Júnia Ferreira (org.). Sons, formas, cores e movimentos na modernidade atlântica. São Paulo: Annablume; Belo Horizonte: Fapemig e PPGH-UFMG, 2008, p.314).

${ }^{862}$ Idem, p.312.
} 
iluminista ${ }^{863}$ ), agora, com Rebelo, predomina a idéia moderna de instantâneo, de flash, em correspondência ao estilo fragmentário de discurso por ele adotado. A partir do segundo número de Cultura Política e durante alguns meses seguintes ${ }^{864}$, os “Quadros e costumes do Centro e do Sul”, passam a ser ilustrados por fotos legendadas e por cartões postais, que procuravam particularizar elementos e pontos de vista diferenciados de um mesmo espaço visitado. Em tal volume, o texto de Rebelo é acompanhado de imagens do porto de Januária (no momento de cheia do São Francisco), da frontaria da igreja matriz da cidade e do plano geral do jardim de uma das praças públicas do lugar. Em geral, as representações corroboram a visualidade pretendida pelo texto, reforçam o estatuto de real reivindicado por este, bem como exprimem um olhar oficial atento tanto ao pitoresco local quanto ao "sopro renovador" estadonovista, que, supostamente, espraiava-se pelo hinterland brasileiro.

Mas Rebelo não tematizara somente os usos e costumes do interior do país. Em três oportunidades, seu foco de atenção deslocou-se da província para a capital federal. Trata-se das colaborações estampadas nos números 5, 9 e 17 de Cultura Política. De maneira geral, tal deslocamento espaço-temático repercutira na própria configuração dos textos. Por mais que o artista continue a privilegiar a ficcionalização do presente, com foco na cotidianidade, os relatos sobre o universo carioca estariam mais próximos não da crônica, mas do conto. Neles, diferentemente, dos retratos sobre a vida provinciana, há ênfase maior na construção de cenários, personagens e situações, com foco específico numa única célula dramática. O autor continua a se valer da técnica de justaposição de fragmentos, mas, ao invés de comporem a imagem cubista de um lugar desconhecido, recém visitado, os estilhaços são usados para retratar os diferentes aspectos da rotina diária e a vida íntima de famílias fluminense de classe média baixa. Ao mesmo tempo, o impressionismo do narrador protagonista em primeira pessoa cede espaço para o ponto de vista objetivo de um narrador onisciente em terceira pessoa, que não só sumariza o que vê como abre maior espaço para a dialogação. Nesse processo, ao adotar como momento de referência o "agora”, Rebelo cria a ilusão de que escreveria à medida que presenciava as cenas mimetizadas em seus escritos, sem deixar de operar também pequenos recuos e projeções.

\footnotetext{
${ }^{863}$ Tal concepção científica da paisagem tinha como principal referência o pensamento do estudioso alemão Alexander von Humbolt, que influenciara boa parte dos viajantes estrangeiros vindos para o país. Para ele, observador deveria ser capaz de “abraçar a natureza em um só olhar”, sem recortá-la ou fragmentá-la, na medida em que a experimentava e a sentia (BELLUZZO, Ana Maria de Moraes. O Brasil dos viajantes. São Paulo: Metalivros; Rio de Janeiro: Fundação Odebrecht, vol.2 Um lugar no universo, 1994, p.24).

${ }^{864}$ Mais especificamente, as colaborações do artista presentes nos números três (maio 1941), quatro (jun. 1941) e seis (ago. 1941) de Cultura Política, também contavam com imagens fotográficas dos espaços por ele visitados.
} 
Duas das fotos (e suas respectivas legendas) que acompanhavam o segundo dos "Quadros e costumes do Centro e do Sul” (Cultura Política, ano 1, n.2, abr. 1941), de Marques Rebelo.
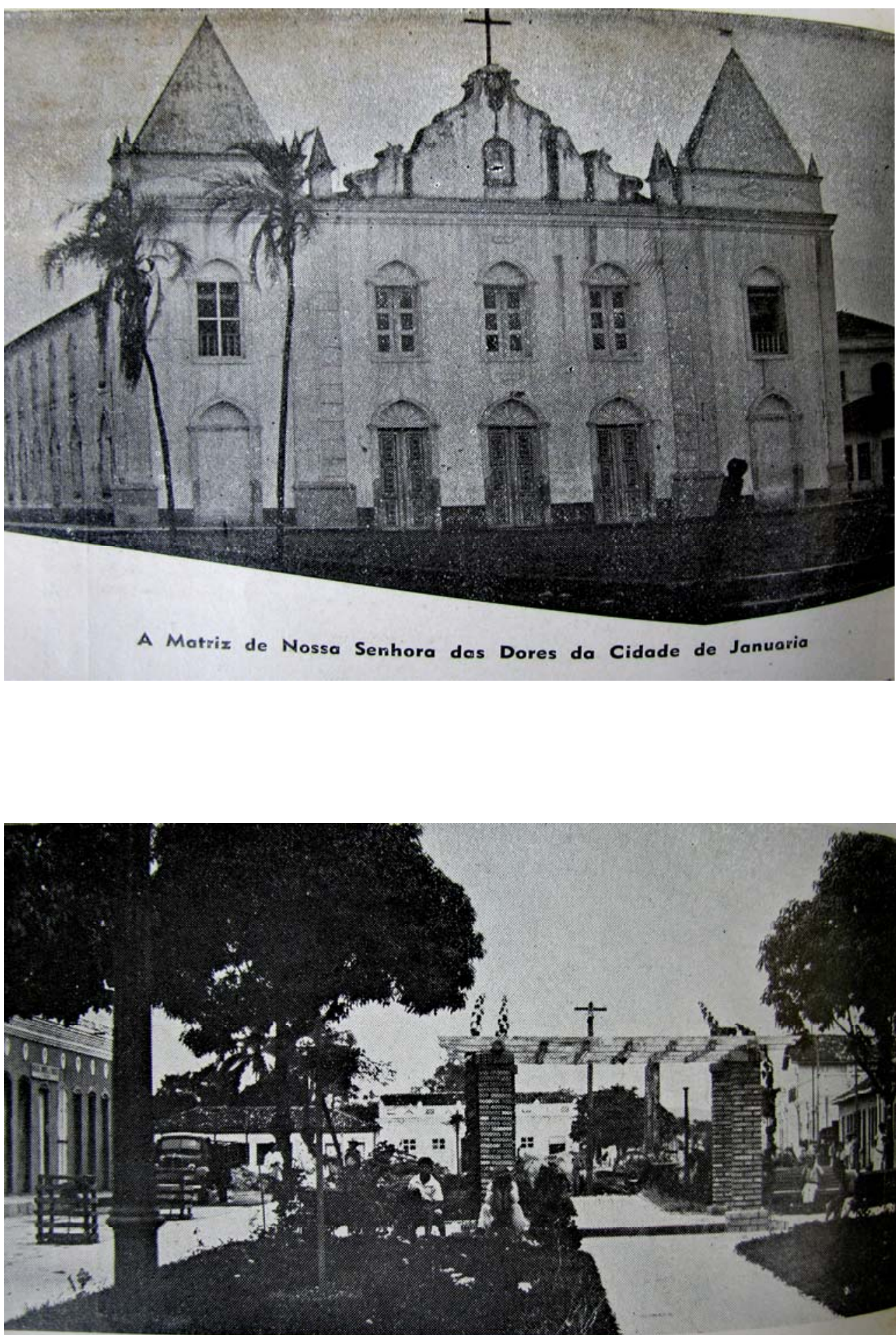

Aspecto do Jardim da Praça Governador Valadares da Cidade de Januario 
Apesar da maior proximidade do registro ficcional do conto, tais textos são constituídos por meio de certo registro realista que procura infundir-lhes o efeito de ilusão referencial, com destaque para a localização objetiva da trama e para ênfase na catalogação de minudências das famílias pequeno-burguesas retratadas. Como aponta Mário de Andrade, tal perspectiva já estaria presente desde o primeiro livro de contos de Rebelo, Oscarina, que se afastaria da "literatura” e se aproximaria da "prosa fala”, com o único fito de "contar a vida tal como ela é»865. Em atitude semelhante, a revista, mediante o paratexto introdutório ao "Quadros e costumes do Centro e do Sul IX”, faz questão de ressaltar o caráter documental da colaboração do autor:

Dá-nos o autor mais um texto desta série. Hoje, focaliza ele a vida cotidiana de uma família burguesa no Rio de Janeiro. É uma descrição simples e realista, sem artifícios, mostrando ao leitor o que é a vida doméstica hoje na Capital da República ${ }^{866}$.

Por mais que o autor, ainda em chave provinciana ${ }^{867}$, não reflita a febre de crescimento da capital federal, sob os auspícios do Estado Novo, ao tematizar a felicidade da vida familiar durante o regime, ele acaba por exaltá-lo por meios indiretos. Na crônica supracitada, depois de abordar o transcorrer de um dia da vida de uma família formada por um funcionário público, uma dona de casa zelosa e dois filhos sapecas, o artista termina o texto da seguinte maneira:

Às dez horas, depois de um copo de leite com biscoito de fubá, cuja receita é do tempo da vovó, recolhe-se ao leito a família feliz, para, no outro dia, com a graça de Deus, recomeçar a vida, com a mesma boa vontade de viver ${ }^{868}$.

Tal exaltação da rotina levada pelos integrantes do núcleo familiar, a repetir-se, contínua e alegremente, todos os dias, dá ensejo à promoção de certo "brazilian way of life”, promovido pelo novo regime. Enquanto o pai trabalhava, a mãe administrava a casa, os filhos estudavam e o país prosperava. Como se sabe para a retórica estadonovista, a família constituía-se na

\footnotetext{
${ }^{865}$ ANDRADE, Mário. Oscarina. In: Táxi e crônicas no Diário Nacional. São Paulo: Duas Cidades; Secretaria de Cultura Ciência e Tecnologia, 1976, p.375.

${ }^{866}$ DÁ-NOS o autor. Cultura Política, Rio de Janeiro, ano 1, n.9, nov. 1941, p.371

${ }^{867}$ Gomes destaca que a literatura" urbana” de Rebelo seria antes "provinciana”, pois espelharia "a cidade naqueles aspectos ainda não homogeneizados pelo progresso que vinha mudando a fisionomia do Rio, a partir da Revolução de 1930” (GOMES, Renato Cordeiro. op.cit, p.133).

${ }^{868}$ REBELO, Marques. Quadros e costumes do Centro e do Sul IX. Cultura Política, Rio de Janeiro, ano 1, n.9, nov. 1941, p.373.
} 
base moral e material do homem brasileiro, além de uma célula política primária, e, portanto, merecia todo amparo e a atenção do governo. "É pela família que o Estado chega ao homem e à pátria, é a família que humaniza e nacionaliza o Estado, porque é ela a realidade primeira, viva, permanente e atual, que concentra os interesses básicos, primitivos, universais, dos

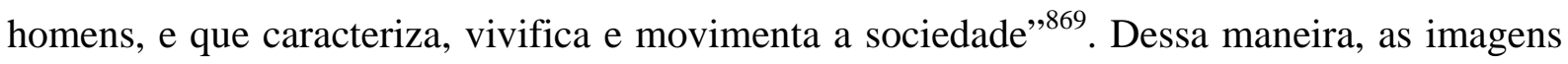
em torno da vida carioca, produzidas pelo artista, atingiam em cheio um dos alvos preferenciais da ideologia oficial, colaborando pra sua legitimação.

\subsubsection{O comprometimento com a ideologia estatal}

Se nos textos centrados na vida carioca, vistos acima, transparece a exaltação indireta do regime de 1937, nos quadros dedicados ao interior brasileiro, examinados logo a seguir, o louvor ao Estado Novo ganha contornos mais explícitos. Nesse sentido, além de diferenças quanto ao gênero, ao estilo e à estruturação do texto, tal caráter de panegírico da ditadura varguista, assumido, muitas vezes, pelos “Quadros e costumes do Centro e do Sul” de Rebelo, opõe-se diretamente à estratégia de colaborar sem se comprometer abertamente, adotada por Graciliano em seus "Quadros e costumes do Nordeste",870.

Em sua primeira participação em Cultura Política, Rebelo dedica todo um longo bloco textual à fábrica de armamento construída pelo Exército Nacional em Itajubá ${ }^{871}$, cidade tema de seu relato:
A tarefa que o Exército Nacional se propôs e vem realizando em prol da nossa civilização, é a mais categórica afirmação do verdadeiro valor patriotismo do soldado brasileiro. Protegendo os silvícolas, abrindo estradas, rompendo sertões, explorando rios, levantando mapas, pacificando regiões, cortando o Brasil em todas as direções com o seu Correio Aéreo e deste modo aproximando interesses, facilitando as comunicações e favorecendo o comércio, desanalfabetizando, incutindo o civismo, nacionalizando as populações, eis os principais marcos dessa obra gigantesca que caminha dia-a-dia dentro de uma reserva e anonimato que a fazem ainda maior e mais digna.

\footnotetext{
${ }^{869}$ FIGUEIREDO, Paulo Augusto de. O Estado Nacional e a valorização do homem brasileiro. Cultura Política, Rio de Janeiro, ano 3, n.28, jun. 1943, p.48

${ }^{870}$ Em geral, a maior adequação das colaborações do autor de Oscarina à revista, se comparada a do romancista de Vidas Secas, poderia ser medida pela própria extensão ocupada por seus respectivos textos. Quase sempre os quadros compostos pelo primeiro, além de serem ilustrados por imagens (fotos e pinturas), conforme visto antes, ocupavam o dobro (ou até mais) das páginas destinadas às narrativas do segundo, sobretudo nos números iniciais do periódico getulista.

871 Juntamente com o Arsenal de Guerra do Rio de Janeiro, a fábrica de Itajubá constituía-se num dos principais pólos de produção de material bélico, sob o comando do Exército brasileiro. (SAMPAIO, Murilo V. O novo exército do Brasil. Cultura Política, Rio de Janeiro, ano 3, n.28, jun. 1943, p.114).
} 
A Fábrica de Itajubá, situada em privilegiada posição para os fins a que se destina, está entre as mais recentes realizações de nossa grande força. Prédios imponentes, instalações técnicas das mais modernas e eficientes, laboratórios de controle perfeitíssimos, eis o que é o grande parque da indústria bélica do sul de Minas, que há cinco anos vem se desenvolvendo normalmente, bafejado pelo patriotismo do Presidente Vargas, que tem sido o animador das reformas porque estão passando o Exército e a Marinha.

Mas o que mais impressiona no parque industrial de Itajubá é a sua organização de trabalho. O operário é cercado de todas as garantias a que tem direito. Pavilhões de trabalho com todos os requisitos higienofabris, sejam, largueza, altura, luz, aparelhos de ventilação, sugadores automáticos de poeira nociva, etc. Refeitórios modelares, onde é servida por preço modicíssimo uma alimentação sadia e limpa, cardápio que poderia servir mesmo de base aos regime alimentares-fabris em nossa terra. Assistência médica, dentária e farmacêutica, com aparelhagem completa, inclusive um pequeno hospital de emergência. Armazéns gerais onde os operários encontram todos os gêneros e objetos de primeira necessidade por um preço que está livre dos juros gananciosos. Campo de esportes completo. Igreja para assistência aos religiosos. Escola para os filhos dos operários e para eles próprios. Banda de música, grupo orfeônico, creche. Uma revista mensal que liga todos os da fábrica, dirigentes e subalternos, num mesmo esforço de cultura. Uma vila operária, pequenas casas com o máximo de conforto a preço razoável, e uma das quais, todos os anos, pelo Natal, é sorteadas entre os funcionários, ficando o vitorioso morando nela independentemente de aluguel. Cercando assim os operários de todos os recursos de assistência, faz dele um homem feliz que sabe que encontra um prêmio para a sua atividade. Mas o prodígio dessa máquina só anda perfeitamente sobre seus trilhos porque acima de tudo impera uma disciplina justa, mas rígida. E o operário obedece porque sabe que está cumprindo um dever e porque é com esta obediência que ele paga os favores que recebe, as tranqüilidades e os confortos que lhe dão. A Fábrica de Itajubá poderia ter na sua entrada as palavras do Presidente Getúlio Vargas: “Esta fábrica é uma lição e um exemplo”. E não haveria legenda mais bela e justa ${ }^{872}$.

Em meio à aparente dispersão de flashes do cotidiano, recolhidos pelo narrador transeunte em suas andanças pela cidade mineira, avulta o apólogo às Forças Armadas nacionais. Metonimicamente, o louvor à fábrica do Exército (de prédios imponentes, instalações técnicas das mais modernas e eficientes, laboratórios de controle perfeitíssimos) funcionava como encômio a "nossa grande força", cujo motor encontrava-se no patriotismo do Presidente Vargas. De maneira semelhante, por meio do relato detido de todos "recursos de assistência", que tornavam os operários da referida indústria bélica em homens felizes e dispostos a obedecer (pois, a sujeição à disciplina seria uma forma de retribuir os favores, tranqüilidade e

\footnotetext{
${ }^{872}$ REBELO, Marques. Quadros e costumes do Centro e do Sul I. Cultura Política, Rio de Janeiro, ano 1, n.1, mar. 1941, p.233-234.
} 
confortos recebidos do governo), o cronista exaltava a política trabalhista e assistencialista do Estado Novo. Subentende-se que o novo regime teria se encarregado de acabar com os antagonismos sociais ao construir um ambiente de suposta paz e harmonia, favorável ao incremento da ordem e do trabalho ${ }^{873}$. Tal exemplaridade conferida por Rebelo ao microcosmo itajubense orientava-se pela "beleza” e "justeza” da própria fala presidencial: "Esta fábrica é uma lição e um exemplo”, o que ampliava os efeitos de propaganda colocados em cena.

O ajuste entre o texto de Rebelo e as diretrizes estadonovistas ficava explícito no paratexto que introduzia a crônica do artista:

\begin{abstract}
Na sua crônica inaugural, descreve o autor a paisagem e a vida de uma das cidades mais expressivas do interior do Brasil Central - Itajubá (Minas Gerais). É um pequeno pedaço do Brasil que encontramos nestas páginas. Do Brasil perdido na imensidade de si mesmo, seguindo o ritmo lento de sua história social. E é curioso ver-se, pelas palavras do autor, à certa altura de sua descrição, como a pequena cidade se sentiu, de uma hora para outra agitada pelo sopro renovador de um Brasil que ressurgia para os novos destinos, com a vitória revolucionária de 1930. Moderniza-se Itajubá, civiliza-se com a construção de prédios novos, laboratórios, obras de perfeição técnica, erguidas ali pela energia construtora do Governo. Um sopro de vida mais sadia percorre o interior brasileiro. Mas o Brasil é grande, imensamente grande: a rotina continua a espreguiçar-se com lentidão secular, porque os governos não operam milagres e a vida social brasileira tem que seguir a sua marcha natural. Se a nossa evolução política segue ritmo veloz de decênios, a nossa evolução social terá que seguir, inevitavelmente, um ritmo paciente de séculos. Porque os povos não improvisam os seus sistemas de vida: arrancam-nos de dentro de si mesmos. E se hoje vamos readquirindo a "posse de nós mesmos", há que esperar muito deste influxo vitalizador; mas há que esperar com paciência, confiando tanto na obra do tempo como na dos homens ${ }^{874}$.
\end{abstract}

Diferentemente do caso de Graciliano, quando os paratextos procuravam domar e orientar possíveis dissonâncias, virtualizadas pelas narrativas, aqui os editores retomam trechos da própria crônica de Rebelo (“E é curioso ver-se pelas palavras do autor”), reforçando abordagens colocadas em cena pelo autor carioca. Se, por um lado, ele ressaltava as

\footnotetext{
${ }^{873}$ Pelas diretrizes oficiais, o trabalho passava a ser visto como "um direito e um dever do homem; uma tarefa moral e ao mesmo tempo um ato de realização; uma obrigação para com a sociedade e o Estado, mas também uma necessidade para o próprio indivíduo encarado como cidadão" (GOMES, Ângela de Castro. A construção do homem novo. In: LIPPI, Lúcia de Oliveira et al. Estado Novo ideologia e poder. Rio de Janeiro: Zahar Editores, 1982, p.153).

${ }^{874}$ CONHECER O BRASIL. Quadros e costumes do Centro e do Sul I. Cultura Política, Rio de Janeiro, ano 1, n.1, mar. 1941, p.232.
} 
particularidades locais, em consonância com a noção de redescoberta do país, que, enfim, “tomava posse de si mesmo", por outro, não deixava de exaltar o influxo vitalizador do regime. Nesse sentido, a fábrica ao mesmo tempo em que atendia a uma demanda do presente, não deixava de prenunciar o término “das hesitações de ontem” e o fato de “já havermos traçado um rumo definido para as nossas caminhadas do porvir”, como indicava Almir de Andrade no editorial de abertura da revista ${ }^{875}$. Orientando-se, sobretudo, pelo lirismo (e deixando de lado o denuncismo crítico ${ }^{876}$ ), o cronista revelava uma espécie de consonância entre novo e antigo. O primeiro, longe de acabar com as tradições encerradas no segundo, promoveria a conciliação entre moderno e tradicional.

Outro procedimento comum ao longo das crônicas de Rebelo era recuperação do passado político (referente à Primeira República) das localidades visitadas como forma de ressaltar, por oposição, o presente estadonovista, tematizado por sua pena. Veja os trechos seguintes, retirados, respectivamente, dos números dois, quatro e sete de Cultura Política:

\begin{abstract}
O lampião de querosene belga reforça a luz elétrica cuja fraqueza tem a sua história. E a história é simples: nos tempos da velha política lembrou-se de se dotar a cidade de energia elétrica. Fez-se o negócio: o negócio foi de molde que a cidade pagasse quatrocentos contos por uma usina que não valia cem. Como a cidade não tinha quatrocentos contos está pagando e ainda pagará juros por muitos anos. E a represa foi feita num riacho tão sem importância que nos seis meses de seca não tem água suficiente para dar à cidade senão uma humílima luz, e somente das 7 às 11 da noite. No entanto, pela quantia que a cidade pagou por essa negociata da velha política - ó coronéis - poder-se-ia buscar na Cachoeira dos Pandeiros, que fica bem perto, uma força capaz de resolver para os cinqüenta anos mais próximos o problema de energia da cidade, que atualmente não pode abrir nenhuma espécie de fábrica movida à eletricidade, porque a usina não comporta. É certo que o atual prefeito, dr. Roberto Monteiro da Fonseca, compreende muito bem que impulso teria Januária se tivesse verdadeiramente uma usina elétrica. E está quebrando lanças; como é moço e corajoso, acabará vencendo. E Januária terá a sua indústria movida a eletricidade, terá a iluminação das ruas independentemente do luar, e o Bileza não precisará reforçar a luz da sala de jantar com um lampião de querosene belga ${ }^{877}$.
\end{abstract}

\footnotetext{
${ }^{875}$ ANDRADE, Almir. A evolução política e social do Brasil. Cultura Política, Rio de Janeiro, ano 1, n.1, mar. 1941, p.8.

${ }^{876}$ Ao se referir, sobretudo, às suítes cariocas de Rebelo, escritas mais tarde, Gomes destaca que o artista adotara perspectiva diversa ao abordar a relação entre as novidades modernas e o passado tradicional: seja pelo sentimentalismo, seja pela ironia, denunciava a marcha do progresso que descaracterizava a fisionomia urbana do Rio de Janeiro, trilhando os passos de Lima Barreto na crítica à modernização excludente e homogenizadora da então capital do país (GOMES, Renato Cordeiro. op.cit. p.118).

${ }^{877}$ REBELO, Marques. Quadros e costumes do Centro e do Sul II. Cultura Política, Rio de Janeiro, ano 1, n.2, abr. 1941, p.244.
} 
O prefeito, que é gaúcho, tem fama como homem duro. Catalão também era terra dura. Se em cada lugar de certa rua que me mostram se plantasse uma cruz pela alma de cada homem caído morto em lutas políticas municipais não passaria nela nem uma bicicleta. Esta história de assaltar cadeias e tirar os presos era proeza de todos os dias. O júri era uma farsa. As autoridades desrespeitáveis. Podia-se matar à vontade. Quando os coronéis não conseguiam dar coito havia o mato que era o mais benevolente dos coronéis. O fugitivo se afundava no mato onde não há estradas, veredas apenas, ficava lá seguro. Se a batida atrás era muito forte ele atravessava o Rio Verde caía em Minas e nunca mais se sabia dele. O gaúcho tinha trabalho. Viera com a revolução, lutava dia e noite. Foi o Estado Novo que tirou de Catalão esses tristes costumes, que deu oportunidade ao prefeito de guardar o seu tempo e a sua energia para obras mais dignas. A cidade prospera. Já tem o seu campo de esporte, suas ruas calçadas, esboço de jardins novos, construções novas, um ar de limpeza. Vive tranqüila agora ${ }^{878}$.

Infelizmente uma cruel luta municipal que durou alguns anos e da qual alguns acontecimentos sangrentos tiveram eco em todo o Brasil, vieram perturbar a vida da cidade. Mas em novembro de 1937, com o advento do Estado Novo, Montes Claros entrou novamente a desenvolver-se aceleradamente e tudo faz crer que em pouco tempo sejas uma das mais prósperas cidades mineiras. Faz crer, não - será.

(...) Doutor Santos , que na vida civil é Antônio Teixeira de Carvalho, tem como encerrada a sua vida clínica e política e diz que só se dedica ao truco, que é jogo de tropeiro. Mas como o truco é de noite no clube novo, de arquitetura moderna e sóbria - durante o dia, ele, como prefeito, vai matando o tempo construindo o estádio municipal, aumentando a receita, fazendo jardins, dando em abundância a água que faltava (e a sobra foi levada em regos aos secos bairros pobres, que já se vestem do verde feliz das plantas), construindo a rede de esgotos, calçando a cidade, padronizando as construções, dando um novo cemitério para os mortos, pondo coisas velhas abaixo, levantando coisas novas, auxiliando a imprensa e o ensino secundário, multiplicando as escolas rurais, construindo a monumental represa de Santa Marta que iluminará realmente a cidade e permitirá a existência de um grande parque industrial, abrindo estradas, consertando estradas e mil outras práticas divertidas ${ }^{879}$.

Em todos os textos, há uma clara oposição entre os tempos da "velha política”, marcados pelo individualismo dos dirigentes, pelas disputas sangrentas em torno do poder, pelo desrespeito às autoridades constituídas, e o momento de enunciação estadonovista, o "agora” do qual fala

\footnotetext{
${ }^{878}$ REBELO, Marques. Quadros e costumes do Centro e do Sul IV. Cultura Política, Rio de Janeiro, ano 1, n.4, jun. 1941, p.219-220.

${ }^{879}$ REBELO, Marques. Quadros e costumes do Centro e do Sul VII. Cultura Política, Rio de Janeiro, ano 1, n.7, set. 1941, p.266-267.
} 
o cronista. Neste, ganharia destaque a atuação de uma nova classe de administradores locais, empenhados no progresso de suas cidades. Rasgando o panegírico, Rebelo louva a atuação enérgica e as obras realizadas por tais sujeitos nos diversos campos de atividade (da construção de hidrelétricas a inauguração de novos espaços de lazer). A suposta mudança de rumos por eles operada na gestão pública, bem como o trabalho efetuado em prol do avanço de suas respectivas coletividades seriam, na opinião do escritor, indícios, ou melhor, “certezas”, de que os municípios interioranos teriam um futuro próspero, muito diferente da estagnação e do descalabro dominantes no período anterior à chegada de Getúlio ao governo.

A adesão de Rebelo aos postulados estadonovista mostrou-se tão clara que, passada a euforia do regime, ao editar suas crônicas sobre o hinterland brasileiro em livro, em $1944^{880}$, e ao reeditá-las, em $1951^{881}$, e no início dos anos de $1970^{882}$, o autor fez alterações ou simplesmente descartou os trechos nos quais avultavam os encômios dirigidos ao Estado Novo, transcritos acima ${ }^{883}$. De maneira geral, tais alterações levam em conta a especificidade de fruição do suporte livresco. Nesse novo espaço de leitura, os panegíricos circunstanciais, ajustados ao teor propagandístico da revista getulista, perturbavam a coesão do texto e, por conseguinte, reduziam o valor intrínseco do mesmo. Nesse sentido, o longo trecho sobre a fábrica do Exército em Itajubá fora totalmente suprimido em ambas as edições em livro. Os excertos sobre a usina hidrelétrica de Januária e sobre o passado sangrento de Catalão, préditadura varguista, sofreram alterações que ou amenizavam ou rebaixavam o tom elevado com que era referido o governo de Getúlio. A última passagem sobre o progresso de Montes Claros, posterior a novembro de 1937, fora modificada na edição de 1944 (mediante a

\footnotetext{
${ }^{880}$ REBELO, Marques. Suíte n.1. Rio de Janeiro: Irmãos Pongetti, 1944, 148p.

${ }^{881}$ REBELO, Marques. Cenas da vida brasileira (suítes 1 e 2). Rio de Janeiro: Ed. O Cruzeiro, 1951, 154p. Nesta segunda edição, sem se restringir ao Estado de Minas Gerais, o cronista acrescenta uma segunda suíte, que contava com textos sobre as seguintes cidades: Barbacena (conteúdo presente em Cultura Política, mas deixado de fora da primeira edição), Resende, Miguel Pereira, Burnier, Tebas de Leopoldina, Vitória, Entre-Rios, Pinheiral, Antônio Carlos, Recreio, Ouro Preto, Curvelo, São Manuel, Miraí, Cataguazes, Leopoldina, Valença, Providência, Porto Novo, Teresópolis, Monte Belo, Correias, Itaipava, Aparecida, Formiga, Belo Horizonte, Rio, Araruama, São Paulo, Campo Grande, Cuiabá, Cáceres, Forte Príncipe da Beira, Guajará-Mirim, Porto Velho, Rio Branco, Manaus, Itacotiara, Santarém, Belém, Salvador, Recife e Florianópolis.

${ }^{882}$ REBELO, Marques. Cenas da vida brasileira. Rio de Janeiro: Edições de Ouro, [1972?]. Livro possivelmente publicado, pouco antes da morte do autor que ocorrera em 26 de agosto de 1973.

${ }^{883} \mathrm{Em}$ 1942, Rebelo já havia publicado dois de seus "Quadros e costumes do Centro e do Sul” no livro de contos Stela me abriu a porta (Porto Alegre: Livraria do Globo), sob o título de "Cenas da vida carioca”. Porém nesse caso, não efetuou alterações, mantendo os textos tal qual foram publicados na revista getulista. Detalhe, quando do lançamento de tal obra, Wilson Louzada emitiu juízos críticos sobre a mesma nas páginas de Cultura Política. Segundo ele, "Stela me abriu a porta, tão rico em sugestões, não é o melhor que seu autor produziu. Também não é o pior, o que aparentemente encerra a idéia de mediocridade. Entretanto nada mais falso e mais longe da verdade, pois, com certeza, esses contos de Rebelo estão situados no extremo de sua evolução técnica no gênero em que se tornou um autêntico virtuose" (LOUZADA, Wilson. O escritor e o assunto. Cultura Política, Rio de Janeiro, ano 3, n.25, mar. 1943, p.141).
} 
inclusão de críticas que relativizavam o crescimento do município, antes dado como certo), para depois ser suprimida na reedição dos anos de $1970^{884}$.

Como referido, as edições em livro das crônicas de Rebelo, editadas em Cultura Política, foram feitas respectivamente no momento de queda iminente do Estado Novo, em 1944, e, sete anos depois, durante o período democrático, com Getúlio novamente a frente do país, e durante a ditadura de 1964. Tratava-se de um novo contexto político, em que o artista carioca procurava ressignificar o compromisso com a ditadura de 1937. Tal processo se consolidaria em $O$ trapicheiro (1959), primeiro volume da autobiografia $O$ espelho partido, no qual o escritor, entre outras lembranças, faz referência a sua passagem pelas páginas da revista getulista, encobrindo com pseudônimos os nomes dos atores sociais envolvidos na trama. Tome-se o trecho:

23 de julho

Operoso Lauro Lago. Eis-me convidado para colaborar na Cultura Política.

- Conto com você, não conto? - telefonou-me, trabalho a que jamais antes se dera, explicando-me que os convites eram selecionados, porém ecléticos, (cultura é cultura!) truque sediço, mas frutífero arregimenta os adversários e debilita os adversários.

Pensei em recusar, mas encabulei - Lauro Lago sempre me dispensou tal deferência, mostrou-se comigo sempre tão afável e cordial, quando sabia-o tão rústico, que não atinei como fazê-lo. Positivamente é uma das nossas fraquezas sentimentais a precariedade de convicções ante as investidas dos nossos amigos ou amistosos conhecidos. E a mais uma leve insistência, manhosamente na qual enumerou Venâncio Neves, Ribamar Lasotti e Gustavo Orlando como nomes já integrando o corpo de colaboradores, cedi imaginando a decepção de Gasparini, a mofa de José Nicácio:

- Sim, pode contar comigo.

- Então para o primeiro número! Daqui a um mês está na rua.

- Farei o possível.

\footnotetext{
${ }^{884}$ O cotejo detalhado entre as versões dos textos de Rabelo saídos e Cultura Política e depois publicados em livro, em 1944, fora realizado por Raul Antelo (ANTELO, Raul. op.cit. p.97-105) No entanto, está ainda por se fazer a comparação entre esta primeira edição das crônicas, realizada pelos Irmãos Pongetti, e a segunda, de 1951, sob a responsabilidade da editora O Cruzeiro, na qual o escritor tornou a fazer alterações.
} 
- Olhe você podia fazer uma seção permanente. Seria mais interessante. Não tenho idéia agora qual poderia ser. Pense e me diga. Confio em você.

- Está bem, vou pensar.

Os escrúpulos, porém, vieram e fico dando tratos à bola - papagaio! Como poderei comparecer ao jornal estadonovista sem falar muito ou sem falar nada do Estado Novo.

24 de julho

Procurei Pedro Morais, mas estava enfermo, retirara-se para o sítio de um parente em Itaipava. Explano as minhas inquietações a Saulo, que me anima:

- Ganhe o seu dinheiro! Você precisa e eles pagam bem. Também fui convidado. Não como colaborador permanente. E também não me neguei. E não só eu aceitei. Quase todos que foram solicitados. O ínclito democrata Gustavo Orlando foi dos primeiros.

- Lauro Lago me disse.

- Pois é. Dos primeiros. Vai escrever umas vinhetas da vida nordestina. Sabe duma coisa? Por que você não faz também umas cenas da vida sulista? Ficaria engraçado.

A idéia caiu em terra necessitada ${ }^{885}$.

$1^{\circ}$ de outubro Lauro Lago errou nos cálculos. Somente há uma semana saiu o primeiro número de Cultura Política. Tirante a parte doutrinária e demagógica, é uma bela revista, com bonito formato, um formato sério, que lembra as melhores estrangeiras. A síntese de nosso panorama literário feita por Martins Procópio tem um mérito - não esquece ninguém, lembra-se até dos mais desconhecidos ou esquecidos fantasmas, e só Arnaldo Tabaiá ficou no olvido. E Gustavo Orlando tem páginas surpreendentes - o que escreveu sobre os comedores de barro é precioso, comovente, antológico,

${ }^{885}$ REBELO, Marques. O Trapicheiro. São Paulo: Livraria Martins Editora, 1959, p.412-413. Nesta obra híbrida, como se sabe, Rebelo procurou romancear diferentes aspectos de sua vida familiar, afetiva, amorosa e profissional por meio da apresentação de uma série de flagrantes aparentemente desconexos, mas cuja relação vai se revelando ao longo da leitura. Nesses fragmentos biográficos, organizados em forma de diário íntimo, são abordados os mais variados aspectos da vida brasileira da segunda metade dos anos 1930 ao início da década seguinte. No entanto, o autor localiza as ações apenas entre 1936 e 1938, quando, na verdade, elas não se restringiriam a essas balizas temporais. O relato da criação de Cultura Política e do convite recebido por Rebelo para colaborar com o periódico, por exemplo, situam-se em 1940, mas são apresentados como tendo acontecido em 1938. Tal procedimento, somado à utilização de nomes fictícios para se referir a algumas das personalidades mais conhecidas da literatura e da política da época, ao mesmo tempo em que prejudica o estatuto de documento da obra, amplia o efeito ficcional da mesma. 
Também eu concorro para o sucesso. Lauro me telefonou:

- O Presidente gostou imensamente...

Obrigado! ${ }^{886}$

Ao recuperar o passado estadonovista a partir de uma perspectiva crítica assumida em seu momento de enunciação, Rebelo desmascarava o "truque sediço" utilizado pelo DIP de utilizar a cultura como forma de arregimentar e debilitar os adversários. Ao mesmo tempo, toma sua participação na revista getulista como resultado de sua incapacidade de declinar o convite feito de maneira "afável” e "cordial” por Lauro Lago (Almir de Andrade). O fato de outros colaboradores de renome terem aceitado o convite também lhe serve de caução. Entre eles, destacava-se o “ínclito democrata” Gustavo Orlando (Graciliano Ramos). Apesar de tais justificativas, o artista não deixa de colocar em cena um autoquestionamento essencial: como colaboraria com o periódico de um governo autoritário sem se referir a ele? Seu dilema pessoal seria contornado pela qualidade da publicação, cujo conteúdo não se restringiria à doutrinação e ao louvor ao novo regime: ela apresentava partes notáveis como as linhas do escritor alagoano dedicadas à vida nordestina.

Como se vê, o panegírico expresso em suas crônicas dos anos 1940 é esquecido. Ao retomar ao passado, o autor passa a privilegiar o império de uma suposta consciência crítica, legitimadora de suas ações. Por mais que tivesse pleno conhecimento da ardilosa estratégia dos editores (de cooptação e emudecimento da crítica), justificava sua presença em Cultura Política em função da amizade com Almir de Andrade, do fato de outros colaboradores terem aceitado participar (inclusive Graciliano, ex-preso político que começaria a trabalhar para o mesmo governo que o enjaulara) e da qualidade da revista, cuja parte cultural suplantava a demagogia propagandística.

\subsection{Graciliano e a republicação dos quadros nordestinos}

Diferentemente de Rebelo, Graciliano não teve a oportunidade e, até mesmo, o interesse imediato em editar seus textos de Cultura Política em livro. Enquanto o autor de Oscarina,

${ }^{886}$ Idem, p.444. 
dois anos após o término de sua colaboração sistemática com a revista, já reunia suas crônicas no volume Suíte n.1, de 1944, o romancista de Infância teve seus "Quadros e costumes do Nordeste” editados apenas postumamente, por seus familiares, em 1962, no volume Viventes das Alagoas. Nesse sentido, enquanto ainda estava vivo, não teve a oportunidade ou mesmo a intenção de reelaborar os escritos que estampara no periódico getulista. Ao mesmo tempo, não construiu um discurso biográfico que reorientasse os elos profissionais que o ligaram à publicação. Após 1945, já filiado ao PCB, endereçou críticas ao Estado Novo (uma "ditadura dos diabos”), em discursos políticos sobre a necessidade de criação de uma Assembléia Nacional Constituinte ${ }^{887}$. Porém, o trabalho de legitimação de sua passagem pelo veículo do DIP fora realizado por terceiros, familiares e amigos, após sua morte ${ }^{888}$.

A falta de interesse do artista em editar em livro os "Quadros e costumes do Nordeste" pode ser atribuída à primazia por ele concedida aos gêneros romance, conto e memórias, aliada ao rebaixamento de trabalhos, escritos, exclusivamente, para o suporte jornalístico, sobretudo, as crônicas $^{889}$. Este seria o caso de seus textos de Cultura Política, que, apesar de guardarem certa distância do protocolo cronístico, foram compostos, em sua maioria, para a revista oficial, sem fazerem parte do projeto maior de um livro ${ }^{890}$. Nesse sentido, a seu ver, os mesmo

\footnotetext{
${ }^{887}$ Esta seria uma forma de se evitar a repetição, “com mais aparato e máscara de legitimidade”, do que ocorrera com o golpe de 1937, quando uma Constituição fascista fora imposta ao país (RAMOS, Graciliano. Exigimos uma Assembléia Constituinte. In: BOSI, Alfredo et. al. Graciliano Ramos. São Paulo: Ática, 1987, p.110).

${ }^{888}$ Além do depoimento de Eneida, relatado anteriormente, Ricardo Ramos e Paulo Mercadante, respectivamente em Graciliano Ramos: retrato fragmentado (1992) e Graciliano Ramos: o manifesto do trágico (1994) procuraram justificar a colaboração do escritor alagoano em Cultura Política, por meio da negação de qualquer tipo de adesismo e do realce de sua integridade artística. Mais especificamente, o filho de Graciliano ia além. Sentindo que a memória de seu pai fora agredida, ele procurava defendê-la de juízos críticos presentes nos textos já citados de Antelo e Facioli (sobretudo, deste último), que, entre outros aspectos, pretenderam examinar a relação entre o autor dos "Quadros e costumes do Nordeste" e o Estado Novo.

${ }^{889}$ Como atesta o levantamento das produções ficcionais de Graciliano saídas na imprensa, presente entre os anexos, grande parcela de Vidas Secas, Infância, Histórias de Alexandre, Insônia e uma pequena parte de Memórias do Cárcere foi estampada primeiramente em jornais e revistas. No entanto, diferentemente dos "Quadros e costumes do Nordeste”, tais colaborações faziam parte de projetos literários maiores, planejados pelo próprio autor para ganharem suporte livresco, que posteriormente as reuniriam. A publicação parcelada de trechos dos referidos volumes, na imprensa, apresentava-se ao escritor como um forma de lucrar com os livros da publicação definitiva dos mesmos. Rubem Braga, por exemplo, refere-se a Vidas Secas como um "romance desmontável”: "Cada capítulo desse pequeno livro dispõe de uma certa autonomia e é capaz de viver por si mesmo. Pode ser lido em separado. É um conto. Esses contos se juntam e formam um romance. Graciliano não fez assim por recreação literária. Fez por necessidade financeira. Ia escrevendo e vendendo o romance à prestação. Vendeu vários contos. Alguns capítulos ele fez de maneira a poder rachar no meio. Foi colocando aquilo a varejo em nosso pobre meio literário. Depois vendeu tudo por atacado, com o nome de romance" (RAMOS, Clara. Mestre Graciliano: confirmação humana de uma obra. Rio de Janeiro: Civilização Brasileira, p.126).

${ }^{890}$ Como referido no segundo capítulo, a proposta de publicação de Viventes das Alagoas, depois da morte do autor, partira de sua família, como expressa Ricardo Ramos em entrevista ao jornal carioca Flan, de 29 de outubro de 1953.
} 
atenderiam a uma demanda circunstancial, sem apresentar o mesmo estatuto de um Vidas Secas, por exemplo.

Em certo sentido, o fato de o próprio escritor não retomar, ressignificar ou justificar sua colaboração em Cultura Política, em moldes semelhantes aos de Rebelo, pode ser creditado, sobretudo, ao caráter ambivalente dos "Quadros e costumes do Nordeste”. Como vem sendo discutido até aqui, tais textos, ao enfocarem diferentes aspectos do interior do país e ao direcionarem seu tom problematizador ao passado, mantendo, porém, como virtualidade interpretativa, a idéia de continuidade histórica das mazelas retratadas, atenderiam tanto às diretrizes do ideário estadonovista como entreabririam uma perspectiva crítica de ruptura. Em outras palavras, essas narrativas apresentavam elementos que permitiam aos editores da revista direcionar-lhes a leitura no sentido de legitimação do Estado Novo, bem como deixavam vislumbrar a insolubilidade dos dilemas nacionais. No entanto, o enquadramento a elas conferido pelo veículo getulista abafava esta última possibilidade interpretativa, privilegiando apenas a primeira: os problemas pretéritos tematizados por Graciliano eram utilizados, tão somente, para rebaixar a Primeira República e, conseqüentemente, exaltar, por oposição, o regime de 1937. Apagava-se, portanto, o potencial de dúvida e dissonância dos escritos.

Assim, apesar dos textos de Graciliano ajustarem-se ao discurso oficial, traziam questionamentos latentes, mostrando que seu compromisso estaria além do partidarismo e, de certa maneira, independia da revista estadonovista, por mais que esta direcionasse o sentido daqueles. Prova disso pode ser encontrada no exame da republicação dos "Quadros e costumes do Nordeste” no periódico comunista Revista do Povo - Cultura e Orientação Popular, entre abril e julho de 1946. Em tal ocasião, ainda em vida, o artista alagoano teve a oportunidade de remodelar seus retratos sobre a vida nordestina, mas os manteve conforme foram veiculados inicialmente na revista getulista. Diferentemente de Rebelo, aparenta não ter o que esconder, tendo em vista, sobretudo, o caráter equívoco de suas colaborações, distante da assertividade dos panegíricos dirigidos ao Estado Novo pelo autor de Oscarina.

Bem verdade que enquanto Rebelo recuperou e reelaborou, em livro, boa parte de seus “Quadros e costumes do Centro e do Sul” getulistas, Graciliano republicou apenas três de seus retratos nordestinos na referida publicação do PCB. Trata-se dos seguintes escritos: “Quadros 
e Costumes do Nordeste - O Carnaval” (inclusive com o paratexto introdutório original) ${ }^{891}$, “Quadros e Costumes do Nordeste - O Casamento”892 e "Quadros e Costumes do Nordeste D. Maria”893. Ao titular os textos, o veículo comunista manteve a antiga designação da seção de Cultura Política, mas acrescentava-lhe um novo termo, que faria referência particular ao tema da narrativa, fosse ele um costume, uma prática ou uma personagem ${ }^{894}$.

De qualquer maneira, em virtude da aludida ambigüidade, os textos de Graciliano ganhariam outra conformação semântica e produziriam efeito diverso ao serem transplantados do órgão de direita para o órgão de esquerda. Nesse sentido, revela-se de suma importância recuperar, a nova moldura conferida a tais quadros nordestinos pela referida Revista do Povo - Cultura e Orientação Popular, na medida em que esta, diferentemente do caráter do propagandístico e legitimador de Cultura Política, privilegiava outras possibilidades de leitura e de direcionamento de sentido.

A Revista do Povo, inaugurada em dezembro de 1945, resultou do esforço do PCB em produzir um periódico informativo e ilustrado, de circulação ampla ${ }^{895}$. Editada por Álvaro Moreyra, O. Froés da Mota e Emo Duarte, o veículo foi pensado, a princípio, para ter periodicidade quinzenal, mas em função de dificuldades logísticas e financeiras oscilava entre uma publicação mensal e bimestral. Como visava atingir um público mais amplo, mesclava conteúdos político, cultural e variedades. Reuniu, em seu corpo de colaboradores, sobretudo, nomes vinculados ao Partidão, que ou se responsabilizavam pela parte informativa e noticiosa, como Brasil Gerson, Dalcídio Jurandir, Oswaldo Peralva e Joel Silveira, ou pela parte literária e artística, caso de Lia Correa Dutra, Orígenes Lessa, Jorge Medauar e Graciliano Ramos. Ao mesmo tempo, a revista abria espaço para autores de orientação liberal, simpáticos à esquerda, como Carlos Drummond de Andrade, dedicados, preferencialmente, à área cultural. Este último, além de um poema, publicou uma série de três textos, intitulada “Poesia social - definição”, em que discorria criticamente sobre tal conceito.

\footnotetext{
${ }^{891}$ Revista do povo: Cultura e Orientação Popular, ano 2, n.4, abr. 1946, p.3-4.

${ }^{892}$ Revista do povo: Cultura e Orientação Popular, ano 2, n.5, maio-jun.1946, p. 5 e 39.

${ }^{893}$ Revista do povo: Cultura e Orientação Popular, ano 2, n.6, jul.1946, p.3-4.

${ }^{894}$ Além dos referidos retratos sobre a vida nordestina, Graciliano também publicou no segundo número da revista (jan. 1946) o texto "Carta aos alagoanos", no qual se dirigia aos eleitores de seu estado natal na condição de candidato do PCB à Câmara Federal.

895 RUBIM, Antônio, Albino Canelas. Partido comunista, cultura e política cultural. 1986. 415f. Tese (Doutorado em Ciências Sociais), FFLCH, USP, São Paulo, 1986, p.49.
} 
Capas do primeiro e segundo números de a Revista do Povo - cultura e organização popular, publicados, respectivamente em dezembro de 1945 e janeiro de 1946
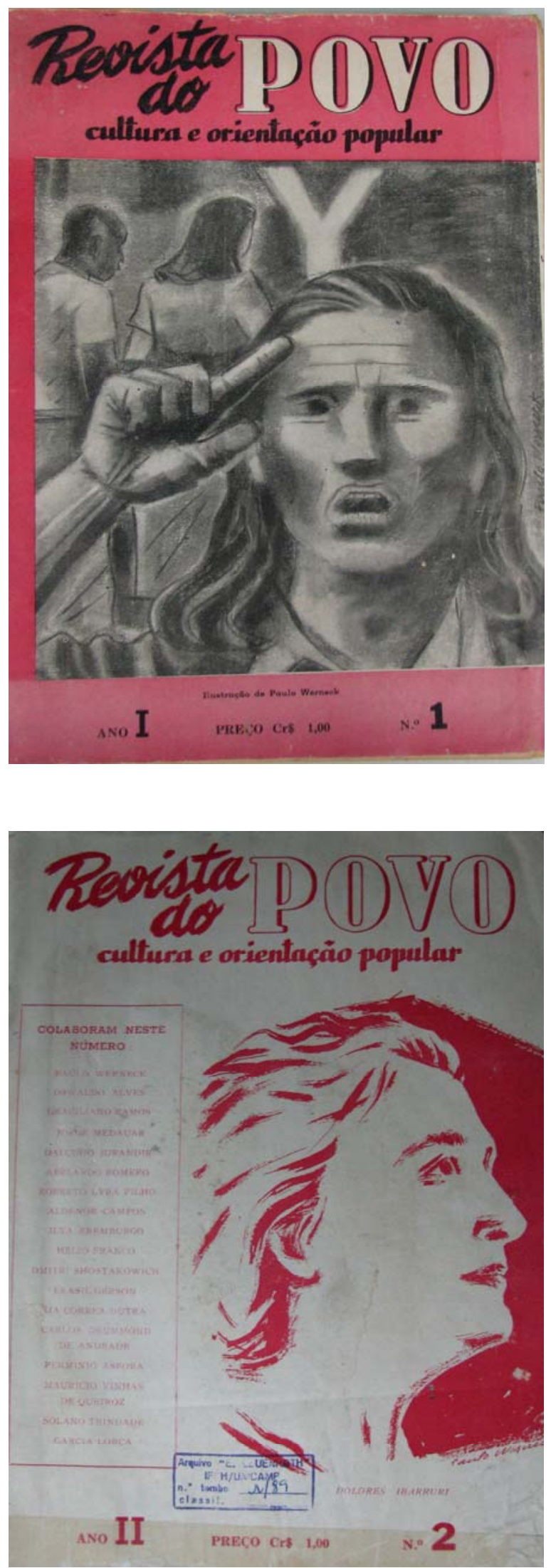
Imagens de "Quadros e costumes do Nordeste - O Casamento", (Revista do Povo - Cultura e Orientação Popular, Rio de Janeiro, ano 2, n.5, maio/jun. 1946, p. 5) e "Quadros e costumes do Nordeste - D. Maria” (Revista do Povo - Cultura e Orientação Popular, Rio de Janeiro, ano 2, n.6, jul. 1946, p.3).
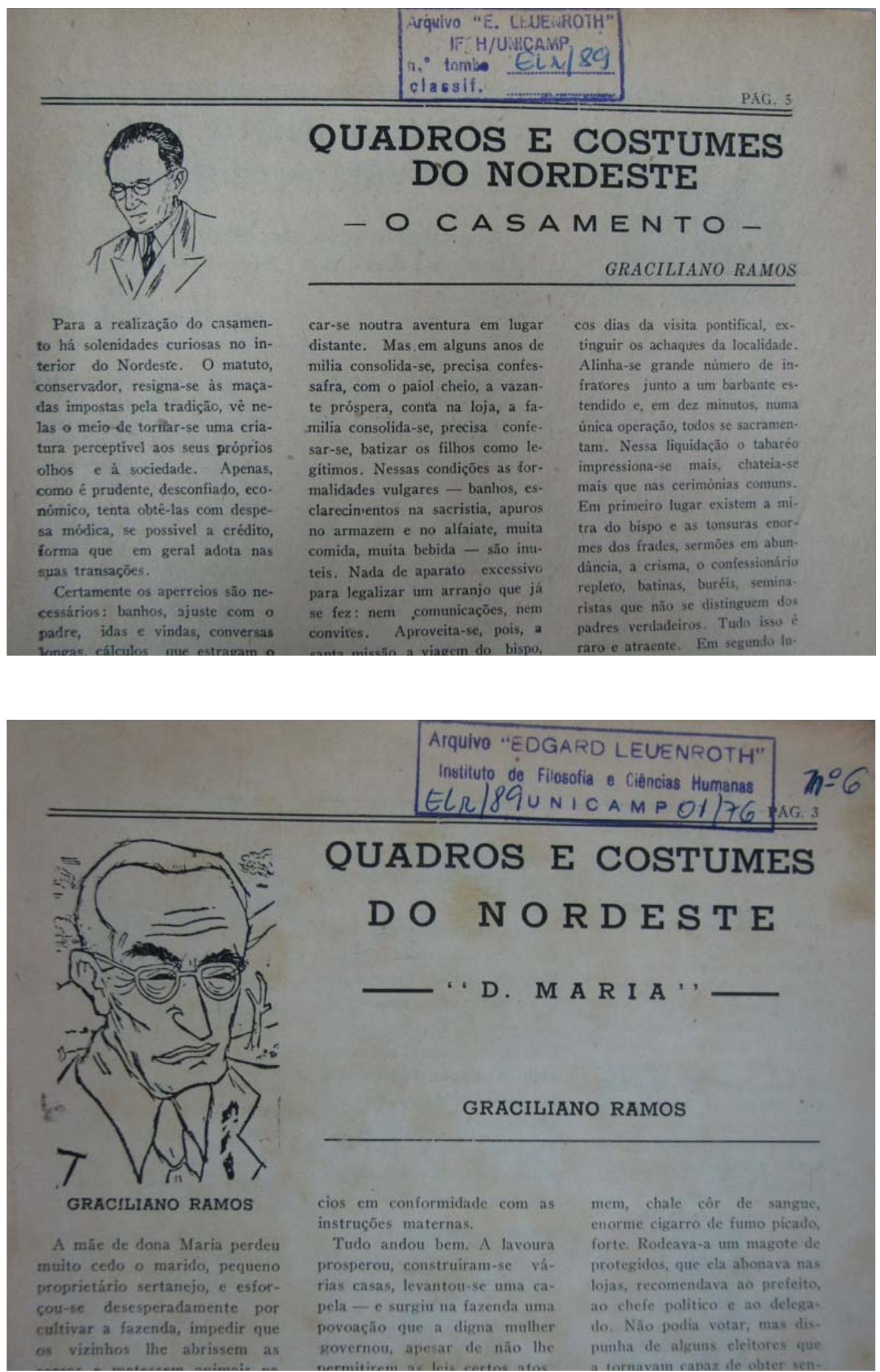
Diferentemente do aspecto livresco de Cultura Política, apresentava um número reduzido de páginas, algo em torno de quarenta. Ao mesmo tempo, estava longe da sistematização e da hierarquização do conteúdo estabelecida pelo periódico getulista. A Revista do Povo continha poucas seções fixas (“Comentários do mês”, "Noticiário Político Internacional”, “O mês literário”), que poderiam ocupar espaços variados. Na própria abertura, era apresentada a lista de colaboradores, mas, em regra, não havia a apresentação ao leitor de um sumário organizado. Além disso, o veículo era caracterizado por certa pobreza na utilização de recursos gráficos. Com exceção da capa, que contava com uma lista vermelha e uma imagem alargada, as demais páginas, diagramadas em três colunas, eram ilustradas por vinhetas ou fotos em tamanho reduzido, sem a utilização de cores.

O volume inicial da publicação teve tiragem de oito mil exemplares, mas num curto espaço de tempo, os editores esperavam que ele chegasse a “dezenas de mil”. Nesse sentido, a partir do número 7, de agosto de 1946, o veículo deixava de circular em retrogravura e passava a ser impresso em rotativa ${ }^{896}$. Como resultado, perde a feição de revista, vindo a assemelhar-se a um jornal tablóide. Tal alteração física repercutiria no conteúdo publicado; o periódico tornou-se cada vez mais informativo e doutrinário ${ }^{897}$, deixando de lado a abordagem do que “de melhor possuíam as nossas letras, tanto nas artes como nas ciências e na literatura”,898, conforme sinalizava o editorial do primeiro número. Nesse processo, inevitavelmente, os quadros e costumes nordestinos de Graciliano perderam espaço e deixaram de ser publicados.

Ao mesmo tempo, de acordo com os exemplares disponíveis para consulta na Biblioteca Nacional e no Arquivo Edgar Leuenroth, as mudanças não surtiram efeito, pois a Revista do Povo - Cultura e Orientação Popular chegava ao fim logo depois, no mês seguinte (set.1946) ${ }^{899}$, totalizando apenas oito números.

\footnotetext{
${ }^{896}$ Segundo os editores, o aumento da tiragem seria acompanhado da ampliação da distribuição do periódico, que atenderia "todos os Estados do Brasil, mesmo os mais distantes" (AOS LEITORES e ao público. Revista do povo: Cultura e Orientação Popular, ano 2, n.6, jul.1946, p.6).

${ }^{897}$ Prova disso pode ser encontrada na capa do referido número 7, levando-se em conta os títulos das matérias de capa: "Como o sr. Carlos Luz procura justificar as violências contra a imprensa livre”; "Não deve o Brasil recuar aos negros dias de 37”; "Rui Barbosa e a Liberdade de Imprensa"; além da manchete: "Mobilização do povo em defesa da Liberdade de Imprensa - O PCB em manifesto de sua Comissão Executiva conclama o povo a lutar pela Tribuna Popular [que estaria sendo perseguida pelo governo, especificamente pelo Ministro da Justiça Carlos Luz]” (Revista do povo: Cultura e Orientação Popular, ano 2, n.7, 16 ago.1946).

${ }^{898}$ MOTA, O. Froés. Esta revista. Revista do povo: Cultura e Orientação Popular, Rio de Janeiro, ano 1, n.1, dez.1945.

${ }^{899}$ Data do último periódico, localizado na seção de manuscritos da Biblioteca Nacional.
} 
No transcorrer de sua trajetória, conforme sublinhava o editorial de abertura, quaisquer que fossem as condições políticas, doutrinárias e financeiras enfrentadas pelo veículo, ele não se afastaria dos seguintes critérios editoriais:

- no setor cultural apresentar assuntos que contribuam para a elevação do nível intelectual de nosso povo, de forma simples e acessível.

- no setor político nossa ação será a de esclarecer o povo, uni-lo contra seus inimigos, e orientá-lo na solução de seus verdadeiros interesses. Neste sentido estaremos sempre alertas em combater e desmascarar os fascistas e os reacionários de toda a espécie, a fim de que, assegurando a liberdade democrática, ingressemos sem choques nesta nova fase do mundo que se inaugurou com a vitória aliada na guerra, e que é de paz, da unidade, e do progresso ${ }^{900}$.

Ao explicitar os objetivos e princípios norteadores da publicação, o articulista os subdividia em duas categorias, demarcando, assim, uma frente de atuação dupla, que já estava presente, inclusive, no próprio título Revista do Povo - $\underline{\text { Cultura e Orientação Popular: }}$ respectivamente, os setores cultural e político. O primeiro era observado sob um prisma utilitarista e ideológico: era preciso fugir do elitismo estéril e fornecer ao público conteúdos socialmente úteis e de fácil assimilação, de acordo com o desejo inicial de orientar e conscientizar um espectro amplo e variado de leitores. Por exemplo, o primeiro número era ilustrado por um desenho em preto e branco de Paulo Werneck, artista que, conforme fazem questão de ressaltar os editores, ajustava-se tais orientações comunistas:

\footnotetext{
O povo para ele é uma realidade que deve ser apresentada tal como existe, e é por isso que seus quadros nos falam de desconforto, de fome e de amarguras. Paulo Werneck sente o povo em toda plenitude de seu drama social. O povo sente a obra de Paulo Werneck porque vê nela a realidade profunda de seus dias. Esta comunhão de sentimentos é uma prova de que a arte tem uma tarefa histórica neste momento, da qual, se esta desincumbindo, isto é, atingir o povo e caminhar com ele para a libertação ${ }^{901}$.
}

Além disso, confere-se destaque à música patriótica de Dmitri Shostakovitch (ainda não censurada), ao papel do cinema russo na educação e disciplina do povo, à obra de Portinari e Pancetti, pintores interessados nos dramas populares, à ânsia de liberdade e justiça da poesia de Castro Alves, entre outros elementos. Percebe-se aqui a ênfase no realismo crítico, bem como o prenúncio do realismo socialista de Zhdanov, mas sem ainda a pressão ideológica que

\footnotetext{
${ }^{900}$ Idem, ibidem.

${ }^{901}$ NOSSA CAPA. Revista do povo: Cultura e Orientação Popular, ano 1, n.1, dez.1945, p.1.
} 
este último irá exercer nos anos 1950, com a intensificação da Guerra fria ${ }^{902}$. Paralelamente, como o mundo acabava de sair da Segunda Guerra, um dos focos principais de atuação continuava a ser o combate ao fascismo, tal como faziam crer a publicação de poemas póstumos de Lorca e de fragmentos da novela ainda inédita, Aconteceu na Hespanha, de J. Landa, “dedicada aos heróis anti-fascitas espanhóis”903.

Quanto ao aspecto político-doutrinário, o periódico assumia deliberadamente a função de conscientizar o povo, na medida em que o tomava enquanto sujeito histórico responsável pela superação do atraso nacional e pela realização da revolução brasileira. Trata-se de um contexto pós-1945, em que o PCB, recém-saído da ilegalidade, procurava reverter o quadro de “escravização e despolitização”"904 vivenciado pela classe trabalhadora ao longo do Estado Novo, quando o "Ministério do Trabalho agia nos sindicatos através da polícia política"905. Para tanto, de acordo com a tese de “união nacional”, defendida desde o apoio ao Queremismo $^{906}$, o partido privilegiava a estratégia colaboracionista, que propunha a cooperação de classes por meio da formação de uma frente com a burguesia nacional na luta contra o imperialismo e o fascismo renitente ${ }^{907}$. O objetivo de tal manobra era ampliar a participação da agremiação no meio sindical, sobretudo, e, conseqüentemente, fortalecer seus laços com os trabalhadores e sua posição no sistema político vigente ${ }^{908}$. Nesse sentido, os comunistas optaram pelo respeito ao jogo constitucional ${ }^{909}$. A revista é lançada num momento

\footnotetext{
902 "Segundo Máximo Gorki, o realismo crítico precedia o realismo socialista do mesmo modo que o capitalismo precedia o socialismo” (FLORENT, Adriana Coelho. Roupa suja se lava em casa. Graciliano Ramos, escritor e comunista na era Vargas. In: RIDENTI, Marcelo et al. Intelectuais e Estado. Belo Horizonte: UFMG, 2006, p.162).

${ }_{903}$ Revista do povo: Cultura e Orientação Popular, Rio de Janeiro, ano 2, n.4, abr. 1946, p.31.

904 GERSON, Brasil. Noticiário Internacional. Revista do povo: Cultura e Orientação Popular, Rio de Janeiro, ano 2, n.4, abr. 1946.

905 Idem, ibidem.

${ }^{906}$ Defesa de uma Assembléia Constituinte com Getúlio, em 1945, de acordo, sobretudo, com as determinações de Moscou, que pedia aos partidos comunistas de todo o mundo que apoiassem seus governos, integrantes da frente antifascista, fossem eles ditaduras ou democracias (FAUSTO, Boris. op.cit, p.386).

907 “...o Partido do proletariado e do povo foi e é o maior esteio da ordem e da tranqüilidade internas, através de sua política de União Nacional, que, conforme acentuou Prestes, significa unir os democratas, separando as víboras fascistas” (MORAES, Santos. A lição de um livro. Revista do povo: Cultura e Orientação Popular, ano 1, n.1, dez.1945, p.35).

908 SILVA, Fernando Teixeira et SANTANA, Marco Aurélio. O equilibrista e a política: o "Partido da Classe Operária” (PCB) na democratização. In: FERREIRA, Jorge et REIS, Daniel A. Nacionalismo e reformismo radical (1945-1964). v.2 As esquerdas no Brasil. Rio de Janeiro: Civilização Brasileira, 2007, p.106.

909 De acordo com os parâmetros eleitorais do sistema vigente, Dalcídio Jurandir argumentava, por exemplo, sobre a necessidade de conscientizar a população que "só um Partido lhes sabe ensinar onde está sua verdadeira força, como obter o pão e o leite para os filhos, como aliviar os anônimos e duros sofrimentos domésticos, como saber votar e porque votar” (JURANDIR, Dalcídio. Mulheres do Povo. Revista do povo: Cultura e Orientação Popular, ano 2, n.2, jan.1946. p.6). Obviamente que, nas eleições de 1945, a Revista do Povo mostrou predileção pelo candidato do PCB à presidência, o engenheiro Iedo Fiuza, descrito como um político que contava com o apoio "todos que desejam a união nacional, justamente porque vêem nela a melhor fórmula de ingressarmos, sem
} 
posterior às eleições de dezembro de 1945, quando o PCB alcançara votação expressiva e iria representar os trabalhadores na elaboração da Carta de $1946^{910}$.

Como se percebe, de maneira semelhante à Cultura Política, a Revista do Povo - Cultura e Orientação Popular privilegiava o intercâmbio entre as esferas política e cultural. Apesar de defender a premência da primeira sobre a segunda, tendo em vista a centralidade exercida pelo conceito de “orientação” das massas, o periódico comunista apresentava perspectiva diversa do veículo getulista. Enquanto para este, a cultura, norteada pela noção de resgate da “realidade brasileira”, buscava legitimar o Estado Novo em seu alegado movimento de recuperação da essência nacional, para aquele, ela teria a função de continuar o combate ao fascismo, além de documentar e denunciar as mazelas do país, visando, ao final, conscientizar os leitores sobre a necessidade de transformação e superação de tal estado de coisas. Nesse sentido, a publicação do PCB colocava-se na oposição ao novo governo, afirmando defender os “verdadeiros interesses” populares, o que pressupunha os vieses de crítica e confronto ${ }^{911}$.

Mostra da comunhão de interesses entre Graciliano e tal orientação do periódico comunista pode ser encontrada em "Carta aos alagoanos", primeiro texto do escritor publicado na Revista do Povo ${ }^{912}$. Nesta colaboração, o artista, na condição de candidato a deputado federal, afirmava que o PCB seria a única organização capaz de "livrar-nos da miséria em que vivemos" ${ }^{913}$, explicitando sua crítica ao momento presente. Paralelamente, exaltava o fato de o partido compor-se de diferentes forças sociais, tanto da burguesia quanto do proletariado, ao passo que as demais siglas reacionárias só seriam formadas por integrantes da classe dominante. Como tal escrito visava às eleições de dezembro de 1945, quando fora eleito um novo congresso, que proporia uma nova constituição, o escritor argumentava sobre a

choques de paixões partidárias, nesta nova fase do mundo” (MOTA, O. Froés da. Comentários do mês. Revista do povo: Cultura e Orientação Popular, ano 1, n.1, dez.1945, p.5).

${ }^{910}$ Além de seu candidato a presidente ter alcançado votação total de quase 10\%, o Partidão elegeu 14 deputados federais (109 suplentes) e um senador, Luiz Carlos Prestes. "Com esse resultado, o PCB saltava da ilegalidade para o quarto posto entre as forças políticas nacionais, contando 180 mil filiados" (SILVA, Fernando Teixeira et SANTANA, Marco Aurélio. op.cit. p.109).

${ }^{911}$ Conforme afirmam seus editores, a Revista do Povo desenvolvia um programa de cultura popular e para tanto, contava com a existência das liberdades democráticas posteriores ao Estado Novo. "Se voltarmos aos negros anos do terror policial, das prisões, dos espancamentos, voltaremos conseqüentemente a ter, como fontes de estudo e cultura, as publicações oficiais editadas pelos departamentos de propaganda do governo em interesse exclusivo do próprio governo. Ora convenhamos que isso seria retroceder ao passado" (INIMIGOS da cultura. Revista do povo: Cultura e Orientação Popular, ano 2, n.5, maio-jun.1946, p.34).

${ }^{912}$ Visando as eleições de 2 de dezembro de 1945, redigiu tal manifesto político, que fora distribuído para o eleitorado da província de maneira avulsa e, depois, inserido na publicação comunista (SANT’ANA, Moacir Medeiros. op.cit. p.311).

${ }^{913}$ Revista do povo: Cultura e Orientação Popular, ano 2, n.2, jan.1946. p.5. 
necessidade de se votar e apoiar o Partidão como forma de se evitar a promulgação de uma carta constitucional restrita aos interesses dos proprietários e desconectada das vontades populares.

Levando em conta as referidas diferenças entre os periódicos e o posicionamento do autor, os quadros nordestinos de Graciliano, ao serem republicados sem alterações na Revista do Povo, perdiam a função específica de contraporem o passado ao presente, assim como enfatizava o enquadramento editorial anterior, que lhes fora conferido por Cultura Política. Logo, na revista comunista, marcada não por um discurso de afirmação, mas de crítica ao status quo, eles abriam-se à discussão de certos problemas nacionais, que perduravam ao longo do tempo, ou seja, que não se restringiam ao período da República "Velha”, como fazia crer, anteriormente, o Estado auto-intitulado "Novo": entre eles, a politicalha interesseira, o clientelismo, a violência coronelística, o cosmopolitismo, a modernização de arremedo, o atraso nacional. Mais do que tópicas incorporadas pelo discurso estadonovista, que procurava legitimar-se ao imputá-las ao regime político anterior, o artista recuperava tais lugarescomuns como problemas estruturais permanentes, perspectiva de leitura enfatizada pela republicação dos textos no veículo do PCB.

Em outras palavras, no órgão de esquerda, as lacunas de seus textos ambivalentes passavam a ser preenchidas segundo parâmetros diferenciados, fazendo vir à tona todo o potencial questionador e contraditório dos mesmos, o qual fora represado e reorientado anteriormente por Cultura Política. Nesse sentido, nada do ímpeto renovador da civilização litorânea; nada do afã modernizador e ufanista do Estado Novo, sobretudo quando se enfatiza que as cenas de miséria narradas no passado poderiam ser tomadas como imagens verossímeis do Nordeste de seu presente. Portanto, na nova ambiência conferida aos textos, Graciliano relembra os tempos idos não como coisa inerte ou morta, mas sim como algo vivo, pouco alterado ao longo dos anos, mas que deveria ser transformado. Nesse sentido, realiza a desnaturalização de certas categorias do passado, buscando um devir politicamente orientado.

Paralelamente, o caráter indireto e alegórico das colaborações do autor, com o tempo, fora se constituindo em ruído no veículo partidário. Apesar de tematizarem o atraso e a brutalidade do sertão brasileiro, sua narrativas, recuadas no passado, não explicitavam suas denúncias nem traziam palavras de ordem contra tal estado de coisas ou mesmo assumir uma perspectiva heróica de triunfo do povo sofrido. Logo, por mais que pressupusessem, em tom de 
problematização, a continuidade histórica das mazelas descritas, não as atualizavam de maneira categórica, como previa a arte "simples, acessível e revolucionária” preconizada pela Revista do Povo. Por conseguinte, com a alteração da rota editorial da publicação, quando ela adota um caráter mais doutrinário e abre-se para o confronto contra a perseguição política exercida pelo governo Dutra, os “Quadros e costumes do Nordeste”, bem como outros textos mais descomprometidos deixam de ser publicados. 


\section{Conclusão}

Levando-se em conta a longa e intermitente trajetória jornalística de Graciliano Ramos, seu trabalho em Cultura Política figura como sua colaboração mais sistemática e duradoura em um único periódico. Como se viu, sobretudo no segundo capítulo da presente pesquisa, o artista estampou, ao todo, 25 textos na revista getulista, entre março de 1941 e agosto de 1944 (com intervalos). Além disso, trabalhou como revisor e manteve-se próximo da rotina administrativa do veículo, como indicam as cartas trocadas com o também colaborador da folha oficial, Nelson Werneck Sodré. Em tais missivas, colocava-se como uma espécie de representante do ex-militar e historiador, intermediando as solicitações de pagamento feitas por este à publicação dipiana (ver capítulo quatro).

Apesar dessa relativa proximidade profissional entre artista e órgão de direita, quando se examinam, de maneira detida, seus "Quadros e costumes do Nordeste”, comparando-os com os textos de outros articulistas, também publicados na revista estadonovista, sobressaem diferenças entre uns e outros. Em linhas gerais, sobretudo quanto ao gênero e o modo de elocução empregados, as colaborações de Graciliano afastavam-se tanto da ladainha laudatória às realizações governamentais, como de artigos e estudos de caráter mais dissertativo e analítico, que se debruçavam sobre diferentes aspectos da vida e cultura nacionais. Ao mesmo tempo, guardavam distância de certas crônicas propriamente ditas, tais como os relatos de viagem de Marques Rebelo, reunidos na seção "Quadros e costumes do Centro e do Sul”.

Por outro lado, tais diferenças não significavam o isolamento dos quadros nordestinos de Graciliano do ambiente editorial de Cultura Política, como se eles aí estivessem, apenas sorrateira e ironicamente, para questionar o governo nas páginas de sua principal publicação, assim como sugere determinada parcela da crítica. Muito pelo contrário, tais textos, ao trabalharem, de maneira inconclusa e alegórica, com certos lugares-comuns norteadores da retórica oficial, tornavam-se passíveis de serem apropriados pelo discurso legitimador veiculado pela revista getulista. Como se mostrou, esta última, mediante um amplo conjunto de textos e paratextos, fornecia toda uma ambiência discursiva estadonovista aos textos do autor, que, a um só tempo, enquadrava-os, disciplinava-os e dirigia-lhes o sentido. Ao mesmo 
tempo, vale lembrar que tal adequação das narrativas gracilianas aos pressupostos propagandeados por Cultura Política era favorecida pela própria especificidade do periódico dipiano, que admitia artigos menos assertivos, sem um viés doutrinário aparente, ao contrário de outros órgãos oficiais, de caráter predominantemente apologético, nos quais a colaboração do autor de Vidas Secas tornar-se-ia menos provável.

Em, resumo, esse processo, incongruente a princípio, de uma participação escrita aparentemente como linha de fuga, que, contudo, revelava-se ajustável às coordenadas traçadas pelo periódico, viabilizava-se mediante as estratégias textuais empregadas pelo autor para colaborar sem se comprometer de maneira direta com os postulados oficiais. Seja num retrato social (como na crônica sobre o carnaval), num retrato individual (no texto sobre D. Maria Amália) ou num conto de enredo (em “Uma visita inconveniente”), Graciliano produz textos a um tempo só críticos, portadores de um sentido negativo, mas adaptáveis aos propósitos legitimadores da publicação propagandística. Entre os procedimentos compositivos utilizados pelo artista para atingir tal propósito e, assim, mover-se em meio ao terreno minadíssimo no qual se encontrava, podem-se listar:

- Trabalho por meios encobertos (em enredos ficcionais e figurativos), com certas tópicas que foram incorporadas e amalgamadas ao ideário do regime de 1937, mas que não se restringiam a este. Destaque para a crítica ao liberalismo, ao internacionalismo, ao desprezo pela "realidade nacional”, ao individualismo político e ao federalismo descentralizador da Primeira República, itens recorrentes nos debates intelectuais desde os anos de 1920, que o Estado Novo se apropria como estratégia para construir, por oposição, sua legitimidade. Por mais que o artista dirigisse suas críticas a problemas estruturais, que não se restringiam à "República Velha”, tal como o discurso getulista fazia crer, elas abriam a possibilidade para a veiculação de um elogio implícito ao governo, tendo em vista, sobretudo, a mediação editorial exercida por Cultura Política.

- Adoção de certo tom de problematização, somado ao uso preferencial da terceira pessoa e à localização, ainda que imprecisa, dos textos no passado, mais especificamente num período anterior a 1930. A conjugação de tais fatores permitia que o artista mantivesse uma postura questionadora, recorrente ao longo de toda sua produção literária anterior, sem, no entanto, confrontar-se abertamente contra o status 
quo getulista. Ao mesmo tempo, as críticas contidas em seus textos apresentam um caráter aberto e inconcluso: em nenhum momento, Graciliano especifica se os problemas situados no pretérito, durante a vigência da Primeira República, teriam sido solucionados pelo Estado que se dizia "novo". Se por um lado, tal postura fugia dos habituais encômios ao regime de 1937, por outro, por oposição, a recuperação desabonadora dos tempos idos servia de contraponto para a glorificação das ações governamentais de seu momento de presente.

- Ainda no que diz respeito ao modo particular de elocução, o autor deixa de lado a composição de crônicas tradicionais, segundo a tradição instituída sobre o gênero até aquele momento, aproximando seus textos de outros registros, com destaque para o conto e para o retrato. Em regra, o efeito ficcional presente nessas composições seria reforçado, sobretudo, pela indeterminação das coordenadas actanciais e espaciais das mesmas, bem como pela ênfase manifesta pelo artista na construção de personagens, ambientes e ações específicas. Tais procedimentos, como se viu, acabavam instaurando a ambivalência e a polissemia, o que, por sua vez, facilitava o tratamento indireto e alegórico de lugares-comuns de interesse do regime sem a necessidade de discorrer abertamente sobre estes, evitando, assim, adesões, como as manifestas pela grande maioria dos outros colaboradores, entre eles Marques Rebelo.

- A opção do autor pela construção de textos com percursos figurativos bem definidos, geradores do efeito de “real”. De maneira geral, essa iniciativa tornava-os passíveis de serem enquadrados pela revista como documentos sobre a vida sertaneja, como se Graciliano não produzisse discursivamente as realidades retratadas, mas sim as captasse com sua “kodak literária”. Paralelamente, a pretensão de verdade dos escritos seria reforçada pela própria postura de especialista, didática, assumida pelo artista, que tomava o espaço e os habitantes do interior nordestino como objetos de saber privilegiados, a serem apresentados a seus leitores presumidos da capital federal. Ao governo convinha tal perspectiva, tendo em vista suas propostas centralistas e autoritárias de composição de um amplo painel do país, com ênfase na valorização de certas particularidades locais e na execução do ideal de unidade nacional.

Ao privilegiar o exame de tais estratégias textuais, bem como dos efeitos de sentido por elas produzidos no contexto histórico e editorial getulista, o presente trabalho procurou recuperar 
as relações estabelecidas entre artista e governo a partir da própria ficcionalidade dos “Quadros e costumes do Nordeste” e do debate cultural do qual eles participaram no interior da maquinaria propagandística do Estado Novo, entre o final da década de 1930 e início da de 1940. E, conforme se viu, ao adotar os procedimentos compositivos listados acima em meio à discursividade de Cultura Política, Graciliano, a um só tempo, produziu narrativas ajustáveis à retórica oficial, habilitando-se a receber os pagamentos por seu longo e sistemático trabalho no periódico, como também preservou sua autonomia e singularidade literárias, ausentando-se de maiores compromissos com o regime ditatorial. Pelo contrário, como se observou, o maior compromisso do autor de Vidas Secas seria com a ficção, pois por meio dela conseguiu equilibrar-se sobre o fio da navalha de emprestar sua arte ao regime de 1937, sem banalizar ou mesmo comprometer sua pena. 


\section{Bibliografia}

\section{Sobre crônica}

ALENCAR, José de. Ao correr da pena. São Paulo: Martins Fontes, 2004. José de Alencar: melhores crônicas. São Paulo: Global, 2003.

AMADO, Teresa. Apresentação crítica. In: LOPES, Fernão. Crônica de D. João I. Lisboa: Editorial Comunicação, 1992, p.17-72

ANDRADE, Carlos Drummond de. Confissões de Minas. In: . Obra Completa. Rio de Janeiro: Nova Aguilar, 1967. Passeios na Ilha. In: . Obra Completa. Rio de Janeiro: Nova Aguilar, 1967.

. Boca de Luar. Rio de Janeiro: Record, 1984. . et al. Elenco de cronistas modernos. Rio de Janeiro: José Olympio, 1976. . Para gostar de ler. São Paulo: Ática, vol. 5. 1980.

ANDRADE. Mário de. Taxi e crônicas no Diário Nacional. São Paulo: Livraria Duas Cidades; Secretaria da Cultura, Ciência e Tecnologia, 1976.

. O turista aprendiz. São Paulo: Duas Cidades; Belo Horizonte: Editora Itatiaia, 1976.

. Vida Literária. São Paulo: HUCITEC; EDUSP, 1993.

. Empalhador de Passarinhos. São Paulo: Livraria Martins Editora, 1972.

ANDRADE, Oswald. Feira das sextas. São Paulo: Globo, 2004.

ASSIS, Machado de. Obra Completa. vol. 3. Rio de Janeiro: Editora Nova Aguilar, 1973.

ARRIGUCCI JÚNIOR, Davi. Fragmentos sobre a crônica. In: Enigma e Comentário. São Paulo: Companhia das Letras, 2001, p. 63.

AZEVEDO, Aluísio. Touro Negro. São Paulo: Livraria Martins Editora, 1954.

BANDEIRA, Manuel. Crônicas da província do Brasil. Rio de Janeiro: Civilização Brasileira, 1937.

BARRETO, Lima. Crônicas Escolhidas. São Paulo: Ática, 1995

BILAC, Olavo. Vossa Insolência. Sao Paulo: Companhia das Letras, 1996. Ironia e Piedade. Rio de Janeiro: F. Alves, 1916.

BOLETIM BLIOGRÁFICO. São Paulo: Biblioteca Mário de Andrade, v.46, n. 14, 
jan./dez. 1985.

BRAGA. Rubem. Os melhores contos de Rubem Braga. São Paulo: Global, 1997. Um pé de milho. Rio de Janeiro: José Olympio, 1948.

CANDIDO, Antonio. et al. A Crônica; o gênero, sua fixação e suas transformações no Brasil. Campinas: Editora da Unicamp; Rio de Janeiro: Fundação Casa de Rui Barbosa, 1992.

CHALOUB, Sidney (org) et al. História em cousas miúdas. Campinas: Editora da Unicamp, 2005.

CRUZ JR, Dílson F. Estratégias e máscaras de um fingidor. São Paulo: Nankin Editorial; Humanitas FFLCH/USP, 2002.

DIMAS, Antonio. Ambigüidade da crônica: literatura ou jornalismo. Littera, Rio de Janeiro, ano IV, n.12, set./out. 1974. . Bilac, o Jornalista. São Paulo: EDUSP; Imprensa Oficial; Editora Unicamp, 2006.

HANSEN. João Adolfo. Drummond e o Livro Inútil. Letterature d'America, Roma, ano XXV, n. 107, 2005, p. 69-98.

JUNIOR, França. Folhetins. Rio de Janeiro: Jacinto Ribeiro dos Santos, 1926.

PICCHIA, Menotti del. O despertar de São Paulo. Rio de Janeiro: Civilização Brasileira, 1933.

PORTELLA, Eduardo. Dimensões I. Rio de Janeiro. Edições Tempo Brasileiro, 1978, p.81-87.

MACEDO, Joaquim Manuel de. Passeio pela cidade do Rio de Janeiro. Rio de Janeiro: Zelio Valverde, [1942]. . Memórias da Rua do Ouvidor. São Paulo: Companhia Editora Nacional, 1952.

RESENDE, Beatriz. et al. Cronistas do Rio. Rio de Janeiro: José Olympio; CCBB, 1995.

SÁ, Jorge de. A crônica. São Paulo: Ática, 1985.

\section{Obras de Graciliano}

RAMOS, Graciliano. Linhas tortas. 2. ed, São Paulo: Livraria Martins Editora, 1962. . Vivente das Alagoas. 2. ed., São Paulo: Livraria Martins Editora, 1967. . Caetés. 4. ed. Rio de Janeiro: Livraria José Olympio Editora, 1953. São Bernardo. 5. ed. Rio de Janeiro: Livraria José Olympio Editora, 1953. 
Angústia. 6. ed. Rio de Janeiro: Livraria José Olympio Editora, 1953. . Vidas Secas. 4. ed. Rio de Janeiro: Livraria José Olympio Editora, 1953. . Insônia. 3. ed. Rio de Janeiro: Livraria José Olympio Editora, 1953. . Infância. 3. ed. Rio de Janeiro: Livraria José Olympio Editora, 1953. . Memórias do Cárcere. Rio de Janeiro: Livraria José Olympio Editora, 1953. $4 \mathrm{v}$. . Viagem. 2 ed. Rio de Janeiro: Livraria José Olympio Editora, 1955. . Cartas. Rio de Janeiro: Record, 1981. Histórias de Alexandre. 1.ed. São Paulo: Livraria Martins Editora, 1962. . A terra dos meninos pelados. Porto Alegre: Livraria do Globo, 1939. . Alexandre e outros heróis. Rio de Janeiro: Record, 2003.

. Paulo Honório. In:CONDÉ, João. 10 romancistas falam de seus personagens. Rio de Janeiro: Edições Condé, 1946. Capítulo XXIV. Novidade, Maceió, n.9, 6 jun. 1931.

RAMOS, Graciliano et al. Brandão Entre o Mar e o Amor. 2 ed. São Paulo: Martins, 1973.

WASHINGTON, Booker. Memórias de um negro. trad. Graciliano Ramos. Rio de Janeiro: Companhia Editora Nacional, 1940.

\section{Sobre Graciliano}

ABEL, Carlos Alberto dos Santos. Graciliano Ramos: cidadão e artista. Brasília: Editora Universidade de Brasília, 1999.

ARROYO, Leonardo. Vida literária, Graciliano e as crianças. Folha de S. Paulo, São Paulo, 22 abr. 1962.

AZEVEDO, Vivice. Apports inédits à l'oeuvre de Graciliano Ramos. In: Graciliano Ramos: Vidas Secas (séminaires de février et juin 1971). Poitiers: Centre de Recherches Latino-Américaines, da Universidade de Poitiers. 1977.

BARBOSA, Rolmes. Graciliano Ramos - Viventes e vivência. O Estado de S. Paulo, São Paulo, 28 abr. 1962. Suplemento literário.

BOSI, Alfredo; FACIOLI, Valentim; GARBUGLIO, José Carlos. Graciliano Ramos. São Paulo: Ática, 1987.

BRAYNER. Sônia (org). Graciliano Ramos. Rio de Janeiro: Civilização Brasileira, 1978. 
BROCA, Brito. Prefácio. In: RAMOS, Graciliano. Linhas Tortas. Rio de Janeiro: Record, 1972.

BUMIRGH, Nádia. Graciliano Ramos e a revista cultura política: pequena abordagem interpretativa na proposta de edição crítica de Viventes das Alagoas. São Paulo, 2003. Tese (Doutorado) - Faculdade de Filosofia Letras e Ciências Humanas, Universidade de São Paulo, 2003.

S. Bernardo de Graciliano Ramos: proposta para uma Edição Crítica. 1998.

341 f. Dissertação (Mestrado em Letras) - Faculdade de Filosofia Letras e Ciências Humanas, São Paulo.

CANDIDO, Antonio. Ficção e confissão: ensaios sobre Graciliano Ramos. Rio de Janeiro: Editora 34, 1992.

CARPEAUX, Otto Maria. “Visão de Graciliano Ramos” In: Angústia. Rio de Janeiro: Record, 1984.

CRISTÓVÃO, Fernando Alves. Graciliano Ramos: estrutura e valores de um modo de narrar. Brasília: Instituto Nacional do Livro, 1975.

FLORENT, Adriana. Roupa suja se lava em casa - Graciliano Ramos, escritor e comunista na era Vargas. In: RIDENTI et. al. Intelectuais e Estado. Belo Horizonte: Editora UFMG, 2006

ENEIDA. Graciliano Ramos: Viventes das Alagoas. Diário de Notícias, Rio de Janeiro, 15 abr. 1962.

GAMA, Maria Lúcia Palma. Projeto para inéditos. Revista do Instituto de Estudos Brasileiros, São Paulo, n.35, 1993, p.201-204.

GIMENEZ, Erwin Torralbo. O olho torto de Graciliano Ramos: metáfora e perspectiva. Revista USP, São Paulo, v. 63, set./nov. 2004, p. 186-196.

IVO, Ledo. O mundo concentracionário de Graciliano Ramos. In: Teoria e celebração. São Paulo: Duas Cidades; Secretaria da Cultura, Ciência e Tecnologia do Estado de São Paulo, 1976.

LIMA, Valdemar de Souza. Graciliano Ramos em Palmeira dos Índios. 2.ed. Rio de Janeiro: Civilização Brasileira, 1980.

LIMA, Yêdda Dias [org]. Catalogo de manuscritos do Arquivo Graciliano Ramos. São Paulo: Edusp, 1992.

LIMA, Mário Hélio Gomes de. Relatórios. Rio de Janeiro: Record, 1994.

MAGALHÃES, Mário. Memórias de um militante stalinista. Folha de S. Paulo, São Paulo, 9 mar. 2003. 
MAIA, Pedro Moacir (org.). Cartas inéditas de Graciliano Ramos a seus tradutores argentinos Benjamin de Garay e Raúl Navarro. Salvador: Editora da UFBA, 2008.

MALARD, Letícia. Ensaio de Literatura Brasileira: Ideologia e realidade em Graciliano Ramos, Belo Horizonte: Editora Itatiaia, 1976.

MELO, Ana Amélia M. C. Pensando o Brasil: os escritos de Graciliano no Estado Novo. In: ALMEIDA, Ângela Mendes de (org). De sertões, desertos e espaços incivilizados. Rio de Janeiro: Faperj; Mauad, 2001.

MERCADANTE, Paulo. Graciliano Ramos - o manifesto do trágico. Rio de Janeiro. Topbooks, 1994.

MORAES, Denis. O Velho Graça. Rio de Janeiro: José Olympio, 1992.

PEREZ, Renard. Literatura - Graciliano: obra póstuma. Última Hora, Rio de Janeiro, 25 abr.1962.

PINTO, Rolando Morel. Graciliano Ramos: autor e ator. Assis, SP: Faculdade de Filosofía, Ciências e Letras de Assis, 1962

RAMOS, Clara. Cadeia. Rio de Janeiro: José Olympio, 1992. . Mestre Graciliano: confirmação humana de uma obra. Rio de Janeiro: Civilização Brasileira, 1979.

RAMOS, Ricardo. Retrato fragmentado. São Paulo: Editora Siciliano, 1992.

SANT’ANA, Moacir Medeiros. A face oculta de Graciliano Ramos. Maceió: Arquivo Público de Alagoas, 1992. . As leituras do jovem Graciliano Ramos: catálogo anotado da exposição Graciliano Ramos: vida e obra. Maceió: Secretaria de Comunicação Social, 1992.

. Graciliano Ramos, achegas biobibliográficas. Maceió: Arquivo Público de Alagoas, SENEC, 1973.

. Graciliano Ramos antes de Caetés. Maceió: Arquivo Público de Alagoas, 1983.

. Graciliano Ramos: vida e obra. Maceió: Secretaria de Comunicação Social, 1992.

. História do romance Caetés. Maceió: Arquivo Público de Alagoas; SEC, 1983.

VERDI, Eunaldo. Graciliano Ramos e a crítica literária. Florianópolis: Editora da UFSC, 1989. 


\section{Textos de Graciliano ainda inéditos em livro (em ordem cronológica)}

LAMBDA [Graciliano Ramos]. No Campo das Letras. Jornal de Alagoas, Maceió, 20 abr. 1909.

Estudante na roça. Jornal de Alagoas, Maceió, 13 mar. 1910.

Pela mocidade. Jornal de Alagoas, Maceió, 22 fev. 1911.

Zé Pereira. Jornal de Alagoas, Maceió, 26 fev. 1911.

Professiomania. Jornal de Alagoas, Maceió, 26 set. 1913.

RAMOS Oliveira. Na terra do fogo as coisas estão frias. Parayba do Sul, Paraíba do Sul (RJ), 07 jan. 1915.

R.O. [Graciliano Ramos]. Coisas do Rio. Jornal de Alagoas, Maceió, 06 mar. 1915. . Linhas Tortas. Jornal de Alagoas, Maceió, 18 abr. 1915.

X [Graciliano Ramos]. Garranchos [1]. O Índio. Palmeira dos Índios, ano 1, n.1, 31 jan. 1921. . Garranchos [2]. O Índio. Palmeira dos Índios, ano 1, n.2, 06 fev. 1921. . Garranchos [3]. O Índio. Palmeira dos Índios, ano 1, n.3, 13 fev. 1921. . Garranchos [4]. O Índio. Palmeira dos Índios, ano 1, n.4, 20 fev. 1921. . Garranchos [5]. O Índio. Palmeira dos Índios, ano 1, n.5, 27 fev. 1921. . Garranchos [6]. O Índio. Palmeira dos Índios, ano 1, n.6, 06 mar. 1921. . Garranchos [7]. O Índio. Palmeira dos Índios, ano 1, n.7, 13 mar. 1921. . Garranchos [8]. O Índio. Palmeira dos Índios, ano 1, n.8, 20 mar. 1921. . Garranchos [9]. O Índio. Palmeira dos Índios, ano 1, n.9, 27 mar. 1921.

J.C [Graciliano Ramos]. Judas. O Índio, Palmeira dos Índios. 27 mar. 1921.

X [Graciliano Ramos]. Garranchos [10]. O Índio. Palmeira dos Índios, ano 1, n.10, 3 abr. 1921.

LAMBDA [Graciliano Ramos]. Como se escreve. O Índio, Palmeira dos Índios, 03 abr. 1921.

X [Graciliano Ramos]. Garranchos [11]. O Índio. Palmeira dos Índios, ano 1, n.11, 10 abr. 1921. . Garranchos [12]. O Índio. Palmeira dos Índios, ano 1, n.12, 17 abr. 1921. . Garranchos [13]. O Índio. Palmeira dos Índios, ano 1, n.13, 24 abr. 1921.

LAMBDA [Graciliano Ramos]. Solidariedade, O Índio, Palmeira dos Índios, 24 abr. 1921.

X [Graciliano Ramos]. Garranchos [14]. O Índio. Palmeira dos Índios, ano 1, n.14, 01 
maio 1921.

CALISTO, J [Graciliano Ramos]. Traços a esmo [14]. O Índio, Palmeira dos Índios. 01 maio 1921.

RAMOS, G. A propósito de uma notícia... O Índio. Palmeira dos Índios, ano 1, n.17, 22 maio 1921.

GUEDES, Lúcio [Graciliano Ramos]. Macobeba Pré-histórico. Jornal de Alagoas, Maceió, 27 abr. 1930, p.3.

. Macobeba Antigo. Jornal de Alagoas, Maceió, 29 abr. 1930, p.3.

G.R. [Graciliano Ramos]. O álcool. Jornal de Alagoas, Maceió, 21 jun. 1930.

Prefeituras municipais I. Jornal de Alagoas, Maceió, 31 jul. 1930, p.3.

Prefeituras municipais II. Jornal de Alagoas, Maceió, 08 ago. 1930, p.3.

RAMOS, Graciliano. Sertanejos. Novidade, Maceió, n.1, 11 abr. 1931.

Chavões. Novidade, Maceió, n.8, 30 mai. 1931.

G.R. [Graciliano Ramos]. O testa de ferro. Jornal de Alagoas, Maceió, 16 ago. 1931, p.3.

RAMOS, Graciliano. Mulheres. Jornal de Alagoas, Maceió, 20 mai. 1933, p. $3^{914}$. . Doutores. Jornal de Alagoas, Maceió, 11 jun. $1933^{915}$.

. Um romancista do Nordeste, Literatura, Rio de Janeiro, ano 1, n.18, 20 jun.

1934.

. O romance do Nordeste, Diário de Pernambuco, Recife, 10 mar. 1935.

Alguns números relativos à instrução primária em Alagoas, A Escola, Maceió, set. 1935.

. Carta de Graciliano Ramos. Revista Acadêmica, Rio de Janeiro, n.28, jun.

1937.

. Mulheres... Vamos Lêr!, Rio de Janeiro, 28 out. 1937, n.65 .

. D. Zizi. Vamos Lêr!, Rio de Janeiro, 11 nov. 1937, n.67.

. Um anúncio. Esfera - revista de letras, artes e ciências, Rio de Janeiro, ano 1, n.1, maio 1938, p.7.

. Uma tentativa de explicação. Revista Acadêmica, n.54, maio 1941. Idéias Novas. Revista do Brasil, Rio de Janeiro, 3ª fase, ano V, n.49, jul.1942 .

\footnotetext{
${ }^{914}$ Tal crônica foi publicada no Jornal de Alagoas, Maceió, 1977. No entanto, ao final do recorte, há seguinte referência: "Hemeroteca do Instituto Histórico e Geográfico de Alagoas”. Além disso, há o local e a data da primeira publicação: Jornal de Alagoas, Maceió, 20 de maio de 1933.

${ }_{915}$ Cópia datilografada em papel timbrado da Secretaria de Estado dos Negócios da Educação e Cultura Arquivo Público de Alagoas que ao final traz local e a data de publicação em periódico.
} 
. Uma visita inconveniente. Cultura Política, ano 2, n. 22, Rio de Janeiro, dez. 1942, p. 154-155.

. O estranho Portinari. O Jornal, Rio de Janeiro, 1 jul. 1943.

. Carta aos alagoanos. Revista do povo: Cultura e Orientação Popular, ano 2,

n.2, jan.1946, p.5 .

. O Partido Comunista e a criação literária. Tribuna Popular, Rio de Janeiro, 22 maio 1946.

. Solilóquio Derramado. O Jornal, Rio de Janeiro, 2 nov. $1947^{916}$.

. Prestes. Classe Operária, Rio de Janeiro, 01 jan. 1949.

. O último romance de Alina Paim. Imprensa Popular, Rio de Janeiro. 15 abr.

1951.

. Convocação, Jornal do IV Congresso, Rio de Janeiro, n.1, 1 set. 1951.

. Viver em paz com a humanidade inteira, Horizonte, Porto Alegre, n.10, out.

1951; Imprensa Popular, Rio Janeiro, 14 out. 1951.

. Unidade em defesa dos direitos do escritor. Imprensa Popular, Rio de Janeiro, 30 ago. 1952.

. Apelo de Graciliano Ramos aos intelectuais brasileiros. Imprensa Popular, Rio

de Janeiro, $1^{\circ}$ nov. 1952.

. De Graciliano Ramos a Obdulio Barthe. Imprensa Popular, Rio de Janeiro, 30

nov. 1952.

\section{Entrevistas de Graciliano}

DE GRACILIANO RAMOS. Dom Casmurro, Rio de Janeiro, 23 dez. 1937.

BROCA, Brito. Vidas Secas na zona árida. A Gazeta, São Paulo, 10 ago. ou mar. 1938.

CONDE, José. Graciliano Ramos. O Cruzeiro, Rio de Janeiro, 15 abr. 1939.

SILVEIRA, Joel. Graciliano Ramos conta sua vida. Caricatura de Augusto Rodrigues. Vamos Lêr!, Rio de Janeiro, 20 abr. 1939, p.8-9.

COUTINHO, Galeão. Um romancista no meio do povo. Leitura, Rio de Janeiro, n.4, maio 1939, p.9-10.

BURLA, Eliezer. Escritores vistos por um leitor. Dom Casmurro, Rio de Janeiro, 16 dez. 1939.

\footnotetext{
${ }^{916}$ Tal notação bibliográfica é feita pelo próprio Graciliano. Contudo, no topo do recorte há informação que a carta também fora publicada no Diário de Natal, Natal, 12 abr. 1952.
} 
BORBA, Osório. As roupas debaixo da glória - impressões do contato pessoal com escritores famosos -, n.5, Major Graça, romancista. Diretrizes, Rio de Janeiro, ago.1940.

BARBOSA, Francisco de Assis. A vida de Graciliano Ramos. Diretrizes, Rio de Janeiro, 29 out. 1942.

AUTO-RETRATO - Graciliano visto por Graciliano. Leitura, Rio de Janeiro, n.1, dez. 1942, 11-12.

NUNES, Osório. O modernismo morreu? Dom Casmurro, Rio de Janeiro, 12 dez. 1942.

AS CELEBRIDADES, suas manias e predileções. A Noite, Rio de Janeiro, 1943 ou 1944, p.1 e 9 .

MAIA, Luís [pseud.]. Os chamados romances sociais não atingiram as massas.

Renovação, Recife, ano 7, n.13, maio-jun. 1944, p.7-8 e 33.

FACÓ, Ruy. Graciliano Ramos, escritor do povo e militante do PC. Fotos Ruy Santos, Tribuna Popular, Rio de Janeiro, 26 ago. 1945.

PACHECO, Armando. Graciliano Ramos conta como escreveu Infância, seu recente livro de memórias. Vamos Lêr!, Rio de Janeiro, 25 out. 1945, p.26-27.

SILVEIRA, Joel. Perfil apressado do velho Graça. Revista Globo, Porto Alegre, 9 fev. 1946, p. 32-33 e 58.

SENNA, Homero. Revisão do Modernismo. Revista Globo, Porto Alegre, ago. 1948.

A A.B.D.E. não é um Clube Recreativo. Folha do Povo, Recife, 19 mar. 1943.

GRACILIANO RAMOS e o Manifesto de Prestes. Imprensa Popular, Rio de Janeiro, 13 [mês?] 1950.

DECLARAÇÕES DO ESCRITOR Graciliano Ramos em Lisboa. Correio da Manhã, Rio de Janeiro, [abr.] 1952.

BARBOSA, Francisco de Assis. Nosso maior romancista vivo completa sessenta anos.

Última Hora, Rio de Janeiro, 27 out. 1952.

“SOU UM HOMEM DE PARTIDO” - afirma Graciliano Ramos. Imprensa Popular,

Rio de Janeiro, [5 mar.] 1953.

\section{Textos teóricos}

ANDERSON, Benedict. Comunidades Imaginadas. São Paulo: Companhia das Letras, 2008.

ARISTÓTELES. Poética. 3. ed. Trad. de Eudoro Fonseca. Lisboa: Imprensa 
Nacional/Casa da Moeda, 1992.

Retórica. Trad. Manuel Alexandre Júnior, Paulo Farmhouse Alberto, Abel do

Nascimento Pena. Lisboa: Imprensa Nacional; Casa da Moeda, 1998.

BARBOZA, Jeronymo Soares. Instituições Oratórias de M. Fábio Quintiliano,

Escolhidas dos seus XII Livros, Traduzidas em linguagem e ilustrada com notas críticas, Históricas e Retóricas, para uso dos que aprendem. Livro I. Coimbra: Imprensa Real da Universidade. MDCCLXXXVIII (1788), p.82-98.

BAKHTIN, Mikhail. Marxismo e filosofia da linguagem. São Paulo: Hucitec, 1981. Estética da Criação Verbal. São Paulo:Martins Fontes, 2003. . Questões de literatura e estética: a teoria do romance. São Paulo, Hucitec,1998

BARROS, Diana Luz Pessoa de. Teoria do Discurso. 3.ed. São Paulo: Humanitas; FFLCH/USP, 2002.

BARROS, Mariana Luz Pessoa de. A arquitetura das memórias - um estudo do tempo no discurso biográfico. 2006. 233f. Dissertação (Mestrado em Lingüística) Faculdade de Filosofia Letras e Ciências Humanas, Universidade de São Paulo, São Paulo, 2006.

BARTHES, Roland. Critica e verdade. São Paulo: Editora Perspectiva, 1970. . "El efecto de realidad". In: . Lo Verosímil. 2. ed. Buenos Aires:

Editorial Tiempo Contemporáneo, 1972. O rumor da língua. Lisboa: Edições 70, 1987.

BHABHA, Homi K. O local da cultura. Belo Horizonte: Editora da UFMG, 2007. BENJAMIN, Walter. Magia e técnica, arte e política , 7. ed. São Paulo: Brasiliense, 1994. Obras escolhidas, v.1.

BENVENISTE, Emile. Da subjetividade na linguagem. In: . Problemas de Lingüística Geral I. Campinas: Pontes, 2005. . “O aparelho formal da enunciação”. In: . Problemas de Lingüística Geral II. Campinas: Pontes, 1989.

BERNUCCI, Leopoldo. Imitação dos Sentidos: Prógonos, Contemporâneos e Epígonos de Euclides da Cunha. São Paulo: Edusp, 1995.

BORGES, Jorge Luís. Prólogos com um prólogo dos prólogos. trad. Ivan Junqueira. Rio de Janeiro: Rocco, 1985

BRAYNER, Sônia. Labirinto do espaço romanesco: tradição e renovação da literatura brasileira. Rio de Janeiro: Civilização Brasileira, 1979. 
CAMINHA, Heda Maciel. Por uma leitura do aparelho liminar. Letras de Hoje, Porto Alegre, 19(2), jun. 1986.

CANDIDO, Antonio. A personagem do romance. In: CANDIDO, Antonio et al. A personagem de ficção. São Paulo: Perspectiva, 1976.

CHARAUDEAU, Patrick. Discurso Político. São Paulo: Contexto, 2006.

CHARTIER, Roger. Os desafios da escrita. São Paulo: Editora UNESP, 2002.

CHARTIER, Roger (org.). Práticas da leitura. São Paulo: Estação liberdade, 2009. Inscrever e apagar. São Paulo: Editora UNESP, 2002.

CULLER, Jonathan D. Teoria literária: uma introdução. São Paulo: Beca Produções Culturais, 1999.

. On Deconstruction: theory and criticism after structuralism. London:

Routledge, 1994.

CURTIUS, Ernst Robert. Literatura européia e idade média latina. São Paulo: Hucitec; Edusp, 1996.

FIORIN, José Luiz. As astúcias da enunciação. 2.ed. São Paulo: Ática, 2008. . Elementos de Análise do Discurso. São Paulo: Contexto; Edusp, 1989. . Quase lógico. Língua Portuguesa, São Paulo, ano 1, n.10, 2006.

FORGET, Danielle. Conquistas e resistências do poder: a emergência do discurso democrático no Brasil (1964-1984). São Paulo: EDUSP, 1994.

FOUCAULT, Michel. As Palavras e as Coisas: Uma Arqueologia das Ciências Humanas. São Paulo: Martins Fontes, 2002.

. Arqueologia do Saber. Rio de Janeiro: Forense Universitária, 2007. . O que é um autor?. Lisboa: Vega, 1992. . Microfísica do Poder. Rio de Janeiro: Graal, 1999. . A ordem do discurso. São Paulo: Edições Loyola, 2007.

FRIEDMAN, Norman. O ponto de vista na ficção: o desenvolvimento de um conceito crítico. Revista USP, São Paulo, n.53, mar./maio 2002.

GENETTE, Gérard. Seuils. Paris: Éditions du Seuil, 1987.

GOMES, Mayra Rodrigues. Jornalismo e Ciências da Linguagem. São Paulo: Edusp, 2000.

GRABO, Carl H. The art of short story. Charleston, SC: Bibliolife, 2009.

GREENBLATT, Stephen. “Novo Historicismo: Ressonância e Encantamento”. In: Revista Estudos Históricos, Rio de Janeiro, v. 4, n. 8, 1991, p. 244-261. . Culture. In: LENTRICCHIA, Frank; MCLAUGHLIN, Thomas. Critical terms 
for literary estudies. Chicago; London: University of Chicago Press, 1995, p.225-232.

GREENBLATT, Stephen; GALLAGHER, Catherine. A prática do novo historicismo.

Bauru, SP: Edusc, 2005.

GREIMAS, Algirdas Julien; COURTES, Joseph. Dicionário de Semiótica. São Paulo: Cultrix, 1979.

HARDMAN, Francisco Foot. Antigos modernistas. In: NOVAES, Adauto (org.).

Tempo e História. São Paulo: Companhia das Letras/Secretaria Municipal de Cultura, 1992.

. A poética de ruínas n’Os Sertões. In: BERNUCCI, Leopoldo (org.). Discurso, Ciência e Controvérsia em Euclides da Cunha. São Paulo: Edusp, 2008.

HORÁCIO. Arte Poética. Introdução, tradução e cometário de R. M. Rosado Fernandes. Lisboa: Editora Inquérito Limitada, 1992.

HANSEN. João Adolfo. Sátira e o Engenho. São Paulo: Companhia das Letras, 1989. Autor. In: JOBIM, José Luís. Palavras da crítica: tendências e conceitos no estudo da literatura. Rio de Janeiro: Imago, 1992, p.11-43.

. Categoria epidíticas da ekphrasis. Revista USP, São Paulo, n.71, set./nov. 2006, p.85-105.

ISER, Wolfgang. The implied reader: patterns of communication in prose fiction from Bunyan to Beckett. Baltimore: The Johns Hopkins University Press, 1987. O ato da leitura. São Paulo: Editora 34, 1996.

JAKOBSON, Roman. Do realismo artístico. In: TOLEDO, Dionísio de Oliveira (org). Teoria da literatura - formalistas russos. Porto Alegre: Editora Globo, 1973, p. 119-127.

."Les embrayeurs, les catégories verbales et le verbe russe”. In: Essais de linguistique générale. Paris: Les Éditions de Minuit, 1973. . Lingüística e Comunicação. São Paulo: Cultrix, 1970.

LAUSBERG, Heinrich. Elementos de retórica literária. Lisboa: Fundação Calouste Gulbenkian, 1972.

LEJEUNE, Philippe. L'autobiographie en France. Paris, Armand Colin, 1971.

LIMA, Luiz Costa. “Desconstruindo Machado”. Folha de S. Paulo, São Paulo, 29 jun. 2003, Caderno Mais, p.14-15.

LINS, Osman. Lima Barreto e o espaço romanesco. São Paulo: Ática, 1976.

MAINGUENEAU, Dominique. Elementos de lingüística para o texto literário. São Paulo: Martins Fontes, 1996. 
OSAKABE, Haquira. Argumentação e discurso político. São Paulo: Martins Fontes, 1999.

PERELMAN, Chaim. Tratado da argumentação: a nova retórica. São Paulo: Martins Fontes, 1996.

PLATÃO. A República. Tradução de Maria Helena da Rocha Pereira. Lisboa: Fundação Calouste Gulbenkian, 1990.

QUINTILIANO. Instituições Oratórias. São Paulo: Cultura, 1944.

TATIT, Luiz. Análise semiótica através das letras. São Paulo: Ateliê Editorial, 2001.

TEIXEIRA, Ivan. Poética Cultural: Literatura e História. Politéia: História e Sociedade, Vitória da Conquista, v.6, n.1, 2006, p. 31-56. . Semiosfera e invenção do autor. In: FILHO, Plínio Martins; TENÓRIO, Waldecy (Orgs). João Alexandre Barbosa: o leitor insone. São Paulo: Edusp, 2007.

Policarpo Quaresma como caricatura de uma idéia de Brasil.

In: BARRETO, Lima. O triste fim de Policarpo Quaresma. Cotia: Ateliê Editorial, 2001.

. Hermenêutica, retórica e poética nas letras da América Portuguesa. Revista USP, São Paulo, n.57, mar./mai 2003, p.138-159.

. Literatura como Imaginário: Introdução ao Conceito de Poética Cultural.

Revista Brasileira, Rio de Janeiro, fase VII, ano IX, n. 37, p. 43-67, out./nov./dez. 2003.

. Construção da Intimidade em Angústia [de Graciliano Ramos]. Revista USP, São Paulo, n.61, mar./mai. 2004, p. 196-209.

. Semiosfera \& invenção do autor. In: MARTINS, Plínio et TENÓRIO, Waldecy. João Alexandre Barbosa: o leitor insone. São Paulo: Edusp, 2007. . Irônica invenção do mundo: leitura histórica de O Alienista. 2009. Tese (Livredocência) - Escola de Comunicações e Artes. Universidade de São Paulo, São Paulo, 2009.

TEOFRASTO. Os caracteres. São Paulo: E.P.U.; FFLCH/USP, 1978.

TURRER, Daisy. O livro e ausência do livro em Tutaméia, de Guimarães Rosa. Belo Horizonte: Autêntica, 2002, p.30.

VESSER, H. Aram (ed). The New Historicism. Nova York: Routledge, 1994. 


\section{Sobre o contexto histórico, literário e jornalístico}

ABREU, Luciano Aronne de. Um olhar regional sobre o Estado Novo. Porto Alegre: EDIPUCRS, 2007.

ALBUQUERQUE, Durval Muniz de. A invenção do Nordeste e outras artes. Recife: Fundação Joaquim Nabuco, Editora Massangana; São Paulo: Cortez, 1999.

ALENCAR, José de. Obras completas. vol 3 e 4. Rio de Janeiro: Aguilar, 1964.

ALMEIDA, José Maurício Gomes de. A tradição regionalista no romance brasileira. Rio de Janeiro: Topbooks, 1999.

AMADO, Jorge. ABC de Castro Alves. $3^{\text {a }}$ ed. São Paulo: Livraria Martins Editora, 1950.

. “O Tempo que Vai”, Dom Casmurro, Rio de Janeiro, 12 ago. 1939.

. A Solidão é triste. Dom Casmurro, Rio de Janeiro, n. 116, 02 set. 1939.

. Resposta de Jorge Amado. Revista do Brasil, Rio de Janeiro, ano III, $3^{\text {a }}$ fase, n.22, abr. 1940, p.109.

. P.S. Boletim de Ariel, Rio de Janeiro, ago. 1933, p.292.

. Literatura, romance e política como resultados sociais. Pan, Buenos Aires, 11

mar. 1936. In: TATIT, Miécio. Jorge Amado: vida e obra. Belo Horizonte: Editora Itatiaia, 1961.

AMARAL, Azevedo. O estado autoritário e a realidade nacional. Rio de Janeiro: José Olimpio, 1938.

ANDRADE, Almir. Forca, cultura e liberdade: origens históricas e tendências atuais da evolução política do Brasil. Rio de Janeiro: José Olympio, 1940. . Aspectos da literatura brasileira. Rio de Janeiro: Schmidt, 1939, p.86. . Resposta de Almir de Andrade. Revista do Brasil, Rio de Janeiro, ano III, $3^{\mathrm{a}}$ fase, n.22, abr. 1940, p.103. . Almir de Andrade (depoimento, 1981). Rio de Janeiro: FGV/Cpdoc-História Oral, 1985, 48p. dat. Entrevista concedida à Lúcia Lippi de Oliveira.

ANDRADE, Mário. Aspectos da literatura brasileira. Belo Horizonte: Itatiaia, 2002.

ANTELO, Raúl. Literatura em revista. São Paulo: Editora Atica, 1984.

APRESENTAÇÃO. Literatura, Rio de Janeiro, ano 1, n.1, set. 1946.

ARQUIVO GUSTAVO CAPANEMA. Estado Novo, um auto-retrato. Brasília: Editora

Universidade de Brasília, Coleção Temas Brasileiros, 24, 1983.

ATHAYDE, Tristão de [Alceu Amoroso Lima]. Síntese. Lanterna Verde, Rio de 
Janeiro, n.4, nov. 1936, p.89.

. Macunaíma. O Jornal, Rio de Janeiro, 9 set. 1928. In: RAMOS JÚNIOR, José

de Paula. A fortuna crítica de Macunaíma: primeira onda (1928-1936). 2006. 2 v.

Tese (Doutorado em Literatura Brasileira) - Faculdade de Filosofia Letras e Ciências

Humanas, Universidade de São Paulo, 2006, v.2.

AZEVEDO, Fernando. Cultura Brasileira. Rio de Janeiro: Instituto Brasileiro de

Geografia e Estatística, 1943.

. Reconstrução educacional no Brasil. Manifesto dos pioneiros da educação

nova. In: A educação entre dois mundos. São Paulo: Edições Melhoramentos, [1958].

BAHIA, Juarez. Jornal, história e técnica. São Paulo: Ática, 1990.

BARROS, Edgar Luiz de. Getúlio!. São Paulo: Nankin, 2004.

BARROS, Francisco Reinaldo Amorim de. ABC das Alagoas: dicionário, histórico e geográfico das Alagoas. Brasília: Senado Federal, Conselho Editorial, 2005.

BASTOS, Elide Rugai; RIDENTI, Marcelo; et ROLLAND, Denis (orgs). Intelectuais: sociedade e política, São Paulo: Cortez Editora, 2003.

BELLUZZO, Ana Maria de Moraes. O Brasil dos viajantes. São Paulo: Metalivros; Rio de Janeiro: Fundação Odebrecht, vol.2 Um lugar no universo, 1994

BOMENY Helena (org.). Constelação Capanema: intelectuais e políticas. Rio de Janeiro: Editora FGV; Universidade São Francisco, 2001.

BORGES, José Carlos. Neblina. Curitiba: Ed. Guaíra Ltda, [1940].

BORTULUCCE, Vanessa Beatriz. A arte dos regimes totalitários do século XX: Rússia e Alemanha. São Paulo: Annablume; Fapesp. 2008.

BOSI, Alfredo. História concisa da literatura brasileira. São Paulo: Cultrix, 2006.

BRANCO, Aloysio. Alguns aspectos da prosa alagoana. Jornal de Alagoas, Maceió, 31 maio. 1933, p.3.

BROCA, Brito. Um livro de Almir de Andrade. A Gazeta, São Paulo, 15 dez. 1939.

BUENO, Luís Gonçales. Uma História do Romance Brasileiro de 30. São Paulo:

Edusp; Campinas: Editora da Unicamp Campinas, 2006.

CABRAL, Elza. O queremismo na redemocratização de 1945. Niterói: Programa de Pós-Graduação em História da Universidade Federal Fluminense, 1984.

CAMPELO DE SOUZA, Maria do Carmo. Estado e partidos políticos no Brasil (19301964), São Paulo, Editora Alfa-Omega, 1976.

CAMPOS, Cynthia M. A política da língua na era Vargas. Campinas: Editora da Unicamp, 2006. 
CAMPOS, Francisco. O estado nacional: sua estrutura seu conteúdo ideológico. Rio de Janeiro: José Olympio, 1940.

CAMPOS, Haroldo de. Miramar na Mira. In: ANDRADE, Oswald de. Obras completas II: Memórias sentimentais de João Miramar e Serafim Ponte Grande. Rio de Janeiro: Civilização brasileira, 1978.

CANDIDO, Antonio. A revolução de 1930 e a cultura. In: A educação pela noite e outros ensaios. São Paulo: Ática, 1987.

CAPELATO, Maria Helena. Multidões em cena. Propaganda política no varguismo e no peronismo. Campinas: Papirus, 1998.

CARONE, Edgar. O Estado Novo (1937-1945). Rio de Janeiro: Difel, 1977. . O PCB São Paulo: Difel, 1982.

CARVALHO, Marta Maria Chagas de. O Manifesto e a Liga Internacional pela Educação Nova. In: XAVIER, Maria do Carmo (org.). Manifesto dos pioneiros da educação: um legado educacional em debate. Rio de Janeiro: Editora FGV, 2004. . O território do consenso e a demarcação do perigo: política e memória no debate educacional dos anos 30. In: FREITAS, Marcos Cezar (org.) et al. Memória intelectual da educação brasileira. Bragança Paulista: EDUSF, 1999. . Molde nacional e fôrma cívica. Bragança Paulista: Edusf, 1998.

CASCUDO, Luís da Câmara. Vaqueiros e Cantadores. Belo Horizonte: Ed. Itatiaia; São Paulo: EDUSP, 1984. . Ludovico Schennhagen. Boletim de Ariel, Rio de Janeiro, ano 5, n.2, nov. 1935.

CAVALCANTI, Valdemar. Cartão de Visitas. Novidade, Maceió, n.1, 11 abr. 1931.

CHASTENET, Jacques. Vida e obra de Anatole France. In: FRANCE, Anatole. O crime de Sylvestre Bonnard. Tradução de Álvaro Moreyra. Rio de Janeiro: Editora Delta, 1963.

CHAUÍ, Marilena. Brasil: mito fundador e sociedade autoritária. São Paulo: Editora Fundação Perseu Abramo, 2000.

COSTA, Craveiro. História das Alagoas. São Paulo: Melhoramentos, 1983.

COSTA, Cristiane. Pena de Aluguel: escritores jornalistas no Brasil 1904-2004. São Paulo: Companhia das Letras, 2005.

COUTINHO, Afrânio [org.]. A polêmica Alencar-Nabuco. Rio de Janeiro: Edições Tempo Brasileiro, 1965.

CUNHA, Célio da. Educação e autoritarismo no Estado Novo. São Paulo: Cortez 
Editora/Autores Associados, 1981.

CUNHA, Fabiana Lopes da. Da marginalidade ao estrelato: o samba na construção da nacionalidade (1917-1945). São Paulo: Annablume, 2004.

CUNHA, Euclides. Os sertões: (campanha de Canudos). São Paulo: Ateliê Editorial, 2004.

CUNHA, Paulo; CABRAL, Fátima (org). Nelson Werneck Sodré entre o saber e a pena. São Paulo: Editora da UNESP, 2006.

D’ARAÚJO, Maria Celina. O Estado Novo. Rio de Janeiro: Jorge Zahar, 2000.

DA SILVA, Márcia Cabral. Infância, de Graciliano Ramos: uma história da formação do leitor no Brasil. 2004, 196 f. Tese (Doutorado em Teoria e História Literária) Instituto de Estudos da Linguagem, Universidade Estadual de Campinas, Campinas, 2004.

DIRETRIZES (revista), S-1. - Boletim n. 88 (pag.XXI). Arquivo Público Estado do Rio de Janeiro, Fundo Polícias Política no Rio de Janeiro, Setor Comunismo, Pasta 4D, Folha 00012 - (21), 12/13 abr. 1941.

DUARTE, Abelardo. Autores alagoanos e peças teatrais, Maceió: Fundação Teatro Deodoro, 1980.

DULLES, John. Comunismo no Brasil. Rio de Janeiro: Nova Fronteira, 1985.

Em MEMÓRIA de Guimarães Rosa, Rio de Janeiro: Livraria José Olympio Editora, 1968.

FARIA, Daniel. Realidade e consciência nacional. O sentido político do Modernismo. História, São Paulo, v. 26, n. 2, 2007, p. 385-405.

FARIA, Octávio. O defunto se levanta. O Jornal, Rio de Janeiro, maio 1937. . Excesso de Norte. Literatura, Rio de Janeiro, ano 4, n.10, jul. 1935.

FAUSTO, Boris. História do Brasil. São Paulo: Edusp, 2003. . A Revolução de 30: História e Historiografia. São Paulo: Brasiliense, 1970. .Getúlio Vargas: o poder e o sorriso. São Paulo: Companhia das Letras, 2006.

FERNANDES, Florestan. O que é revolução, São Paulo: Abril Cultural; Brasiliense, 1984.

FRANCHETTI, Paulo. Apresentação. In: QUEIRÓS, Eça de. O primo Basílio: episódio doméstico. São Paulo: Ateliê Editorial, 2001.

FREYRE, Gilberto. Sociologia e literatura. Lanterna Verde, Rio de Janeiro, n.4, nov. 1936, p.15.

FONSECA, Cláudia Damasceno. Irregularidades ou pitorescas? Olhares sobre as 
paisagens urbanas mineiras. In: FURTADO, Júnia Ferreira (org.). Sons, formas, cores e movimentos na modernidade atlântica. São Paulo: Annablume; Belo Horizonte: Fapemig e PPGH-UFMG, 2008.

FUSCO, Rosário. Política e letras. Rio de Janeiro: Livraria José Olympio Editora, 1940.

GARCIA, Nelson Jahr. Estado novo: ideologia e propaganda política; a legitimação do Estado autoritário perante as classes subalternas. São Paulo: Loyola, 1982.

GAY, Peter. Modernism: the lure of heresy. New York: W.W. Norton, 2008.

GOMES, Ângela Castro (org). Capanema: o ministro e seu ministério. Rio de Janeiro: Editora FGV, 2000. História e historiadores. Rio de Janeiro: Editora FGV, 1999.

GOMES, Paulo Emílio Sales. Cinema: trajetória no subdesenvolvimento. São Paulo: Paz e Terra, 1996.

GOMES, Renato Cordeiro. Todas as cidades, a cidade. Rio de Janeiro: Rocco, 1994.

GUIMARÃES, Silvana Goulart. Sob a verdade oficial: ideologia, propaganda e censura no Estado Novo. São Paulo: Marco Zero; Programa Nacional do Centenário da República e Bicentenário da Inconfidência Mineira: MCT/CNPq, 1990.

GUIMARÃES, Osias. Amor à terra. Rio de Janeiro: Departamento de Imprensa e Propaganda, 1941.

HILAIRE, Auguste de Saint. Viagem pelas províncias do Rio de Janeiro e Minas Gerais. São Paulo: Edusp; Belo Horizonte: Itatiaia, 1975.

HOLANDA, Aurélio Buarque de. Linguagem e estilo de Machado de Assis. Revista do Brasil, Rio de Janeiro, $3^{\text {a }}$ fase, ano II, n.13, p.55.

HORTA, José Silvério Baía. O hino, o sermão e a ordem do dia: a educação no Brasil (1930-1945). Rio de Janeiro: Ed. UFRJ, 1994.

JUNIOR, Peregrino. Sobre Graciliano Ramos e Gilberto Freyre. Careta, Rio de Janeiro, 14 set. 1935.

KAREPOVS, Dainis. Luta subterrânea, O PCB em 1937-1938. São Paulo: Editora Hucitec; Editora UNESP, 2003.

LEAL, Vitor Nunes. Coronelismo, enxada e voto: o município e o regime representativo no Brasil. São Paulo, Alfa-Ômega, 1975.

LAFETÁ, João Luiz. 1930: a crítica e o Modernismo. São Paulo: Duas Cidades; Editora 34, 2000. 
LAMPEÃO entrevistado por Novidade, Novidade, Maceió, n.6, 16 maio 1931, p.8.

LOVE, Joseph et. al. O poder dos Estados. Análise regional. In: FAUSTO, Boris

(dir.).História Geral da Civilização Brasileira. São Paulo: Difel, vol. 1, tomo 3, 1975.

LIMA, Nísia Trindade. Um sertão chamado Brasil. Rio de Janeiro: Revan, 1999.

LUCA, Tania Regina. Coerção e persuasão no Estado Novo. São Paulo, BrHistória, ano 1, n.5, [?], p.22-33.

MARTIN, Gabriela, Pré-história do Nordeste do Brasil. 4. ed. Recife: Ed. Universitária da UFPE, 2005.

MELO, J.M. Jornalismo Brasileiro. Porto Alegre, Sulina, 2003.

MELO, Ana Amélia M. C. Pensando o Brasil: os escritos de Graciliano Ramos durante o Estado Novo. In: ALMEIDA, Angela Mendes de; ZILLY, Berthold; LIMA, Eli Napoleão de (orgs). De sertões, desertos e espaços civilizados. Rio de Janeiro: Mauad; Faperj, 2001.

MELO E SOUZA, Gilda de. Tupi e o alaúde. São Paulo: Duas Cidades; Ed. 34, 2003.

MENDES, Rogério Baptistini. “Os intelectuais e a construção do Brasil moderno”, In: VECCHIO, Angelo Del; TELAROLLI, Sylvia. Literatura e política brasileira no século XX. Araraquara: Laboratório Editorial FCL/Unesp; São Paulo: Cultura Acadêmica Editora, 2006.

MENDONÇA, Marina Gusmão de. Imprensa e política no Brasil: Carlos Lacerda e a tentativa de destruição da Última Hora. Histórica - revista eletrônica do Arquivo do Estado, São Paulo, n.31, jun. 2008. Disponível em: <http://www.historica.arquivoestado.sp.gov.br/materias/anteriores/edicao31/ materia04/ >. Acesso em 06 out. 2009.

MENEZES, Djacir. O outro Nordeste: formação social do Nordeste. Rio de Janeiro: José Olympio, 1937.

MICELLI, Sérgio. Intelectuais à brasileira. São Paulo: Companhia das Letras, 2001.

MOREYRA, Álvaro. Dom Casmurro, ano 1, n.1, 13 maio 1937, p.1.

MOTA, Carlos Guilherme. Ideologia da cultura brasileira (1933-1974). São Paulo: Ática, 2002.

NETTO, Rubens F. O sentido da União Nacional, Cultura: Mensário Democrático, ano 1, n.2, nov. 1938.

OLIVEIRA, Lúcia Lippi. et al. Estado Novo: ideologia e poder. Rio de Janeiro: Zahar Editores, 1982. 
“Estado Novo e a conquista de espaços territoriais e simbólicos”. Política \&

Sociedade, Dossiê Estado Novo: Idéias, Práticas e Instituições, Florianópolis, vol. 7, n. 12, abr. 2008.

Americanos: representações da identidade nacional no Brasil e nos EUA. Belo

Horizonte: Editora da UFMG, 2000.

OLIVEIRA, José Eduardo. O discurso democrático no pós-guerra: a voz do PCB.

2003, 338f. Tese (Doutorado) - Faculdade de Filosofia Letras e Ciências Humanas.

Universidade de São Paulo, São Paulo, 2003.

ORTIZ, Renato. Cultura brasileira e identidade nacional. São Paulo: Editora Brasiliense, 1985.

PACHECO, Eliezer. O Partido Comunista Brasileiro (1922-1964). São Paulo: Alfa Ômega, 1984.

PANDOLFI, Dulce Chaves. Os anos 1930: as incertezas do regime. In: Ferreira, J.;

DELGADO, L. A. N. Brasil Republicano. O tempo do nacional-estatismo: do início da década de 1930 ao apogeu do Estado Novo. Rio de Janeiro: Civilização Brasileira, 2007.

PARANHOS, Adalberto. Os desafinados do samba na cadência do Estado Novo. Rio de Janeiro, Nossa História, ano 1, n.4, fev. 2004.

PATARRA, Neide. Dinâmica populacional e urbanização no Brasil: o período pós 1930. In: O Brasil Republicano. Rio de Janeiro: Bertrand Brasil, vol. 3, 1995.

PAULO, Heloísa. Estado Novo e propaganda em Portugal e no Brasil: o SPN/SNI e o DIP. Coimbra: Livraria Minerva, 1994.

PÉCAUT, Daniel. Intelectuais e a política no Brasil: entre o povo e a nação. São Paulo: Ática, 1990.

PENHA, Eli Alves. A criação do IBGE no contexto da centralização política do Estado Novo. Rio de Janeiro: Secretaria de Planejamento, Orçamento e Coordenação, Fundação Instituto Brasileiro de Geografia e Estatística, Centro de Documentação e Disseminação de Informações, 1993.

PINTO, Estevão. História de uma estrada de ferro do Nordeste. Col. Documentos Brasileiros. Rio de Janeiro: José Olympio Editora, 1949.

PORTO, Walter Costa (coord). As constituições brasileiras. v.4. A Constituição de 1937. Brasília, Ministério da Ciência e Tecnologia, Centro de Estudos Estratégicos, 1999.

PRESTES, Anita Leocádia. Da insurreição armada (1935) à “união nacional” (1938- 
1945): a virada tática na política do PCB. São Paulo: Paz e Terra, 2001.

QUEIROZ, Maria Isaura Pereira de. Carnaval Brasileiro: o vivido e o mito. São Paulo:

Editora Brasiliense, 1992.

REBELO, Marques. Oscarina / Três caminhos. Rio de Janeiro: Edições O Cruzeiro, 1948.

. A estrela sobe. Rio de Janeiro: Edições O Cruzeiro, 1949.

. Marafa. Rio de Janeiro: Edições O Cruzeiro, 1947.

. Cenas da vida brasileira (suítes n.1). Rio de Janeiro: Pongetti, 1944.

. Cenas da vida brasileira (suítes n.1 e 2). Rio de Janeiro: Edições O Cruzeiro, 1951.

. Cenas da vida brasileira. pref. Herberto Sales. Rio de Janeiro: Edições de

Ouro, [?].

. Stela me abriu a porta. Porto Alegre. Edição da Livraria do Globo, 1942.

. O espelho partido. v.1 O trapicheiro. São Paulo: Martins, 1959.

. O espelho partido. v.2 A mudança. São Paulo: Martins, 1963.

REGO, José Lins. Gordos e magros ensaios. Rio de Janeiro: C.E.B., 1942.

A Literatura Proletária. Dom Casmurro, Rio de Janeiro, ano 1, n.3, maio 1937,

p. 6.

. O comunista Graciliano Ramos. [?], [Rio de Janeiro?], 1945. Arquivo

Graciliano Ramos, Instituto de Estudos Brasileiros, Série Recorte, Pasta 16, Documento 30).

RICARDO, Cassiano. Marcha para o oeste. Rio de Janeiro: Jose Olympio, 1940. . Getúlio Vargas e a nova inteligência do Brasil. Estudos e Conferências, Rio de Janeiro, p.34-35.

. Viagem no tempo e no espaço. Rio de Janeiro: José Olympio, 1970.

RIDENTI, Marcelo et al. Intelectuais e Estado. Belo Horizonte: Editora da UFMG, 2006.

RUBIM, Antônio Canelas. Partido Comunista, Cultura e Política Cultural. 1986. 415fl.

Tese (Doutorado) - Faculdade de Filosofia Letras e Ciências Humanas. Universidade de São Paulo, São Paulo, 1986. . Marxismo, cultura e intelectuais no Brasil. Salvador: Centro editorial e didático da

UFBA, 1995.

RUGENDAS, Johann Moritz. Voyage pittoresque dans le Brésil. Paris: Engelmann \& Cie., 1835. 
RUGENDAS, João Maurício. Viagem pitoresca através do Brasil. trad. Sérgio Milliet, Belo Horizonte: Ed. Itatiaia; São Paulo: Ed. da Universidade de São Paulo, 1979, p.167.

SAINT-HILAIRE. Quadro geral do sertão. In: . Viagem pelas províncias do Rio de Janeiro e Minas Gerais. São Paulo: Edusp; Belo Horizonte: Itatiaia, 1975.

SANT’ANA, Moacir Medeiros. História da imprensa em Alagoas (1831-1981).

Maceió: Arquivo Público de Alagoas, 1987.

SCHMIDT, Augusto Frederico. Nós literatos. Literatura, Rio de Janeiro, ano 1, n.2, 20 jul. 1933.

SCHWARTZMAN, Simon. Tempos de Capanema. São Paulo: Paz e Terra; Fundação Getúlio Vargas, 2000.

SCHWENNHAGEN, Ludwig. Antiga História do Brasil, de 1100 A. Crh. a 1500 Dep. Chr. Theresina: Imprensa Official, 1928.

SEBE, José Carlos. Carnaval, carnavais. São Paulo, Ática, 1986.

SENNA, Homero. República das letras. Rio de Janeiro: Gráfica Olímpica Editora Ltda, 1968, p.188.

SEVCENKO, Nicolau. Literatura como missão: tensões sociais e criação cultural na Primeira República. São Paulo: Brasiliense, 1983.

SILVA, Fernando Teixeira et SANTANA, Marco Aurélio. O equilibrista e a política: o "Partido da Classe Operária” (PCB) na democratização. In: FERREIRA, Jorge et REIS, Daniel A. Nacionalismo e reformismo radical (1945-1964). v.2, As esquerdas no Brasil. Rio de Janeiro: Civilização Brasileira, 2007.

SILVEIRA, Joel. Onda Raivosa. 1.ed. São Paulo: Editora Rumo Limitada, 1939. Fala um Tostão. Dom Casmurro, Rio de Janeiro, 12 set. 1939.

SKIDMORE, Thomas. Brasil: de Getúlio a Castelo (1930-1964). Rio de Janeiro: Paz e Terra, 1962.

SOARES, Lucila. Rua do Ouvidor 110. Rio de Janeiro: José Olympio, 2006.

SOARES, Fábio de Macedo. “Divisão regional do Brasil”. Revista Brasileira de Geografia, Rio de Janeiro, ano 3, n. 2, p. 318-373, abr.-jun.1941.

SODRÉ, Nelson Werneck. História da imprensa no Brasil. Rio de Janeiro: Civilização Brasileira, 1966.

SODRÉ, Antonio. Santos=Dumont, um herói brasileiro. São Paulo: Arindiuva Editora, 2006.

SOUZA, José Inácio de Melo. O estado contra os meios de comunicação (1889-1945). 
São Paulo: Annablume/Fapesp, 2003.

SPIX, Johann Baptist von. Viagem pelo Brasil: 1817-1820. Belo Horizonte: Ed. Itatiaia; São Paulo: Ed. da Universidade de São Paulo, 1981.

SUSSEKIND, Flora. Tal Brasil, qual romance?. Rio de Janeiro: Achiamé, 1984.

TAKAMI, Marina. Fotografia em marcha: revista S.Paulo - 1936. 2008. 186f.

Dissertação (Mestrado). Programa de Pós-graduação Interunidades em Estética e História da Arte. Universidade de São Paulo, São Paulo, 2008.

TÁVORA, Franklin. Cartas a Cincinato. Estudos críticos de Semprônio sobre O gaúcho e Iracema. Pernambuco: J. W. Medeiros, 1872. . O Cabeleira. São Paulo: Ática, 1977.

TEIXEIRA, Baptista (Cap. Delegado Especial). Relatório ao Exmo. Sr. Dr. Chefe de Polícia. Arquivo Público Estado do Rio de Janeiro, Fundo Polícias Política no Rio de Janeiro, Setor Comunismo, Pasta 4D, Anexo 174, 3 nov. 1939.

VARGAS, Getúlio. A nova política do Brasil. Rio de Janeiro: Livraria José Olympio Editora, [1938-1941]. 8v. . O governo trabalhista do Brasil. Rio de Janeiro: Livraria José Olympio Editora, 1952.

VELLOSO, Mônica Pimenta. Literatura como espelho da nação. Estudos Históricos, Rio de Janeiro, vol. 1, n.2, 1988.

. Os intelectuais e a politica cultural no Estado Novo. In: FERREIRA, Jorge; NEVES, Lucília de Almeida (orgs). O Brasil Republicano. 1 ed. livro 2. Rio de Janeiro: Civilização Brasileira, 2003.

. A brasilidade verde-amarela: nacionalismo e regionalismo paulista. Rio de Janeiro, Estudos Históricos, 1993.

XAVIER, Libânia Nacif. O manifesto dos pioneiros da educação nova como divisor de águas na história da educação brasileira. In: XAVIER, Maria do Carmo (org.). Manifesto dos pioneiros da educação: um legado educacional em debate. Rio de Janeiro: Editora FGV, 2004

\section{Coleções de periódicos}

Periódicos getulistas

ATLÂNTICO. Lisboa: Secretariado da Propaganda Nacional de Lisboa; Departamento 
de Imprensa e Propaganda. 1942-1947.

AUTORES E LIVROS (suplemento de A MANHÃ). Rio de Janeiro. São Paulo, 19411945.

BRASIL NOVO. Rio de Janeiro: Departamento Nacional de Propaganda. 1938-1941 (com falhas).

BRASIL DE HOJE, DE ONTEM E DE AMANHÃ. Rio de Janeiro: Departamento de Imprensa e Propaganda. 1940-1943. Mensal.

BRASIL REPORTAGENS. Rio de Janeiro: Departamento de Imprensa e Propaganda. 1944. Mensal.

CIÊNCIA POLÍTICA. Rio de Janeiro: Instituto Nacional de Ciência Política. 19401945.

CULTURA POLÍTICA. Rio de Janeiro: Departamento de Imprensa e Propaganda. 1941-1945. Mensal.

DOS JORNAIS. Rio de Janeiro: Departamento de Imprensa e Propaganda. 1941-1943. Mensal.

ESTUDOS E CONFERÊNCIAS. Rio de Janeiro: Departamento de Imprensa e Propaganda. 1940-1944. Mensal.

PLANALTO. São Paulo: Departamento de Imprensa e Propaganda de São Paulo. 19411942. Quinzenal.

POLÍTICA - ARQUIVO DE ESTUDOS POLÍTICOS. São Paulo. 1944-1945.

SÃO PAULO DE HOJE, ONTEM E AMANHÃ. São Paulo: Departamento de Imprensa e Propaganda de São Paulo. 1941-948.

Periódicos comunistas ou influenciados pelo PCB

CULTURA: mensário democrático. São Paulo. 1938-1940. Mensal (com falhas).

CLASSE OPERÁRIA. São Paulo: Partido Comunista do Brasil. 1949 (com falhas).

DIRETRIZES. Rio de Janeiro. 1938-1945 (com falhas).

ESFERA: revista de letras, artes e ciências. Rio de Janeiro. 1938 e 1944 (com falhas).

FUNDAMENTOS. São Paulo: Empreza O Papel Ltda. 1948-1953 (com falhas).

IMPRENSA POPULAR. Rio de Janeiro. 1947-1951 (com falhas).

LEITURA: crítica e informação bibliográfica. Rio de Janeiro. 1942-1946 (com falhas).

RENOVAÇÃO: revista universitária de cultura. Rio de Janeiro. 1939-1940 (com falhas). 
REVISTA DO POVO: Cultura e orientação popular. Rio de Janeiro. 1945-1946.

Mensal (com falhas).

PARTIDÁRIOS DA PAZ. Rio de Janeiro: Movimento Brasileiro dos Partidários da Paz. 1951-1952 (com falhas).

PARATODOS. Rio de Janeiro. 1949-1950 (com falhas).

PROBLEMAS. São Paulo: Gr. A Propagandista Ltda. 1937-1938 (com falhas).

TRIBUNA POPULAR: Unidade, Progresso, Democracia. Rio de Janeiro. 1945-1947 (com falhas).

Periódicos alagoanos

JORNAL DE ALAGOAS. Maceió: Empresa Jornal de Alagoas. 1909-1915, 1930-1933. Diária.

O ÍNDIO: jornal independente, litterario e noticioso. Palmeira dos Índios. 1921

NOVIDADE. Maceió. 1931.

Periódicos diversos

ANUÁRIO BRASILEIRO DE LITERATURA. Rio de Janeiro: Pongetti, 1937-1944.

Anual.

BOLETIM DE ARIEL: mensario critico-bibliographico de lettras, artes e sciencias. Rio de Janeiro: Ariel. 1932-1934. Mensal.

$1^{\circ}$ SUPLEMNTO (suplemento do DIÁRIO DE NOTÍCIAS). Rio de Janeiro: 19371943. Semanal

DIÁRIO DE PERNAMBUCO. Pernambuco: Diário de Pernambuco. 1935-1936.

DOM CASMURRO. Rio de Janeiro: Grande Hebdomadário Brasileiro. 1937-1942. Semanal.

LANTERNA VERDE: boletim da Sociedade Felippe D'Oliveira. Rio de Janeiro: A Sociedade. 1934-1944.

LITERATURA. Rio de Janeiro. 1933-1934. Quinzenal.

OBSERVADOR ECONÔMICO E FINANCEIRO. Rio de Janeiro. 1937-1945.

O CRUZEIRO. Rio de Janeiro: Empresa Grafica O Cruzeiro. 1937-1941

PARAYBA DO SUL. Paraíba do Sul, Rio de Janeiro. 1915.

REVISTA ACADÊMICA. Rio de Janeiro. 1935-1941. 
REVISTA DO BRASIL (3 ${ }^{a}$ fase). Rio de Janeiro: 1938-1944.

VAMOS LER!. Rio de Janeiro. 1937-1945.

\section{Instituições de pesquisa visitadas}

Arquivo Edgar Leuenroth da Universidade Estadual de Campinas

Arquivo do Estado - São Paulo

Arquivo Nacional

Arquivo Público de Alagoas

Arquivo Público do Estado do Rio de Janeiro

Biblioteca Mário de Andrade

Biblioteca da Faculdade de Filosofia Letras e Ciências Humanas (USP)

Biblioteca da Faculdade de Educação

Instituto Histórico e Geográfico de Alagoas

Casa Museu Graciliano Ramos (Palmeira dos Índios)

Fundação Casa de Rui Barbosa

Centro de Documentação e Memória da Universidade Estadual Paulista (Unesp)

Centro de Pesquisa e Documentação da Fundação Getúlio Vargas (FGV)

Instituto de Estudos Brasileiros da Universidade de São Paulo (USP)

Junta Comercial de São Paulo (JUCESP)

Museu Paulista

Projeto Portinari 
Thiago Mio Salla

\title{
O FIO DA NAVALHA: Graciliano Ramos e a revista Cultura Política
}

\author{
Volume II
}


Thiago Mio Salla

\title{
O FIO DA NAVALHA: Graciliano Ramos e a revista Cultura Política
}

\author{
Volume II
}

Tese de Doutorado apresentada ao Programa de Pósgraduação em Ciências da Comunicação, Área de Concentração "Teoria e Pesquisa em Comunicação", Linha de Pesquisa "Estética e História da Comunicação", da Escola de Comunicações e Artes da Universidade de São Paulo, como exigência parcial para obtenção do Título de Doutor em Comunicação.

Orientador: Prof. Dr. Ivan Prado Teixeira. 
SALLA, Thiago Mio

O fio da navalha: Graciliano Ramos e a revista Cultura Política. São Paulo, 2010, $2 \mathrm{v}, 721 \mathrm{f}$

Tese de Doutorado apresentada ao Programa de Pós-graduação em Ciências da Comunicação, Área de Concentração “Teoria e Pesquisa em Comunicação”, Linha de Pesquisa "Estética e História da Comunicação", da Escola de Comunicações e Artes da Universidade de São Paulo, como exigência parcial para obtenção do Título de Doutor em Comunicação.

Orientador: Prof. Dr. Ivan Prado Teixeira.

1. Graciliano Ramos 2. Cultura Política 3. Estado Novo 4. Viventes das Alagoas 5. "Quadros e costumes do Nordeste" 
Thiago Mio Salla

\section{O FIO DA NAVALHA: Graciliano Ramos e a revista Cultura Política.}

Tese de Doutorado apresentada ao Programa de Pós-graduação em Ciências da Comunicação, Área de Concentração "Teoria e Pesquisa em Comunicação”, Linha de Pesquisa "Estética e História da Comunicação", da Escola de Comunicações e Artes da Universidade de São Paulo, como exigência parcial para obtenção do Título de Doutor em Comunicação.

Orientação: Prof. Dr. Ivan Prado Teixeira.

BANCA EXAMINADORA

$\operatorname{Prof(a).~Dr~(a).~}$

$\operatorname{Prof}(\mathrm{a}) . \operatorname{Dr}(\mathrm{a})$.

$\operatorname{Prof}(a) . \operatorname{Dr}(a)$.

$\operatorname{Prof}(\mathrm{a}) . \operatorname{Dr}(\mathrm{a})$.

Prof(a). Dr (a).

São Paulo de de 2010 


\title{
Sumário - Volume 2
}

\section{ANEXO 1 - Proposta de edição de textos de Graciliano Ramos inéditos em livro, intitulada Garranchos}

\author{
Breve apresentação dos textos

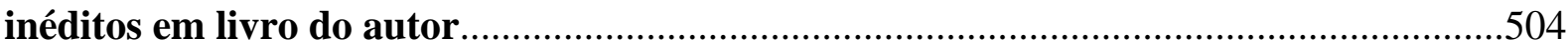

\section{Garranchos}

\section{Anos 10}

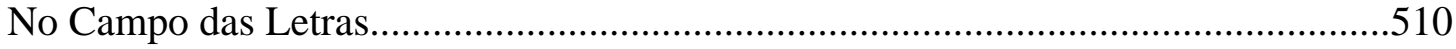

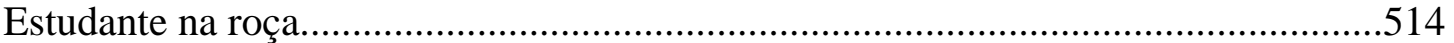

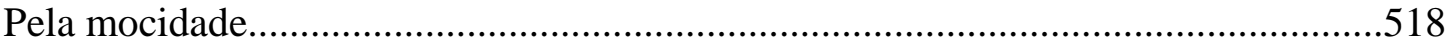

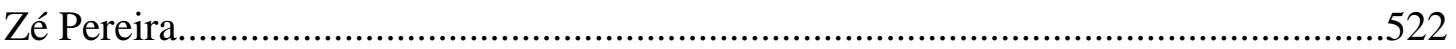

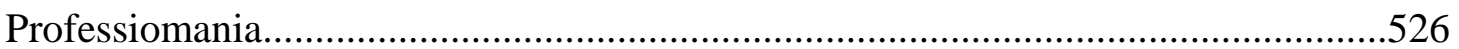

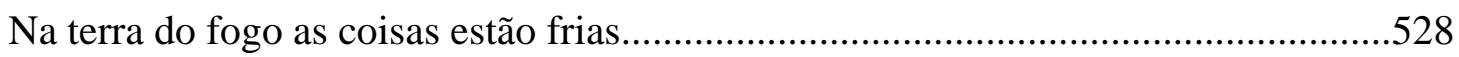

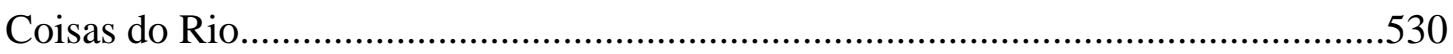

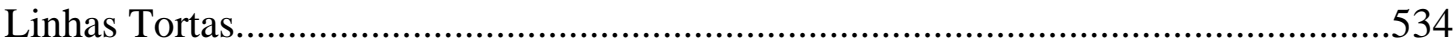

Anos 1920
Garranchos




XIV

\section{Anos 1930 ainda em Maceió}

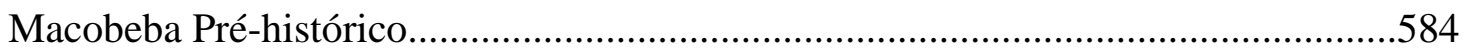

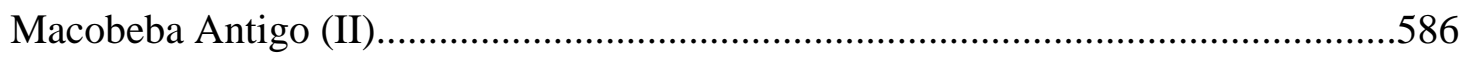

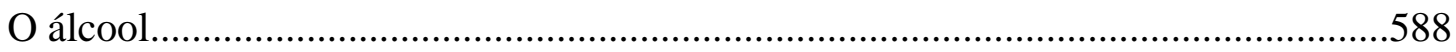

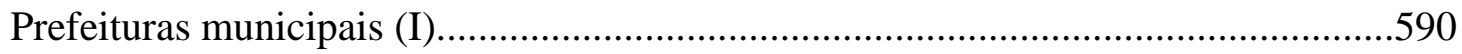

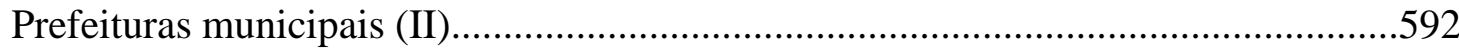

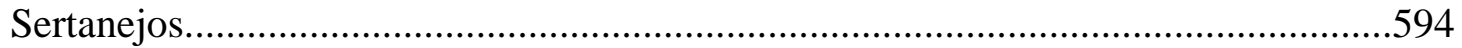

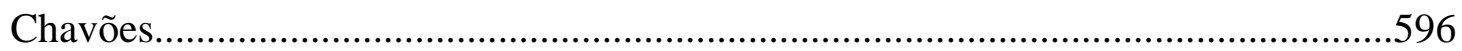

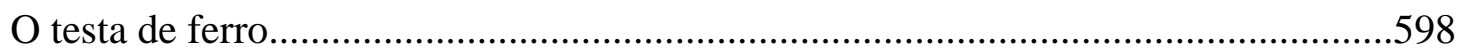

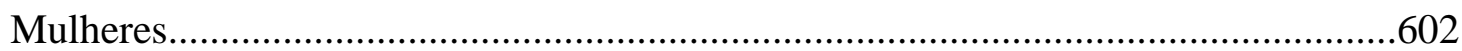

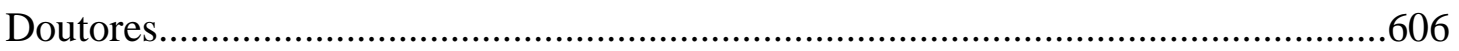

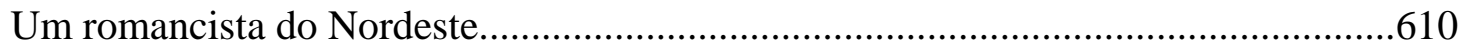

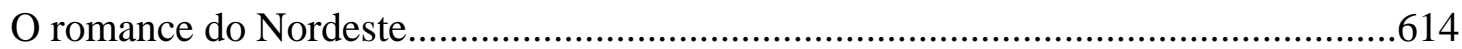

Alguns números relativos à instrução primária em Alagoas.......................................618

\section{Depois da saída da prisão (em 1937)}

Uma carta de Graciliano Ramos..............................................................................624

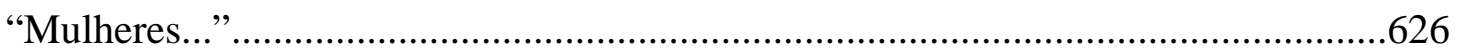

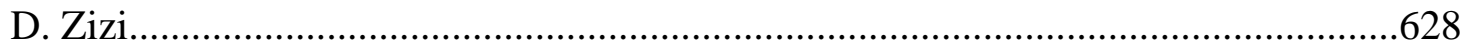

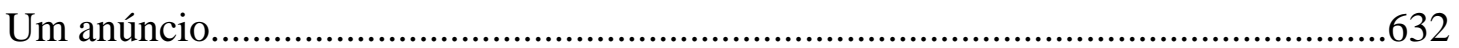

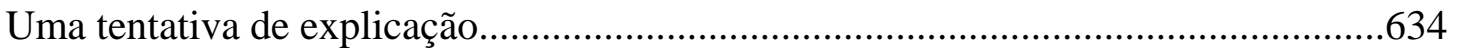

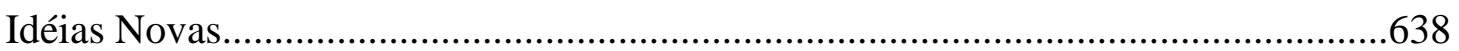

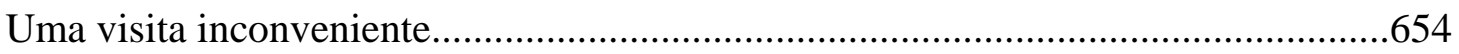

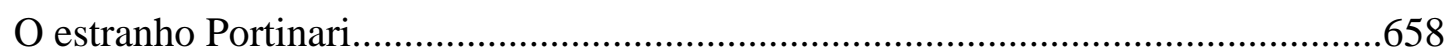


Depois da entrada no PCB (em 1945)

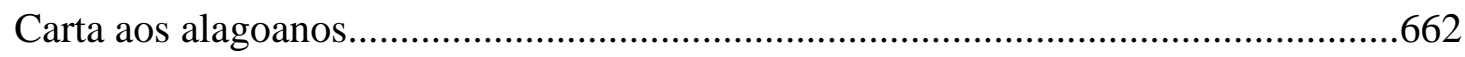

O Partido Comunista e a criação literária..............................................................664

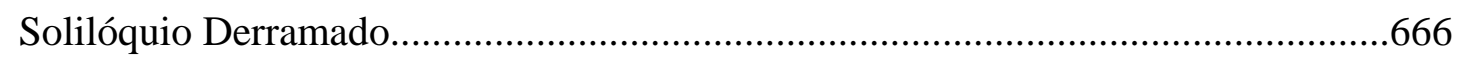

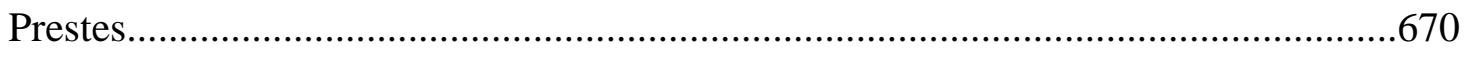

O último romance de Alina Paim..........................................................................674

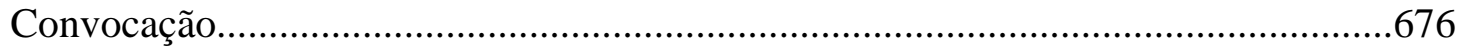

Viver em paz com a humanidade inteira................................................................678

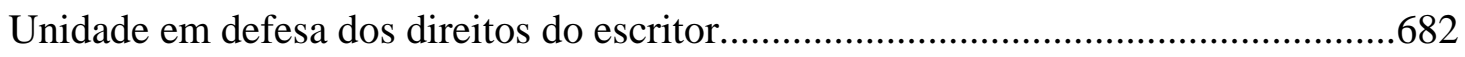

Apelo de Graciliano Ramos aos intelectuais brasileiros..........................................686

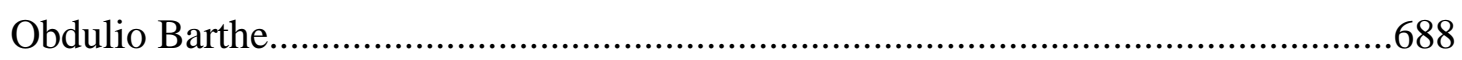

\section{Anexo II - Graciliano e os periódicos: referências}

Produções ficcionais localizadas na imprensa...............................................................692

Dados coletados sobre local e data da primeira veiculação em

periódico das crônicas de Linhas Tortas e Viventes das Alagoas. .698

Índice geral dos textos do autor veiculados na imprensa por ordem de data. .704 
Anexo 1

Proposta de edição de textos de Graciliano Ramos inéditos em livro, intitulada Garranchos 


\section{Breve apresentação dos textos inéditos em livro do autor}

Conforme exposto na Introdução ao Volume I, reúnem-se aqui 58 textos de Graciliano Ramos ainda inéditos em livro, recolhidos ao longo das pesquisas de campo em diferentes acervos brasileiros. Nesse conjunto, estão presentes desde crônicas e artigos de crítica literária, até discursos, cartas e o primeiro ato de uma peça de teatro intitulada "Idéias Novas", na qual o artista alagoano utiliza o gênero dramático para discutir, fundamentalmente, literatura.

Ao mesmo tempo, nessa coletânea, figuram desde escritos nos quais o autor ainda se vale de diferentes pseudônimos, abreviaturas e iniciais (Lambda, J. Calisto, Lúcio Guedes, X, R.O., J.C. G.R.) $)^{917}$ até aqueles em que já os assina com o nome pelo qual se tornou literariamente consagrado. Se variam também quanto ao gênero e aos traços de autoria, o mesmo se pode dizer no que diz respeito aos assuntos. Destaque para aspectos da vida provinciana, para exaltação da arte dos romancistas nordestinos, para o apoio à gestão do governador Álvaro Paes na década de 1930, para os debates literários da capital do país, num momento posterior a sua saída do cárcere, e para a militância comunista em seus últimos anos de vida.

Nesse sentido, como abarcam diferentes fases e inflexões da atividade intelectual do escritor, os textos foram agrupados em cinco blocos distintos:

- “Anos 1910”, momento de início do trabalho cronístico do jovem escritor;

- “Anos 1920”, ocasião de retomada da atividade jornalística no jornal provinciano $O$ Índio, de Palmeira dos Índios;

- “Anos 1930 ainda em Maceió”, quando Graciliano ocupa cargos administrativos na burocracia estadual e convive com o grupo de intelectuais que residia na capital alagoana, entre os quais Rachel de Queirós e José Lins do Rego;

- “Depois da saída da prisão (em 1937)”, período em que o romancista passa a morar de maneira definitiva no Rio de Janeiro e a viver de seu trabalho literário, o que o obriga a colaborar intensamente com jornais e revistas;

\footnotetext{
${ }^{917}$ Uma série de estudiosos da obra do autor confirma que ele se valera de tais pseudônimos: MIRANDA, Wander de Melo. Graciliano Ramos. São Paulo: Publifolha, 2004; PINTO, Rolando Morel. Graciliano Ramos: autor e ator. Assis, SP: Faculdade de Filosofía, Ciências e Letras de Assis, 1962; GAMA, Maria Lúcia Palma. Projeto para inéditos. Revista do Instituto de Estudos Brasileiros, São Paulo, n.35, 1993, p.201-204; SANT’ANA, Moacir Medeiros. Graciliano Ramos antes de Caetés. Maceió: Arquivo Público de Alagoas, 1983.
} 
- “Depois da entrada no PCB (em 1945)”, fase de militância política, na qual seus escritos destinam-se, sobretudo, à imprensa partidária.

Ao mesmo tempo, escolheu-se o nome Garranchos para nomear a presente miscelânea, em decorrência do fato de quatorze dos textos, ora apresentados, terem sido publicados em seção com este mesmo nome no jornal $O$ Índio, de Palmeira dos Índios ${ }^{918}$. Como se pode observar, tais escritos formam uma unidade específica no conjunto dispersivo de cerca de sessenta escritos aqui transcritos.

Ao mesmo tempo, a opção pelo referido título, recupera a tradição instaurada pelo volume póstumo Linhas Tortas (1962). Apesar de este apresentar os problemas relatados no primeiro capítulo do volume 1, a denominação "Linhas Tortas”, assim como “Garranchos” traduz bem a precariedade atribuída pelo autor a suas colaborações na imprensa, item que aparece como um lugar-comum recorrente ao longo de toda a produção jornalística de Graciliano. Visto enquanto fingimento artístico, o uso de tal artifício retórico procura antes conquistar a benevolência do leitor do que efetivamente expressar a recusa do artista pelo próprio trabalho.

De maneira geral, o objetivo desta iniciativa é ampliar o corpus do autor alagoano, e, assim, fornecer mais subsídios tanto para a recomposição de sua trajetória literária e jornalística, como para melhor fundamentação de determinados elementos concernentes a sua poética.

Como se trata de textos publicados na imprensa em diferentes períodos, eles obedecem a padrões ortográficos variados. Dessa maneira, como forma de uniformizar as grafias, optou-se pela atualização das mesmas, de acordo com as regras correntes.

\footnotetext{
${ }^{918}$ Para mais informações sobre a seção, bem como sobre a trajetória intelectual de Graciliano, ver o segundo capítulo do primeiro volume.
} 
Garranchos 
Anos 1910 


\title{
No campo das Letras
}

\author{
Ilustre sr. Redator
}

Não tenho orgulho nem pretensão de ser filólogo nem ao menos vaidade quero nutrir de saber nomear os caracteres do alfabeto ${ }^{919}$ com que sábios irradiam a luz pelo universo.

Apenas desejo compartilhar a satisfação de ver em nosso continente desenvolver-se mais vivo ardor pelo estudo e pelo movimento evolutivo das letras.

Avaliando a simplicidade e a pequena importância de que se reveste a questão, que não reclama valor algum a quem tem a honra de levantá-la, submeto o assunto à consideração dos mestres, que o saberão grandemente fazer realçar; e da luz dos comentários e da agitação da crítica espero ganhar os proventos a que tenho direito como dedicado e humilde discípulo, certo de que o vencedor não será o indivíduo mais robusto, mas a liga de operários que devem erguer o monumento, para cujo alicerce tenho a honra de conduzir meu grosseiro fragmento de sílex.

Parece que os mestres ocupando-se de certas questões gramaticais prestam menos atenção à lógica do que às páginas dos compêndios oficiais - sempre lacunares - em que inspiram-se, dando quase nenhuma originalidade a suas preleções, conforme procedem autoridades religiosas que sacrificam a razão por amor do vício da letra que mata.

Confesso que não sei elucidar muitas dificuldades na linguagem, porque a confusão, a divergência, o abuso das figuras entre os autores clássicos, não convida a um estudo perfeito, completo, agradável, ou menos penoso.

Entretanto, percebe-se o quanto são limitados os campos da ciência da gramática geral e da arte da especial.

\footnotetext{
${ }^{919}$ No original está escrito erroneamente “analfabeto”.
} 
Nas proposições implícitas expressas por verbos unipessoais é “praxe” subentender-se a palavra “tempo" como seu sujeito. Chove-o[,] “tempo” chove, ou faz cair água sob a forma de chuva.

Compreende-se bem facilmente que o "tempo" não é mais que uma circunstância e não sujeito ou agente.

O Professor Grivet, escandalizado com tal disparate, diz que estas frases, como - chove troveja - relampeja - orvalha - são destituídas de sujeito.

O meu respeito com este notável mestre - de saudosa memória - não impede-me de afirmar com apoio da lógica ter-se ele enganado redondamente.

Dizer-se que uma oração não tem sujeito vale o mesmo que admitir-se um efeito sem causa.

Não acho jeito de em aceitar a opinião de Grivet em tal sentido, nem tão pouco a dos doutos oficiais.

O sujeito de “chove” é tão claro como a água - é a própria água; e não acho desconcertado afirmá-lo.

No sentido figurado a matéria de que se compõe a chuva é sempre o sujeito: Chovem pedras; Chuveram flores sobre o orador. A elegante frase de João de Deus - “O maná que o céu lhe chove” - deve ser analisada: - O maná que lhe chove pela mercê do céu.

A idéia de ser uma redundância não exclui a virtude ser o sujeito de “chove” - água; além de que a água não se manifesta somente sob a forma divina, pulverizada pela resistência das camadas atmosféricas, sem a qual a água, em vês de “chover”, jorraria na terra.

A água vaporiza-se, condensa-se em nimbus, chove, orvalha, gela, funde-se, desliza-se no leito dos rios, jorra das cascatas, dorme na bacia dos lagos, agita-se nas extensões dos mares.

Chove: o sujeito está incluso no verbo; pelo que não deixa de existir. 
Choveu água quente, como no período primário choveu mineral fundido. Na primeira proposição, a não ser “água” o sujeito, seria lógico dizer-se choveu tempo quente, ou chuva quente?

Encarando a questão de modo análogo, afirma-se que o sujeito de troveja, de relampeja é a eletricidade, ou o fluido elétrico, de que se [acham $]^{920}$ impregnados os gazes aéreos.

Sabe-se que a eletricidade manifesta-se de várias formas: troveja, relampeja, move etc.

Figuradamente diz-se:

Os canhões trovejam; O povo trovejava gargalhadas (Camilo); ... Quando só devíamos trovejar contra seus vícios e contra seus escândalos (Mont Alverne); O leão troveja na floresta.

Faz frio - faz sol - faz calor - faz bom tempo: a estação, o inverno, a corrente de ar, o éter modificando suas vibrações, ou a causa que as modifica, é o seu sujeito. Dirá algum crítico: A estação, o inverno, o verão, é uma parte do tempo. E portanto fica sem efeito a minha argumentação, em que nego o tempo como sujeito.

Mas o bom senso percebe que a estação é caracterizada pela posição que toma a terra em sua viagem de translação, fazendo variar a intensidade dos raios solares nas diferentes zonas. E porque a estação tem o seu tempo, não segue-se que ela seja o tempo.

Desculpai-me; devo terminar aqui, sr. Redator, até que a vibrante e autorizada luz da crítica magistral venha fazer-me voltar.

Entregai aos mestres vossas colunas, incitando-os, a suscitarem questões de elevado alcance no vastíssimo campo das letras, sob as luzes que a minha pobre retina deslumbram ${ }^{921}$.

\footnotetext{
${ }^{920}$ No original está escrito “chama”. De acordo com a lógica da frase, trata-se de um erro de digitação.

${ }^{921}$ LAMBDA [Graciliano Ramos]. No Campo das Letras. Jornal de Alagoas, Maceió, 20 abr. 1909.
} 


\section{Estudante na roça}

O coronel Urbano Silvestre não podia conter o júbilo que lhe abrazava o peito ao sentir a recepção de seu filho, Constantino, a não ser bem acompanhado de todos os amigos e vizinhos, com que se distribuía o contentamento.

Toda aquela inocente aldeia, que sabia dominar, estremecia ao chegar a notícia telegráfica levada ao conhecimento do pessoal sobre o galope mais veloz que era possível conseguir-se de uma bem possante cavalgadura.

A maior parte dos que animavam a caravana, que ia receber o doutor na cidade próxima, eram mais arrastados pelos atrativos da festa do que pela simpatia que inspirava-lhe o recémchegado, porquanto era notório ligar este mais importância aos abacaxis do que aos amigos que lhos presenteavam.

D. Angélica, depois de acabado o serviço da [mesa], que animadamente se devorava em menos de quinze minutos, certa de que o filho, a quem ela unicamente servia, estava bem confortado, trata de tomar-lhe a chave do grosso baú cheio de roupa suja, sapatos, livros em desalinho, papéis, cartas, jornais e vários objetos de serventia da "república”, tendo o cuidado de os desembaraçar do "ninho de galinha choca”, colocando os livros sobre uma banca.

Em seguida punha-se a exercitar o sentido muscular, experimentando assim o peso dos mais volumosos, a correr-lhes as folhas, a lastimar a ausência de gravuras nesses "livrões que a gente não pode saber quando estão de pernas p’arriba”.

Ao mesmo tempo o velho Urbano, fazendo descansar as maxilas alguns segundos, tirando o respeitável cachimbo e deixando cair a pesada saliva, põe-se a considerar a soma de conhecimentos científicos adquirida quando um indivíduo tiver obtido a vitória de ler todos aqueles grossos livros. 
O estudante, sempre muito verboso a expandir-se exibindo seus vários conhecimentos aos visitantes curiosos a admiradores de seu “talento”, era incansável no empenho de corrigir os barbarismos e propagar as eloqüentes frases e costumes das grandes cidades que os tabaréus conhecem.

A “Boca da Mata” era um belo sítio à margem de uma riquíssima estrada comercial, onde seu proprietário mantinha um grande estabelecimento em que monopolizava os diversos ramos da vida que anima o deus do comércio em círculo respeitável assim acreditado.

Todos sabiam buscar a indispensável amizade, as necessárias garantias, que proporcionava o “chefe” aos que lhe satisfazem a cobiça.

Os produtores lhe compravam anualmente os gêneros pelo duplo de seu valor - em troca do algodão, peles, cereais, entregues sob as melhores condições, por menos da metade de seu valor intrínseco, ficando estes pobres lavradores satisfeitos pelo simples fato de gozarem do crédito e proteção do "Coroné”, que usando das prerrogativas conferidas pelo direito de chefe político, soubera fazer bem exalçar a simpatia de sua nobre posição; sem o que nenhum valor teria feito realçar a inteligência do estudante, que em dois anos conquistou (na pura decência do molde político) os preparatórios todos do enciclopédico repositório da instrução pública, sob o compasso das originais variações executadas no Liceu...

Foi no ano de 1893 em que chegou na "Boca da Mata", formado em humanidades, o dr. Constantino "Hipólito” da Silva.

Dispondo de toda fortuna de seu pai, ele, como filho único, não tendo necessidade de empregos públicos, aliás, tão disputados pelos homens de ciência e letras no País, lembrou de montar um "engenho de açúcar”, aproveitando a vastíssima extensão de terras apropriadas à cultura da cana.

No estrondoso dia de inauguração da fábrica ficaram bem patentes a popularidade e o prestígio do Doutor, por intermédio de seus discursos, a “cativar” um grande número de operários, a dispensar sua valiosa atenção a todos que se julgavam bem venturosos naquele momento por merecê-la. 
Dentre seus admiradores salienta-se o vigário francês chamado, contratado para benzer o “engenho”, o qual, graças ao gênio do Doutor, depois de repetidos exercícios, conseguiu modificar o sotaque francês que emprestava ao latim; mas sempre deixava escapulir o "vobis côme” na pronúncia instintiva da missa.

D. Angélica não deixava de ser interrogada pelo cura, a quem dava-lhe contas do estado moral de seu povinho: - Que fim levou o malvado que fez mal à menina?

- Já o "não sei o que” o levou para o inferno (meu Deus me perdoe) e ela também devia morrer pra não ser desavergonhada...

E ouvindo soar o sino a chamada da missa, logo tomou uma inflexão de voz eclesiástica e articulou "angelicalmente":

- Vamos descontar os pecados na missa; não é assim?

- Depois da confission, com certeza, senhora!

Todos aplaudiram a feliz idéia que teve o proprietário em espalhar centenas de avulsos mostrando "gramaticalmente” que em vez de “A Boca da Mata” fiquem chamando a propriedade de "O Boca da Mata”. Sem o menor trabalho o Doutor demonstrou à prole o valor da elegância da inovação, excetuando-se alguns que ele repreendia severamente, considerando que a maior desgraça de um país é alimentar-se uma população iletrada.

Foi então que os demais proprietários seguiram a moda; e os indivíduos que se esforçavam em parecer menos rústicos, já sabiam dizer: "Eu venho do Prata, passei pelo Volta e pretendo ainda chegar hoje no Lama”.

Graças à baixa do câmbio, durante uns cinco anos, o Doutor teve a "felicidade bruta" de multiplicar a sua fortuna, que, reunida à herança de seu velho pai falecido, constituía uma grande soma entre os pobres capitalistas do norte; o que dera-lhe a coragem de montar uma usina. 
Sem nenhum embaraço de cogitações, o proprietário letrado, no dia de inauguração de sua usina, fez espalhar novos avulsos por toda a parte no sentido de levar ao conhecimento de todos a mudança para a primitiva forma feminina da denominação do sítio, que voltou à propriedade, a chamar-se “A Boca da Mata”.

D. Angélica, o tipo das velhas caturras, ficou muito contente com a restauração almejada e bem convencida de que "toda essa moderna república, toda essa pouca vergonha tem de cair com os poderes de Deus”.

Clama sempre contra a civilização moderna: “- Não posso mais comer na mesa junto do meu filho com aquela moda de chamar à carne fresca “carne verde”; é uma coisa que me arrepugna e lembra-me a carne daquele marvado (meu Deus me perdoe, si é pecado, que a treva lhe seja leve, já que não teve encomendação na Igreja) aquele excomungado que os demonho levoulhe a alma (que não lhe sirva lá de pena); quando a justiça desenterrou-lhe aqui a carne, era verde que nem as asas do cão daquele quadro da morte do pecador que seu vigário me deu. Uma coisa também eu desconfio que meu filho parece não ter mais o temor de Deus: quando ele ensina tal regência da gramática ao [primo], vem com uma idéia do bode:

"Deus é sujeito”! Eu não fico em mim, quando me entra isso pelo ouvido! Não é esse o inzemplo da criação que lhe dou.

Como não querem mais a escravidão, acham bom que Deus fique sujeito”.

LAMBDA $^{922}$.

${ }^{922}$ LAMBDA [Graciliano Ramos]. Estudante na roça. Jornal de Alagoas, Maceió, 13 mar. 1910. 


\section{Pela mocidade}

Quando estudante, uma tarde, ao passar pela rua dos Borbons, à pequena distância do quartel, viera de encontro a mim apressadamente um homem com ares de comerciante, trajando paletó de palha de seda; uns quatro passos distantes de mim vi cair-lhe do bolso um grosso rolo de papel moeda: ,quando lhe quis avisar, já ele a passos largos distanciava-se; soltei-lhe uma série de interjeições que a ventania desviara.

Dir-se-ia ser um sopro diabólico a tentar-me a alma. A sentinela do quartel deteve-lhe os passos apontando para mim e ele deu a meia volta, avistou-me com a bengala sobre o rolo de dinheiro, que o vento queria esbanjar e partiu para meu lado.

Antes que o indivíduo se aproximasse de mim, - para fugir dessa tradicional cena de agradecimento, daquela mais triste e revoltante do pagamento do achado - retirando-me incontinenti, acrescentei: aqui está o que lhe pertence. A passos dobrados afastei-me virando a esquina das Marrecas, em busca de minha residência na rua do Passeio.

Embriagado pelo contentamento, o nosso homem deu a correr atrás de mim, reproduzindo o que eu lhe houvera feito, sem dúvida no "louvável” intuito de recompensar-me, visto como nem eu, nem o vento tivera subtraído parcela alguma daquela soma.

E logo teve ele de recuar em vista de minha severa indiferença.

Nem sequer tive o tempo de lhe guardar os traços fisionômicos.

Chegando na "república”, aos companheiros, naturalmente narrei-lhes o ocorrido.

Maioria deles revoltaram-se.

- Impossível! 
- Se procedeu assim, não tem bom juízo!

- Eu tal não praticaria - declarara um outro - e por isso não creio que homem algum era tão besta...

Eram desse teor os protestos que se levantaram contra mim, pelo simples fato de haver narrado aquele caso.

- Nem ao menos - observa um dos menos escrupulosos - quiseste apresentar-te a esse homem, para que ficasses conhecido como tipo conhecido como um tipo sui generis... Só em romances costuma-se honrar a humanidade com esses feitos heróicos...

São teorias desmentidas pela prática diária.

Eis porque eu classificaria como degenerado quem assim procedesse.

Umas duas horas foram gastas na expansão dos conhecimentos filosóficos de meus colegas, que, segundo minha consciência, pelo contrário, exalçavam meu amor próprio cada vez que achavam aquele ato superior à dignidade humana, - não lhes parecendo mais que um gracejo meu.

Respondendo às apreciações menos lisonjeiras de meus colegas, observei-lhes que apenas defendia a Humanidade, em vista das acusações injuriosas que eles acabavam de atirar-lhe, sendo eu a causa involuntária.

O mundo ainda não está inteiramente pervertido. Eu sou um homem comum e não sou dos melhores. Como eu deve ser a maioria dos homens e melhores que eu há milhões de homens bem-educados.

O mundo não é o que aqui percebemos nestas quatro paredes, nem pode lhe servir de termo de comparação uma “república” de estudantes que ainda não completaram a sua educação intelectual e moral. 
É o meu voto de consciência em favor da Humanidade, que profundamente venero na pessoa dos homens dotados de amor e luz.

Aborrece a Humanidade aquele que se considera superior a ela e nesse caso não passa de um ser muito atrasado.

A mocidade, que sempre aspira ao progresso, deve inspirar-se nos grandes feitos da Humanidade.

Bem se vê que a caridade praticada com ostentação perde o seu valor; e os impulsos do coração não podem ser premeditados.

Aquele que pratica um ato bom calculadamente, no intuito de acreditar-se como homem de prestígio, sem que o coração tenha a força precisa para conservar-lhe a persistência na virtude, cedo ou tarde será desmascarado na sua hipocrisia.

Eu mereço de meus colegas a mais acre censura.

Reconheço a minha leviandade em ter feito uma tal revelação, que levaram a mal embora não a tenha sido confiada com menos simplicidade do que fora praticada aquela ação tão comum $\mathrm{a}^{923}$ muitos homens ordinários.

Só as almas obcecadas tentam justificar os seus erros.

A mocidade não deve alimentar o orgulho, que é uma barreira contra a docilidade indispensável para assimilar pela inteligência e pelo coração a sabedoria dos mestres.

LAMBDA $^{924}$.

\footnotetext{
923 No jornal a um erro tipográfico ao invés de “a”, foi colocada a conjunção “e”.

${ }^{924}$ LAMBDA [Graciliano Ramos]. Pela mocidade. Jornal de Alagoas, Maceió, 22 fev. 1911.
} 


\section{Zé Pereira}

Nos belos tempos, das melhores bernardices debaixo do Céu mais complacente, harmonia, inocência, tolerância, no fastígio imperial, florescentes energias, sedentas de luz, se fariam nutrir nessa vida tentadora do Rio de Janeiro.

Naquele tempo a esperançosa mocidade já sabia sonhar à brasileira, isto é inspirando-se na excelência do encanto intertropical - sonho invejável, - sonho vivo, rico de amor e luz.

Libertando-se dos moldes preconizados pelas fadas carunchosas, conservadoras das velharias, a mocidade tentaria desembaraçar-se da obscuridade...

Foi ali, naquela grande cidade exuberante de pompas espetaculosas que teve origem o "Zé Pereira” das folias carnavalescas.

Dois meninos - José Pereira e José Moura - tiveram a idéia de celebrizar-se, percorrendo as principais rua da cidade, atraindo um respeitável número de colegas, todos os curiosos despreocupados, como os operários e os comerciantes, alarmando a população, colhendo os jovens chefes as mais ardorosas aclamações e vias entusiasticamente elevados acima de todas as bulhas produzidas pelas gaitas e pancadarias de bombos e tambores:

\section{Zé Pereira! Viva Zé Pereira! Zé de Moura!}

E assim todos os anos subseqüentes reproduziram-se com esplendor progressivo inúmeras instituições espirituosas, fazendo perpetuarem-se as aclamações ao imortal Zé Pereira.

Quando o carnaval das províncias começou a sua imitação - o prefácio carnavalesco - hoje vulgarizados nas vésperas do "grande culto”, - os indivíduos que "por desgraça” tinham aquele apelido familiar vulgarizado, sentiram-se amargamente insultados e fugiram das janelas injuriados... 
E alguns "cazuzas", desequilibrados, corriam perseguindo o grupo inocente, atirando-lhe pedras...

- Aquele negro, Joaquim Benedito, é muito astucioso exclamava a Vovó - é ele quem vem ali dirigindo aquele insulto ao rapaz... retira-te, meu filho, fazes que não entendes...

- Deixe estar... eu tenho fé em Nossa Senhora das Dores que ele tem de levar o diabo, na faca e na bala! Meu Deus me perdoe.

Bacias d’água e vasos cheios de porcarias eram lançados sobre os “inocentes loucos”, arrastados pelas sugestões dominadoras dessas extravagâncias e fogosas manifestações carnavalescas, que sempre demonstram a fama e o valor do espírito público em um país.

Hoje é a vaidade dos “grandes” que mais ferem essas boas críticas...

Os “grandes”, que se alimentam e se ${ }^{925}$ elevam à custa do vício, não toleram essa liberdade, que desmascara pela força da crítica o que é-lhes muito caro - a infâmia...

O carnaval é, por assim dizer, a medida pela qual se avalia muito bem a capacidade moral de um governo.

Como deve ter bem o leitor observado, estas administrações impopulares, defeituosas, costumam armar toda a sua polícia, para impedirem as expansões populares e o reflexo da verdade nas manifestações francas das massas, tornando cada vez mais insípida essa tradicional festa de todas as classes, amordaçando o povo, cujo espírito a força pública detém, amoldando-o à fantasia, à conveniência do gênio despótico, usurpador e, destruidor da vida nacional e criador de parasitas sociais.

Receiam que a bulha carnavalesca chegue a espantar os ratos...

Temem que os ânimos do povo nessa orgia operem a destruição do ninho de misérias...

\footnotetext{
${ }^{925}$ Este “se” não está presente no original.
} 
Pedro II sofria calmo e respeitoso as críticas das sociedades carnavalescas, a que assistia, admirando com atenção patriótica o espírito popular. Os pseudo-soberanos são demasiado sensíveis e não toleram a mais tênue alusão que se lhes dirija...

Evitam que os calos sejam magoados e que a lepra sangre ou arda sob o calor das massas compactas...

LAMBA $^{926}$.

${ }^{926}$ LAMBDA [Graciliano Ramos]. Zé Pereira. Jornal de Alagoas, Maceió, ano IV, n. 45, 26 fev. 1911. 


\section{Professiomania}

A originalidade que se observa nos diferentes escritores sempre tem o cunho das idéias predominantes alimentadas nas respectivas profissões. Isto acentua-se tão exatamente que um qualquer letrado descobre sempre o escritor que, por modéstia - o que é raro - ou por malícia - que é comum entre os astuciosos - apresenta-se embuçado em um pseudônimo; no primeiro caso o escritor poderá mostrar nobreza de sentimentos; no segundo caso é perverso, desconfiado de suas “virtudes”, máxime tratando-se de polêmicas, onde então revela mau caráter, covardia e receia estampar a sua falida reputação.

Promovendo-se um concurso de homens de letras com o fim de obter-se uma opinião, uma definição qualquer, é comum observar-se o dedo de cada profissional que move a pena a seu modo particular.

Assentemos o binóculo sobre eles, que se aproximam tomando assento:

- A mulher - mimosa pudica - é a flor delicada sugestiva, que precisa ser tratada com toda carícia, não suporta o rigoroso hábito no clima tropical, sem modificá-lo esta doce aragem das belíssimas horas vespertinas tangidas brandamente pelo doce fragor dos saudosos leques das palmeiras, vitalizando os prados, alentando as vidas; - não resistiria às intempéries, à friagem, sem o paterno socorro da brisa do mar sereno e tépido - sem o prestigioso orvalhar das pérolas vivas do pranto a desalterar a insolação [abrasadora] do lar...

O tom acetinado de suas olorosas pétalas precisa, requer os eflúvios perpétuos de um céu benévolo, harmonioso, criado pelo soberano do amor conjugal, mantendo uma primavera eterna. 
- A mulher é a igual do homem sob o ponto de vista moral, posto que no domínio anatômico alguma diferença venha indicar as suas especiais aptidões para a vida social e doméstica, ou a falta de requisitos para o desempenho das funções varonis.

No campo da filosofia parece que a mulher ainda não se define, bem como nas ciências positivas poucos traços bem visíveis ela tem deixado escapar de suas energias latentes; o seu cultivo intelectual não chegou (geralmente falando) a um certo grau apreciável, se bem que a estrutura nervosa coisa alguma denuncie a certeza da inferioridade mental. Se o homem se conhece, não está longe de perceber os pontos de contato de sua companheira, que é um ser da mesma espécie.

- A mulher é o alicerce para a família, como esta, para a sociedade - é divina operária do Supremo Arquiteto, encarregada de fazer homens. É a força geratriz do mecanismo doméstico: - ilustrada, é alavanca do progresso espiritual; ignorante é o demônio familiar. Elevada em seus dotes naturais, torna-se a mola propulsora da eloqüência - a mira da educação moral - expoente do amor pátrio.

- A mulher é um metal finíssimo, de grande valor nas transações da vida social; dotado de extrema ductilidade, facilmente maleável, dispensa o calor das forjas e dos cadinhos; alguma variedade um pouco rara, semelhante à cera mole, mesmo a frio, não precisa dos golpes do martelo e do malho para chegar-se ao molde que lhe quer imprimir o artista.

Se, porém, não for obtido puro o doce metal, não tendo sido fornecido pelas casas acreditadas na superior indústria, as quais lhe garantam a boa procedência, alguns artistas que se reputam mais amestrados e conhecedores do segredo da arte, costumam levá-lo à bigorna e ao processo da tempera aplicado ao aço ordinário.

\section{LAMBDA $^{927}$.}

\footnotetext{
${ }^{927}$ LAMBDA [Graciliano Ramos]. Professiomania. Jornal de Alagoas, Maceió, ano VI, n.213, 26 set. 1913.
} 


\section{Na terra do fogo as coisas estão frias...}

Conforme telegrama publicado, há dias, em um de nossos melhores jornais há uma grande carência de mulheres na Terra do Fogo. Semelhante fato coisa que não [acontece com freqüência felizmente] constitui - não há sombra de dúvida - uma calamidade para um povo. Pudesse alguém interrogar os colonos portugueses das primeiras expedições que vieram ao Brasil... Mas, se vão longe esses tempos indecisos da Idade Média, ainda se não apagaram do espírito de alguns cariocas os dias agitados de 93, o período em que a República lutava contra a fúria da revolução. Houve então aqui um considerável decrescimento do número das mulheres, o que determinou, segundo a opinião do Dr. Pires de Almeida, profunda corrupção nos costumes da cidade. A judiciosa asserção do ilustre clínico leva a gente a pensar que os habitantes da Terra do Fogo não devem estar em situação muito agradável. Mas quais seriam os motivos de haverem as gentis representantes do sexo frágil abandonado essa ilha tão fria, que tem um nome tão quente? Terá havido por lá alguma extraordinária epidemia, que se haja limitado a atacar apenas a constituição delicada dessas encantadoras criaturas? Terão os gelos das proximidades do Pólo Sul arrefecido o caráter de seus compatriotas a ponto de, sentindose desprezadas, terem as pobrezinhas a necessidade de bater a linda plumagem? Ou continuaram os homens de lá com aquele hábito de que fala Darwin - o péssimo costume de, em tempo de penúria, comer as mulheres, porque as consideram inferiores aos animais? Se esta última hipótese é verdadeira devem agora os habitantes da Terra do Fogo estar arrependidos de sua voracidade, porque se privaram, por não haverem sido mais sóbrios, do único meio que tinham de perpetuar o alimento das ocasiões difíceis. Mas não se pode atinar com a causa do desaparecimento das pobres flores da vida na grande ilha do sul. E a gente vê, pela tristeza do telegrama, que os homens estão angustiados, estão aflitos, vítimas de uma viuvez geral. Mas caso é para uma pessoa pôr se a pensar tristemente nas grandes desigualdades que há neste mundo. Desapareceram as mulheres ali, aqui promanam mulheres em quantidade. Parece até uma injustiça. Bem se está vendo que os bens da terra não foram feitos para todos...

\section{RAMOS OLIVEIRA $^{928}$}

\footnotetext{
${ }^{928}$ OLIVEIRA, Ramos [Graciliano Ramos]. Na terra do fogo as coisas estão frias..., Parayba do Sul, Paraíba do Sul, RJ, n.54, 7 jan. 1915.
} 


\section{Coisas do Rio}

A guerra acabou-se. Já se não ouvem pelas ruas aquelas graves dissertações sobre o movimento europeu. É em vão que os jornais continuam a prodigalizar ao público suas longas colunas repletas de telegramas - essas vagas notícias já não produzem em nosso espírito aquele entusiasmo de outrora. Foi-se a ânsia dos elegantes que devoravam folhas com sofreguidão, esperando saber talvez se as botas do general Pau estavam bem lustradas no último combate, ou se os bigodes de S.M. germânica continuam irrepreensivelmente frisados. Findaram-se as ponderosas lições daqueles geógrafos circunspectos que discursavam em frente das redações, falando largamente sobre o volume d'água do Marne ou sobre a posição de Antuérpia. Hoje o negociante rico da rua da Quitanda não sente, ao montar seus óculos no nariz e ao desdobrar seu diário matutino, aquelas apreensões que há cinco meses sentia, quando julgava que a conflagração lhe podia prejudicar o comércio.

Ingratos... Como vos esquecestes tão depressa daquilo em que ocupáveis todos os vossos cuidados, todos os vossos pensamentos?

Não sois patriotas, "franceses” que rebentáveis a cara de vossos antagonistas quando estes ousaram afirmar que o cerco de Paris era um fato... Não tendes amor a vossa terra, "alemães" que combatíeis pacificamente na Avenida e na rua do Ouvidor... Porque abandonastes covardemente essa Germânia gloriosa que o dr.Topsins chamava "a mãe espiritual dos povos”? Como pudestes esquecer essa França tão pródiga que [n]os oferecia tudo - artes e moda, fazendas e literatura, mulheres e idéias; essa França generosa que fornecia nosso mercado de todos os instrumentos inventados pela civilização e enriquecia nossa língua com todas as palavras de seu vocabulário.

Ingratos... Hoje sentis pela conflagração o mesmo que sentiríeis se vos dissessem que a Lua tinha voado pelos ares ou que os habitantes de Marte se matavam uns aos outros, servindo-se de grossos canhões 42 . 
E se algum antiquário desocupado tem o mau gosto de referir-se a esses acontecimentos vermelhos que lentamente se vão desdobrando lá nas estepes brancas e nos pérfidos mares cheios de minas traidoras, torceis o nariz e abris a boca em longos bocejos.

Não sei quem fez esta observação sagaz: "Nós somos um povo muito volúvel”. Grande verdade, que não passaria desapercebida ao espírito arguto do conselheiro Acácio.

Dizem aqui que houve um poeta muito amado por toda a gente que faz versos e amarra ao pescoço bonitas gravatas. Era um ídolo, mais que um ídolo - um figurino. Imitavam-lhe o formato dos metros e o feitio da roupa.

(Há alguém que se queixe da falta da originalidade que nos leva a seguir cegamente pegadas de algum mestre. Tolice! É muito mais cômodo percorrer os caminhos que os outros vão abrindo do que meter-se uma pessoa por veredas escusas e intrincadas).

Pois o nosso homem era uma espécie de pontífice de todos os indivíduos que deitavam olhos cobiçosos às musas do Rio antigo.

Um dia - dia fatal! - O poeta teve de fazer uma longa viagem. Viagem funesta! Voltou anos depois. Trazia versos. Mas seus adoradores notaram que lhe não ficava bem o laço da gravata... Foi uma grande apostasia - todos os devotos passaram a queimar incenso nos altares de outros deuses.

E o figurino das letras exilou-se, pensando talvez na ingratidão daqueles gregos que decretaram o ostracismo de Aristides.

O caso é para a gente pôr-se a pensar na versatilidade dos cariocas. Pensando bem, vê-se que há muita semelhança entre o ídolo literário da geração passada e a conflagração européia. Nosso povo tudo esquece. O que é necessário é que haja um fato qualquer que lhe afaste o pensamento do objeto de suas preocupações. 
A viagem determinou o desterro do poeta. A indiferença com que olhamos hoje às coisas da Europa tem muitas causas - a crise, ambigüidade sobre o presidente do E. do Rio, o carnaval...

Decididamente somos um povo extremamente falto de memória.

Rio - 25-2-1915

R.O ${ }^{929}$.

${ }^{929}$ R.O. [Graciliano Ramos]. Coisas do Rio. Jornal de Alagoas, Maceió, 06 mar. 1915. No original há um erro tipográfico na data apresentada, pois está escrito 1914 ao invés de 1915. 


\section{Linhas Tortas}

Abrindo um parêntesis na agitação de uma vida pouquíssima devota e muitíssimo prática, todo o grande rebanho religioso resolveu, durante três ou quatro dias, recordar-se de que outrora, lá em uma velha cidade do Oriente, um pobre rapaz, por amor dos homens se deixou amavelmente pendurar numa cruz.

Recordou-se, mas não como naqueles tempos em que a cristandade, com um pranto mais ou menos verdadeiro, batia piedosamente nos peitos e se mortificava e ralava os joelhos e passava semanas estragando o estômago com um detestável e insulso bacalhau ascético.

Hoje - ai! - As coisas mudaram.

Há até algumas condenadas que não hesitam, nos dias da Paixão, em meter dentes ímpios no saboroso "beef" cheio de pecados, britanicamente tresandando a heresia. A religiosidade pacata que transita pelas ruas, visita as igrejas, beija os pés do Senhor e critica rindo a linguagem dos graves eclesiásticos que pregam sermões de lágrimas; abandonou o antigo e salutar costume de penetrar funebremente em fatos cor de treva, amarrar ao pescoço gravatas tétricas e apresentar à gente um ar compungido de quem acaba de receber o mais doloroso golpe que se pode imaginar.

Anda-se com botas amarelas, chapéu branco, calças claras, coisas que são apenas atenuadas pelo rigor de um ou outro paletó severamente escuro e que traduzem uma crença muito dúbia, um fervor religioso muito ambíguo.

Mas que querem? É o progresso. Já não há necessidade de meter um indivíduo numa cela e ali passar horas e horas prostrado, com sangrentos calos nas rótulas, batendo nos peitos ou arrancando os cabelos, faminto, a rezar com desespero, os olhos esbugalhados presos no teto, como se estivesse vendo aparecer lá em cima o vulto do amável Jesus tal qual ele estava 
quando o desceram do aviltante instrumento de suplício, boca aberta, a cabeça pendida para um lado, as mãos negras de sangue coalhado.

Há processos modernos de adoração.

Chora-se alegremente a morte do Redentor nos teatros, onde as empresas suspendem temporariamente as representações de revistas idiotas e de peças “gênero livre”, para oferecer ao público a "Vida, Paixão e Morte de Nosso Senhor Jesus Cristo", coisa muito bem feita e pelos preços do costume. E os cartazes dos cinemas proclamam também reproduções daquelas coisas peregrinas que S. Mateus, S. Marcos, S. Lucas e S. João ingenuamente introduziram em seus evangelhos.

Magnífico! Por cinco tostões, tem um cristão uma morte de Jesus em segunda classe, com tudo que uma alma pia pode desejar - as pregações, as curas milagrosas, os brinquedos infantis do pequeno Rabbi e os bigodes dos legionários romanos. É barato.

De sorte que com a desleal concorrência que os teatros fazem á igrejas, vão entrando os empresários suavemente na seara sagrada.

Essa gente frivolamente religiosa nem se dá ao trabalho de comemorar a sério a morte do pobre revolucionário judeu, a quem a posteridade pregou um logro formidável e que é hoje representado por qualquer comediante de revistas.

E pensar que há mil setecentos e cinqüenta e sete anos, S. Policarpo teve o louvável incômodo de ir de Esmirna a Roma conferenciar com Santo Aniceto sobre a grave questão da Páscoa! Pensar que S. Vitor e a Igreja do oriente andaram numa grossa [barulhada] por não terem chegado a um acordo sobre o dia em que a cristandade devia comer um carneiro e exercer outras práticas difíceis! Para nada serviram tantos discursos, tanta condenação, tanta balbúrdia entre aqueles respeitáveis santos, até que o conselho de Nicéia resolvesse por termo à questão.

Hoje chega a parecer que se não estabelece distinção entre a mais séria de todas as sextasfeiras e essas reles sextas-feiras ordinárias. E o sábado é uma pândega, uma “aleluia” de todos os pecados. 
Mandam-se à fava as parcas roupas pretas que ainda surgiam por acaso, veste-se qualquer cômoda vestimenta de "pierrot” ou de arlequim, pega-se um lança-perfumes e vai-se para a Avenida.

Ali é que a vida é uma coisa deliciosa.

“Confeti”, serpentinas, caras com pinturas artísticas, sorrisos tentadores e postiços mostrando alvos dentes de porcelana...

Sublime!

A semana passada foi-se, vai longe.

Agora é o Carnaval, a patuscada, a alegria, a “evoé”, a “Filomena”...

Ah! Venerandos sumo pontífices do segundo século! S. Policarpo, Santo Irineu e outros que tais! Empertigados e simplórios bispos do concílio de Nicéia! - Felizmente estais mortos. Se pudésseis ver o que aqui se passa mil novecentos e quinze anos depois da execução do messias, mandáveis à breca todas as controvérsias que tivestes para reputar aquelas coisas da Páscoa.

$$
\begin{array}{r}
\text { Rio 5 - abril - } 1915 \\
\text { R.O }{ }^{930} .
\end{array}
$$

${ }^{930}$ R.O. [Graciliano Ramos]. Linhas Tortas. Jornal de Alagoas, Maceió, ano 8, n.83, 18 abr. 1915. 
Anos 1920 


\section{GARRANCHOS}

Leitor amigo: Bom dia. Bom dia, boa tarde ou boa noite?

Não o posso dizer ao certo, porque não me é dado adivinhar a que horas volverás os olhos para este meu escrito tão cheio de senões como de banalidades... Mas, ao pegares nesta folha, consulta o teu relógio e, de acordo com o seu mostrador, aceita os meus cumprimentos...

Meu bom leitor: abro hoje esta seção fazendo-te um pedido e uma promessa: quando, aos domingos, à hora em tranquilamente te sentares a tua mesa, onde fumega, saboroso e escuro, o habitual café das "sete”, eu te levar, pelo Índio, as minhas frases insulsas e tolas, peço-te que volvas a memória para o passado remoto e sigas o edificante exemplo de Jó, o expoente máximo que foi da paciência humana.

Quero com isso dizer-te que deves ser paciente e caridoso comigo e que, por eu ficar impingindo-te todos os domingos uma injeção desta, não me deves ficar querendo mal.

Mas eu lembrei-te Jó. E muitíssimo mais do que isto ele sofreu sem uma palavra de ironia ou um gesto de vingança. Também eu te prometo que nem mandarei matar os teus filhos nem saquearei os teus haveres... E tudo isto e mais ainda sofreu o pobre homem da Bíblia...

Não ficamos bem assim?

[Tão] Fazendo-me o pedido e eu cumprindo a minha promessa?

De resto, quem sabe se esta seção não te irá fazer algum bem... Sofres de insônia, meu paciente leitor? Então não usarás melhor narcótico! Talvez nem seja preciso ler a garrancheira toda, para o sono chegar-te. Estive no meio de uma gente, que, para dormir não 
era preciso mais que a minha presença. Ora, se a presença de uma criatura é bom narcótico, claro está que [o] que ela escreve o será ainda melhor. Pois não concordas? Manda a boa lógica que se pense assim. Bem, o teu café já deve estar esfriando para não maçar-te mais, faço ponto antes que de tua boca saia esta expressão tão em moda agora na nossa pacata Palmeira: Que [bucha]! 
Começo hoje a minha crônica com esta frase chocarreira e tola dos namorados patans: “gostaste de mim”, leitor?

Porque se gostaste, com efeito, dou por pago o meu sacrifício de passar estes longos minutos estragando à luz de uma escassa lâmpada Garcia, que mal ilumina a mesa em que escrevo, sentado nesta velha e dura cadeira coberta de sola...

E, para outra coisa não é que a isto me exponho, senão para agradar-te.

Mas, se te não serviu a xaropada que te meti portas adentro no domingo, sê franco e dize-me a verdade.

Então o maior malho que houver na minha terra servirá para rebentar esta pena e, para destruir os meus “Garranchos”, eu mandarei fazer uma fogueira como não haverá notícia de outra igual. Serviu-te bem o narcótico?

Então não era mais que o teu dever que eu recebesse hoje de tuas mãos coisas com que pudesse render o meu culto a Momo, nestes dias que lhe são consagrados. E como perfumarei a minha Colombina, se a Vlan ${ }^{932}$ chegou tão aristocrática para os meus bolsos humildes! Então cinco dezenas dos meus “Garranchos” não valem uma de “lança”?

Diabo! Estou vendendo muito barato meu artigo!

Enquanto vais tagarelar com Pierrot, fecho esta crônica com a velha chave dos discursos, enferrujada como uma de que me sirvo todos os dias e igualmente velha: “tenho dito”...

\footnotetext{
${ }^{932}$ Marca de um dos primeiros lança-perfumes produzidos.

${ }^{933}$ X [Graciliano Ramos]. Garranchos [2]. O Índio. Palmeira dos Índios, ano 1, n.2, 06 fev. 1921.
} 


\section{III}

Era de doidos a festa, amigo? Era de bêbados? Fizeste muito bem em enlouquecer e embebedar-se também. Ficaste otimamente pondo a máscara de papel pintado sobre a máscara moral com que cobres eternamente o rosto, meu pérfido! Ser bobo é chic, está na moda!

E, como gostas dela, foste bobo também! Que pândego que te achei, envolvidos em panos encarnados, arrotando vinho! Que tem que fizeste abandonando a gravidade da vida! Quem é que quer ser sério no carnaval. Há lá seriedade nisso! E ainda que quisesse exibir alguma, pensas que Baco consentiria? Passarias por idiota se procedesses assim...

Bateu-te à porta a orgia e com a sedução das bacantes, caíste-lhes bêbado aos braços, tratante! Melhor não poderias ter feito. Se o vinho é deus, se o vinho impera, era mister que te entregasses de corpo e alma ao seu domínio! Beber! Transportar-se de um trago às paragens encantadas do prazer... Que delícia!

E, depois de todas essas loucuras, depois de tantas noites a braços com o vício, ir, genuflexo e piedoso, receber na testa a cruz cinza!

Que contraste! E que é a vida, afinal, senão uma intérmina sucessão de contrastes?

${ }^{934}$ X [Graciliano Ramos]. O Índio. Palmeira dos Índios, ano 1, n.3, 13 fev. 1921. 


\section{IV}

Talvez o leitor se admire hoje deste artigo. Esta seção ainda não trouxe a seus olhos senão futilidades e coisas inúteis. Muda hoje um pouco na forma e na essência. Vai tratar de um assunto imperioso e grave; vai unir a debilidade de sua voz ao eco desta folha em prol da instrução. Talvez fique por aqui, talvez continue. Se este artigo for bem recebido por aqueles aos quais se dirige, munirei o braço de forças e continuarei. Vai como uma súplica endereçarse ao governo; partiu pela minha pena desses infelizes pais de família que vêem, dia a dia, a miséria invadir-lhes o lar onde não penetrou ainda, balsâmica e divina, a fonte do bem humano: o livro!

Criam-se aqui todos os dias, quase, centros de diversões, e no entanto uma escola não se abre!

É simplesmente horroroso que numa cidade como a nossa (já não digo o município, contentome com a sua capital) não tenhamos quem nos ensine a ler, arrancando-nos a cegueira da alma. Bem longe ainda vai de nós o progresso... O governo, descurando a maior necessidade do povo, entrega a sua instrução a criaturas tão ineptas que mal poderiam freqüentar o primeiro ano de um estabelecimento de ensino! Que podem elas ensinar, santo Deus, se nada sabem? Só por milagre. Milagres? Ah! Mas a poeira dos séculos apagou-lhes o vestígio! E a ignorância aumenta, e os crimes multiplicam-se! Temos (miséria!) escolas de vício, aprendizagem de crime, escadas para a prostituição. É a casa de jogo, é o álcool, é a aluvião de mendigas, crianças à puberdade, que infestam a cidade, oferecendo-se quase.

E não falarão essas misérias todas bastante alto para penetrar os ouvidos do governo? Não estarão ainda bem expostas à luz as pústulas que maculam a alma das multidões sertanejas?

Abri escolas, senhores do governo, esses “viveiros de esperança”, como lhes chamou Rosendo Muniz, e tereis prestado um grande bem à nossa pátria.

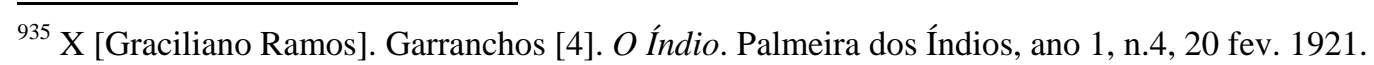




\section{V}

Andamos, positivamente a passos de tartaruga em questões de letras. Toda a gente, quase, aqui assina jornais, e quase ninguém aqui lê os jornais que assina. Se lê, não compreende. E por não saberem ler e pela vaidade que têm os ignorantes de entenderem de tudo, indivíduos há que têm uma maneira muito original de julgar a obra pelo título e pelo nome que a subscreve, sem a ler, entretanto.

Por isso, certo cidadão da roda, que tem título de eleitor, que usa gravata e meias, que discute literatura, pegando certa vez um número d’O Índio, em que vinha publicado um artigo um pouco extenso, jogou-o para um canto, exclamando espumante de raiva, como se lhe ele tivesse ferido a sensibilidade:

- Isto é jornal! Eu bem disse logo que aqui não há assunto para fazer-se um jornal! Um artigo deste tamanho, misericórdia! Está-se vendo logo que é falta de assunto. Pode-se lá ler uma porcaria destas?!

E, no fundo, assistia muita razão ao pobre homem: habituado a ler a carta A.B.C. (único livro que mal conhece) que "Paulinha mastigou pimenta e que "Delfina comprará araçás” não podia passear os olhos sobre um artigo de quatro coluna, fosse bom ou mau o assunto, e ter um gesto diferente daquele!

E, acima de todos os defeitos d'O Índio, colocou o que achou mais grave:

- Uns anúncios insignificantes, que a gente nem pode ler, tão pequenos são! Isto é jornal! Leio lá esta porcaria!

Que imbecil! Julga que o valor disto está no tamanho dos artigos e no formato dos anúncios!...

$$
\mathrm{X}^{936}
$$

${ }^{936}$ X [Graciliano Ramos]. Garranchos [5]. O Índio. Palmeira dos Índios, ano 1, n.5, 27 fev. 1921. 


\section{VI}

Voltamos a encarar de novo o grave mal que ameaça derruir a moral do povo: o analfabetismo. A ignorância arrasta, a passos gigantescos, a multidão sertaneja ao abismo tenebroso do crime!

Tinge ainda a terra do "Candará”, o sangue da criança inocente que tombou aos golpes fatais de enxada que seu tio e companheiro de travessuras infantis, com idade de pouco mais de dois lustros, lhe projeta no crânio.

Enche ainda o coração do povo de Vitória os gritos lancinantes do rapazelho que expira com a garganta entre as garras ferozes de um soldado de polícia na praça pública, à luz meridiana.

Não se apagou ainda da retina dos habitantes do sítio “Lagoa Mourão” a visão trágica e canibalesca de uma cena em que três indivíduos apunhalam um homem por motivos fúteis, por cachaçadas talvez...

São desta natureza os dramas terríveis que nos oferece a selvageria do meio em que vivemos. E tudo por que? Porque, em vez de uma carta de A.B.C., se dá ao povo a carta de baralho; porque, em vez de um ensinamento são, que lhe ilumine o cérebro, se lhe deita na boca o copo de aguardente que lhe devasta o organismo e relaxa o caráter!

Urge, pois, que ponha termo a tamanhas misérias.

Como fazê-lo?

Projetando na treva que há na alma do analfabeto o clarão radioso que vem do livro! Não serão acaso tantos crimes o resultado da ignorância que caracteriza o povo? Precisamos abrir escolas. E é na palavra autorizada de Guerra Junqueiro que vamos achar este conceito de suprema verdade: “Alongar a escola é diminuir o cárcere”. 
$X^{937}$

${ }^{937}$ X [Graciliano Ramos]. Garranchos [6]. O Índio. Palmeira dos Índios, ano 1, n.6, 06 mar. 1921. 


\section{VII}

Eu tinha deixado a cidade na agonia da luz elétrica e noctívaga estrada em fora. Passei as águas verdes e podres do velho açude, passei a padaria Mog e caminhei ainda.

Mas ao enfrentar a casa dos mortos, branca na treva, tolheu-me os passos uma visão: era uma procissão de almas que se iam, enchendo o caminho de espanto e de medo! Fiquei branco com elas; as pernas tremiam-me como tenros galhos que o vento açoitasse; os cabelos encrisparam-se-me. Estive quase a pedir socorro! Mas ninguém me valeria, porque só almas me rodeavam...

Depois uma que me ficara perto falou:

- O senhor vota no governo, pois não vota? Então vai fazer-me um grande favor. Fui eleitor também. Votava na chapa oficial. Ora o senhor me vai levar um recado lá na rua. Está vendo? Depois que o portão caiu, os companheiros deixaram-me sós! Vão-se sem mais aquelas, sem licença de ninguém. De tantos habitantes desta casa imensa, já poucos restam. Eu gosto de cumprir ordens. Fui militar. Um dia, por uma simples infração, mandaram-me ao xadrez, 15 dias, a pão e água! Depois deste castigo, nunca mais desobedeci. Ninguém nos disse ainda que nós podíamos ir; por isso continuo no meu posto. É certo que arrancaram o portão, mas nada nos disseram... Vê o senhor? Aquilo ali faz dó! Os cães invadem-nos os leitos, os porcos chafurdam tudo, as galinhas nos martirizam remexendo a terra que nos cobre, à cata de alimentos. É uma invasão danada. A vida aqui vai se tornando insuportável! Os outros fogem apavorados! Parece até que me julgam alguma autoridade aqui, porque saem às escondidas. Mas eu fico, todo cheio de aflições. O senhor parece ter bom coração, porque está com os olhos cheios d'água. Quando chegar à rua vá ao palacete da águia e faça-me o favor de dizer tudo isto ao governo e pedir-lhe que mande um portão para cá. Do contrário isto ficará às moscas. 
É certo que não fui pessoalmente à intendência, mas creio que reproduzindo aqui, textualmente, as palavras que ouvi à alma, satisfaço-lhe o pedido.

$\mathrm{X}^{938}$

${ }^{938}$ X [Graciliano Ramos]. Garranchos [7]. O Índio. Palmeira dos Índios, ano 1, n.7, 13 mar. 1921. 


\section{VIII}

Era uma vez uma cidade do interior de um Estado, que tinha a sua iluminação confiada aos cuidados de um certo Manoel Xororó... À luz tênue dos lampiões, fabricados com engenho por um cidadão que tinha o nome pouco comum de José Urubu, os habitantes daquela pitoresca terra podiam, à noite, sem se arriscarem ao perigo de quebrar as pernas, passear tranqüilos nas ruas esburacadas...

Veio um dia a doença, Xororó foi à cama, agonizou e morreu. Nomeou-se um substituto, que não limpava os vidros dos candeeiros, nem deitava para a combustão o líquido necessário. E a luz enfraqueceu... Então o povo dali aborreceu-se do clarão que vinha dos pavios embebidos em querosene e pediu luz elétrica. Vai o intendente e acedendo ao pedido dos munícipes, tratou do caso. Apareceu um cidadão jeitoso e amável, arran[cou] privilégio de vinte anos e firmou um contrato com a municipalidade...

O povo como era natural, bateu palmas. Meses depois o homem enterrou e enrolou (salvo seja) em fios amarelos... Os proprietários queriam fazer instalações em suas casas, mas receavam o preço. O empresário dizia que aquilo era muito barato. E os prédios encheram-se de fios.

Chegaram por fim os aparelhos e a primeira experiência foi anunciada. Gente curiosa encheu as imediações da empresa. O dínamo enrascou-se, as crianças gargalhavam e os garotos riscavam fósforos para iluminar a luz elétrica... No dia seguinte, depois de um labor insano, a luz se fez. Houve risos, felicitações e as janelas se encheram de rostinhos curiosos.

Dias após ao arrasta pé de valsas e ao tilintar de copos transbordando espumas, inaugurou-se a iluminação pública. E a cidade se vestia de júbilo... Música, discursos, o diabo. Tudo muito bem. As ruas ficaram claras. O povo satisfeito, abriu os bolsos, cruzou os braços e mandou o proprietário da empresa servir-se à vontade. 
Este, não contente com o lucro, dobrou o número de instalações, e a luz esmoreceu. Achou pouco ainda; triplicou... e a luz ficou agonizante. Houve reclamações. O homem mandou cartas para a América e marcou prazo para a chegada de aparelhos que não foram pedidos...

E hoje a gente da cidade, obrigada a andar às apalpadelas pelas ruas, arrisca-se a quebrar as pernas nos buracos, manda aos diabos as transparentes lâmpadas de Edson e fala com saudades dos bons tempos em que a iluminação da terra era confiada aos cuidados do finado Manoel Xororó, de saudosa memória. 


\section{IX}

Com as suas vias-sacras e os seus crepes, as suas matracas e os seus jejuns, a semana santa passou... Passou com a serenidade das coisas sagradas. Igrejas e mesas encheram-se, estas de gostosas iguarias, aquelas de crentes que rezavam e de indiferentes que nada faziam. E já que o tempo é de jejum, falemos um pouco sobre ele. Todos jejuam, uns por penitência, outros por gula. E, como para isso, precisam sair das comidas vulgares, correm às feiras, batem os mercados, andam de mercearia para mercearia, a comprar bonitos peixes, bons acepipes, ótimos doces e escolhidos temperos. O povo jejua. Não em português, que diz que jejuar é abster-se de alimentos, mas comendo bem e muito. Aqui se ensina que jejuar é passar à farta. Com efeito, tomar-se café pela manhã, almoçar-se às onze, como se não tivesse de jantar, não comer nada no intervalo das refeições e jantar-se às seis, tanto como se não tivesse de comer jamais, é um grande sacrifício e, consequentemente, uma grande penitência. Andar o povo empanturrado, desmanchando-se em suor, asfixiado, caindo ao peso do estômago, abrindo-se em bocejos, arrotando, enchendo o ambiente de gases malcheirosos, não é estúpido? Aí está o jejum...

${ }^{940}$ X [Graciliano Ramos]. Garranchos [9]. O Índio. Palmeira dos Índios, ano 1, n.9, 27 mar. 1921. 


\section{$\mathbf{X}$}

Vem de novo à baila a velha questão do abastecimento d’água à cidade. O povo já discute as cláusulas de que se comporá o contrato e, com a febre que soe acompanhar o assunto, já meia dúzia de homens andou fazendo sondagens, “Cafurna” em fora, escalando acidentados terrenos, até às águas serenas que fertilizam a terra serrana do “Amaro”.

Tu leitor, com certeza estás contentíssimo com o veres em foco uma questão que de perto te interessa.

Entretanto, eu, em vez de ficar alegre como tu, entristeço sempre que se me fala em tal assunto... Nem imaginas o mal que nos vem trazer esse melhoramento que se discute com tanto calor, apesar de ser uma coisa tão fria o que ele nos traz.

Pensas então leitor amigo, que beberemos d’água e nos banharemos nela, andando de bolsos escasso como andamos? Qual nada! Aquilo é coisa que só virá servir os ricos. Bem entendido, no caso imaginário de vir o que é tão fácil como transportar-se para o lado oposto aquela serra ali defronte, embora o mestre Jovino me dissesse que no tempo em que estudava certa ciência, era capaz de fazê-lo, com a fé que lhe povoava a cabeça, que anda cheia hoje em dia de notas de música e de águas sulfurosas...

Ora, se o líquido em questão, transportado em velhas e ferrugentas latas, nas costas de bons animais, lentos e orelhudos, que andam a trote as estradas, ruminando a sua filosofia, já ninguém o bebe, tão alto é o preço, imagine-se o que será quando vier entre as paredes redondas de canos americamente caros! Aí sim! Teremos de comprar água de acordo com o câmbio...

E sendo propriedade de empresa... Empresa! Só por si esta palavra apavora! E cá sabemos porque... Por isso vamos fazer promessas para que se deixem as fontes em paz, se é que não queremos morrer de sede... 
$X^{941}$

${ }^{941}$ X [Graciliano Ramos]. Garranchos [10]. O Índio. Palmeira dos Índios, ano 1, n.10, 3 abr. 1921. 


\section{$\mathbf{X I}$}

Palmeira não tem árvores. Já repararam na tristeza que há nas cidades desarborizadas? Por isso Palmeira é triste... As ruas têm o ar pesado dos rostos que não riem. Como o riso é a beleza do rosto, a árvore é o riso da rua... É preciso, pois, que a nossa cidade ria. Arborizemola o quanto antes. $\mathrm{O}$ atual intendente cogita agora do assunto, mas de uma maneira assaz demorada e que talvez não dê resultado satisfatório. As mudas pedidas para o Rio poderão com a viagem chegar imprestáveis ou depois do inverno, obrigando assim o adiamento da questão. Mas, para que irmos tão longe, quando temos às portas variados espécimes de fruteira que tão bem serviam para o caso? Plantemos mangueiras, laranjeiras, outras árvores, tão belas, que as há em nossos sítios.

Florença é povoada de laranjeiras, o seu ambiente é perfumado, temo cheiro especial dessa árvore.

As grandes ruas de Belém são cheias de mangueiras. E é dever a beleza do aspecto, às tardes e às manhãs, quando morre o sol ou raia a aurora. Em roda tudo é festa; são os homens que se acolhem a sua sombra, ouvindo-lhes nos galhos os pássaros a cantar, os garotos que esperam a queda do fruto desejado.

A arborização é necessária ao embelezamento de uma cidade.

O inverno chega. Não devemos perder a ocasião. Façamos a nossa Palmeira alegre. Vistamola de festa, plantemos árvores.

Além da arborização precisamos também de jardins.

Palmeira em breve receberá de Paris, como oferta de um digno filho seu, o major de engenheiros Manoel Cavalcanti, o busto do velho político e grande palmeirense padre Maia. Foi desejo do ofertante que se erigisse o busto à praça da Matriz, o que será observado. Ora, em face disto, seria ao bom alvitre que se cuidasse logo de preparar a praça para tal fim. 
$\mathrm{X}^{942}$.

${ }^{942}$ X [Graciliano Ramos]. Garranchos [11]. O Índio. Palmeira dos Índios, ano 1, n.11, 10 abr. 1921. 


\section{XII}

“C Cinema é hoje! É hoje é hoje!” Grita rapaziada da canela suja!

E a molecoreba, com o cartaz às costas, berra, e os ganzás réco-requeiam...

E assim que se anuncia o cinema de Palmeira! É simplesmente espantoso que, a trinta quilômetros da via - férrea, uma cidade com um relativo progresso, em cujas ruas, cortadas de fios elétricos, transitam carros Ford e sapatos a Luiz XV, que usa perfumes Caron e figurinos de Paris, que dança one-step, que toca piano e faz jornais, esteja a usar as velhas coisas de seu Procópio do circo!

É maluco isto!

Um cinema instalado à eletricidade, que exibe Edie Polo e Francisco Ford, Prescilla Dean e Lida Boreli, usando o anúncio tão reles e canalha que o próprio Cardoso, o Cardoso reumático, desprezava!

É provocante! Irrita o sistema nervoso do mais pacífico habitante deste mundo!

Ora, senhor empresário, sejamos coerentes. A César o que é de César. Deixemos aquele reclamo para o "Pastoril”, do Alfredo ou para coisa pior! Bem vedes, é pouco o que desejamos. Já vos não pedimos que corrijais a vossa desgraçada projeção, que nos vai aos poucos desgraçando os órgãos visuais; não exigimos também que endireiteis os vossos escangalhados bancos, que se rebentam sob as nossas infelizes pernas. Não queremos sacrifícios.

Mas ao menos poupe-nos a vergonha de ver as ruas cheias de esfarrapados garotos a gritar o cinema! 
Não notastes como o povo daqui tem boa vontade para convosco? Exibis os filmes de trás para a diante, pelo avesso, de cabeça para baixo; pára o vosso motor por falta de combustível e de cuidado - e ele, o povo, a esperar paciente, quieto, calmamente, a cochilar sobre a dura madeira dos vossos móveis, sem reclamar, sem ao menos atirar-vos às costas uma chuva de pedras como protesto.

Tendes razão.

O povo é assim? Pois que espere!

Pois bem. Fazei tudo, mas não nos martirizeis com a vergonha que aquilo faz!

Deixai em paz os cartazes, amarrados aos postes da luz elétrica, já que não tem outro meio de os exibir aos olhos da cidade.

Fazei-nos um favor, senhor empresário, um favor que nada vos custa: não nos mandei os vossos garotos gritando que há cinema hoje...

$$
X^{943}
$$

${ }^{943}$ X [Graciliano Ramos]. Garranchos [12]. O Índio. Palmeira dos Índios, ano 1, n.12, 17 abr. 1921. 


\section{XIII}

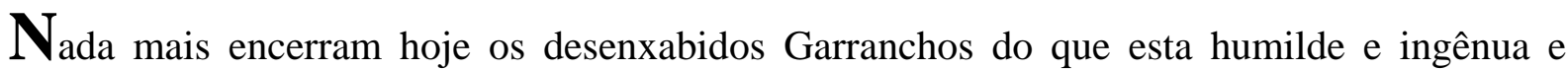
inofensiva pergunta:

Por que será que todos os sábados, mais ainda do que nos outros dias da semana a luz elétrica se encrenca?

Já daqui vejo as pregas que o senhor empresário fará na testa, e os meus ouvidos já se enchem com as palavras de enjôo com que ele responderá a modéstia desta argüição.

Dirá talvez que nada tem com o fato e que por isso é intruso com a pergunta deste seu criado, tronco donde brotam parca e descoloridamente estes desnudados garranchos. Mas, se esta criatura, que do canto desta coluna ousa dirigir-lhe a palavra lhe disser que para custear a despesa da luz que vem de sua empresa, paga todos os meses duzentos réis por vela de luz que recebe, que lhe responderá s.s.?

Responderá por certo que uma vez que o governo do município nada lhe reclamar, é porque está satisfeito...

O seu fiscal com certeza boa vista não tem e por isso não vê os desleixos da iluminação!

Por que, novo Diógenes, não se mune ele da luz de um feixe $e^{944}$, não para procurar homens de bem, mas para ver se consegue descobrir os defeitos da Empresa de Luz Elétrica, invisíveis a seus olhos?

\footnotetext{
${ }^{944}$ No original, está marcado "faixe".

${ }^{945}$ X [Graciliano Ramos]. Garranchos [13]. O Índio. Palmeira dos Índios, ano 1, n.13, 24 abr. 1921.
} 


\section{XIV}

O sr. Empresário da luz elétrica melindrou-se com o meu artigo de domingo, em que apenas lhe fiz uma simples pergunta a respeito de um dos defeitos de sua empresa.

Por que se zangou? Fiz-lhe eu alguma acusação injusta? Menti, porventura em dizer que “todos os sábados mais ainda do que nos outros dias” a sua luz nos chega péssima, depois de longo atraso no horário?

Não admite ele que se chame ao cumprimento do dever a sua empresa... Que intransigência...

Que é do compromisso assumido para com a municipalidade e, consequentemente, para com o povo, de que sou ínfima partícula? Onde [está] o respeito à terceira cláusula do contrato firmado com o município, no qual o empresário se obriga a "fornecer a luz pública das 18 às 24 horas”, durante o período do verão e meia hora antes no inverno?

Tem feito ele isto?

Aí está toda gente para dizer que não! Em dia nenhum a luz pública foi feita sem um atraso pelo menos de trinta minutos da hora estabelecida naquela obrigação contraída com o povo.

E daqui se conclui que nenhuma razão teve o sr. empresário em zangar-se com a queixa contida nesta seção no número de domingo.

Ele bem sabe que além dos defeitos citados, há ainda muitos em sua empresa, que me eximo de mostrar por serem muito conhecidos do público.

E, como ele demonstrou desejar conhecer o reclamante, aqui lhe declaro que encontrará todas as noites, das oito às dez horas, na redação d’O Índio, o autor dos Garranchos, pronto a atendê-lo. 


$$
\mathrm{X}^{946}
$$

Nota.

Sr. Crisanto, pelo amor de Deus, acabe com aquele anúncio! Puxa! O Sr. tem cabeça dura.

${ }^{946}$ X [Graciliano Ramos]. Garranchos [14]. O Índio. Palmeira dos Índios, ano 1, n.14, 01 maio 1921. 


\section{Judas}

Ontem, como acontece todos os anos em igual época, os garotos das ruas excitaram-se no ardor de arrancar as tripas de um pobre boneco de palha e trapo.

É uma vingança tardia e inócua que a ralé toma periodicamente contra um cidadão que há tempos se chamou Iehouda de Kerioth, vulgarmente conhecido por Judas Iscariotes, homem de maus bofes, segundo a tradição, apóstolo diletante, provavelmente traidor. Provavelmente, digo eu, mas não exijo que ninguém dê crédito ao que aqui fica, pois seria difícil apurar o grau de verdade que existe nessa trapalhada de coisas antigas.

Possuímos uma certa quantidade de noções que julgamos verdades inconcussas, embora nunca tenhamos tomado a mais insignificante informação sobre elas. Quem vai lá tocar em coisas antigas, cobertas de uma grossa camada de mofo tradicional, polvilhadas da venerável poeira de milênios? Ficaríamos assombrados se nos viessem dizer que elas estão falhadas, rachadas, que há soluções de continuidade por baixo da espessa crosta que as reveste.

Longe de mim a idéia de defender o Iscariotes. Todos nós estamos convencidos de que ele foi um tratante. Deixemo-lo tal qual está, até que os esmerilhadores das pedras do Oriente nos venham demonstrar que ele foi um ótimo rapaz.

Por hora não vejo mal nenhum em que o consideremos o mais acabado representante da infâmia. Se ele não foi tão mal como se diz, naturalmente há de perdoar-nos a má opinião que temos a respeito de sua pessoa. É possível que nosso juízo sobre ele não esteja muito distante da verdade.

Judas suicidou-se, o que é motivo bastante para que o detestemos. O suicida não está muito longe do assassino. A diferença que há entre os dois é que o primeiro rouba a vida a uma pessoa e o segundo pode fazer o mesmo a muitas. Questão de número apenas. 
Continuemos, pois, a dizer que Judas foi um patife. Não há nada de extraordinário em semelhante julgamento. Mais difícil é admitir a santidade de uma criatura. Os santos são raros, e o mundo está cheio de malvados. Eu ficaria pasmo se entre os discípulos de Jesus não houvesse aparecido nenhum birbante. Até me espanta que só um tivesse aberto exceção à monótona bondade que naquelas almas cândidas se encerrava. O que era razoável era surgirem pelo menos quatro ou cinco traidores entre os companheiros do Mestre. Só houve um, o que é lisonjeiro para a humanidade daqueles tempos remotos.

Se o doce Jesus viesse hoje ao mundo, talvez não lhe fosse fácil encontrar tantos espíritos fiéis. A proporção agora seria de cinqüenta por cento de safados.

Quem é santo nestes tempos prosaicos em que o dólar governa o mundo? As consciências tornaram-se mercadoria vulgar. As almas vendem-se e vendem-se caro.

Judas hoje não se enforcaria. Já nenhum traidor se enforca. Trinta dinheiros eram talvez uma quantia insignificante, capaz de levar um homem ao desespero de passar uma corda ao pescoço. Atualmente é possível obter somas tentadoras que dão rendimentos consideráveis a um traidor que se respeita.

Nenhum Iscariotes se suicida. Se os contemporâneos seguissem o exemplo antigo, não haveria no mundo figueiras que bastassem, para pendurar tantos laços...

$$
\text { J.C }{ }^{947} \text {. }
$$

\footnotetext{
${ }^{947}$ J.C [Graciliano Ramos]. Judas. O Índio, Palmeira dos Índios. 27 mar. 1921.
} 


\section{Como se escreve}

Para se encher um jornal não faltam assuntos: haja quem queira escrever, e o jornal será pronto levado aos leitores, mais ou menos aceito. Se o mau é preferido ou não, é sempre questão inerente ao meio, conforme a educação dos leitores.

Boa ou má imprensa, será lida ou apenas se guarda o papel para qualquer mister, quando menos para manter a vaidade de quem acha bonito saber ler e não querer ler.

Como?

Haja o porquê e o como está feito, porquanto este é complemento daquele. Assim os homens que foram ou ainda querem ser crianças, hajam freqüentado sem constrangimento ao menos a escola primária e tenham gostado de possuir livros para lerem; - queiram fazer-se leitores.

Escrever é fácil a qualquer que se dedique a atualidade, trazendo do berço algum cabedal, mantendo porém, a energia de vontade: começa sempre como os escritores de grande vulto começaram, escrevendo coisas triviais e progredindo sempre, pelo trabalho persistente, até chegar onde todos nunca chegam, - à perfeição absoluta, escrevendo “obras bem acabadas”.

Qualquer lugar do sertão, por mais inculto que seja, sempre fornece abundância de assuntos. Os hábeis pescadores é que os desenvolvem, entregando-os ao critério do chefe preparador do manjar para o serviço do banquete dos intelectuais, contanto que não causem perturbações na assimilação dos convivas, que raras vezes representam a sã opinião e são menos justos e mais exigentes que as mulheres das comissões...

Certo é que ninguém está isento de crítica; e aquele que não foi o primeiro a submeter ao cadinho da crítica os seus próprios trabalhos não passará de reles escrevinhador. 
Habituado a essas operações, receberá calmamente da parte de outrem a crítica mesmo severa que lhe toque.

E saberá mostrar valor e atrair simpatias nas mais profundas contendas, sem fugir da causa e sem atacar individualidades, porque saberá dispor de elementos para mantê-la.

A escrever com a suma perfeição, o indivíduo - na plena consciência - nunca se achará completamente habilitado.

O contrário julgam os ingênuos primitivos mestres.

Infelizmente poucos sabem que o Ruy não é a última expressão do que se pode chamar o sábio, embora se lhe não tenha apresentado um rival na ilustração, como no critério, no talento, na atividade...

Em todo o caso não sejamos pessimistas, esperemos com a fé transformadora de montanhas que os pescadores, sob a inspiração do brilho dos sóis e a calma do azul celeste, se façam irmãos gêmeos daquele que, no País como entre as nações cultas, é acatado como sábio.

Tratemos de fazer muitos leitores, criando escolas e mais escolas, sem esperarmos que baixe o nível da politiqueira, e para curar-se a mais terrível chaga - o analfabetismo, os escritores, em grande número saídos dentre aqueles - a imprensa terá o seu firme apoio na consciência viva dos leitores, contanto que o ciúme dos revoltosos, inimigos da verdade, não queiram levantar a greve, cabendo aos escritores o recurso de levar aos peixes os seus penosos trabalhos.

Escrever sempre deve ser o empenho do escritor; pelo menos ganha o exercício mental; não se avilta com o voto da preguiça intelectual do meio menos são, certo de que escrevendo para o público escreve também para si.

Lambda $^{948}$.

${ }^{948}$ LAMBDA [Graciliano Ramos]. Como se escreve. O Índio, Palmeira dos Índios, 03 abr. 1921. 


\section{Solidariedade}

Palavra bem definida e de raríssima aplicação entre os seres humanos deste grão de areia.

“Um por todos e todos por um” gritam, e, repetindo a mesma reza, os populares cantam emocionados, obedecendo à sugestão gravada no centro nervoso pela melodia dos oradores de praças públicas.

Tal como pelo canto da sereia, os ingênuos são levados pelas ondas tempestuosas e atirados ao abismo.

No início da civilização, ainda mal compreendida, aplicam seu egoísmo nas lutas religiosas, habilitando-se às lutas políticas, entregam-se de corpo e alma às lutas das pátrias, que dizem obedecer ao mesmo Deus de paz e amor, a quem pretendem, loucamente, perverter conferindo-lhe o título do antigo deus dos exércitos.

Os homens já chegaram ao mais elevado grau das torturas que os devem fazer [alçar] a fronte para fora da lama da terra.

O pessimismo e a descrença resultantes da falta de amor e falta de juízo [geraram] e alimentaram a hipocrisia das nações.

Pobre humanidade!

Nenhum dos métodos empregados até hoje tem conseguido manter a fraternidade.

“A união que faz a força” tem sido aplicada no sentido de erguer a força destruidora do resto de energia moral, desumanizando a humanidade.

E quando deixaremos de ficar perplexos, assim, sem acharmos em nós elemento moral que nos tire deste plano inclinado em que nos precipitamos pela degradação abaixo?! 
Poderá valer-nos o grito [do] poeta nas “Vozes d’África”?

Ao brado hiperbólico do ardoroso poeta respondemos pela consciência, pela razão, que nos homens se não extingue de vez, por ser um reflexo da eterna Luz: ninguém para sentir Deus precisa viajar muito para dele ser ouvido basta pensar levemente.

Os que procuram senti-lo e não conseguem, ficando descrentes ou invadidos pela dúvida, não se lembram que estando ele em todos os lugares, não devem procura-lo onde não podem chegar com a mesquinha imaginação.

Por intermédio dos seres diminutos o infinitamente grande se faz presente.

Observemos, por exemplo, as formigas, a abelhas, que - solidárias e amantes de seu próximo - conseguem melhor que esta pobre humanidade a vitória almejada e atingem gloriosamente o fim a que se propõem.

No seu reino não medram as greves nem os horrores do anarquismo que tanto infelicitam os maiores seres da criação, caprichosamente empenhados em perverter os sentimentos da solidariedade humana, substituindo o amor do próximo pelo egoísmo, o amor da espécie humana pela ambição partidária.

Mas a dor coletiva, as calamidades farão despertar os homens que desconfiam de Deus, e confiam na força desorganizadora da paz e do progresso de todas as nações.

Quando a inteligência humana serenamente inspirar-se no bem comum e deixar de ser egoísta, alcançará que o mal - a guerra - não combate o mal; antes o desafia perpetuando a luta, destruindo absolutamente a solidariedade na espécie humana, ficando toda a humanidade forçada pela mundana praxe a destruir os seres mais preciosos do Criador.

$\operatorname{Lambda}^{949}$.

${ }^{949}$ LAMBDA [Graciliano Ramos]. Solidariedade, O Índio, Palmeira dos Índios, 24 abr.1921. 


\section{Traços a Esmo}

\section{XIV}

Aqui vai, para variar, a descrição de um antro muito meu conhecido, no alto sertão de Pernambuco.

Isto não tem importância nenhuma. De resto o que nesta coluna se escreve nunca tem importância. Mas enfim pode ser que algum leitor tenha necessidade a viajar por aquelas regiões meio selvagens, e sempre é bom saber onde vai cair.

É uma casa baixa, de taipa, cheia de esconderijos, lúgubre. O teto, chato, acaçapado, quase sem declive; é negro o chão sem ladrilho, de terra batida, esburacado e sujo; negras as paredes sem reboco, com o barro que as reveste a rachar-se, deixando ver aqui e ali o frágil madeiramento que serve de carcaça ao prédio.

Três portas de frente e duas janelas. As portas têm altura suficiente para que possa entrar uma pessoa de mediana estatura sem curvar-se. As janelas, aberturas pequenas, quase quadradas, estão situadas lá em cima, perto da telha. Para atingi-las trepa-se a gente a um caixão. Tem dobradiças de couro e não tem fechaduras - trancam-se com um pedaço de pau roliço, envernizado pelo uso, que se introduz em uma cava aberta no portal, preso a um cordel amarrado a um prego. As portas fecham-se interiormente com taramelas.

Em frente há um alpendre, o copiar, sustentado por esteios baixos, grossos, resistentes ao caruncho. Limita-o uma plataforma que se ergue meio metro acima do solo, de terra solta e pedra. É ali que dormem alguns hóspedes sem importância, na desagradável companhia dos bodes, que lá vão fazer idílios.

Na sala principal, há três redes amarradas em paus recurvos que saem do esqueleto das paredes. A um canto, um enorme traste de pernas descomunais, que atravessam uma tábua de dez centímetros de espessura, magnífico para rasgar a roupa de quem nele se senta. Aqui e 
ali, em tornos de madeira, à guisa de cabides, penduram-se chapéus de couro, gibões, perneiras e peitorais. Alguns sacos e surrões de cereais substituem as cadeiras que faltam. Enormes cordas de laçar, cabresto de cabelo, encerados, cangalhas, alpercatas, prodigiosos sapatões de montar, com grossas esporas de rosetas incríveis, espalham-se desordenadamente.

Sobre uma tosca mesa, lavrada a enxó, um oratório envolto numa coberta vermelha, de florões. Há dentro dele uma litografia de N. Senhora, desbotada, em caixilho sem vidro, um crucifixo, alguns santos de barro e de gesso, enfeites de papel, uma lamparina e uma vela benta. Na mesa uma gaveta. Na gaveta, um museu - rolos de cera, novelos de barbante, agulhas para sacos, pedaços de sola, um tabaqueiro, um couro de faze rapé, um martelo, uma torquês, sovelas, chifres de veado, pontiagudos, pacotes de orações, sementes, bolas de sebo, látegos, chocalhos, pregos, fivelas, um macete e um lunário perpétuo.

À direita de quem entra, há um cubículo com um monte de algodão.

À esquerda, um salão mal assombrado, onde se misturam, numa confusão de mil diabos, montanhas de queijo, cestos, caçuás, samburás, rolos de fumo, cuias, cabaços, gamelas, selas de campo, cavaletes, pedras de amolar, arame farpado, facões, espingardas de perneiras, machados, foices e enxadas.

Da sala principal segue para os fundos um corredor estreito e sombrio, preto de pucumã e teias de aranha. Dão para ele dois quartos fronteiros. Um das meninas, nunca se abre. O outro, dos donos da casa, deixa ver, através da porta meio aberta, algumas arcas onde se aferrolha o tesouro da família, e uma cama baixa, sem colchão, com o lastro de couro de boi, em cabelo, gasto pelo atrito de algumas gerações que ali se fizeram, viveram e morreram.

O corredor desemboca na sala de jantar. Há ali uma pequena mesa, que raramente se forra. É toda ela escalavrada, cheia de altos e baixos, pelo hábito de picar-se fumo em cima dela, a faca de ponta. Ladeiam-na dois bancos medonhos. Perto, uma velha máquina de costura em cima de um caixão vazio. À entrada, um pote sobre uma forquilha em triângulo, plantada no chão. Nas pontas das varas que saem das paredes, candeeiros de folha, pendurados pela asa, desses de torcidas de algodão em rama, negras, fumegantes e fedorentas. 
Com a sala de jantar confinam a cozinha de um lado, do outro o quarto das criadas, três pretas que foram escravas e que ali continuam, porque não sabem o que fazer da liberdade. Uma delas dá-se ao luxo de dormir em uma cama de varas, a isidora, erguida sobre quatro estacas pregadas no chão. As outras dormem em esteiras. Têm caixas de pinho, onde guardam roupa, e cumbucos cheios de bugigangas - espelhos, voltas de contas, alfinetes, frasquinhos de perfume, anéis, brincos, pulseiras, rosários.

A cozinha é de proporções exíguas. Uma grossa camada de fuligem dá-lhe um novo teto, sotoposto ao primeiro. Um jirau, a que frequentemente se bate com a cabeça, substitui a dispensa. Amontoam-se nele mochilas de sal, réstias de cebola, espigas de milho, botijões de manteiga. Mantas de carne, lingüiças, panos de toucinho penduram-se a uma corda que vai de uma parede a outra. O fogo é feito no chão, entre grandes pedras dispostas em trempe. A um canto, um montão de cinzas e carvões apagados. Todos os dias uma preta, de rastos, varre aquilo a vassourinha. Frigideiras, caldeirões, panelas, marmitas de folha, ralos, canecos, abanos formam o sistema planetário de um tacho velho, rachado, cheio de nódoas verdes. Em cima de um pilão deitado, um gato ronca. Junto ao lume há quase sempre uma velhota acocorada, a acender o cachimbo de canudo de taquari com uma brasa espetada a um garfo. Encostada a uma das pedras da trempe, uma banda de casca de coco com um cabo de pau. É a quenga. Na parede, o caritó, pequena cava em forma de concha onde se guardam objetos miúdos - pedras de sal, pontas de cigarros de palha, dentes de alho, cordões, retalhos de pano, agulhas, peles de fumo que se oferecem a Santa Clara, a troco de pequenos milagres caseiros.

Uma janela baixa, onde se senta um rapagão indolente a esquentar-se ao fogo, dá para o quintal, nu, com um barreiro cheio de água turva, coberto pela sombra escassa de uma árvore morta.

Junto ao quintal há um jardim povoado de algodoeiros, verduras, vasos com alecrim e losna, urtigas e até flores. Cobre-o a imensa ramagem de uma baraúna secular.

Do lado oposto três currais de cercas eternas, mourões gigantescos.

Um pouco afastado, o chiqueiro dos bodes. 
Em frente, um grande pátio, branco, limitado por árvores sempre verdes que roubam um pouco a vista dos morros distantes, levemente azulados à luz crua do sol.

No terreiro, no pátio, na calçada, confraternizam galinhas, bacorinhos, cabras, carneiros, alguns cachorros com extravagantes coleiras feitas de rodela de sabugo queimado, enfiado em pedaços de embira.

Aí está a descrição de uma casa sertaneja, sem tirar nem por. Não aconselho o leitor a que se vai alojar nela. Mas há gente que mora ali, o que prova que o homem é um ser capaz de se adaptar a tudo.

J. Calisto ${ }^{950}$

${ }^{950}$ CALISTO, J [Graciliano Ramos]. Traços a esmo [14]. O Índio, Palmeira dos Índios. 01 maio 1921. Uma versão similar desse texto foi veiculada nos "Quadros e costumes do Nordeste" da revista Cultura Política, em agosto de 1941. 


\section{Senhores Redatores d'O Índio}

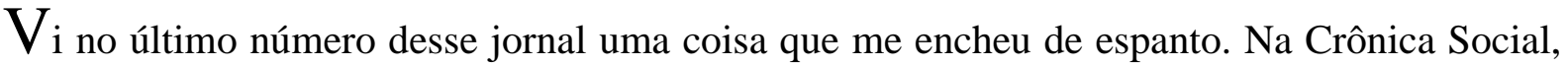
em uma notícia de aniversário, alude-se a minha insignificante pessoa como tendo eu pertencido ao número dos que fazem essa folha.

Não sei muito bem se me quiseram colocar entre os que dirigem, redigem, colaboram, revêem as provas ou varrem a casa.

Ora a verdade é que não tive a honra de trabalhar nesse semanário. Nunca juntei idéia para a fabricação de artigos, crônicas, notícias; nunca juntei tipos para a composição da prosa com que gente hábil enche linguados; nunca juntei os braços para puxar a alavanca do prelo que ali guincha e grita à noite, ao dar à luz o pensamento rabiscado em pedaços de papel com que se embrulha o público. Qualquer das três ocupações seria magnífica para mim, mas não quero receber o que me não pertence.

Quando vi meu nome na tal notícia, graciosamente circulado por deliciosos pastéis, tremi.

Julguei-me vítima de uma pilhéria - desculpem-me a franqueza - pilhéria de muito mau gosto, porque aqui toda a gente sabe que sou um camelo. Jamais em minha vida escrevi sequer uma dessas cartas de namorados, que se encontram [profusamente] em dicionários de flores e outros livros úteis que as senhoritas por aí muito bem conhecem. Não me dei o trabalho de copiar um desses pitorescos discursos do Orador Popular, para impingi-lo como coisa minha em festas de casamento, batizados, e outras reuniões fúnebres. Não escrevo, meus caros redatores, nunca escrevi, graças a Deus, como diria o Damaso Salcede. Sou inteiramente impenetrável à arte que os senhores publicistas possuem de embromar superiormente os leitores metendo-lhes caraminholas na cabeça. Até versos, coisa que todo mundo fez e que ali o senhor Felinto Santos Lima com abundância fabrica, não tenho jeito para manufaturar. 
Como poderia eu, pois, ter trabalhado nesse jornal? Nunca meu nome lá figurou para sossego de minha alma, que muito se aflige agora na camisa de onze varas em que os senhores a meteram.

Refletindo, a hipótese da mistificação não me parece aceitável, porque enfim o número a que me refiro não é de primeiro de abril. Naturalmente, aquilo foi um erro de composição, erro que desejo ver corrigido.

E ao manifestar assim, de um modo que talvez pareça impertinente, devo dizer-lhes que a retificação que peço é para mim de muita importância. Tenho uma profissão de que está naturalmente banido qualquer animal que tenha a veleidade de escrevinhar para a imprensa. Se os indivíduos de minha classe soubessem que há no corpo humano um órgão chamado cérebro ficariam assustados. Eu e os meus companheiros estamos muito bem sem inteligência. Não temos necessidade disso. Imaginem que meus credores soubessem que dei em garatujar papéis. Adeus, crédito! Eu era um homem perdido.

Há ainda outra razão para que eu não deixe passar despercebido o lamentável equívoco que os senhores cometeram. Sem dúvida seria para mim uma grande honra encontrar-me em tão nobre companhia.

Observei, com grande prazer, que esse hebdomadário passou por uma transformação radical. Encontra-se agora muito melhorado, e não me posso esquivar a aqui lhes enviar as minhas mais calorosas felicitações. Até o número quatorze, esteve ele em estado de larva; hoje é a borboleta livre a esvoaçar com brilho e graça.

A qual das duas fases teria eu pertencido, na hipótese de deixar passar sem protesto a notícia que os senhores deram? Certamente à primeira, pois a segunda conta apenas duas semanas.

Ah! Não! Digo com energia, como os garotos cá da terra:

- Não vou nisso!

O Índio tem apenas dois números bons - os últimos. Os outros, com exceção talvez de um ou outro artigo, estão perfeitamente desarranjados, cá em minha opinião. 
Não me queiram , pois, atribuir a fatura de uma coisa que acho má. Tenham a bondade de desculpar-me esta linguagem descosida e rude. É que pouco percebo dessas coisas de papel impresso.

Sou, meus caros senhores, um seu leitor sofrível.

G. Ramos ${ }^{951}$

${ }^{951}$ RAMOS, G. A propósito de uma notícia... O Índio. Palmeira dos Índios, ano 1, n.17, 22 maio 1921. 
Anos 1930 ainda em Maceió 


\title{
Macobeba Pré-histórico
}

\begin{abstract}
Antigamente Alagoas era um paraíso - a desordem, a confusão, o caos, todas as desgraças em fúria contra o pobre bicho desengonçado que penosamente começava a levantar a espinha e a caminhar, sem motivo aceitável, sobre as patas traseiras. Não era um paraíso cômodo, mas afinal era um paraíso como qualquer outro.
\end{abstract}

Pelos estudos dos fósseis, isto é, pelo exame de algumas pedras que por aí andam e se imaginam vivas, vê-se que naquele tempo não havia crimes. Os bípedes alagoanos matavamse inocentemente, na boa lei natural e, como todos os bens pertenciam aos coronéis, a noção de roubo ainda não tinha aparecido. Circulava regularmente dinheiro falso. E essa coisa de tomar à força as mulheres e as filhas dos outros estava nos hábitos de quase todos os antigos mandões. Não havia castigos, nem aqui nem no inferno, porque Moisés é judeu e porque ninguém conhecia o código.

Ora no meio dessa balbúrdia dos pecados surgiu um indivíduo animoso, resolvido a escangalhar tudo: um sujeito de "rosto carregado e barba esquálida, os olhos encovados e a postura medonha e má, e a cor terrena e pálida, cheios ${ }^{952}$ de terra (isto é exagero) e crespos os cabelos, a boca negra, os dentes”... de lobisomem.

Era Macobeba. Pelo menos dizem que era Macobeba. Que eu, para falar com franqueza, não acredito muito nele. Uma criatura positiva e constitucional, leitora de jornais, iluminada a eletricidade, não admite, é claro, as crenças que enchiam a alma dos homens antigos. Não acredito. E, para descrever Macobeba, recorri ao Camões: furtei uns pedaços do gigante Adamastor.

Macobeba nunca existiu. Ou antes existiu... Eu sei lá! Isto, como vêem, se vai encrencando consideravelmente. Sinto que não me sairei de semelhante dificuldade.

\footnotetext{
${ }^{952}$ Ver se não seria “cheio”.
} 
Houve talvez dois Macobebas. O primeiro, nascido numa idade heróica, tinha como todos os heróis que se respeitam, uma existência subjetiva; o segundo, atual e bacharel, é um ser de carne e osso, como qualquer um de nós. Julgo que este foi pouco a pouco tomando o lugar daquele, até confundir-se com ele e, de longe, parecerem formar os dois um todo indivisível.

É o primeiro o que agora nos interessa, o Macobeba pré-histórico. Como veio ele ao mundo? Se me não engano, gerou a necessidade que tinha a gente primitiva de um salvador. Havia então, como sempre houve, espíritos inquietos e descontentes que tencionavam desmantelar a velha ordem, criar outra nova, pintar o diabo. E, como se sentissem fracos, laboriosamente imaginaram um super-homem com atributos das divindades grosseiras daquela época. Dizia um:

- Necessitamos um homem de dentes acavalados.

Outro afirmava:

- Para arrasar isto é indispensável um senhor de engenho que faça versos.

Lentamente as qualidades exigidas se foram fixando, deram origem a um ser ideal que infundiu ao povo a coragem precisa para vencer. E, como às vezes acontece, um sujeito manhoso, fabricante de açúcar, poeta e prógnato, começou a gritar:

- Eu sou Macobeba!

Não era. Mas os outros pensaram que era.

E o homem se transformou definitivamente em Macobeba.

LÚCIO GUEDES ${ }^{953}$

\footnotetext{
${ }^{953}$ GUEDES, Lúcio [Graciliano Ramos]. Macobeba Pré-histórico. Jornal de Alagoas, Maceió, 27 abr. 1930, p.3.
} 


\section{Macobeba Antigo (II)}

Tendo-se tornado Macobeba para todos os efeitos, o indivíduo a que nos referimos ficou sendo um grande homem. E, como grande homem, achou bom mandar à fava os que o tinham engendrado, colocar os filhos, uma chusma de Macobebinhas sacudidas, e algumas respeitáveis Macobebas do outro sexo, que logo entraram a governar isto macobebamente.

Nos cafés, nos botequins, nas tavernas, admiradores exaltados levantavam os copos de cerveja e berravam:

- Macobeba caiu do céu. É um portento!

E os outros adeptos asseveravam, convictos, arregalando os olhos:

- Um portento, sim senhor.

Macobeba sorria. Alagoas macobebizou-se. Da capital aos mais remotos sertões fervilhavam bichos destruidores de incisivos aguçados e caninos enormes, que estragavam, sem cerimônia o que iam encontrando. Uns devoravam com avidez. Outros se contentavam roendo modestamente, mas coisa que lhes caísse entre as garras era coisa roída. Nos hotéis, nos bares, nas esquinas [,] partidários, já pouco convencidos bradavam com animação descorada:

- Macobeba vai endireitar tudo isto. Viva Macobeba!

Outros sectários hesitavam e respondiam tristes:

- Viva!

Macobeba, resplandecente, mostrava o forro das algibeiras e sorria. Fundaram-se asilos, abriram-se estradas, derramou-se gasolina - a família de Macobeba engordava e era feliz. Descobriu-se que havia no interior, entre os amigos de Macobeba, uma quantidade razoável 
de assassinos e ladrões de cavalos. Era grave. Começaram sussurros. Que diabo! Teriam trocado o Macobeba? A coisa assim não prestava, era necessário fazer outra.

Macobeba continuava a sorrir. E, para demonstrar que podia varrer num momento bagatelas que lhe não perturbavam o sono, tomou uma resolução adequada às circunstâncias. Pegou um jornal, meteu-o numa garrafa, que foi arrolhada, lacrada, atirada ao mar. Em seguida, pelo telégrafo, comunicou o fato ao sr. Pereira Lobo e esperou os acontecimentos.

Nas praças, nos bilhares, no relógio oficial, vagos amigos de Macobeba defendiam-no encolhidos:

- Não senhor, é exagero. Macobeba tem as suas fraquezas, como toda gente, mas é honesto. E quanto ao tino político, sejamos justos, isto ninguém lhe pode negar. Veja o soneto que ele escreveu a respeito dos xexéus.

Outros amigos baixavam a cabeça, constrangidos, engoliam em seco.

E Macobeba sorria. Sorriu sempre, Ultimamente sorria desconfiado. Mas sorria.

LÚCIO GUEDES ${ }^{954}$

${ }^{954}$ GUEDES, Lúcio [Graciliano Ramos]. Macobeba Antigo (II). Jornal de Alagoas, Maceió, 29 abr. 1930, p.3. 


\section{O álcool}

Noticiou esta folha que o Sr. Governador do Estado e o Sr. Secretário da Fazenda, em viagem realizada a 14 deste mês, demonstraram ser o álcool excelente para motores de automóveis. $\mathrm{O}$ artigo que nos oferece a interessante novidade encerra informações preciosas a respeito de força, velocidade, preço, etc...; tem grande número de algarismos; soma, diminui, multiplica, divide - mete num chinelo a gasolina ou, pelo menos, coloca-a na modesta situação de contribuir apenas com 15\% na mistura que há de por em movimento, dentro em pouco, os veículos de Alagoas. Teremos, pois, se a minha aritmética não falha, uma redução de $85 \%$ no consumo do combustível gringo.

Há alguns dias, no senado, o Sr. Messias de Gusmão declamou lamentações patrióticas e atacou, em falta de coisa maior, uma bomba americana pintada de vermelho, aqui instalada para substituir outra mais antiga, pintada de branco e nacional. As jeremiadas do ilustre senador indignaram toda a gente, e podemos prever o fim dessas máquinas exóticas, que nos impingem líquidos nauseabundos da América do Norte, trapalhona e protestante.

Ora vejam como um simples adjetivo alarga o assunto e rende períodos novos. Está claro que os brasileiros, especialmente os católicos, devem elevar aos cornos da lua o produto da cana, ortodoxo e econômico. Resistam, cristãos e amigos, mandem à fava o dólar, empreguem nas suas viaturas (os que as possuírem, naturalmente) substâncias nossas.

Parece que em Pernambuco a [rusga] triunfa. E o deputado Castro Azevedo afirmou ao “Jornal de Alagoas” que há seis meses vem alimentando com álcool um carro de passeio e vários caminhões, cujos motores funcionam de maneira exemplar.

Não admira. Conheço indivíduos que passam seis anos sem ingerir outro alimento e têm os motores em perfeito estado. Se utilizassem a gasolina, sentiriam talvez algumas perturbações.

Ninguém ignora que o álcool é um excitante aconselhado às vezes pela medicina, em pequenas doses. Para a espécie humana, já se vê. Com organismos de ferro o caso é diferente. 
A experiência mencionada no princípio dessas linhas evidenciou que um automóvel absorve quarenta litros de álcool e anda centro e trinta quilômetros sem se embriagar. É assombroso. Com a intemperança natural dos maquinismos, bebe sempre, e só de longe em longe necessita algum repouso e amoníaco. Finda a carraspana, continua a rodar como se nada houvesse acontecido.

Julgo, pelo que aqui fica, terem carradas de razão o Sr. Álvaro Paes e os seus secretários, o “Jornal de Alagoas”, o deputado Castro Azevedo, o senador Messias de Gusmão e Pernambuco.

Só faz medo que as latas de folha vençam as garrafas e prejudiquem a respeitável classe dos paus d’água.

G.R. ${ }^{955}$

${ }^{955}$ G.R. [Graciliano Ramos]. O álcool. Jornal de Alagoas, Maceió, 21 jun. 1930. 


\section{Prefeituras municipais (I)}

Há algum tempo fizemos ligeiras observações a respeito das prefeituras municipais de Alagoas. Foram simples notas, não pudemos tocar nas minudências que exige um assunto interessante, mas que tem sido até agora desprezado pela nossa imprensa.

Quem, há anos, tratou da questão foi o Sr. L. Lavenére, numa série de artigos que, embora misturados com um pouco de fel, corrigiram numerosos absurdos e prestaram excelentes serviços ao Estado; mas os escritos de S.S. deixaram em paz a administração dos municípios e alvejaram especialmente os legisladores sertanejos, criaturas na verdade bastante originais.

Não nos ocupamos com elas, por enquanto. Apenas desejamos mencionar alguns homens de boa vontade, indivíduos que, privados de recursos e agindo num meio hostil, praticaram feitos consideráveis. Certamente ninguém imagina que no curto lapso de alguns anos a evolução intelectual de nosso povo haja atingido seu ponto culminante e que as resoluções municipais de Alagoas sejam muito diferentes do que eram quando o Sr. Lavenére, razoavelmente indignado, andou espicaçando os bisonhos conselheiros do interior. São talvez um pouco menos ruins.

Mas deixemos as posturas. Elas têm de ordinário um valor bastante duvidoso. Se são boas, ou pelo menos aceitáveis, entram em vigor e o matuto se conforma com elas, depois de eloqüentes protestos, porque o matuto protesta sempre; se são ruins caducam logo, ficam escondidas na gaveta do secretário da prefeitura, somem-se.

De resto a lei orgânica de 1926, essa malsinada lei 1087, que, segundo afirmam, deu um golpe de morte na autonomia dos municípios, etc., etc., veio endireitar muita coisa péssima. $\mathrm{O}$ intendente de outras eras administrava para o conselho; mas como o conselho nunca se reunia, o intendente não administrava para ninguém. Em dezembro organizava-se uma sessão e declaravam-se aprovadas as contas que não tinham sido feitas. Um biênio era prazo bem curto, mas sempre dava para um homem diligente liquidar as suas dívidas e juntar um pequeno pecúlio. 
Hoje, com essa história de balancete bimestral e nota das despesas efetuadas, gastos não raro de explicação difícil, e mais um relatório dos trabalhos que às vezes um cidadão executa porque tem de contá-los no fim do ano, tudo mudou. “Já não convém ser prefeito!”, exclamava, há meses, indignado e espumante, um chefe político de formação carbonífera ou devoniana. E não convém. Atualmente o poder executivo não se entende apenas com esse corpo legislativo que o Sr. Lavenére, justamente, escalavrou: presta conta de seus atos ao governo do Estado. E esses atos, que antigamente eram confusos, atrapalhados, esotéricos, vão para o Diário Oficial, vão para as mensagens, vão para o público, que os julga, analisa, compara, esmerilhando, vintém por vintém, o dinheiro arrecadado.

Dirão talvez que um sujeito de medíocre imaginação, sabendo dois dedos de aritmética, poderia facilmente apresentar e justificar uma lista considerável de trabalhos fictícios. Afirmam os roceiros que o papel agüenta tudo. O indivíduo, porém, que adotasse semelhante processo logo seria desmascarado. Nestes últimos tempos os governadores de Alagoas apanharam o hábito de viajar, hábito incômodo para eles, para os que os acompanham, para os que são visitados e fiscalizados. O atual é viajante incansável. Mora num automóvel. Chega aos lugarejos do interior, ouve as embaraçadas conversas dos matutos e sugere idéias, aconselha, discute, anima, exige. Não é fácil um administrador declarar a ele, que despendeu mundos e fundos numa estrada imaginária.

As obras públicas têm hoje existência real. Todos podem examiná-las, medi-las, apalpá-las, saber quanto custaram, como foram construídas, a quem foram pagas. Há por aí vários trabalhos realizados. Não são, de certo, os trabalhos de Hércules. As pretensões dos que os executaram não chegam tão longe. Ainda estão em começo. Mas bastam para demonstrar que Alagoas vai em bom caminho.

LÚCIO GUEDES ${ }^{956}$

${ }^{956}$ GUEDES, Lúcio [Graciliano Ramos]. Prefeituras municipais I. Jornal de Alagoas, Maceió, 31 jul. 1930, p.3. 


\section{Prefeituras municipais (II)}

Em 1927 o Sr. Costa Rego, em documento oficial, declarou que as prefeituras alagoanas, com exceção de uma, gastavam mais com empregados que com obras públicas. A observação produziu bom resultado, pois os orçamentos para 1928 mostram já uma transformação muito louvável. Quase todos consignam para despesas de administração, pensões, gratificações, classe inativa, menos do que determinam para obras de utilidade.

Naturalmente uma prefeitura que arrecada dez contos de réis por ano não pode reservar para trabalhos públicos metade das suas rendas. Seria inconsideração esperar semelhante coisa, pois a receita apenas chega para as miudezas de secretaria, publicações, lampiões de petróleo e funcionários, ainda que estes sejam reduzidos e facilmente contentáveis.

Não podemos, pois, razoavelmente supor que todas as municipalidades de Alagoas estejam em condições de executar um programa. Há algumas de recursos tão parcos que, em conformidade com a lei orgânica, deveriam incorporar-se a outras vizinhas, pois ainda não conseguiram o rendimento exigido a um município.

Houve este ano prefeitura do interior que em um só dia arrecadou mais do que outras, menos favorecidas, alcançaram em todo o ano de 1929. Se considerarmos que apenas três municipalidades, excluindo a da capital, têm orçamentos superiores a cem contos, compreenderemos as dificuldades que oprimem os municípios pobres. Uma calçada de pedras toscas, em pedaço de caminho, alguns reparos nas ruas da vila representam para eles esforço imenso.

Muita energia é necessária, muito desprendimento, para que um homem suporte, durante três anos, abundantes maçadas e obrigações de toda casta, obrigações e maçadas que lhe não darão nenhum proveito.

Um pouco acima desses municípios mirins, que julgam a chegada de um telegrama acontecimento extraordinário, aparecem alguns menos desprotegidos, com agricultura e 
pecuária, vestígios de comércio e indústria, orçamentos que vão de vinte a cinqüenta contos. Aí começam a surgir realizações dignas de encômios. Em certos lugares por aí se têm feito verdadeiros milagres. Causa espanto que tanta coisa se haja conseguido com tão pouco dinheiro.

Vêm afinal as prefeituras mais ricas, porque estão localizadas em regiões prósperas ou porque, em virtude de uma fiscalização rigorosa na cobrança dos impostos, puderam elevar as suas rendas. Estão hoje no galarim umas que por aí se arrastavam, bisonhas e em pasmaceira, entregues a cidadãos resignados que diziam com displicência: “ - Encontrei mole, e mole deixo”. Tudo está mudado. Examinando algumas terras e alguns homens, tentaremos mostrar o que têm realizado os substitutos desses cavalheiros displicentes.

LÚCIO GUEDES ${ }^{957}$

957 GUEDES, Lúcio [Graciliano Ramos]. Prefeituras municipais II. Jornal de Alagoas, Maceió, 08 ago. 1930, p.3. 


\section{Sertanejos}

Para o habitante do litoral o sertanejo é um indivíduo meio selvagem, faminto, esfarrapado, sujo, com um rosário de contas enormes, chapéu de couro e faca de ponta. Falso, preguiçoso, colérico, vingativo. Não tem morada certa, desloca-se do Juazeiro de Padre Cícero para o grupo de Lampião, abandona facilmente a mulher e os filhos, bebe cachaça e furta como rato.

É esse, pouco mais ou menos, o sertanejo que a gente da cidade se acostumou a ver em jornais e livros. Como, porém, livros e jornais de ordinário são feitos por cidadãos que nunca estiveram no interior, o tipo que apresentam é um produto literário. Essa mistura de retirante, beato e cangaceiro, enfeitada com patuá, duas alpercatas e muitas figuras de retórica, torna-se rara. Os homens de minha terra podem ter por dentro a cartucheira e os molambos, mas exteriormente são criaturas vulgares sem nenhum pitoresco.

Os sertanejos dos campos estiveram no Amazonas, em São Paulo e no Espírito Santo; tiraram borracha, plantaram café, voltaram com maços de notas e dispostos a esbanjá-las depressa. Alguns, incapazes de exercícios pesados, meteram-se no exército e na marinha, e os que haviam ido à cadeia e levado pancada, entraram na polícia e vingaram-se.

Todos esses sujeitos regressaram muito sabidos, estranhando tudo, falando difícil, desconhecendo os amigos, ignorando os nomes dos objetos mais corriqueiros, confundindo bode com onça. Naturalmente não quiseram mais criar bodes. Tornaram-se negociantes ambulantes ou adquiriram um pedaço de terra e foram explorar o trabalho dos outros.

Os moradores das cidades leram jornais e aprenderam bastante. A literatura e a ciência deles, que estavam contidas no Carlos Magno e no Lunário Perpétuo, aumentou de modo considerável. Conhecem o José de Alencar, o Júlio Verne, a constituição brasileira e a seleção natural. 
Aparecem entre eles alguns doutores que defendem a liberdade, outros atacam o vigário. E há o rábula, o farmacêutico, o tabelião, o caixeiro que estuda gramática, o redator da folha semanal.

A pessoas notáveis do lugar são comerciantes que passam metade dos dias encostados à carteira, cochilando, e a outra metade debaixo das árvores do largo da feira, tesourando a vida alheia, tecendo mexericos. O assunto preferido é a política. Escangalham o prefeito e delegado de polícia, vão subindo e, com ligeiras paradas nas secretarias e no gabinete do governador, acabam desmantelando o ministério e o presidente da República.

Falam demais não ganham quase nada e começam a sentir necessidades exorbitantes. Têm rodovias, estradas de ferro, luz elétrica, cinema, praças com jardins, filarmônicas, máquinas de escrever e pianos. Só faltam escolas e hospitais. Por isso os sertanejos andam carregados de muita verminose e muita ignorância.

Trabalham pouco, pensam pouco. Mas querem progresso, o progresso que vêem, encantados nas fitas americanas. E progridem sem tomar fôlego. Numa casa velha de taipa, arranjam uma sala bonita e metem dentro quadros, cortinas e penduricalhos.

Dançam o charleston, jogam o futebol, ouvem jazz, conhecem o box e o flirt. Até nos jogos de cartas esqueceram o honesto sete-e-meio e adotaram, sem nenhuma vergonha, as ladroeiras do pocker. Daí tiraram o bluff, que invadiu o comércio e a política. Em algumas regiões já existe o turfe. E em toda a parte a gasolina, o motor U.S.A

Entretanto, os rios estão secos, o gado morre, a lagarta rosada deu no algodão. Tudo tão pobre...

Para que esse bando de coisas de nomes esquisitos? Não era melhor que continuassem a cultivar o terço, o reisado, o pastoril, a quadrilha, a cavalhada, o bozó pelo natal, as sortes em noites de São João? Isto é nosso e é barato. O resto é dos outros e caro.

Dentro e pouco estarão todos no sertão falando inglês. Mas nós não somos inglesses... ${ }^{958}$

\footnotetext{
${ }^{958}$ RAMOS, Graciliano. Sertanejos. Novidade, Maceió, n.1, 11 abr. 1931.
} 


\section{Chavões}

Atacam por aí o lugar comum. Não sei porque. Sendo comum, deve ser conveniente ao público, e não valem contra ele as opiniões de alguns cavalheiros que não são comuns.

Se me dão licença, declaro que tenho predileção especial pelos clichês. E a minha razão está aqui: é mais cômodo viajar em automóvel por uma estrada de rodagem sem buracos que percorrer os caminhos sertanejos cheios de surpresas de espinho rasga-beiço.

Comparando mal (ou comparando bem, como quiserem), a literatura encrencada dos homens de talento é como as veredas de minha terra: tem curvas fechadas, rampas que escangalham um carro, tocos prejudiciais aos pneumáticos, atoleiros, riachos, precipícios, a [ilegível] e ramos indiscretos que batem na cara da gente.

Tudo isso é agradável e produz abalos e interrupções freqüentes na viagem e na leitura.

Vejam agora a rodovia bem conservada e a crônica literária de um cidadão inofensivo. Ambas são planas, batidas, retas, extensas - e resvalamos por elas facilmente, com velocidade de oitenta quilômetros por hora, sem precisão de entendê-las. Quando muito, perguntamos ao chofer ou ao conhecido que entra no café: - Quem foi que fez isso?

Com efeito, nenhum viajante ou leitor, por muito exigente que seja, sentiu nunca a necessidade de compreender uma estrada ou um artigo campanudo.

E precisamente pela sensação de preguiça que experimentamos lendo frases bombásticas simpatizo com certos autores. Sem eles, jornais e livros se tornariam depressa intoleráveis.

Imaginem a maçada de estar um cristão a catar pensamentos em todas as linhas em que se encontra. É trabalho penoso, porque há sujeitos que pensam bem, mas não se exprimem com clareza, outros que se agarram a assuntos terríveis e nos obrigam a olhar para cima e a procurar uma brecha que não aparece. Quase sempre detestamos mistérios. 
Por isso lemos com imenso prazer os escritores que não dizem nada. Excelentes criaturas. Têm boas intenções e portam-se decentemente.

Ora vejam. Coberto de Glória, o sr. Graça Aranha resolve morrer, o que é uma perda irreparável para a sua excelentíssima família e para a Academia Brasileira de Letras.

Um doutor que há vinte e tantos anos leu Canaã e entusiasmou-se, como então era costume, lembra-se de compor necrológio do ilustre diplomata. Arma-se de gramáticas, dicionários e outros instrumentos análogos, senta-se, bebe café, fuma cigarros e atira quatro colunas em cima do finado. Pois essas quatro colunas, com pequenas modificações no tipo, no título, e em alguns adjetivos, servem perfeitamente para defender o divórcio, para fazer declarações de amor e para insultar a Rússia. Têm minas de ouro, cachoeiras, florestas, a pátria, a bandeira, o céu, o mar, um grande número de instituições consideráveis que a gente lê pensando na vida, pensando no câmbio, ou não pensando em coisa nenhuma. É admirável.

Comparem um capítulo do sr. Oliveira Vianna sobre o Brasil colonial a um desses artigos que por aí se publicam a respeito de Castro Alves ou da prefeitura municipal de Porto de Pedras. A primeira tem latifúndios, engenhos de bangüê, nobreza rural, pecuária, mineração e governadores gerais; o segundo tem tudo. Ou não tem nada. É ótimo. Não nos perturba as ocupações ordinárias, pode ler-se no banho, em cima duma bicicleta, ou junto a um tabuleiros de xadrez. E adapta-se admiravelmente às nossas condições interiores. Se estamos zangados, afirmamos que aquilo é insensatez; se estamos de bom humor, achamos engraçado e útil como objeto de estudo. Os católicos levantam os olhos para o céu e sorriem docemente: Pobrezinhio, é um bem-aventurado; os ateus rasgam o jornal e gritam: - Ora, sebo!

Apresento uma sugestão aos homens inteligentes: deixem de escrever e entreguem a pena aos imbecis $^{959}$.

\footnotetext{
${ }^{959}$ RAMOS, Graciliano. Chavões. Novidade, Maceió, n.8, 30 mai. 1931.
} 


\section{O testa de ferro}

$\mathrm{N}$ aquele tempo os jornalistas eram homens que fabricavam desaforos com tinta.

Os de hoje também fabricam, mas antigamente os desaforos eram mais pesados e mais numerosos.

Dedicar-se alguém a essa hidrofobia impressa, agradável aos leitores e desagradável aos políticos, é arriscado e exige músculo abundante e ossos espessos, atributos que dificilmente se encontram em articulistas. Eles têm, é verdade, bastante coragem, mas a coragem dura apenas o tempo necessário à produção dos artigos. Com as portas cerradas e Deus por testemunha, todos nós somos criaturas naturalmente dispostas e arranjamos sozinhos diálogos admiráveis em que espatifamos adversários com habilidade espantosa.

É impossível conhecer-se toda a dignidade que há nos homens: de ordinário ela fica escondida. Surge às vezes nas conversas em que pessoas imaginosas contam rasgos de heroísmo que praticaram e nos insultos escritos para jornais.

É aí que o indivíduo se supera, como dizia o Zaratustra, e se, em horas de trabalho, o literato valente visse aparecer-lhe um perigo sério, é provável que, impossibilitado de se transformar de repente, tivesse um pouco das qualidades que julga ter.

Infelizmente as folhas descem para a composição - e certas idéias importunas começam a picar o redator. Na revisão cortam-se alguns adjetivos cabeludos; como, porém, a coragem ainda existe, outros permanecem. De resto é preciso que um intelectual não se acanalhe perante os tipógrafos. Resultado: no dia seguinte há conveniência em o jornalista não sair de casa ou sair com precaução, olhando para os cantos e evitando encontros prejudiciais à ordem pública. 
Realmente a tranqüilidade só chega quando vem a certeza de que a vítima, fingindo superioridade não ligou importância ao ataque. Aí o articulista sabe, sem nenhuma sombra de dúvida, que é bravo.

Com exercício, no decorrer dos anos, a bravura aumenta.

Podem advir, entretanto, mal-entendidos e sucessos deploráveis. Criaturas de índole selvagem, ignorando que a imprensa é um sacerdócio e pode gritar, arranhar, morder impunemente, indignam-se quando são alvejadas com retórica e vingam-se com pancadas. Temos visto alguns desses mártires da liberdade do pensamento, cobertos de glórias e de esparadrapos.

Para poupar sacrifícios inúteis foi que, em épocas passadas, se instituiu o testa de ferro, figura de que os escritores idosos se lembram.

Era o padrasto das diatribes que as folhas publicavam.

Não valia nada, falava difícil, discutia todos os assuntos, conhecia frases latinas, não escrevia, não se ocupava em coisa nenhuma e ganhava cinqüenta mil réis por mês, uma insignificância atualmente, mas quantia razoável no tempo em que havia câmbio.

Se um jornal trazia publicação escandalosa, os ofendidos tinham dois caminhos, é claro: partir a cara do autor ou levá-lo à justiça. Quem foi, quem não foi - e o barulho começava.

Nesse ponto o testa de ferro assinava uma declaração responsabilizando-se pelas injúrias e calúnias presentes e futuras. E a parte contrária, desarmada, metia a viola no saco, porque ninguém quereria entreter com semelhante personagem uma briga chinfrim em calçadas ou uma pendência ridícula no foro.

Daí em diante a gazeta podia insultar à vontade. Ah! Já tivemos liberdade de pensamento.

E a reputação do testa de ferro crescia. O testa de ferro era considerado. 
Sofria, é certo, alguns dissabores sem conseqüências graves: quebravam-lhe uma costela ou duas, de longe em longe, em noites de escuro. Tolice. Em toda parte há sempre costelas quebradas.

Enquanto o nosso homem se consolidava, a literatura política florescia jogando bilhar, dançando na Phenix ou declamando discursos.

O testa de ferro desapareceu. Habituado a viver em redações, acabou mexendo os pronomes, fez sonetos e compôs arengas compridas. Depois morreu. Faz pena.

Por isso deixam de circular hoje me dia muitas descomposturas.

$$
\text { G.R }{ }^{960} \text {. }
$$

${ }^{960}$ G.R. [Graciliano Ramos]. O testa de ferro. Jornal de Alagoas, Maceió, 16 ago. 1931, p.3. 


\section{Mulheres}

Afinal temos aqui vencedor o nosso pequeno feminismo caboclo.

Pouca importa as opiniões irritantes que pessoas biliosas manifestam a respeito do cérebro da mulher. A esta hora nas mais distantes povoações do Estado senhoras decididas se aprumam, projetam vestidos e discursos de aparato, organizam comissões para atenazar o governo.

Exatamente como os homens. Os mesmos pedidos, as mesmas embromações, mas a aparência muito melhor.

É possível que bom número delas se esteja preparando para a futura assembléia estadual e imaginando alterações em códigos de posturas e orçamentos municipais, que sempre foram ruins, apesar da competência dos conselhos e dos prefeitos. Por baixo dos cabelos curtos, como os nossos, fervilham programas que os homens não souberam executar em quarenta anos ou, se acharem pouco, em quatrocentos e trinta.

Para usar de franqueza, tudo pelo interior está desorganizado, e a culpa não é delas. Ninguém tem o direito de julgá-las incapazes. Podem fazer as promessas mais elásticas.

A verdade é que nossas matutas estão muito mais preparadas que os matutos. Até a idade de doze anos, vão à escola, enquanto os meninos arrastam a enxada ou se exercitam, em calçadas ou em bilhares de ponta de rua, para uma vida fácil de malandros. Crescem um pouco, e os ardores da puberdade as levam para os romances amorosos, que lhes corrigem a sintaxe. Um dia dão uma topada sentimental, casam-se e, algum tempo depois do casamento, quase nunca menos de nove meses, passam à categoria de mães. São agentes do correio, telegrafistas, professoras interinas, datilógrafas num banco popular e agrícola, mulheres de negociantes. Como mulheres de negociantes, tomam conta da loja, compram, vendem, escrituram, arrumam, desarrumam, varrem, espanam, brigam com o caixeiro (ou não brigam), escrevem bilhetes de cobrança, entendem-se com os representantes dos fornecedores. 
Enquanto isso acontece, os maridos passam oito meses do ano jogando gamão, discutindo os telegramas dos jornais, atacando o governo e o imposto nas barbearias, nas farmácias, nas esquinas.

É assim na cidade pequena, que hoje, por desconto dos nossos pecados, tem eletricidade, cinema, automóvel, gasolina, outras infelicidades americanas que nos deixam de esmola.

No campo é diferente. Em cada sítio, quando falta a professora pública, há uma velha sabida, perita em décimas e ladainhas. É ela que ensina as quatro espécies de contas às meninas e lhes mete o almanaque entre os dedos. $\mathrm{O}$ almanaque resume a ciência toda.

Os meninos sapecam-se na queimada, enegrecem na coivara e, logo que ficam taludos, dançam o coco em festas de S. João e bem aguardente nas sentinelas de defuntos. Casam-se novos e entregam às companheiras tudo quanto exige pensamento: correspondência, palestras com as visitas, explicações das coisas da natureza, leituras piedosas, comunicações com a Divindade e com o vigário da freguesia.

A conseqüência disso é existirem no sertão mulheres terríveis, que transformam os maridos em quincas, administram propriedades, arengam com os coronéis, têm cabroeira, mandam matar gente e protegem criminosos no júri.

Há a mulher de chefe político. Sempre houve. Tem um cunhado secretário da prefeitura, um irmão delegado de polícia, muitos afilhados cobradores de impostos municipais e um marido que serve para pedir ao governo a demissão do promotor e a remoção do cabo comandante do destacamento.

Ora as senhoras não votavam. Agora votam. As matutas foram à eleição de 3 de maio e comportaram-se perfeitamente. Assinaram as folhas com desembaraço, entraram no gabinete, meteram a chapa no envelope e, em conformidade com os conselhos da Liga de Ação Católica, sufragaram os candidatos do Partido Nacional, do Partido Democrata e do Partido Socialista. 
Os matutos em geral não se comportaram bem. Sentaram-se tremendo e estiveram dez minutos sujando os dedos com tinta e procurando tirar um fiapo inexistente no bico da pena. Fizeram borrões no papel, foram à saleta secreta, voltaram e deitaram o título de eleitor dentro da urna.

Vão agora pensar que esses pobres homens continuarão a atrapalhar a política e a administração do Estado. Não continuam. Os municípios serão dirigidos por mulheres. Dirigidos claramente. Porque em alguns, conforme ficou dito, já elas dominavam à socapa no tempo em que só os homens podiam votar.

Imaginem a que nos reduziremos no futuro.

GRACILIANO RAMOS ${ }^{961}$

${ }^{961}$ RAMOS, Graciliano. Mulheres. Jornal de Alagoas, Maceió, 20 mai. 1933, p.3. 


\section{Doutores}

Aqui na capital os doutores são indivíduos quase como os outros: vestem-se como todo o mundo, falam como todo o mundo, é possível a gente desprevenida passar junto a eles sem perceber nenhum sinal que os denuncie.

Têm, naturalmente, as suas honras de sabedoria oficial no consultório ou na repartição, mas findo o trabalho, escondem o anel, dobram a carta e vão para os cafés discutir fitas do Floriano, literatura, sociologia e outras habilidades. Um sujeito da rua grita para eles:

- Oh Théo! Oh Moacir! Como vai, Zé Lins?

E os que jogam dados na mesa próxima ficam sem saber que um daqueles fregueses é especialista em moléstias de crianças, outro ensina física, o terceiro escreve romances.

São bem razoáveis os doutores da capital.

Os do interior são muito diferentes deles. Dogmáticos, eriçados e carrancudos.

A diferença explica-se: o bacharel, o médico ou o engenheiro que mora na cidade encontra frequentemente, dentro da sua classe ou fora dela, homens sabidos. Daí uma aproximação, uma familiaridade útil a todos.

No interior não é assim. O rapaz que salta da Academia para a roça sente-se isolado. Vai com a cabeça cheia de fórmulas, algum pensamento e muito bons desejos: quer abrir uma escola, criar o horrível grêmio literário, fundar um desses pequeninos jornais onde os talentos cambembes engatinham. Mas só percebem em redor brutalidade e chatice. O pensamento e os desejos encolhem-se.

Busca fugir à brutalidade ambiente, procura alguma saliência naquela chatice toda. Nada. 
Na primeira visita que faz ao prefeito ouve o sermão declamado no domingo, sermão que o vigário há dez anos profere todas as semanas, com muito fervor e pouco êxito. A mulher do prefeito defende o vigário. Mas o prefeito é livre pensador. Não se entendem. E o visitante sai zonzo.

É atraído por umas risadas enormes. Anda meio quilômetro e afinal descobre um malandro ocupado em fazer relatório dos amores ilícitos da localidade, história complicada e antiga a que a imaginação tacanha do narrador todos os dias acrescenta um pormenor.

Afasta-se, enjoado.

- Gente estúpida! Gente ruim!

Convidam-no para um casamento. Vai, constrangido. No meio da festa dão-lhe a palavra. Se é um bacharel afoito e linguarudo, muito bem. Mas às vezes é agrônomo ou cirurgião dentista e confessa honestamente que não sabe fazer discursos. Está arrasado: daí em diante não inspira nenhuma confiança.

O matuto é um ser que fala abundantemente. Dizendo as coisas mais simples, usa tiradas absurdas, circunlóquios, que não têm fim. Acha que os outros devem ser também tagarelas.

Para ele qualquer doutor tem a obrigação de saber fazer tudo: requerimentos, defesa no júri, correspondências para o jornal, demarcações de terra, extração de dentes, eleições, orçamentos municipais e receitas de remédios.

Assim, o letrado oficial que vive em cidade pequena, se não quer passar por ignorante, entrega-se a ocupações numerosas. Torna-se um charlatão.

Com aprumo que faz pena, diz cinicamente: "Para matuto é isto: ensinar o que ele sabe e comer o que ele tem”.

Muita arrogância e uma frase latina: dura lex sed lex ou outra. Se o latim falha, agarra-se ao francês. 
Os roceiros ficam embasbacados. E o doutor triunfa.

Desde que arranja um conceito regular, fala pouco para não se comprometer: sorri, gesticula.

É, naturalmente, o consultor da povoação onde reside. Se fazem pergunta difícil, evita o obstáculo usando expressões arrevesadas.

Esquece as fórmulas que trouxe da Academia, mas os fragmentos de algumas ficam, inúteis e sempre repetidos, a adornar-lhe os restos do espírito.

Admira os personagens consagrados pelo artigo de fundo, tem horror à poesia sem rima, acata o governo e a oposição, gosta do progresso e de dois em dois anos manda fazer uma roupa de casimira e torna-se importantíssimo.

Escrevendo arrazoados, examinando doentes ou fabricando xaropes, emprega José de Alencar, Rui Barbosa, Castro Alves, Euclides da Cunha.

O matuto baba-se por ele, e quando é rico, tenta casá-lo com uma filha, que o grande desejo do tabaréu é ter um parente doutor. Busca tratá-lo familiarmente, mas isto é impossível. Julgase muito pequeno. Dirige-se a ele, diz senhor ele, em resposta, diz você.

Este tratamento leva os homens da aldeia a sacrifícios.

Um soletra quatro livros pacientemente e faz-se rábula ou tabelião. O doutor auxilia-o.

Outro estabelece loja de fazenda, ganha dinheiro. O doutor visita-o depois do jantar e conta anedotas, com superioridade.

O negociante passa da loja para o armazém, arranca uma fortuna do couro do madioqueiro. $\mathrm{O}$ doutor continua a olhá-lo de cima para baixo. 
O desgraçado mete-se em política, transforma-se em prefeito e, se há constituição, vira deputado, com o favor do governo. Diante do doutor é sempre mesquinho. Acredita no que ele diz, deixa-se enganar candidamente. Declara, com uma espécie de orgulho:

- Doutor Fulano risca e eu corto.

É esse doutor parlapatão e ignorante, que domina as cidadezinhas do interior. Lá não há livros, e os jornais, raros, servem para embrulhar sabão nas bodegas.

Quando o governo conhecer isso bem, cortará muitas despesas inúteis.

E a opinião pública, pelo menos na aldeia, estará com ele.

GRACILIANO RAMOS ${ }^{962}$

${ }^{962}$ RAMOS, Graciliano. Doutores. Jornal de Alagoas, Maceió, 11 jun. 1933 


\section{Um romancista do Nordeste}

O sr. Prudente de Morais Neto, falando sobre a nossa literatura de ficção, pobre demais, fezme há tempo uma observação que achei curiosa. O romance brasileiro é ruim, os melhores escritores emperram nesse gênero. Por que será? Impotência? Talvez o ambiente não ofereça material que preste.

Fiquei surpreendido e com desejo de contrariar uma pessoa inteligente e autorizada como o sr. Prudente de Morais Neto. Pensei que ele havia sido rigoroso em demasia com alguns novelistas indígenas e especialmente com o país, que deve ser como os outros países, salvo pequenas diferenças. Em todos os lugares há romances, disse comigo, o que falta às vezes é o romancista.

Liliput e Brobdingnag nunca existiram e não obstante Swift pôs lá o seu Gulliver. Um urso, uma pantera, uma cobra, um tigre, vários macacos e lobos, deram a Kipling, que não viveu na floresta e de homens só utilizou um, que era quase bicho, assunto para dois livros da Jungle. Onde houver um ser dotado de imaginação há uma obra de arte em perspectiva.

É certo que as criaturas que nos rodeiam são ordinárias, mas também pode que o Raskolnikoff e a Sonia de Dostoievski fossem na realidade uma assassino comum e uma prostituta vagabunda, sem nenhuma espécie de grandeza. Vendo-se impressos, talvez não se reconhecessem.

Matutei nessas coisas quando li, há alguns meses, o segundo volume da série que o sr. José Lins do Rego iniciou com a publicação duma novela escrita em brasileiro. É um bom romancista, creio eu. E entretanto decorre num ambiente de estreiteza lastimosa. Constituem o meio físico as quatro paredes dum colégio - prisão do Nordeste, um rio, pedaços de natureza entrevistos de relance. O meio social compõe-se de cinco ou seis meninos de importância medíocre, um professor brutíssimo, a mulher e o sogro do professor, uma preta, uma vaga meretriz assanhada, mais algumas figuras que entram e saem discretamente. Muito pouco, 
mas apesar disso, e talvez por isso o sr. José Lins do Rego fez um bom trabalho. Julgo que é um trabalho admirável.

Se o escritor dispusesse de grande número de tipos que se mexessem numa cidade, é possível que não resistisse à tentação de, como tantos outros, fornecer-nos pormenores inúteis. Jogando com elementos escassos, teve que extrair quase tudo do seu interior.

Até agora o sr. José Lins do Rego publicou dois livros. Os críticos andaram a compará-los. Qual seria o melhor? Pensando bem, acho que a pergunta não tem cabimento: há apenas uma obra em dois volumes. Provavelmente virão outros - e teremos uma pequena Comédia Humana nordestina.

O que há é que no primeiro, o Menino de Engenho celebradíssimo, existem descrições que poderiam desaparecer sem desvantagem, uma queimada e uma seca por exemplo, bem feitas, mas que já foram exploradas por literatos de outras épocas, o finado José de Alencar e o finado Graça Aranha, inclusive. Esta opinião não tem importância. De ordinário o que se julga melhor no romance é exatamente a parte objetiva, e é provável, que essas duas tiradas, ricas em minudências, semelhantes às fotografias que Balzac e os realistas aproveitaram, hajam concorrido para tornar Menino de Engenho uma história admirada por toda a gente.

A verdade é que o sr. Lins do Rego não precisa recorrer ao pitoresco para dar vida às suas criações. Nesse Doidinho excelente não há excesso de tintas. As coisas não nos aparecem como são (e quem sabe lá como são as coisas?), mas como o personagem principal as vê. Esse personagem, sujeito inteligente e com um parafuso solto, transmite-nos ampliados e interessantes os fatos mais corriqueiros.

Não sabemos como é por fora essa criança carregada de taras e cacoetes. Será loura ou morena? Terá os olhos pretos, azuis, verdes ou amarelos? E o resto? Estamos longe do tempo em que o cidadão gastava eternidades para descrever um tipo das unhas dos pés às pontas dos cabelos. Não esquecia uma ruga, não esquecia um botão da camisa. No fim de tudo apresentava um manequim.

Presumimos que o protagonista do sr. Lins do Rego tem rugas, botões, olhos e cabelos, como todos nós, mas o autor não nos amola com semelhantes bagatelas: mostra-nos o rapaz por 
dentro. Surge então, vivo, bulindo, um sujeito que não é como os outros, um sujeito cheio de curiosidades e caprichos, indiferente às lições e à chatice da escola, incapaz de marcar passo e marchar na fileira, movendo-se desordenadamente e transformando, com os olhos e os ouvidos muito abertos, o mundo exterior num universo novo.

Tudo se anima. A água do rio não serve apenas para tirar-lhe a porcaria ganha no colégio imundo: lava-lhe alma e transporta, para o sítio onde viveu, as suas tristezas de estudante maltratado. O bueiro do engenho é um amigo velho que o chama de longe. Na sua memória o avô deixa de ser o explorador da cabroeira que se esfalfa no eito: muda-se numa espécie de santo que se preocupa com a sorte dum assassino preso.

A obra do sr. Lins do Rego tem coesão. Às vezes a de escritores grandes demais não a tem. Os livros do velho Hugo, os de Anatole France, os de Machado de Assis, estão cheios de soluções de continuidade, intercalações, enxertos. Vendo esses parêntesis, somos levados a pensar que certos autores ou trabalham com interrupções ou escrevem nas horas vagas folhas avulsas que entremeiam nas suas narrações com mais ou menos habilidade. Entre nós o comum é encontrarem-se romances arranjados com pedaços desconexos. Lemos uma página boa, em seguida vinte páginas que não são boas nem ruins, adiante uma péssima, depois uma sofrível - e o leitor tem a impressão de estar vendo um desses gráficos do serviço de estatística em que as linhas descem e sobem desesperadamente.

É possível que um olhar agudo descubra altos e baixos na obra do sr. Lins do Rego. Não notei isso. Também não me esforcei para encontrar preciosidades. Pouco me satisfaria encontrar aqui um diálogo natural, ali uma descrição encaixada a propósito, acolá uma frase original. Essas descobertas só serviriam para prejudicar o conjunto, seriam como elevações em uma planície. Se me recomendassem uma estátua por ter as mãos e os pés bem feitos, eu não ficaria contente. Preferiria que nem as mãos nem os pés fossem demasiado bem feitos, mas que estivessem em harmonia com as outras partes do corpo.

De resto esse trabalho de expor minúcias revela mão de especialista, e no romance, campo vastíssimo, o especialista, a começar pelo gramático, não ultrapassa as fronteiras de seu distrito. 
O sr. Lins do Rego não é especialista em coisa nenhuma. Nada de terminologias embaraçosas. Mostra simplicidade extraordinária, põe-se facilmente em contato com o povo ignaro, como dizia Camões.

Outra dificuldade, e terrível, foi ter conseguido tornar-se interessante servindo-se dessa pobre língua do Nordeste, língua bronca, incerta, de vocabulário minguado. Língua braba, que o sr. Mário Marroquim procura domesticar. Notem que o matuto fala pouco diante de pessoas sabidas. Quando o obrigam a falar, recorre aos gestos, usa circunlóquios - e o discurso é charada. Uma só expressão, variando com o tom da cantiga que é conversa ordinária de tabaréu, tem significações que nos atrapalham. Dialeto horrível para a língua escrita.

Outra coisa. Tenho estado a pensar que o sr. Lins do Rego escreveria, se quisesse, excelentes biografias. Como as de André Maurois. Valeria a pena? Seria preferível transformar o velho Cotegipe numa espécie de Disraeli ${ }^{963}$ ? Talvez não fosse. Onde achar personagens? Parece que estou inutilizando o que afirmei no começo deste artigo.

Mas na biografia a imaginação não poderia fazer tudo ${ }^{964}$.

963 Benjamin Disraeli (21 de dezembro de 1804, Londres - 19 de abril de 1881, Londres) foi um escritor e político britânico de origem judaica portuguesa (sefardita) e primeiro-ministro do Reino Unido. Sobre ele, Maurois escreveu o livro La vie de Disraeli.

${ }^{964}$ RAMOS, Graciliano. Um romancista do Nordeste. Literatura, Rio de Janeiro, ano 1, n.18, 20 jun. 1934 , p.1. 


\section{O romance do Nordeste}

Nestes quatrocentos anos de colonização literária recebemos a influência de muitos países. Sempre tentamos reproduzir com todas as minudências a língua, as idéias, a vida de outras terras. Não sei donde vem esse medo que temos de sermos nós mesmos. Queremos que nos tomem por outros.

Talvez seja porque entre nós é fácil um preto casar com uma branca, uma preta viver com um branco sem casar. Os mulatinhos escondem-se dos pais e, com o intuito de clarear a descendência, sujaram-se de pó de arroz e imitaram os modos dos estrangeiros. A religião negra, a arte negra, tudo quanto a África nos pode dar foi sufocado pelo ingênuo desejo de arianizar isto depressa.

Havia em Portugal uma certa quantidade de gramáticos. Arranjamos gramáticos mais numerosos e procuramos a alguns anos escrever melhor que os portugueses. Nunca houve lugar no mundo onde se discutisse tanta sintaxe.

Tudo nos vinha de fora.

Na literatura de ficção é que a falta de caráter dos brasileiros se revelou escandalosamente. Em geral os nossos escritores mostraram uma admirável ignorância das coisas que estavam perto deles. Tivemos caboclos brutos semelhantes aos heróis cristãos e bem falantes em excesso. Os [patriotas] do século passado, em vez de estudar os índios, estudaram tupi nos livros e leram Walter Scott. Tivemos Damas das Camélias de segunda mão. Tivemos paisagens inúteis em linguagem campanuda, pores-do-sol difíceis, queimadas enormes, secas cheias de adjetivos. Descrições. José Veríssimo construiu um [candieiro] em não sei quantas páginas.

Muito pouco - rios, poentes cor de sangue, incêndios, candieiros. 
Os ficcionistas indígenas engancharam-se regularmente na pintura dos caracteres. Não mostraram os personagens por dentro: apresentaram o exterior deles, os olhos, os cabelos, os sapatos, o número de botões. Insistiram em pormenores desnecessários, e as figuras ficaram paradas.

Os diálogos antigos eram uma lástima. Em certos romances os indivíduos emudeciam; em outros falavam bonito demais, empregavam linguagem de discurso. Dois [extregeiros], perdidos nas brenhas, discutiam política, sociologia, trapalhadas com pedantismo horrível que se espalhavam por dezenas de folhas. Via-se perfeitamente que o autor nunca tinha ouvido nada semelhante ao palavrório de seus homens.

Felizmente vamo-nos dessa absurda contrafação de literaturas estranhas. Os romancistas atuais compreenderam que para a execução da obra razoável não bastam retalhos de coisas velhas e novas importadas da França, da Inglaterra e da Rússia. E como deixaram de ser obrigatórias as exibições da porta do Garnier, os provincianos conservaram-se em suas cidadezinhas, acumulando documentos, realizando uma honesta reportagem sobre a vida no inteiror.

O trabalho que há no Nordeste é mais intenso do que em qualquer outra parte do Brasil, tão intenso que um crítico, visivelmente alarmado com as produções daqui, disse ultimamente que não é só no Norte que se faz literatura. De certo. Era indispensável, porém, que nossos romances não fossem escritos no Rio, por pessoas bem intencionadas, sem dúvida, mas que nos desconheciam inteiramente.

Hoje desapareceram os processos de pura composição literária. Em todos os livros do Nordeste, nota-se que os autores tiveram o cuidado de tornar a narrativa, não absolutamente verdadeira, mas verossímil. Ninguém se afasta do ambiente; ninguém confia demasiado na imaginação.

E é assim que deve ser. Se o sr. Gastão Cruls vivesse aqui, não teria podido escrever o seu Vertigem. Apesar de médico e romancista, foi-lhe necessário estar habituado à cidade grande.

Também não seria possível a um carioca, ainda que tivesse visitado o interior do Ceará, conceber e realizar o João Miguel. Para fazê-lo a sra. Rachel de Queiroz consumiu largo 
tempo examinando uma prisão da roça, registrou as palavras do cabo Salu, conversou com Filó, viu como ela enchia o cachimbo de barro.

O sr. Lins do Rego criou-se na bagaceira de uma engenho, e julgo que nem sabe que é bacharel. Conservou-se garoto de bagaceira, o que não lhe teria acontecido se morasse no Rio, freqüentando teatros e metendo artigos nos jornais. Aqui está bem. Quando o cheiro das tachas vai esmorecendo, dá um salto a uma engenhoca, escuta Zé Guedes, seu Lula, a velha Sinhazinha.

O sr. Jorge Amado nasceu numa fazenda no sul da Bahia - e por isso escreveu Cacau. Instalou-se depois na ladeira do Pelourinho 68, onde travou relações com várias criaturas que entraram na composição de seu último livros.

Esses escritores são políticos, são revolucionários, mas não deram a idéias nomes de pessoas: os seus personagens mexem-se, pensam como nós, preparam as suas safras de açúcar, bebem cachaça, matam gente e vão para a cadeia, passam fome nos quartos sujos de uma hospedaria.

Os romancistas não saíram de casa a procura de reformas sociais: a revolução chegou a eles e encontrou-os atentos, observando uma sociedade que se decompõe.

Está claro que ninguém aqui pretende haver construído monumentos. Estamos ainda no começo, mas um excelente começo que nos á excelente quantidade de volumes todos os anos.

Nessa produção excessiva há falhas, topadas, marcas de trabalho feito à pressa. Naturalmente porque estamos a correr sem nos termos acostumado a andar.

O que é certo é que o romance do Nordeste existe e vai para adiante. As livrarias estão cheias de nomes novos. Não é razoável pensarmos que toda essa gente escreva porque um dia o sr. José Américo publicou um livro que foi notado com espanto no Rio:

- Um romance do Nordeste! Que coisa extraordinária ${ }^{965}$.

${ }_{965}^{9}$ RAMOS, Graciliano. O romance do Nordeste, Diário de Pernambuco, Recife, 10 mar. 1935. 


\section{Alguns números relativos á instrução primaria em Alagoas}

O quadro que nos apresentava, há poucos anos, a instrução em Alagoas era: dezena e meia de grupos escolares, ordinariamente localizados em edifícios impróprios, e varias escolas isoladas na capital e no interior, livres de fiscalização, providas de material bastante primitivo e quase desertas. As professoras novas ingressam comumente nos grupos; as velhas ficavam nas escolas isoladas, desaprendendo o que sabiam, longe do mundo, ensinando coisas absurdas. Salas alcunhadas, palmatória, mobília de caixões, santos nas paredes, em vez de mapas. Em 1932 eram assim as escolas rurais, as distritais e também grande parte das urbanas.

De 17 grupos escolares que possuímos 8 estavam em casas arranjadas á pressa, sem nenhuma aparência de escolas. Depois da revolução adotaram o sistema de criar grupos escolares que, para bem dizer, só existiam nos decretos. Armava-se um grupo de papel, nomeava-se o corpo docente e depois se procurava uma casa.

Em Palmeira dos Índios havia um desses, pessimamente instalado no prédio da prefeitura. Mobília nenhuma. Cada aluno levava a sua cadeira, cada professora adquiria uma banca. Quatro mulheres e 152 crianças trabalhavam ali em 1933. Provido de bom material, esse estabelecimento tem hoje oito professores e 374 alunos. Dentro de dois meses será inaugurado o excelente edifício, que para ele se está construindo.

O "Deodoro da Fonseca”, na cidade de Alagoas, esteve em casa alugada até o fim de 1934, quando passou a funcionar em um prédio conveniente.

Varias das escolas que existiam em salas pequenas, onde as crianças não tinham nenhum conforto e se privavam dos objetos indispensáveis ao estudo, vão desaparecendo. $\mathrm{O}$ ano passado fecharam-se dez na capital. Em compensação foram abertos dois grupos que utilizam 19 professoras. 
Este ano criaram-se grupos escolares em Muricy, Pão de Açúcar, Atalaia e São José da Lage. Os decretos relativos a esses estabelecimentos foram escritos depois de construídas e mobiliadas as casas. Isso nos da a supressão de 19 escolas isoladas.

Este ano será iniciada a construção de oito grupos escolares em Maceió, Rio Largo, Coruripe, S. Miguel de Campos, Anadia, Quebrangulo e Sant’Anna de Ipanema. Desaparecerão 36 escolas isoladas.

Em 1932 havia nas escolas publicas 15.826 alunos, 22.821 em 1933, 25.840 em 1934. A freqüência media de 11.285 em 1932, subiu a 15.264 em 1933, a 16.900 em 1934.

Excetuados os municípios de Água Branca, Porto Calvo, Igreja Nova, Camaragibe e Maragogy, em todo o Estado a matricula e a freqüência aumentaram. Na capital a matricula era 3.055 em 1932, 5.576 em 1933, 7.264 em 1934; a freqüência cresceu de 2.308 em 1932 para 3.654, em 1933 e 4.859 em 1934.

Em 1932 existiam 434 professores em 337 estabelecimentos de ensino, compreendidos 17 grupos escolares. Temos hoje 473 professores em 358 estabelecimentos: 335 escolas isoladas e 23 grupos escolares.

Em 1932 houve 4.089 promoções e 544 conclusões de curso; em 1934 tivemos 7.697 promoções e 1.519 conclusões de curso.

Em 1934 as crianças pobres dos estabelecimentos públicos receberam 3.865 cadernos e 9.064 metros de fazenda. É pouco, mas talvez este ano os fornecimentos cresçam.

Sobre o ensino municipal ha os seguintes números: 45 escolas isoladas em 1932, 56 em 1933; 1.622 crianças matriculadas em 1932, 1.994 em 1933; freqüência media de 1.412 em 1932, de 1.487 em 1933; 45 professores em 1932, 56 em 1933.

Ensino particular: 95 escolas em 1932, 169 em 1933; matriculas - 4.144 em 1932, 7.365 em 1933; freqüência - 3.605 em 1932, 5.775 em 1933; 159 professores em 1932, 225 em 1933. Ainda nos faltam as cifras relativas a 1934. Essas escolas não nos remetem os mapas que o 
serviço de estatística exige: vai um inspetor colher nelas os dados necessários, e isto demora o trabalho.

De resto só de 1933 para cá o serviço de estatística existe. O que antes havia é bastante nebuloso $^{966}$.

${ }^{966}$ RAMOS, Graciliano. Alguns números relativos à instrução primária em Alagoas, A Escola, Maceió, set. 1935. 
Depois da saída da prisão (em 1937) 


\title{
Uma carta de Graciliano Ramos
}

\author{
Murilo Miranda:
}

Estou muito agradecido a você, aos membros do Júri que me conferiu o prêmio Lima Barreto, aos colaboradores que, no último número da "Revista”, contribuíram para melhorar a situação dum romance que nasceu infeliz e arrasta nas prateleiras das livrarias uma existência bastante precária. Se, depois de tantos trabalhos e tantos artigos, ele continuar inédito, a culpa não terá sido dos generosos amigos que tencionaram publicá-lo: você, Annibal Machado, Alvaro Moreyra, Mario de Andrade, Rubem Braga, Peregrino Junior, Tavares Bastos, Oswald de Andrade, Emil Fará, Jorge Amado, Aydano de Couto Ferraz, Bezerra de Freitas, João da Silva Mello, José Bezerra Gomes, Paulo Saraiva, Portinari, Adami e o misterioso Nicolau Moutzuma, o estranho Nicolau Moutezuma, que não é Nicolau nem Moutezuma e se manifestou há tempo, antes desta confusão em que vivemos.

Eu pretendia entender-me pessoalmente com os escritores e os pintores que olharam com otimismo excessivo o meu romance magro e minha figura física, magra também. Não o fiz por dois motivos. Principalmente achei que, tendo sido publicas as manifestações de simpatia, os agradecimentos deviam também ser impressos. Em segundo lugar pareceu-me redundância escrever dezoito cartas diferentes para dizer a mesma coisa. Eu encontraria nelas uma dupla dificuldade: não poderia aceitar a opinião dos meus amigos, sob pena de mostrar-me presunçoso; não me seria possível discordar deles abertamente porque isto seria impertinência. O meu assunto ficaria muito reduzido.

É melhor fazer uma carta só, uma carta que explique em ligeiras palavras o procedimento de alguns homens que, nos tempos que correm, são verdadeiras preciosidades. Tenho a certeza de que todos aí estão de acordo comigo.

Confesso que, nesse negócio de concursos literários, não se leva em conta apenas o valor das obras que se apresentam. Talvez o publico não ache razoável que seja assim, mas é. Há 
sempre fatos importantes que a platéia ignora e que influem no julgamento. O livro considerado bom por uma instituição é recusado por outra - e ficamos sabendo que a vitória de qualquer deles é duvidosa, que o júri que o escolheu teve o intuito, não de formular uma sentença, mas de oferecer ao escritor desconhecido um estimulo necessário.

A decisão refere-se menos ao trabalho executado que a trabalhos futuros. E como examinar coisas possíveis é mais difícil que analisar coisas realizadas, explica-se perfeitamente que haja divergência entre os pareceres de varias comissões.

Esse caso do prêmio Lima Barreto é diferente dos outros. Parece que não houve precisamente a intenção de julgar um romance nem de saber se o autor dele poderia fazer trabalho menos mau.

Estou convencido de que me quiseram dar uma compensação. Annibal Machado, Alvaro Moreyra e Mario de Andrade desfizeram agravos e combateram moinhos reais. Eu estava sendo triturado por um destes moinhos. E a solidariedade de alguns intelectuais brasileiros teve para mim significação extraordinária.

Refletindo bem, penso que o prêmio não foi concedido a mim, mas a várias centenas de criaturas que se achavam como eu. Não se tratou de literatura, evidentemente. O que não quer dizer que, achando a decisão injusta, como acho, eu não a considere um ato de coragem indispensável num momento de covardia generalizada, ato imensamente útil, senão a mim, pelo menos a outros, que poderão respirar com alivio e dizer o que pensam.

Abraços de GRACILIANO RAMOS Rio, 11 de junho de $1937^{967}$.

\footnotetext{
${ }^{967}$ RAMOS, Graciliano. Carta de Graciliano Ramos. Revista Acadêmica, Rio de Janeiro, n.28, jun.1937.
} 


\section{Mulheres...}

Há alguns dias, percorrendo as salas dum ministério para tratar de certo negócio terrivelmente embrulhado, desses que dão aneurismas e cabelos brancos, eu e um amigo encontramos numerosas funcionárias bonitas. Uma delas forneceu-nos informações bastante vagas: deu-nos dois ou três números e, com os olhos redondos e úmidos, que um ligeiro estrabismo entortava, pareceu indicar a direção do lugar onde nossos papéis deviam estar.

Corremos a outro ministério e vimos várias senhoras difíceis entregues a trabalhos incompreensíveis. Não achamos nossos papéis, é claro. Andamos em repartições diferentes, voltamos ao primeiro ministério, ao segundo, tornamos a voltar, percorremos infinitos canais competentes - e em toda a parte esbarramos com senhoras atarefadas, que executavam operações estranhas, usavam uma linguagem desesperadamente confusa e recebiam indiferentes as nossas queixas e nossos rogos.

Com o coração grosso e indignado, resolvi abandonar esse negócio infeliz e fui deitar uma carta ao correio. Tomei lugar na fila, mas antes que chegasse a minha vez a mulher que vendia selos deixou o guichê. Esperei uma eternidade a volta dela e fui-me aproximando devagar, na fila. A carta foi pesada, o selo comprado e uma prata falsa recebida no troco.

Marchei para o guichê dos registrados, onde uma espécie de mulher portadora de óculos e bastante idade se mexia como figura de câmara lenta.

Enquanto me arrastava seguindo os desgraçados que ali estavam sofrendo como eu, pensei nas deputadas, nas telefonistas, na professora primária que me atormentava e nos versos de certa poetisa que em vão tento esquecer. Evidentemente nenhuma dessas pessoas, deputadas, telefonistas, professora e poetisa, tinha culpa de haverem corrido mal os meus negócios nos ministérios, nenhuma me dera prata falsa, e era estupidez responsabilizá-las pela preguiça da mulher do registrado. Mas relacionei todas e julguei perceber os motivos de certos hábitos novos. 
Antigamente, quando uma senhora entrava num carro cheio, havia sempre sujeitos que se levantavam. Hoje, nos trens da central elas viajam espremidas como num meeting.

Ninguém fumava nos primeiros bancos dos bondes. Ainda existe a proibição num aviso gasto e metrificado, que tem o mesmo valor dos outros alexandrinos: ninguém o lê. A autoridade do condutor ficou muito reduzida, e o letreiro proibitivo tornou-se lei como as outras, artigo de regulamento.

Há pouco tempo uma senhora declarou num romance que as mulheres são diferentes dos homens. É claro. Mas, apesar da diferença, elas se tornaram nossas concorrentes temíveis. Eu queria ver um examinador que tivesse a coragem de reprovar aquela moça de olhos redondos, úmidos e ligeiramente estrábicos, que encontrei um dia destes no corredor do ministério. Só se ele fosse cego.

O Sr. Plínio Salgado quer acabar com os banhos de mar, porque as pernas das mulheres se descobrem neles. Não vale a pena. São pernas de concorrentes, para bem dizer nem são pernas. Pensa que lá temos tempo de pensar nessas coisas? Tinha graça que, nos banhos de mar, fossemos espiar as canelas da moça de olhos estrábicos ou as da mulher que nos impingiu uma prata falsa de dois mil réis. Não olhamos. Se elas chegarem perto do estribo do bonde cheio, ficaremos sentados porque pagamos passagem e temos o direito de ficar sentados. Isto. Somos pouco mais ou menos iguais, apesar da afirmação da mulher do romance. Vão no estribo, se quiserem, de pingente. Ou fiquem junto do poste. Vão para o diabo. É isto. Concorrentes, inimigas. Ou amigas. Dá tudo no mesmo ${ }^{968}$.

\footnotetext{
${ }^{968}$ RAMOS, Graciliano. Mulheres... Vamos Lêr!, Rio de Janeiro, n.65. 28 out. 1937.
} 


\section{Zizi.}

Eu ia terminando o jantar quando D. Zizi se sentou, e, como sempre acontece, mostrou os dentes num sorriso amável e principiou a contar casos interessantes da sua vida no colégio.

Essas conversas agradam-me, porque circulam nelas uns tipos curiosos de freiras e porque os dentes de D. Zizi são brancos. Infelizmente eu não dispunha de tempo bastante para escutá-la: precisava escrever umas coisas e por isso havia jantado mal, procurando um assunto inutilmente.

A presença de D. Zizi pôs em fuga umas idéias que eu tentava segurar. Olhei o relógio. Como eram oito horas, calculei que as freiras se retirariam de cena ali por volta das onze. Se D. Zizi [n]ão se lembrasse de contar a sua viagem a Cambuquira, acontecimento notável já narrado quatro ou cinco vezes, ainda me seria possível redigir a coluna magra esboçada vagamente durante o jantar. Agarrei-me à esperança de que a coluna engrossaria no decorrer da história e plantei os cotovelos em cima da mesa, resignado, pronto para receber as freiras.

Vieram: primeiro a madre superiora, boa mulher, a que prestava no estabelecimento, mas de ordinário invisível; depois as outras, medonhas, seres hipócritas odiados pelas alunas. É o que D. Zizi me diz sempre, e não tenho motivo para duvidar dela.

A minha excelente vizinha rezou tanto que enjoou as rezas, e, como a obrigaram ajoelhar-se no chão em cima de caroços de milho, foge da igreja como um diabo.

O arrombamento do cofre de S. José e conseqüente roubo das moedas que lá estavam realizou-se por volta das nove horas. Ouvi a façanha com todas as minudências e aproveitei-a, achei que as meninas tinham procedido com acerto espoliando o santo.

Animada por algumas interjeições que reforçaram os movimentos de cabeça que fiz, D. Zizi atacou a professora de francês, mulher que aborrece por causa de seu comportamento horrível no dia em que a mocinha chegou à porta em companhia do namorado. Isto aconteceu pouco 
mais ou menos às nove e meia, e quando a professora de francês se dirigiu ao telefone, dez horas tinham passado, porque houve um grande espalhafato, a velha ameaçando, a moça defendendo-se, gritando que ia aos jornais narrar uns casos feios.

D. Zizi entusiasmava-se com a antiga colega. Uma dor nos cotovelos obrigou-me a retirar da mesa os braços cansados, que sustentavam a cabeça cansada. Pensei nos joelhos agudos da minha amiga, nos pobres joelhos que anos antes se haviam martirizado em cima de caroços de milho.

- Perfeitamente. D. Zizi. Continue.

E D. Zizi continuou até onze horas, exatamente o que eu tinha previsto. Hábitos pretos enchiam a sala de jantar, mãos brancas e magras escondiam-se nas mangas largas, olhos parados pregavam-se no chão, beiços amarelos mexiam-se quase sem vida:

- Louvado seja Nosso Senhor Jesus Cristo.

- Para sempre seja louvado, bocejavam as alunas.

D. Zizi resmungou isso longamente e nunca se acostumou a resmungar. Fez caretas às irmãs quando elas davam as costas, abafou níqueis e pratas do cofre de S. José. Hoje é ímpia, sem alma. Entrará no inferno sem nenhuma formalidade. E vai meter o filho num colégio de religiosos.

- É preciso que ele veja isso de perto. O senhor não acha?

- Perfeitamente, D. Zizi.

- Se ficar de fora, pode enganar-se, imaginar coisa diferente. Vou interná-lo. Não é bom?

- É D. Zizi. Boa noite. 
Subi a escada às onze e meia. Felizmente a viagem a Cambuquira não veio. Mas as idéias necessárias ao pagamento da pensão tinham desaparecido. Paciência. Em falta de coisa melhor, utilizei o negócio das freiras e as opiniões de Dona Zizi ${ }^{969}$.

${ }^{969}$ RAMOS, Graciliano. D. Zizi. Vamos Lêr!, Rio de Janeiro, n.67, 11 nov. 1937. 


\section{Um anúncio}

Leio num jornal de bastante circulação na capital da República este anúncio curioso em letras grandes: "Intelectual sem emprego. Amadeu Amaral Júnior, jornalista, desempregado, aceita esmolas, donativos, roupa velha, pão dormido...” Sinto um arrepio e acompanho de longe os diferentes gestos e frases que essa publicação naturalmente provocaria entre as diversas espécies de leitores - razões espalhadas e incompletas, fragmentos de verdades contraditórias. E, como os outros leitores, penso coisas inconciliáveis, deixo escapar, num espanto verdadeiro, algumas exclamações de sentido vário.

A primeira idéia que me chega é desfavorável a Amadeu Amaral Júnior homem de letras, agora inúteis: acho que ele procedeu mal expondo com franqueza as suas necessidades. Evidentemente esse apelo à caridade que se imprime nos diários traz prejuízo a numerosa e vaga classe dos intelectuais. Afinal que vem a ser isso? Quais são os membros dessa classe? Os que escrevem para se livrar do tédio, investigam questões difíceis e levantam a cabeça ou os que produzem artigos de encomenda, atrapalham-se nas dívidas e olham o chão com desgosto, porque os buracos dos sapatos insubstituíveis aumentam?

Amadeu Amaral Júnior, articulista sem trabalho, não pertence ao primeiro grupo, é claro. Mas o público ignora essas diferenças. Pois um sujeito que escreve declara em anúncio que tem fome e anda com as calças furadas? Ninguém pergunta donde veio Amadeu Amaral Júnior, que fez, que idéia sustentou ou combateu. Ninguém pergunta se ele tem idéias. Amadeu Amaral Júnior aparece como escritor, num canto de jornal, pedindo esmolas, porque tem o estômago vazio e a camisa em tiras. É horrível.

- Literatura! Boceja um funcionário de subúrbio.

Na opinião dele, um escritor não possui estômago nem camisa. O escritor é um símbolo. E o país necessita de símbolos. Amadeu Amaral Júnior, esse homem louro e fichado, é um símbolo. Não deveria trazer-nos o espetáculo das suas misérias: sapatos estragados e fundilhos rotos, incompatíveis com a profissão de símbolo. 
Os meus sentimentos brigam, uma grande piedade me atira a Amadeu Amaral Júnior. Agora não julgo que ele tenha procedido mal. Vejo-o desocupado, trocando as pernas pelas calçadas, forjando à toa projetos irrealizáveis, rondando as mesas dos cafés sem poder sentar-se. Os níqueis se sumiram e é preciso não ampliar o rasgão das calças. Pobre Amadeu Amaral Júnior. Em casa, na casa pior que a cadeia, no quarto escuro da pensão desconhecida, talvez use aquelas medonhas cuecas pretas que vestia há dois anos, passe as noites caminhando como um sonâmbulo ou compondo, para não perder o hábito, dezenas de crônicas que ficam inéditas ou não representam valor.

Refletindo, digo comigo que o jornalista não foi imprudente exibindo-se assim cheio de precisões, com os cotovelos roídos e as bainhas das calças esfiapadas. É possível que ele tenha sido impelido por um excesso de amor próprio, uma vaidade imensa que os fiapos das bainhas e as manchas do casaco irritam. Comparando-se a outros que estão livres dessas inconveniências, reputa-se acima de muitos - e publica o seu escandaloso pedido lembrandose de tipos ilustres que mendigaram. Considera-se vítima de uma injustiça. O anúncio barulhento não é pois, declaração de insuficiência do autor, é grito de protesto, ataque à sociedade que não [o] compreende. Amadeu Amaral Júnior nos aparece como criança zangada que não pode sofrer em silêncio, bate o pé e deseja que todos conheçam a sua zanga.

Se ele dispusesse duma coluna de jornal a sua pobreza seria menor e revelar-se-ia sob forma artística; não dispondo, redige com raiva o anúncio espalhafatoso. O seu ofício é redigir, não sabe fazer outra coisa e não quer ficar de braços cruzados. Lança a queixa violenta, que, pelo menos, durante alguns dias, chamará para ele a atenção do público.

Enfim o procedimento de Amadeu Amaral Júnior mostra coragem. Supomos a princípio que ele não está com a cabeça regulando bem e acabamos reconhecendo que seu ato não foi tão desarrazoado como parecia. O que há é que não estamos habituados a ler coisas desse gênero. Mas se todos os literatos fossem francos como Amadeu Amaral Júnior, quantos pedidos de roupa velha, níqueis e pão duro surgiriam nas folhas! Se elas quisessem publicar isso de graça, naturalmente ${ }^{970}$.

\footnotetext{
${ }^{970}$ RAMOS, Graciliano. Um anúncio. Esfera - revista de letras, artes e ciências, Rio de Janeiro, ano 1, n.1, maio 1938, p.7.
} 


\section{Uma tentativa de explicação}

O sr. José Osório Oliveira, ensaísta e crítico português, a propósito de um concurso da Revista Acadêmica, para saber quais os melhores romances brasileiros, escreveu um artigo em que, depois de citar numerosos livros de literatura brasileira, dela se despedia, mal dissimulando um rancor justo. Esse artigo anterior a blitzkrieg, ainda é oportuno. Depois dele muita gente nasceu, mais gente morreu, e os habitantes de cidades grandes começaram a dormir debaixo do chão como tatus.

Mas, graças a Deus, estamos longe disso, pelo menos por enquanto, e podemos, como diz o poeta Carlos Drummond de Andrade, beber honradamente a nossa cerveja. Bebendo a cerveja, com fatalismo, esperando ser chamados ao tribunal divino antes que ela se acabe, esquecemos os bombardeios aéreos, pensamos nas letras nacionais, coitadas, e no descontentamento dum amigo que se cansou de nos prestar favores e afinal se aborreceu da nossa ingrata indiferença.

O sr. José Osório de Oliveira tem razão. Contudo várias pessoas ficaram magoadas com ele, talvez igualmente com razão. O que há nesse caso é apenas um equívoco; tanto nos diferençamos dos europeus que já nem nos entendemos. Será bom tentarmos, embora tarde, uma explicação desse negócio.

O escritor português desejou que nos comportássemos como se estivéssemos à direita do Atlântico, ao norte; aqui imaginaram que o sr. José Osório de Oliveira, tendo vivido no Rio, conhecesse nossos hábitos e os tolerasse. Para o estrangeiro do velho mundo a correspondência é coisa séria. O cidadão envia um bilhete a outro, não obtém resposta - e naturalmente se ofende: é como se falasse a um indivíduo e este se conservasse calado. Nós, brasileiros, sabemos o que se deve fazer, mas procedemos de modo contrário. Deixamos para amanhã as conversas com pessoas ausentes, arranjamos novo prazo, as cartas fervilham, envelhecem e excelentes relações desanimam. 
É possível que a nossa descortesia seja involuntária. Talvez preguiça, talvez excesso de escrúpulo, receio de, arrumando algumas linhas à pressa, cometer leviandades, dizer inconveniências. A verdade é que somos assim. Não agradecemos os livros que nos remetem, não agradecemos as críticas que nos dispensam. Apoiamo-nos em desculpas frágeis: os livros ainda não foram lidos ou nos desagradam, recusamos o juízo do crítico. Evasivas: se admirarmos os livros, aceitarmos a crítica, também permaneceremos em silêncio.

Certamente nos consideram bárbaros. E somos. A extrema urbanidade reside no extremo oriente. À medida que avançam para oeste os povos se tornam cada vez menos mesureiros. No Brasil atingimos a culminância.

Nossos vizinhos não se espantam. Por estes meridianos mais próximos o defeito a que nos referimos é comum. Se recebermos uma proposta de qualquer país da América do Sul e, contrariando o mau costume, nos interessarmos por ela, é quase certo que o avião da Panair vai levar ao proponente um papel que já não terá para ele nenhuma significação.

Realmente há entre nós quem ponha os seus escritos em ordem e numa gavetinha do bureau guarde as folhas timbradas, os envelopes, o frasco de goma e a caixa de selos. Isto, porém, é exceção: as censuras, que nos vem de Lisboa mostram que em geral somos desleixados.

Poderemos justificar-nos dizendo que possuímos idéias escassas, as indispensáveis à composição da nossa minguada literatura. Seremos com efeito literatos? Este nome encerrava há pouco um sentido prejudicial, herança provável do tempo em que arte era indício de boêmia e sujeira. Escrevemos efetivamente, mas desconfiamos, no íntimo desgostosos com um gênero de trabalho que não pode ser profissão. A nossa mercadoria vai sem verniz para o mercado e não nos desperta, posta em circulação, nenhum entusiasmo. Somos diletantes. Receamos que nos discutam, que nos analisem, que nos exibam os aleijões. Se eles começarem indicados multiplicar-se-ão, ocuparão toda a terra. A referência que nos contenta é o elogio bem derramado. Não faz mal que seja idiota: precisamos vê-lo, repeti-lo, convencer-nos de que realizamos qualquer coisa de notável.

Trabalhamos um pouco a toa, e o pensamento que surge no café e briga às vezes com outros pensamentos acha meio de estabelecer-se: em falta de argumentos, é defendido com gritos. Esses gritos são impossíveis na carta, onde as incongruências avultam. Gostamos de falar[,] 
discutir e opiniões antagônicas já têm rolado no chão, atracadas, resistindo a murros. Somos bastante expansivos, mas a expansão só se manifesta cara a cara. Separados arrefecemos, murchamos. Para que nos gastarmos em correspondência que nos roubaria grande parte do tempo? Desejamos ler sobre nós o que julgamos conveniente. Podemos até redigir nós mesmos os louvores, celebrar-nos com exagero. Há quem faça isto à força de imaginação, enganar-se, acreditar no panegírico, chegar quase a apertar a mão do pseudônimo ${ }^{971}$.

${ }^{971}$ RAMOS, Graciliano. Uma tentativa de explicação. Revista Acadêmica, n.54, maio 1941. 


\title{
Idéias Novas
}

\author{
Interior de Alagoas. Atualidade.
}

Personagens do $1^{\circ}$ quadro:

Capitão Lobo (negociante e delegado de polícia)

D. Aurora (sua mulher)

Mariana (filha do casal)

Adelaide (amiga de Mariana)

Seu Rodrigues (oficial do registro civil)

Cabo Feliciano (comandante do destacamento)

$1^{\circ}$ Quadro

Manhã. Escritório em casa do capitão Lobo. Mesa com livros comerciais, tinteiros, réguas,etc. Um cofre, uma pequena máquina de escrever, um relógio, um calendário, o retrato do capitão, algumas cadeiras.Portas laterais e ao F. Janela aberta ao F., mostrando um pedaço de rua com árvores, lampiões, tabuletas. Passam transeuntes na calçada. Ouvem-se pregões de vendedores ambulantes. D.Aurora e seu Rodrigues, sentados à mesa, discutem.

\section{CENA 1}

D.Aurora e seu Rodrigues

D.Aurora (Folheia um volume) - Ora, seu Rodrigues, já lhe pedi muitas vezes que não trouxesse para a menina livros dessa natureza. A sapequinha larga o estudo e fecha-se no quarto para ler em segredo histórias... Como se diz? Histórias dissolventes. (Solta o volume). 
Seu Rodrigues (Pega o volume) - Respeito as suas idéias, d. Aurora, mas afirmo que está enganada. Eu seria incapaz de inculcar a sua filha uma leitura imprópria. A senhora me conhece. Não era preciso que Marianinha se trancasse por causa deste romance: podia andar com ele na rua, mostrá-lo ao vigário. O autor disto é uma glória nacional, uma glória ainda nova, mas coisa sólida, no parecer dos entendidos.

D. Aurora - Conversa. Abri um romance moderno e fiquei arrepiada. Nunca vi tanta porcaria junta.

Seu Rodrigues (Bate na capa da brochura) - Já leu este?

D. Aurora - Eu? Deus me livre. Tudo safadeza.

Seu Rodrigues - Que desconchavo, pai do céu! É incrível que uma professora jubilada fale assim.

D. Aurora - Que diz o seu livro, seu Rodrigues?

Seu Rodrigues - É um estudo sério, d.Aurora. Há aqui fatos econômicos, sociais, políticos. Excelente.

D. Aurora - E o senhor quer arrumar isso na cabeça de uma normalista! Absurdo. Devia oferecer a minha filha obras calmas e refrigerantes, a biblioteca das moças. Nada de revoluções. O mundo já anda tão atrapalhado! Qual é o enredo desse? (Aponta o volume).

Seu Rodrigues - Enredo? A senhora ainda se ocupa com enredo? Eu procuro no que leio a substância, o tutano.

D. Aurora - Ah! Eu sou diferente. O que me interessa é ver o fim, saber se o protagonista casa ou não casa. Esse casa ou morre?

Seu Rodrigues - Que pergunta ingênua!

D. Aurora - Pergunto porque o senhor admira o romance. 
Seu Rodrigues - Eu sou um bom patriota, admiro todas as grandezas da minha terra: a cachoeira de Paulo Afonso, Itabira, o Amazonas, Castro Alves e o Guarani.

D. Aurora - Está parecendo que o senhor não leu a história.

Seu Rodrigues - Ora essa! Também nunca estive no Amazonas, graças a Deus, que tenho medo de beribéri. Mas admiro o Amazonas, é claro, imenso reservatório de riquezas latentes. Não me canso de repetir isto, d. Aurora, por ser uma grande verdade e uma bela frase.

D. Aurora - Afinal o senhor leu ou não leu?

Seu Rodrigues - Ia explicar-me. Neste caso, como em outros, deixei-me levar pela opinião dos críticos, ou antes pela decisão deles. Que valia o julgamento dum oficial do registro civil em Sant'Ana do Ipanema?

D. Aurora - Quer dizer que não leu.

Seu Rodrigues - Efetivamente não li. Eu gosto de elogiar. Se lesse, talvez achasse aqui dentro alguma coisa desagradável. O meu sistema é cômodo: fio-me em juízos melhores que o meu e livro-me de complicações.

D. Aurora - E recomenda uma obra desconhecida?

Seu Rodrigues - Sim senhora. Isto é, os literatos é que recomendam. Eu sou apenas intermediário. Um oficial do registro civil em Sant’Ana do Ipanema não tem direito de pensar demais. E agora, se me dá licença... (Levanta-se) Vistos e discutidos os autos, etc., quer que eu deixe o romance? Quem sabe a senhora não iria entreter-se com ele?

D. Aurora (Ofendida) - Oh! Seu Rodrigues!

Seu Rodrigues - Está bem, está bem. Respeito as suas idéias, d.Aurora. (Toma o chapéu e despede-se) Lembranças ao capitão. (Sai pela porta do F.) 


\section{CENA II}

D. Aurora e capitão Lobo

D. Aurora (Sopra, abana-se com as mãos) - Que tesoura cega!

Capitão Lobo (Entra pela D., chega-se à janela, grita para fora) - O’ rapazinho, dá um salto ali no quartel e pede ao cabo Feliciano que venha cá. (Volta-se, desce, monologando) Vamos ver como termina aquele sarapatel. Está provado que foi ele. Foi ou não foi? Sem dúvida. Então não há motivo para se amoitar. Espirra tudo hoje à noite direitinho. Comigo é no pau. (Descobre D.Aurora) Ah! Está aí? Vinha tão distraído que não enxerguei você. Esse ladrão de cavalos me faz dor de cabeça. O princípio da autoridade sofreu um colapso.

D. Aurora - Como?

Capitão Lobo - Colapso. Foi o juiz de direito quem disse. Deve estar certo. Colapso. Necessário esticar a corda. Governo é governo. É ou não é?

D. Aurora - Sei lá! Não me importo com isso, vivo no meu canto.

Capitão Lobo - Falta de espírito público. Lastimoso. Uma professora jubilada que só cuida em galinhas.

D. Aurora - Natural.

Capitão Lobo - Bem. Cada qual como Deus o fez. Não questionemos. Alguém me procurou?

D.Aurora - Não. Quem esteve aí foi o seu Rodrigues, aquele sem-vergonha.

Capitão Lobo - Sem-vergonha? É um funcionário. Bom velho, coitado. Sem-vergonha porquê?

D.Aurora - Anda querendo corromper nossa filha.

Capitão Lobo - Hã? Está doida mulher? Naquela idade! 
D.Aurora - Não é o que você está supondo não. Anda querendo corrompê-la com leituras... Como se diz? Perniciosas.

Capitão Lobo - Ah! Tirou-me um peso do coração. Papel sujo, lorotas.

D.Aurora - Lorotas? Então você deixa sua filha se estragar com romances indecentes?

Capitão Lobo - Eu? Isso não é comigo. Quem me forçou a mandar a pequena estudar na capital foi você. Posso observar daqui os progressos dela na escola normal? Não posso. A verdade é que ela gasta como piranha, mas não sei em quê. Quanto à escolha dos livros, acho bom consultar os professores. Talvez esse que o velho Rodrigues deu a ela esteja no programa.

D. Aurora - É um romance, homem de Deus.

Capitão Lobo - Ah! Entendo. Uma educação liberal.

D.Aurora - Você não se revolta com o procedimento do seu Rodrigues?

Capitão Lobo - Revoltar-me? (Indeciso) É. Parece irregular. Refletindo , chegamos à conclusão...Um abuso, creio eu. (Anima-se) Aproveitar-se da inocência duma criaturinha de dezoito anos e meter-lhe nas mãos obras...De que espécie?

D.Aurora - Realistas.

Capitão Lobo - Patife! (Zangado) Ele me paga. Infelizmente é um funcionário. Se não fosse, dormia hoje na cadeia, junto ao ladrão de cavalos. Mas eu me vingo. Não é à toa que me chamo Lobo. Vou cobrar uma letra de quinhentos mil réis que aquele safado me deve e sapeco-lhe juro de cinco por cento ao mês.

\section{CENA III}

D.Aurora, capitão Lobo e cabo Feliciano 
Cabo Feliciano (Fora, bate à porta do F.) - O’ de casa!

Capitão Lobo - É o cabo Feliciano.

D. Aurora (Com uma careta de enjôo) - Política! (Vai abrir a porta) Entre, cabo Feliciano.

Cabo Feliciano - (Entrando) - Bom dia, d. Aurora. (Desce, leva a mão ao quepi e senta-se familiarmente) Que é que há, capitão?

D. Aurora (À parte) - Essa mania de política ainda lhe dá na cabeça. (sai pela D.)

\section{CENA IV}

Capitão Lobo e cabo Feliciano

Cabo Feliciano (Escanchado na cadeira, às avessas, os braços apoiados no encosto) - Que é que há, capitão?

Capitão Lobo (Grave) - O sujeito abriu o bico?

Cabo Feliciano - Até agora não.

Capitão Lobo - Oh! Cabo Feliciano! Isso é um achincalhe à autoridade. Faz três dias que estamos para cima e para baixo, numa gangorra. O homem não quer falar, não fala. Em resumo, foi ele ou não foi?

Cabo Feliciano - Pelo jeito, foi.

Capitão Lobo - Pois arranje a confissão. Já botou os anjinhos nesse infeliz?

Cabo Feliciano - Ainda não. Tenho procedido com bons modos.

Capitão Lobo - Bons modos depois de três dias! Comigo é no pau. Bons modos no principio, lambanças, etc. Mas se o tipo endurece, cacete e cipó de boi. É a regra. E ninguém descobriu 
coisa melhor, nem aqui nem em parte alguma. (Senta-se à mesa) Diga-me cá, vocês fizeram ameaças?

Cabo Feliciano - Muitas vezes, sem resultado. Não ligou importância a elas.

Capitão Lobo - Não ligou importância! Não ligou importância porque tomou o fôlego de vocês, homem. Nem uma lamborada para mezinha?

Cabo Feliciano (Tira a faca de ponta, um pedaço de fumo, palha de milho, faz lento um cigarro) - Para usar de sinceridade, não. Dá-se uma esquisitice. Quando vejo esse bandido, falo grosso, ronco, prometo rebentá-lo mais tarde. Saio completamente resolvido, volto a interrogá-lo e esqueço o propósito. Será que o desgraçado tem mandinga?

Capitão Lobo -Disparate! Um agente da lei, neste século do rádio, admitir semelhante abusão! Que, para ser franco, não sei se haverá incompatibilidade entre a lei, o rádio e a mandinga. Mas nos tempos que correm é feio acreditarmos em feitiço.

Cabo Feliciano (Continua a preparar o cigarro) - Também acho. É uma explicação tola, em falta de outra. O que me parece é que há duas classes de pessoas: as que nasceram para levar pancada e as que nasceram para não levar pancada. Veja o senhor. Certos indivíduos entram no xadrez e amunhecam, entregam os pontos. Não fizeram nada, mas acusam-se, amolecem tanto que somos obrigados a dar neles meia dúzia de pescoções. Como estão livres de culpa, arrumam os picuás, pagam carceragem e saem logo, esmorecidos e de cabeça baixa, que o natural deles é isto mesmo: agüentar cascudos. Esse ladrão de cavalos pertence ao segundo grupo.

Capitão Lobo - Nasceu para não levar pancada.

Cabo Feliciano - (Acende o cigarro) - É cá a minha idéia. Tem um olho de coruja, uma ponta de língua... Fala direitinho um promotor. E cada muque... Faz gosto ver aquilo, não lá dentro, é claro. Lá dentro não simpatizamos com esses brutos robustos demais. Dão muito trabalho.

Capitão Lobo - Que declaração, cabo Feliciano! Quer dizer que não esquentou o lombo do sujeito porque ele é forte. Podemos dar a isso - não se ofenda - o nome de covardia. 
Cabo Feliciano - Hã? Covardia? É o que não existe no destacamento policial desta cidade, capitão Lobo. Coragem lá é como pulga: todo bichinho tem. Mas tomo a liberdade de comunicar-lhe o seguinte. O destacamento policial de Sant’Ana do Ipanema compõe-se de quatro figuras: um soldado velho, que possui uma ferida incurável no pé, um doente de peito, um menino amarelo e este seu criado. Valentia é uma coisa que não nos falta, mas estamos certos de que um fuzuê com aquele ferrabrás não convém aos achaques dos meus companheiros. O que um deles tem no pé, o outro no bofe e o terceiro no sangue são moléstias que os médicos tratam, e nenhuma delas es chama covardia. Enfim, o senhor não deu ainda as suas ordens. (Levanta-se, aproxima-se da janela, atira a rua a ponta do cigarro. Cumprimenta alguém, encosta um cotovelo ao parapeito e durante o resto da cena fica lá, meio voltado ao exterior, alheio à conversa e gesticulando).

Capitão Lobo - Não dei ordens? Vocês precisam de ordens para surrar presos?

Cabo Feliciano - Às vezes precisamos. Quando o suplicante é um desses que nasceram para não levar pancada, precisamos. Pode haver...(Para de repente, sorri, dirige-se a uma pessoa invisível) Alô, benzinho!

Capitão Lobo - Que é que pode haver, cabo Feliciano?

Cabo Feliciano (Estremece)- Hum! Sangue, capitão. Com um selvagem daquela marca pode haver sangue, pode haver morte. Se acontecer desgraça, a responsabilidade é lá para o senhor.

Capitão Lobo - Cabo Feliciano!

Cabo Feliciano (Faz a contingência, dengoso, olhando a rua) - Pronto!

Capitão Lobo - Eu sou uma autoridade enérgica. Não consinto que me pisem nos calos. Esse povo tem de entrar na linha, cabo Feliciano, entende?

Cabo Feliciano (Longe) - Hã! Hã! 
Capitão Lobo - Comigo é no pau. Não é à toa que me chamo Lobo. Já me viu alguma vez trastejar, cabo Feliciano?

Cabo Feliciano - Hã!

Capitão Lobo -Já me viu alguma vez trastejar?

Cabo Feliciano (Mole) - Ainda não.

Capitão Lobo - Pois é. Brandura no começo, amabilidade, tapeação. Agora o meliante incha o papo e se faz besta, porrada nele. Cabo Feliciano!

Cabo Feliciano - Capitão!

Capitão Lobo - Vou interrogar esse miserável hoje à noite. Quero ver se ele escarra o sucedido ou se ficou mudo. Madeira do mato quebra nas costas dele. Sem dúvida. Hei de ver isso. Cabo Feliciano!

Cabo Feliciano - Hã!

Capitão Lobo - Ouviu o que eu disse?

Cabo Feliciano - Ouvi, capitão. Isto é, ouvi, mas não guardei bem na memória. Se quiser repetir...

Capitão Lobo - Vou interrogar esse ladrão hoje à noite. Conserve o destacamento a postos, de fogos acesos.

Cabo Feliciano (Faz para fora um sinal, afasta-se da janela, desce esfregando as mãos) - É muito boa.

Capitão Lobo - Como? 
Cabo Feliciano - Muito boa idéia, capitão. (Perturba-se) O senhor... É lógico...Hum! Deve interrogá-lo. Hum! Excelente idéia. Mais alguma coisa?

Capitão Lobo - Vai chover bordoada. Se o destacamento emperrar, contrate uns homens.

Cabo Feliciano - Oh! Seria vergonha. O destacamento impõe-se. Está meio avariado, mas o que não falta lá é coragem. (Faz a continência, bate os tacões, cambaleia, dá meia-volta, retira pela porta do F.) (Capitão Lobo sai pela D.)

\section{CENA V}

Adelaide e Mariana (Entram pela E.)

Adelaide - Um horror, minha filha, um horror. Nunca vi tanta miséria. Eu lhe conto porque sou sua amiga. Um horror. Sabe o que andam espalhando por aí, na farmácia, no bilhar, na porta da igreja?

Mariana - Não. Você ainda não se manifestou.

Adelaide - Posso falar?

Mariana - Pode, pode. Fale à vontade.

Adelaide - Pois sim, meu coração. Juram que você não é moça.

Mariana - Diabo! Com dezoito anos? São bem exigentes.

Adelaide - Não zombe, meu anjo. Você comprometeu-se namorando três rapazes ao mesmo tempo.

Mariana - Ao mesmo tempo não.

Adelaide - Os três num dia. Vivem brigando por sua causa, e essa gente desocupada julga que você fez tudo com eles. 
Mariana - Coisa nenhuma. O filho do juiz de direito é um menino bem comportado e cheio de sentimentos nobres. Deu-me um beijo nos dedos, e eu ofereci a ele uma rosa, um botão de rosa. Cena muito casta e em conformidade com os hábitos da terra. O estudante de medicina foi menos romântico, beijou-me na boca.

Adelaide - E você ofereceu a ele outra rosa?

Mariana - Para quê? Deixei-me beijar. Com o instrutor de tiro dei um passeio nos arredores. E à noite nos sentamos juntos no cinema.

Adelaide - Felizmente só foram três, não é? (Suspira) Você se inutilizou, meu bem. Aqui não arranja casamento.

Mariana - E quem lhe disse que pretendo casar-me e ficar aqui mofando?

Adelaide - Não pretende?

Mariana - Ah! Não. O ano vindouro findo o meu curso e bato as asas. Arrumo aí um emprego qualquer e depois uma comissão no Rio. Este negócio está apalavrado. Lá faço concurso e engancho-me num ministério. É certo. Se em seis meses não conseguir o que desejo, é porque só sirvo para ser professora em Sant’Ana do Ipanema.

Adelaide - Professora com uma reputação estragada, Mariana. Uma professora que namora três homens num dia.

Mariana - Bobagem. Os três não valem um homem. Mas não há receio. Atraco-me no Sul e viro carioca. Outra coisa, Adelaide, fale com seu Rodrigues, peça a ele que me mande o livro que mamãe devolveu.

Adelaide - Está doida? Um romance imoral! 
Mariana - Conversa. Mamãe é idiota e não conhece um pingo de literatura. A mais velha ranzinza do mundo. Chi! Que amolação! Interrompeu-me a leitura na melhor passagem: uma brincadeira de meninos com uma negrinha, num areal.

Adelaide - Não me meto nisso não, Mariana. Se d.Aurora pensa que o romance é perigoso, deve ter lá as suas razões.

Mariana - Mamãe não leu o romance. Nunca leu nada. Leu uma gramática miudinha antigamente e ficou aí. (D.Aurora aparece à E.) Procure seu Rodrigues, Adelaide. Eu queria ver o resto da brincadeira das crianças no areal. É o que há de mais inocente.

\section{CENA VI}

Adelaide, Mariana e D.Aurora

D.Aurora (Severa) - Mariana!

Mariana - Oh! Mamãe! Como vai? Já melhorou da enxaqueca?

Adelaide (À parte) - Que bagunça! Virgem Maria!

D.Aurora (Zangada) - Mariana, tenha vergonha. Quem lhe disse que eu estava com enxaqueca?

Mariana - Pensei que estivesse. Amanheceu tão nervosa!

D. Aurora - Deixe de ser descarada, Mariana. Ouvi perfeitamente o que você dizia a essa...

Adelaide (À parte) - Valha-me Deus! Agora é comigo. Porquê? Não fiz nada.

Mariana - É. Esmiuçávamos uns contos piedosos. Contos infantis.

D. Aurora - Mentirosa. Um recado para seu Rodrigues. 
Mariana - Efetivamente. A senhora se enjoou do romance que ele me emprestou e mandei pedir outro. Os dias aqui são tão compridos! O jeito que tenho é fazer cultura.

Adelaide - Mariana...D.Aurora...(Aproxima-se ora da mãe, ora da filha, para se despedir. Chega-se à porta, recua) Por favor...(À parte) Eu queria achar meio de me escapulir.

D. Aurora - Mariana, você é uma pessoa depravada.

Mariana - Tolice.

D. Aurora - Mas fica estabelecido que de hoje em diante não se recebe nesta casa safadeza escrita.

Mariana - Naturalmente. Nunca se recebeu.

D. Aurora - E faça o obséquio de me respeitar, insolente. Vamos deixar esse arzinho de galinha assada...

\section{CENA VII}

Adelaide, Mariana, d.Aurora e Capitão Lobo

Capitão Lobo (Entra pela D.) - Que barulho é esse?

D. Aurora - São as conseqüências da bela educação que você deu a sua filha.

Capitão Lobo - Eu? Tem graça. Não dei educação nenhuma. Entendo lá disso? Gemo com as despesas dela na capital. Simplesmente.

Mariana - É. Mas, acabando o meu curso, não precisarei de ninguém.

D. Aurora (A capitão Lobo) - Está ouvindo? Senhora do seu nariz, com rédea no pescoço, inteiramente livre. Bonito. 
Mariana (Desafiando-a) - Pois é.

Capitão Lobo (Coloca-se entre as duas, tentando apaziguá-las. Volta-se para a esquerda, para a direita) - Oh! Oh! Oh! É um equívoco, não há motivo para desordem. Calma, calma. Tudo se explica.

Adelaide (À parte) - Que é que estou fazendo aqui, santo Deus?

Mariana - O ano vindouro estarei longe disto. Hei de viver e morrer muito longe de tudo isto.

Capitão Lobo - Menina, seus avós e seus bisavós foram enterrados no cemitério de Sant’Ana do Ipanema. Eu, sua mãe e você, quando fecharmos os olhos, iremos descansar na catacumba deles.

Mariana - Eu? Que esperança! Apodrecer junto desses fosseis.

D. Aurora (Com voz estridente, a capitão Lobo) - Preste atenção a isso, homem. Abra os ouvidos.

Capitão Lobo (A d. Aurora) - Calma, calma. Não se excite. Foi uma palavra sonora que a pequena decorou. Talvez nem saiba a significação dela.

D. Aurora (A capitão Lobo) - Você aprova esses modos?

Capitão Lobo (A d. Aurora) - Ah! Não, evidentemente. Mas tenha paciência. É o calor da mocidade, fogo de palha. Depois ela endireita.

Mariana (A capitão Lobo) - Mamãe é insuportável, é uma criatura paleolítica.

Capitão Lobo (A Mariana) - Hã?

Mariana (A capitão Lobo) - Paleolítica. 
Capitão Lobo (A Mariana) - É. Sempre foi. Mas temos de aguentá-la assim mesmo. Naquela idade não endireita.

D. Aurora - Perdi a saúde, envelheci, cuidando dessa ingrata.

Capitão Lobo (A d.Aurora) - Oh! Oh! Exagero. Ela tem bom coração. É meio esquentada, o sangue dos Lobos, mas tem ótimo coração. E quanto às idéias modernas, potocas, não valem nada.

Adelaide (À parte) - Só queria que me dissessem que é que estou fazendo aqui.

Mariana - Gasta-se a vida sapecando as pestanas, adulando professores analfabetos, cavando pistolões para os exames - e no fim coice. Dou o fora em tudo isto. Ora se dou!

Capitão Lobo (A Mariana) - Calma, calma. Sua mãe fala demais e se desconchava, mas é uma boa alma. Infelizmente não compreende as idéias modernas. Mulher atrasada.

Adelaide (À parte) - Arrelia tão grande por causa dum romance que não foi lido. Que despropósito, meu Deus, que despropósito! Imaginem se soubessem que ela beijou três homens num dia.

D. Aurora (Puxa o braço do marido) - Escute, examine este caso com todos os ff e rr.

Mariana (Puxa o braço do pai) - Veja se eu tenho razão ou não tenho.

Capitão Lobo (A d. Aurora) - Já escutei, estou surdo de escutar. Um livro indecente, seu Rodrigues, já sei. Está certo. (A Mariana) Claro que tem razão. O progresso. Não há dúvida nenhuma. (Afasta-se das duas. À parte) Com os diabos! Eu sei lá quem é que tem razão! Um inferno. No princípio do século não havia disso.

(Fim do $1^{\circ}$ quadro)

GRACILIANO RAMOS ${ }^{972}$

\footnotetext{
${ }^{972}$ RAMOS, Graciliano. Idéias Novas. Revista do Brasil, Rio de Janeiro, 3ª fase, ano V, n.49, jul.1942.
} 


\section{Uma visita inconveniente}

O sociólogo estrangeiro desembarcou, dirigiu-se ao hotel, aboletou-se e no dia seguinte percorreu a cidade, exibindo a roupa de sábio, surrada e com joelheiras, o guarda-chuva de cabo torto, o chapéu de palha, sujo, roído nas abas, um grande pacote amarelo debaixo do braço.

Conhecidas várias ruas, encaminhou-se ao palácio do governo, entregou a um contínuo o cartão de visita e sentou-se. Pouco depois mandaram-no entrar, pois tinha vindo pelo telégrafo recomendação forte. Ergueu-se, afastou o reposteiro verde com símbolos bordados a ouro e achou-se na presença do poder executivo, a quem endereçou um pequeno discurso organizado na antecâmara, mentalmente.

Em seguida, sobre a mesa larga onde o expediente se acumulava, desatou os cordões do embrulho e ofereceu a S. Excia. diversas brochuras grossas, que encerravam, com largo saber, as transações humanas dos tempos pré-históricos e as do futuro.

O governador incluiu num rápido balanço os títulos sisudos, as dedicatórias amáveis, os milheiros de páginas cobertas de letra miúda, floresta raramente quebrada por espaços brancos. Juntou a isso as duas linhas que negrejavam no cartão, sob o nome do visitante, os termos da recomendação telegráfica, ministerial - e disse as palavras aplicáveis à situação.

Conversou durante os minutos precisos e regulamentares, pensando nos encrencados artigos dum vago decreto e numa criatura feminina, também vaga e encrencada. Ditas as frases necessárias, calcou o botão da campainha e mandou chamar um funcionário de vulto, conveniente às exigências do sociólogo que ali descansava na cadeira de espaldar alto, encimado por uma águia e outros objetos oficiais. Vindo o burocrata, fez a apresentação:

- Professor Fulano, da universidade de... (Onde era a universidade, santo Deus?) A universidade de tal parte. Deseja... 
Houve uma pausa, exame de papéis - e o sociólogo explicou minuciosamente o que desejava.

O governador não entendeu e transportou-se aos parágrafos difíceis do decreto e a certas palavras da mulher vaga. O funcionário balançou a cabeça:

- Perfeitamente.

Despedidas protocolares, sorrisos, agradecimentos. O contínuo percebendo que o sujeito era importante, franziu, curvando-se, os símbolos dourados do reposteiro verde.

- Às suas ordens, professor, disse o funcionário deixando o palácio.

E entrou num automóvel, dispôs-se, chateado, a mostrar ao homem do guarda-chuva de cabo torto as curiosidades indispensáveis à fabricação duma obra séria e acadêmica.

Percorreram secretarias, diretorias, o serviço de algodão. Viram e comentaram a estrada de rodagem, o hóspede exigindo pormenores, os construtores alargando-se em considerações alheias às perguntas. Estudaram, no aprendizado agrícola, o banheiro carrapaticida, as pocilgas, o estábulo e o galinheiro, coleções de animais desenvolvidos cientificamente e improdutivos. Foram ao tribunal e aos jornais, leram sentenças e artigos de fundo. As sentenças eram o que no lugar havia de melhor em sintaxe; os artigos, mal escritos, revelavam energia e lirismo. Visitaram o mercado, o Instituto Histórico, os clubes de football, os cafés, os cinemas, casas de família e casas onde não existiam famílias, em pontas de rua.

O sociólogo estrangeiro, de olhos abertos, ouvidos abertos, a carteira aberta, o lápis na mão, possuía, decorrida uma semana, material suficiente para um livro de quinhentas páginas, corpo 8. Figurariam nele, com auxílio de algumas crônicas pesadas, as origens, o desenvolvimento, o fim provável duma sociedade que, partindo daqui, andando ali, chegaria necessariamente acolá.

Nesse ponto, como era preciso estirar o volume, exploraram-se as escolas. Tudo correu bem nas elementares. As professoras disseram o que sabiam e os meninos indicaram no mapa o sítio onde frei Henrique de Coimbra rezou a missa de estréia. Mas num estabelecimento secundário houve desastre. 
- Esse tipo, cochichou o funcionário a um lente sabido, quer uns esclarecimentos sobre os índios. Vou levá-lo a sua classe. Pensei em você para explicar direito esse negócio. Conte umas lorotas que o homem é de universidade.

- Muito bem, respondeu a douta personagem agradecida, feliz por sair da sombra e manifestar-se diante de quem pudesse compreendê-la.

Meia hora depois, numa preleção muito verbosa, dizia aos alunos (dirigia-se na verdade ao estrangeiro, que o escutava assombrado ali perto, o guarda-chuva entre os joelhos) coisas admiráveis a respeito de inscrições achadas no sertão. Garantiu que elas tinham sido feitas pelos egípcios e pelos fenícios, desembarcados no Brasil tantos séculos antes de Jesus (estabeleceu a data), agentes de colônias prósperas, ligadas por um comércio regular às metrópoles. Tentou decifrar alguns caracteres, percebeu neles os nomes de Osíris e dos engenheiros que, há quatro mil anos, executaram obras notáveis na cachoeira de Paulo Afonso. Sim senhor. Os devotos de Osíris e de Isis misturados aos selvagens nacionais, que ainda não eram tupis.

- Não senhor.

O estrangeiro embasbacava, arregalava os olhos. E o funcionário suava, agitava-se desesperadamente na cadeira, parecia mordido de pulgas. Trincava os beiços e fazia gestos inúteis. Segurava-se à idéia de que o sujeito importante, conhecedor de fatos relativos à préhistória e ao fim do mundo, não entendesse a linguagem do professor cambembe, provinciana e corrupta.

- Ora muito bem. Dessas relações entre o elemento indígena, os egípcios e os fenícios, nasceram os tupis.

Os estudantes maus bocejaram. Os estudantes bons sorriram. Os medíocres pegaram os cadernos e tomaram notas.

- Felizmente lá fora ninguém entende um português assim estragado, consolou-se o funcionário. Estamos em segurança. 
O sociólogo estrangeiro desiludiu-o, fulminou-o com uma pergunta brutal:

- Os senhores não têm programa? Um homem pode aqui ensinar isso na escola? ${ }^{973}$

${ }^{973}$ RAMOS, Graciliano. Uma visita inconveniente. Cultura Política, ano 2, n. 22, Rio de Janeiro, dez. 1942, p. 154-155. 


\section{O estranho Portinari}

- Você vai trazer-me os seus livros, disse-me Portinari ao almoço. Quero guardar os livros dos meus amigos. Talvez não tenha tempo de ler tudo, mas quero guardar. Você sabe como é que é. Só tenho tempo de ler isto.

Abriu volumes pesados, técnicos e álbuns preciosos. Em seguida, fomos ao "atelier” e o trabalho recomeçou, numa conversa meio monologada, que longos silêncios interrompiam. Às cinco horas julguei que a cabeça estivesse pronta: certamente não, era preciso acrescentar-lhe um cabelo ou uma ruga. Portinari examinou-a, virou-a, mediu-a, murmurando frases soltas, repetindo uma que se ia tornar estribilho:

- Eles não sabem como é que é.

Tive de lá voltar. Da cadeira onde me imobilizava, conseguia entortando um pouco os olhos, avistar um pedaço do "S. João”, que ocupava uma parede da sala pequena. Tinham-me aparecido fotografias desse quadro um ano antes, no jornal. Estava então findo, mas a composição continuava. Fora colorido, branco e negro, novamente colorido, e tinha experimentado numerosas transformações. Corrigira-se o molequinho que sobe na palmeira, uma lata d’água mudara de tamanho; o pixaim da mulata vistosa, penteado, estirado com esmero, muito se diferençava da carapinha original. O que me preocupava nessas devastações e renascimentos eram uns anjinhos mestiços que avultavam à direita, admirável tríade onde se concentram, depois de excessivos retoques, os sentimentos bons e os sentimentos puros da favela. No grupo, as minhas simpatias se fixavam na cabrochinha mais taluda, viva, iluminada por um sorriso encantador.

- O Portinari, você ainda vai mexer com esta inocente?

- Não. Acho que está acabada. 
Respirei, com agradecimento e alívio. Mas, na outra visita que fiz ao pintor, encontrei a minha amiga triste e desfeita: uma sombra perturbara o sorriso maravilhoso. Com certeza essa luz destoava do conjunto.

Homem estranho, Portinari, homem de enorme exigência com a sua criação, indiferente ao gosto dos outros, capaz de gastar anos enriquecendo uma tela, descobrindo hoje um pormenor razoável, suprimindo-o amanhã, severo, impiedoso. Dessa produção contínua e contínua destruição ficou o essencial, o que lhe pareceu essencial.

Não é arte fácil: teve um longo caminho duro, impôs-se a custo nestes infelizes dias de logro e charlatanismo, de poemas feitos em cinco minutos. E até nos espanta que artista assim, tão indisposto a transigências, haja alcançado em vida uma consagração. Devemos, porém, levar em conta as opiniões que não se manifestam porque seria feio discordar da crítica dos Estados Unidos. Embora considerem disforme o pé do cavador de enxada, cavalheiros prudentes o elogiam. Isto não tira nem põe. Insensível agora às lisonjas, como foi insensível aos ataques naqueles princípios ásperos, o trabalhador honesto continua a aperfeiçoar seus meios de expressão, alheio às coisas que não lhe impressionem o olho agudo. Tudo sacrifica à ocupação que o domina, o tiraniza. Só assim poderá realizar obras que não lhe desagradem. Porque o seu público é ele mesmo. Naturalmente. Encolhe os ombros a certas admirações:

- Eles não sabem como é que é ${ }^{974}$.

\footnotetext{
${ }^{974}$ RAMOS, Graciliano. O estranho Portinari. O Jornal, Rio de Janeiro, 1 jul. 1943.
} 
Depois da entrada no PCB (em 1945) 


\section{Carta aos alagoanos}

Meus raros amigos de Alagoas:

Depois de longa ausência, aqui me vejo conversar com vocês, como se nos achássemos em Palmeiras dos Índios, na Imprensa Oficial, no café do Cupertino ou numa das redações onde batamos papo. Não sei bem se a conversa é impertinente. Uma única vez, depois de nos separarmos, tive ensejo de falar sobre as pessoas e fatos alagoanos: referi-me a Nelson Flores, a Pedro Lima e às enchentes, mas parece que estes assuntos foram aí considerados impróprios.

Arrisco-me a nova palestra, ou antes sou obrigado a ela. Nestes últimos dez anos o mundo tem dado tantas voltas que estive a ponto de fazer uma viagem a Alagoas, só abandonando a idéia por que, tendo aqui, aportado em porão de navio muito vagabundo, não achei conveniente regressar num aeroplano. Perdoem-me a citação de pequeninos casos pessoais, absolutamente desprovidos de interesse. Mas convém talvez lembrá-los.

Não é que resolveram fazer de mim candidato a deputado? Vejam só. Pois nesse caráter dirijo-me a vocês - duas dúzias de pessoas, se tanto, o público de que disponho na terra dos marechais e dos generais. Seria adequado exibir-lhes um rol de serviços notáveis, expor diversas obras realizadas e outras possíveis, mas receio que alguém se engane e vote em mim julgando-me sujeito importante, um desses operadores de milagres, nunca percebidos. Vocês sabem que não levarei o S. Francisco a Quebrangulo, feito aí já praticado com honra e glória.

Aludo, portanto, a minha saída, em 1936, dessa província, caso minguadamente glorioso, que pouco me recomenda à simpatia do eleitor. E com isto declaro não desejar pertencer a qualquer instituição em que seja necessário fazer discursos.

- Uvas verdes, pensarão vocês. 
De modo nenhum, pois venho pedir - incongruência aparente, que desmancho com esta explicação. Entre ser literato medíocre ou deputado insignificante, prefiro continuar na literatura e na mediocridade. E digo isto sem falsa modéstia. Reparem no sentido exato das palavras. Não considero a minha literatura insignificante: ela é apenas medíocre, e por conseguinte, mais ou menos aceitável. Na livraria sinto-me à vontade, mas na Câmara é certo que me daria um papel bem chinfrim. Nenhuma conveniência em mudar de ofício neste fim de vida.

Esta explicado, suponho, a desambição carecente de valor. Contudo, se me falta o desejo de passar algumas horas por dia cochilando, rosnando apartes chochos, isto não quer dizer que feche os olhos à política nacional e encolho os ombros à eleição. Entreguei-me de corpo e alma a um Partido, o único, estou certo, capaz de livrar-nos da miséria em que vivemos, e este Partido apresenta-se às urnas. Sou forçado a solicitar a vocês, para os nossos candidatos (os outros: insisto em declarar-me isento de pretensões), os vinte e quatro votos que estão dispostos a conceder-me.

Examinem as chapas dos partidos reacionários. Só existem nelas, em toda a parte, figuras da classe dominante. Nós, comunistas, escolhemos gente da burguesia e do proletariado: operários, camponeses, militares, industriais, comerciantes, artistas, professores, médicos, engenheiros, jornalistas, advogados, escritores. Quando nos preparamos para dar ao país uma constituição, não é razoável agora que ela seja uma constituição de proprietários.

Vocês, meus excelentes amigos, poderiam contribuir para se afastarem da nova carta alguns desses artigos ou parágrafos em que os infelizes se apertam como em torniquetes. Realmente vocês são bem pouco numerosos. Mas cada um, nestes breves dias que nos restam, convencerá facilmente uma tia ou comadre, que influirá na vizinha com rapidez - e assim por diante. Serão eleitas pessoas que represente o Estado. Porque até hoje - com franqueza - que foi que os nossos deputados representaram?

Com isto, meus velhos amigos, despeço-me de vocês e envio-lhes muitos abraços ${ }^{975}$.

\footnotetext{
${ }^{975}$ RAMOS, Graciliano. Carta aos alagoanos. Revista do povo: Cultura e Orientação Popular, ano 2, n.2, jan.1946, p.5.
} 


\section{O Partido Comunista e a criação literária}

Meia dúzia de palavras, somente. Como não falo em nome dos escritores do Partido, resolvo-me a dirigir-lhe algumas amabilidades escassas.

Afirmam cidadãos vultosos que no Comunismo não existe ambiente favorável à criação literária; chegando aqui, murchamos, deitamos um pouco de chumbo nos miolos e somos utilizados em serviços módicos: distribui folhas volantes, bater palmas em comícios, pichar muros. Isso - e nada mais.

Afirmação contraditória. Por volta de 1936 esses mesmos cavalheiros impugnaram com vigor os produtos vermelhos. Sem examiná-los, sem declará-los bons ou maus como arte, exigiram simplesmente a prisão dos autores. Chegaram a ver realizados seus desejos e hoje não é razoável negarem o que ontem badalaram, numa crítica policial muito safada.

É desnecessário asseverarmos que o Partido Comunista nenhum dano causa à produção literária. Inútil exibirmos figurões do exterior, engrandecidos pela distância: mostremos apenas a gente que aqui está.

Nada de queimar incenso à toa. Estes homens e estas mulheres recusam lisonjas, mas provavelmente os nossos opositores gostariam de tê-los a seu lado. E se pensam de outra forma, é que o julgamento lá fora é precário. Neste grupo, ainda exíguo, há escritores que se revelaram em diversos gêneros. Certamente continuarão a crescer, apesar dos agouros ruins espalhados sobre eles.

Tolice imaginar que lhes vão torcer as idéias, impor o trabalho desta ou daquela maneira. Foram as idéias que os trouxeram, todos vieram de olhos muito abertos, conhecendo perfeitamente o caminho. Ninguém está aqui por sentimento ou religião.

E é claro que não haveria conveniência em fabricar normas estéticas, conceber receitas para a obra de arte. Cada qual tem a sua técnica, o seu jeito de matar as pulgas, como se diz em 
linguagem vulgar. A literatura revolucionária pode ser na aparência mais conservadora. E isto é bom: não terão o direito de chamar-nos selvagens e sentir-se-ão feridos com as próprias armas.

Afinal para expormos as misérias desta sociedade meio decomposta não precisamos de longo esforço nem talento extraordinário: abrimos os olhos e ouvimos, jogamos no papel honestamente os fatos.

Difícil seria defendê-la. Por isso nossos inimigos se desesperam. E afastam-se da terra. E vivem a descobrir mundos imaginários ${ }^{976}$.

${ }^{976}$ RAMOS, Graciliano. O Partido Comunista e a criação literária. Tribuna Popular, Rio de Janeiro, 22 maio 1946. 


\section{Solilóquio derramado}

Documento de importância para a compreensão da obra e dos pontos de vista de Graciliano Ramos é a carta que ele dirigiu ao escritor Allyrio Meira Wanderley, pedindo a este transmitisse a Monte Brito o que o romancista chamou de "solilóquio derramado". O modo como Graciliano Ramos encara a critica literária e especialmente os críticos que estudaram os seus romances e a "concordância de juízos” que observou existir entre os dele e os juízos de Monte Brito dão singular interesse a esse depoimento que a seguir publicamos:

Rio, 22 de outubro, 1947.

Prezado Allyrio: Tenho procurado avistar-me com Monte Brito, mas esse seu amigo é vaporoso, é abstrato, abala-me as convicções, atira-me ao idealismo, insinua-me a suspeita de que um ser livre de carne e osso é capaz de escrever extensos rodapés. Na Livraria e no jornal percebemos a sombra de Monte Brito: em vão nos esforçamos por ver-lhe a figura, ponderável com as suas fraquezas e as suas incongruências, imperceptíveis na folha onde se alarga e aprofunda o pensamento. Você, ótimo Allyrio, me afirma conhecer de perto o vivente singular. Não indago mistérios - e, como a asserção me é útil, peço-lhe que transmita á personagem fugitiva, pelos meios convenientes, este solilóquio derramado.

Quero referir-me ao longo ensaio de Monte Brito, exposto no O JORNAL em seis domingos. Tendo fornecido assunto ao homem, deveria achar-me vaidoso, imaginar haver ganho nestes últimos tempos algumas polegadas. Não sucede, porém, isso, pois as minhas letras apenas servem de pretexto ao admirável estudo: com elas ou com outra qualquer matéria-prima, as largas colunas teriam sido lançadas no suplemento, graves e valiosas. Assim, recolho-me discreto, dou a Fabiano, Luis da Silva e Paulo Honório o mérito escasso que eles tiveram na vida.

Ao ler Monte Brito, muitas vezes me pareceu distinguir os meus insetos sociais através de uma lente de microscópio. Nesse aumento excessivo com certeza surgiram pormenores 
invisíveis a olho nu, mas convém antes de tudo mencionar a honestidade rigorosa do observador: as criaturas, ampliadas e vistas sob luz forte, de nenhum modo se deturparam: as conclusões nasceram de fatos irrecusáveis.

É essa a principal virtude, suponho, do seu amigo, rara num país onde não precisamos justificar opiniões. A nossa crítica, decisiva, dogmática, pouco importância liga ás cobaias que lhe chegam ás garras; tem preguiça de investigar, arroja-se a dissertações inoportunas, falsifica um texto com citações inverídicas. Naturalmente não são todos os críticos: aludo aos que procedem assim.

Nem sempre julgo, o comportamento leviano revela irresponsabilidade ou malicia: enxerguemos nele talvez deficiência de método. Em vez de se considerar um livro, medi-lo, pesá-lo, toma-se de ordinário uma parte dele, abandonando passagens nocivas a afirmações apriorísticas. Desse modo um católico provará que também sou católico; outros alinharão princípios morais, quererão obrigar-me a escorar-me neles. Pregam-nos rótulos, matriculamnos á força numa ou noutra escola; exumam padroeiros exóticos, os figurinos que dizem adotarmos. Como se tivéssemos a pretensão de avizinhar-nos dessa gente grande. Enfim nos atribuem as suas idéias, as suas preferenciais, os seus ódios.

Pergunto a mim mesmo se poderia ser de outra forma, se não estão certos. Devem estar. Não somos nunca, é possível, inteiramente objetivos: reproduzimo-nos tentando ocupar-nos de outra pessoa. Monte Brito, porém, identifica-se tanto com as minhas histórias que nos dá a impressão esquisita de sair de si mesmo, analisar, comparar, aceitando casos e indivíduos como estão no romance, bem ou mal, não como ele acaso desejasse vê-los. Nada trunca, nada enxerta.

Se não me engano, é razoável imputarmos isso a uma concordância de juízos. Como admitimos certo número de noções e apreciamos de igual jeito a sociedade, não lhe terá sido muito difícil explicar e comentar sem receber choques, sem ferir-se em nenhuma aresta.

Aliás, excluindo essa analogia de conceitos alcançaremos uma interpretação verdadeira? As minhas narrativas, confessemos, são chinfrins, mas foram construídas na terra, as minhas mãos bisonhas pretenderam cavar alicerces. Não terá isso contribuído para que Monte Brito me olhasse com simpatia? Se eu conseguisse uma obra-prima isenta de realidade, feita com 
pedaços de sonho, não lhe torceria Monte Brito o nariz? Foi presumo, a afinidade que lhe excitou a perspicácia e o levou a descobrir nos meus escritos o material necessário ao seu trabalho. Isso e o conhecimento perfeito da região estudada por mim, dos nossos hábitos, da nossa economia, das nossas tradições, da nossa língua.

Visitas a distância, essas coisas se mostram às vezes desprovidas de interesse; buscamos selecionar minúcias, agrupá-las - e os leitores recebem delas um reflexo pálido e frio. Certas observações perturbam a rotina, lesam modelos consagrados. Se exibirmos, por exemplo, desavenças familiares, pais a brigar com filhos, arrepiar-se-ão como se resvalássemos em sacrilégio. Não investigam se as discórdias existem: preferem negá-las, reputar-nos inimigos por nos arriscarmos a desacatar os seus padrões velhos.

Monte Brito e eu percorremos o sertão do Nordeste - e não temos conveniência em cantar loas aos mandantes de lá.

Teve o bom gosto de não me oferecer amabilidades irritantes, comuns na literatura nacional. A mingua da substancia é freqüente rechearem-se artigos com adjetivos. E já alguém se lembrou de ornando um cavalheiro vastamente impresso e discutido elogiar-lhe as gravatas. Veja só, um homem trata de poesia e desce a usar recursos de natureza indumentária. Longe disso, Monte Brito desdenhou até a minha sintaxe, que afinal é superior à roupa. Muitos agradecimentos a ele, prezado Allyrio. E abraços para você.

Graciliano Ramos $^{977}$

${ }^{977}$ RAMOS, Graciliano. Solilóquio Derramado. O Jornal, Rio de Janeiro, 2 nov. 1947. 


\section{Prestes}

Atribuem a Carlos Prestes um papel diversamente considerado neste vivo tempo de exaltações ásperas: ídolo da massa. Isto lhe ocasiona louvores excessivos e objurgatórias às vezes não isentas de algum despeito. Doces panegiristas e detratores amargos concordam num ponto: responsabilizam, pelo menos fingem responsabilizar essa estranha figura por se haver tornado uma espécie de mito nacional.

Vamos refletir um pouco. Será que realmente se tornou? No caso afirmativo, poderia ter evitado essa canonização leiga? Afinal é ela conveniente ou inconveniente?

O que sucede a Carlos Prestes ocorre, em maior ou menor grau, a todos os indivíduos forçados a romper o casulo e entrar na vida pública. Não os vêem como de fato são: enxergam-nos através de lentes deformadoras. Qualquer literato sabe isto: pequenas alterações, acumuladas, chegam a transformar uma pessoa: a frase largada na livraria modifica-se no jornal, emprestando a um sujeito opinião que ele nunca teve; críticos sagazes decifram complicados enigmas em livros comuns. De repente surgimos autores de pensamentos alheios, recebemos ataques ou elogios por uma entrevista dada pelo telefone, em meia dúzia de palavras desatentas. Ora, se tal acontece ao modesto colecionador de idéias mirins, em país analfabeto, que não se dará com o dirigente político, em horas de efervescência como as atuais? Lenda? Com certeza. Mas na história também fervilham exageros - e às vezes, conhecendo as deturpações, não nos livramos delas, tanto nos imbuíram.

Conseguiria o homem assim crescido eximir-se da grandeza e readquirir o tamanho natural? Pouco provável. Esse gigantismo significa a força criadora da multidão. Tolice negá-lo ou condená-lo. É um fato. Não se improvisa, não se encomenda: absurdo pretender forjá-lo nas escolas ou na caserna, com hinos e lugares-comuns. Está no espírito do povo- e não o extirparemos daí. 
Vantajoso? Desvantajoso? A um formigueiro de pigmeus bem acomodados é desagradável. A turba imagina heróis para defender-se de bichinhos importunos. Na verdade uns insetos, mas tão numerosos que formam pragas. De alguma forma os semideuses são um reflexo dela- e apenas ela é capaz de concebê-la. Esses eleitos obtêm consagração espontânea que lhes interpreta os atos em conformidade com os interesses da maioria. Esta não se engana: sente neles a sinceridade infalível, deixa-se arrastar, parece possuir antenas, dotes divinatórios que nos assombram.

EVIDENTEMENTE não experimentaríamos a fascinação, o entusiasmo doido que leva o popular, num comício, a despojar-se do paletó e queimá-lo, transformá-lo em archote, ou supor-se bastante sólido para agüentar sozinho uma carga de cavalaria. Não, em geral não queimamos os paletós, e no dia 23 de Maio víamos bem que tantos cavalos, galopando para cima de gente, nos iriam causar sério transtorno. Somos prudentes, calculistas: as nossas palmas ao discurso mais enérgico são abafadas, lentas; as nossas almas encolhidas se embotaram - em conseqüência inspiramos ao habitante ingênuo do morro uma vaga repulsa. Certo não concedemos auréola a Prestes: o que nos atrai nele é a parte humana, de ordinário deixada na sombra.

Logo nos surpreende ao conhecê-lo, uma desmedida paciência. Criatura tão cheia de ocupações acha vagar para longas cavaqueiras. Quatro anos atrás cavalheiros abundantes o amolaram com receitas admiráveis para salvar a pátria. Um afirmou que ele, simulando escutar, não lhe dava atenção devida aos planos. Vistos os programas em curso por aí, admitiremos sem dificuldade a informação. É inegável, porém, que muitos badalaram tenazmente, em busca de um comunismo eleitoral, para uso dos patrões. Decepcionaram-se e houve muitas injúrias nas folhas. As vezes, entretanto, a paciência estala, uma fenda se alarga e aprofunda a superfície convencional. Em sabatina realizada no sertão mineiro, uma pergunta incômoda teve esta elucidação fulminante:

- Falo de coisas sérias. Não me ocupo de miseráveis, patifes, vendidos.

Essas manifestações devem ser raras. Há em Prestes excessiva polidez. Viajará horas em pé num aeroplano se alguém se avizinhar da cadeira dele e puxar conversa. A voz clara, baixa, sacudida, não se eleva - e é como se nos martelasse. Ouvindo-a através dos alto-falantes, 
desconcertamo-nos ao perceber que finda a lhaneza e as marteladas batem rijo no adversário e lhe metem pregos.

HÁ QUEM o julgue intolerante, escarpado, fanático. Ninguém mais acessível. A urbanidade ali não é máscara política, mas junta-se à franqueza - e não ficaremos iludidos um minuto. Fazemos-lhes uma exposição. Queda pensativo, o sorriso cansado a iluminar-lhe o rosto pálido. Ao concluirmos dirá simplesmente:

- Discordo. Não conheço direito o assunto: é possível que esteja um erro. Venha almoçar comigo qualquer dia e traga elementos para convencer-me.

Temos a impressão de que nele se equilibram sentimentos opostos. Ou não será isso: talvez se combinem qualidades naturais e qualidades adquiridas, umas e outras a convergir, com força terrível, para a concretização de uma idéia. A intensidade se explica pelo afastamento impiedoso de tudo quanto de leve perturbe a execução de um plano estudado com rigor, criticado e corrigido sempre, segundo as circunstâncias.

Frieza? Quase nos desorienta a contradição. Sob as cinzas que se espalham na face torturada, lavra fogo medonho, pavoroso incêndio a custo perceptível. Raramente uma labareda rompe a crosta gélida. Noutras épocas essa alma ardente se teria enchido de visões celestes; hoje se prende á terra.

Novo contraste: achamo-nos diante de um tímido. Esta observação tem visos de contra-senso e dificilmente será tolerada. Contudo insistimos nela. Ninguém como os tímidos para a dedicação completa a uma empresa- e na coragem que revelam sentem-se a impossibilidade de recuar. Não os detêm obstáculos: nenhum desvio do caminho escolhido.

Delicadeza interior, pureza quase infantil trava a fala desse homem, turva-lhe os olhos ao reler um trecho de carta materna; por outro lado imenso vigor o induz as façanhas mais temerárias. Sobre a aguda sensibilidade nascem calos, alastraram-se, vestiram-na por fim de espêssa couraça impenetrável. Uma natureza emotiva refreou a emoção e aparenta a firmeza de um compressor. 
AINDA uma dualidade: afigura-se-nos que a singular personagem apreende com igual nitidez os objetos próximos e os distantes, graúdos e miúdos, o panorama e o pormenor. Os mais graves acontecimentos internacionais e os efeitos de ligeiras desavenças existentes nas brenhas de um território meio deserto.

Chegamos agora a um ponto a um ponto em que não distinguimos nenhum sinal de oposição: há em Prestes uma dignidade fundamental, incontrastável. É a essência do seu caráter. Admiram-no com exaltação, odeiam-no com glória, glorificam-no e caluniam-no. Seria difícil achar quem lhe negasse respeito á austeridade imutável, maciça, que o leva a afrontar serenamente duras fadigas e sacrifícios horríveis- coisas previstas e necessárias ${ }^{978}$.

${ }^{978}$ RAMOS, Graciliano. Prestes. Classe Operária, Rio de Janeiro, 01 jan. 1949. 


\section{O último romance de Alina Paim}

Alina Paim deve pesar uns quarenta dois quilos, ou menos. É distraída, silenciosa, tem um sorriso tímido. Ninguém diria que uma pessoa tão leve, de modos tão inofensivos, se resolvesse a cometer um crime.

Ninguém - exceto um juiz de direito em Cruzeiro. Esse homem extraordinário ordenou a prisão de Alina Paim, que, no parecer dele, se embrulhou em atividades subversivas lá pela comarca. A moça é uma agitadora perigosa, merece cadeia.

Vamos examinar esse caso, ver em que se resumem o perigo e a agitação. Alina Paim dedicase à literatura. Chegou da Bahia há alguns anos com um romance, e, apesar de nova, quase garota, desconhecida na livraria e no jornal, achou facilmente editor. Deu-nos mais dois livros, e em geral a crítica lhe foi favorável. Escreve com segurança, observa, atenta as personagens, tem realizado sensíveis progressos. Conhece bem o ofício. Gosta de velhos e de mulheres, adora as crianças: são as figuras mais interessantes de suas histórias. Há nelas umas solteironas magníficas.

Ora, ultimamente surgiu uma greve de ferroviários em Cruzeiro, e Alina teve a idéia de aproveitar isto para assunto de uma novela. Profissional honesta, foi olhar as coisas de perto, colher informações, saber como tinham procedido os grevistas, especialmente as companheiras deles. Muitas se haviam deitado na via férrea, diante das máquinas, suspendendo o trânsito.

Findos os estudos, a escritora nos apareceu cheia de entusiasmo com a sua coleção de tipos e iniciou o trabalho. Mas o juiz de Cruzeiro [achou] isso um atentado à ordem. Exige a prisão da moça. Não tínhamos notícia de fato igual no Brasil. Passamos tempos duros; anos atrás qualquer denúncia podia arremessar um indivíduo para lá das grades. No entanto ninguém se lembrou, nos piores dias, de excomungar uma obra literária em projeto. Sim, o mais curioso é que esse esquisito magistrado condena um livro que ainda não foi escrito. Possivelmente, no juízo dele, greve não é matéria digna de ficção. Numerosas criaturas aí pensam do mesmo 
jeito; contudo é a primeira vez que uma se revela com tanta clareza e falta de cerimônia. Se a moda pega, seremos forçados, antes de começar um romance, a pedir licença ao rigoroso censor de Cruzeiro ${ }^{979}$.

${ }^{979}$ RAMOS, Graciliano. O último romance de Alina Paim. Imprensa Popular, Rio de Janeiro. 15 abr.1951. 


\section{Convocação}

A Comissão Organizadora do IV Congresso Brasileiro de Escritores, a realizar-se em Porto Alegre, na data de 20 de setembro próximo, dirige-se a todos os membros da Associação Brasileira de Escritores, a todos os escritores brasileiros, convocando-os para participar dos trabalhos da importante reunião.

Reunir escritores de todo o país para discutir seus problemas, deveres e direitos, debater teses e apreciar os atuais acontecimentos no país e no mundo, ligados à atividade do escritor e às questões culturais, é para a nação um fato de incalculável importância, como o comprovam os congressos anteriores. Os escritores do Brasil não se encontram separados do povo nem procuram fugir às solicitações da hora presente, em que se exige do escritor a sua indispensável e constante participação.

Essa participação de escritores constitui em nossa história um dos capítulos mais ricos de compreensão dos deveres da inteligência, fé nos destinos nacionais e mais idéias progressistas. É o que nos diz o exemplo dos intelectuais nas lutas pela Independência, pela Abolição e pela República. Hoje, mais do que nunca, os escritores brasileiros sentem o inelutável dever de participar também em todos os movimentos nacionais em defesa da democracia, do progresso e da paz, de que depende o desenvolvimento de nossa cultura. Assim cresce e continuará a crescer a influência que sempre exerceu o escritor na vida social brasileira.

O IV Congresso saberá reunir escritores das mais variadas tendências, com o objetivo de formar rigorosa unidade na defesa dos interesses profissionais do escritor, da solução correta e urgente das questões imediatas da cultura brasileira, e na declaração de princípios que ajudem o nosso povo a resolver seus inadiáveis problemas e reflitam ao mesmo tempo a justa e ardente aspiração de todos os povos, que é a paz mundial. Com esse espírito, convocamos os 
escritores para o seu IV Congresso, congresso em defesa da cultura, em defesa das liberdades e pelo progresso do Brasil $^{980}$.

${ }^{980}$ RAMOS, Graciliano. Convocação, Jornal do IV Congresso, Rio de Janeiro, n.1, 1 set. 1951. 


\section{Viver em paz com a humanidade inteira ${ }^{981}$}

Sr. Representante do sr. governador do Estado

Senhoras

Senhores

Companheiros da Associação Brasileira de Escritores.

Começo agradecendo a hospitalidade que nos ofereceram em Porto Alegre. Isto é lugarcomum: os habitantes desta cidade podem julgar que recebi a tarefa de expor aqui salamaleques e cortesias. Não é verdade: estamos realmente agradecidos. Não esperávamos tanto: acomodar-nos-íamos de qualquer modo - e o que o Rio Grande do Sul nos deu foi excessivo e nos sensibiliza.

Adiante. O IV Congresso de Escritores se sentiu honrado e fortalecido com o apoio do povo. Sem isso, nada teríamos podido fazer. Não nos reunimos para lá de portas fechadas: as portas, durante uma semana, estiveram abertas - e pedimos que toda a gente viesse trabalhar conosco. Não somos vaidosos: aceitamos, com humildade, a colaboração do homem da rua.

Cavalheiros sabidos andaram a afirmar seguros, em jornais ricos, que somos uns pobresdiabos, mais ou menos analfabetos. Paciência. Não nos zangamos. Quando no correr do tempo, essas grandes, essas enormes suficiências perceberem que não temos propósitos subversivos, descerão um pouco, chegarão até nós - e nos ensinarão qualquer coisa. Não somos vaidosos, repito.

Ninguém teve o intuito de jogar bombas em Porto Alegre. Desejaríamos fixar a alegria que esse nome nos apresenta. Não estamos a serviço de nenhuma potência estrangeira. Nunca diríamos ao gringo: "Entre, tome conta disto. A casa é sua".

Não, meus amigos. A casa, pobre, à nossa. E denunciamos os traidores que desejam vendê-la.

981 (Discurso proferido pelo escritor Graciliano Ramos, presidente da Associação Brasileira de Escritores (ABDE) no ato de encerramento do IV Congresso, realizado em Porto Alegre, em setembro de 1951. 
Enfim, pequeninas calúnias, pequeninas infâmias, não nos atingem. O Congresso, bem ou mal, deu conta do recado, provou ser possível conseguirmos entendimentos para objetivo comum. Escritores de várias tendências aqui se encontram - e, apesar de todo o veneno espalhado lá fora, não houve barulho, graças a Deus. Estamos de acordo.

Encontros como este são indispensáveis, parece-me. Divergências, pontos obscuros, equívocos, tudo afinal desaparece, tudo se explica. E saímos com uma firmeza que não tínhamos quando chegamos. Amanhã não nos separaremos: em Belém, no Rio, em São Paulo, em Porto Alegre, continuaremos a trabalhar junto.

Agridem-nos por sermos políticos. Bela novidade. Claro que somos políticos. Quiseram afastar-nos. Norte conta sul: materialistas contra idealistas; o realismo e o romantismo de mangas arregaçadas, coléricos. Atiraram-nos uns aos outros. Para tal fim, utilizaram-se diversos disparates. Temos nascido por acaso no nordeste não é razão para atacarmos o pampa e a planície amazônica.

Não faremos isso. Nesta semana mostramos que não faremos isso. Política? Perfeitamente. Nem só idiotas e os malandros devem ocupar-se dela. Resolveremos as nossas questões em família. Política? Perfeitamente. É uma vergonha ouvirmos o que ouvi de um estrangeiro, há pouco tempo, num banquete: "Façam isto, façam aquilo". O dedinho ameaçador: "Façam isto, façam aquilo”. Não. Faremos o que acharmos razoável fazer. Seremos inimigos desse homem que nos vem dar ordens, em língua estranha? De nenhum modo. Apenas desejamos que ele não nos dê ordens. Já não somos crianças. Queremos viver em paz com ele, viver em paz com a humanidade inteira.

Necessitamos novas reuniões. Falar muito, discutir, brigar às vezes. Ótimo. Sairemos dessa luta fortalecidos. Lá fora defenderemos os nossos interesses e a cultura exígua de que somos capazes. Surgirão descontentamentos, numerosos descontentamentos, é claro. Sempre haverá quem diga de nós cobras e lagartos. Que fazer? Estamos habituados, essas ofensas não nos perturbarão. 
Agradecemos especialmente à senhora Lilá Ripoll, admirável mulher franzina que realizou sozinha o trabalho de vinte homens fortes ${ }^{982}$.

${ }^{982}$ RAMOS, Graciliano. Viver em paz com a humanidade inteira, Horizonte, Porto Alegre, n.10, out.1951; Imprensa Popular, Rio Janeiro, 14 out. 1951. 


\section{Unidade em defesa dos direitos do escritor}

A ABDE considera de seu dever manifestar-se a respeito da fundação, nesta capital, de uma sociedade de escritores cujos objetivos são do conhecimento do público.

Serão sempre louváveis e dignas de apoio as novas iniciativas que se destinassem a congregar os escritores brasileiros em torno da defesa de seus interesses e a combater os obstáculos às suas atividades profissionais.

Parece, entretanto, óbvio que o caminho para assegurar o êxito de tais iniciativas não é aquele que alguns membros da diretoria da Sociedade Carioca de Escritores desejam seguir.

Não deve haver entre os escritores brasileiros interesses antagônicos, nem grupos inconciliáveis, nem diferenças de idéias ou de opiniões capazes de forçá-los a permanecer dispersos ou divididos, quando os problemas que todos defrontam quer os de ordem profissional quer os de ordem geral, exigem, agora mais que nuca, sólida unidade de ação e princípios.

A grande maioria dos intelectuais brasileiros jamais consentiu que em seu seio se desenvolvessem idéias e práticas discriminatórias, como as que alguns pretendem agora estabelecer, com o propósito evidente de comprometer possíveis entendimentos, cercear a liberdade de associação, e justificar, daqui em diante, todas as medidas restritivas da liberdade de criação.

Se permitirmos que se inaugure nos meios intelectuais, a qualquer pretexto, o policiamento de idéias, em breve teremos formas drásticas de supressão das liberdades democráticas, transformando-se em regra a exigência de atestados de ideologia para a publicação de livros, a edição de jornais, as exposições de artes plásticas e quaisquer outras atividades de cultura.

A tradição cultural no Brasil não é, felizmente, a dos capitães-do-mato, não é a da escravização do pensamento, mas a luta pela livre atividade criadora. Se quisermos referir-nos 
aos tempos próximos relembremos a unidade conseguida em debates democráticos, nos congressos de escritores realizados desde 1945.

No I Congresso Brasileiro de Escritores, promovido pela ABDE, os congressistas presentes, por decisão unânime, firmaram uma declaração que confirma toda a sua atualidade. Por ela se comprometeram a defender a “completa liberdade de expressão do pensamento”, a "paz e a cooperação internacionais” e a “independência econômica dos povos”.

Esses princípios têm sido reafirmados por meio de resoluções aprovadas no II, III e IV Congressos, sendo que no último realizado no Rio Grande do Sul a maioria e a minoria dos delegados expressaram livremente sua concordância com aqueles pontos de vista gerais, em termos diferentes e da maneira que lhes pareceu mais própria.

Ainda recentemente, na reunião convocada pela Sociedade Paulista de Escritores, declarações de paz entre os povos, pela expressão do pensamento e contrárias à apreensão de livros foram prova de que os intelectuais brasileiros não esquecem seus compromissos de princípio.

Há, portanto, razões muito fortes para confiarmos na possibilidade de aproximar ainda mais os escritores brasileiros em torno de seus interesses profissionais e dos grandes problemas da cultura. Nossos esforços devem combinar-se no propósito honesto de dissipar equívoco, não no de romper a unidade de objetivos e ações já esboçadas.

A ABDE, cujas portas estão abertas a todos os escritores brasileiros, quaisquer que sejam os setores de sua especialidade, sem indagar sua orientação estética ou sua filiação políticopartidária, manifesta-se contrária às discriminações e lança apelo aos homens de cultura de nosso país, a fim de [que] ponham acima dos interesses pessoais, de grupo ou partido, os interesses comuns a todos os que se dedicam ao trabalho intelectual.

A liberdade de associação e opinião, de criação literária, a garantia de melhores condições de trabalho, a cooperação pela paz entre todos os povos do mundo continuam a ser os princípios 
básicos que podem e devem unir, num só movimento de solidariedade cultural e humana, todos os intelectuais brasileiros ${ }^{983}$.

Rio, agosto de 1952

Graciliano Ramos - presidente.

983 RAMOS, Graciliano. Unidade em defesa dos direitos do escritor. Imprensa Popular, Rio de Janeiro, 30 ago. 1952. 


\section{Apelo de Graciliano Ramos aos intelectuais brasileiros ${ }^{94}$}

Há várias maneiras de querermos a paz. Cada um de nós a sentirá diversamente. Mas quando é preciso defendê-la, quem não ficará de acordo? O que está em jogo, num momento como este em que o perigo de guerra parece tão denso, é a paz de cada um e é a paz de todos. Tratase de defendê-la pela unidade de todos os esforços. Buscamos salvaguardar valores, conceitos diferentes. Nossas contribuições à luta pela paz serão também diferentes, mas por isso mesmo nosso entendimento há de ser mais sólido, nossa frente mais ampla e representativa de anseios da humanidade inteira.

Daí meu apoio sem restrições ao Congresso dos Povos pela Paz, que vai realizar-se em Viena no dia 12 de dezembro. Juliet Curie em seu apelo para a convocação do Congresso:

“O Congresso dos Povos pela Paz reunirá, em torno de objetivos definidos em comum, os homens de todas as tendências e os grupos ou associações de toda natureza que desejam o desarmamento, a segurança, a independência, nacional, a livre escolha de seu modo de vida e a cessação de toda tensão internacional.

O Congresso dos Povos pela Paz reunirá todos os que desejam que prevaleça o espírito de negociação sobre as soluções de força.

A paz pode ser salva!

A paz deve ser salva!

Concordo plenamente e faço meu este apelo generoso. Que a vontade de paz dos brasileiros seja ouvida em Viena.

Graciliano Ramos ${ }^{985}$

\footnotetext{
984 Texto antecedido pela seguinte nota dos editores: “O romancista Graciliano Ramos, cujo sexagésimo aniversário vem de ser comemorado entre excepcionais homenagens, acaba de dirigir a todos os intelectuais brasileiros o seguinte apelo"

${ }^{985}$ RAMOS, Graciliano. Apelo de Graciliano Ramos aos intelectuais brasileiros. Imprensa Popular, Rio de Janeiro, $1^{\circ}$ nov. 1952.
} 


\section{Obdulio Barthe}

Há mais de dois anos está preso Obdulio Barthe, chefe da luta de libertação do povo paraguaio, modelo de homem e de dirigente político.

Por que o mantém preso? Já ninguém seria capaz de dizê-lo em termos legais, depois que os três processos contra Barthe se desmoronam um a um. No entanto, ele permanece encarcerado, e nas piores condições. Testemunhos irrecusáveis nos relatam o que é a Cadeia Pública de Assunção: um atentado aos direitos do homem. Laudos médicos oficiais nos descrevem o estado de Barthe: sua vida corre perigo.

Isto significa que um líder popular, sem outra culpa senão a de dedicar sua vida à causa da democracia e da libertação do Paraguai, está sendo lentamente exterminado.

Não nos podemos conformar com tamanho crime. A força de nossa solidariedade a Obdulio Barthe deve chegar aos governantes paraguaios.

A todos os homens honestos - em particular, aos escritores - cumpre sem demora erguer a voz, protestar. Abram-se as portas da cadeia de Assunção, que seja novamente livre, para glória de seu povo e alegria de toda a América, o grande Obdulio Barthe.

Rio de Janeiro, 27 de novembro de $1953^{986}$.

\footnotetext{
${ }^{986}$ RAMOS, Graciliano. De Graciliano Ramos a Obdulio Barthe. Imprensa Popular, Rio de Janeiro, 30 nov. 1952.
} 
Anexo 2

Graciliano e os periódicos: referências 


\section{Produções ficcionais localizadas na imprensa (89)}

Caetés (4)

- “Capítulo XXIV”, Novidade, Maceió, 6 jun. 1931, n.9.

- "Luiza” (trecho que abarca o capítulo 18 e parte do 19 da obra publicada), Boletim de Ariel, Rio de Janeiro, ano 3, n.3, dez. 1933, p.81.

- “Capítulo VII” (Caetés), Momento Crítico-Bibliográfico, Recife, ano 1, n.2, dez. 1933.

- "Precipitação” (primeiro capítulo e parte do segundo da versão publicada de Caetés), A Noite Ilustrada, Rio de Janeiro, 7 fev. 1934, p.14.

S. Bernardo (4)

- “Capítulo VII”, Jornal de Alagoas, Maceió, 31 maio 1933.

- Capítulo XIX”, Jornal de Alagoas, Maceió, 31 maio 1933.

- “Capítulo XXI” (de S. Bernardo), Momento Crítico-Bibliográfico, Recife, ano 1, n.4, ago. 1934.

- “Ciúmes” (trecho que abarca os capítulos 29 e 30 da obra publicada), Boletim de Ariel, Rio de Janeiro, ano 3, n.12, set. 1934, p.325.

Angústia (2)

- "Marina” (trecho de Angústia, romance ainda no prelo), Revista Acadêmica, Rio de Janeiro, ano 3, n.19, jun. 1936, p.9. (Angústia)

- “Infância” (trecho de Angústia, romance ainda no prelo), Boletim de Ariel, Rio de Janeiro, ano 5, n.10, jul. 1936, p.255.

Vidas Secas (13)

- “Baleia”, O Jornal, Rio de Janeiro, 23 maio 1937. 
- “O mundo coberto de penas" (trecho de romance a sair - Vidas Secas), Revista Acadêmica, Rio de Janeiro, n.32, nov. 1937, p.3. (Vidas Secas)

- "Pedaço de Romance” (excerto do capítulo “Cadeia”), Diário de Notícias, Rio de Janeiro, 5 dez. 1937.

- "Mudança”, O Jornal, Rio de Janeiro, 19 dez. 1937, p.1 e 2; e Diário de São Paulo, São Paulo, 22 mar. 1953.

- “Trecho de romance” (parte do capítulo Sinhá Vitória), Anuário Brasileiro de Literatura, Rio de Janeiro, 1938.

- “Travessura” (do capítulo “O menino mais novo”), Diário de Notícias, Rio de Janeiro, 23 jan. 1938 (Copyright de I.B.R).

- “Fabiano”, O Cruzeiro, Rio de Janeiro, 29 jan. 1938, p.22 e 23.

- “Desgraças” (outra versão de “Fabiano”), Diário de Notícias, Rio de Janeiro, 30 jan. 1938 (Copyright de I.B.R).

- “Serão” (fragmento do capítulo “Inverno”), Folha de Minas, Belo Horizonte, 16 mar. 1938 e Diário de Notícias, Rio de Janeiro, 3 abr. 1938 (Do romance inédito “Baleia”Copyright de I.B.R).

- “Cadeia”, O Cruzeiro, Rio de Janeiro, 26 mar. 1938, Il. Borsoi, p.26 e 27; e Revista do Globo, [Rio de Janeiro], 23 fev. 1946, Il. Vitório Gheno, p.53, 54 e 56.

- “Festa”, Lanterna Verde, Rio de Janeiro, abr. 1938.

- “Viagem” (fragmento do capítulo “Fuga”), Diário de Notícias, Rio de Janeiro, 14 abr. 1938 (Do romance Vidas Secas - Copyright de I.B.R).

- “Capítulo de Vidas Secas: Final de romance - Fuga”, A Manhã, Rio de Janeiro, ano 9, n.2, 20 jun. 1948, p.27-28.

3.5) Terra dos Meninos Pelados (2)

- “Terra dos Meninos Pelados”, Pan Infantil, Rio de Janeiro, 31 ago. 1937.

- “Terra dos Meninos Pelados”, Pan Infantil, Rio de Janeiro, 15 set. 1937.

Histórias de Alexandre (11)

- “Um papagaio falador”, Diário de Notícias, Rio de Janeiro, Il. Gonçalvez, 25 dez. 1938. 
- “História dum Bode”, O Jornal, Rio de Janeiro, $1^{\circ}$ jan. 1939, 4a seção, il. Cortez.

- “Primeira aventura de Alexandre”, Diário de Notícias, Rio de Janeiro, 22 jan. 1939.

- “O olho torto de Alexandre”, Diário de Notícias, Rio de Janeiro, 21 maio 1939, Suplemento p.2.

- “A espingarda de Alexandre”, Diário de Notícias, Rio de Janeiro, 30 jul. 1939, Suplemento p.1.

- “Moqueca”, Diário de Notícias, Rio de Janeiro, 3 set. 1939.

- "Estribo de Prata”, O Jornal, Rio de Janeiro, 10 set. 1939, 3ª seção, ano 21, il. Cortez, p.1 e 2; Jornal de Alagoas, Maceió, 26 set. 1954; Diário de Minas, Belo Horizonte, 19 dez. 1954; [Folha do Norte], [Belém], [24 fe. 1957]; e Diário Mercantil, s.l. abr. 1958, Suplemento Dominical, ano 48.

- “História duma Guariba”, Diário de Notícias, Rio de Janeiro, 12 nov. 1939, Suplemento p.8; e Folha do Norte, Belém, 24 fev. 1957.

- “O marquesão de jaqueira”, O Jornal, Rio de Janeiro, 19 nov. 1939.

- “Um missionário”, Jornal de Alagoas, Maceió, 8 jun. 1952.

- “Uma aventura de Alexandre”, Jornal do Brasil, Rio de Janeiro, 29 jun. 1957 (texto publicado postumamente), Il. Santa Rosa.

Infância (30)

- “Samuel Smiles”, Diário de Notícias, Rio de Janeiro, 13 nov. 1938 (Especial para o Diário de Notícias).

• “Os astrônomos” (conto), Diário de Notícias, Rio de Janeiro, 27 nov. 1938.

- “O Menino da Mata e o seu Cão Piloto”, O Jornal, Rio de Janeiro, Il. Santa Rosa, 27 nov. 1938.

- “História dum cinturão” (não se trata da versão exata publicada em livro como "Um cinturão”), O Jornal, Rio de Janeiro, 21 maio 1939, 4a seção, ano 21, il. Cortez; e Jornal do Comércio, Lisboa, 19 nov. 1944.

- “Fernando" (não se trata da mesma versão publicada em livro), Diário de Notícias, Rio de Janeiro, 18 jun. 1939.

- “Verão”, O Jornal, Rio de Janeiro, 2 fev. 1940.

- “Uma bebedeira”, O Jornal, Rio de Janeiro, 2 nov. 1940, $3^{\text {a }}$ seção, ano 22.

- “Chegada à vila”, Diretrizes, Rio de Janeiro, Il. Santa Rosa, 6 mar. 1941. 
- “Nuvens”, Revista do Brasil, Rio de Janeiro, ano 4, n.33, mar. 1941, p.28-32.

- “Vida Nova”, O Cruzeiro, Rio de Janeiro, 1 nov. 1941.

- “A Vila”, A Manhã, Rio de Janeiro, 18 jan. 1942, vol.2, Suplemento Literário, Il. Goeldi, p.31 e 32.

- “Padre João Ignácio”, A Manhã, Rio de Janeiro, 16 ago. 1942, vol.3, Suplemento Literário, p.73.

- “O fim do mundo”, Atlântico, Lisboa, n.2, Il. Antônio Duarte, 1942, p.306-310; Revista do Brasil, Rio de Janeiro, n.55, set. 1943, p. 57.

- “O moleque José”, Atlântico, Lisboa, n.3, Il. Manuel Lapa, 1943, p.111-114.

- “José da Luz”, Diretrizes, Rio de Janeiro, ano 6, n.162, Il. Percy Deane, 12 ago. 1943, p.13 e 23.

- “Escola”, Diretrizes, Rio de Janeiro, Il. Percy Deane, 21 out. 1943.

- “O barão de Macaúbas”, Atlântico, Lisboa, n.4, Il. Carlos Botelho, 21 nov. 1943.

- “Chico Brabo”, Diretrizes, Rio de Janeiro, 23 dez. 1943.

- “Adelaide”, Anuário Brasileiro de Literatura, Rio de Janeiro, n.7-8, 1943-1944, p.104-106.

- “Um novo professor”, Correio da Manhã, Rio de Janeiro, 6 ago. 1944 e Correo Literario, Montevidéu, 14 ago. 1944, p.3, trad. Norberto A. Frontini.

- “Leitura”, Correio da Manhã, Rio de Janeiro, 27 ago. 1944.

- “Cegueira”, Vamos Ler!, Rio de Janeiro, Il. Jeronymo Ribeiro, 5 out. 1944, p.62.

- “Um incêndio”, Unidade, Rio de Janeiro, nov. 1944, p.7.

- “Um intervalo”, Correio da Manhã, Rio de Janeiro, 24 dez. 1944.

- “Venta-Romba”, O Jornal, Rio de Janeiro, 14 jan. 1945, p.1 e 8.

- “Minha irmã natural”, O Jornal, Rio de Janeiro, 28 jan. 1945.

- “Jerônimo Barreto”, O Jornal, Rio de Janeiro, 18 fev. 1945.

- “A criança infeliz”, O Jornal, Rio de Janeiro, 11 mar. 1945.

- “Um enterro”, O Jornal, Rio de Janeiro, 15 abr. 1945.

- “Manhã”, Diretrizes, Rio de Janeiro, s.d, Suplemento Literário, Il. Augusto Rodrigues, p.1 e 8.

Insônia (13) 
- "Paulo”, O Jornal, Rio de Janeiro, 18 abr. 1937, 4a seção, ano XIX e Diário de Notícias, Rio de Janeiro, s.d., 2ª seção, ano 112.

- “Um pobre diabo”, O Jornal, Rio de Janeiro, 11 jul. 1937 e Estado de São Paulo, São Paulo, s.d.

- “El reloj del Hospital” (O relógio do Hospital), La Prensa, Buenos Aires, 24 out. 1937; Correio Paulistano, São Paulo, 12 abr. 1953, Suplemento: O conto brasileiro, p.5 e 14; Correio Paulistano, São Paulo, 19 fev. 1956, p.3 e Folha do Norte, Belém, 26 fev. 1961.

- “A testemunha”, Revista do Brasil, Rio de Janeiro, ano 1, n.1, jul. 1938, p.81-87.

- “Silveira Pereira” (conto), Diário de Notícias, Rio de Janeiro, 16 out. 1938, il. Luiz Jardim (Especial para o Diário de Notícias); e Diário de Lisboa, Lisboa, 15 fev. 1954.

- “Ciúmes” (conto), Diário de Notícias, Rio de Janeiro, 30 out. 1938, Il. Santa Rosa.

- “Uma visita”, Revista do Brasil, Rio de Janeiro, ano 2, n.9, mar. 1939, p.30-37.

- “Um ladrão”, Brasil Novo, Rio de Janeiro, 1 jun. 1939; A Tribuna, Santos, 10 mar. 1946; e La défense, [Paris], s.d. [n. 260-264], trad. Noel A. François.

- “Insônia”, O Jornal, Rio de Janeiro, 30 jun. 1939, il. Cortez, p.1 e 3.

- “La prision de J. Carmo Gomes”. La Nación, Buenos Aires, Il. Santa Rosa, $1^{0}$ jan. 1940; e Revista do Brasil, Rio de Janeiro, ano 3, n.24, jun. 1940, p.17-25.

- “Luciana”, O Jornal, Rio de Janeiro, 27 out. 1940, il. Atayuan(?) e A Tribuna, Santos, 17 mar. 1946.

- “Minsk”, A Manhã, Rio de Janeiro, 5 out. 1941, Suplemento Literário; A Tribuna, Santos, 26 mar. 1946; Autores e Livros, Rio de Janeiro, 20 jun. 1948, p.26; A Tarde, Salvador, 2 abr. 1953; Correio do Povo, Porto Alegre, 11 abr. 1953; Diário da Tarde, Belo Horizonte, 14 mar. 1954; e Diário de Minas, Belo Horizonte, 22 nov. 1953.

- “Dois dedos”, A Tribuna, Santos, 9 dez. 1945.

Memórias do Cárcere (9)

- "Página inédita de Memórias da Cadeia” [parágrafo final do capítulo 13, $1^{\circ}$ volume $^{987}$ ], Fundamentos, São Paulo, n.1, jun. 1948, p.26 e 27.

- Capítulo XVII, Para Todos, Rio de Janeiro, 20 out. 1949, n.1, ano 1 (nova fase).

\footnotetext{
${ }^{987}$ Toma-se como base, aqui, a $2^{\mathrm{a}}$ edição das Memórias do Cárcere, em quatro volumes, realizada pela Livraria José Olympio em 1954.
} 
- "M.Lima e Aporelly” (trecho com algumas modificações do capítulo 5, 2 volume), Diário Carioca, Rio de Janeiro, 24 dez. 1950.

- “O Porão do Manaus”. Jornal do IV Congresso, Rio de Janeiro, 1 set. 1951, n.1, p.4 e 7.

- “Seu Mota” (capítulo 24, $3^{\circ}$ volume), Temário, Rio de Janeiro, v.2, n.4, jan.-abri. 1952, p.21-23.

- “Paraíba” (capítulo 25, 3 volume), s.l., abr. 1952.

- “Birinyi” (capítulo 6, 2º volume), Fundamentos, São Paulo, n.31, jan. 1953, p.4 $4^{988}$.

- “Casa de Correção - Capítulo XIII”, Correio Paulistano, São Paulo, 25 out. 1953 (texto publicado postumamente), p.16.

- “Uma comédia” (capítulo 13, 4º volume do livro), s.l, s.d.

Viagem (1)

- “O Kolkhoze Kheivani” (capítulo 27 com algumas modificações), Imprensa Popular [?], Rio de Janeiro, jul. 1952.

${ }^{988} \mathrm{O}$ texto é acompanhado de uma ilustração e da reprodução fac-similar de um trecho do manuscrito de "Birinyi”. Na capa da revista há um desenho de Graciliano feito por Virgínia Artigas e a chamada no topo: GRACILIANO RAMOS - Memórias da Cadeia. 


\section{Dados coletados sobre local e data da primeira veiculação em periódico das crônicas de Linhas Tortas e Viventes das Alagoas}

\section{1) Linhas Tortas}

- “Álvaro Paes”, Jornal de Alagoas, Maceió, 12 jun. 1930.

- [ “O romance de Jorge Amado”] - “Suor”, Folha de Minas, Belo Horizonte, 17 fev. 1935.

- “Os donos da literatura”, O Popular, Rio de Janeiro, 10 set. 1937.

- “Os amigos de Machado de Assis”, Revista do Brasil (3 ${ }^{\circ}$ fase), ano II, n.12, Rio de Janeiro, jun. 1939.

- “Uma personagem curiosa” Cultura: mensário democrático, ano 1, n.5, São Paulo, fev.mar. 1939, p.13.

- “As mulheres do sr. Amado Fontes”, Diário de Notícias, Rio de Janeiro, 24 jul. 1938 (Copyright de I.B.R).

- “Baía de Todos-os-Santos”. Anuário Brasileiro de Literatura, Rio de Janeiro, n.3, 1939, p.97.

- “A livraria José Olímpio”, Folha de Minas, Belo Horizonte, 26 set. 1937.

- “A propósito da seca”, Observador Econômico e Financeiro, Rio de janeiro, ano II, n.13, fev. 1937.

- “Norte e Sul”, Diário de Notícias, Rio de Janeiro, 25 abr. 1937 (Copyright de I.B.R exclusividade no Distrito Federal para o Diário de Notícias).

- “Caminho de Pedras”, Diário de Notícias, Rio de Janeiro, 16 maio 1937 (Copyright de I.B.R).

- “Pureza”, Diário de Notícias, Rio de Janeiro, 29 ago. 1937; Jornal do Commércio, Recife, 27 ago. 1937. (Copyright de I.B.R)

- “Uma tradução de Pero Vaz”, Diário de Notícias, Rio de Janeiro, 20 mar. 1938. (O mesmo texto também fora publicado em 7 abr. do mesmo ano na Folha da Manhã)

- “Romances”, Diário de Notícias, Rio de Janeiro, 03 jul. 1938. 
- Uma justificação de voto, Rio de Janeiro, Dom Casmurro, ano 4, n.157, 13 jul. 1940 (originariamente se trata do prefácio escrito para o livro de contos Neblina (Curitiba: Editora Guaíra LTDA) de José Carlos Cavalcanti Borges em 1940) ${ }^{989}$.

- “Contos do Vigário”, Vamos Ler!, Rio de Janeiro, 20 maio 1937.

• “A opiniões do respeitável público”, Diário de Notícias, Rio de Janeiro, 11 jul. 1937 (Copyright de I.B.R).

- “Jardins”, Diário de Notícias, Rio de Janeiro, 18 jul. 1937 (Copyright de I.B.R).

- “Terra de Espanha”, Surto, Belo Horizonte, set. 1937. (O mesmo texto fora também publicado no Diário de Notícias, $1^{0}$ Suplemento, Rio de Janeiro, 12 set. 1937 (Copyright de I.B.R)).

- “O teatro de Oswald de Andrade”, Surto, [Belo Horizonte], n.8, set. 1937; Diário de Notícias, Rio de Janeiro, 19 jun. 1938 e Dom Casmurro, Rio de Janeiro, 2 dez. 1939, ano 3, n.127.

- “O Rio”, O Popular, Rio de Janeiro, 19 set. $1937^{990}$.

- “Jibóias”, Diário de Notícias, Rio de Janeiro, 21 nov. 1937 (Copyright de I.B.R).

- “Um velho cartão postal”, Diário de Notícias, Rio de Janeiro, 07 nov. 1937 (Copyright de I.B.R) e Dom Casmurro, Rio de Janeiro, 23 set. 1939, ano 3, n.119.

- “Um novo ABC”, Vamos Ler!, Rio de Janeiro, 21 abr. 1938.

- “Sociedade de Amigos”, Diário de Notícias, Rio de Janeiro, 26 jun. 1938.

- “Uma eleição”, Diário de Notícias, Rio de Janeiro, 21 ago. 1938.

- “O sr. Krause”, Diário de Notícias, $1^{0}$ Suplemento, Rio de Janeiro, 8 jan. 1939.

- “Os sapateiros da literatura”, Anuário Brasileiro de Literatura, Rio de Janeiro, n.4, 1940.

- “A viúva Lacerda”, Cultura Política, ano IV, n.42, Rio de Janeiro, jul. 1944, p.173174.

- “Alguns tipos sem importância”, Dom Casmurro, Rio de Janeiro, 19 ago. 1939, ano 3, n.114. (Texto também estampado em Publicações Médicas, São Paulo, 1939).

\footnotetext{
${ }^{989}$ Texto introdutório à crônica "Justificação de voto” de Graciliano Ramos: “O autor é um dos maiores escritores do Brasil atual. Dispensa, pois, comentários e apresentações. É lido em todo o país. Um dia DOM CASMURRO obteve que ele fizesse parte do júri para o "Grande Concurso de Contos” que realizou. Graciliano, cujo nome é uma garantia a honestidade intelectual de qualquer [prélio] desse gênero, virou, mexeu, leu, releu, impôs respeito na coisa e um escritor novo apareceu, vencendo no meio de 800 e tantos concorrentes. Chama-se José Carlos Cavalcanti Borges e não se contentou com o primeiro lugar somente. Obteve o segundo também. Agora acaba ele de publicar o seu primeiro livro - Neblina - onde incluiu esses trabalhos. Graciliano prefaciou o livro. É esse prefácio magnífico que aqui transcrevemos”.

${ }^{990}$ Ver página 75 do Catálogo de Manuscritos.
} 
- “Atribulações de Papai Noel”, O Cruzeiro, Rio de Janeiro, 23 dez. 1939, p.2-3.

- “Desordens”, A Tarde, Rio de Janeiro, 03 fev. 1938.

- “Conversa fiada”, Vamos Ler!, Rio de Janeiro, n.199, 23 maio 1940.

- Paulo Barreto, S. João Batista e D. Mariana, Vamos Ler!, Rio de Janeiro, 8 ago. 1940.

- “Booker Washington”, Cultura Política, ano IV, n.43, Rio de Janeiro, ago. 1944, p.217-219.

- “Aurora e ‘seu’ Oscar”, O Cruzeiro, Rio de Janeiro, fev. 1941.

- [ “Para nós humildes”] - “A poesia de Beatrix Reynal”, Dom Casmurro, Rio de Janeiro, 31 maio 1941, ano 5, n.202.

- “A última noite de natal”, Correio da Manhã, Rio de Janeiro, 24 dez. 1955 e Imprensa Popular, Rio de Janeiro, 22 dez. 1957.

- “Milagres”, Novidade, Maceió, n.14, 11 jul. 1931.

- “O que deveríamos fazer”, Renovação, Rio de Janeiro, mar. 1943 (Especial para Renovação).

- “Um homem forte”, O Cruzeiro, Rio de Janeiro, 11 set. 1943.

- “Monólogo numa fila de ônibus”, Renovação, Rio de Janeiro, 02 fev. 1943.

- “Conversa de Bastidores”, A Casa, Rio de Janeiro, jun. 1946. (O mesmo texto fora também publicado em A Tribuna, Santos, 06 jun. 1946).

- “O fator econômico no romance brasileiro”, Observador Econômico e Financeiro, Rio de janeiro, ano II, n.15, abr. 1937; e Tribuna Popular, Rio de Janeiro, 17 jul. 1945.

- “Os amigos do povo”. Tribuna Popular, Rio de Janeiro, 09 dez. 1945.

- “Prefácio para uma antologia”, Para todos, Rio de Janeiro, 1957(?) (In: RAMOS, Graciliano (org). Contos e Novelas. Rio de Janeiro: Casa do Estudante do Brasil, vol. 1, 1957. (obra póstuma em três volumes, dispostos da seguinte maneira: v.1 - Norte e Nordeste; v.2 - Leste ; e v.3 - Sul e Centro-Oeste).

- “Álvaro Moreira”, Imprensa Popular, Rio de Janeiro, 10 ago. 1950.

- “Simão Dias”, In: PAIM, Alina. Simão Dias. Rio de Janeiro: Liv. Ed. Casa do estudante do Brasil, 1949.

- “Dois Mundos”, Leitura - crítica e informação bibliográfica, Rio de Janeiro, n.2, jan. 1943, p.7.

\section{2) Viventes das Alagoas}


- “Carnaval 1910” - O Cruzeiro, Rio de Janeiro, 14 fev. 1942; e O Estado de Fortaleza, Fortaleza, 16 fev. 1958.

- [“Natal”] - “Natal no interior” - O Cruzeiro, Rio de Janeiro, 21 dez. 1940.

- [“Caranaval”] - “Quadros e Costumes do Nordeste I” - Cultura Política, Rio de Janeiro, n.1, mar. 1941.

- [“D. Maria Amália”] - “Quadros e Costumes do Nordeste II” - Cultura Política, Rio de Janeiro, n.2, abr. $1941^{991}$.

- [ [OO moço da farmácia”] - “Quadros e Costumes do Nordeste III”, Cultura Política, Rio de Janeiro, n. 3, maio 1941.

- [“Casamentos”] - “Quadros e Costumes do Nordeste IV”, Cultura Política, Rio de Janeiro, n.4, jun. 1941.

- [“Ciríaco”] - “Quadros e Costumes do Nordeste V”, Cultura Política, Rio de Janeiro, n.5, jul. 1941.

- ["Habitação”] - “Quadros e Costumes do Nordeste VI”, Cultura Política, Rio de Janeiro, n.6, ago. 1941.

- [“Teatro I”] - “Quadros e Costumes do Nordeste VII”, Cultura Política, Rio de Janeiro, n.7, set. 1941.

- [“Teatro II”] - “Quadros e Costumes do Nordeste VIII”, Cultura Política, Rio de Janeiro, n.8, out. 1941.

- [“Bagunça”] - “Quadros e Costumes do Nordeste IX”, Cultura Política, Rio de Janeiro, n.9, nov. 1941.

- [“D. Maria”] - “Quadros e Costumes do Nordeste X”, Cultura Política, Rio de Janeiro, n.10, dez. 1941.

- [“Libório”] - “Quadros e Costumes do Nordeste XI”, Cultura Política, Rio de Janeiro, n.11, jan. 1942.

- [“Desafio”] - “Quadros e Costumes do Nordeste XII”, Cultura Política, Rio de Janeiro, n.12, fev. 1942.

- [“Funcionário Independente”] - “Quadros e Costumes do Nordeste XIII”, Cultura Política, Rio de Janeiro, n.13, mar. 1942.

- [“Um antepassado”] - “Quadros e Costumes do Nordeste XIV”, Cultura Política, Rio de Janeiro, n.14, abr. 1942.

${ }^{991}$ Publicada originariamente no Jornal de Alagoas de Maceió em 18 de junho de 1933. 
- [“Um homem de letras”] - “Quadros e Costumes do Nordeste XV”, Cultura Política, Rio de Janeiro, n.15, maio 1942.

- [“Um gramático”] - "Quadros e Costumes do Nordeste XVI”, Cultura Política, Rio de Janeiro, n.16, jun. 1942.

- [“Dr. Pelado”] - “Quadros e Costumes do Nordeste XVII”, Cultura Política, Rio de Janeiro, n.17, jul. 1942.

- [“Transação de Cigano”] - “Quadros e Costumes do Nordeste XVIII”, Cultura Política, Rio de Janeiro, n.18, ago. 1942.

- ["A decadência de um senhor de engenho"] - "Quadros e Costumes Regionais I", Cultura Política, Rio de Janeiro, n.19, set. 1942.

- ["Recordações de uma indústria morta”] - "Quadros e Costumes Regionais II", Cultura Política, Rio de Janeiro, n.20, out. 1942.

- [“Está aberta a sessão do juri”] - “Quadros e Costumes Regionais IV”, Cultura Política, Rio de Janeiro, n.25, mar. 1943.

- [“Um homem notável”] - “Quadros Regionais I”, Cultura Política, Rio de Janeiro, n.27, maio 1943.

- “Inácio da Catingueira e Romano”, Diário de Notícias, Rio de Janeiro, 19 dez. 1937 (Copyright de I.B.R).

- [ “O fator econômico do cangaço”] - "O fenômeno do cangaço”, Observador Econômico e Financeiro, Rio de Janeiro, n.33, out. $1938^{992}$.

- “Lampião”, Novidade, Maceió, n.3, 25 abr. 1931.

- [“Virgulino”] - “Lampeão”, A Tarde, Rio de Janeiro, 27 jan. 1938.

- “Cabeças”, Diário de Notícias, Rio de Janeiro, 2 out. 1938.

- “Um desastre”, Folha Carioca, Rio de Janeiro, 23 ago. 1944.

- [“Comandantes de burros”] - “O comandante dos burros”, Jornal de Alagoas, Maceió, 27 maio 1933.

- “Antônio Silvino" - O Jornal, Rio de Janeiro, 11 set. 1938.

\section{Textos não localizados}

- “O Dr. Jacarandá” 993

\footnotetext{
${ }^{992}$ Trata-se da crônica editada no livro como "O fator econômico do cangaço", com alguns acréscimos: o $12^{\circ}$ parágrafo não consta no texto da revista, bem como o último período do $16^{\circ}$.
} 
- “Um profeta",994

- "Professores improvisados"

- “Corisco”

- "O jogo do bicho, fator econômico"

\section{Publicações póstumas}

- “O fator econômico do cangaço”, Diário de Notícias, Rio de Janeiro, 18 out. 1953.

- “Dois Cangaço”, Diário de Notícias, Rio de Janeiro, $1^{\circ}$ nov. 1953.

993 O manuscrito do texto data de 8 de fevereiro de 1941.

${ }^{994}$ Parte do manuscrito desta crônica é datada de 27 de abril de 1930. 


\section{Índice geral dos textos do autor veiculados na imprensa por ordem de data}

1909

1) “No Campo das Letras”, Jornal de Alagoas, Maceió, 20 abr. 1909 (inédita; com pseudônimo Lambda).

1910

2) “Estudante na roça”, Jornal de Alagoas, Maceió, 13 mar. 1910 (inédita; com pseudônimo Lambda).

3) “Pela mocidade”, Jornal de Alagoas, Maceió, 22 fev. 1911 (inédita; com pseudônimo Lambda).

4) “Zé Pereira”, Jornal de Alagoas, Maceió, 25 fev. 1911 (inédita; com pseudônimo Lambda).

5) “Literatura”, Correio de Maceió, Maceió, 04 out. 1911 (inédita; com pseudônimo Soeiro Lobato).

6) “Professiomania”, Jornal de Alagoas, Maceió, 26 set. 1913 (inédita; com pseudônimo Lambda).

7) “Na terra do fogo as coisas estão frias...”, Parayba do Sul, Paraíba do Sul (RJ), 07 jan. 1915 (assinada com os sobrenomes Ramos de Oliveira).

8) “Eu estava convencido...”, Jornal de Alagoas, Maceió, mar. 1915 (Linhas Tortas). 
9) “Os antigos religiosos fanáticos...”, Jornal de Alagoas, Maceió, mar. 1915 (Linhas Tortas).

10) “Coisas do Rio”, Jornal de Alagoas, Maceió, 06 mar. 1915 (inédita; com as iniciais R.O.).

11) Início da seção “Traços a Esmo”, Parayba do Sul, Paraíba do Sul (RJ), 15 abr. 1915, que contará com 13 textos.

12) “Linhas Tortas”, Jornal de Alagoas, Maceió, 18 abr. 1915 (inédita; com as iniciais R.O.).

13) Segundo texto (continuação) da seção “Traços a Esmo”, publicado em 22 abr. 1915, no semanário Parayba do Sul, que circulava todas as quintas-feiras. A seção continua sendo publicada até 5 de agosto de 1915, com algumas interrupções (não circula nos dias 10 e 24 de junho e 15 e 29 de julho).

14) Os 14 textos da série “Traços a Esmo” publicados no jornal palmeirense $O$ Índio, ininterruptamente, de 31 de janeiro a $1^{\circ}$ de maio de 1921.

15) Os 14 textos da série “Guarranchos” publicados no jornal palmeirense $O$ Índio, ininterruptamente, de 31 de janeiro a $1^{\circ}$ de maio de 1921.

16) “Judas”, O Índio, Palmeira dos Índios. 27 mar. 1921 (inédita; com as iniciais J.C., do pseudônimo J. Calisto).

17) “Como se escreve”, O Índio, Palmeira do Índios, 03 abr. 1921 (inédita; com pseudônimo Lambda).

18) Solidariedade, O Índio, Palmeira do Índios, 24 abr. 1921 (inédita; com pseudônimo Lambda).

19) “Macoeba préhistórico”, Jornal de Alagoas, Maceió, 27 abr. 1930, p.3 (inédita; com pseudônimo Lúcio Guedes).

20) “Macoeba” Jornal de Alagoas, Maceió, 29 abr. 1930, p.3 (inédita; com pseudônimo Lúcio Guedes).

21) “Álvaro Paes”, Jornal de Alagoas, Maceió, 12 jun. 1930 (Linhas Tortas). 
22) “O álcool”, Jornal de Alagoas, Maceió, 21 jun. 1930 (inédita; com as iniciais G.R.).

23) “Prefeituras municipais I”, Jornal de Alagoas, Maceió, 31 jul. 1930, p.3 (inédita; com pseudônimo Lúcio Guedes).

24) “Prefeituras municipais II”, Jornal de Alagoas, Maceió, 08 ago. 1930, p.3 (inédita; com pseudônimo Lúcio Guedes).

25) “Sertanejos”, Novidade, Maceió, n.1, 11 abr. 1931 (Inédita).

26) “Lampião”, Novidade, Maceió, n.3, 25 abr. 1931 (Viventes das Alagoas).

27) “Lampeão entrevistado por Novidade”, Novidade, Maceió, n.6, 16 maio 1931, p.8 e 9 (Inédita).

28) “Chavões”, Novidade, Maceió, n.8, 30 mai. 1931 (inédita).

29) “Capítulo XXIV”, Novidade, Maceió, 6 jun. 1931, n.9. (Caetés)

30) “Milagres”, Novidade, Maceió, n.14, 11 jul. 1931 (Linhas Tortas).

31) “O testa de ferro”, Jornal de Alagoas, Maceió, 16 ago. 1931, p.3 (inédita; com as iniciais G.R.).

32) “Mulheres”, Jornal de Alagoas, Maceió, 20 maio 1933, p.3 (inédita).

33) “Comandante de Burros”, Jornal de Alagoas, Maceió, 27 maio 1933 (Viventes das Alagoas a partir de 1992).

34) Capítulos 7 e 19 (de S. Bernardo), Jornal de Alagoas, Maceió, 31 maio 1933.

35) “D. Maria Amália”, Jornal de Alagoas, Maceió, 18 de jun. 1933; e [“Quadros e Costumes do Nordeste II”], Cultura Política, Rio de Janeiro, n.2, abr. 1941 (Viventes das Alagoas).

36) “Doutores”, Jornal de Alagoas, Maceió, 11 jun. 1933 (inédita).

37) “Luiza” (trecho que abarca o capítulo 18 e parte do 19 da obra publicada), Boletim de Ariel, Rio de Janeiro, ano 3, n.3, dez. 1933, p.81. (Caetés) 
38) “Precipitação”, A Noite Ilustrada, Rio de Janeiro, 7 fev. 1934, p.14 (primeiro capítulo e parte do segundo da versão publicada de Caetés). (Caetés)

39) “Um romancista do Nordeste”, Literatura, Rio de Janeiro, ano 1, n.18, 20 jun. 1934 (inédita).

40) Capítulo 21 (de S. Bernardo), Momento, Recife, ano 1, n.4, ago. 1934.

41) "Ciúmes” (trecho que abarca os capítulos 29 e 30 da obra publicada), Boletim de Ariel, Rio de Janeiro, ano 3, n.12, set. 1934, p.325. (S. Bernardo)

1935

42) [“O romance de Jorge Amado”] - “Suor”, Folha de Minas, Belo Horizonte, 17 fev. 1935 (Linhas Tortas).

43) “O romance do Nordeste”, Diário de Pernambuco, Recife, 10 mar. 1935 (inédita).

44) “Alguns números relativos a instrução primária em Alagoas”, A Escola, Maceió, set. 1935 (inédita).

45) “Marina” (trecho de Angústia, romance ainda no prelo), Revista Acadêmica, Rio de Janeiro, ano 3, n.19, jun. 1936, p.9. (Angústia)

46) “Infância” (trecho de Angústia, romance ainda no prelo), Boletim de Ariel, Rio de Janeiro, ano 5, n.10, jul. 1936. (Angústia)

47) “A propósito da seca”, Observador Econômico e Financeiro, Rio de janeiro, ano II, n.13, fev. 1937 (Linhas Tortas).

48) “O fator econômico no romance brasileiro”, Observador Econômico $e$ Financeiro, Rio de janeiro, ano II, n.15, abr. 1937; e Tribuna Popular, Rio de Janeiro, 17 jul. 1945 (Linhas Tortas).

49) “Paulo”, O Jornal, Rio de Janeiro, 18 abr. 1937, 4ª seção, ano XIX (Insônia) 
50) “Norte e Sul”, Diário de Notícias, Rio de Janeiro, 25 abr. 1937 (Copyright de I.B.R - exclusividade no Distrito Federal para o Diário de Notícias) (Linhas Tortas).

51) “Caminho de Pedras”, Diário de Notícias, Rio de Janeiro, 16 maio 1937 (Copyright de I.B.R) (Linhas Tortas).

52) “Contos do Vigário”, Vamos Ler!, Rio de Janeiro, 20 maio 1937 (Linhas Tortas).

53) “Baleia”, O Jornal, Rio de Janeiro, 23 maio 1937. (Vidas Secas)

54) “O relógio de hospital”, Lanterna Verde, Rio de Janeiro, n.5, jul. 1937, p.64-70 (Insônia).

55) “Um pobre diabo”, O Jornal, Rio de Janeiro, 11 jul. 1937. (Insônia)

56) “A opiniões do respeitável público”, Diário de Notícias, Rio de Janeiro, 11 jul. 1937 (Copyright de I.B.R) (Linhas Tortas).

57) “Jardins”, Diário de Notícias, Rio de Janeiro, 18 jul. 1937 (Copyright de I.B.R) (Linhas Tortas).

58) “Pureza”, Jornal do Commércio, Recife, 27 ago. 1937. (Copyright de I.B.R) (Linhas Tortas)

59) “Pureza”, Diário de Notícias, Rio de Janeiro, 29 ago. 1937 (Copyright de I.B.R) (Linhas Tortas).

60) “Terra dos Meninos Pelados [I]”, Pan Infantil, Rio de Janeiro, 31 ago. 1937.

61) “O teatro de Oswald de Andrade”, Surto, [Belo Horizonte], n.8, set. 1937 (Linhas Tortas);

62) “Terra de Espanha”, Surto, Belo Horizonte, set. 1937 (Linhas Tortas).

63) “Os donos da literatura”, O Popular, Rio de Janeiro, 10 set. 1937 (Linhas Tortas).

64) “Terra de Espanha”, Diário de Notícias, $1^{0}$ Suplemento, Rio de Janeiro, 12 set. 1937 - (Copyright de I.B.R) (Linhas Tortas).

65) “Terra dos Meninos Pelados [II]”, Pan Infantil, Rio de Janeiro, 15 set. 1937.

66) “O Rio”, O Popular, Rio de Janeiro, 19 set. 1937 (Linhas Tortas).

67) “A livraria José Olímpio”, Folha de Minas, Belo Horizonte, 26 set. 1937 (Linhas Tortas).

68) “El reloj del Hospital” (O relógio de hospital), La Prensa, Buenos Aires, 24 out. 1937. (Insônia).

69) “Mulheres...”, Vamos Lêr!, Rio de Janeiro, 28 out. 1937, n.65 (inédita). 
70) “Um velho cartão postal”, Diário de Notícias, Rio de Janeiro, 07 nov. 1937 (Copyright de I.B.R) (Linhas Tortas).

71) “O mundo coberto de penas” (trecho de romance a sair - Vidas Secas), Revista Acadêmica, Rio de Janeiro, n.32, nov. 1937, p.3. (Vidas Secas)

72) “D. Zizi”, Vamos Lêr!, Rio de Janeiro, 11 nov. 1937, n.67 (inédita).

73) “Jibóias”, Diário de Notícias, Rio de Janeiro, 21 nov. 1937 (Copyright de I.B.R) (Linhas Tortas).

74) “Pedaço de Romance” (excerto do capítulo “Cadeia”), Diário de Notícias, Rio de Janeiro, 5 dez. 1937. (Vidas Secas)

75) “Mudança”, O Jornal, Rio de Janeiro, 19 dez. 1937, p.1 e 2. (Vidas Secas)

76) “Inácio da Catingueira e Romano”, Diário de Notícias, Rio de Janeiro, 19 dez. 1937 (Copyright de I.B.R) (Viventes das Alagoas).

77) “Trecho de romance” (parte do capítulo Sinhá Vitória), Anuário Brasileiro de Literatura, Rio de Janeiro, 1938. (Vidas Secas).

78) “Travessura” (do capítulo “O menino mais novo”), Diário de Notícias, Rio de Janeiro, 23 jan. 1938 (Copyright de I.B.R). (Vidas Secas)

79) [“Virgulino”] - “Lampeão”, A Tarde, Rio de Janeiro, 27 jan. 1938 (Viventes das Alagoas).

80) “Fabiano”, O Cruzeiro, Rio de Janeiro, 29 jan. 1938, p.22 e 23. (Vidas Secas)

81) “Desgraças” (outra versão de “Fabiano”), Diário de Notícias, Rio de Janeiro, 30 jan. 1938 (Copyright de I.B.R). (Vidas Secas)

82) “Desordens”, A Tarde, Rio de Janeiro, 03 fev. 1938 (Linhas Tortas).

83) “Serão” (fragmento do capítulo “Inverno”), Folha de Minas, Belo Horizonte, 16 mar. 1938 (Do romance inédito “Baleia” - Copyright de I.B.R). (Vidas Secas)

84) “Uma tradução de Pero Vaz”, Diário de Notícias, Rio de Janeiro, 20 mar. 1938 (Linhas Tortas).

85) “Cadeia”, O Cruzeiro, Rio de Janeiro, 26 mar. 1938, Il. Borsoi, p.26 e 27. (Vidas Secas)

86) “Festa”, Lanterna Verde, Rio de Janeiro, abr. 1938. (Vidas Secas)

87) “Serão” (fragmento do capítulo “Inverno”), Diário de Notícias, Rio de Janeiro, 3 abr. 1938 (Vidas Secas) 
88) “Viagem” (fragmento do capítulo “Fuga”), Diário de Notícias, Rio de Janeiro, 14 abr. 1938 (Do romance Vidas Secas - Copyright de I.B.R). (Vidas Secas)

89) “Um novo ABC”, Vamos Ler!, Rio de Janeiro, 21 abr. 1938 (Linhas Tortas).

90) Um anúncio. Esfera - revista de letras, artes e ciências, Rio de Janeiro, ano 1, n.1, maio 1938, p.7. (Inédita)

91) “O teatro de Oswald de Andrade”, Diário de Notícias, Rio de Janeiro, 19 jun. 1938 (Linhas Tortas).

92) “Sociedade de Amigos”, Diário de Notícias, Rio de Janeiro, 26 jun. 1938 (Linhas Tortas).

93) “A testemunha”, Revista do Brasil, Rio de Janeiro, ano 1, n.1, jul. 1938, p.81-87. (Insônia)

94) “Romances”, Diário de Notícias, Rio de Janeiro, 03 jul. 1938 (Linhas Tortas).

95) “As mulheres do sr. Amado Fontes”, Diário de Notícias, Rio de Janeiro, 24 jul. 1938 (Copyright de I.B.R) (Linhas Tortas).

96) “Uma eleição”, Diário de Notícias, Rio de Janeiro, 21 ago. 1938 (Linhas Tortas).

97) “Antônio Silvino”, O Jornal, Rio de Janeiro, ano 10, 11 set. 1938, Quarta seção (Viventes das Alagoas a partir de 1992).

98) “O fenômeno do cangaço”, Observador Econômico e Financeiro, Rio de Janeiro, n.33, out. $1938^{995}$.

99) “Cabeças”, Diário de Notícias, Rio de Janeiro, 2 out. 1938 (Viventes das Alagoas).

100) "Silveira Pereira” (conto), Diário de Notícias, Rio de Janeiro, 16 out. 1938, il.

Luiz Jardim (Especial para o Diário de Notícias). (Insônia)

101) “Ciúmes” (conto), Diário de Notícias, Rio de Janeiro, 30 out. 1938, Il. Santa Rosa. (Insônia)

102) “Samuel Smiles”, Diário de Notícias, Rio de Janeiro, 13 nov. 1938 (Especial para o Diário de Notícias). (Infância)

103) “Os astrônomos” (conto), Diário de Notícias, Rio de Janeiro, 27 nov. 1938. (Infância)

104) “O Menino da Mata e o seu Cão Piloto”, O Jornal, Rio de Janeiro, Il. Santa Rosa, 27 nov. 1938. (Infância)

\footnotetext{
${ }^{995}$ Trata-se da crônica editada no livro como "O fator econômico do cangaço”, com alguns acréscimos: o $12^{\circ}$ parágrafo não consta no texto da revista, bem como o último período do $16^{\circ}$.
} 
105) “Um papagaio falador”, Diário de Notícias, Rio de Janeiro, Il. Gonçalvez, 25 dez. 1938. (Alexandre e Outros Heróis)

106) “Baía de Todos-os-Santos”. Anuário Brasileiro de Literatura, Rio de Janeiro, n.3, 1939, p.97.

107) "História dum Bode”, O Jornal, Rio de Janeiro, $1^{0}$ jan. 1939, $4^{\text {a }}$ seção, il. Cortez.

108) “O sr. Krause”, Diário de Notícias, $1^{0}$ Suplemento, Rio de Janeiro, 8 jan. 1939 (Linhas Tortas).

109) “Primeira aventura de Alexandre”, Diário de Notícias, Rio de Janeiro, 22 jan. 1939. (Alexandre e Outros Heróis)

110) “Uma personagem curiosa”, Cultura- Mensário Democrático, ano 1, n.5, São Paulo, fev.mar. 1939, p.13. (Linhas Tortas)

111) “Uma visita”, Revista do Brasil, Rio de Janeiro, ano 2, n.9, mar. 1939, p.30-37. (Insônia)

112) “Um ladrão”, Brasil Novo, Rio de Janeiro, 1 jun. 1939. (Insônia)

113) “História dum cinturão” (não se trata da versão exata publicada em livro como “Um cinturão”), O Jornal, Rio de Janeiro, ano 21, il. Cortez, 21 maio 1939, 4 seção. (Alexandre e Outros Heróis)

114) “O olho torto de Alexandre”, Diário de Notícias, Rio de Janeiro, 21 maio 1939, Suplemento p.2. (Alexandre e Outros Heróis)

115) “Fernando" (não se trata da mesma versão publicada em livro), Diário de Notícias, Rio de Janeiro, 18 jun. 1939. (Infância)

116) “Insônia”, O Jornal, Rio de Janeiro, 30 jun. 1939, il. Cortez, p.1 e 3. (Insônia)

117) “Os amigos de Machado de Assis”, Revista do Brasil ( $3^{\circ}$ fase), ano II, n.12, Rio de Janeiro, jun. 1939 (Linhas Tortas).

118) “A espingarda de Alexandre”, Diário de Notícias, Rio de Janeiro, 30 jul. 1939, Suplemento p.1 (Alexandre e Outros Heróis).

119) “Alguns tipos sem importância”, Dom Casmurro, Rio de Janeiro, 19 ago. 1939, ano 3, n.114. (Texto também estampado em Publicações Médicas, São Paulo, 1939) (Linhas Tortas). 
120) “Moqueca”, Diário de Notícias, Rio de Janeiro, 3 set. 1939. (Alexandre e Outros Heróis).

121) “Estribo de Prata”, O Jornal, Rio de Janeiro, ano 21, il. Cortez, 10 set. 1939, $3^{\text {a }}$ seção, p.1 e 2. (Alexandre e Outros Heróis).

122) “Um velho cartão postal”,Dom Casmurro, Rio de Janeiro, ano 3, n.119, 23 set. 1939 (Linhas Tortas).

123) “História duma Guariba”, Diário de Notícias, Rio de Janeiro, 12 nov. 1939, Suplemento p.8. (Alexandre e Outros Heróis).

124) “O marquesão de jaqueira”, O Jornal, Rio de Janeiro, 19 nov. 1939. (Alexandre e Outros Heróis).

125) “O teatro de Oswald de Andrade”, Dom Casmurro, Rio de Janeiro, 2 dez. 1939, ano 3, n.127 (Linhas Tortas).

126) “Atribulações de Papai Noel”, O Cruzeiro, Rio de Janeiro, 23 dez. 1939, p.2-3 (Linhas Tortas).

127) “Os sapateiros da literatura”, Anuário Brasileiro de Literatura, Rio de Janeiro, n.4, 1940. (Linhas Tortas)

128) “La prision de J. Carmo Gomes”. La Nación, Buenos Aires, Il. Santa Rosa, $1^{\circ}$ jan. 1940. (Insônia)

129) “Verão”, O Jornal, Rio de Janeiro, 2 fev. 1940. (Infância)

130) “Conversa fiada”, Vamos Ler!, Rio de Janeiro, n.199, 23 maio 1940 (Linhas Tortas).

131) “Uma justificação de voto”, Rio de Janeiro, Dom Casmurro, ano 4, n.157, 13 jul. 1940 (Linhas Tortas).

132) Paulo Barreto, S. João Batista e D. Mariana, Vamos Ler!, Rio de Janeiro, 8 ago. 1940 (Linhas Tortas).

133) “Luciana”, O Jornal, Rio de Janeiro, Il. Atayuan(?), 27 out. 1940. 1946. (Insônia).

134) “Uma bebedeira”, O Jornal, Rio de Janeiro, ano 22, 2 nov. 1940, $3^{\text {a }}$ seção. (Infância).

135) [“Natal”] - “Natal no interior”, O Cruzeiro, Rio de Janeiro, 21 dez. 1940 (Viventes das Alagoas). 
136) “Aurora e ‘seu’ Oscar”, O Cruzeiro, Rio de Janeiro, fev. 1941 (Linhas Tortas).

137) [“Caranaval”] - “Quadros e Costumes do Nordeste I”, Cultura Política, Rio de Janeiro, n.1, mar. 1941(Viventes das Alagoas).

138) “Chegada à vila”, Diretrizes, Rio de Janeiro, Il. Santa Rosa, 6 mar. 1941. (Infância).

139) “Nuvens”, Revista do Brasil, Rio de Janeiro, ano 4, n.33, mar. 1941, p.28-32. (Infância).

140) [“D. Maria Amália”] - “Quadros e Costumes do Nordeste II”, Cultura Política, Rio de Janeiro, n.2, abr. 1941 (Viventes das Alagoas).

141) [“O moço da farmácia”] - “Quadros e Costumes do Nordeste III”, Cultura Política, Rio de Janeiro, n. 3, maio 1941(Viventes das Alagoas).

142) [“Para nós humildes”] - “A poesia de Beatrix Reynal”, Dom Casmurro, Rio de Janeiro, 31 maio 1941, ano 5, n.202 (Linhas Tortas).

143) [“Casamentos”] - “Quadros e Costumes do Nordeste IV”, Cultura Política, Rio de Janeiro, n.4, jun. 1941 (Viventes das Alagoas).

144) [“Ciríaco”] - “Quadros e Costumes do Nordeste V”, Cultura Política, Rio de Janeiro, n.5, jul. 1941 (Viventes das Alagoas).

145) [“Habitação”] - “Quadros e Costumes do Nordeste VI”, Cultura Política, Rio de Janeiro, n.6, ago. 1941 (Viventes das Alagoas).

146) [“Teatro I”] - “Quadros e Costumes do Nordeste VII”, Cultura Política, Rio de Janeiro, n.7, set. 1941 (Viventes das Alagoas).

147) [“Teatro II”] - “Quadros e Costumes do Nordeste VIII”, Cultura Política, Rio de Janeiro, n.8, out. 1941 (Viventes das Alagoas).

148) "Minsk”, A Manhã, Rio de Janeiro, 5 out. 1941, Suplemento Literário. (Insônia)

149) [“Bagunça”] - “Quadros e Costumes do Nordeste IX”, Cultura Política, Rio de Janeiro, n.9, nov. 1941 (Viventes das Alagoas).

150) “Vida Nova”, O Cruzeiro, Rio de Janeiro, 1 nov. 1941. (Infância)

151) “Decadencia de la novela brasileña” (Decadência do romance brasileiro), Nueva Gazeta, Buenos Aires, dez. 1941.

152) [“D. Maria”] - “Quadros e Costumes do Nordeste X”, Cultura Política, Rio de Janeiro, n.10, dez. 1941 (Viventes das Alagoas). 
153) “Decadência do romance brasileiro”, Nueva Gazeta, Buenos Aires, dez. 1941. (Graciliano Ramos).

154) “O fim do mundo”, Atlântico, Lisboa, n.2, Il. Antônio Duarte, 1942, p.306-310. (Infância)

155) [“Libório”] - “Quadros e Costumes do Nordeste XI”, Cultura Política, Rio de Janeiro, n.11, jan. 1942 (Viventes das Alagoas).

156) “A Vila”, A Manhã, Rio de Janeiro, vol.2, Il. Goeldi, 18 jan. 1942, Suplemento Literário, p.31 e 32. (Infância)

157) [“Desafio”] - “Quadros e Costumes do Nordeste XII”, Cultura Política, Rio de Janeiro, n.12, fev. 1942 (Viventes das Alagoas).

158) “Carnaval 1910”, O Cruzeiro, Rio de Janeiro, 14 fev. 1942 (Viventes das Alagoas).

159) [“Funcionário Independente”] - “Quadros e Costumes do Nordeste XIII”, Cultura Política, Rio de Janeiro, n.13, mar. 1942 (Viventes das Alagoas).

160) [“Um antepassado”] - "Quadros e Costumes do Nordeste XIV”, Cultura Política, Rio de Janeiro, n.14, abr. 1942 (Viventes das Alagoas).

161) [“Um homem de letras”] - "Quadros e Costumes do Nordeste XV”, Cultura Política, Rio de Janeiro, n.15, maio 1942 (Viventes das Alagoas).

162) [“Um gramático”] - “Quadros e Costumes do Nordeste XVI”, Cultura Política, Rio de Janeiro, n.16, jun. 1942 (Viventes das Alagoas).

163) [“Dr. Pelado”] - “Quadros e Costumes do Nordeste XVII”, Cultura Política, Rio de Janeiro, n.17, jul. 1942 (Viventes das Alagoas).

164) [“Transação de Cigano”] - “Quadros e Costumes do Nordeste XVIII”, Cultura Política, Rio de Janeiro, n.18, ago. 1942 (Viventes das Alagoas).

165) "Padre João Ignácio”, A Manhã, Rio de Janeiro, 16 ago. 1942, Suplemento Literário, p.73. (Infância)

166) [“A decadência de um senhor de engenho”] - "Quadros e Costumes Regionais I”, Cultura Política, Rio de Janeiro, n.19, set. 1942 (Viventes das Alagoas).

167) [“Recordações de uma indústria morta”] - “Quadros e Costumes Regionais II”, Cultura Política, Rio de Janeiro, n.20, out. 1942 (Viventes das Alagoas). 
168) “Uma visita inconveniente”, Cultura Política, ano 2, n. 22, Rio de Janeiro, dez. 1942, p. 154-155 (inédita).

169) “O moleque José”, Atlântico, Lisboa, n.3, Il. Manuel Lapa, 1943, p.111-114.

170) “Dois Mundos”, Leitura - crítica e informação bibliográfica, Rio de Janeiro, n.2, jan. 1943, p.7. (Linhas Tortas).

171) "Monólogo numa fila de ônibus”, Renovação, Rio de Janeiro, 02 fev. 1943 (Linhas Tortas).

172) “O que deveríamos fazer”, Renovação, Rio de Janeiro, mar. 1943 (Especial para Renovação).

173) [“Está aberta a sessão do juri”] - “Quadros e Costumes Regionais IV”, Cultura Política, Rio de Janeiro, n.25, mar. 1943 (Viventes das Alagoas).

174) [“Um homem notável”] - “Quadros Regionais I”, Cultura Política, Rio de Janeiro, n.27, maio 1943 (Viventes das Alagoas).

175) “O estranho Portinari”. O Jornal, Rio de Janeiro, 1 jul. 1943. (Inédita)

176) “José da Luz”, Diretrizes, Rio de Janeiro, ano 6, n.162, Il. Percy Deane, 12 ago. 1943, p.13 e 23. (Infância).

177) “O fim do mundo”, Revista do Brasil, Rio de Janeiro, ano IV, n.55, set. 1943, pp. 14-17.

178) “Um homem forte”, O Cruzeiro, Rio de Janeiro, 11 set. 1943 (Linhas Tortas).

179) “Escola”, Diretrizes, Rio de Janeiro, Il. Percy Deane, 21 out. 1943. (Infância).

180) “O barão de Macaúbas”, Atlântico, Lisboa, n.4, Il. Carlos Botelho, 21 nov. 1943 (Infância).

181) “Chico Brabo”, Diretrizes, Rio de Janeiro, 23 dez. 1943. (Infância).

182) “Adelaide”, Anuário Brasileiro de Literatura, Rio de Janeiro, n.7-8, 19431944, p.104-106. (Infância).

183) "Insônia”, Atlântico, Lisboa, n.5, Il. Magalhães Filho, 1944, p.153-157. (Insônia). 
184) “A viúva Lacerda”, Cultura Política, ano IV, n.42, Rio de Janeiro, jul. 1944, p.173-174 (Linhas Tortas).

185) “Booker Washington”, Cultura Política, ano IV, n.43, Rio de Janeiro, ago. 1944, p.217-219 (Linhas Tortas).

186) “Um novo professor”, Correio da Manhã, Rio de Janeiro, 6 ago. 1944 (Infância).

187) “Um novo professor”, Correo Literario, Montevidéu, 14 ago. 1944, p.3, trad. Norberto A. Frontini. (Infância)

188) “Um desastre”, Folha Carioca, Rio de Janeiro, 23 ago. 1944 (Viventes das Alagoas).

189) “Leitura”, Correio da Manhã, Rio de Janeiro, 27 ago. 1944. (Infância)

190) “Cegueira”, Vamos Ler!, Rio de Janeiro, Il. Jeronymo Ribeiro, 5 out. 1944, p.62. (Infância)

191) “Um incêndio”, Unidade, Rio de Janeiro, nov. 1944, p.7. (Infância)

192) “História de um cinturão”, Jornal do Comércio, Lisboa, 19 nov. 1944. (Infância)

193) “Um intervalo”, Correio da Manhã, Rio de Janeiro, 24 dez. 1944. (Infância)

194) “Venta-Romba”, O Jornal, Rio de Janeiro, 14 jan. 1945, p.1 e 8. (Infância)

195) “Minha irmã natural”, O Jornal, Rio de Janeiro, 28 jan. 1945. (Infância)

196) “Jerônimo Barreto”, O Jornal, Rio de Janeiro, 18 fev. 1945. (Infância)

197) “A criança infeliz”, [O Jornal], [Rio de Janeiro], [11 mar. 1945]. (Infância)

198) “Um enterro”, O Jornal, Rio de Janeiro, 15 abr. 1945. (Infância)

199) “Dois dedos”, A Tribuna, Santos, 9 dez. 1945. (Insônia)

200) “O fator econômico no romance brasileiro”, Tribuna Popular, Rio de Janeiro, 17 jul. 1945 (Linhas Tortas).

201) “A tarefa principal: Constituinte” (discurso), Tribuna Popular, Rio de Janeiro, 10 out. 1945.

202) “Os amigos do povo”. Tribuna Popular, Rio de Janeiro, 09 dez. 1945 (Linhas Tortas). 
203) “Carta aos alagoanos”, Revista do povo: Cultura e Orientação Popular, ano 2, n.2, jan.1946, p.5.

204) “Quadros e Costumes do Nordeste - O Carnaval”, Revista do povo: Cultura e Orientação Popular, ano 2, n.4, abr. 1946, p.3-4 (Viventes das Alagoas).

205) “O Partido Comunista e a criação literária”. Tribuna Popular, Rio de Janeiro, 22 maio 1946 (inédita).

206) “Quadros e Costumes do Nordeste - O Casamento”, Revista do povo: Cultura e Orientação Popular, ano 2, n.5, maio-jun.1946, p.5 e 39 (Viventes das Alagoas).

207) “Conversa de Bastidores”, A Casa, Rio de Janeiro, jun. 1946. (Linhas Tortas).

208) “Conversa de Bastidores”, A Tribuna, Santos, 06 jun. 1946 (Linhas Tortas).

209) “Quadros e Costumes do Nordeste - D. Maria”, Revista do povo: Cultura e Orientação Popular, ano 2, n.6, jul.1946, p.3-4 (Viventes das Alagoas).

210) “Decadência do romance brasileiro”, Literatura, Rio de Janeiro, n.1 set. 1946 (Graciliano Ramos).

211) “Um ladrão”, La Défense, n.260-263, provavelmente entre 1947 e $1950^{996}$.

212) "Página inédita de Memórias da Cadeia” [parágrafo final do capítulo 13, volume 1], Fundamentos, São Paulo, n.1, jun. 1948, p.26 e 27. (Memórias do Cárcere)

213) “Capítulo de Vidas Secas: Final de romance - Fuga”, A Manhã, Rio de Janeiro, ano 9, n.2, 20 jun. 1948, p.27-28.

214) “Contos”, Tworczosc, Varsóvia, n.2, 1949, p.24-27.

215) “Prestes”, Classe Operária, Rio de Janeiro, 01 jan. 1949 (inédita).

\footnotetext{
${ }^{996}$ Fonte: Catálogo de Manuscritos, p.31.
} 
216) “Capítulo XVII”, Para Todos, Rio de Janeiro, 20 out. 1949, n.1, ano 1 (nova fase). (Memórias do Cárcere)

217) “Álvaro Moreira”. Imprensa Popular, 21 maio 1950 (inédita).

218) “Lembrança do III Congresso”, Para Todos, Rio de Janeiro, n.4 maio-jun. 1950 (Graciliano Ramos).

219) “M.Lima e Aporelly” [“Votos de boa viagem”(...)“escrever algumas linhas”] (outra versão), Diário Carioca, Rio de Janeiro, 24 dez. 1950 (Memórias do Cárcere).

220) “Alina Paim”, Imprensa Popular, Rio de Janeiro. 15 abr. 1951 (inédita).

221) “Uma tentativa de explicação”. Revista Acadêmica, n.54, maio 1951(inédita).

222) “O Porão do Manaus”. Jornal do IV Congresso, Rio de Janeiro, 1 set. 1951, n.1, p.4 e 7. (Memórias do Cárcere).

223) “Viver em paz com a humanidade inteira”, Horizonte, Porto Alegre, n.10, out. 1951.

224) “Cadeia”, Otohek, Moscou, 1952, p.20-22 ${ }^{997}$.

225) “Um missionário”, Jornal de Alagoas, Maceió, 8 jun. 1952. (Alexandre e Outros Heróis).

226) O Kolkhoze Kheivani. Imprensa Popular, Rio de Janeiro, jul. 1952 (inédita).

227) Unidade em defesa dos direitos do escritor. Imprensa Popular, Rio de Janeiro, 30 ago. 1952 (inédito).

\footnotetext{
${ }^{997}$ Pode se tratar de uma outra revista. Há uma carta de Boris Polevoi, de julho de 1952, que diz o seguinte: “Prezado sr. Graciliano Ramos / Remeto-vos um exemplar da revista 'Ogoniok' com um trecho do vosso romance, indicado à leitura do povo soviético. Sinto-me alegre em comunicar-vos que o citado trecho de romance obteve boa repercussão entre os leitores soviéticos Ficarei agradecido se nos enviardes um conto dedicado à vida atual dos trabalhadores brasileiros. / Felicitações à vossa esposa. / Aproveito a oportunidade para enviar um caloroso aperto de mão a Jorge Amado e sua família. Respeitosamente, / Boris Polevoi
} 
228) “Birinyi”, Fundamentos, São Paulo, n.31, jan. 1953, p.4 (o texto é acompanhado de uma ilustração da reprodução fac-similar de um trecho do manuscrito de “Birinyi”. Na capa da revista há um desenho de Graciliano feito por Virgínia Artigas (a mesma da imagem que ilustra o texto) e a chamada no topo: GRACILIANO RAMOS - Memórias da Cadeia). (Memórias do Cárcere)

229) “Lampeão”, Diário de Notícias, Rio de Janeiro, 04 out. 1953 (Viventes das Alagoas).

230) “O fator econômico do cangaço”, Diário de Notícias, Rio de Janeiro, 18 out. 1953 (Viventes das Alagoas).

231) “Dois Cangaço”, Diário de Notícias, Rio de Janeiro, $1^{\circ}$ nov. 1953 (Viventes das Alagoas).

1953

232) “Casa de Correção - Capítulo XIII” [“Esteve conosco”(...)“incompreensíveis”], Correio Paulistano, São Paulo, 25 out. 1953 (texto publicado postumamente), p.16. (Memórias do Cárcere)

233) “A última noite de natal”, Correio da Manhã, Rio de Janeiro, 24 dez. 1955 (Linhas Tortas).

234) “Prefácio para uma antologia”, Para todos, Rio de Janeiro, ano 1, n.25, maio 1957 (Linhas Tortas).

235) “Uma aventura de Alexandre”, Jornal do Brasil, Rio de Janeiro, 29 jun. 1957 (texto publicado postumamente), Il. Santa Rosa. (Alexandre e Outros Heróis) 236) “A última noite de natal”, Imprensa Popular, Rio de Janeiro, 22 dez. 1957 (Linhas Tortas). 
237) “Literatura Infantil”, Leitura, Rio de Janeiro, n.1, jul. 1957, p.7-8 (Linhas Tortas).

238) “A vendedora de bilhetes”, Leitura, Rio de Janeiro, n.2, ago. 1957, p.7 (Linhas Tortas).

239) “Canções belicosas”, Leitura, Rio de Janeiro, n.3, set. 1957, p.8-9 (Linhas Tortas).

240) “Semana Santa”, Leitura, Rio de Janeiro, n.4, out. 1957, ano 15 (Linhas Tortas).

241) “Beatas”, Leitura, Rio de Janeiro, n.5, nov. 1957, p.7 (Linhas Tortas).

Sem data

242) “Manhã”, Diretrizes, Rio de Janeiro, s.d, Suplemento Literário, Il. Augusto Rodrigues, p.1 e 8. (Infância)

243) “Os que não são ladrões”. Diário carioca?, Rio de Janeiro, s.d ${ }^{998}$ (Inédita).

244) “Uma comédia” (capítulo XIII do $4^{\circ}$ volume do livro), s.l, s.d. (Memórias do Cárcere)

245) “Carnaval em Palmeira dos Índios”, Leitura, Rio de Janeiro, s.d. p.7.

998 Dúvidas quanto à autoria. 